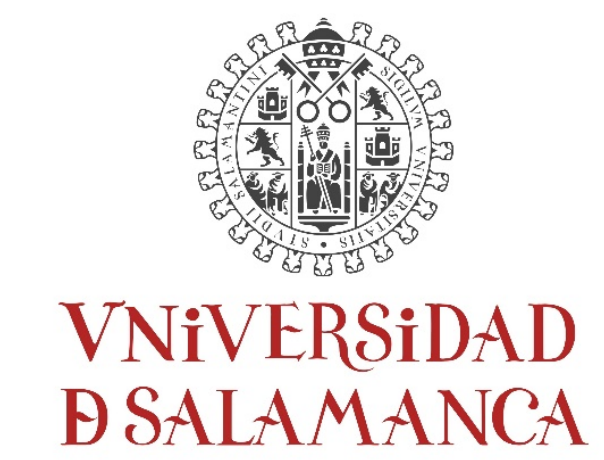

CAMPUS DE EXCELENCIA INTERNACIONAL

PROGRAMA DE DOCTORADO EN ESTADO DE DERECHO Y GOBERNANZA GLOBAL

TESIS DOCTORAL

\title{
EL ACCESO A LA JUSTICIA Y LA ASISTENCIA JURÍDICA GRATUITA DE LOS GRUPOS VULNERABLES EN CHILE: DISEÑO JURÍDICO- CONSTITUCIONAL, ADECUACIÓN CONVENCIONAL E INSTITUCIONALIDAD
}

Augusto Marcelo Santis Poblete

Autor

Dra. María Mercedes Iglesias Bárez

Directora de Tesis

2020 
Universidad De Salamanca

Campus de excelencia internacional

Escuela de doctorado

Plan de estudio: Estado de derecho y gobernanza global

Tesis doctoral

EL ACCESO A LA JUSTICIA Y LA ASISTENCIA JURÍDICA GRATUITA DE LOS GRUPOS VULNERABLES EN CHILE: DISEÑO JURÍDICO- CONSTITUCIONAL, ADECUACIÓN CONVENCIONAL E INSTITUCIONALIDAD

Autor: Augusto Marcelo Santis Poblete

augustosantis@yahoo.com

Directora: Dra. María Mercedes Iglesias Bárez

Año 2020

Salamanca, España 


\section{ÍNDICE}

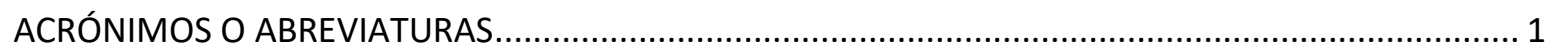

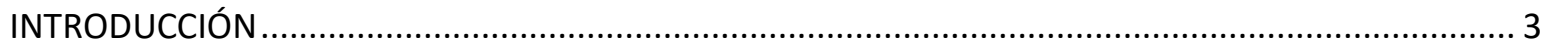

CAPITULO I. DIGNIDAD DE LA PERSONA Y LOS DERECHOS FUNDAMENTALES COMO GARANTÍA DEL

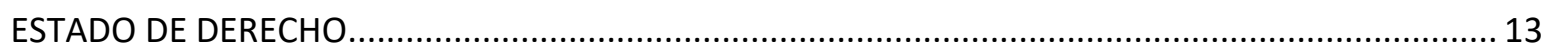

1. LA DIGNIDAD DE LA PERSONA. FUNDAMENTO BÁSICO EN LA PROTECCIÓN DE LOS DERECHOS 13

2. EI CONSTITUCIONALISMO Y SU ROL EN EL RECONOCIMIENTO Y GARANTÍA DE LOS DERECHOS 16

3. ESTADO DE DERECHO COMO IDEAL PROTECTOR. CONCEPTO Y EVOLUCION HISTÓRICA........ 22

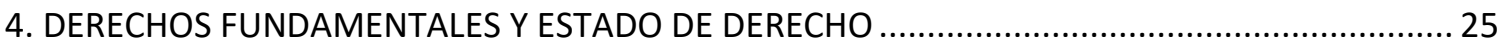

4.1. Conceptualización, denominaciones e importancia de su reconocimiento y

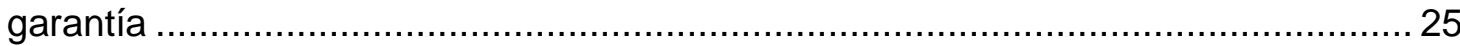

4.2. Criterios de clasificación de los derechos fundamentales ........................... 29

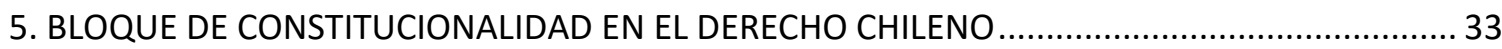

5.1. Contextualización, análisis y proyección jurisprudencial .............................. 33

5.2. Control de Constitucionalidad y convencionalidad ...................................... 37

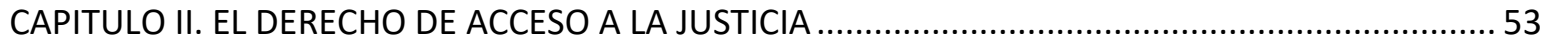

1. REFLEXIONES PREVIAS SOBRE TRATO IGUALITARIO Y SIN DISCRIMINACIÓN ESPECIALMENTE

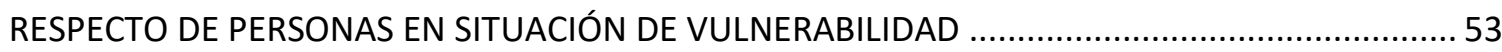

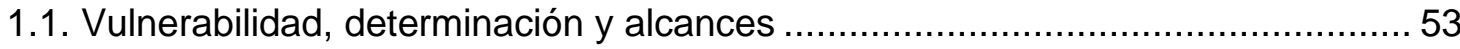

2. CONCEPTO, ENFOQUES Y EVOLUCIÓN DEL DERECHO AL ACCESO A LA JUSTICIA ..............................59

2.1. Concepción restringida y amplia de acceso a la justicia.............................. 59

2.2. Evolución. Olas de Acceso a la Justicia ................................................ 63

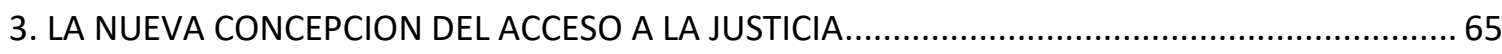

3.1. Obligaciones de Estado en cuanto a la concesión de recursos judiciales con garantías de debido proceso............................................................................ 66

3.2. Obligación positivas del Estado en la concreción del derecho de acceso a la

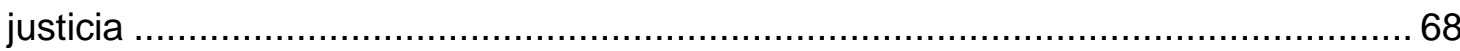

3.3. Barreras, obstáculos u trabas concretas en el acceso a la justicia.................... 72

4. ESTÁNDARES DE ACCESO A LA JUSTICIA Y DEBIDA DILIGENCIA .......................................... 75 
5. LA TUTELA JUDICIAL EFECTIVA Y EL DEBIDO PROCESO COMO ELEMENTO INTEGRANTE DEL

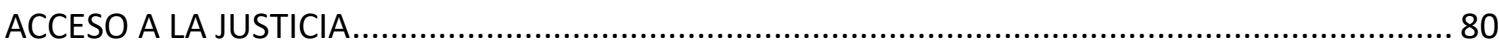

5.1. Tutela judicial efectiva y debida proceso. Presentación y línea demarcatoria .... 80

5.2. Aspectos constitucionales del debido proceso ...................................... 83

5.3. El debido proceso como principio y garantía ....................................... 88

6. ELEMENTOS DEL DEBIDO PROCESO EN CONFORMIDAD A LA NORMATIVA VIGENTE Y A LA LUZ DE LA INTERPRETACIÓN DE LOS ÓRGANOS DE PROTECCIÓN DE LOS DERECHOS HUMANOS ..... 90

6.1. El derecho a ser juzgado por un juez natural y competente dotado de independencia e imparcialidad ........................................................... 91

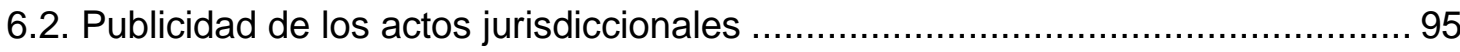

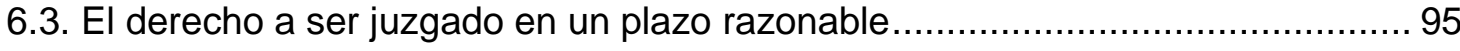

6.4 Derecho a la presunción de inocencia ................................................ 96

6.5 Derechos de defensa propiamente tales ......................................... 97

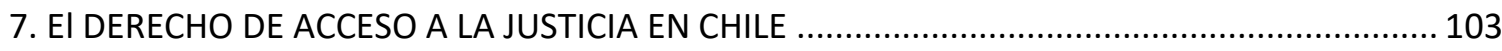

7.1. El derecho de concurrir ante los órganos que ejercen jurisdicción y la igual protección de la ley en el ejercicio de los derechos conforme al bloque de

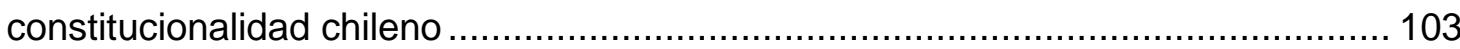

7.2. Tratamiento jurisprudencial del derecho de acceso a la justicia en Chile ......... 106

7.3. El acceso a la justicia en una nueva Constitución para Chile ........................ 109

7.4. Covid 19 y su impacto en el acceso a la justicia en Chile............................. 112 CAPITULO III. ANÁLISIS DE LOS GRUPOS EN CONDICIÓN DE VULNERABILIDAD Y DE LA POBREZA

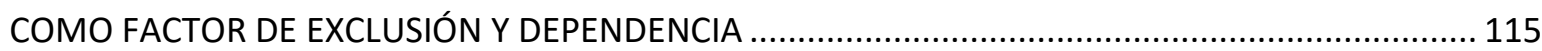

1. ALCANCE METODOLÓGICO RELATIVO A LOS GRUPOS VULNERABLES Y CRITERIOS DE

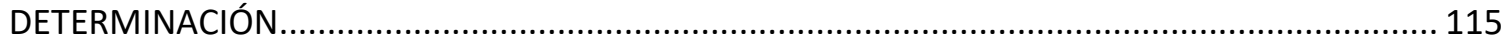

2. DIAGNÓSTICOS DE ORGANISMOS INTERNACIONALES REFERENTE AL ACCESO A LA JUSTICIA DE

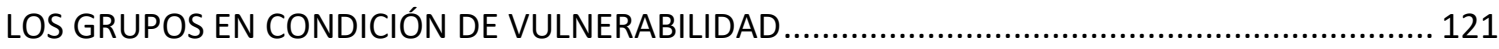

3. REGLAS DE BRASILIA PARA EL ACCESO A LA JUSTICIA DE PERSONAS EN CONDICIÓN DE

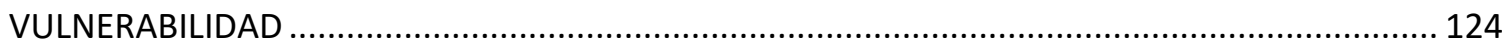

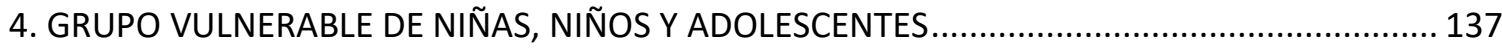

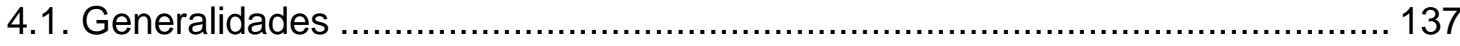

4.2. Normativa internacional aplicable, principios y jurisprudencia..................... 139

4.3. Acceso a la Justicia en Chile de los NNA. Obstáculos estructurales y normativos

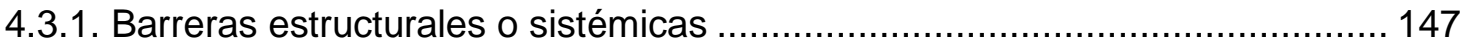

4.3.2. Trabas y deficiencias legislativas en el acceso a la justicia de los NNA ........ 156 
4.4. Políticas públicas y buenas prácticas en Chile respecto de los NNA............... 163

5. PERSONAS CON DISCAPACIDAD COMO GRUPO VULNERABLE ......................................... 171

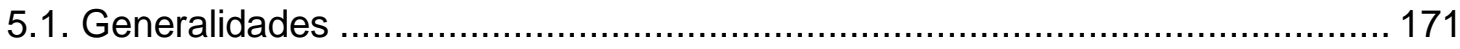

5.2 Normativa internacional aplicable, principios y jurisprudencia ....................... 172

5.3. Premisas y recomendaciones en base a estos principios .......................... 180

5.4. Acceso a la justicia de las personas con discapacidad en Chile .................... 182

5.4.1. Barreras estructurales de acceso a justicia existentes en Chile respecto de las personas en condición de discapacidad ................................................. 182

5.4.2. Obstáculos o deficiencias legislativas de acceso a la justicia de las personas en condición de discapacidad ........................................................................... 185

5.5. Políticas públicas y buenas prácticas de acceso a la justicia en Chile respecto de las personas en condición de discapacidad ............................................ 187

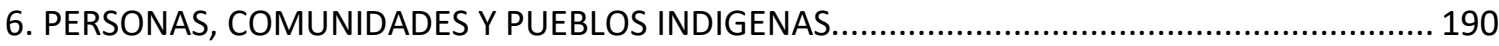

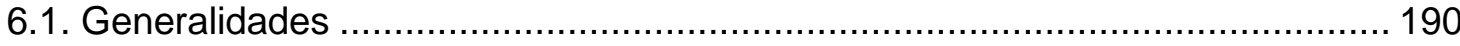

6.2. Normativa internacional aplicable, principios y jurisprudencia ...................... 191

6.3. Premisas básicas derivada de los principios protectores y experiencias de acceso a la justicia de comunidades indígenas en América Latina ............................... 198

6.4. Experiencias de justicia comunitaria indígena en América Andina .................. 202

6.5. Acceso a la Justicia de las comunidades indígenas en Chile ........................ 206

6.5.1. Fenómeno del Conflicto indígena en Chile como obstáculo en el acceso a la

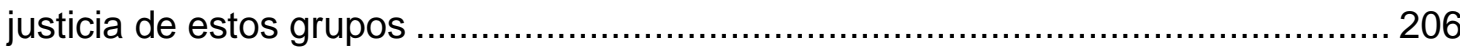

6.5.2. Aplicación de las formas de resolución de conflictos de las comunidades

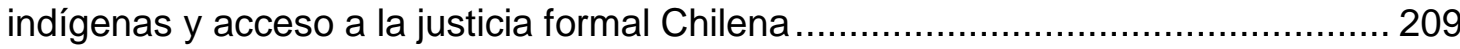

6.6. Políticas públicas en materia de acceso a la justicia de personas o comunidades

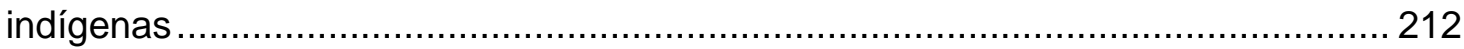

7. PERSONAS MIGRANTES Y SUJETAS A PROTECCION INTERNACIONAL .................................. 213

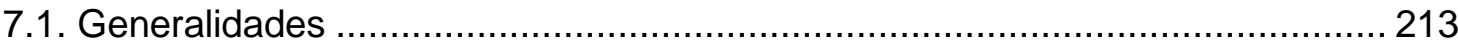

7.2. Normativa internacional aplicable, principios y jurisprudencia ....................... 214

7.3. Obstáculos normativos y estructurales de acceso a la justicia en Chile para

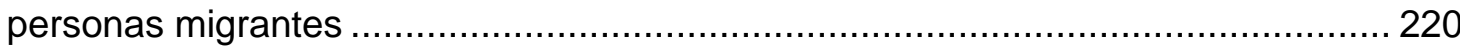

7.4. Políticas públicas y buenas prácticas de acceso a la justicia en Chile respecto de

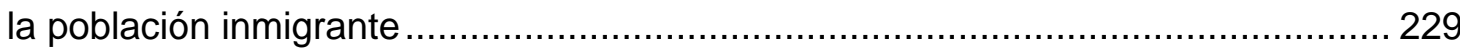

7.5. Alcances de la jurisprudencia migratoria en Chile ..................................... 233

8. MUJERES VÍCTIMAS DE VIOLENCIA DE GÉNERO ............................... 240

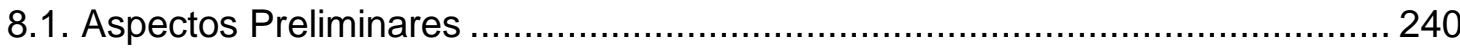


8.2. Normativa internacional aplicable y obstáculos al acceso a la justicia de las mujeres víctimas de violencia

8.3. Recomendaciones de la CIDH sobre la remoción de trabas en el acceso a la justicia por parte de los Estados

8.4. Acceso a la justica de la mujer víctima de violencia en Chile 254

8.4.1 Panorama de la violencia contra la mujer en Chile y el déficit legislativo en cuanto a su protección.

8.4.2. Ruta crítica en cuanto a la denuncia, investigación, sanción y reparación de los actos de violencia hacía la mujer 262

8.5. Jurisprudencia y políticas públicas de acceso a la justica de las mujeres víctimas de violencia de género en Chile 266

8.6. El peregrinaje de las víctimas de violencia de género para acceder a la justicia en tiempos de Covid 19 ................................................................................... 269

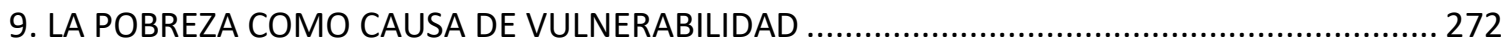

9.1. Aspectos estadísticos y preliminares de la Pobreza.................................... 272

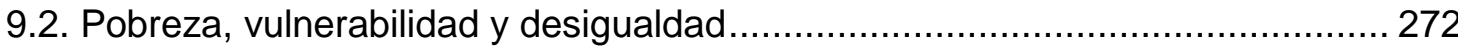

9.3. La Pobreza como una cuestión de derechos humanos. Ser pobre y vulnerable como obstáculo en el ejercicio de los derechos

9.4. ¿Quiénes se consideran pobres en Chile? Relevancia de esta distinción en materia de acceso a la justicia y asistencia jurídica gratuita................................. 276

9.5. Población pobre como beneficiaria de la asistencia jurídica gratuita por parte del Estado 278

9.5.1. Mecanismos de focalización o de determinación de usuarios por parte de los servicios de Asistencia Jurídica Gratuita........................................................... 278

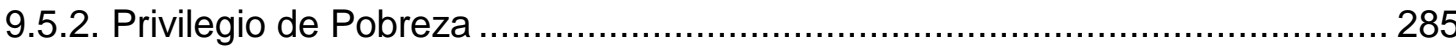

CAPÍTULO IV. DERECHO FUNDAMENTAL A LA ASISTENCIA JURÍDICA GRATUITA. DESCRIPCIONES,

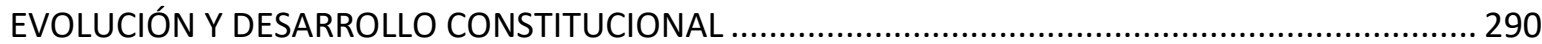

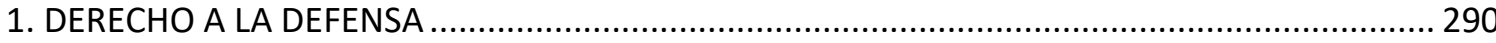

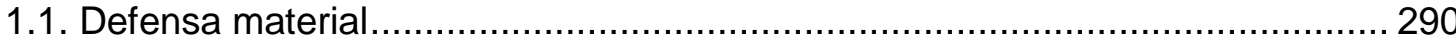

1.2. Defensa jurídica o técnica. Concepto y ámbito de aplicación ........................... 291

1.3. Rasgos característicos de la defensa jurídica o técnica ................................. 293

2. DEFENSA JURÍDICA O TÉCNICA COMO ELEMENTO DEL DEBIDO PROCESO ............................ 294

2.1. Fundamentación de la defensa jurídica como garantía del debido proceso ..... 294

2.2. Defensa personal y análisis de la compatibilidad con la defensa técnica .......... 295

3. LA DEFENSA JURÍDICA EN LA CONTITUCIÓN Y LEGISLACIÓN CHILENA. DEBATE EN LA CENC Y APLICACIÓN DEL DERECHO DE DEFENSA 
3.1. Debate en torno a la defensa jurídica en la CENC y su proyección constitucional 297

3.2. Exigencia de patrocinio de abogado en la legislación chilena 300

4. DERECHO A LA DEFENSA JURÍDICA EN EL DERECHO INTERNACIONAL DE DERECHOS HUMANOS 302

5. DERECHO A LA ASISTENCIA JURÍDICA GRATUITA. APROXIMACIÓN A UN CONCEPTO Y SU

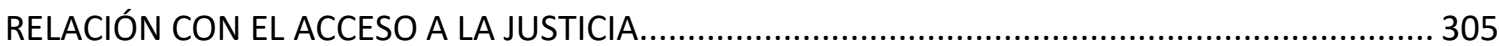

6. CARACTERÍSTICAS DEL DERECHO DE ASISTENCIA JURÍDICA GRATUITA EN CHILE .................. 308

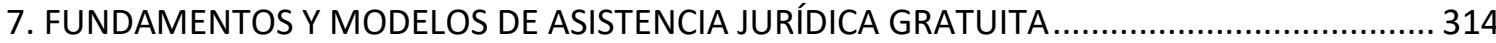

7.1. Motivos que justifican la Existencia de un sistema de Asistencia Jurídica Gratuita

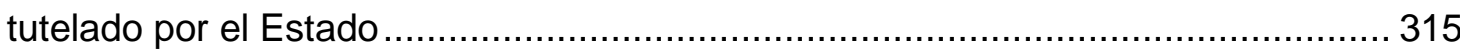

7.2. Modelos de Asistencia Jurídica Gratuita .................................................. 316

8. EVOLUCIÓN HISTÓRICA, LEGAL Y CONSTITUCIONAL DE LA ASISTENCIA JURÍDICA GRATUITA319

8.1. Evolución histórica de la Asistencia Jurídica Gratuita ................................... 319

8.2. Desarrollo histórico y legal de la Asistencia Jurídica Gratuita en Chile............. 321

8.3. Análisis histórico Constitucional del derecho a la Asistencia Jurídica Gratuita en Chile 323

9. ASISTENCIA JURÍDICA GRATUITA. PERÍODO DE GESTACIÓN Y DESARROLLO CONFORME AL BLOQUE DE CONSTITUCIONALIDAD VINCULANTE PARA CHILE

9.1. Periodo formativo de la Constitución de 1980. Comisión de Estudios para una Nueva Constitución.

9.2. Regulación normativa de la Asistencia Jurídica Gratuita conforme al bloque de constitucionalidad chileno 332

10. CRÍTICAS A LA ASISTENCIA JURÍDICA GRATUITA EN CHILE 333

CAPÍTULO V. CONFORMIDAD CONSTITUCIONAL Y CONVENCIONAL DE LA ASISTENCIA JURÍDICA GRATUITA EN CHILE

1. ESTÁNDARES DE ASISTENCIA JURÍDICA GRATUITA CONFORME AL BLOQUE DE CONSTITUCIONALIDAD. 338

2. INCUMPLIMIENTO DEL DEBER DE ASISTENCIA JURÍDICA GRATUITA DEL ESTADO Y VÍAS IDONEAS EN POS DE SU REESTABLECIMIENTO

2.1. Situaciones de incumplimiento del deber de Asistencia Jurídica Gratuita estatal 359

2.2. Vías idóneas ante un no otorgamiento de asistencia jurídica gratuita o que este derecho no cumpla con los estándares constitucionales y convencionales.... 361

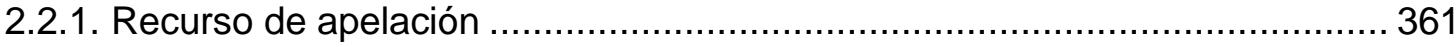

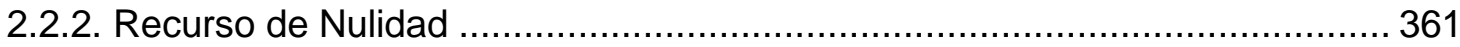




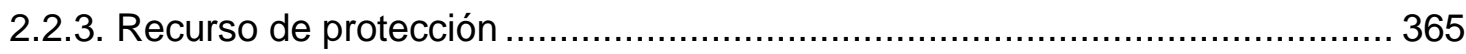

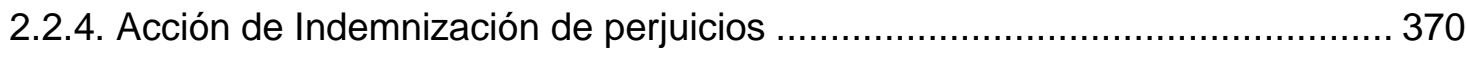

3. PROYECTOS POR UNA NUEVA INSTITUCIONALIDAD DE LA ASISTENCIA JURÍDICA GRATUITA EN

CHILE 373

4. CONSTRUCCIÓN DE UNA POLÍTICA PÚBLICA QUE AYUDE A LA CREACIÓN DE UN SERVICIO DE

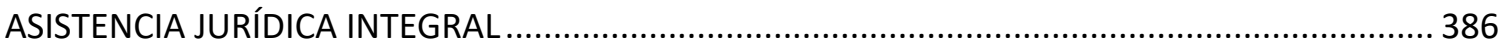

4.1. Obligaciones positivas del Estado en Asistencia Jurídica Gratuita.................... 386

4.2. Principios orientadores de un ideal de Asistencia Jurídica Gratuita para lograr un efectivo acceso a la justicia 387

4.3. Participación y empoderamiento en una política pública de Asistencia Jurídica Gratuita. 390

5. CARACTERÍSTICAS Y FUNCIONES DE UNA ASISTENCIA JURÍDICA GRATUITA COHERENTE CON LOS ESTÁNDARES DE DERECHOS HUMANOS 392

5.1. Valores de una moderna Asistencia Jurídica Gratuita..................................... 392

5.2. Funciones del sistema de Asistencia Jurídica Gratuita ..................................... 393

5.3. Revisión y propuestas de Asistencia Jurídica Gratuita..................................... 394 CAPÍTULO VI. POLITICAS PÚBLICAS, NECESIDADES JURÍDICAS DE LA POBLACIÓN E INSTITUCIONALIDAD DE LA ASISTENCIA JURÍDICA GRATUITA EN CHILE ....................................... 396

1. POLÍTICAS PÚBLICAS Y BUENAS PRÁCTICAS EN AMÉRICA LATINA Y EN CHILE EN MATERIA DE

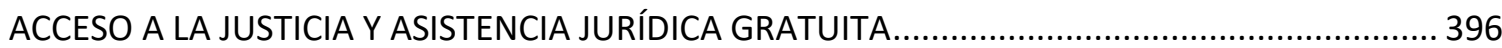

2. NECESIDADES JURÍDICAS DE LA POBLACIÓN EN CHILE ...................................................... 402

3. INSTITUCIONALIDAD DE LA ASISTENCIA JURÍDICA GRATUITA EN CHILE. ASPECTOS PRELIMINARES Y AUSENCIA DE UNA PERSPECTIVA ENFOCADA EN LOS GRUPOS EN CONDICION DE VULNERABILIDAD ..... 410

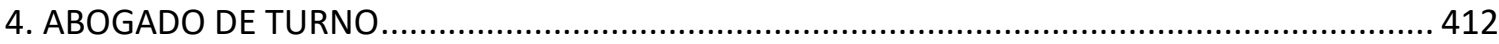

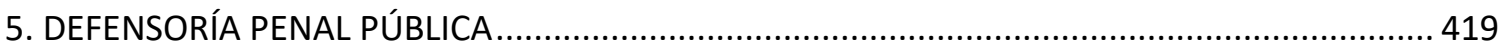

5.1. La Asistencia Jurídica Gratuita en el sistema procesal penal chileno. El derecho a la defensa en el nuevo sistema de justicia penal ............................................. 419

5.2. Defensoría Penal Pública. Ley que la crea, funcionamiento y organización ..... 422

5.3. Apreciaciones sobre la calidad y adecuación der servicio brindado por la DPP y

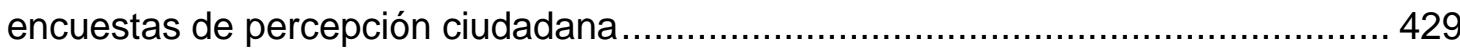

6. CORPORACIÓN DE ASISTENCIA JUDICIAL. GENESIS, DIMENSIÓN INSTITUCIONAL, ESTRUCTURA Y ORGANIZACIÓN ........................................... 431

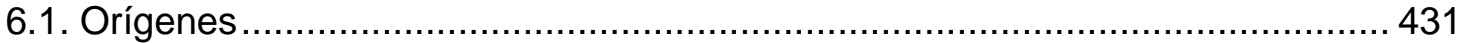

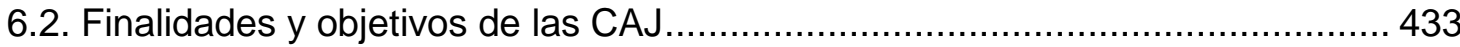

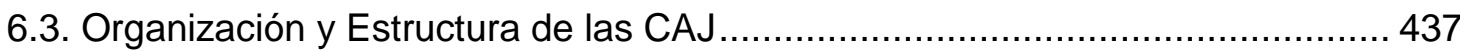


6.4. Recursos humanos y financieros de las CAJ

6.5. Debilidades de la estructura organizacional y críticas desde una perspectiva constitucional en torno a las CAJ ............................................................. 443

6.6. Aspectos positivos, desafíos y recomendaciones de Mejora de las CAJ.......... 447

6.7. Percepción ciudadana del servicio de Asistencia Jurídica Gratuita brindado por

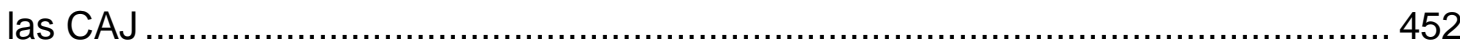

6.7.1 Finalidad del estudio y criterios evaluados ........................................ 452

6.7.2. Análisis de los resultados de la encuesta en relación a los criterios establecidos

CONCLUSIONES

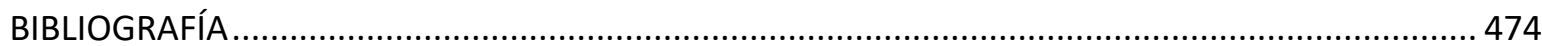




\section{AGRADECIMIENTOS}

A mi hija Antonia, por ser la luz de mis ojos. A mis padres y hermano por su apoyo incondicional. A todos aquellos que de una u otra forma han influido en mi desarrollo como persona, profesional y docente.

Especialmente a mi Directora de Tesis, Mercedes. Generosa, comprensiva y asertiva en sus consejos. 


\section{ACRÓNIMOS O ABREVIATURAS}

CA

$\mathrm{CADH}$

CAJ

CDPD

CE

CEDAW

$\mathrm{CEDH}$

CENC

$\mathrm{CIDH}$

CIDN

CJS

CMED

CORTE IDH

COT

CPC

CPP

CPR

CS

$\mathrm{DIDH}$

DUDH

DL

DPP

DS

NNA

OC

ODL
Corte de Apelaciones

Convención Americana de Derechos Humanos

Corporación de Asistencia Judicial

Convención sobre los Derechos de las Personas con

Discapacidad

Constitución Española

Convención sobre la Eliminación de todas las formas de Discriminación contra la Mujer

Convenio Europeo para la Protección de Derechos Humanos y

Libertades Fundamentales

Comisión de Estudios Nueva Constitución

Comisión Interamericana de Derechos Humanos

Convención Internacional de los Derechos del Niño

Centro Jurídico y Social

Centro de Mediación

Corte Interamericana de Derechos Humanos

Código Orgánico de Tribunales

Código de Procedimiento Civil

Código Procesal Penal

Constitución Política de la República de Chile

Corte Suprema

Derecho Internacional de Derechos Humanos

Declaración Universal de Derechos Humanos

Decreto Ley

Defensoría Penal Pública

Decreto Supremo

Niñas, Niños y Adolescentes

Opinión Consultiva

Oficina de Defensa Laboral 
PNUD Programa de Naciones Unidas para el Desarrollo

PIDCP Pacto Internacional de Derechos Civiles y Políticos

RAC

Resolución Alternativa de Conflictos

$\mathrm{RSH}$

Registro Social de Hogares

$\mathrm{SCC}$

Solución Colaborativa de Conflictos

SENADIS

Servicio Nacional de la Discapacidad

SENAME

Servicio Nacional de Menores

SERNAMEG

Servicio Nacional de la Mujer y Equidad de Género

$\mathrm{SIDH}$

Sistema Interamericano de Derechos Humanos

SUDH

Sistema Universal de Derechos Humanos

UNICEF

Fondo de la Naciones Unidas para la Infancia

TC

Tribunal Constitucional Chileno

TCE

Tribunal Constitucional Español

TEDH

Tribunal Europeo de Derechos Humanos 


\section{INTRODUCCIÓN}

La dignidad de la persona es un valor supremo y fuente sustantiva de los derechos fundamentales, irradiando con ello todo el sistema jurídico, el que debe interpretarse y aplicarse conforme a las condiciones en que dicha dignidad pueda realizarse de mejor forma.

Este atributo distintivo de los seres humanos nos permite ser titulares de una serie de prerrogativas, y para que los derechos puedan ejercerse en condiciones de igualdad y sin discriminación debe existir una estructura organizativa y legal que vele por ese resguardo y protección.

El Estado de Derecho parece ser el mecanismo más efectivo en ese sentido, garante de los derechos inherentes e inviolables a la persona. Existe esta forma de Estado, allí donde el ciudadano, conforme la Constitución, y actualmente, al orden convencional, es puesto en la situación de hacer valer cada derecho que ha adquirido de acuerdo a la ley, frente al mismo poder ejecutivo y ante sus congéneres.

Enmarcado en el neoconstitucionalismo, el derecho de acceso a la justicia no se conformará con la no interferencia estatal, como su par moderno, sino que exige que se remuevan obstáculos que impiden el goce y ejercicio legal, y así propender a que las personas puedan alcanzar su máxima realización y espiritual posible. De esta forma, la dignidad y los derechos fundamentales conforman el fundamento del orden político y de la paz social. El acceso a la justicia, y sus múltiples dimensiones, dentro de las cuales se contempla la asistencia jurídica gratuita, deben ser garantizadas por el Estado, creando una institucionalidad adecuada en pos de la efectividad jurídica. Para ello, el sistema de justicia debe funcionar adecuadamente y desarrollar su trabajo con eficacia. Si en una comunidad hay colectivos que, por diversas razones, sociales, económicas o culturales no pueden acceder a la justicia, es porque algo falta. Sin lugar a dudas, la calidad de una democracia se mide, entre otros factores, por la posibilidad o no que tienen sus ciudadanos de proteger o dilucidar sus derechos, accediendo a un sistema de justicia independiente, sea a través de dispositivos estatales, no estatales, o comunitarios. 
Estos conceptos de dignidad de la persona, derechos fundamentales, constitucionalismo y Estado de derecho, conforman el marco teórico constitucional de nuestro tópico de estudio.

La voz acceso a la justica la escuchamos recurrentemente en variados ámbitos y no solo en el jurídico. Por cierto, también es utilizada como un recurso electoral, incluyéndose dentro de las proclamas de necesidades no cubiertas por el gobierno de turno, junto con la educación, la salud, la seguridad, y un extenso número de etcéteras. Antes de ingresar al doctorado tuve la oportunidad de leer el texto de Mauro Cappelletti y Bryant Garth, titulado "El Acceso a la Justicia. La tendencia en el movimiento mundial para hacer efectivo los derechos". De breve extensión, pero de una riqueza conceptual y de trascendencia práctica invaluable, se constituyó en una invitación a interpretar el fenómeno jurídico de una forma cabal y no fragmentaria, entendiendo que la norma jurídica sustantiva no es una isla, sino que está vinculada a la norma procesal y al fin último, que es buscar resultados justos y adecuados a cada realidad personal y acordes con el interés social. Asimismo, me permitió corroborar de que no hay abogados procesalistas y civilistas, que esa disputa es artificial, y que el abogado debe esmerarse en interpretar la norma antiformalísticamente, y en el sentido más favorable al acceso efectivo de la jurisdicción de todas las personas, en pos de la protección de sus derechos e intereses legítimos en igualdad y no discriminación. Como dice el maestro Humberto Nogueira, se debe interpretar la ley "en clave de derechos humanos".

Ya inmerso en el doctorado y analizándolo con mi estimadísima Directora de Tesis, consensuamos que la inquietud inicial por el acceso a la justicia, sumado a las diversas dimensiones que explorar en torno a ella, fundamentarían un estudio del acceso a la justicia, que con la requerida rigurosidad científica pudiese llegar a constituir un aporte a nuestra disciplina.

De las diversas dimensiones del acceso a la justicia, la asistencia jurídica gratuita es fundamental, pues permite la igualdad material entre las personas y la de armas dentro de un proceso. Esta tarea, implica la revisión de la asistencia jurídica gratuita, tanto en el plano de consagración constitucional y convencional vinculante para Chile, como la conformidad que presenta la institucionalidad nacional con este 
bloque de derechos fundamentales. Por cierto, el hecho de desempeñarme desde el año 2005 como abogado de la CAJ, uno de los organismos que presta asistencia jurídica gratuita, ha contribuido a motivar la selección de este tópico de investigación.

El método científico adoptado para la elaboración de esta tesis ha sido fundamentalmente el lógico deductivo, mismo que se ha desarrollado a través de la recolección de información, en libros, revistas, manuales, protocolos, informes y documentos referidos a los temas directamente relacionados con la investigación, así como de la necesaria consulta de las fuentes legislativas y especialmente jurisprudenciales. Para ello, evidentemente fue necesario clasificar y analizar la información recabada de acuerdo con la temática tratada en cada uno de los capítulos y sus correspondientes subdivisiones. De esta forma, el presente trabajo significa una investigación teórica, descriptiva y argumentativa, fundada en un amplio acervo bibliográfico y hemerográfico seleccionado, tanto por la trascendencia de los autores, pertinencia de informes y documentos, como por su aplicabilidad al objeto de estudio.

Es dable señalar que desde lo metodológico el objetivo de esta tesis será conjugar el acervo documental, con una marcada proyección práctica de las instituciones abordadas, procedimientos y principios, en la cotidianidad del derecho y de la realidad social.

Para los efectos de una exacta comprensión de los aspectos centrales que componen esta tesis doctoral, así como de delimitar conceptos o nociones que emplearemos durante su desarrollo, procederemos a continuación a precisar los elementos centrales de la tesis, a través de los siguientes 4 puntos, que además de constituir objetivos de investigación se consideran hipótesis de constatación.

1) Bajo el enfoque integral de acceso a la justicia, una vez resuelto el significado y su carácter fundamental, derivado del auge del neo constitucionalismo y de la inclusión de la normativa internacional protectora en las constituciones locales, se sostiene que los diversos avances de derechos humanos en materia de acceso a la justicia se vinculan en primer término con el derecho de tutela judicial efectiva y el debido proceso; en segundo lugar, con la obligación de remover barreras 
geográficas, culturales, de género y económicas, que nos propicie en tercer orden, el análisis particular de cada grupo y sus dificultades singulares, que debe constituirse en una preocupación y ocupación de los Estados.

2) De las categorías de población vulnerable, en consideración a las Reglas de Brasilia, privilegiando los criterios de determinación del Protocolo Iberoamericano y Protocolo Chileno de Acceso a la Justicia de Grupos Vulnerables, y en base a criterios de realidad empírica, los déficit legislativos y problemas interpretativos detectados en la experiencia chilena y latinoamericana de acceso a la justicia, se han seleccionado como grupos de análisis, entre otros, los siguientes:

a) Niñas, Niños y Adolescentes

b) Personas con discapacidad

c) Personas migrantes y sujetos de protección internacional.

d) Personas, comunidades y pueblos indígenas

e) Mujeres víctimas de violencia de género.

3) La defensa jurídica y la asistencia jurídica gratuita, se presentan como elementos del acceso a la justicia y del debido proceso, en base a su génesis histórica y constitucional, siendo relevante para efectos de medir su nivel de eficacia, determinar la conformidad de la asistencia jurídica gratuita en Chile, con los estándares que se desprenden de los textos internacionales y de la jurisprudencia de sus órganos de protección.

4) Nuestra institucionalidad de asistencia jurídica gratuita corresponde a las CAJ, DPP y abogados de turno, que representan la política pública nacional en cuanto a la satisfacción de las necesidades jurídicas de la población. Presentan debilidades y fortalezas que deben ser abordadas desde diversos puntos de vista, entre los que destacan la consagración legal y constitucional, la estructura organizacional, dotación de recursos humanos y financieros, percepción ciudadana, y la sostenibilidad de su mantención o urgencia de modificaciones legales y sistémicas. En cuanto a la estructura, esta tesis se compone de seis capítulos, cada uno de los cuales, si bien abordan distintas temáticas, incluso desde perspectivas y con finalidades diversas, se encuentran relacionados con los demás a través de un hilo conductor, que es destacar el derecho de toda persona, especialmente las 
pertenecientes a grupos desfavorecidos, a ejercer los derechos en condiciones de igualdad y no discriminación, a través de instrumentos idóneos con estándares de calidad, dentro de los que se contempla la asistencia jurídica gratuita que debe prestar el Estado a través de su institucionalidad.

En el Capítulo I denominado "Dignidad de la persona y los derechos fundamentales como garantía del Estado de Derecho", destacaremos que el proceso, los derechos fundamentales y Constitución son los pilares del Estado de Derecho, siendo los derechos fundamentales su elemento edificante. En primer lugar se aclarará el uso variopinto en el ámbito latinoamericano y chileno de los términos de derechos fundamentales y humanos, a diferencia del ámbito universal, en que existe una distinción expresa; y en segundo lugar, se desarrollará una clasificación, con el objetivo de determinar posteriormente si el acceso a la justicia y el derecho a la asistencia jurídica pueden considerarse como un derecho de ese carácter y las implicaciones que aquello tendría.

El Artículo 5 inciso 2 de la CPR, consagra que "el ejercicio de la soberanía reconoce como limitación el respeto de los derechos esenciales que emanan de la naturaleza humana, siendo deber de los órganos del Estado respetar y promover tales derechos, garantizados por la Constitución y por los tratados internacionales ratificados por Chile y que se encuentren vigentes". En mérito de este precepto se examinará la institución jurídica del bloque de constitucionalidad, como asimismo, la doctrina del control de constitucionalidad y de convencionalidad, sus alcances y limitaciones, a través de una amplia revisión doctrina y jurisprudencial.

En el Capítulo II titulado el "acceso a la justicia", abordaremos este derecho, reflexionando primeramente sobre el trato igualitario y sin discriminación especialmente respecto de personas en situación de vulnerabilidad.

Los Estándares de acceso a la justicia y de debida diligencia, serán analizados desde una perspectiva de las obligaciones del Estado, encontrándonos con una serie de directrices, condensadas en el informe de la $\mathrm{CIDH}$, titulado "Acceso a la Justicia para las Mujeres Víctimas de Violencia en las Américas", que repercuten en la forma que se van generando las políticas públicas, no solo restringidas al tópico principal del referido informe, sino con una perspectiva general. 
Por la relevancia que adquiere, se profundizará en la tutela judicial efectiva y el debido proceso como elemento integrante del acceso a la justicia, esmerándonos en fijar la línea demarcatoria que se ha trazado en el TC y CS respecto de ambas instituciones, como asimismo el tratamiento jurisprudencial que le otorgan estas judicaturas. Asimismo, a la luz de la norma vigente internacional vinculante para Chile y de la jurisprudencia de la Corte IDH se desarrollarán los diversos elementos del debido proceso dentro del derecho a ser oído con las debidas garantías.

En el Capítulo III, titulado "Análisis de los grupos en condición de vulnerabilidad y de la pobreza como factor de exclusión y dependencia", comenzaremos con un análisis de los postulados del PNUD año 2005 y las Reglas de Brasilia de Acceso a la Justicia de Personas en condición de Vulnerabilidad, sancionadas en el marco de la XIV Cumbre Judicial Iberoamericana, celebrada en Brasilia, del 4 a 6 abril de 2008. Las Reglas enmarcadas en el enfoque amplio e integral se traducen en recomendaciones vinculantes para todos los poderes del Estado y sus funcionarios, en cuando a propiciar la defensa de los derechos, dentro de las que destacan las directrices respecto de la defensa pública y asistencia legal y el acceso a dispositivos diversos al proceso judicial, a través de los métodos alternativos de resolución de conflictos.

Será relevante en este capítulo determinar cuáles son los grupos en condición de vulnerabilidad, tanto en Chile como Latinoamérica. Se revisaran los principios que emanan de tratados internacionales de protección que han sido aplicados por los tribunales locales y especialmente internacionales, que servirán de base para la detección de trabas de diverso tipos. A modo ejemplar, el interés superior del NNA, el principio de accesibilidad y participación e inclusión plenas y efectivas en la sociedad en caso de personas con discapacidad, el principio de autoidentificación en las comunidades indígenas, y el de unidad familiar en caso de migrantes, deben ser considerados por el juez al determinar derechos a su respecto y también en la implementación de cualquiera política pública en pos de su protección.

En primer orden, se revisaran las barreras legislativas que presenta cada grupo, que operan como limitantes de entrada y que aumentan las brechas de desigualdad. En ese sentido, la ausencia de un sistema integral de garantías de la infancia, la 
falta de un reconocimiento constitucional a los pueblos originarios en Chile, el hecho de circunscribir la violencia de género dentro del núcleo familiar que regula la Ley 20.066, y otras deficiencias, se traducen en un serio divorcio entre la realidad de estos colectivos y la respuesta legislativa. Este proceso de invisivilización se acrecenta con las falencias de las estructuras estatales que deberían satisfacer las necesidades jurídicas de cada grupo en atención a sus condiciones singulares. Por otra parte, las políticas de migración selectiva y de procesos de expulsión por la vía administrativa, como asimismo, la escasa cobertura de programas de asistencia jurídica a favor de la discapacidad, repercutirán del mismo en una falta de acceso a la justicia.

La pobreza si bien por sí misma es una causa de vulnerabilidad, al mismo tiempo se considera una agravante de las que ya presentan estos grupos. Si bien es cierto, no se configura en todos los casos, acrecientan los efectos perniciosos ya instalados. La pobreza, como precariedad o penuria que impide la satisfacción de necesidades básicas, como alimentación y vivienda, dista del concepto de pobre desde una óptica jurídica en que es considerada población pobre la que carece de medios para acceder al sistema de justicia y al proceso. Luego de revisar los aspectos preliminares de la pobreza y la perspectiva de análisis como cuestión de derechos humanos, nos esmeraremos en definir los instrumentos de medición validados en Chile, y su conexión con el privilegio de pobreza y los mecanismos de focalización, que cada institución de asistencia jurídica debe aplicar para determinar quiénes son calificados socioeconómicamente para ser usuarios potenciales del respectivo servicio, sin perjuicio de las causales de ingreso automático por factores de vulnerabilidad que se contemplan.

En el Capítulo IV denominado "Derecho fundamental a la asistencia jurídica, descripción, evolución y desarrollo constitucional", se abordará primeramente el derecho a la defensa material como la facultad de toda persona para realizar alegaciones y planteamientos en el proceso. Definir por su parte la defensa jurídica, y proyectar su análisis como un derecho constitucional consagrado en al artículo 19 número 3 inciso segundo de nuestra CPR, nos permitirá cotejarlo con la normativa internacional, y fundamentar la justificación de su establecimiento, cada vez más 
necesario por el carácter técnico y complejo de los procedimientos. Los debates en la CENC y su génesis constitucional, nos permitirá visualizar la relevancia de la exigencia de patrocinio de abogado en la legislación Chilena.

El no tener recursos económicos para acceder al proceso, y en lo concreto pagar los honorarios de un abogado y los costos de la Litis debe ser una ocupación del Estado, emergiendo la obligatoriedad de la asistencia jurídica gratuita. Sus características, especialmente su carácter social prestacional, la esencialidad de la gratuidad y su configuración legal por mandato de la Constitución, conlleva efectos que le dan identidad como derecho fundamental de carácter instrumental, pues propicia el ejercicio del resto de los derechos sustantivos, evitando la autotutela y la desigualdad de armas procesales. La evolución de la asistencia jurídica gratuita, desde una carga honorífica hasta la concepción como un derecho constitucional irrenunciable, recepcionado por la CENC, previo desarrollo histórico de larga data, nos permitirá además justificar los diversos modelos de asistencia jurídica que actualmente se aplican.

En el Capítulo V, denominado "Conformidad Constitucional y Convencional de la Asistencia Jurídica Gratuita en Chile", deberemos cotejar si el Estado logra dotar a la asistencia jurídica gratuita de ciertos requisitos mínimos para que se pueda considerar adecuada, y de esta manera cumplir con los objetivos de su justificación. Del mismo modo, se deberá evaluar el cumplimiento de ciertos estándares a la luz de las directrices impuestas por las normas protectoras internacionales y por su jurisprudencia.

En caso de incumplimiento a estos parámetros de asistencia jurídica gratuita analizaremos la procedencia y viabilidad de las distintas vías o sanciones contempladas en el ordenamiento jurídico nacional, destacando la revisión del recurso de apelación, de nulidad, de protección e indemnización de perjuicios.

Ante ciertas falencias en cuanto a la institucionalidad existente y a la forma de brindarse la asistencia jurídica gratuita, nos avocaremos al estudio de diversos proyectos de reforma legal y constitucional, orientándonos a precisar cuáles serían los objetivos de una nueva institucionalidad. 
El Capítulo VI es denominado "Políticas públicas, necesidades jurídicas de la población e institucionalidad de la asistencia jurídica en Chile". Toda política pública debe adecuarse a los problemas que efectivamente presenten los destinatarios de las mismas. En este sentido las acciones destinadas al acceso de los grupos vulnerables a los sistemas de justicia, jurisdiccionales o no jurisdiccionales, deben ajustarse a las necesidades jurídicas de la población. A modo ejemplar, un niño para acceder a la justicia requiere que se propicie el derecho a ser oído por el juez que adoptara una decisión a su respecto, y que se eliminen los obstáculos legislativos y en general de todo tipo que le impidan gozar de esta prerrogativa. Por su parte, en caso de una persona con discapacidad visual, el hecho de que en el servicio de justicia no se disponga de un sistema braile o que no se hayan realizado los respectivos ajustes razonables, redundaría en una limitación de su derecho a acceder a la justicia, por no haberse eliminado o mitigado ese obstáculo estructural. El trabajo de diagnóstico es básico para que las políticas o buenas prácticas que se implementan puedan satisfacer la necesidad jurídica de cada grupo en forma singularizada.

El abogado de turno, la DPP y las CAJ, son los instrumentos creados por el Estado para otorgar asesoramiento y defensa jurídica a quienes no puedan procurárselo por sí mismos. Serán analizados, desde una perspectiva de su génesis legal, contenidos, fortalezas y debilidades.

Específicamente, en cuanto a la CAJ, se analizará su actual modelo, las razones de su mantención, organización y estructura, como los recursos humanos y financieros con que cuentan.

Los aspectos de ventaja y desventaja que presenta esta serán examinados en función de su proyección de mejoramiento o supresión, según el caso. En cuanto a las deficiencias, la carencia de una unidad organizacional y de profesionalización absoluta, escasa dotación presupuestaria, será cotejada en una lógica crítica constructiva, en relación con sus aspectos positivos, dentro de los que destacan la experiencia de sus funcionarios de planta y por el rol de vanguardia que han tomado en las reformas de justicia de familia y laboral, como en la temática de derechos humanos. Se analizarán las distintas líneas de servicio, entre las que destaca la 
orientación e información y patrocinio judicial, como asimismo el régimen de trabajo de postulante, el factor de elegibilidad de los patrocinados y el procedimiento de atención de usuarios. Asimismo nos permitiremos entregar algunas recomendaciones operativas y estratégicas en cuanto al funcionamiento de este servicio y dar a conocer un estudio de percepción ciudadana en que se miden diversos criterios, entre los que destaca la calidad de atención, sostenibilidad de los acuerdos, fidelidad, cumplimiento de expectativas y estructura e equipamiento. Al terminar esta parte introductoria, indicar que el lector se encontrará con un serio esfuerzo de abordar el acceso a la justicia de los grupos vulnerables desde la perspectiva procesal constitucional, permitiendo que las diversas aristas que implica sean abordadas con claridad. Si bien, en atención al sustrato que nos brinda la metodología por la cual optamos, se observará un análisis teórico, igualmente nos esmeraremos en no perder de vista la utilización de un enfoque práctico, en cuanto a la revisión y constatación en la realidad nacional e interamericana, respecto del actual desarrollo del acceso a la justicia y la asistencia jurídica, con sus respectivas proyecciones de mejora. Asimismo, los estándares internacionales de derechos humanos en cuanto a la obligación del Estado de remover las barreras de acceso y la conformidad de las leyes y estructura sistémica nacional con las exigencias protectoras internacionales, con énfasis en la asistencia jurídica gratuita, constituirán una constante durante este trabajo y nos acompañarán por la senda que hemos comenzado a transitar. 


\section{CAPITULO I. DIGNIDAD DE LA PERSONA $Y$ LOS DERECHOS FUNDAMENTALES COMO GARANTÍA DEL ESTADO DE DERECHO}

\section{LA DIGNIDAD DE LA PERSONA. FUNDAMENTO BÁSICO EN LA PROTECCIÓN DE LOS DERECHOS}

La dignidad humana emerge como una cualidad intrínseca, irrenunciable e inalienable de todo ser humano, constituyendo un elemento que cualifica al individuo en cuanto tal, siendo esta dignidad un dato antropológico y ontológico asumido tanto por la Constitución Política de la República de Chile (CPR), como asimismo por el derecho internacional vigente ${ }^{1}$. Es esta dignidad humana la que es asegurada, respetada, garantizada y promovida por el orden jurídico estatal e internacional, sin que pueda ser retirada a alguna persona por el ordenamiento jurídico, ella no desaparece por más baja y vil que sea la persona en su conducta y en sus actos². Como se advertirá, la aplicación efectiva del derecho de acceso a la justicia, del cual el debido proceso y la asistencia jurídica gratuita forman parte, reviste especial importancia en una sociedad democrática, pues sin él, la exigibilidad de los derechos consagrados en la Constitución, en las leyes y en los tratados internacionales sería solo una declaración de buenas intenciones, pero carecería de eficacia práctica ${ }^{3}$.

La dignidad de la persona es el rasgo distintivo de los seres humanos respecto de los demás seres vivos, la que constituye a la persona como un fin en sí mismo, impidiendo que sea considerada un instrumento o medio para otro fin. Tal dignidad

\footnotetext{
${ }^{1}$ NOGUEIRA, H. (2015). “El Bloque Constitucional de Derechos en Chile, El parámetro y consideraciones comparativas con Colombia y México: Doctrina y Jurisprudencia”. EN Estudios Constitucionales, vol. 13 número 2. Santiago. p. 302.

${ }^{2}$ GONZALEZ, J. (2017). La Dignidad de la persona. Navarra. Editorial Aranzadi. Observatorio p. 25.

${ }^{3}$ UNIVERSIDAD DIEGO PORTALES. (2008). “Acceso a la Justicia en Chile” EN Informe Anual de Derechos Humanos en Chile 2008. Santiago. p. 175.
} 
se constituye en la fuente de todos los derechos humanos. En palabras del profesor Humberto Nogueira, "podemos sostener que dada la primacía de la dignidad de la persona sobre los derechos, debe rechazarse el ejercicio de cualquier derecho que suponga un atentado a ella. La dignidad de la persona constituye una barrera insuperable en el ejercicio de los derechos fundamentales" ${ }^{4}$. La CPR que data de 1980, con las modificaciones que se le han introducido desde 1989 hasta el presente, instituye una concepción e idea de derecho de una sociedad de tipo personalista, que organizada en un régimen político democrático, asegura, garantiza y promueve los derechos esenciales de la persona humana o los derechos humanos. Todo ello de acuerdo con los artículos 1 inciso $1^{\circ}$, artículo 1 inciso $4^{\circ} \mathrm{y}$ artículo 5 inciso $2^{\circ}$ de la Carta Fundamental ${ }^{5}$.

De esta manera, la persona es el objetivo y finalidad de toda la actuación estatal, estando el poder público y el Estado como organización jurídica básica, al servicio de la dignidad y de los derechos de la persona, aspectos esenciales que integran el bien común como fin y tarea de los órganos estatales. Toda sociedad para alcanzar la justicia y la equidad, y para garantizar la dignidad a todas las personas que la componen, no solo debe reconocer formalmente y obligarse al respeto de los derechos humanos básicos, tanto individuales como sociales, sino que debe desarrollar mecanismos que garanticen un efectivo reconocimiento y ejercicio de éstos por parte de todos y cada uno de sus integrantes ${ }^{6}$. El ejercicio de la ciudadanía, la garantía y el respeto del Estado de Derecho y de la democracia, pasan a ser meramente formales, ilusorios y a veces simplemente privilegios para algunos, cuando estos mecanismos no existen o funcionan inadecuadamente.

\footnotetext{
${ }^{4}$ NOGUEIRA, H. (2003). "Los Derechos Esenciales o Humanos contenidos en los Tratados Internacionales y su ubicación en el ordenamiento jurídico nacional: Doctrina y Jurisprudencia”. EN Revista Ius et Praxis vol.9 número 1. Talca. pp 1-2.

${ }^{5} \mathrm{CPR}$. Artículo 1 inciso $1^{\circ}$ : "Las personas nacen libres e iguales en dignidad y derechos". Artículo 5 inciso $2^{\circ}$ : "La soberanía reside esencialmente en la nación. Su ejercicio se realiza por el pueblo a través del plebiscito y de elecciones periódicas y, también, por las autoridades que esta Constitución establece. Ningún sector del pueblo ni individuo alguno puede atribuirse su ejercicio. Artículo 1 inciso $4^{\circ}$ : "El Estado está al servicio de la persona humana y su finalidad es promover el bien común, para lo cual debe contribuir a crear las condiciones sociales que permitan a todos y a cada uno de los integrantes de la comunidad nacional su mayor realización espiritual y material posible, con pleno respeto a los derechos y garantías que esta Constitución establece”.

6 CONFERENCIA DE MINISTROS DE JUSTICIA DE LOS PAISES IBEROAMERICANOS Y MINISTERIO DE JUSTICIA DE CHILE. Reunión de expertos en acceso a la justicia. Santiago de Chile 28, 29 y 30 de noviembre de 2007. p. 2
} 
Tal como sostiene David Lovatón, "las democracias incipientes en América Latina no han logrado hasta ahora y salvo excepciones, traducir la democracia en mayor bienestar y desarrollo para la mayoría de sus ciudadanos(as)" ${ }^{\text {" }}$. En este contexto se estima que los sistemas democráticos no han sido capaces de satisfacer necesidades básicas de la población ${ }^{8}$. De lo que se trata es que la democracia suponga desarrollo y bienestar y, en ese empeño, mejorar el acceso a la justicia es un aspecto central. A juicio del mismo autor, "se suele decir que la calidad de una democracia se puede medir por la posibilidad o no que tienen sus ciudadanos y ciudadanas de proteger o dilucidar sus derechos acudiendo a un sistema de justicia independiente y eficiente, sea estatal o no estatal" ${ }^{\prime}$. Es dable destacar, que cuando se hace referencia al sistema de justicia, se alude a la institucionalidad, tanto orgánica como funcional, encargadas de proteger derechos de las personas, abarcando cortes o tribunales, cualquier otro dispositivo y política pública tendiente a satisfacer las necesidades jurídicas de la población ${ }^{10}$.

Siguiendo al profesor Nogueira "en el sistema constitucional chileno, la dignidad de la persona se constituye así, en el valor supremo y en el principio jurídico que constituye la columna vertebral básica de todo el ordenamiento jurídico constitucional en virtud del artículo $1^{\circ}$ y $4^{\circ}$ de la Constitución y de los preámbulos de los tratados o convenciones de derechos humanos que el Estado ha hecho suyos, mediante la respectiva ratificación, los que determinan a la dignidad humana como la fuente sustantiva de todos los derechos fundamentales, irradiando con ello

\footnotetext{
${ }^{7}$ LOVATÓN, D. (2010). "Experiencias de acceso a la justicia en Latinoamérica”. EN Revista Interamericana de Derechos Humanos. San José de Costa Rica. Litografia Universal S.A. p. 227. "Como era de esperar, ello ha generado el 'represamiento' (acumulación) y hasta la exacerbación de diversas y legítimas demandas populares y locales, en salud, educación carreteras y obras públicas, empleo, manejo del agua, contaminación, etcétera., que con frecuencia jaquean a regímenes democráticos y ponen en cuestión, inclusive, la viabilidad del sistema democrático en algunos países de la región y, a la vez, abren la puerta a nuevas protestas autoritarias que, a diferencia de las pasadas dictaduras militares, suelen instrumentalizar las formas democráticas para, paradójicamente, vaciar de contenido a la democracia a través de la concentración del poder en el líder, el control de instituciones o la desaparición fáctica del equilibrio de poderes”.

${ }^{8}$ IBIDEM. p. 228. "Hay pues, un serio y preocupante problema de legitimidad y respeto ciudadano al sistema democrático, fundamentalmente porque hasta ahora las democracias se han mostrado insuficientes o incompetentes para satisfacer las necesidades básicas de sus ciudadanos y ciudadanas en materia de seguridad, empleo, salud, educación, acceso a la justicia, etcétera”.

${ }^{9}$ IBIDEM.

${ }^{10}$ En este sentido nos apartamos del concepto de sistema de administración de justicia, que dice relación con la facultad que tienen los tribunales de justicia, de conocer, juzgar y hacer ejecutar lo juzgado.
} 
todo el sistema jurídico, el que debe interpretarse y aplicarse conforme a las condiciones en que dicha dignidad se realice de mejor forma, lo cual ha sido asumido jurisprudencialmente, tanto por el Tribunal Constitucional Chileno (TC), como por la Corte Suprema (CS)"11.

\section{EI CONSTITUCIONALISMO Y SU ROL EN EL RECONOCIMIENTO Y GARANTÍA DE LOS DERECHOS}

Desde una perspectiva de constitucionalismo moderno, el objeto del Estado es arbitrar la autoridad y consagrar los derechos de los hombres y mujeres, cuyo origen se encuentra a ambos lados del atlántico a finales del siglo XVIII, con las declaraciones de derechos de las colonias norteamericanas de 1776 y la Constitución de 1787 y por otro lado, la revolución francesa con su correspondiente Declaración de Derechos del Hombre y del Ciudadano en 1789 y Constitución de 1791. Se converge en esta conceptualización constitucional, en la prevalencia de la figura del denominado "Estado de Derecho", en cuanto modelo estructural ideal, pues permite el establecimiento del bien común, basado en el irrestricto respeto de la persona humana, la libre generación del poder y un orden jurídico de imperio de la ley aplicable a gobernantes y gobernados.

Los fundamentos del constitucionalismo moderno se sustentaban primeramente en los siguientes postulados ${ }^{12}$ :

a) Soberanía popular.

b) Anclaje de la Constitución en principios universales.

\footnotetext{
11 NOGUEIRA, H. (2015). “El Bloque Constitucional de Derechos en Chile, El parámetro y consideraciones comparativas con Colombia y México: Doctrina y Jurisprudencia”. Op. Cit., p. 302. “En este sentido, tal perspectiva ha sido asumida por el tribunal constitucional chileno, el cual en la sentencia de 26 de junio de 2008, ha determinado: “vigésimo tercero. Que de la dignidad que singulariza a toda persona humana se deriva un cúmulo de atributos, con los que nace y conserva durante toda su vida, Entre tales atributos se hallan los derechos públicos subjetivos o facultades que el ordenamiento jurídico le asegura con carácter de inalienables, imprescriptibles e inviolables en todo momento lugar y circunstancia”.

12 DIPPEL, H. (2205). “Constitucionalismo moderno. Introducción a una historia que necesita ser escrita”. EN Revista electrónica historia Constitucional. n 6. p. 182.
} 
c) Una declaración de derechos.

d) Gobierno limitado.

e) Constitución como ley suprema.

Estos fundamentos condicionaron otros cinco principios con el objeto de hacer a la Constitución funcionar, de acuerdo con las metas del constitucionalismo moderno, los que corresponden a los siguientes ${ }^{13}$ :

a) Gobierno representativo para ampliar su legitimidad y para prevenir al gobierno aristocrático y la corrupción.

b) La separación de los poderes para excluir la concentración tiránica del poder.

c) La exigencia de responsabilidad política y de un gobierno responsable para controlar el poder.

d) Independencia judicial para que la ley prevaleciera sobre el poder y perdurara.

e) Procedimiento ordenado de reforma de la Constitución ante el simple paso del tiempo o para corregir errores u omisiones, con la participación del pueblo o sus representantes mientras que se previene alteraciones arbitrarias o pobremente pensadas.

Es preciso indicar que en este constitucionalismo moderno, en aras de los principios reseñados, se contempla la garantía de efectividad de los derechos civiles y políticos mediante la no interferencia del Estado, en que prima una libertad de acción de los particulares. En esta etapa, la obligación del Estado es de tipo negativa, relacionada con la mera tolerancia y no intervención en los actos y en las libertades de los particulares. Como lo afirman Mauro Cappeletti y Bryan Garth, "en la era burguesa el acceso a la protección judicial es un derecho a favor del quejoso a litigar o defender una reclamación. Un derecho natural, que no exigía una acción

${ }^{13}$ DIPPEL, H. Op. Cit., p. 184. 
estatal afirmativa para su protección"14. Posteriormente, conforme las sociedades burguesas crecieron en tamaño y complejidad, el concepto de derechos humanos comenzó a sufrir una transformación radical aperturándose a un reconocimiento de derechos que traspasaron el ámbito individual ${ }^{15}$.

De esta manera, este constitucionalismo moderno, estrictamente liberal, atravesó por múltiples crisis, tanto en el ámbito de la libertad, igualdad y justicia, siendo superado por un constitucionalismo social, cuyas fundamentaciones ideológicas se sustentaron en ${ }^{16}$ :

a) Concepto positivo de libertad e igualdad.

b) Participación política.

c) Intervención estatal en todas sus formas.

d) Dignificación de trabajadores y Justicia social.

En esta etapa destaca la Constitución Mexicana de 1917 y la de Weimar de 1918. En épocas de éste constitucionalismo social, no resalta la conquista de derechos individuales, sino que se lucha por los ideales sociales (derecho a la salud, trabajo, educación).

Posteriormente, cuando se terminan las guerras mundiales, va a nacer una nueva etapa, cuyos iconos son la Constitución de Italia de 1947 y la Ley Fundamental de Bonn de 1949, en el contexto de un constitucionalismo que no solo declaran derechos, sino establece herramientas para hacerlos efectivos. En la ley de Bonn, en la que se reconocen los derechos fundamentales, estos se admiten preexistentes a la norma constitucional que los recoge y se diseña un mecanismo de protección

\footnotetext{
${ }^{14}$ CAPELLETTI, M y GARTH, B. El acceso a la justicia. La tendencia en el movimiento mundial para hacer efectivos los derechos. Ciudad de México. Fondo de Cultura Económica. Op. Cit. p. 10.

${ }^{15}$ IBIDEM. "Como las acciones y las relaciones adquirieron cada vez más un carácter colectivo en lugar de un carácter individual, las sociedades modernas necesariamente fueron más allá de la opinión individualista de laissez-faire sobre los derechos que se reflejó en las declaraciones de derechos y garantías del siglo XVIII Y XIX”.

${ }^{16}$ DIPPEL, H. Op. Cit., p. 191.
} 
de los mismos, a través de técnicas como su directa aplicabilidad, la garantía del contenido esencial y el recurso de amparo ante el tribunal constitucional.

El denominado neo constitucionalismo, entonces, buscará concretar esa protección de los derechos ya declarados. Se señala que la Constitución solo podía interpretarse por la Justicia constitucional y podría alterar la voluntad del constituyente $^{17}$. Será éste, el constitucionalismo de la segunda mitad el siglo XX y que presentará las siguientes características ${ }^{18}$ :

a) Constitución rígida con distinción entre quórum del poder legislativo y aquellos para cambiar la Constitución. Además se consagra la supremacía constitucional a través del órgano correspondiente.

b) Constituciones que contienen "Garantías jurisdiccionales de la supremacía de la Constitución", que se definen a sí mismas o bien se empiezan a considerar por doctrina o tribunales como textos con carácter normativo y derecho directamente aplicable, en contraste con las ideas antes de la II guerra, en que la Constitución había sido considerada como un conjunto de declaraciones políticas sin posible aplicación como derecho.

c) Los catálogos de derechos fundamentales que en conjunto con otras disposiciones de la Constitución, pasan a ser considerados valores o bien principios, que no se limitan a regular la organización del poder, las relaciones de los poderes públicos, sino que irradian y proyectan todo el ordenamiento jurídico, de modo que ya no existen espacios jurídicos exentos de regulación constitucional, aunque ésta sea mera directriz (fenómeno conocido como constitucionalización del derecho).

d) Un efecto horizontal respecto de los derechos fundamentales que en los constitucionalismos anteriores se consideraban como preceptos dirigidos al ejercicio del poder.

\footnotetext{
${ }^{17}$ ALDUNATE, E. (2010). “Neo constitucionalismo” EN Anuario de Derecho público Universidad Diego Portales. Santiago de Chile. p. 361. "El neo constitucionalismo caracteriza la evolución del diseño y de la praxis constitucional tras la segunda guerra mundial en Italia, Alemania, Portugal y España, para posteriormente pasar a América Latina y propagarse también hacía otros países europeos”.

${ }^{18}$ IBIDEM. Op. Cit., pp. 362-364.
} 
e) Método para la aplicación de estos principios o valores (en especial plasmado en el catálogo de derechos fundamentales), no siendo adecuado el principio de subsunción propio del positivismo jurídico, sino el de ponderación de carácter moral, de justicia material de los principios constitucionales y de modo tal, de afirmar siempre su vigencia y validez y que apunta a apreciar solo en el caso concreto que se produzca una colisión de valores o principios a cuál de ellos debe darse en ese caso prevalencia.

Enmarcado en el neo constitucionalismo, el derecho de acceso a la justicia, pasa a ser una preocupación para los Estados y no se conforma con la no interferencia, sino que se le exige un rol más preponderante, mediante obligaciones positivas, especialmente respecto de las personas que no se encuentran en igualdad de condiciones para ejercer con plenitud los derechos que les confiere el ordenamiento jurídico. En este contexto, podemos sostener que aliviar la pobreza legal si se contempla como una obligación positiva de los Estados. Como sostiene Carlos Almela "el objetivo primordial de los sistemas de justica es la defensa de los derechos de las personas, garantizando que todas ellas sean respetadas y que la vulneración de sus derechos sea restaurada. Para ello el sistema de justicia debe funcionar adecuadamente y desarrollar su trabajo con eficacia. Si en una comunidad hay colectivos que, por diversas razones sociales, económicas, o culturales, no pueden acceder a la justicia, es que algo falta" ${ }^{19}$.

Otorgando relevancia al rol del Estado en cuanto a la remoción de obstáculos que impidan el desarrollo personal en condiciones de igualdad de cada persona, Pedro Frías, expresa que "el Estado de Derecho como tipo de Estado debe remover obstáculos que impidan el goce y ejercicio de los derechos reconocidos por los ordenamientos jurídicos y así propender que las personas puedan alcanzar su máxima realización material y espiritual posible en un plano de igualdad ${ }^{20}$. Se debe

\footnotetext{
${ }^{19}$ ALMELA. C. (2020). Manual para la Construcción de políticas públicas sobre acceso a la justicia de personas en condición de vulnerabilidad. Madrid. Eurosocial. p. 6.

${ }^{20}$ FRIAS, P (1992). El Constitucionalismo Actual, EN Revista Chilena de Derecho, Pontificia Universidad Católica de Chile. vol. 19. n¹.p.54. "El Estado social de derecho sería aquel especifico tipo de Estado, que asiste a los individuos en su procura existencial, les garantiza un mínimo vital, y persigue lograr que estos hagan efectivo ejercicio de los derechos y libertades del Estado de Derecho. El Estado está obligado de a
} 
considerar que en este contexto, el acceso a la justicia, y sus múltiples aristas, deben ser garantizadas por el Estado, creando la institucionalidad adecuada para permitir que todas las personas puedan hacer efectivos sus derechos.

De este modo, los derechos se comienzan a transformar en una prerrogativa prestacional, existiendo una obligación positiva del Estado en cuanto a su satisfacción. En el evento de que una persona no pueda acudir en igualdad de condiciones ante el órgano encargado de administrar justicia, en post de ejercer un derecho reconocido, u obtener una solución justa a su conflicto con otro particular o con el mismo Estado, debe éste procurarle los medios tanto jurídicos como materiales, para que acceda en el plano de igualdad requerido a la obtención de resultados justos. Cuando surge una necesidad social, el Estado como responsable de satisfacer y garantizar estas necesidades, debe adoptar aquellas medidas que sean adecuadas para darles respuesta. Las reformas judiciales exitosas solo pueden darse en contextos institucionales democráticos y de respeto del Estado de Derecho y que, por ende, fortalecen la independencia judicial y mejoran el acceso a la justicia y la tutela de los derechos fundamentales ${ }^{21}$. Por ello, para que una reforma judicial sea exitosa, ajustándose a las exigencias de un Estado de Derecho, debe incrementar la independencia judicial -y, por lo tanto- modificar el contexto político en el que operan y promover el acceso efectivo y equitativo a la justicia ${ }^{22}$. Tal como lo expresan, Lucía Arbeláez de Tobón y Esmeralda Ruíz González "actualmente los marcos jurídicos y la institucionalidad protectora internacional, se centran en el cumplimento de la normativa en post de garantizar efectivamente los derechos, especialmente de los grupos considerados vulnerables, pues se considera que se encuentran en una situación de especial dificultad para ejercer en plano de igualdad los derechos que se le reconocen ${ }^{23}$. Precisamente, se entiende

\footnotetext{
desarrollar políticas públicas que eliminen impedimentos que dificulten el disfrute de los derechos de la ciudadanía y establezcan mecanismos que pueden compensar las desigualdades existentes”.

${ }^{21}$ LOVATÓN, D. Op. Cit., p. 228.

22 IBIDEM.

${ }^{23}$ ARBELAEZ DE TOBON, L y RUIZ, E. (2018). Cuadernos de Buenas Prácticas para incorporar la Perspectiva de Género en las Sentencias. Santiago. Poder Judicial. p. 24. "Hoy existe un marco jurídico internacional de derechos humanos dotado de mecanismos internacionales de cumplimiento, destacan: El Consejo de Derechos Humanos Junto con sus procedimientos especiales y el examen periódico universal. Asimismo, los comités, órganos creados en virtud de tratados de derechos humanos para apoyar a los Estados
} 
que sólo cuando la dignidad y la igualdad de derechos inherentes de todos los miembros de la familia humana sean verdaderamente respetadas podremos confiar en la existencia de libertad, justicia y paz en este mundo ${ }^{24}$.

\section{ESTADO DE DERECHO COMO IDEAL PROTECTOR. CONCEPTO Y EVOLUCION HISTÓRICA.}

En 1829, el término Estado de Derecho alcanza su consagración e ingresa a la discusión de la publicista alemana a través de la obra de Robert von Mohl, "Derecho de Estado del reino de Wurttemberg", orientada desde planteamientos propios de la concepción racional del derecho, usándose esta expresión para referirse al Estado del Derecho racional, esto es a la luz de los predicamentos de Ernest-Wolfgang Böckenförde, quién sostiene que es "el Estado que realiza los principios de la razón en y para la vida en común de los hombres, tal y como estaban formulados en la tradición de la teoría del derecho racional”25.

Bajo este concepto, en su origen, Estado de Derecho es un "estado de razón", "estado de entendimiento", en el cual se gobierna a través de una voluntad general racional y en que la única finalidad perseguida es lo mejor para todos. Es por ello que el concepto de ley se sitúa en el corazón de este concepto de Estado de Derecho ${ }^{26}$. A entender de Enrique Aldunate, "el Estado de Derecho, desde su creación conceptual, se ha concebido como una organización fundada en ciertos principios racionales, dentro de los cuales se incluían, en primer lugar: el reconocimiento de los derechos fundamentales, como la libertad (personal, de

en su obligación de garantizar los derechos humanos de todas las personas, en especial de las mujeres, los niños, las personas con discapacidad, los pueblos indígenas, los migrantes y otros grupos en situación de desventaja”.

${ }^{24}$ IBIDEM. "Nos corresponde entonces redoblar esfuerzos para cumplir la responsabilidad colectiva de promover y proteger los derechos y la dignidad de todas las personas en todo el mundo".

${ }^{25}$ BÖCKENFÖRDE, E. (1987). Estudios sobre el Estado y la Democracia. Madrid. Editorial Trotta. p. 19.

${ }^{26}$ ALDUNATE, E. (2008). Derechos Fundamentales. Santiago de Chile. Editorial Thomson Reuter. p. 64. "Se trata de una res pública, una organización existente para permitir a cada individuo su desarrollo individual, y que en esa medida tiene limitados sus fines y tareas, los que deben circunscribirse a garantizar la libertad y la seguridad del individuo, para permitir la prosecución por parte de éste de sus propios fines, sean temporales o espirituales". 
conciencia, religiosa, de prensa, contractual, entre otras), la igualdad jurídica, la garantía de la propiedad regularmente adquirida; y en segundo lugar: el establecimiento de ciertas definiciones institucionales, como la independencia del juez, un gobierno constitucional responsable, el imperio de la ley, la existencia de un órgano de representación popular y su participación en el poder legislativo"27. A mediados del Siglo XIX, el concepto de Estado de Derecho va a sufrir una reducción a partir de la obra de Stahl $(1856)^{28}$. Se explica esta reducción en que concretado ya el contenido material de Estado de Derecho en la mayor parte de los Estados alemanes de la época, se justificaba concentrar la noción en aquello que aún restaba por alcanzar y que era el sometimiento del actuar de la administración al derecho. Bajo este aporte doctrinario, se puede señalar que hay Estado de Derecho allí donde el ciudadano a través del derecho, conforme al orden constitucional, es puesto en la situación de hacer valer cada derecho que ha adquirido de acuerdo a la ley, frente al mismo poder ejecutivo ${ }^{29}$. El Estado de Derecho en sentido formal se manifiesta en rasgos bien perfilados: supremacía de la ley como acto del poder legislativo, legalidad de la administración y legalidad de la acción de la justicia ${ }^{30}$.

Es importante en este orden de ideas no identificar derecho con ley, precisamente por el origen político representativo de ésta última, pero no menos interesado, por uno u otro interés que pudiese revestir ${ }^{31}$. La representación popular legislativa no se alza siempre como una defensa frente a un poder ejecutivo amenazante, sino que se empieza a constatar que la intervención legislativa en la regulación de los derechos puede ser la principal fuente de afectación de los mismos, visualizándose

\footnotetext{
27 IBIDEM.

${ }^{28}$ Tal como lo señala Aldunate, para Stahl, el concepto de Rechtsstaat no apunta a su objetivo ni al contenido de su actuar, sino que, exclusivamente a la forma y modo de concretar sus propios fines. Esta forma y modo consisten en determinar y asegurar, a través del Derecho, el ámbito de acción del Estado y la esfera de libertad de los ciudadanos, y en lo referente a esta última, solo en cuanto corresponda a una regulación jurídica imprescindible. Surge así, con Stahl, un concepto de Estado de Derecho que posteriormente se ha venido en denominar Estado de Derecho en sentido formal.

${ }^{29}$ ALDUNATE, E .Op. Cit. p. 65.

30 IBIDEM.

${ }^{31}$ IBIDEM. "La aspiración de que la ley no atente contra el sentido material del Estado de Derecho, que es precisamente asegurar a cada uno su libertad y de orientar el actuar del Estado en vista al pleno desarrollo de los individuos, no precisamente se concreta en la práctica, porque al identificar derecho con ley, se olvida de que la ley también puede ser objeto de un actuar interesado del poder político”
} 
con mayor claridad en momentos de convulsión o agitación social, en que se pueden tomar decisiones legislativas o de tipo administrativas inclusive, con la finalidad de neutralizar el descontento, o de índole especulativa, y con prismas de cálculo electoral. En este sentido, el derecho a la asistencia jurídica proporcionada por el Estado, en la Comisión de Estudios Nueva Constitución para Chile (CENC), creada por Decreto Supremo (DS) del Ministerio de Justicia ${ }^{32}$, previo al proceso de aprobación de la Constitución de $1980^{33}$, se entendió que podía tener un sentido político, porque sería el gobierno de turno quién podría tener el monopolio de los servicios jurídicos y así poder establecer sesgos partidistas en el otorgamiento de este derecho-beneficio.

La necesidad de que un ordenamiento superior sostenga y legitime la decisión política que se traduce en la ley, hace necesario que emerja un ordenamiento jurídico básico dotado de legitimidad, que es la Constitución. Esta idea es explicada por Antonio Peña, en el entendido que "las limitaciones de la ley como elemento excluyente de la creación y sostenimiento del Estado hace que sea necesario un sustrato dotado de una legitimidad y proyección temporal mayor, respecto del cual pueda girar la ley y la institucionalidad creada para cumplirla ${ }^{34}$. Ante este predominio del poder legislativo y a la disminución del valor representativo de la ley, se buscó limitar esta superioridad, lo que se logra con la Constitución ${ }^{35}$.

\footnotetext{
${ }^{32}$ DS 1064 de 12 de noviembre de 1973.

${ }^{33} \mathrm{Al}$ contrario de lo que se puede decir, esta Comisión jamás fue constituyente, sino fue una Comisión de estudios que preparó un anteproyecto, que posteriormente fue aprobado por el Consejo de Estado, organismo asesor de la junta de gobierno y de su Presidente. Posteriormente fue sometido a plebiscito el 11 de septiembre de 1980, en que la opción "sí”, obtuvo un 67,04 \% de los sufragios y la opción “no”, un 30,19 \%, más los votos nulos y blancos. Es dable señalar que el país era gobernado por orden de una junta nacional de gobierno, conformada por los comandantes y jefes de las fuerzas armadas, presidida por el Comandante en jefe del ejército Augusto Pinochet Ugarte. Esta junta de gobierno asumió el poder con fecha 11 de septiembre de 1973, a raíz de un golpe militar que desestabilizó la democracia constitucional, derrocando al Presidente Salvador Allende Gossens, disolviéndose el Congreso.

${ }^{34}$ PEÑA. A. (1997). La garantía en el Estado constitucional de derecho. Madrid. Editorial Trota. p.127. "Se toma conciencia a partir de este reduccionismo teorizado por Sthal, de que lejos de formar parte de un ámbito separado de lo real, la ley es parte del conflicto social, y que no es solamente expresión pura de la voluntad general, pues la ley es producida por una mayoría contingente, interesada y dispersa, por lo cual la norma general y abstracta dejará de ser considerada el instrumento adecuado para asegurar la paz social, y particularmente que revele la indisponibilidad de aquellos valores y principios respecto de los que existe un amplio consenso social, como son los derechos fundamentales”.

${ }^{35}$ En este sentido, la Constitución deja de ser un marco de referencia jurídica sostenido por el consenso del comportamiento político, y pasa a ser fuente directa de proposiciones normativas vinculantes para todos los órganos del Estado. Por lo mismo y por este paso de Estado de Derecho legislativo a constitucional, la
} 
En un régimen o sistema constitucional, cualquier ley debe ser fundamentada en la Constitución, por lo que todas las leyes quedan reguladas y supeditadas al articulado general de la misma. Por primera vez, la idea tradicional de limitar el poder habría derivado en la concesión de derechos positivizados a los individuos, la protección de los cuales podría reclamarse en un tribunal contra las pretensiones del gobierno. De acuerdo con la ley natural, no fue el orden divino de los tiempos inmemoriales el que otorgaba legitimidad a la Constitución, sino únicamente el pueblo. A nuestro entender, la consideración de los derechos como principios y su ponderación por las judicaturas constitucionales, ha sido determinante en la concepción y alcance de los derechos fundamentales.

Reforzando esta idea, a la luz de las reflexiones de Aldunate, es precisamente la ponderación de los derechos fundamentales, el elemento que ha resultado determinante en el cambio de paradigma de la concepción de Estado de Derecho, de legal a constitucional ${ }^{36}$.

\section{DERECHOS FUNDAMENTALES Y ESTADO DE DERECHO}

\subsection{Conceptualización, denominaciones e importancia de su reconocimiento y garantía}

Nogueira define a los derechos fundamentales, como "el conjunto de facultades e instituciones que concretan las exigencias de la libertad, igualdad y seguridad humana, en cuanto expresión de la dignidad de los seres humanos, considerados tanto en su aspecto individual como comunitario, en un contexto histórico determinado, las cuales deben ser aseguradas, respetadas, promovidas y

Constitución va a ser sometida a una fuerte presión en vista de exprimir de ella su posible contenido normativo a partir de estructuras de texto usualmente pobres y escuetas.

${ }^{36}$ ALDUNATE, E. Derechos Fundamentales. Op. Cit., p. 68. "el efecto de la evolución del Estado, meramente legal a constitucional, ha sido profundo en el ámbito del tratamiento normativo de los derechos fundamentales, considerándose los derechos como valores o principios, cuya ponderación o jerarquización se ha desplazado del legislador democrático a la judicatura constitucional, con los consiguientes problemas jurídicos y políticos que ello conlleva”. 
garantizadas por los ordenamientos jurídicos a nivel nacional, supranacional e internacional, formando un verdadero subsistema dentro de estos"37.

Los derechos fundamentales se han concebido como aspectos inherentes a la persona, anteriores a la positivización, y que no se pueden expresar de forma agotada y taxativa. Sin embargo, el concepto de derechos fundamentales no es el único utilizado, sino que constituye solo uno de ellos, para referirse a los que concretan las exigencias tan bien descritas por el maestro Nogueira. Es importante señalar que en el ámbito latinoamericano, se asimilan los conceptos de derechos fundamentales y humanos, a diferencia del ámbito europeo y global, en los que existe una línea demarcatoria clara, en cuanto a que los derechos fundamentales son los reconocidos por la Constitución y los derechos humanos son los consagrados en los instrumentos internacionales.

No obstante esta distinción, se puede sostener al tenor de lo expresado por Antonio Perez Luño, que "los derechos humanos poseen una insoslayable dimensión deontológica. Se trata de aquellas facultades inherentes a la persona que deben ser reconocidas por el derecho positivo y solo cuando se produce ese reconocimiento aparecen los derechos fundamentales, cuyo nombre evoca su función fundamentadora del orden jurídico de los Estados de Derecho"38. De esta forma, según el mismo autor, los derechos fundamentales representarían la fase más avanzada del proceso de positivización de los derechos naturales en los textos constitucionales del Estado de Derecho, proceso que tendrá su punto intermedio de conexión en los derechos humanos ${ }^{39}$.

Como hemos señalado, la dignidad de la persona y sus derechos fundamentales establecen los valores esenciales en que se cimienta el consenso de la sociedad y legitiman el Estado, además de las garantías básicas para el desarrollo de la república democrática y del Estado de Derecho.

La CPR siguiendo un modelo latinoamericano utiliza variopintamente distintas alusiones a estos derechos. En este orden de ideas, en el artículo 1 inciso $1^{\circ}$, utiliza

\footnotetext{
${ }^{37}$ NOGUEIRA, H. (2006). Lineamientos de interpretación constitucional y del bloque constitucional de derechos. Santiago. Editorial Librotecnia. p. 25.

${ }^{38}$ PEREZ LUÑO, A (2000). La tercera generación de derechos humanos. Navarra. Ed. Aranzadi. pp 235-236.

${ }^{39}$ IBIDEM
} 
el concepto de "derechos" ${ }^{40}$, en el artículo 5 inciso $2^{\circ}$, se refiere a "derechos esenciales que emanan de la naturaleza humana", como asimismo en el artículo 9 se refiere a "derechos humanos"41; a su vez, se refiere a "derechos constitucionales", en el encabezado del artículo 19.

Más allá del derecho constitucional chileno, la denominación utilizada de derechos esenciales o humanos, consideramos que explicita la prioridad axiológica y su esencialidad, respecto de la persona humana ${ }^{42}$.

Asimismo, es necesario destacar el carácter objetivo que se le otorgan a estos derechos. En este orden de ideas, Hans-Peter Schneider, sostiene que "los derechos esenciales, fundamentales o humanos, no solo otorgan facultades a las personas y un estatus jurídico en un ámbito de la existencia, ellos tienen también una significación objetiva ${ }^{43 " . ~}$

En Chile, la Constitución explicita un aseguramiento genérico a la existencia de derechos esenciales, humanos o fundamentales, lo que da lugar a un catálogo de derechos abiertos, ya que el constituyente reconoce sus eventuales limitaciones y está consciente del desarrollo progresivo de los derechos y garantías acorde a la naturaleza y necesidades esenciales del ser humano ${ }^{44}$. Los derechos esenciales o fundamentales constituyen preceptos directamente vinculantes y aplicables, que configuran y dan forma de modo esencial al Estado, siendo éste, un Estado

\footnotetext{
${ }^{40} \mathrm{CPR}$. Artículo 1 inciso $1^{\circ}$ : "Las personas nacen libres e iguales en dignidad y derechos".

${ }^{41}$ IBIDEM. Artículo 9: "El terrorismo en cualquiera de sus formas, es por esencia contrario a los derechos humanos".

${ }^{42}$ SCHNEIDER, H. (1979). "Peculiaridad y función de los derechos fundamentales de un estado constitucional democrático". EN Revista de estudios políticos. Madrid. p. 23. "Hay una sola fuente de la fundamentalidad de los derechos, su relación con la dignidad humana, ya que son expresión inmediata y positiva de la misma, constituyendo el núcleo básico irreductible e irrenunciable del estatus jurídico de la persona. Por otra parte, tal denominación denota el carácter fundamentador del orden jurídico y político de la convivencia en sociedad de tales derechos, constituyendo elementos básicos del ordenamiento jurídico”.

${ }^{43}$ IBIDEM. "Los derechos fundamentales son la condictio sine qua non de Estado constitucional democrático, ya que no pueden dejar de ser pensados sin que corra un riesgo inminente el Estado constitucional contemporáneo. Así, los derechos cumplen también funciones estructurales de gran importancia para los principios conformadores de la Constitución”.

${ }^{44}$ NOGUEIRA, H. (2003) "Los Derechos Esenciales o Humanos contenidos en los Tratados Internacionales y su ubicación en el ordenamiento jurídico nacional: Doctrina y Jurisprudencia”. Op. Cit., p.4. En este sentido, los derechos esenciales o humanos son:

a) Los que la Carta fundamental explicita sin taxatividad en el artículo 19. b) Los que asegura el Derecho internacional a través de los principios de ius cogens, los que asegura el derecho convencional internacional de derechos humanos y derecho humanitario y los que asegura el derecho internacional consuetudinario. c) Los derechos esenciales implícitos que puedan desarrollarse en el futuro, respecto de los cuales no hay reconocimiento aún a través de las diversas fuentes del derecho interno o internacional”.
} 
instrumental al servicio de la dignidad y de los derechos de la persona humana y del bien común.

En el ámbito español, europeo y global, existe una conexión de sentido entre los derechos fundamentales y la Constitución en cuanto a que éstos nacen y acaban con la Constitución ${ }^{45}$.

La tesis que sostiene Pedro Cruz Villalón para el ámbito español, que por lo demás compartimos, radica en que "la concepción de 'derechos fundamentales' en el sentido de la CE de 1978, y con la sola reserva de su significado más restringido en el artículo 81.1, son los derechos contenidos en el capítulo segundo del título I, sección primera de la misma, es decir artículos 15 a 29"46. Sin embargo, el autor referido los extiende, argumentando que "nuestros derechos fundamentales, son básicamente, los derechos y libertades que nuestra Constitución reconoce a lo largo de sus artículos 14 a 38"47. Se realza en ésta tesis los elementos de tutela judicial y respeto a su contenido esencial, que son los que configuran el carácter de un derecho como fundamental ${ }^{48}$.

A este respecto siguiendo la línea argumentativa de Gregorio Peces-Barba, entendemos que una mejor comprensión del concepto de derechos fundamentales, resulta de concebirlos bajo la premisa de consistir en una pretensión moral justificada tendiente a facilitar la autonomía y la independencia personal, enraizadas en las ideas de libertad e igualdad, con los matices que aportan conceptos como

\footnotetext{
${ }^{45}$ CRUZ, P. (1989). “Formación y evolución de los derechos fundamentales”. EN Revista Española de Derecho Constitucional. Año 9. Número 25. Enero-Abril 1989. p. 38. "Los derechos fundamentales acaban con las Constituciones. Ello es tanto como afirmar que acaban, hoy por hoy, con los Estados, dentro de los Estados, en el interior del ordenamiento estatal. Sin duda alguna, el CEDH supone hoy el punto culminante en la protección de los derechos en el ámbito europeo, y ello ha tenido enormes implicaciones en el ámbito interno de los distintos ordenamientos estatales”.

${ }^{46}$ IBIDEM. p. 39.

${ }^{47}$ IBIDEM. "Entiendo, pues, que el significado restringido, que por lo demás me parece inobjetable, de los derechos fundamentales es absolutamente excepcional y operativo solo en relación con la reserva de ley orgánica y que cuantas veces -fuera de este supuesto- el tribunal se pronuncia acerca de los derechos fundamentales, lo hace refiriéndose a los derechos del capítulo II del título I sección segunda de la Constitución”.

${ }^{48}$ IBIDEM. Dichos razones motivan las declaraciones de Pedro Cruz Anabalón en el siguiente tenor "pero sobre todo si atendemos a su fuerza o virtualidad. Si existen hoy día algunos elementos o datos que hagan reconocibles a los derechos fundamentales como categoría, estos son: la tutela judicial y el respeto de su contenido esencial por el legislador”.
} 
solidaridad y seguridad jurídica ${ }^{49}$. Además agrega Peces-Barba, "ésta pretensión moral justificada, ha de satisfacer cualquier demanda o reivindicación que aspire instituirse como derecho fundamental, como asimismo la necesidad de que esta pretensión moral sea incorporada a una norma que puede obligar a algún destinatario correlativo de las obligaciones jurídicas que se desprenden, para que el derecho sea efectivo, que sea susceptible de garantía y que se pueda atribuir como derecho subjetivo, y potestad a favor de unos titulares determinados" 50 .

\subsection{Criterios de clasificación de los derechos fundamentales}

Nos referiremos brevemente en esta etapa a la clasificación de los derechos fundamentales, con la finalidad de posicionar el derecho de acceso a la justicia y el derecho a la asistencia jurídica en alguno de estos criterios clasificatorios ${ }^{51}$. Debemos partir de la premisa que un derecho puede ser contemplado en uno o más criterios clasificatorios, siendo aquello relevante para su categorización como fundamental y su ponderación tendiente a la mayor optimización.

Siguiendo primeramente, a Luis María Diez-Picazo, cuya postura ha sido considerada como clásica, clasifica los derechos fundamentales en función y estructura ${ }^{52}$. Según este autor, al atender a su función y estructura, permite profundizar acerca de la naturaleza de cada derecho, con sus alcances y efectos,

\footnotetext{
${ }^{49}$ PECES-BARBA, G. (1995). Curso de Derechos Fundamentales. Teoría General. Madrid. Universidad Carlos III. Madrid. Boletín oficial del Estado. pp. 109-110. "Pretensión moral justificada que, además, sea generalizable desde el punto de vista de sus contenidos, residiendo aquí el fundamento de los derechos, esto es, el 'por qué' de su existencia. Afirma además, que "los derechos fundamentales necesitan, para ser estimados como auténticos derechos, de su recepción en el derecho positivo, residiendo en este nivel el concepto de los derechos, lo que responde a su finalidad o función, es decir, el 'para qué' de los derechos".

${ }^{50}$ IBIDEM.

${ }^{51}$ ALMELA, C. (2020). Op. Cit., p. 6. “Aunque es una cuestión debatida si el acceso a la justicia es un derecho fundamental o no lo es, viene cobrando cada vez con más fuerza, la idea de su importancia”.

52 Sin perjuicio de esta clasificación, sistematizada por Luis María Diez- Picazo, en su obra "Sistema de Derechos Fundamentales", existen otras clasificaciones, que no solo se centran en su función y estructura, sino también: a) criterio formal (de carácter sistémico referente a su ubicación en las constituciones, y en cuanto a fuentes y garantías de cada uno). Según éste criterio formal, pero ahora desde un punto de vista exclusivamente garantista. Además, se cuentan dentro del criterio formal, clasificaciones, que atienden al grado de resistencia jurídica en el sentido de noción escalonada o gradual de garantía de los derechos y según un criterio formal de carácter relacional, basada en los diversos tipos de relaciones jurídicas posibles que generan los derechos fundamentales, y desde el punto de vista del titular. b) criterio material ( según el tipo de prestación que generan, en cuanto a la clase de comportamiento que configuran, en cuanto a la generación de derechos que pertenecen, según los destinatarios de los derechos y según el modo de su ejercicio).
} 
al momento de ponderar la correcta aplicación o interpretación de estos derechos contenidos en la Constitución o en los tratados. En cuanto a la función se refiere a los valores que representan los derechos fundamentales, dentro de estos podemos encontrar a los derechos civiles, políticos y sociales, cada uno de ellos obedece a las exigencias del Estado de Derecho, del Estado democrático y del Estado social, respectivamente ${ }^{53}$.

En lo que nos concierne, en cuanto al criterio de estructura, los derechos fundamentales se clasifican según la naturaleza de la facultad que otorgan a su titular. Diez-Picazo distingue entre los "derechos de defensa", que facultan a exigir la no interferencia; los "derechos de participación", que facultan a realizar actos con relevancia pública; y los "derechos de prestación", que facultan a reclamar un beneficio ${ }^{54}$. La finalidad genérica de todos los derechos se cumple aquí a través de la prestación que satisface necesidades básicas, sin las cuales no se considera que los afectados puedan alcanzar plenamente su condición de personas, ejercer el resto de sus derechos fundamentales, y desde luego, elegir libremente sus planes de vida.

Dentro de los derechos de prestación se sitúan los derechos fundamentales procesales, entre los que destaca el derecho de acceso a la justicia, el debido proceso y sus garantías intrínsecas, como la asistencia jurídica gratuita. Estos derechos fundamentales procesales son propiamente instrumentales, pues precisamente constituyen el medio que permite restablecer el ejercicio de aquellos derechos que hubiesen sido desconocidos o vulnerados. Los derechos de prestación, a diferencia de los derechos de no interferencia, suponen una acción positiva, normalmente de los poderes públicos, aunque también puede ser excepcionalmente de los particulares, para ayudar a la satisfacción de necesidades básicas, que no pueden ser resueltas por la propia y exclusiva fuerza del afectado. No siempre estamos ante necesidades económicas, pueden ser culturales, educativas y jurídicas, pero generalmente el trasfondo es económico. Entre los

\footnotetext{
${ }^{53}$ DIEZ-PICAZO, L. (2005). Sistema de derechos fundamentales, Madrid, Thomson Civitas. p. 57.

${ }^{54}$ IBIDEM. p. 58.
} 
derechos comprendidos en este grupo se sitúan derechos como la asistencia letrada, que supone una obligación del Estado de proporcionar abogado a quien no lo tiene ${ }^{55}$.

Dentro de los criterios clasificatorios se identifican también los derechos deber, dentro de los cuales forman parte el derecho de acceso a la justicia, la asistencia jurídica gratuita y en general, los derechos fundamentales procesales ${ }^{56}$.

Peces Barba, añade dentro de los criterios clasificatorios, los referidos al contenido de los derechos, en cuanto a la finalidad perseguida con la protección, que es la dignidad de la persona, mereciendo especial atención, los derechos de seguridad jurídica, mediante las garantías procesales, que benefician al individuo, producen tranquilidad, la certeza y el saber a qué atenerse, y tienen importante trascendencia social. Entre estos derechos fundamentales procesales, se encuentran el derecho a la libertad personal y a la seguridad, las garantías en caso de detención, el derecho de asistencia letrada, el derecho a obtener la tutela efectiva de los jueces y tribunales, los derechos en el proceso, y los derechos del condenado.

Es necesario hacer presente, que cuando faltan las garantías procesales básicas, se vulnera la existencia misma del Estado de Derecho. Estas garantías, justamente, conforman el "debido proceso", que facilita que un justiciable pueda hacer valer sus derechos y defender sus intereses en forma efectiva y en condiciones de igualdad procesal con otros justiciables, en base a los principios de igualdad y no

\footnotetext{
${ }^{55}$ Aquí aparece una situación compleja para analizar, puesto que no se proporciona letrado solo a quien carece de medios, si no a quién no quiere designar abogado propio, aunque tenga medios, como ocurre en la mayoría de los sistemas procesales penales latinoamericanos. Así podría no ser propiamente una necesidad con trasfondo económico por parte del titular del derecho, sino que estamos ante una necesidad estructural del propio sistema garantista que tiene que ser satisfecha para que éste funcione.

${ }^{56} \mathrm{Si}$ bien, la persona no tiene la obligación de acudir a los tribunales, en caso que acuda, tanto por propia iniciativa o es forzado en calidad de demandado, tiene el deber derivado de su derecho, de someterse a las reglas procedimentales, dentro de las cuales se encuentra la comparecencia con abogado, en sentido contrario, las consecuencias de la rebeldía procesal harán que los efectos del proceso sean igualmente aplicables hacía él, siendo de esta forma, el acceso a la justicia, considerado un derecho-deber. En este contexto, se asimila al derecho prestacional a un derecho de crédito, en el sentido de que sus titulares pueden reclamar una acción positiva de los poderes públicos o de otros particulares, por ejemplo, cuando se presenta una demanda y se pide consecuentemente la apertura del proceso o cuando se solicita la designación de abogado de oficio, la facilitación de intérprete o se solicita el respeto de algunas garantías del debido proceso, como la concesión de medios para la justificación probatoria, acciones todas, que se encuadran dentro del derecho de acceso la justicia.
} 
discriminación. Estas garantías procesales han alcanzado, en general, un enorme grado de uniformidad, encontrándose consagradas tanto a nivel de legislación interna en cada país, como también a través de múltiples instrumentos internacionales, formando parte de este bloque de constitucionalidad vinculante para Chile que abordaremos en el apartado $5^{\circ}$ del presente capítulo.

Por su parte, brevemente mencionar, que las garantías procesales son las que permiten la debida administración de justicia, asegurando la tutela efectiva de los derechos de los ciudadanos en juicio, o tal como se ha definido por Guillermo Cabanellas de Torres, estas garantías están constituidas por "los medios que se reconocen en juicio para hacer valer los derechos y para oponerse a injustificadas pretensiones del adversario. La audiencia de los distintos interesados, las diversas pruebas, los alegatos y los debates configuran este sistema generalizado, aunque con matices en cuanto a sinceridad y eficacia"57. Respecto del órgano jurisdiccional, en doctrina se distinguen las garantías de independencia, imparcialidad, autoridad y responsabilidad. Además, entre las garantías individuales existen algunas que se relacionan directamente con la función judicial, como la de petición, la que prohíbe el juzgamiento por leyes privativas o tribunales especiales, la garantía de audiencia, la que exige juicio seguido ante los tribunales previamente establecidos en el que se cumplan las formalidades esenciales del procedimiento, la que establece el principio de legalidad, entre otros.

En la Constitución Española (CE), los derechos fundamentales de naturaleza procesal son los referidos principalmente en su artículo 24 inciso $1^{\circ 58}$, cuya redacción se ha tachado de poco acertada por un sector de la doctrina, toda vez que puede inducir a confusión de cuáles sean efectivamente esos derechos procesales, pues podría pensarse que el único derecho fundamental procesal

\footnotetext{
57 CABAnEllas, G. (2008). Diccionario Enciclopédico de Derecho Usual, Buenos Aires. Editorial Helenista. p. 43.

${ }^{58} \mathrm{CE}$. Artículo $24 \mathrm{n}^{\circ} 1$ : "Todas las personas tienen derecho a obtener la tutela efectiva de los jueces y tribunales en el ejercicio de sus derechos e intereses legítimos, sin que, en ningún caso, pueda producirse indefensión”. $2^{\circ}$ "Asimismo, todos tienen derecho al juez ordinario predeterminado por la ley, a la defensa y a la asistencia de letrado, a ser informado de la acusación formulada contra ellos, a un proceso público sin dilaciones indebidas y con todas las garantías, a utilizar los medios de prueba pertinentes para su defensa, a no declarar contra sí mismos, a no confesarse culpables y a la presunción de inocencia. La ley regulará los casos en que, por razón de parentesco o secreto profesional no se estará obligado a declarar sobre hechos presuntamente delictivos”.
} 
protegido en aquel articulado es la tutela judicial efectiva del apartado primero y el resto de derechos-garantías enunciados en su apartado segundo, integrarían el contenido concreto de aquel derecho. Ello nos llevaría a plantearnos primeramente un problema que atañe al contenido esencial del artículo 24 de la CE, que puede ser más extensivo o restrictivo, dependiendo del mayor o menor número de derechos que pueda implicar su ejercicio, sin perjuicio que se puede considerar a las garantías del número 2, como un derecho autónomo, dentro de las formula de debido proceso.

A nuestro parecer el constituyente español en el artículo 24 garantiza el derecho a la tutela judicial efectiva y una serie de derechos también fundamentales. Resulta aclaratoria la explicación de Belén Ureña al respecto, en cuanto "el artículo 24 CE consagra, en su apartado primero, el denominado derecho a la tutela judicial efectiva, esto es, el derecho de acceso a la jurisdicción, para seguidamente, aludir a la prohibición de indefensión. Mientras que, en el párrafo segundo, incluye una serie de garantías procesales que, en puridad, derivan del primero y permiten que dicho derecho sea realmente efectivo. Estas garantías son replicables en todas las jurisdicciones -civil, penal, laboral, contencioso, administrativa y militar-, aunque algunas de ellas rigen, fundamentalmente, en el ámbito penal”59.

\section{BLOQUE DE CONSTITUCIONALIDAD EN EL DERECHO CHILENO}

\subsection{Contextualización, análisis y proyección jurisprudencial}

Cuando hablamos de constitucionalidad de un derecho o de una institución creada para satisfacer una necesidad social determinada, no solo se debe analizar si cumple con los requisitos, parámetros y estándares constitucionales, sino especialmente, si se ajusta a los requisitos, parámetros y estándares establecidos en la normativa internacional que un determinado Estado ha incorporado en su ordenamiento jurídico interno, como asimismo si de adecúa a los lineamientos

${ }^{59}$ UREÑA, B. (2014). Derechos Fundamentales Procesales. Navarra. Editorial Aranzadi. p. 123. 
jurisprudenciales de los órganos de protección internacional que interpretan las referidas normas internacionales de derechos humanos.

En el escenario constitucional chileno se puede señalar que la CPR no contiene todo el derecho constitucional. En este sentido, haciendo eco del razonamiento de Nogueira, "la noción de bloque de constitucionalidad posibilita asumir el hecho de que la 'constitucionalización de los derechos', es mucho más amplia que el texto constitucional formal, puesto que existen otros atributos y garantías de derechos fundamentales que no se encuentran en el texto, pero que la Constitución reconoce en su calidad de tales y los inserta como Constitución material, al remitir a los atributos y garantías de ellos, asegurados por disposiciones que se encuentran contenidas en instrumentos que forman parte del derecho convencional internacional" 60 . Además se entienden que forman parte del bloque de constitucionalidad: los derechos implícitos, los fallos y Opiniones Consultivas (OC) de los órganos jurisdiccionales de protección internacional, como la Corte Interamericana de Derechos Humanos (Corte IDH), asimismo los informes de la Comisión Interamericana de Derechos Humanos (CIDH), según corresponda. Cabe hacer presente que el vocablo "Bloque de Constitucionalidad" en Chile dista del utilizado en otras legislaciones ${ }^{61}$.

Nuestra CPR, en el artículo 5 inciso $2^{\circ}$ establece que también forma parte de lo "constitucional", los derechos esenciales que emanan de la naturaleza humana, contenidos en los tratados internacionales, bajo la condición que hayan sido ratificados y se encuentren vigentes ${ }^{62}$.

\footnotetext{
60 NOGUEIRA, H. "El Bloque Constitucional de Derechos en Chile, El parámetro y consideraciones comparativas con Colombia y México: Doctrina y Jurisprudencia”. Op .Cit., p. 313.

${ }^{61}$ En este sentido, el autor Nogueira desarrolla esta idea , señalando que "el bloque constitucional español constituye una creación pretoriana del tribunal Constitucional Español, como es la sentencia 10/82, caracterizado por un contenido abierto e impreciso, siendo en una de sus versiones el conjunto de normas que posibilitan la delimitación competencial entre el Estado y las comunidades autónomas, siendo el parámetro para enjuiciar las normas que desarrollan competencias y que permiten enjuiciar su constitucionalidad, lo que posibilita determinar la constitución territorial del Estado español, el que nada tiene que ver con la norma del artículo 10.2 de la Constitución referente a la interpretación de los derechos fundamentales”.

${ }^{62} \mathrm{La}$ importancia que reviste este bloque de constitucional, radica precisamente, en que al interpretar o aplicar una norma relativa a un derecho fundamental, no solo se debe estar a lo que señala la Constitución, sino a la protección que le han dado los diversos Tratados internacionales ratificados por Chile y que se encuentran vigentes. Esta relevancia del bloque de constitucionalidad y del carácter vinculante de las normas internacionales que regulan derechos fundamentales, fue dado por el caso "la última tentación de cristo", que la Corte Interamericana, en virtud de sentencia de 5 de febrero de 2001, condenó al Estado de chile, pues la
} 
Dicha perspectiva de bloque de constitucionalidad, independiente de la nomenclatura, se encuentra en el enfoque que la mayoría de las Constituciones latinoamericanas han instaurado, las cuales consideran, además de los derechos directamente asegurados en la Constitución formal, la remisión a los derechos asegurados por el derecho convencional internacional ratificado, como las Constituciones de Argentina, Bolivia, Brasil, Colombia, Costa Rica, Ecuador, Guatemala, México, por señalar solo alguna de ellas ${ }^{63}$.

El bloque constitucional de derechos fundamentales, en virtud de su naturaleza, presenta como finalidad constituir atributos y garantías que concretan derechos, y tiene su fundamento en la dignidad humana reconocida constitucionalmente, constituyendo un grupo unificado sustantivo o material de atributos y garantías de derechos, al cual la misma Carta Fundamental le reconoce una fuerza normativa superior, permitiendo que constituya una limitación para el ejercicio de la soberanía y de las competencias de los órganos constituidos del poder público estatal, como lo determina la Constitución en su artículo $5^{\circ}$ inciso $2^{\circ}$, debiendo todas las normas internas del Estado y todos los actos de sus órganos y autoridades estatales conformarse materialmente a los contenidos fundamentales de dicho bloque de derechos ${ }^{64}$.

Respecto de los atributos de los derechos y sus garantías contenidos en el derecho convencional internacional ratificado y vigente, estos son Constitución material en virtud de la norma atributiva de fuerza normativa de reenvió del artículo 5 inciso $2^{\circ}$ de la Constitución, constituyendo también limitaciones a la soberanía o poder estatal ${ }^{65}$. En este sentido resulta importante observar la génesis indirecta de nuevos

Constitución Chilena, contemplaba un sistema de censura previa a la exhibición cinematográfica, condenando al Estado de Chile, por violar ese derecho fundamental de expresión, ordenando la adecuación del derecho interno, mediante la abolición de este pasaje constitucional, en un plazo razonable, lo que se cumplió a través de la modificación constitucional de 25 de agosto de 2001, que suprimió la censura previa como requisito de las exhibiciones cinematográficas.

${ }^{63}$ NOGUEIRA, H. "El Bloque Constitucional de Derechos en Chile, El parámetro y consideraciones comparativas con Colombia y México: Doctrina y Jurisprudencia”. Op. Cit., p. 315.

${ }^{64} \mathrm{CPR}$. Artículo 5 inciso $2^{\mathrm{o}}$. "El ejercicio de la soberanía reconoce como limitación el respeto a los derechos esenciales que emanan de la naturaleza humana. Es deber de los órganos de Estado respetar y promover tales derechos, garantizados por esta Constitución, así como por los tratados internacionales ratificados por Chile y que se encuentran vigentes".

${ }^{65}$ En tal perspectiva se ha pronunciado la CS en sentencia rol 3452-2006,en que se precisa "En definitiva los derechos humanos asegurados en un tratado se incorporan al ordenamiento jurídico interno, formando parte de 
derechos mediante la técnica de reenvío, que incluso algunos de ellos, han adquirido posteriormente una consagración constitucional expresa ${ }^{66}$, tal como lo ha ratificado la jurisprudencia interamericana ${ }^{67}$.

A mayor abundamiento, cuando un juez nacional debe resolver un caso en que exista afectación a un derecho fundamental, no solo debe aplicar la ley chilena, sino también los derechos contenidos en la legislación protectora internacional, aunque el determinado derecho no se encuentre consagrado explícitamente en la legislación interna ${ }^{68}$. Además el sentido y alcance que el juez nacional le otorga a una norma de derechos humanos, debe ceñirse a los lineamientos que ha dado la jurisprudencia vinculante de los órganos de protección, tanto los netamente jurisdiccionales como los consultivos. Esta interpretación, búsqueda de su sentido y alcance, debe ser en clave de derechos humanos, en el sentido que permita el pleno acceso a la justicia y disfrute de esos derechos a todas las personas, sin distinción de ninguna clase, especialmente respecto de los más vulnerables de la población.

En atención al contenido y atributos del debido proceso, específicamente en cuanto al derecho al defensor técnico, en sentencia de dieciocho de abril de 2007, en causa rol número 4182-06, la CS reitera la misma perspectiva, en el sentido de considerarlos parte del bloque de constitucionalidad, señalando en su considerando decimo: "que, a lo anterior, y conforme a la norma de reenvio contenida en el artículo 5 de la Constitución debe extenderse el reconocimiento con rango constitucional del

\footnotetext{
la Constitución material adquiriendo plena vigencia, validez y eficacia jurídica, no pudiendo ningún órgano del Estado desconocerlos y debiendo todos ellos respetarlos y promoverlos, como asimismo protegerlos a través de un conjunto de garantías constitucionales destinadas a asegurar el pleno respeto de los derechos. Esta obligación no solo se deriva del mencionado artículo $5^{\circ}$, sino también del artículo inciso primero y cuarto, del artículo 19 número 26 de la Carta magna y de los mismos tratados internacionales”.

66 “.......El desarrollo histórico del proceso, consecuente con la protección del individuo y la realización de la justicia, ha traído consigo la incorporación de nuevos derechos procesales. Son ejemplo de este carácter evolutivo del proceso los derechos a no autoincriminarse y a declarar en presencia de abogado, que hoy día figuran en la legislación y en la jurisprudencia de los sistemas jurídicos más avanzados. Es así como se ha establecido, en forma progresiva, el aparato de las garantías judiciales que recoge el artículo 14 del Pacto Internacional de Derechos Civiles y Políticos, al que pueden y deben agregarse, bajo el mismo concepto, otras garantías aportadas por diversos instrumentos del Derecho Internacional”.

${ }^{67}$ CORTE IDH. OC 16/99. El derecho a la información sobre la asistencia consular en el marco de las garantías del debido proceso legal, de 1 de octubre de 1999. Párr. 117.

${ }^{68}$ Por ejemplo, esto ocurre con el derecho a la identidad, la tutela judicial efectiva, y con la figura del defensor técnico hasta la reforma constitucional de 2011, con la que obtuvo reconocimiento constitucional expreso.
} 
derecho de defensa, también a los derechos garantizados por los tratados internacionales ratificados por Chile y que se encuentren vigentes, como lo son los artículos 11.1 de la Declaración Universal de Derechos Humanos (DUDH); el artículo 14.3 del Pacto Internacional de Derechos Civiles y Políticos (PIDCP); el artículo 8.2 de la Convención Americana de Derechos Humanos (CADH); de todo lo anterior se puede sostener que se trata de un derecho fundamental, como gozar de la defensa técnica que lleva a cabo el abogado defensor, y que comprende la facultad de intervenir en el procedimiento penal y de llevar a cabo en él todas las actividades necesarias para poner en evidencia la eventual falta de potestad penal del Estado o cualquier circunstancia que la excluya o la atenué, por ello en interés de la transparencia del proceso penal, y para el hallazgo de la verdad, constituye un requisito procesal esencial de todo juicio"69. El TC entre otras sentencias, como la recaída en causa rol 1340-2008, protege el derecho de la identidad como derecho implícito, es decir el reconocimiento de la expansión de un derecho no consagrado de forma explícita, no asegurado por el texto constitucional ${ }^{70}$.

\subsection{Control de Constitucionalidad y convencionalidad}

Dilucidado el carácter vinculante de la normativa internacional protectora de derechos humanos, a la que nuestro país ha adherido en conformidad al artículo 5 inciso $2^{\circ}$ de la CPR, anexándolo en su ordenamiento jurídico interno por la técnica del reenvió, resulta relevante profundizar sobre la forma y alcances en que el juez nacional y/o la judicatura constitucional ejerce el control de constitucionalidad y el de convencionalidad, que consiste en el ejercicio de armonización de la normativa

\footnotetext{
${ }^{69}$ Lo anterior, debido a que a la fecha de dictación de esta sentencia, el derecho al defensor técnico en materia penal no estaba consagrado de forma específica en la Constitución. Sólo la ley 20.516 de 11 de julio de 2011, agregó el inciso $4^{\circ}$ a la Constitución en el siguiente tenor: “Toda persona imputada de un delito tiene derecho irrenunciable a ser asistida por un abogado defensor proporcionado por el Estado sino nombrare uno en la oportunidad establecida por la ley”.

${ }^{70}$ Esta interpretación significa que “aun cuando la Constitución Chilena, no reconozca en su texto, el derecho a la identidad, ello no puede constituir un obstáculo para que el juez constitucional le brinde adecuada protección precisamente por su estrecha vinculación con la dignidad humana y porque se encuentra protegido en diversos tratados internacionales ratificados por chile, y vigentes en nuestro país”.
} 
legal, con la Constitución y los tratados internacionales, respectivamente. Así existe un deber de los jueces, órganos de la administración de justicia y demás autoridades públicas, de realizar un examen de compatibilidad entre los actos, como asimismo normas nacionales, y la Constitución, la $\mathrm{CADH}$, sus protocolos adicionales, la jurisprudencia de los órganos y demás instrumentos del SIDH Y SUDH.

Como hemos revisado, al momento de interpretar cualquier ley que regule los diversos aspectos de los derechos fundamentales, incluido el derecho a la asistencia jurídica, al juez nacional no le resulta vinculante solamente la letra de la norma nacional, sino el imperativo constitucional que lo consagra, como asimismo la regulación protectora internacional y las sentencias de estos organismos, a la luz del propio bloque de constitucionalidad.

En primer término, en lo relativo al control de constitucionalidad, es decir, al ejercicio de conformidad entre la ley y la Constitución, que debe hacer el juez, el TC, o ambos, (según el modelo que se adopte), al existir una eventual vulneración de la Carta Fundamental, nos adherimos a las certeras apreciaciones de Ignacio Rojo ${ }^{71}$, quien realiza un acabado análisis de la evolución y consolidación de este mecanismo de control.

De esta forma, el autor expresa que "como bien se enseña, el estudio del control de constitucionalidad de las normas pertenece al ámbito de la justicia constitucional. Ella tiene su origen en 1803 en los Estados Unidos, en el conocido caso Marbury vs Madison, fundando la doctrina judicial review o control de constitucionalidad de la legislación. En los Estados Unidos, el término judicial review se refiere a la práctica jurídica de darle a las cortes el poder de determinar si una norma se encuentra conforme con los requisitos de la constitución, es decir, si la norma se encuadra dentro de los poderes que el pueblo le ha otorgado a su gobierno o si viola algún derecho reconocido por la constitución"72. Marshall, juez del caso mencionado,

\footnotetext{
${ }^{71}$ ROJO, I. (2020). “Ejerce el Poder Judicial Control de Constitucionalidad”. EN DIARIO CONSTITUCIONAL.https://www.diarioconstitucional.cl/articulos/bueno-ejerce-el-poder-judicial-control-deconstitucionalidad/. p. 1. [consulta 3 de septiembre de 2020].

${ }^{72}$ IBIDEM. p. 2.
} 
decía "... hay sólo dos alternativas demasiado claras para ser discutidas, o la constitución controla cualquier ley contraria a ella, o la legislatura puede alterar la constitución mediante una ley ordinaria. Entre tales alternativas no hay términos medios: o la constitución es la ley suprema inalterable por medios ordinarios o se encuentra en el mismo nivel que las leyes y de tal modo cualquiera de ellas puede reformarse o dejarse sin efecto siempre que al congreso le plazca. Si es cierta la primera alternativa, entonces una ley contraria a la constitución no es ley; si, en cambio, es verdadera la segunda, entonces las constituciones escritas son absurdos intentos del pueblo para limitar un poder ilimitable por naturaleza"73.

En cuanto a los modelos existentes del control de constitucionalidad, al tenor de las palabras de Luis Marinoni, Álvaro Pérez y Raúl Núñez, se consigna que "en modelos comparados, existen básicamente dos grandes sistemas de control de constitucionalidad de normas, el difuso y el concentrado. Hablamos de control concentrado de constitucionalidad cuando se asigna a un órgano exclusiva y excluyentemente la función de pronunciarse sobre la inconstitucionalidad de una norma ${ }^{74}$. Los mismos autores establecen que "por oposición se denomina sistema de control difuso aquél en que cualquier tribunal puede declarar la inaplicabilidad de un precepto, en el caso particular del cual conoce ${ }^{75}$.

En el caso chileno, se optó por un sistema de control concentrado, desde la reforma constitucional del año 2005, pues en principio sería un solo órgano, en este caso el TC, quién ejercería este control. En esta línea, Gastón Gómez señala que "se otorgó jurisdicción al TC de definir la inaplicabilidad de una norma cuando contraviene a la CPR, a través del control de constitucionalidad de leyes ex ante yex post, traspasándose incluso la facultad que tenía la CS de declarar inaplicables preceptos legales en un caso concreto, cuando producía efectos

\footnotetext{
${ }^{73}$ TUSHNET, M. Constitucionalismo y Judicial Review. Lima. Palestra Editores. p. 71.

${ }^{74}$ MARINONI, L; PEREZ, A; NUÑEZ, R. (2010). Fundamentos del Proceso Civil: Hacía una teoría de la adjudicación. Santiago. Abeledo perrot. p. 47.

${ }^{75}$ IBIDEM.
} 
inconstitucionales ${ }^{76}$. El congreso pareciera que también tenía este propósito ${ }^{77}$. TC es el intérprete final o definitivo de los derechos constitucionales, pero con especial énfasis en el proceso de inaplicabilidad ${ }^{78}$, ya que en este proceso, las partes pueden promover un requerimiento para obtener una sentencia constitucional resguardando sus derechos constitucionales frente a la aplicación de un precepto que produce efectos contrarios a ellos. En este sentido, se debe destacar, que la acción de inaplicabilidad es de carácter facultativa, pues "podrá" ser planteada por cualquiera de las partes o por el juez que conoce del asunto. No es una obligación para el juez o para las partes de la gestión pendiente promover un requerimiento al TC para que declare inaplicable por inconstitucional un precepto, lo que implica que el juez ordinario o especial que conoce de la gestión, o las partes involucradas, lo deben decidir libre y voluntariamente ${ }^{79}$. Si existen a lo menos dos declaraciones de inaplicabilidad, el mismo TC puede declarar el precepto como inconstitucional ${ }^{80}$ y expulsarlo del ordenamiento jurídico nacional, como ocurrió con la expresión "gratuitamente" del Artículo 595 del COT, respecto

\footnotetext{
${ }^{76}$ GOMEZ, G. (2013). Las Sentencias del TC y sus efectos sobre la jurisdicción común. Santiago. Edición Universidad Diego Portales. p. 17. “Como se sabe, el año 2005 se reformó la constitución, concentrándose la jurisdicción constitucional referida al control de la ley con el fin de alcanzar la unidad interpretativa y una aplicación uniforme de la carta”.

77 SENADO DE LA REPUBLICA. (2006). Reformas Constitucionales 2005, Historia y tramitación. Santiago. Edición Senado de la República. p. 318. "En la discusión general en la sala del senado (reforma de 2005), respecto de las atribuciones del tribunal constitucional (En adelante TC), el senador Díez decía: 'Al sustraer del conocimiento de la corte suprema el recurso de inaplicabilidad a que se refiere el artículo 80 de la constitución y entregarlo al tribunal constitucional, se ha querido concentrar el resguardo del principio de la supremacía constitucional en un solo organismo".

${ }^{78} \mathrm{El}$ Recurso de Inaplicabilidad por inconstitucionalidad de la ley es la acción que el ordenamiento supremo franquea para evitar la aplicación de uno o más preceptos legales, invocados en una gestión judicial pendiente, produzca efectos, formal o sustantivos, contrarios al Código Político. Lo consideramos un derecho público subjetivo cuyo ejercicio lo reconoce la propia CPR para poner en movimiento la actividad jurisdiccional del Estado, a fin de proteger determinadas garantías. Por tanto, no está incluido dentro de los recursos procesales propiamente tales. La CPR en su artículo 93, señala que dentro de la funciones del TC, en el no 6: "Resolver por la mayoría de sus miembros en ejercicio, la inaplicabilidad de un precepto legal cuya aplicación en cualquier gestión que surja ante un tribunal ordinario o especial, resulte contrario a la Constitución”.

${ }^{79}$ En efecto, en el proceso de inaplicabilidad, se le pide al TC para que se decida si aplicar determinado precepto legal, produce efectos inconstitucionales.

${ }^{80} \mathrm{CPR}$. Artículo $93 \mathrm{n}^{\circ}$ 7: "Resolver por la mayoría de los cuatro quintos de sus integrantes en ejercicio, la inconstitucionalidad de un precepto legal declarado inaplicable en conformidad a lo dispuesto en el numeral anterior”.
} 
de la institución del abogado de turno, que será tratado en el Capítulo VI de la presente tesis.

En este orden de ideas, y para entender la relevancia práctica del recurso de inaplicabilidad por inconstitucionalidad de la ley, y por aludir además a dos grupos vulnerables, como las comunidades indígenas y las mujeres víctimas de violencia en cualquiera de sus formas, nos referiremos brevemente al requerimiento de inaplicabilidad por inconstitucionalidad, formulado por el Juez de Isla de Pascua al TC, el que fue acogido con fecha 3 de septiembre de 2020, en causa rol 8792-2020, por considerar que preceptos de la denominada "ley pascua", que contemplan penas diferenciadas, por ciertos más bajas referente a delitos de índole sexual, perpetradas por naturales de la comunidad "Rapa Nui" y en el territorio de la isla, afectaría el principio constitucional de igualdad ante la ley, como asimismo constituiría una discriminación arbitraria hacía las mujeres ${ }^{81}$.

\footnotetext{
${ }^{81}$ DIARIO ELECTRONICO EN ESTRADO. http://enestrado.com/imputado-por-violacion-pedia-aplicacionde-norma-que-rebajaria-su-pena-tribunal-constitucional-acoge-inaplicabilidad-por-inconstitucionalidad [consulta 3 de septiembre de 2020]. "Fue en junio que el magistrado Alex Guzmán, juez titular del Juzgado Mixto de Rapa Nui-Isla de Pascua, recurrió al TC y presentó un recurso de inaplicabilidad por inconstitucionalidad por la aplicación de la denominada «Ley Pascua» en un caso de violación ocurrido en la isla. Fueron los artículos 13 y 14 de la Ley n 16.441 los que fueron impugnados por el magistrado, lo que establecían que los delitos cometidos por personas naturales del lugar tendrían penas inferiores en un grado y que podrían cumplir dos tercios de la condena fuera de la cárcel. Si existen derechos fundamentales, tanto para la víctima como para el imputado, resulta necesario decidir sobre la limitación legítima de algunos de ellos en pos de la realización de otros. Parece ser, entonces, que las normas de protección de la mujer son más recientes, y además, tienen un fin mucho más universal que aquellas destinadas a las personas que han sido objeto de la persecución penal por ende, podemos entender, que existe un interés público de carácter imperativo comprometido -protección de la mujer y eliminación de toda forma de discriminación de ésta, prevención del delito, protección de los derechos y libertades ajenas-, cuya inaplicación, vendría a reforzar la desproporción en relación a su tipificación abstracta del artículo 361 del Código Penal, en relación al monto de la penuria establecida en éste, por lo que subpreciar la libertad o indemnidad sexual de la víctima en el caso que nos ocupa, pareciera encontrarse en contradicción con las normas y principios constitucionales que nos unifican e inspiran como sociedad», señalaba el juez en el requerimiento. Hoy, el Tribunal Constitucional emitió un comunicado en que señalan que se acogió el recurso y se declaró inaplicable ambos artículos en este caso". Artículo 13: "En los delitos contemplados en los Títulos VII y IX del Libro Segundo del Código Penal, cometidos por naturales de la Isla y en el territorio de ella, se impondrá la pena inferior en un grado al mínimo de los señalados por la ley para el delito de que sean responsables". Artículo 14: "En aquellos casos en que el Tribunal deba aplicar penas de presidio, reclusión o prisión podrá disponer que hasta dos tercios de ellas puedan cumplirse fuera del establecimiento carcelario, fijando en la sentencia las condiciones de trabajo y residencia que deba llevar el condenado y el tiempo por el cual se concede este beneficio, el que podrá suspenderse o revocarse por el Juez, de oficio o a petición de parte, por medio de una resolución fundada, que se apoye en el incumplimiento de las condiciones impuestas, estipulan las normas impugnadas. Votaron por acoger el requerimiento la Presidenta del Tribunal, Ministra señora María Luisa Brahm Barril, los Ministros señores Iván Aróstica Maldonado, Gonzalo García Pino, Cristián Letelier Aguilar, Nelson Pozo Silva, José Ignacio Vásquez
} 
Sin perjuicio de esta función de control de constitucionalidad concentrada del TC, esta definitividad constitucional no implica exclusividad. No debemos olvidar que la protección directa de los derechos constitucionales en el sistema chileno es de competencia del poder judicial y no del $\operatorname{TC}^{82}$ (a excepción de la acción de inaplicabilidad). Del mismo modo, como sostiene Andrés Bordalí "los tribunales ordinarios se sienten vinculados directamente a la constitución y comienzan a interpretarla y aplicarla compitiendo así con los tribunales constitucionales"83. De esta manera, en palabras de Aldunate "el poder judicial también debe interpretar y decidir conforme a la Constitución, porque ella tiene fuerza normativa" ${ }^{84}$.

La consideración de la Constitución como baremo de interpretación es imperiosa, precisamente por la fuerza imperativa con la que se encuentra revestida. En este punto, Rojo expresa que "en el Estado constitucional, el parámetro de interpretación conforme es la constitución y no la ley. En ese sentido, como la constitución tiene fuerza normativa, todos los órganos del Estado, incluso el poder judicial debe tenerla presente al momento de interpretar y aplicar una norma inferior a ella" ${ }^{85}$. Además,

Márquez, Miguel Ángel Fernández González y Rodrigo Pica Flores, con diversas fundamentaciones, que serán explicitadas en la sentencia y sus prevenciones», indica el comunicado. Agrega que por su parte, el Ministro señor Juan José Romero Guzmán votó por rechazar el requerimiento debido a que el efecto de la sentencia que declara la inaplicabilidad no es compatible con la garantía que tiene todo imputado de no ser castigado con una pena más alta que la aplicable en el momento de la comisión del delito. Esta regla está contenida expresamente en nuestra Constitución, así como en diversos Tratados Internacionales de Derechos Humanos. Lo anterior no significa desconocer que se está ante una diferencia legal arbitraria que le corresponde remediar de manera urgente al legislador”.

${ }^{82}$ El poder Judicial tiene las facultades conservadoras que se refieren a la tutela o protección de los derechos constitucionales. El poder judicial conoce y resuelve las acciones de protección, amparo, indemnización por error judicial, amparo económico, no discriminación arbitraria, recurso de nulidad por afectación de garantías constitucionales, entre otras.

${ }^{83}$ BORDALI, A. (2010). "La unidad en la interpretación jurisdiccional de los derechos fundamentales: una tarea pendiente en el derecho chileno”. EN Revista Chilena de Derecho. p. 518.

${ }^{84}$ ALDUNATE, E. (2009). “La fuerza normativa de la Constitución y el sistema de fuentes del derecho”. EN Revista de Derecho de la Pontificia Universidad Católica de Valparaíso. pp. 449-450. "Si lo que se afirma es que la Constitución es obligatoria para todos, y que su carácter vinculante no está sujeto a condiciones de las que dependa su eficacia ni está sometido a la necesidad de una mediación por la vía de otras fuentes o actos normativos, la única conclusión posible es que dicho carácter obligatorio e inmediato también lo tiene la Constitución al ser considerado por el juez de cualquier instancia o recurso que haya de resolver".

${ }^{85}$ ROJO, I. Op. Cit., p. 4. "En consecuencia, la interpretación y aplicación de la Constitución no puede ser concebida como una potestad reservada exclusiva y excluyente, a un solo órgano estatal, configurando un monopolio de la Constitución, ya que sostenerlo así es plantear una fórmula inconsistente con el Estado democrático y constitucional de derecho, pues no se trata de reemplazar la soberanía de la ley por la de un solo juez o tribunal, sino que, antes bien, de situar los derechos de las personas por sobre las potestades públicas, cualquiera sea el órgano que las ejerza y esto sólo se logra abriendo al máximo y sin restricciones, especialmente 
también resulta acorde con los fines de la Constitución que nadie pueda atribuirse el monopolio exclusivo de la interpretación constitucional. En palabras de Miguel Fernández, reforzando la tesis de la inconveniencia del carácter excluyente del control de constitucionalidad, sostiene que "recuérdese que el propio constitucionalismo surge como una respuesta al absolutismo, y a la pretensión de éste de monopolizar toda la producción jurídica, idea heredada después por el Estado $^{86}$. La CS, en ocasiones, como se ha sugerido, ha ejercido el control de constitucionalidad ${ }^{87}$.

Existiendo claridad sobre el control de constitucionalidad ejercido tanto por el TC, como por los tribunales de justicia nacionales, el control de convencionalidad por su parte, ha significado una transformación de fondo en los sistemas de justicia nacionales. La idea del control de convencionalidad proviene una creación conceptual jurídica del jurista Mexicano Sergio García Ramírez, quien fuera juez de la Corte IDH, y en esta calidad, precisamente en un voto concurrente que dictó en el caso Myrna Mc Chang vs Guatemala propuso este concepto ${ }^{88}$, que luego fue

fundadas en formalismos las acciones y recursos que hagan expedita, en todo momento y en todo lugar, como lo exige el pacto de san José de Costa Rica, la defensa y promoción de los derechos de que son titulares”.

${ }^{86}$ FERNANDEZ, M. (2006). Los derechos fundamentales en 25 años de jurisprudencia del tribunal constitucional 1980-2005. Cuadernos del Tribunal Constitucional nº 33. p. 19.

${ }^{87}$ ROJO, I. Op. Cit., p. 6 "Nótese que la CS ha hecho pronunciamientos importantes que a nuestro juicio corresponden a control de constitucionalidad. Por ejemplo, la sentencia rol $\mathrm{n}^{\circ} 35.236-2016$, que ha sido comentado por la doctrina, es un caso importante en esta materia. La CS conociendo de un recurso de apelación de una acción de protección, en que un ciudadano húngaro y una ciudadana chilena solicitan hora para contraer matrimonio ante el oficial de registro civil, la cual le fue negada por la autoridad al no contar el extranjero con cédula de identidad para extranjeros, siendo imposible obtener dicho documento, ya que si bien contaba con pasaporte, registraba pendiente un decreto de expulsión del país desde 2010. La administración pública sustentó su actuación en el artículo 76 del Decreto Ley (DL) 1094 de 1975, que dispone "los servicios y organismos del Estado o municipales deberán exigir a los extranjeros que tramiten ante ellos asuntos de la competencia de esos servicios, que previamente comprueben su residencia legal en el país y que están autorizados o habilitados para realizar el correspondiente acto o contrato". Es decir, la disposición legal permitía a las autoridades estatales, exigir a los extranjeros que comprueben la legalidad de su residencia. Sin embargo, la posibilidad de contraer matrimonio a juicio de la CS es un derecho que emana de la naturaleza humana que no puede estar sometido a exigencias formales previas. Por tanto, surge una antinomia, contradicción o falta de armonía que es necesario resolver (Considerando $9^{\circ}$ ).

${ }^{88}$ CORTE IDH. Caso Myrna Mack Chang vs Guatemala. Sentencia de 25 de noviembre de 2002. Voto concurrente razonado del Juez Sergio García Ramírez. Párrafo 27: "Para los efectos de la Convención Americana y del ejercicio de la jurisdicción contenciosa de la Corte Interamericana, el Estado viene a cuentas en forma integral, como un todo. En este orden, la responsabilidad es global, atañe al Estado en su conjunto y no puede quedar sujeta a la división de atribuciones que señale el Derecho interno. No es posible seccionar internacionalmente al Estado, obligar ante la Corte sólo a uno o algunos de sus órganos, entregar a éstos la representación del Estado en el juicio -sin que esa representación repercuta sobre el Estado en su conjunto- y 
desarrollado en otros votos particulares del mismo juez y finalmente adoptado como propio por la Corte IDH, en el caso Almonacid Arellano y otros vs Chile. Se asume en esta sentencia, la doctrina del control de convencionalidad ${ }^{89}$, y de a poco la va perfilando, mejorando, extendiéndose en sus efectos, hasta llegar a darle una conformación muy amplia como la que tiene hoy en día. Esta misma línea se retoma en los casos Aguado Alfaro vs Perú ${ }^{90}$, y en el caso Rosendo Radilla Pacheco Vs México ${ }^{91}$.

sustraer a otros de este régimen convencional de responsabilidad, dejando sus actuaciones fuera del 'control de convencionalidad' que trae consigo la jurisdicción de la Corte internacional”.

${ }^{89}$ CORTE IDH. Caso Almonacid Arellano y otros vs Chile. Sentencia de 26 de septiembre de 2006. Párrafo 124: "La Corte es consciente que los jueces y tribunales internos están sujetos al imperio de la ley y, por ello, están obligados a aplicar las disposiciones vigentes en el ordenamiento jurídico. Pero cuando un Estado ha ratificado un tratado internacional como la Convención Americana, sus jueces, como parte del aparato del Estado, también están sometidos a ella, lo que les obliga a velar porque los efectos de las disposiciones de la Convención no se vean mermadas por la aplicación de leyes contrarias a su objeto y fin, y que desde un inicio carecen de efectos jurídicos. En otras palabras, el Poder Judicial debe ejercer una especie de "control de convencionalidad" entre las normas jurídicas internas que aplican en los casos concretos y la Convención Americana sobre Derechos Humanos. En esta tarea, el Poder Judicial debe tener en cuenta no solamente el tratado, sino también la interpretación que del mismo ha hecho la Corte Interamericana, intérprete última de la Convención Americana”.

${ }^{90}$ CORTE IDH. Caso Aguado Alfaro vs Perú. Sentencia de 24 de noviembre de 2006. Párrs. 1, 2. Párrafo 1: "En esta Sentencia la Corte se ha pronunciado sobre el "control de convencionalidad" (párr. 128) que pueden y deben ejercer los órganos de la justicia nacional con respecto a actos de autoridad -entre ellos, normas de alcance general -, conforme a las atribuciones que les confieren los ordenamientos a los que se hallan sujetos y las disposiciones del derecho internacional de los derechos humanos, a las que se encuentran vinculados por diversos actos de carácter soberano -ratificación o adhesión a un tratado, reconocimiento de una competencia-, los Estados a los que corresponden esos órganos nacionales. En este mismo año el Tribunal aludió dicho 'control' en la Sentencia del Caso Almonacid (párr. 124)". Párrafo 2: "En la especie, al referirse a un 'control de convencionalidad' la Corte Interamericana ha tenido a la vista la aplicabilidad y aplicación de la Convención Americana sobre Derechos Humanos, Pacto de San José. Sin embargo, la misma función se despliega, por idénticas razones, en lo que toca a otros instrumentos de igual naturaleza, integrantes del corpus juris convencional de los derechos humanos de los que es parte el Estado: Protocolo de San Salvador, Protocolo relativo a la Abolición de la Pena de Muerte, Convención para Prevenir y Sancionar la Tortura, Convención de Belém do Pará para la Erradicación de la Violencia contra la Mujer, Convención sobre Desaparición Forzada, etcétera. De lo que se trata es de que haya conformidad entre los actos internos y los compromisos internacionales contraídos por el Estado, que generan para éste determinados deberes y reconocen a los individuos ciertos derechos".

${ }^{91}$ CORTE IDH. Caso Radilla Pacheco vs México. Sentencia de 23 de noviembre de 2009. "En relación con las prácticas judiciales, este Tribunal ha establecido en su jurisprudencia que es consciente de que los jueces y tribunales internos están sujetos al imperio de la ley y, por ello, están obligados a aplicar las disposiciones vigentes en el ordenamiento jurídico. Pero cuando un Estado ha ratificado un tratado internacional como la Convención Americana, sus jueces, como parte del aparato del Estado, también están sometidos a ella, lo que les obliga a velar porque los efectos de las disposiciones de la Convención no se vean mermados por la aplicación de leyes contrarias a su objeto y fin, que desde un inicio carecen de efectos jurídicos. En otras palabras, el Poder Judicial debe ejercer un control de convencionalidad ex officio entre las normas internas y la Convención Americana, evidentemente en el marco de sus respectivas competencias y de las regulaciones procesales correspondientes. En esta tarea, el Poder Judicial debe tener en cuenta no solamente el tratado, sino 
Para entender los contornos de este control de convencionalidad, debemos decir que es en sede interna pero con otros parámetros, símil al control de constitucionalidad. Como bien lo explica Miguel Carbonell "en este contexto, el control de convencionalidad debe entenderse como una herramienta que permite a los jueces contrastar las normas generales internas frente a las normas del sistema convencional internacional (tratados internacionales, pero también derecho derivado de los mismos) ${ }^{92}$. Bajo esta nueva lógica, se debe considerar no solo una norma constitucional y compararla con una norma de rango inferior, para verificar si la norma de jerarquía menor es o no compatible con la Constitución. En el control de convencionalidad se presenta otro paramento, porque en vez de tomar únicamente como baremo de control, la Constitución, se contemplan las normas de protección contenidas en tratados internacionales. Chile ha firmado múltiples tratados, convenios, que contienen derechos humanos y éste debe ser el parámetro para ejercer el control de convencionalidad. De esta forma, se pasa a un baremo de control ampliado, que se relaciona con el intensivo uso que se puede hacer ante los tribunales locales de los tratados internacionales que contienen derechos humanos.

Según la Corte IDH, El control de convencionalidad se ha caracterizado por dos elementos:

a) La Corte IDH ha señalado que el control de convencionalidad es ex oficio, es decir el juez debe ejercer este control en un proceso que está conociendo, aunque las partes no lo solicitan. Deriva de un deber objetivo asumido por el Estado al firman una convención internacional, y el estado deberá preservar ese medio de garantía y tutela de derechos humanos, aún si los abogados no lo piden o invocan. E cumplimiento de una obligación internacional, establecida en un pacto internacional firmado, no puede estar condicionado de que los abogados conozcan o no el

también la interpretación que del mismo ha hecho la Corte Interamericana, intérprete última de la Convención Americana".

${ }^{92}$ CARBONELL, M. (2016). Introducción General al Control de Convencionalidad. Ciudad de México. Editorial Porrúa. p.71. "Esto significa que los jueces nacionales deberán desarrollar -de oficio- una serie de razonamientos que permitan la aplicación más amplia posible y el mayor respeto a las obligaciones establecidas por los tratados internacionales. Lo anterior puede conducir, en un caso extremo, a que un juez inaplique una norma interna cuando esté en contradicción con una norma internacional”. 
tratado, lo invoquen o no, o sepan cómo utilizar o argumentar en base al propio tratado. La obligación de observar los tratados es del juez, desde una perspectiva oficiosa. Las Sentencias de la Corte IDH, referidas expresamente al ejercicio ex officio del control difuso de convencionalidad, ya han resuelto que todas las normas meramente internas (y por lo tanto sus operatividades jurídicas, como también las decisiones emitidas conforme a ellas, incluidas las de tipo jurisdiccional que las aplican), que son contrarias al objeto y fin de la $\mathrm{CADH}$, desde un principio carecen de efectos jurídicos ${ }^{93}$. De igual manera, los fallos interamericanos han resuelto que los tribunales de justicia de los Estados signatarios de la CADH, no pueden invocar normas de derecho interno, para excusarse de cumplir el tratado y acatar las sentencias de la Corte IDH ${ }^{94}$. En este punto, dista del control de constitucionalidad concentrado, a través del recurso de inaplicabilidad, que como revisamos, solo procede a petición de parte o a requerimiento del juez.

b) Este control de convencionalidad, es de carácter difuso, es decir lo tiene que llevar todos los jueces, en el ámbito que ejercen su jurisdicción o en el fuero que se desarrollan, siendo una actividad del poder judicial en su conjunto ${ }^{95}$. La Corte IDH, en un desarrollo ulterior, ha señalado que este control también debe llevarse a cabo por cualquiera otra autoridad que debe desarrollar, observar, garantizar y tutelar debidamente los derechos humanos previstos en los tratados internacionales. Así, el Ministerio Público y la propia administración pública, deben avanzar para brindar tutela y garantía de los derechos humanos, en la esfera de su competencia con las herramientas jurídicas que tiene a su alcance. En efecto, la CS ha expresado que

\footnotetext{
${ }^{93}$ Hemos podido observar esta premisa, en los fallos Almonacid Arellano vs Perú, Atala Riffo vs Chile, Radilla Pacheco vs México; más todas sus sentencias formativas, anexas y complementarias.

${ }^{94}$ Premisa que se ha expresado, entre otras, en los fallos Villagrán Morales y otros vs Guatemala, Velásquez Rodríguez vs Honduras, más todas las sentencias formativas anexas y complementarias.

${ }^{95}$ CASO AGUADO ALFARO vs PERU. Op. Cit. Párrs 11, 12. Párrafo 11: "Si existe esa conexión clara y rotunda --o al menos suficiente, inteligible, que no naufrague en la duda o la diversidad de interpretaciones--, y en tal virtud los instrumentos internacionales son inmediatamente aplicables en el ámbito interno, los tribunales nacionales pueden y deben llevar a cabo su propio control de convencionalidad. Así lo han hecho diversos órganos de la justicia interna, despejando el horizonte que se hallaba ensombrecido, inaugurando una nueva etapa de mejor protección de los seres humanos y acreditando la idea --que he reiterado-- de que la gran batalla por los derechos humanos se ganará en el ámbito interno, del que es coadyuvante o complemento, pero no sustituto, el internacional. Párrafo 12: "Este control de convencionalidad, de cuyos buenos resultados depende la mayor difusión del régimen de garantías, puede tener --como ha sucedido en algunos países-- carácter difuso, es decir, quedar en manos de todos los tribunales cuando éstos deban resolver asuntos en los que resulten aplicables las estipulaciones de los tratados internacionales de derechos humanos”.
} 
"los tribunales tienen la obligación de intentar una interpretación de las normas nacionales que afecten derechos humanos que sea armónica con las obligaciones internacionales de Estado en este campo, aun cuando dichas normas en sí mismas no se ajusten a la Convención" 96 . A mi juicio, el control de convencionalidad, impuesto al Estado de Chile en primer lugar por la sentencia de la Corte IDH, Caso Almonacid Arellano y otros vs Chile de 2006 y reiterado en el Caso Atala y niñas vs Estado de Chile de 2012, importaría para los tribunales de justicia nacionales una verificación de no contradicción -o compatibilidad- entre las normas jurídicas susceptibles de aplicarse en un caso concreto y la CADH, además de su respectiva jurisprudencia. En otras palabras, el Poder Judicial debe ejercer una especie de "control de convencionalidad" entre las normas jurídicas internas que aplican en los casos concretos y la CADH. En esta tarea, el Poder Judicial debe tener en cuenta no solamente el tratado, sino también la interpretación que del mismo ha hecho la Corte Interamericana, intérprete última de la $\mathrm{CADH}$.

Desde esta perspectiva, el control de convencionalidad, según lo propuesto por la Corte IDH en el mencionado caso Almonacid Arellano y otros vs Chile, tendría las siguientes características:

a) Sería un control normativo entre las disposiciones jurídicas internas, ya sean constitucionales, legales o reglamentarias, y la normativa interamericana.

b) El parámetro de control estaría constituido por las normas contenidas en la CADH y la Jurisprudencia de la propia Corte, asignándole la Corte IDH a esta última un carácter de fuente formal del derecho. De esta forma el parámetro de control sería lo que parte de la doctrina nacional denomina "bloque de convencionalidad".

c) De existir un conflicto normativo entre la normativa interna y la normativa interamericana, el mismo se resolvería conforme al criterio jerárquico.

d) Tal control normativo debería ser efectuado por todos los órganos del Estado, pero especialmente por todos los jueces nacionales, incluso de oficio. Sin perjuicio

${ }^{96} \mathrm{CS}$. Sentencia causa rol 27.543-2016, de 3 de octubre de 2016. 
de acogerse ampliamente la teoría del control de convencionalidad, no significa que toda sentencia interamericana o universal, va tener que ser necesariamente aplicada directamente por el juez de instancia nacional, sino que a nuestro parecer solo cuando exista una controversia entre la normativa interna y la regulación protectora internacional, como asimismo de los pronunciamientos de los organismos de protección, a través de sus sentencias, OC e informes.

No obstante la acogida generalizada de la tesitura del control de convencionalidad, de ninguna forma puede ser considerada como una herramienta jurídica que deba ser utilizada a ultranza o a todo evento, debiendo a nuestro juicio emplearse de manera razonada. En este punto, entendemos, que resulta del todo pertinente formular ciertas observaciones, alcances o críticas al control de convencionalidad en el orden interamericano:

a) La ausencia de un consenso en cuanto al valor de los tratados sobre derechos humanos ratificados y vigentes. Una suerte similar arrastrará al control de convencionalidad.

b) Aceptar como obligatoria la doctrina de la Corte IDH exigiría como supuesto que la jurisdicción ordinaria y constitucional adopten la tesis de que el principio de supremacía constitucional integra los derechos esenciales contenidos en tratados internacionales sobre derechos humanos ratificados y vigentes.

Por tanto, dichos derechos serán también fuente superior en nuestro ordenamiento y parámetro de control de constitucionalidad y convencionalidad. Precisamente bajo este razonamiento, la Corte IDH en el caso Gelman vs Uruguay, incluye dentro del control de convencionalidad, el de constitucionalidad, pues las preceptivas de derechos fundamentales han ingresado por vía de remisión a las cartas fundamentales de los diversos países de la región, incluido el nuestro. En esta sentencia se razona que "en consecuencia, la pretensión de oponer el deber de los tribunales internos de realizar el control de constitucionalidad al control de convencionalidad que ejerce la Corte, es en realidad un falso dilema, pues una vez que el Estado ha ratificado el tratado 
internacional y reconocido la competencia de sus órganos de control, precisamente a través de sus mecanismos constitucionales, aquéllos pasan a conformar su ordenamiento jurídico. De tal manera, el control de constitucionalidad implica necesariamente un control de convencionalidad, ejercidos de forma complementaria ${ }^{97}$. Siguiendo en este punto la línea argumentativa de Juan Hitters "hemos querido adelantar a modo propedéutico que ese tribunal internacional ha sentado la postura en el sentido de que por regla, él no se ocupa de modificar en forma directa el derecho interno, ya que su misión consiste en 'controlar' si las normas locales acatan -o no- las convenciones internacionales; y por ende no se convierte en una 'cuarta instancia' que deja sin efecto las leyes de los países" ${ }^{\prime 98}$. Surge de lo antedicho que la misión prístina de la Corte IDH está en llevar a cabo una inspección de convencionalidad comparando la norma del derecho interno ${ }^{99}$ en relación a la convención y desentrañar si aquélla violenta a ésta.

c) La doctrina del control de convencionalidad se sostiene sobre la base de la preferencia de la norma más favorable a la protección de los derechos humanos. Si existiera contradicción y fuera más garante la norma contenida en la Constitución, debiera preferirse ésta y no la que se contiene en la CADH. Pero los tratados no deben dejar de ser cumplidos, entonces esto acarrearía la responsabilidad internacional del Estado. El principio favor persona entrega al juez un amplio margen para determinar en cada caso concreto, cuál es la norma más favorable a la protección del derecho que se discute. No se trataría de una estructura rígida sino flexible, primará la norma más garantista, y eso es un asunto

\footnotetext{
${ }^{97}$ CORTE IDH. Caso Gelman vs Uruguay. Sentencia de 24 de febrero de 2011. Párrafo 88. 98 HITTERS, J. (2008). ¿Son vinculantes los pronunciamientos de la Comisión y de la Corte Interamericana de Derechos Humanos. Buenos Aires. Editorial La Ley. p. 1169.

${ }_{99}$ CORTE IDH. Caso Palamara Iribarne Vs. Chile. Sentencia de 22 de noviembre de 2005. Párrafo 121: "En casos similares, esta Corte ha establecido que el esclarecimiento de si el Estado ha violado o no sus obligaciones internacionales por virtud de las actuaciones de sus órganos judiciales puede conducir a que el Tribunal deba ocuparse de examinar los respectivos procesos internos. Con base en los precedentes, el Tribunal considerará la totalidad de los procesos nacionales relevantes en el presente caso, con el fin de realizar una determinación informada sobre si se han violado las normas de la Convención mencionadas relativas al debido proceso y a la protección judicial. Para ello, se tendrá especial consideración que los hechos del presente caso se produjeron, principalmente, en el marco de la jurisdicción militar chilena en tiempos de paz en dos procesos penales en contra del señor Palamara Iribarne, uno por los delitos de desobediencia e incumplimiento de deberes militares y otro por el delito de desacato".
} 
que puede variar de un caso a otro. Desde esta perspectiva, en la cúspide del ordenamiento se encontraría la norma más favorable. El principio pro homine es una fórmula, un canon de interpretación vacío de contenido específico. Según este planteamiento, en la parte superior de los ordenamientos no se encontraría la fuente (Constitución o tratado), si no la norma que mejor proteja el derecho.

d) La ausencia de una cultura jurídica del precedente, es decir, de la creación de doctrina obligatoria por parte de los órganos superiores de justicia.

e) El seguimiento dispar de las sentencias condenatorias a Chile, por ejemplo en el caso Almonacid Arellano y otros vs Chile. La jurisdicción ordinaria acoge favorablemente y reabre la investigación, mientras el legislador aun no priva de efectos jurídicos al Decreto Ley (DL) de amnistía ni legisla sobre la imprescriptibilidad de los crímenes de guerra y de lesa humanidad. La Corte de Apelaciones (CA) de Rancagua asume la tesis de la cosa juzgada aparente 0 fraudulenta que fue desarrollada por la misma Corte IDH para volver a la investigación de los hechos.

f) La ausencia de un desarrollo sistemático para la doctrina del margen de apreciación en el Sistema Interamericano de Derechos Humanos (SIDH). Se señala que no existe una doctrina clara en este sentido, a diferencia de lo que ocurre en el sistema europeo de protección a los derechos humanos donde esta doctrina se viene desarrollando ya desde hace un tiempo y permite salidas para los Estados en materias de orden valórico.

g) Se considera por otra parte, que la doctrina el control de convencionalidad excede el marco de los compromisos asumidos por el Estado a partir de la ratificación de la CADH, y por ende, se trataría de una obligación jurisprudencial construida por la Corte a partir de su propia interpretación, sin contar con texto expreso en el que fundar el surgimiento de la obligación, a lo que se puede contrarrestar invocando el artículo $62 \mathrm{n}^{\circ} 3$ de la CADH que hace obligatoria su doctrina. 
En este contexto, el Juez Sergio García Ramírez en su voto razonado ${ }^{100}$ en el caso Tibi vs. Ecuador, reflexionó sobre el trabajo de la Corte, luego de 25 años de funcionamiento y creyó necesario impulsar su trabajo. Se refirió al sentido y trascendencia que debieran derivarse de sus resoluciones y OC, para extender sus criterios más allá de un caso concreto y en este sentido sostuvo que en cierto sentido, la tarea de la Corte se asemeja a la que realizan los tribunales constitucionales. Estos examinan los actos impugnados, disposiciones de alcance general, a la luz de las normas, los principios y los valores de las leyes fundamentales. La Corte IDH, por su parte, analiza los actos que llegan a su conocimiento en relación con normas, principios y valores de los tratados en los que funda su competencia contenciosa. Dicho de otra manera, si los tribunales constitucionales controlan la "constitucionalidad", el tribunal internacional de derechos humanos resuelve acerca de la "convencionalidad" de esos actos. García Ramírez, agrega que "a través del control de constitucionalidad, los órganos internos procuran conformar la actividad del poder público, y eventualmente, de otros agentes sociales, al orden que entraña el Estado de Derecho en una sociedad democrática"101. Añade el autor que "el tribunal interamericano, por su parte, pretende conformar esa actividad al orden internacional acogido en la convención fundadora de la jurisdicción interamericana y aceptado por los Estados partes en ejercicio de su soberanía. Consecuentemente, en la lógica del sistema, y en las aspiraciones institucionales de la Corte IDH, como elemento de éste reside la idea de que los pronunciamientos del tribunal deben trasladarse en la forma y términos que provea el derecho Interno, que son el puente entre el sistema internacional y el nacional, a las leyes nacionales, a los criterios jurisdiccionales domésticos, a los programas específicos en este campo y a las acciones cotidianas que el Estado

\footnotetext{
100 CORTE IDH. Caso Tibi vs. Ecuador. Sentencia de 7 de septiembre de 2004. Voto Concurrente Razonado Juez Sergio García Ramírez. Párrs 2-6.

${ }^{101}$ IBIDEM. "Es esto -un poder de influencia, reconstrucción, orientación, información- lo que explica y justifica, a la postre, una jurisdicción internacional que no tiene la posibilidad ni la capacidad para abocarse al conocimiento de millares de juicios en los que se ventilen idénticos litigios y se reproduzcan razonamientos y pronunciamientos establecidos y reiterados con antelación”.
} 
despliega en materia de derechos humanos; trasladarse, en fin, al conjunto de la experiencia nacional"102.

102 IBIDEM. 


\section{CAPITULO II. EL DERECHO DE ACCESO A LA JUSTICIA}

\section{REFLEXIONES PREVIAS SOBRE TRATO IGUALITARIO Y SIN DISCRIMINACIÓN ESPECIALMENTE RESPECTO DE PERSONAS EN SITUACIÓN DE VULNERABILIDAD}

Prima actualmente en nuestro continente y país, una concepción de acceso a la justicia, que se alinea con un enfoque amplio, centrado especialmente en la satisfacción de necesidades jurídicas de los grupos vulnerables, procurando respecto de ellos un trato igualitario y sin discriminación, considerando que el acceso a la justicia constituye un derecho humano y debe ser entendido como la posibilidad que tiene toda persona, independiente de su condición económica o de otra naturaleza, de acudir al sistema previsto por el Estado, para dar solución a los conflictos jurídicos y la vindicación de los derechos protegidos de los cuales es titular. Por lo tanto, la falta de acceso a la justicia constituye un problema grave, pues frustra el ejercicio real de la ciudadanía y, por tanto debilita el Estado democrático de derecho ${ }^{103}$.

De esta forma, resulta necesario en esta etapa de desarrollo, una revisión somera de la vulnerabilidad, como asimismo los principios de igualdad y no discriminación, sin perjuicio del estudio particular de los grupos en condición de vulnerabilidad, cuyo análisis se ha reservado para el Capítulo III.

\subsection{Vulnerabilidad, determinación y alcances}

En Palabras de Almela, "el sistema Judicial que quiera mejorar el acceso a la justicia de los grupos en condición de vulnerabilidad, tendrá que identificar cuáles son las debilidades o insuficiencias que se presentan, que impiden o limitan su derecho a

${ }^{103}$ ARBELAEZ DE TOBON, L y RUIZ, E. Op. Cit., p. 28. 
obtener una respuesta adecuada en igualdad de condiciones que el resto de personas" 104 .

Los Estados a medida que van ratificando diversos tratados que protegen grupos en condición de vulnerabilidad se obligan a tomar medidas especiales respecto de los diferentes colectivos tutelados respectivamente por cada instrumento, para asegurar el pleno reconocimiento y ejercicio de los derechos de sus miembros y poder ofrecer los referidos medios de compensación que no tornen ilusorio el efectivo acceso a la justicia. En este sentido, tal como se proclamó en la XIV Cumbre Judicial Iberoamérica, en que se aprobaron las Reglas de Brasilia sobre Acceso a la Justica de las personas en Condición de Vulnerabilidad, las políticas públicas del Estado deben fijarse en satisfacer las necesidades jurídicas de estos grupos ${ }^{105}$. En consonancia con este fundamento y dichas reglas, podemos sostener que aunque el problema de efectividad de los derechos y especialmente de algunos de ellos, como los sociales, económicos y culturales afecta con carácter general a todas y a todos los ciudadanos, obviamente las dificultades son mayores cuando se trata de personas en condición de vulnerabilidad

Precisamente, el concepto de vulnerabilidad está presente en las Reglas de Brasilia, como el eje central que articula todos los esfuerzos tendientes a garantizar un acceso igualitario a la justicia, constituyendo causas de vulnerabilidad: la edad, la discapacidad, la pertenencia a comunidades indígenas o minorías, la pobreza, el género, entre otras. Ante lo cual, se encuentran las personas que las presentan con especiales dificultades para ejercitar con plenitud ante el sistema de justicia los derechos reconocidos por el ordenamiento jurídico.

Para explicar por qué una persona o un grupo está vulnerable hace falta explorar situaciones en las cuales alguna característica especial de estos grupos les

\footnotetext{
${ }^{104}$ ALMELA, C. Op. Cit., p. 2. “Además expresa que "hay que fijar los criterios y establecer los procedimientos que deben seguirse para la elaboración de un diagnóstico certero que permita identificar claramente las barreras que existen y cuál es el problema a resolver".

${ }^{105}$ XIV CUMBRE JUDICIAL IBEROAMERICANA. (2008). Reglas de Brasilia sobre acceso a la justicia de las personas en condición de vulnerabilidad. Brasilia. Regla 3: "Se consideran en condición de vulnerabilidad aquellas personas que, por razón de su edad, género, estado físico o mental, o por circunstancias sociales, económicas, étnicas y/o culturales, encuentran especiales dificultades para ejercitar con plenitud ante el sistema de justicia los derechos reconocidos por el ordenamiento jurídico”.
} 
convierte en vulnerables según determinadas condiciones sociales, jurídicas, económicas y políticas del escenario social en que se encuentren, y que les condiciona negativamente en su supervivencia o les impide el ejercicio sus derechos y libertades, y por ende, la facultad de acceder a la justicia en condiciones de igualdad.

A nuestro entender, la vulnerabilidad se presenta especialmente gravosa cuando se tiene respecto a determinados escenarios que se consideran relevantes para el mantenimiento de la vida, de la calidad de vida o el ejercicio de las libertades básicas, como el ser vulnerable frente a la administración de justicia.

Así, la vulnerabilidad de ciertos grupos, se manifiesta de múltiples maneras y varía entre los individuos del mismo grupo. A la vez, una persona puede pertenecer a más de un grupo vulnerable, con lo cual se suma su vulnerabilidad y se aumenta también la discriminación que sufre por ellas, por lo que se justifica que el trato legislativo y del Estado deba ser positivamente diferenciado.

\subsection{Igualdad y no discriminación}

La igualdad y no discriminación constituyen parte de la base de un Estado democrático y son principios esenciales de las normas internacionales de derechos humanos. El principio de igualdad viene consagrado en múltiples instrumentos 
internacionales ${ }^{106}$, y no implica que todas las personas deban ser tratadas de la misma manera ${ }^{107}$.

Los esfuerzos por cierto, no se deben quedar en el avance legislativo ${ }^{108}$. Precisamente por ello, las políticas en materia de acceso a la justicia de los grupos en condiciones de vulnerabilidad, tienen que tender a eliminar las discriminaciones que por las circunstancias físicas, culturales o sociales, dificultan a estos grupos obtener una respuesta adecuada del sistema de justicia, equilibrando el desnivel que estos colectivos tienen en relación con el resto de la ciudadanía.

Las actuales visiones en esta temática ponen de manifiesto la importancia de visibilizar aquellas brechas que aún existen entre el cuerpo de derechos proclamados dentro del ordenamiento jurídico y su efectivo ejercicio, dado que la dificultad para identificar las diversas formas de desigualdad limita la posibilidad de

\footnotetext{
${ }^{106}$ CARTA ORGANIZACION DE ESTADOS AMERICANOS. Artículos 3.l y 17: Los Estados Americanos proclaman los derechos fundamentales de la persona humana sin hacer distinción de raza, nacionalidad, credo o sexo. Cada Estado tiene el derecho de desenvolver libre y espontáneamente su vida cultural, política y económica. En este libre desenvolvimiento el Estado respetará los derechos de la persona humana y los principios de la moral universal.

CADH. Artículo 24: que determina que: Todas las personas son iguales ante la ley. En consecuencia, tienen derecho, sin discriminación, a igual protección de la ley.

CONVENIO EUROPEO DE DERECHOS HUMANOS Y LIBERTADES FUNDAMENTALES (CEDH). Artículo 14: Convenio Europeo de Derechos Humanos: El goce de los derechos y libertades reconocidos en el presente Convenio ha de ser asegurado sin distinción alguna, especialmente por razones de sexo, raza, color, lengua, religión, opiniones políticas u otras, origen nacional o social, pertenencia a una minoría nacional, fortuna, nacimiento o cualquier otra situación.

DECLARACION AMERICANA DE DERECHOS HUMANOS. Artículo II: Todas las personas son iguales ante la Ley y tienen los derechos y deberes consagrados en esta declaración sin distinción de raza, sexo, idioma, credo ni otra alguna.

PIDCP. Artículo 26: Todas las personas son iguales ante la ley y tienen derecho sin discriminación a igual protección de la ley. A este respecto, la ley prohibirá toda discriminación y garantizará a todas las personas protección igual y efectiva contra cualquier discriminación por motivos de raza, color, sexo, idioma, religión, opiniones políticas o de cualquier índole, origen nacional o social, posición económica, nacimiento o cualquier otra condición social.

DUDH. Artículo 2: Toda persona tiene los derechos y libertades proclamados en esta Declaración, sin distinción alguna de raza, color, sexo, idioma, religión, opinión política o de cualquier otra índole, origen nacional o social, posición económica, nacimiento o cualquier otra condición.

${ }^{107}$ ALMELA, C. Op. Cit., p. 5. "Se debe trascender del concepto de igualdad formal, para dar paso al concepto de igualdad real”.

${ }^{108}$ ARBELAEZ DE TOBON, L y RUIZ, E (2018). Op. Cit., p. 19. "En el entendido que todas las leyes no son neutras, dado que están afectadas por elementos culturales y subjetivos que contribuyen a normalizar situaciones de desigualdad y discriminación, Chile ha avanzado en derogar o reformar, normas como la diferencia de derechos entre hijos legítimos y naturales, el trato diferente para hombre y mujer en la sanción del adulterio; la autorización del marido a la mujer para trabajar; el voto de la mujer, etcétera. Hoy estas situaciones resultan inaceptables. De otra parte, Chile cuenta hoy con normas que avanzan en la paridad como las recientes leyes de cuotas, sindicatos y régimen electoral”.
} 
ver con claridad la discriminación ${ }^{109}$.

En base a esta realidad marcada por el divorcio entre la consagración normativa y el andamiaje de políticas públicas e institucionalidad creada al efecto, que no posibilitan el cumplimiento de los derechos proclamados, el Estado debe asumir la existencia de estos factores de desigualdad real y establecer las medidas de compensación precisas para superar los obstáculos y permitir una defensa eficaz de los derechos de la población. Este rol garante del Estado en cuanto al trato formal y material, en un plano de igualdad y no discriminación, se exige y se refleja nítidamente en el proceso mismo ${ }^{110}$. Para alcanzar sus objetivos, el proceso debe reconocer y resolver los factores de desigualdad real de quienes son llevados ante la justicia. Es así como se atiende al principio de igualdad ante la ley y los tribunales y a la correlativa prohibición de discriminación. En la OC 18/03 se expresa que "la presencia de condiciones de desigualdad real obliga a adoptar medidas de compensación que contribuyan a reducir o eliminar los obstáculos y deficiencias que impidan o reduzcan la defensa eficaz de los propios intereses"111. En este mismo sentido en la OC 16/99, "que si no existieren esos medios de compensación ampliamente reconocidos en diversas vertientes del procedimiento, difícilmente se podría decir que quienes se encuentran en condiciones de desventaja disfrutan de

\footnotetext{
${ }^{109}$ Igualdad y vulnerabilidad son dos conceptos íntimamente entrelazados. Estimamos, que corresponde a los poderes públicos proporcionar las condiciones para que la igualdad entre las personas sean reales y efectivas, estableciendo mecanismos que sean capaces de eliminar los obstáculos y las barreras que impiden a aquellos que se encuentran en condición de vulnerabilidad, tomar parte en la vida política, económica, cultural y social, y en definitiva hacer valer sus derechos, accediendo a la justicia, en igualdad de condiciones que el resto de personas.

${ }^{110}$ CORTE IDH. OC 18/03. Condición Jurídica y Derechos de los Migrantes indocumentados, de 17 de septiembre de 2003. Párrafo 121: “.......y que: Para alcanzar sus objetivos, el proceso debe reconocer y resolver los factores de desigualdad real de quienes son llevados ante la justicia. Es así como se atiende el principio de igualdad ante la ley y los tribunales y a la correlativa prohibición de discriminación. La presencia de condiciones de desigualdad real obliga a adoptar medidas de compensación que contribuyan a reducir o eliminar los obstáculos y deficiencias que impidan o reduzcan la defensa eficaz de los propios intereses. Si no existieran esos medios de compensación, ampliamente reconocidos en diversas vertientes del procedimiento, difícilmente se podría decir que quienes se encuentran en condiciones de desventaja disfrutan de un verdadero acceso a la justicia y se benefician de un debido proceso legal en condiciones de igualdad con quienes no afrontan esas desventajas”.

${ }^{111}$ CORTE IDH. OC 16/99. Op. Cit., párr. 119.
} 
un verdadero acceso a la justicia y se benefician de un debido proceso legal en condiciones de igualdad con quienes no afrontan estas desventajas"112.

De esta forma, la vulnerabilidad expresa una desigualdad y como tal, se manifiesta en una discriminación, con lo que mientras más profunda sea la vulnerabilidad, mayor será la desigualdad sufrida y más amplia la discriminación que se produzca.

Los Estados no se deben desplegar únicamente sus esfuerzos en constatar un hecho de la causa de nuestra América Latina real, que la constituye la grave desigualdad existente y la vulneración de algunos grupos de personas. En sentido contrario, se deben esmerar en todos los ámbitos, pero especialmente en materia de acceso a la justica, siendo proactivos en propugnar una política de discriminación positiva, que permita dotar a las personas pertenecientes a sectores desfavorecidos o excluidos de los medios adecuados que les permita efectivamente participar en los derechos que los ordenamientos jurídicos han implementado, a lo menos en teoría, para todos, sin distinción ${ }^{113}$. En este ámbito se promueve la denominada discriminación positiva ${ }^{114}$.

En este ámbito, tal como se ha declarado por la Corte IDH, "se debe reconocer y seguir protegiendo la discriminación positiva, partiendo por lo tanto de la base de que no todos los colectivos o grupos de personas están en la misma situación y que existen desigualdades causadas por muy diversas razones, las políticas públicas que se lleven a cabo, tienen que tender a establecer mayores oportunidades para quienes están en desventaja (leyes de igualdad)"115.

\footnotetext{
112 IBIDEM

${ }^{113}$ IBIDEM. "Latinoamérica sigue siendo un continente donde se dan unas altas cotas de desigualdad. Las situaciones de exclusión, vulnerabilidad y desigualdad, son una realidad. Hay un alto porcentaje de personas en situación de vulnerabilidad social, existiendo serias insuficiencias en materia de acceso a la justicia”.

${ }^{114}$ ALMELA, C. Op. Cit., p. 5. "Es lo que se ha venido llamando discriminación positiva y más recientemente acción positiva o acción afirmativa y que consiste en desarrollar acciones que tiendan a equilibrar las condiciones de discriminación que sufren determinadas personas, dándoles una serie de ventajas para compensar su situación”.

${ }^{115}$ CORTE IDH. Caso trabajadores de la hacienda Brasil Verde vs Brasil. Sentencia de 20 de octubre de 2016. Párr. 337: "Toda persona que se encuentre en una situación de vulnerabilidad es titular de una protección especial, en razón de los deberes especiales cuyo cumplimiento por parte del Estado es necesario para satisfacer las obligaciones generales de respeto y garantía de los derechos humanos”.
} 


\section{CONCEPTO, ENFOQUES Y EVOLUCIÓN DEL DERECHO AL ACCESO A LA JUSTICIA}

\subsection{Concepción restringida y amplia de acceso a la justicia}

Como manifestación de la dignidad humana, destaca el derecho fundamental del igualitario acceso a la Justicia, en lo referido a la garantía de las personas de tener la legitima posibilidad de que sus problemas, colisiones de intereses 0 contravención a sus derechos, transformados en necesidad jurídica, sean resueltos por la tutela del Estado ${ }^{116}$.

De esta forma, el derecho de acceso a la justicia traspasa la mera existencia de una ley que consagre un derecho, sino que requiere que exista la posibilidad de un acceso real a un remedio eficaz para un problema de carácter jurídico, debiendo contarse con una política pública de acceso a la justicia. De tal manera, esta política pública debe superar un acceso formal a tribunales, sino que implica la remoción de barreras de todo tipo, en especial, atendiendo las condiciones de vulnerabilidad en que se encuentran ciertas personas o grupos, con el propósito que se logre un real acceso a los tribunales de justicia y órganos que ejerzan jurisdicción. Además se debe contemplar dentro del acceso a la justicia, la posibilidad de contar con otros mecanismos no judiciales. En todos estos supuestos, para que podamos concebir un genuino y verdadero acceso a la justicia, deben respetarse las garantías del debido proceso a todas las personas, sin distinción de sexo, raza, edad, identidad sexual, creencias religiosas y capacidad económica. Una aproximación conceptual en este sentido la entrega Daniela Heim, en el siguiente tenor "el derecho de acceso a la Justicia hace referencia a un conjunto de derechos y garantías que los Estados tienen que asegurar a sus ciudadanos sin ningún tipo de distinción para que puedan acceder a la administración de Justicia a resolver sus conflictos y obtener una

\footnotetext{
116 UNIVERSIDAD DIEGO PORTALES. (2017). “Acceso a la justicia en Chile” EN Informe Anual sobre derechos humanos en Chile 2017. Santiago. p. 362. "El acceso a la justicia es un derecho fundamental que exige a los Estados garantizar que todos los ciudadanos que así lo requieran puedan recurrir al sistema de justicia y obtener una respuesta efectiva a una necesidad legal, normalmente asociada a la resolución de conflictos o disputa de relevancia jurídica”. p. 355.
} 
sentencia justa de conformidad con el ordenamiento jurídico. Se aplica a todas las jurisdicciones y tiene un sentido amplio, siendo concreciones del mismo, la asistencia jurídica y la defensa por un abogado independiente, la especialización de la justicia, la eliminación de barreras arquitectónicas y de todo tipo, la gratuidad, la asistencia de un intérprete si fuese necesario, como las garantías del debido proceso"117.

En cuanto a las prerrogativas o elementos que se engloban dentro del concepto, nos adherimos a lo expresado por Haydee Birgin y Beatriz Kohen ${ }^{118}$.

No obstante circunscribirse frecuentemente el derecho de acceso a la justicia al acceso a tribunales o más precisamente a la prerrogativa de toda persona de contar con recursos judiciales efectivos para lograr el restablecimiento de sus derechos a través de la tutela judicial efectiva, cuando éstos hayan sido desconocidos o vulnerados, o identificarlo a las garantías del debido proceso o incluso circunscribirlo en ocasiones a la asistencia jurídica gratuita, resulta indiscutible incluir actualmente en el concepto, la facultad de todas las personas sin distinción alguna, preferentemente las vulnerables, de ejercer los derechos concedidos por el ordenamiento jurídico, como asimismo la obligación del Estado de remover los obstáculos de acceso a ella.

Existen dos formas para comprender este derecho. La primera, en un sentido estricto e institucionalista, en que el acceso a la justicia es entendido como la capacidad para acudir a los tribunales y obtener una resolución justa sobre un conflicto en disputa. En esta concepción institucionalista, el tratamiento y diagnóstico se circunscribe al sistema preexistente de cortes y tribunales, abordando reformas de cara a su mayor capacitación, a su reorganización y a una

\footnotetext{
117 HEIM, D (2014). Mujeres y Acceso a la Justicia. De la tradición formalista del derecho a un derecho androcéntrico. Barcelona. Tesis Doctoral Universitat Autónoma de Barcelona. p. 26.

${ }^{118}$ BIRGIN, H y KOHE, B. (2006). "El acceso a la justicia como derecho” EN BIRGIN, H y KOHE, B. Acceso a la Justicia como garantía de igualdad, instituciones, actores y experiencias comparadas. Buenos Aires. Biblos. p. 20. "Aunque existen diferencias al momento de delimitar conceptualmente el acceso a la justicia, suelen incluirse dentro de este concepto diversas manifestaciones: la posibilidad de llegar al sistema judicial contando con la representación de un abogado, de obtener un pronunciamiento judicial en un tiempo prudencial, de conocer los derechos y garantías para poder ejercerlos, de contar con asistencia jurídica gratuita para los sectores más desaventajados, entre otras”.
} 
mayor dotación de recursos materiales y para mejorar su rendimiento, y de esta manera ampliar su alcance y mejorar su eficacia.

La segunda forma, propone una mirada amplia, en virtud de la cual los Estados tienen la obligación de garantizar no solamente la posibilidad efectiva de acceder a los tribunales (acceso al proceso en sentido estricto), sino también a otros tipos de dispositivos que permitan a las partes sin discriminación alguna, resolver sus conflictos en forma directa y colaborativa, como es el caso de la mediación, la negociación, la conciliación o la generación de políticas públicas o dispositivos estatales, comunitarios o de otra índole, tendientes a propiciar el ejercicio y tutela de los derechos, en forma diversa que la meramente judicial.

Esta segunda forma, en coherencia con lo sostenido por el Programa de Naciones Unidas para el Desarrollo (PNUD) del año 2005, siguiendo la línea trazada por Cappelletti con el Proyecto de Florencia de 1979119, que buscaba promover un movimiento mundial por el acceso a la Justicia, insta por abandonar la noción de acceso a la justicia circunscrita a un mero acceso a los tribunales estatales, "restrictiva" o "meramente institucional" y considerarlo, no solo como el poder de acceder los tribunales, sino como el acceso a un remedio eficaz para un problema tutelado por el derecho, a favor de todas las personas, en condiciones de igualdad y sin discriminación.

En este sentido, tal como lo promueve el proyecto florentino "una política de acceso a la Justicia implica crear o fortalecer toda instancia, estatal o comunitaria, centralizada o descentralizada, que coadyuve a garantizar el ejercicio de los

\footnotetext{
${ }^{119}$ Se entiende que el movimiento de acceso a la justicia se inauguró con el denominado proyecto florentino de acceso a la justicia dirigido por Mauro Cappelletti, que se llevó a cabo por más de 5 años, formando parte de él, más de cien investigadores de distintas disciplinas de las ciencias jurídicas y de otras ciencias sociales, provenientes de una treintena de diferentes países. En este proyecto se analizaron los obstáculos para el acceso a la justicia( el costo del litigio y la diferencia de poder entre los litigantes, dada por la situación económica, la eficiencia para reconocer y hacer valer una demanda o una defensa y la situación de los litigantes ocasionales contra los repetitivos), todo ello especialmente desde la óptica de la pobreza y la exclusión social pero también se reflexionó sobre otras problemáticas, entre las cuales destacan: la emergencia de los llamados derechos difusos, la implementación de medios técnicos que pudiesen coadyuvar a mejorar la vinculación de la ciudadanía con los tribunales de justicia; la simplificación y abreviación de esos procedimientos; la necesidad de usar un lenguaje jurídico y judicial más sencillo y de personas no versadas en la materia; la descentralización de la administración de justicia; el uso de mecanismos alternativos de resolución de conflictos; la creación de servicios de asistencia jurídica gratuita, la incorporación de figuras como el defensor de derechos, etcétera.
} 
derechos y que sea capaz de dar respuesta a las demandas de las personas, en especial de aquellas más desfavorecidas"120.

No es suficiente contar con derechos sustantivos y subyacentes, consagratorios de valores superiores, como la vida, libertad y propiedad, si estos no pueden hacerse realizables, por ello se obliga a los Estados ofrecer a la ciudadanía un sistema capaz de procesar y resolver sus conflictos de relevancia jurídica, mediante una herramienta idónea para hacer valer los derechos. A la luz de la jurisprudencia de la Corte IDH no basta solo con la presencia de un orden normativo, sino que la conducta gubernamental debe asegurar la existencia en realidad de una eficaz garantía del libre y pleno ejercicio de los derechos humanos ${ }^{121}$.

El acceso a la justicia, entones, no se agota en el ámbito americano a la garantía estatal de un mero acceso a tribunales o a la tutela judicial efectiva, sino que necesariamente debe contemplar la generación de acciones de diverso tipo, tendientes a dar respuestas satisfactorias a las necesidades jurídicas sobrevinientes, especialmente de las personas que ni siquiera tienen la posibilidad de acudir a un tribunal, dentro de las cuales contar con un abogado gratuito y con todas las garantías de un debido proceso, si bien es fundamental, no reviste el carácter, de única y excluyente ${ }^{122}$.

\footnotetext{
${ }^{120}$ UNIVERSIDAD DIEGO PORTALES. (2017). “Acceso a la justicia en Chile”. Op. Cit., p. 363. “En este nuevo paradigma cualquier traba o barrera tendiente a impedir que una persona pueda hacer valer sus derechos y resolver sus disputas bajo el auspicio del Estado, afecta a la dignidad del hombre"

${ }^{121}$ CORTE IDH. Caso Velásquez Rodríguez vs. Honduras. Sentencia de 29 de julio de 1988, párrafo 167: “La obligación de garantizar el libre y pleno ejercicio de los derechos humanos no se agota con la existencia de un orden normativo dirigido a hacer posible el cumplimiento de esta obligación, sino que comparta la necesidad de una conducta gubernamental que asegure la existencia, en la realidad, de una eficaz garantía del libre y pleno ejercicio de los derechos humanos".

${ }^{122}$ UNIVERSIDAD DIEGO PORTALES. (2017). “Acceso a la justicia en Chile”. Op. Cit., p. 363. "Por supuesto que esta definición amplia del 'acceso a la justicia', comprende también el acceso al sistema estatal de justicia, eso es, a la tutela judicial efectiva que los Estados están en la obligación de otorgar a sus ciudadanos y ciudadanas, pero no se agota en él, es decir, que 'acceso a la justicia', no es equivalente a 'tutela judicial efectiva' sino mucho más. Las acciones estatales también debería contemplar medidas de promoción de otros mecanismos no judiciales o no estatales de respuestas satisfactorias a las necesidades jurídicas de los ciudadanos y ciudadanas de las Américas que, con frecuencia, ni siquiera tienen posibilidad de acudir a los tribunales, como es el caso de muchos pueblos indígenas.
} 


\subsection{Evolución. Olas de Acceso a la Justicia}

La nueva concepción de acceso a la justicia en un sentido amplio, basada en el trato igualitario y sin discriminación, y que se centra en los grupos más vulnerables de la población, solo corresponde a uno de los enfoques del devenir histórico-social en cuanto a ésta temática, y que por lo demás ha sido precedida de diversas "Olas" de acceso a la justicia, descritas acertadamente en el trabajo de Cappelletti, expuesto adecuadamente por Javier La Rosa Calle ${ }^{123}$.

En efecto, desde 1965 nos encontramos con una primera ola de acceso a la Justicia centrada únicamente en el asesoramiento legal, avocándose los primeros esfuerzos en mejorar el acceso a la Justicia en los países occidentales, centrándose en la prestación de servicios legales a los pobres ${ }^{124}$. En la mayoría de las sociedades modernas, la ayuda de un abogado resulta esencial, sino obligatoria, para descifrar las leyes cada vez más complejas y los procedimientos para llevar a cabo una demanda, por ello los mecanismos de representación legal a los que no la pueden pagar resultan de importancia esencial ${ }^{125}$. Sin embargo, en general, los esquemas de ayuda legal en la mayoría de los países eran fundamentalmente inadecuados, pues dependían estos servicios en su mayor parte, de los servicios prestados por los abogados privados sin compensación (munus honrificum) ${ }^{126}$.

Bajo este lógica, al no emprender el Estado acción alguna más que el mero reconocimiento los instrumento de ayuda legal no fueron idóneos ni eficaces ${ }^{127}$. En

\footnotetext{
${ }^{123}$ LA ROSA CALLE, J. (2014). “Acceso a la justicia: elementos para incorporar en un enfoque integral de política pública” EN Acceso a la Justicia en el mundo rural. Lima. p. 21. “"Esta noción ha transitado por sucesivas etapas que van desde el establecimiento de una asociación directa con garantías procesales básicas (tutela judicial), de acuerdo con las cuales resultaba suficiente proveer al ciudadano de más tribunales de Justicia y de mejor calidad, con lo que se estaría satisfaciendo esta noción, hasta una visión vinculada a un derecho más complejo referido a toda clase de mecanismo eficaz que permitía solucionar un conflicto de relevancia jurídica"

${ }^{124}$ CAPPELLETTI, M y GARTH, B. Op. Cit., p. 24.

${ }^{125}$ IBIDEM. p .24. "Lo ideal sería que un caso venciera por sí mismo, por su mérito netamente jurídico, pero bien sabido es, que la igualdad de armas en sentido puro no existe y existen ciertas barreras y obstáculos difíciles de vencer, que pueden desequilibrar la balanza de la justicia a favor de los más poderosos, si es que no existen sistemas de compensación o que tiendan al equilibrio".

${ }^{126}$ IBIDEM. Op. Cit., p. 25. "Los esquemas franceses, alemán y cierto número de otros esquemas estatutarios de la segunda mitad del siglo xix establecen la obligación de los abogados particulares de prestar servicios jurídicos gratuitos a los pobres”.

${ }^{127}$ IBIDEM "El derecho al acceso fue entonces reconocido y recibió cierto apoyo; sin embargo, el Estado no emprendió ninguna acción afirmativa para garantizarlo, y como resultó predecible, dichos sistemas de ayuda
} 
este sentido resulta interesante el análisis de la Sentencia de 29 de julio de 2009, rol 1254-2008 del TC, que se refiere a la evolución del rol del abogado en el sistema judicial nacional, y a la expulsión a través de ésta sentencia del artículo 595 del Código Orgánico de Tribunales (COT), que elimina del ordenamiento jurídico la expresión "gratuitamente" a la labor del "abogado de turno", cuando el tribunal impone a un abogado la carga de asistir jurídicamente a una persona que carece de los medios económicos para proveerse de los servicios de un abogado particular, y que hubieran obtenido o debieran obtener privilegio de pobreza ${ }^{128}$.

Una segunda Ola, se enfocó en la representación legal a los intereses difusos, que son colectivos, como la defensa al derecho a vivir en un medio ambiente libre de contaminación, que se ven mermados en su capacidad de ejercicio por parte de la ciudadanía, en tal que nadie tiene el derecho de remediar el daño al interés colectivo, o bien el interés de cada quien para remediarlo es demasiado pequeño para inducirlo a emprender una acción.

La tercera Ola, que es la que se identifica con esta visión amplia, reconocida por la legislación internacional, en el plano americano y europeo, que es coherente con un Estado de Derecho, denominada simplemente enfoque de acceso a la justicia. Precisamente, es la que incluye los enfoques anteriores y va mucho más allá, representando así un intento de atacar las barreras de acceso en una forma más articulada y compleja, pues venciéndose estas barreras de forma integral y cabal, los grupos vulnerables podrán acceder efectivamente a la justicia, tutelándose adecuadamente sus derechos y resolviéndose sus conflictos, en atención a sus singulares condiciones. Lo anterior, en el entendido que no son los mismos obstáculos los que encuentra una persona con discapacidad o las que presenta un niño, para acceder a un remedio jurídico eficaz ante el desconocimiento o transgresión de sus derechos, especialmente fundamentales, por un tercero o por el Estado, y de esta manera, a través de la remoción estatal de obstáculos, puede alcanzar su máxima realización espiritual y material posible, que es una de las finalidades esenciales del Estado.

legal resultaron ineficaces, pues los abogados en las economías de mercado tendieron a dedicar su tiempo más al trabajo remunerativo, que a la ayuda legal gratuita".

${ }^{128}$ TC. Sentencia causa rol 1.254-08, de 29 de julio de 2009. 
Bajo el prisma de esta tercera Ola, la reflexión en relación a la forma de hacer valer efectivamente los derechos, debe pasar necesariamente, como se ha esbozado, por cuestionar las visiones tradicionales que señalan que este acceso queda asegurado solamente con sumar tribunales y/o adecuadas garantías formales para el debido proceso. Esta nueva concepción no funciona como un derecho que persigue solamente la satisfacción de necesidades jurídicas, sino como una herramienta para atacar los problemas sociales, que en la mayoría de las veces constituyen barreras de acceso, que dan por resultado que finalmente no existan igualdad de oportunidades y se generen desigualdades sociales ${ }^{129 " .}$.

Este nuevo acceso a la justicia no se agota en el aspecto cualitativo ni cualitativo de los recursos judiciales, sino debe entenderse a la justicia como un medio y un fin, es decir, se debe comprender el acceso a la justicia como un instrumento para la transformación de las relaciones de poder que perpetúan la exclusión, la pobreza y la dependencia de tales grupos.

Dentro de las finalidades del PNUD, se posiciona la garantía del acceso a la justicia, mediante la promoción de un Estado de Derecho en los diversos órdenes. "Asimismo, uno de los objetivos del PNUD para el desarrollo de la Organización de Naciones Unidas, establece la promoción de sociedades pacificas e inclusivas para el desarrollo sostenible, facilitar el acceso a la justicia para todos y crear instituciones eficaces, responsables e inclusivas a todos los niveles. Una de las más que implica dicho objetivo, consiste en promover el Estado de Derecho en los planos nacional e internacional y garantizar la igualdad de acceso a la justicia para todos" 130 .

\section{LA NUEVA CONCEPCION DEL ACCESO A LA JUSTICIA}

Tal como lo hemos señalado, esta nueva concepción no solo se circunscribe a la

\footnotetext{
${ }^{129}$ Ejemplificando, una mujer víctima de violencia doméstica, que denuncia una agresión y ésta es desestimada, sin investigarse los hechos o sancionarse al autor de dichos actos, ni tomándose medidas para que no vuelvan a repetirse, es impedida de esta forma a acceder a la justicia, en cuanto sus derechos de protección a su vida e integridad, entre otros, no pueden hacerse efectivo.

${ }^{130}$ ALMELA. C. Op. Cit., p. 3.
} 
existencia de recursos judiciales, sino también a la acción positiva del Estado, tendiente a la remoción de obstáculos u trabas, para que todas las personas, sin distinción alguna, especialmente las vulnerables, puedan no solo acceder a tribunales y formular recursos judiciales con debidas garantías, sino poder ejercerlos de forma igualitaria, por ejemplo, a través de una asistencia jurídica gratuita con estándares de calidad ${ }^{131}$

El acceso a la justicia en esta nueva concepción, se construye en base a tres avances de derechos humanos, que se cimientan de los contenidos de los instrumentos de protección, tanto generales como específicos, que se han ido aprobando por la comunidad internacional. Esta concepción amplia e integral los acoge íntegramente, traduciéndose en:

a) Primer avance: Incluir dentro del acceso a la justicia, el derecho de toda persona de contar con una tutela judicial efectiva de sus derechos e intereses legítimos, como las garantías del debido proceso.

b) Segundo avance: Obligación del Estado de Remover las barreras, obstáculos u trabas de todo tipo que impiden o dificultan el ejercicio de los derechos que consagra el ordenamiento jurídico nacional o internacional vinculante.

c) Tercer avance: Que el acceso a la justicia debe considerar las particularidades de cada grupo vulnerable, significando que la remoción de barreras de acceso a la justicia por parte del Estado debe especialmente centrarse en los grupos que se cataloguen según determinados factores en situación de vulnerabilidad, atendiéndose siempre sus condiciones singulares, que precisamente los sitúan en una posición más dificultosa que el resto de la población para el ejercicio de los derechos.

\subsection{Obligaciones de Estado en cuanto a la concesión de recursos judiciales con garantías de debido proceso}

\footnotetext{
${ }^{131}$ Además se cumple exigiéndose al Estado, la implementación de medidas de compensación para que los más desfavorecidos puedan ejercer sus derechos, y que contemple una visión integral en la forma de resolver los conflictos o en el modo de ejercitarse los derechos.
} 
Se exige, en conformidad al bloque de constitucionalidad vinculante para Chile, no solo otorgar una serie de garantías judiciales mínimas para la determinación de derechos y obligaciones a través de instituciones y procedimientos que cumplan con los requerimientos del artículo 8 de la $\mathrm{CADH}$, sino también proveer a los individuos, especialmente a los que se encuentran en condiciones de vulnerabilidad, los medios necesarios para poder acceder a dichos procedimientos e instituciones a través de recursos rápidos, sencillos y efectivos.

En este constante, se inserta el primer avance de derechos humanos relacionado con una concepción amplia de acceso a la justica, que consiste en el reconocimiento de que el respeto por parte del Estado de las garantías del debido proceso o a un proceso justo, y el derecho a la tutela judicial efectiva en caso de violación a un derecho fundamental, implica el derecho de acceso a la justicia ${ }^{132}$. En cuanto al Artículo 25 de la $\mathrm{CADH}^{133}$ se ha observado, además, que el derecho a un recurso rápido y sencillo respecto a actos que violen estos derechos fundamentales, se aplica no solo respecto de los derechos contenidos en la $\mathrm{CADH}$, sino también de aquéllos que estén reconocidos por la Constitución o por la ley ${ }^{134}$.

La exigencia de garantía real más que formal de recursos ha sido recepcionada por la jurisprudencia de la Corte IDH. Esta magistratura ha sostenido en reiteradas oportunidades, que la garantía de un recurso efectivo constituye uno de los pilares básicos, no solo de la CADH sino del propio Estado de Derecho en una sociedad democrática en el sentido de la Convención, y que para que el Estado cumpla con lo dispuesto en el artículo 25 de la $\mathrm{CADH}$ no basta con que los recursos existan

\footnotetext{
132 IBIDEM.

${ }^{133} \mathrm{CADH}$. Artículo 25. 1. “Toda persona tiene derecho a un recurso sencillo y rápido o a cualquier otro recurso efectivo ante los jueces o tribunales competentes, que la ampare contra actos que violen sus derechos fundamentales reconocidos por la Constitución, la ley o la presente Convención, aun cuando tal violación sea cometida por personas que actúen en ejercicio de sus funciones oficiales. 2. Los Estados partes se comprometen: a) a garantizar que la autoridad competente prevista por el sistema legal del Estado decidirá sobre los derechos de toda persona que interponga tal recurso. b) a desarrollar las posibilidades del recurso judicial, y c) a garantizar el cumplimiento, por las autoridades competentes, de toda decisión en que haya estimado procedente el recurso”.

${ }^{134}$ CORTE IDH. Caso Cantos vs ARGENTINA. Sentencia de 28 de noviembre de 2002. Párrafo 52.
} 
formalmente, sino que los mismos deben tener efectividad, es decir, debe brindarse a la persona la posibilidad real de interponer un recurso que sea sencillo y rápido ${ }^{135}$.

La jurisprudencia europea llega a una conclusión similar, pues de acuerdo a la opinión del Tribunal Europeo de Derechos Humanos (TEDH), "no sería concebible que el párrafo 1 del artículo 6 del $\mathrm{CEDH}$, describa en detalle las garantías procesales concedidas al as personas en un proceso pendiente y no proteja en primer término aquella que hace de hecho beneficiarse de esas garantías, es decir, el acceso a un tribunal"136.

\subsection{Obligación positivas del Estado en la concreción del derecho de acceso a la justicia}

El segundo avance importante en materia de derechos humanos consiste en la aplicación concreta al derecho de acceso a la justicia de la existencia de obligaciones positivas al Estado en materias de derechos humanos, destinadas a remover aquellas barreras y obstáculos de orden jurídico y social, económico y cultural que dificultan o impiden el pleno ejercicio de los derechos humanos por parte de sus titulares. EI TEDH había llegado a esta conclusión en el caso Airey vs Irlanda ${ }^{137}$, tal como lo cita Federico Andreu- Guzmán y Christian Courtis.

En esta línea, la Corte IDH ha determinado "que en aquellos casos en que resulta necesaria la representación legal para el ejercicio del debido proceso, si la persona no puede obtenerla, por ejemplo por carecer de recursos, y el Estado no la brinda,

\footnotetext{
${ }^{135}$ CORTE IDH. Caso Claude Reyes y otros vs chile. Sentencia de 19 de septiembre de 2006. Párrafo 127: “El recurso efectivo del artículo 25 de la Convención( derecho a ser oído) debe tramitarse conforme a las normas del debido proceso establecidas en el artículo 8.1 de la misma, todo ello dentro de la obligación general de los mismos Estados, de garantizar el libre y pleno ejercicio de los derechos reconocidos por la Convención a toda persona que se encuentre bajo su jurisdicción, no bastando que los recursos existan formalmente, sino que los mismos deben tener efectividad, pues la garantía consagrada en el artículo 25 de la Convención, constituye un pilar básico dentro de un estado de Derecho. Cualquier norma o medida que impida o dificulte hacer uso del recurso de que se trata constituye una violación del derecho al acceso a la justicia, bajo la modalidad consagrada en el artículo 25 de la Convención Americana".

${ }^{136}$ TEDH. Golder vs Reino Unido. Sentencia de 21 de febrero de 1975. Párrafo 25.

137 ANDREU.GUZMAN, F y COURTS, C. (2011). Comentarios sobre las 100 Reglas de Brasilia sobre Acceso a la Justicia de Personas en Condición de Vulnerabilidad. San José. Ediciones Corte IDH. Op. Cit., p.53. "En ese caso, se condenó a Irlanda por la existencia de requisitos legales onerosos, que impidieron a una persona de condición socioeconómica modesta iniciar un juicio de divorcio”.
} 
no es obligatorio agotar los recursos internos"138. Así se debe enfatizar, que en cuanto a los derechos sociales no hay solo una obligación negativa del Estado, en cuanto a no impedir disfrutar los recursos judiciales o de otra índole, que resulten idóneos y efectivos para reclamar la vulneración de derechos fundamentales, sino más positivo, en cuanto a que los Estados deben remover los obstáculos normativos, sociales, económicos que impiden o limiten la posibilidad de acceso a la justicia.

La Corte IDH ha señalado que "los Estados tiene la obligación de remover aquellos obstáculos que impidan o limiten el acceso a la justicia producto de la posición económica de las personas. Para ello, ha venido reconociendo que factores como los costos del proceso, la ubicación geográfica de los tribunales, o ciertas situaciones estructurales de desigualdad pueden afectar la posibilidad de acceder a la justicia y ocasionar la consecuente violación de ese derecho fundamental"139.

Es responsabilidad de los Estados derribar las barreras de acceso a la justicia, porque menoscaban el derecho a la igualdad en la medida que es manifestación de discriminación. Los Estados tienen la obligación internacional de prestar todos sus esfuerzos en remover las barreras y obstáculos para el ejercicio del derecho a acceder a la justicia. Esta obligación internacional, radica en la creciente toma de consciencia acerca de las barreras para el acceso a la justicia y para el ejercicio de cualquier otro derecho que ya no se consideran de carácter individual, sino social o grupal $^{140}$. Precisamente al incluirse este enfoque en las singularidades de los grupos o conglomerados que se encuentran en una situación de mayor

\footnotetext{
${ }^{138}$ CORTE IDH. OC 11/90, de 10 de agosto de 1990. Excepción al agotamiento de los recursos internos. Párrafo 28: "las circunstancia de un procedimiento particular, su significación, su carácter y su contexto en un sistema legal particular, son factores que fundamentan la determinación de si la representación legal es o no necesaria para el debido proceso".

139 UNIVERSIDAD DIEGO PORTALES. (2017). “Acceso a la Justicia en Chile”. Op. Cit., p. 363. “En esos casos, la Corte IDH ha destacado que contar, entre otros mecanismos, con la provisión de asistencia jurídica gratuita bajo ciertas condiciones, con el fortalecimiento de dispositivos comunitarios y la provisión de información sobre los derechos, son fórmulas adecuadas para asegurar el derecho de acceso a la justicia”.

${ }^{140}$ Esto significa que las dificultades experimentadas por las personas para acceder a la justicia y para ejercer sus derechos se deben en parte a su pertenencia a grupos sociales en situación de vulnerabilidad.
} 
vulnerabilidad, justifica la asociación con el tercer avance en materia de derechos humanos aplicable en la nueva concepción de acceso a la justicia ${ }^{141}$.

La Asamblea General de la ONU, en resolución aprobada el 24 de septiembre de $2011^{142}$, recalca la noción de igualdad en el acceso a la justicia ${ }^{143}$.

A la luz de las reflexiones de Arbeláez de Tobón y Ruiz "ha de resaltarse que un eje clave en la superación de barreras en el acceso a la justicia y la promoción del derecho a la igualdad, radica en logar que quienes hacen parte del ejercicio de la jurisdicción, logren legitimidad tres aspectos: a) Los componentes que pueden confluir en contra del acceso a la justicia. b) la necesidad de darles un abordaje multidimensional c) las implicaciones de no contribuir en superar barreras, tales como: (i) no cumplir con el deber de diligencia, referida a la obligación de garantizar la igualdad jurídica y la no discriminación contra las mujeres y demás poblaciones en situación de vulnerabilidad, vinculada con las acciones del Estado para la sensibilización, prevención, investigación, sanción y remedios contra la violencia, con una mirada integral para la reparación de las víctimas; (ii) no identificar para entender y superar las causas y situaciones de desprotección y discriminación en el contexto social y judicial, analizando las creencias, prácticas y actitudes, que lesionen a las personas involucradas por contener estereotipos, coerción o violencia, y (iii) encontrar si falta la legislación adecuada, o si se desconoce o no se cumple por diferentes razones" 144 .

\footnotetext{
${ }^{141}$ UNIVERSIDAD DIEGO PORTALES. (2017). “Acceso a la Justicia en Chile”. Op. Cit., p. 363. “Esto implica que el Estado debe garantizar que las personas que forman parte de grupos en condición de vulnerabilidad puedan ejercer este derecho de manera equivalente a los demás. Estas Barreras atentan contra el derecho a la igualdad de los individuos, en la medida que hay que reconocerlas como manifestaciones de discriminación material, por esa razón los Estados tienen la obligación de prestar todos sus esfuerzos de revisar y derribar todas esas barreras y obstáculos que impiden un libre acceso a la justicia, respecto de las personas en condición de vulnerabilidad".

${ }^{142}$ ASAMBLEA GENERAL DE LAS NACIONES UNIDAS DE 24 DE SEPTIEMBRE DE 2012. Declaración de la reunión de alto nivel sobre el Estado de Derecho en los planos nacional e internacional.

${ }^{143}$ IBIDEM. Párrafo 115: "Ponemos de relieve el derecho a la igualdad de acceso a la justicia para todos, incluido los miembros de los grupos vulnerables y la importancia de la concienciación sobre los derechos jurídicos, y, a este respecto nos comprometemos a adoptar todas las medidas necesarias para prestar servicios justos, transparentes, eficaces, no discriminatorios, responsables y que promuevan el acceso a la justicia para todos, entre ellos, la asistencia jurídica”.

${ }^{144}$ ARBELAEZ DE TOBON, L y RUIZ , E. Op .Cit., p. 29
} 
Tal como se desarrolla en el texto de los autores Claudio Nash, Constanza Núñez y Camila Troncoso, es necesario, para cumplir con los compromisos internacionales, que el Estado asuma un rol activo y adopte un conjunto de medidas especiales que permitan que ciertos sujetos en situaciones desventajadas puedan acceder efectivamente a la justicia para la protección de sus derechos ${ }^{145}$. En este sentido se deben promover acciones estatales concretas para que el Estado logre remover estas trabas u obstáculos:

a) Creación de servicios jurídicos, gratuitos e integrales para la protección de derechos sociales organizados por el Estado.

b) Establecimiento de servicios legales gratuitos privados.

c) Organizar políticas para remover obstáculos financieros, materiales o culturales, que impiden el acceso a tribunales, oficinas públicas que ofrezcan recursos de mediación o conciliación para resolver cuestiones sobre derechos sociales en todo el territorio.

De esta manera, en las Reglas de Brasilia que analizaremos con especial detención en el apartado 3 del Capítulo III, nos encontramos con una serie de directrices en canto a la capacidad estatal para remover los diversos obstáculos de acceso a la justicia $^{146}$. Estas obligaciones en concordancia con las Reglas de Brasilia, son para los tres poderes del estado, exigiendo un rol activo a tribunales para remover

\footnotetext{
${ }^{145}$ NASH, Claudio; NUÑEZ, Constanza; TRONCOSO, Camila. (2017). “¿Existe en Chile una garantía efectiva del acceso a la justicia en condiciones de igualdad y particularmente en grupos en situación de discriminación?”. EN C. Nash (coord.). Derecho de Acceso a la justicia. Aporte para la construcción de un acervo latinoamericano. Ceja - JSA. Santiago.

${ }^{146}$ En este documento, se promueven las condiciones necesarias para que la tutela judicial sea efectiva (Regla 25). Se establece que los funcionarios y operadores trabajen en el diseño, divulgación y capacitación de una cultura cívica (Reglas 26-27); calidad de la asistencia especializada y gratuita (Reglas 28-31), derecho a intérprete, la necesidad de revisar las reglas de procedimiento para facilitar el acceso a la justicia a las personas en condición de vulnerabilidad, medidas procesales en cuanto a la tramitación ( tasas judiciales y peritajes) y los requisitos exigidos para la práctica de los actos procesales( remover la obligación de estar presente cuando implica costos de traslados, promoviendo oralidad y mejor agilidad en los procesos, especialmente alimentos, vivienda y necesidades básicas (Reglas 33-37), y medidas de organización y gestión judicial para que la misma organización del sistema judicial facilite el acceso a la justicia de las personas en condición de vulnerabilidad (Reglas 38-50).
} 
obstáculos estructurales y asegurar el real ejercicio de los derechos por parte de todos $^{147}$.

Conviene señalar que en varias sentencias la Corte IDH ha hecho referencia a las obligaciones del Estado en relación a la efectividad del derecho de acceso a la justicia proponiendo romper las barreras que frenan tal derecho, aspectos que también se toman en cuenta por la CADH. En este orden de ideas, la obligación estatal de remoción de obstáculos, se desarrollan en las sentencias de los casos Villagrán Morales vs Guatemala ${ }^{148}$, de 19 de noviembre de 1999 y el fallo del caso Ivcher Bronstein vs Perú ${ }^{149}$, de 6 febrero de 2001.

\title{
3.3. Barreras, obstáculos u trabas concretas en el acceso a la justicia
}

\author{
Existen diversos tipos de barreras que enfrentan las personas en condición de \\ vulnerabilidad, cuando interaccionan con el sistema judicial, entre ellas: de \\ infraestructura, de comunicación e información y actitudinales. En ese tanto, los
}

\footnotetext{
${ }^{147}$ ARBELAEZ DE TOBON, L y RUIZ, E. Op. Cit., p. 24

${ }^{148}$ CORTE IDH. Caso Villagrán Morales vs Guatemala. Sentencia 19 de noviembre de 1999. Párrafo 237: "Además, la Corte ha señalado que la inexistencia de un recurso efectivo contra las violaciones a los derechos reconocidos por la Convención constituye una transgresión de la misma por el Estado Parte en el cual semejante situación tenga lugar. En ese sentido debe subrayarse que, para que tal recurso exista, no basta con que esté previsto por la Constitución o la ley o con que sea formalmente admisible, sino que se requiere que sea realmente idóneo para establecer si se ha incurrido en una violación a los derechos humanos y proveer lo necesario para remediarla. No pueden considerarse efectivos aquellos recursos que, por las condiciones generales del país o incluso por las circunstancias particulares de un caso dado, resulten ilusorios...”.

${ }^{149}$ CORTE IDH. Caso Ivcher Bronstein vs Perú. Sentencia 6 de febrero de 2001. Párrs 136,137. Párrafo 136: "Además, la Corte ha señalado que la inexistencia de un recurso efectivo contra las violaciones a los derechos reconocidos por la Convención constituye una transgresión de la misma por el Estado Parte en el cual semejante situación tenga lugar. En ese sentido debe subrayarse que, para que tal recurso exista, no basta con que esté previsto por la Constitución o la ley o con que sea formalmente admisible, sino que se requiere que sea realmente idóneo para establecer si se ha incurrido en una violación a los derechos humanos y proveer lo necesario para remediarla. No pueden considerarse efectivos aquellos recursos que, por las condiciones generales del país o incluso por las circunstancias particulares de un caso dado, resulten ilusorios”. Párrafo 137: "Los recursos son ilusorios cuando se demuestra su inutilidad en la práctica, el Poder Judicial carece de la independencia necesaria para decidir con imparcialidad o faltan los medios para ejecutar las decisiones que se dictan en ellos. A esto puede agregarse la denegación de justicia, el retardo injustificado en la decisión y el impedimento del acceso del presunto lesionado al recurso judicial”.
} 
esfuerzos institucionales deben estar orientados a la eliminación de esos obstáculos ${ }^{150}$.

Entre otras barreras, que reducen considerablemente la eficacia de este derecho y que por ende deben ser superadas, dentro de las cuales se pueden nombrar las siguientes, sin perjuicio que serán revisadas en profundidad en el Capítulo III, en que se analizará con precisión los distintos grupos en condición de vulnerabilidad y las trabas que enfrentan.

a) Barreras lingüísticas y culturales: Son aquellas trabas que conllevan una limitación de acceso a la justicia para quienes integran grupos étnicos o indígenas, dado que existe dificultad de comunicación por desconocimiento del idioma oficial y no reconocimiento de su propia lengua, como asimismo que su cosmovisión y formas particulares de resolver sus conflictos jurídicos, no son consideradas como válidas por el Estado.

b) Barreras socioeconómicas: La pobreza es una causa de vulnerabilidad que agrava otras, que puede enfrentar la persona, y dificulta el pleno ejercicio de los derechos que reconoce el ordenamiento jurídico, especialmente debido a que el costo que entrañan los procesos judiciales para las personas que viven en condición de pobreza es tan alto, que deben priorizar la satisfacción de necesidades inherentes a su subsistencia, a lo que se suma el desconocimiento de los mecanismos de asistencia jurídica.

c) Barreras de género: Los factores económicos, geográficos, sociales y culturales afectan de manera diferenciada a mujeres y hombres, confirmando que se encuentran en una situación de desventaja, debido a estereotipos dañinos y roles discriminatorio que la sociedad en circunstancias determinadas les ha otorgado.

\footnotetext{
${ }^{150}$ ALMELA, C. Op. Cit. p.7. "Mejoras en las infraestructuras físicas de las instalaciones judiciales, pueden resolver o eliminar las barreras que afectan a personas con discapacidad o mujeres víctimas de violencia, y que le impiden el ejercicio de sus derechos, a veces porque materialmente es muy difícil acceder y otras veces porque la persona, cree que no va a poder ejercer sus derechos en igualdad de condiciones que los demás y renuncia a su ejercicio".
} 
d) Barreras geográficas: Hace referencia a la dificultad que pueden presentar los ciudadanos que residen en zonas alejadas del radio urbano, especialmente zonas rurales, para acudir a las sedes jurídicas en búsqueda de la tutela de sus derechos.

e) Barreras de infraestructura: El diseño de la infraestructura y de los lugares de trabajo en los cuales se llevan a cabo los actos procesales tienen incidencia no solo en la comodidad y accesibilidad de los ambientes para el usuario común, sino que se relaciona directamente también con el servicio brindado a las personas con discapacidad, niños o en caso de las mujeres víctimas de violencia.

f) Barreras institucionales: Son las barreras procesales y procedimentales que atañen a los poderes judiciales e instituciones públicas, las cuales son bien caracterizadas en las Reglas de Brasilia y se refieren a requisitos y actuaciones procesales que pueden significar una afectación o traba para personas en situación de vulnerabilidad, sea por un exceso de formalismo o porque las características de los actos procesales afectan de forma diferenciada a distintas personas usuarias, debido a factores particulares o por circunstancias sociales, culturales 0 económicas, siendo las deficiencias de la asistencia jurídica gratuita y la escasez de recursos económicos del poder judicial, un obstáculo relevante ${ }^{151}$.

g) Barreras procesales: El idioma, como asimismo la discapacidad, constituye una traba procesal, pues los procedimientos no se adaptan a estas condiciones, imposibilitando acceder a la justicia a una persona que no entiende la lengua oficial del juzgado o que no puede darse a entender por la discapacidad que presenta ${ }^{152}$.

\footnotetext{
${ }^{151}$ ARBELAEZ DE TOBON, L y RUIZ, E. Op. Cit., p. 28. "La asistencia jurídica, también se configura como una barrera institucional en la medida que los sistemas de defensa pública no cuentan con los requerimientos necesarios para que los defensores presten un servicio adecuado; y a esta falta de asistencia jurídica se suma la desinformación sobre las normas jurídicas. También se presenta una barrera institucional- económica en los poderes judiciales, la cual se manifiesta por la falta de recursos suficientes para resolver todos los conflictos que se presentan".

152 IBIDEM. "Una barrera importante a nivel del proceso en cualquier escenario jurídico, es el lenguaje utilizado en la redacción de resoluciones, notificaciones, y para llevar a cabo las audiencias y la falta de intérpretes cuando se atienden personas que usan dialectos, como en el caso de las etnias (ya mencionado en las barreras lingüísticas y culturales), o personas con discapacidad auditiva o visual, a sabiendas que se debe contar con las herramientas adecuadas para facilitar la participación de usuarios dentro del proceso (sean testigos, partes o terceros), como son los interpretes o peritos".
} 
El Estado tiene la obligación de garantizar a todas las personas la accesibilidad a ciertos mecanismos judiciales que permitan la tutela de los derechos humanos y hacer así operativo el derecho de acceso a la Justicia ${ }^{153}$. Para ello debe asumir las desigualdades económicas y sociales que pueden enfrentar ciertos grupos al momento de hacer visibles las afectaciones que experimentan, especialmente en sociedades marcadas por la desigualdad, como la latinoamericana y chilena.

\section{ESTÁNDARES DE ACCESO A LA JUSTICIA Y DEBIDA DILIGENCIA}

Para algunos "estándar" es tratado, para otras es la norma del tratado, jurisprudencia, principio, a nuestro parecer, es eso y mucho más, es todo. Estándar es la construcción que se hace a partir de un valor que va a generar un principio, una garantía, que puede ser la conjunción de la norma del tratado internacional más la interpretación de la norma que hace el órgano de protección (Corte IDH, CIDH, Comité IDH), construye y desarrolla la norma, le da vida, la amplia o restringe, si se equivoca. Esos son los estándares que pueden coincidir con la norma, o es la jurisprudencia que los "toma prestado", y entrega unas guías, lineamientos, como los que se detallarán.

Como son lineamientos internacionales pueda que surja de un tratado, de una declaración o de un derecho emergente, estos últimos que surgen de un organismo especializado, que genera una guía, protocolo o instrucciones mínimas. Se puede decir que el principio es más importante, pues las fuentes del derecho internacional no solamente se encuentran constituidas por los tratados sino también por los principios, que nos permite ir más allá de la norma, interpretando o buscando su verdadero sentido y alcance. Así el principio pro persona humana, es indiciario de entender que lo más relevante para el acceso a la justicia es la persona y no el

153 IBIDEM. "De acuerdo al informe Regional sobre Desarrollo Humano para América Latina y el Caribe 2010 del Programa de las Naciones Unidas para el desarrollo, actuar sobre el futuro: romper la transmisión intergeneracional de la desigualdad, de los quince países más desiguales del mundo, diez son de América Latina, Entre ellos se encuentra Chile”. 
Estado y que cuando hay una duda, y la probanza lo evidencia, necesariamente se debe interpretarla a favor de la persona.

Como lo hemos adelantado, Los Estados deben garantizar que todas las personas dispongan de recursos accesibles y efectivos para reivindicar derechos, pero a la luz de un enfoque integral de acceso a la justicia, estimamos que estos recursos deben proteger a personas en situación de vulnerabilidad, entre otros: niños, personas en situación de discapacidad, pueblos o comunidades indígenas o mujeres, migrantes. Además no es posible reducirlo al derecho a ser oído, o interponer recursos con determinadas características, sino que debe buscar compensar la desigualdad material que enfrentan estos grupos, ciñéndose a los siguientes parámetros:

a) Justicia accesible para todos y todas, diferenciada y multicultural.

b) Quitar obstáculos, materiales y económicos para que las personas puedan tener protección. La gratuidad, la eliminación de costas, tasas y tributos, la existencia de servicios de asistencia gratuita no solo en sede penal, la supresión de formalidad, la accesibilidad territorial, son demostraciones de aquello.

c) Eliminación de obstáculos jurídicos, como la supresión de la excesiva formalidad, la transversalidad del debido proceso, que incluye entre otras, el plazo razonable, el derecho a la defensa, tiempo y medios para resolver, igualdad de armas, igualdad de oportunidades, publicidad y oralidad de los procesos, derecho a la prueba, fundamentación de las sentencias, derecho a impugnar y cumplimiento efectivo del fallo.

La CIDH ha tenido la oportunidad de condensar y actualizar el contenido de este derecho al acceso a la justicia en lo que respecta a la tutela judicial efectiva, en el informe "Acceso a la Justicia para las Mujeres Víctimas de Violencia en las Américas" que fue presentado en marzo de 2017 en Washington DC ${ }^{154}$. Tal como

${ }^{154}$ CIDH. (2007). Acceso a la Justicia para las Mujeres Víctimas de Violencia en las Américas. Washington D.C. párrafo.2. “.......La Comisión Interamericana de Derechos Humanos observa que la gran mayoría de los casos de violencia contra las mujeres se encuentran marcados por la impunidad, lo cual alimenta la perpetuidad de esta grave violación a los derechos humanos”. 
se expresa en el informe, la fundamentación del mismo se debió a que faltaban recomendaciones a los Estados para que actuaran con diligencia debida para garantizar, en este caso específico a la mujeres, los recursos judiciales eficaces ${ }^{155}$. Los insumos para la elaboración de este informe provinieron de diversos sectores de la sociedad ${ }^{156}$. Este informe ha establecido ciertos estándares para ofrecer una respuesta judicial efectiva, no solo a incidentes de violencia que afecten mujeres, sino de carácter general, y especialmente, cuando personas vulnerables requieren acceder a la justicia, abordando este informe, entre otros aspectos, el alcance de la debida diligencia. Los estándares de debida diligencia estatal, son los siguientes: a) Existencia de recursos judiciales idóneos: El Sistema Interamericano de Derechos Humanos (SIDH), se basa en la premisa de que el acceso a recursos judiciales idóneos y efectivos, constituye la primera línea de defensa de los derechos fundamentales ${ }^{157}$. La CIDH ha interpretado una dimensión particular del derecho a la protección judicial efectiva consagrada en el artículo 25 de la CADH, como el derecho a acceder también a una tutela cautelar efectiva, en concordancia

\footnotetext{
155 IBIDEM. Párrafo 3.

${ }^{156}$ IBIDEM. "El análisis de este informe incluye información remitida a la CIDH por una diversidad de sectores que incluye la administración de la justicia, funcionarios y representantes del gobierno, la sociedad civil, el sector académico y mujeres de diferentes razas, etnias, y condiciones socioeconómicas, como parte de un proceso de investigación emprendido durante los últimos dos años por la relatoría, con el apoyo financiero del gobierno de Finlandia”.

${ }^{157}$ IBIDEM. Párrafo 23: "El sistema interamericano de derechos humanos se basa en la premisa de que el acceso a recursos judiciales idóneos y efectivos constituye la primera línea de defensa de los derechos básicos, que incluye los derechos de las mujeres en casos de violencia. En las Américas, los principios vinculantes de igualdad y no discriminación representan el eje central del sistema interamericano de derechos humanos y de los instrumentos vinculantes y aplicables al presente análisis, como la Convención Americana sobre Derechos Humanos (en adelante la 'Convención Americana"), la Declaración Americana de los Derechos y Deberes del Hombre (en adelante la "Declaración Americana") y la Convención Interamericana para Prevenir, Sancionar y Erradicar la Violencia Contra la Mujer (en adelante la "Convención de Belém do Pará"). Estos instrumentos afirman el derecho de las mujeres a acceder a un recurso judicial sencillo y eficaz que cuente con las debidas garantías cuando denuncian hechos de violencia, así como la obligación de los Estados de actuar con la debida diligencia para prevenir, investigar, sancionar y reparar estos hechos”.
} 
con lo preceptuado en la OC $11 / 90^{158}$. Siguiendo esta misma línea de razonamiento, la Corte IDH interpreta la norma en conformidad al artículo 29 de la CADH ${ }^{159}$.

Se consagra el derecho de todas las personas a acceder a recursos judiciales y a ser oídas, con las debidas garantías y dentro de un plazo razonable, por un tribunal independiente e imparcial cuando estiman que sus derechos han sido violados. La protección de estos derechos se ve reforzada por la obligación general de respetar, impuesta por el artículo 1.1 de la $\mathrm{CADH}^{160}$.

b) Los principios de igualdad y no discriminación representan el eje central deI SIDH. Al respecto, la CIDH ha señalado que "el sistema interamericano no solo recoge una noción formal de igualdad, limitada a exigir criterios de distinción objetivos y razonables y, por tanto, a prohibir diferencias de trato, irrazonables, caprichosas o arbitrarias, sino que avanza hacía un concepto de igualdad material o estructural que parte del reconocimiento que ciertos sectores de la población requieren la adopción de medidas especiales de equiparación. Ello implica la necesidad de trato diferenciado cuando, debido a las circunstancias que afectan a un grupo

158 CORTE IDH. OC 11/90 de 11 de agosto de 1990. Op. Cit., Párrafo 23: "La protección de la ley la constituyen, básicamente, los recursos que ésta dispone para la protección de los derechos garantizados por la Convención, los cuales, a la luz de la obligación positiva que el artículo 1.1 contempla para los Estados de respetarlos y garantizarlos, implica, como ya lo dijo la Corte el deber de los Estados Partes de organizar todo el aparato gubernamental y, en general, todas las estructuras a través de las cuales se manifiesta el ejercicio del poder público, de manera tal que sean capaces de asegurar jurídicamente el libre y pleno ejercicio de los derechos humanos (Caso Velásquez Rodríguez, Sentencia de 29 de julio de 1988. Serie C No. 4, párr. 166; Caso Godínez Cruz, Sentencia de 20 de enero de 1989. Serie C No. 5, párr. 175)”.

${ }^{159}$ CADH. Artículo 29: "Ninguna disposición de la presente Convención puede ser interpretada en el sentido de: a) permitir a alguno de los Estados partes, grupo o persona , suprimir el goce y ejercicio de los derechos y libertades reconocidos en la Convención o limitarlos en mayor medida que la prevista en ella; b) Limitar el goce y ejercicio de cualquier derecho o libertad que pueda estar reconocido de acuerdo a las leyes de cualquiera de los estados partes o de acuerdo con otra convención en que sea parte uno de dichos Estados; c) excluir otros derechos y garantías que son inherentes al ser humano o que se derivan de la forma democrática representativa de gobierno, y d) excluir o limita el efecto que puedan producir la Declaración Americana de Derechos y Deberes del Hombre y otros actos internacionales de la misma naturaleza".

160 CADH. Artículo 1: "Los Estados Partes en esta Convención se comprometen a respetar los derechos y libertades reconocidos en ella y a garantizar su libre y pleno ejercicio a toda persona que éste sujeta a su jurisdicción, sin discriminación alguna por motivos de raza, color, sexo, idioma, religión, opiniones políticas o de cualquier otra índole, origen nacional o social, posición económica, nacimiento o cualquier otra condición social”. 
desaventajado, la igualdad de trato suponga coartar o empeorar el acceso a un servicio, bien o el ejercicio de un derecho ${ }^{161}$.

c) El acceso a la justicia es un instrumento para eliminar la impunidad en la violación sistemática de derechos humanos: EI SIDH considera que la falta de acceso a la justicia, entendida como el derecho a la tutela judicial efectiva o protección judicial, propicia la impunidad de las violaciones de derechos humanos y la repetición de las mismas $^{162}$.

d) Respeto y promoción de las garantías del debido proceso: Los instrumentos internacionales, tanto del SIDH como del Sistema Universal de Derechos Humanos (SUDH), contemplan un conjunto de garantías básicas que todo proceso judicial debería ostentar para la vigencia efectiva del derecho al acceso a la justicia ${ }^{163}$.

e) Responsabilidad del Estado se extiende a otros entes gubernamentales o no gubernamentales: EI SIDH ha afirmado que la responsabilidad de los Estados de actuar con la debida diligencia frente a actos violentos comprende las acciones de actores no estatales, terceros y particulares ${ }^{164}$. La CIDH ha señalado que el deber de diligencia para prevenir situaciones de violencia, es especial en un contexto de prácticas extendidas o estructurales, como en el caso de los pueblos indígenas, afro descendientes, mujeres, niños, inmigrantes, entre otros, impone a los Estados el correlativo deber de vigilar la situación social mediante la producción de información

${ }^{161}$ CIDH. (2007). Acceso a la justicia para las mujeres víctimas de violencia en las Américas. párr. 26. El párrafo en cuestión señala: "Los objetivos principales del sistema regional de derechos humanos y el principio de eficacia requieren la implementación de dichas garantías. En consecuencia, cuando el ejercicio de cualquiera de estos derechos aún no está garantizado de jure y de facto por los Estados en el ámbito de su jurisdicción, de acuerdo con el artículo 2 de la Convención Americana, tienen el compromiso de adoptar medidas legislativas y de otro tipo necesarias para llevarlos a la práctica. Por lo tanto, el deber de los Estados de proveer recursos judiciales no se limita a ponerlos formalmente a disposición de las víctimas, sino que tales recursos deben ser idóneos para remediar las violaciones de derechos humanos denunciada

162 IBIDEM. párrafo 28. "La impunidad ante las violaciones de derechos humanos existe cuando hay falta en su conjunto de investigación, persecución, captura, enjuiciamiento y condena de los responsables de las violaciones de los derechos protegido por la Convención Americana....la impunidad propicia la repetición crónica de las violaciones de Derechos Humanos y la total indefensión de las víctimas y sus familiares”.

163 IBIDEM. Párrafo. 52. "Establecen que la recopilación de evidencias físicas en los casos debería ser efectuada por especialistas capacitados en el tipo de violencia que se está investigando. En todo momento, la cultura de la víctima y el contexto en el que se produjo la violencia deben tomarse en consideración y de ser necesario un intérprete, este debe hacerse disponible”.

${ }^{164}$ IBIDEM. Párrafo 29. 
estadística adecuada que permita el diseño y la evaluación de políticas públicas, así como el control de las políticas que se implementen por parte de la sociedad civil ${ }^{165}$.

En cuanto a estos estándares, se concluye que el SIDH ha consagrado y desarrollado el deber de los Estados de obrar con debida diligencia, lo que se traduce en que el deber de los Estados de proveer recursos judiciales no se limita a ponerlos formalmente a disposición de las víctimas, sino que tales recursos deben ser idóneos para remediar las violaciones de derechos humanos denunciadas ${ }^{166}$.

\section{LA TUTELA JUDICIAL EFECTIVA Y EL DEBIDO PROCESO COMO ELEMENTO INTEGRANTE DEL ACCESO A LA JUSTICIA}

\subsection{Tutela judicial efectiva y debida proceso. Presentación y línea demarcatoria}

La pretensión de proteger un derecho fundamental en forma efectiva, debe incorporar en su reconocimiento constitucional y legal, la existencia de una acción procesal destinada a hacerla valer en un proceso ante un Tribunal, siendo su presencia, un elemento necesario para el cumplimiento del acceso a la justicia.

La Tutela Judicial se cumple con la existencia de la acción y de la viabilidad de proceso llamado a hacerlo valer. Para que exista acceso a la justicia, vinculado al primer avance de derechos humanos, es necesario además que haya un debido proceso, con la finalidad de que la persona que debe someterse a un tribunal de justicia, pueda hacer valer sus derechos y defender sus intereses en forma efectiva y en condiciones de igualdad con otros justiciables, con la correspondiente obligación del Estado de romper las barreras que frenan tales derechos, conforme

\footnotetext{
165 IBIDEM. Párrafo 20.

166 IBIDEM. Párrafo 26: "La Corte Interamericana ha afirmado que......debe subrayarse que, para que tal recurso exista, no basta con que esté previsto por la Constitución o la ley o con que sea formalmente admisible, sino que se requiere que sea realmente idóneo para establecer si se ha incurrido en una violación a los derechos humanos y proveer lo necesario para remediarla”.
} 
al segundo avance. De esta manera, y en virtud del tercer avance, se desprende la necesidad de que los grupos que se encuentran en situación de vulnerabilidad tengan una protección especial y puedan acceder a un debido proceso con sus garantías inherentes y en condiciones de igualdad.

Resulta atingente lo establecido por la Corte IDH en la OC 18-03, respecto al acceso a la justicia en relación al debido proceso, al referirse a las medidas de compensación procesal que deben adoptar los tribunales ante sujetos vulnerables ${ }^{167}$.

En el derecho chileno, nos encontramos con elementos comunes a la tutela judicial efectiva y al debido proceso ${ }^{168}$. Sin embargo, El TC ha intentado trazar una frontera distintiva ente ambas instituciones protectoras. En efecto el TC, en Sentencia de 28 de enero de 2010, rol número 1535-2010, considerando 32, concluye que "se puede decir que la tutela judicial efectiva, se traduce, en la concurrencia de todos los presupuestos jurídicos que hacen efectiva esta tutela de derechos e intereses, y que operan con independencia al proceso. La tutela será plena cuando se pueda accionar ante la Jurisdicción, directa o indirectamente, con requisitos, que permitan llegar a ella, que den una respuesta de fondo a los intereses o derechos legítimos, respecto de los que se reclama y se traduzca en una sentencia fundada pública con la efectividad de cosa juzgada y con garantías de su cumplimiento. El derecho al debido proceso en cambio, se puede definir, como aquel que franqueado el acceso a la jurisdicción, permite que el proceso se desarrolle con todas las garantías

167 CORTE IDH. OC 18/03. Op. Cit., Párrafo 121: "El debido proceso legal es un derecho que debe ser garantizado a toda persona, independientemente de su estatus migratorio. Al respecto, este Tribunal ha opinado, en la referida Opinión Consultiva sobre El Derecho a la Información sobre la Asistencia Consular en el marco de las Garantías del Debido Proceso Legal, que [...] para que exista “debido proceso legal” es preciso que un justiciable pueda hacer valer sus derechos y defender sus intereses en forma efectiva y en condiciones de igualdad procesal con otros justiciables. Al efecto, es útil recordar que el proceso es un medio para asegurar, en la mayor medida posible, la solución justa de una controversia”.

${ }^{168}$ GARCIA, G y CONTRERAS, P. (2013). "El derecho a la tutela judicial efectiva y al debido proceso en la jurisprudencia del Tribunal Constitucional Chileno”. EN Estudios Constitucionales vol.11, número 1, Santiago. p.7. "Estos elementos comunes corresponden a: Mandato al legislador, apertura al derecho administrativo sancionador y a otros derechos, Garantías adaptadas a la naturaleza de los procedimientos, Inexistencia de un procedimiento tipo, interpretación amplia y de carácter supletorio de los procedimientos de la justicia ordinaria”. 
esenciales, racionales y justas que contribuyan a un procedimiento equitativo y no arbitrario"169.

El TC, se ha pronunciado sobre el contenido de la tutela judicial efectiva, sosteniendo que incluye el libre acceso a la jurisdicción, entendido como la posibilidad de formular pretensiones ante el juez, y obtener una resolución acerca de las mismas, independiente del ente persecutor estatal, así como el derecho a la ejecución de las resoluciones judiciales, la interdicción de la indefensión y el derecho al debido proceso, con plena eficacia de las garantías que le son propias ${ }^{170}$. Nogueira cita en la dirección de los fundamentos descritos por el TC, el considerando 10 de la sentencia rol 1244-08 de la CA de Santiago, caratulada "Cosmética vegetal con 4to Juzgado de Garantía de Santiago"171 172.

EI TC además ha sostenido, que el procedimiento legal debe ser racional y justo. Racional para configurar un proceso lógico y carente de arbitrariedad y justo, para orientarlo a un sentido que cautele los derechos fundamentales de los participantes en un proceso ${ }^{173}$.

Bordalí, acertadamente, y esmerándose en descartar algún sesgo de la judicatura, en cuanto a confundir ambas instituciones sostiene que "lo más esencial del derecho a la tutela judicial efectiva, es que mediante él, los individuos se aseguran el poder de acceso a los Tribunales y a obtener de estos, una decisión según lo que el derecho prescriba que deba resolverse en ese caso. Por lo mismo, se asegura con la tutela judicial, que el individuo pueda contar con la potestad jurisdiccional del Estado, para obtener tutela de derechos o intereses invocados. En cambio, el debido proceso garantiza que las actividades que se desarrollan ante un tribunal de justicia, desde que el individuo incoa su actuación o se hace parte en un proceso y obtiene una respuesta por parte de este, sea llevada a cabo de una manera que

\footnotetext{
169 TC. Sentencia causa rol 1535-2010, de 28 de enero de 2010.

${ }^{170}$ NOGUEIRA, H. (2007). El Debido Proceso en la Constitución y en el Sistema interamericano. Doctrina y Jurisprudencia. Santiago. Librotecnia. p. 197.

${ }^{171}$ IBIDEM.

${ }^{172}$ IBIDEM. Op, Cit., p. 198. "Este fallo clarifica que la tutela tiene una parte adjetiva, respecto de otros derechos e intereses, y por la otra sustantiva, pues es en sí mismo un derecho fundamental autónomo, que tiene por finalidad que las personas accedan finalmente al proceso, como medio ordinario de resolución de los conflictos jurídicos, lo que resulta un presupuesto mínimo de todo Estado de Derecho, la cual da eficacia al principio de acceso a la jurisdicción”.

${ }^{173}$ IBIDEM.
} 
presenta un buen desenlace, de forma justa y racional"174. Estimamos, que con el debido proceso se busca la justicia dentro de una decisión judicial, incidiendo en el contenido mismo de la resolución, no como en la tutela judicial efectiva, en que se busca solo obtener una resolución.

\subsection{Aspectos constitucionales del debido proceso}

El debido proceso en nuestro ordenamiento jurídico, está constituido por una serie de elementos contenidos en el artículo $19 n^{\circ} 3$ de la CPR, asegura a todas las personas la igual protección de la ley en el ejercicio de sus derechos, consagrándolo en el siguiente tenor: "toda persona tiene derecho a defensa jurídica en la forma que la ley señale y ninguna autoridad o individuo podrá impedir, restringir, o perturbar la debida intervención del letrado si hubiere sido requerida. Tratándose de los integrantes de las fuerzas armadas y de orden y seguridad pública, este derecho se regirá en lo concerniente a lo administrativo y disciplinario, por las normas pertinentes de sus respectivos estatutos. La ley arbitrará los medios para otorgar asesoramiento y defensa jurídica a quienes no puedan procurárselos por sí mismos. La ley señalará los casos y establecerá la forma en que las personas naturales víctimas de delitos dispondrán de asesoría y defensa jurídica gratuita, a efecto de ejercer la acción penal reconocidas por esta Constitución y las leyes. Toda persona imputada de delito tiene derecho irrenunciable a ser asistida por un abogado defensor proporcionado por el Estado sino nombraré uno en la oportunidad establecida por ley. Nadie podrá ser juzgado por comisiones especiales, sino por el tribunal que señalare le ley y que se hallare establecido por ésta con anterioridad a la perpetración del hecho. Toda Sentencia de un órgano que ejerza jurisdicción debe fundarse en un proceso previo legalmente tramitado. Corresponderá al legislador establecer siempre las garantías de un procedimiento y una investigación racionales y justos. La ley no podrá presumir de derecho la responsabilidad penal. Ningún delito se castigará con otra pena que la que señale una ley promulgada con

\footnotetext{
${ }^{174}$ BORDALI, A. (2011). Análisis Crítico de la jurisprudencia del tribunal constitucional sobre el derecho a la
} tutela judicial. EN Revista Chilena de Derecho. Vol. 38. pp. 321-322. 
anterioridad a su perpetración, a menos que una nueva ley favorezca al afectado. Ninguna ley podrá establecer penas sin que la conducta que se sanciona esté expresamente descrita en ella"175.

Es dable señalar que el debido proceso en Chile no solo se reduce a la garantía establecida en el artículo $19 \mathrm{n}^{\circ} 3$ inciso 6 de la Constitución, consagratoria del principio de que toda sentencia debe fundarse en un proceso previo legalmente tramitado, sino a las diversas expresiones de garantía del referido artículo, entre las que se cuentan el derecho a la defensa y la asistencia jurídica gratuita, que posibilitan que se acceda en igualdad a los órganos que ejercen jurisdicción y poder hacer valer o ejercitar efectivamente los derechos que la CPR y la ley consagran. La persona debe estar protegida en caso de cualquier acto del Estado o de otro particular que pueda afectarlos. Es decir, debido proceso no equivale a que una sentencia debe haber sido precedida por un proceso con características de legal, racional y justo, sino que todo el proceso y toda afectación jurisdiccional o administrativa respecto de una persona, debe ajustarse a todas las garantías que señala el referido artículo y las que conforman el bloque de constitucionalidad. En este orden de ideas como se desprende del articulado constitucional ya referido, las disposiciones del artículo $19 \mathrm{n}^{\circ} 3$ se refieren a diversas materias, destacando la defensa jurídica (inciso segundo y tercero), establecimiento y oportunidad del tribunal competente (inciso cuarto), protección constitucional de victima e imputados (inciso quinto), oportunidad del proceso y características del procedimiento (inciso sexto).

Al señalar la CPR "que corresponde al legislador establecer siempre las garantías un procedimiento e investigación racionales y justas", hace referencia a una clausula abierta, delegada o encomendada a la constante labor de perfeccionamiento procesal que la Constitución impone a la ley ${ }^{176}$. El debido proceso es un concepto abierto al estar inmerso en un desarrollo dinámico, pues va incorporando o perfeccionando nuevas vertientes de acuerdo a las exigencias de nuevas realidades. Compartiendo la opinión de Salvador Mohor y Paulino Varas, "no basta

\footnotetext{
${ }^{175}$ CPR. Artículo $19 \mathrm{n}^{\circ} 3$.

${ }^{176}$ Es una tarea de bien común inacabable, pues nadie y nunca ha agotado lo que implica la justicia procesal y sustantivamente concebida.
} 
solo un proceso previo, sino que este debe ser un proceso legalmente tramitado, es decir, las diversas actuaciones que configuran el proceso, deben adecuarse en su producción, orden y secuencia, a los requerimientos de un procedimiento que haya sido establecido por ley"177.

Es importante que el proceso sea legalmente tramitado, es decir su substanciación debe ser acorde a la legislación vigente y no puede tratarse de un mero arbitrio del juez que conoce del caso. Así, es necesario que el legislador establezca las garantías de un procedimiento e investigación racionales y justos. Para ello el legislador va a considerar los principios formativos básicos que rige el procedimiento, y además va a tomar en cuenta la naturaleza jurídica que posee cada uno de ellos, ya que las condiciones de racionalidad y justicia no son las mismas para todo tipo de regulación procesal. Por ello un proceso que se adapta a la ley que contiene los caracteres de racionalidad y justicia es considerado un debido proceso.

En lo que respecta al proceso previo, su importancia no solo se da cuando se pretende sancionar sin previo proceso y de espalda a los requerimientos constitucionales y legales vigentes, sino también en aquellos casos en que la inexistencia del proceso previo aparece encubierta bajo un manto de aparente legalidad, como cuando se presume de derecho la responsabilidad penal o no se notifica una demanda o la notificación adolece de vicios.

La CENC, se preocupó del tema, lo debatió y no obtuvo consenso en cuanto a los requisitos que exige un procedimiento para que integrados finalicen en un proceso que merezca los calificativos de racional y justo, o sea, legítimo. En definitiva, dicha Comisión mencionó elementos, sin agotarlos, habiendo señalando que son tres por lo menos los requisitos mayores y esenciales de un racional y justo procedimiento ${ }^{178}$ :

a) Que se deduzca y notifique la acción a las partes, otorgando a la parte contraria el plazo razonable para preparar su defensa y responderla adecuadamente.

\footnotetext{
177 MOHOR, S; VARAS, P. (1998). "Procedencia del Recurso de Protección frente a las disposiciones del artículo 19 no 3 de la Constitución”. EN Revista Chilena de Derecho. número especial. p. 283.

${ }^{178}$ CEA, J. (2012). Derecho Constitucional Chileno. Santiago. Ediciones Universidad Católica de Chile. Op. Cit., p. 172.
} 
b) Que exista real e igual oportunidad entre los litigantes, de producción y refutación de pruebas, bilateralidad de audiencia y de evidencias, que rige sin perjuicio de las constataciones que la autoridad competente ordene y obtenga de oficio.

c) Que se dicte la sentencia con respeto a la Constitución y a las leyes en procesos de doble instancia como regla general, de manera que la única instancia, o sin revisión del tribunal superior, sea nada más que excepcional.

Es dable mencionar que los requisitos señalados por la CENC no son ni siquiera los mínimos de un proceso justo, ya que quedan muchos por mencionar y lo integran. A todas luces faltarían a mi parecer a lo menos las siguientes: a) Acceso amplio a la magistratura, b) medios suficientes para una asesoría y defensa jurídicas idóneas, c) independencia institucional e imparcialidad de los jueces y funcionarios judiciales, d) rapidez y oportunidad de las decisiones y fundamentaciones de las sentencias en raciocinios lógicamente inobjetables.

Estos diversos preceptos constitucionales han sido concebidos todos y cada uno de ellos en función de una persona, que debe acceder a un tribunal e intervenir en un proceso, como actor o como sujeto pasivo, haciendo valer una pretensión o bien, sólo defendiéndose, y persiguen cada uno bajo su propia perspectiva y especificidad la configuración de un todo o unidad normativa que se propone a quienes deben intervenir en un proceso, otorgándoles la seguridad de que, tanto desde un punto de vista orgánico procedimental como sustantivo, habrá de recibir el tratamiento más equitativo, razonable y eficaz jurídicamente posible, en aras de los valores de justicia, libertad e igualdad en que se inspira nuestro régimen democrático constitucional y de acuerdo a los requerimientos de los principios de interdicción de la arbitrariedad y del Estado de Derecho.

En el ámbito del derecho internacional de derechos humanos (DIDH), y como parte del bloque de constitucionalidad chileno, el derecho a ser oído impide que una persona sea juzgada en cualquier sede de determinación de derechos, sin el respeto de las garantías mínimas consagradas, tanto en el artículo 10 de la 


\section{DUDH $^{179}$, artículo 8 de la $\mathrm{CADH}^{180}$ y artículo 14 del PIDCP ${ }^{181}$. El artículo 6 del CEDH, lo destacamos, pues es considerado en algunos fallos de los tribunales de protección regionales, aunque su texto no es vinculante para nuestro país ${ }^{182}$.}

${ }^{179}$ DUDH. Artículo 10: “Toda persona tiene derecho, en condiciones de plena igualdad, a ser oída públicamente y con justicia por un tribunal independiente e imparcial, para la determinación de sus derechos y obligaciones o para el examen de cualquier acusación contra ella en materia penal”.

${ }^{180} \mathrm{CADH}$. Artículo 8:

“1. Toda persona tiene derecho a ser oída, con las debidas garantías y dentro de un plazo razonable, por un juez o tribunal competente, independiente e imparcial, establecido con anterioridad por la ley, en la sustanciación de cualquier acusación penal formulada contra ella, o para la determinación de sus derechos y obligaciones de orden civil, laboral, fiscal o de cualquier otro carácter.

2. Toda persona inculpada de delito tiene derecho a que se presuma su inocencia mientras no se establezca legalmente su culpabilidad. Durante el proceso, toda persona tiene derecho, en plena igualdad, a las siguientes garantías mínimas:

a)derecho del inculpado de ser asistido gratuitamente por el traductor o intérprete, si no comprende o no habla el idioma del juzgado o tribunal;

b)comunicación previa y detallada al inculpado de la acusación formulada;

concesión al inculpado del tiempo y de los medios adecuados para la preparación de su defensa;

c)derecho del inculpado de defenderse personalmente o de ser asistido por un defensor de su elección y de comunicarse libre y privadamente con su defensor;

d)derecho irrenunciable de ser asistido por un defensor proporcionado por el Estado, remunerado o no según la legislación interna, si el inculpado no se defendiere por sí mismo ni nombrare defensor dentro del plazo establecido por la ley;

e)derecho de la defensa de interrogar a los testigos presentes en el tribunal y de obtener la comparecencia, como testigos o peritos, de otras personas que puedan arrojar luz sobre los hechos;

f) derecho a no ser obligado a declarar contra sí mismo ni a declararse culpable, y g) derecho de recurrir del fallo ante juez o tribunal superior. 3. La confesión del inculpado solamente es válida si es hecha sin coacción de ninguna naturaleza. 4. El inculpado absuelto por una sentencia firme no podrá ser sometido a nuevo juicio por los mismos hechos. 5. El proceso penal debe ser público, salvo en lo que sea necesario para preservar los intereses de la justicia”.

${ }^{181}$ PIDCP. Artículo 14: “Toda persona tendrá derecho a ser oída públicamente y con las debidas garantías por un tribunal competente, independiente e imparcial, establecido por la ley, en la substanciación de cualquier acusación de carácter penal formulada contra ella o para la determinación de sus derechos u obligaciones de carácter civil. La prensa y el público podrán ser excluidos de la totalidad o parte de los juicios por consideraciones de moral, orden público o seguridad nacional en una sociedad democrática, o cuando lo exija el interés de la vida privada de las partes o en la medida estrictamente necesaria en opinión del tribunal, cuando por circunstancias del asunto la publicidad pudiera perjudicar a los intereses de la justicia; pero toda sentencia en materia penal o contenciosa será pública, excepto en los casos en que el interés de menores de edad, exija lo contrario, o en las acusaciones referente a pleitos matrimoniales o a la tutela de menores. En sus posteriores numerales 2 a 7 enumera las garantías mínimas.

${ }^{182} \mathrm{CEDH}$. Artículo 6: Derecho a un proceso equitativo. 1. "Toda persona tiene derecho a que su causa sea oída equitativa, públicamente y dentro de un plazo razonable, por un tribunal independiente e imparcial, establecido por la ley, que decidirá los litigios sobre sus derechos y obligaciones de carácter civil o sobre el fundamento de cualquier acusación en materia penal dirigida contra ella. La sentencia debe ser pronunciada públicamente, pero el acceso a la sala de audiencia puede ser prohibido a la prensa y al público durante la totalidad o parte del proceso en interés de la moralidad, del orden público o de la seguridad nacional en una sociedad democrática, cuando los intereses de los menores o la protección de la vida privada de las partes en el proceso así lo exijan o en la medida considerada necesaria por el tribunal, cuando en circunstancias especiales la 
Nunca deja de ser útil recordar que el proceso es un medio para asegurar en la mayor medida posible la solución justa de una controversia y distinguir, tal como lo ha hecho el TC, el proceso del procedimiento ${ }^{183}$. Al tenor de lo razonado por el juez Sergio García Ramírez en el caso Usón Rodríguez vs Venezuela, es de relevancia destacar las características intrínsecas de la judicatura, como elementos esenciales condicionantes de otras garantías, como la defensa jurídica, el derecho al interprete, etcétera ${ }^{184}$.

\subsection{El debido proceso como principio y garantía}

\section{El debido proceso es un principio que rige todo el ordenamiento jurídico y a su vez} es una garantía para exigir el resguardo de derechos fundamentales.

El carácter de principio deriva precisamente de su identidad de derecho fundamental. De hecho, el debido proceso es "un principio general del derecho, fuente del derecho jurisdiccional" ${ }^{185}$.

publicidad pudiera ser perjudicial para los intereses de la justicia. 1. Toda persona acusada de una infracción se presume inocente hasta que su culpabilidad haya sido legalmente declarada. 2. Todo acusado tiene, como mínimo, los siguientes derechos: a) A ser informado en el más breve plazo, en una lengua que comprenda y detalladamente, de la naturaleza y de la causa de la acusación formulada contra él. b) A disponer del tiempo y de las facilidades necesarias para la preparación de su defensa. c) A defenderse por sí mismo o a ser asistido por un defensor de su elección y, si no tiene medios para pagarlo, poder ser asistido gratuitamente por un abogado de oficio, cuando los intereses de la justicia lo exijan. d) A interrogar o hacer interrogar a los testigos que declaren contra él y a obtener la citación y el interrogatorio de los testigos que declaren en su favor en las mismas condiciones que los testigos que lo hagan en su contra. e) A ser asistido gratuitamente de un intérprete, si no comprende o no habla la lengua empleada en la audiencia”.

${ }^{183}$ La jurisprudencia del T.C ha considerado pertinente referirse a la distinción entre proceso y procedimiento, realizando una adecuada conceptualización de los mismos, considerando al proceso "una serie de actos que se desarrollan progresivamente con el objeto de obtener la dictación de una sentencia, mientras que el procedimiento es el conjunto de reglas en que se desenvuelve el proceso. Así el TC concluye que es una garantía del proceso, que el procedimiento sea racional y justo, objeto cuyo cumplimiento el constituyente encomienda al legislador".

${ }^{184}$ CORTE IDH. Caso Usón Ramírez vs Venezuela. Sentencia 20 de noviembre de 2009. Voto razonado del Juez Sergio García Ramírez. Párr. 7, 8 y 10: "Si en un procedimiento se hubiesen observado formalmente todas las garantías judiciales mínimas señaladas en el artículo 8.2 de la CADH, pero no la garantía del juez competente, independiente e imparcial en el artículo 8.1, no se entendería que hubo debido proceso ni se aceptaría que su culminación constituye sentencia definitiva, ya que todas las actuaciones fueron realizadas ante un órgano que no cumplía las condiciones del artículo 8.1, lo cual es un defecto insubsanable. A modo de ejemplo se señala que, si se trató de un juez incompetente, parcial y dependiente, pero que hizo efectiva las garantías del 8.2, esta última situación no lo dota de la capacidad para resolver la controversia ni convalida la violación del artículo 8.1, puesto que el justiciable no fue oído por quién debió oírlo”.

${ }^{185}$ ESPARZA, I. (1995). El principio del proceso debido. Barcelona. J.M Bosch Editor. p. 243. 
Así, el debido proceso reviste la condición de un derecho fundamental, y como tal ha sido reconocido en las constituciones y en los tratados internacionales de derechos humanos. Debido a su carácter de derecho fundamental parece adecuado concebirlo como un principio, sin perjuicio que del debido proceso se derivan una serie de garantías judiciales que pueden revestir forma de reglas.

El Estudio de las garantías procesales de un proceso permite determinar si los procedimientos establecidos por el legislador, se satisfacen en forma adecuada con los estándares que estas garantías exigen. El bien jurídico que se resguarda es la protección de la persona como sujeto ante el derecho, siendo indispensable el respeto de las garantías de tutela judicial efectiva y debido proceso para evitar un menoscabo y precaver una imposible indefensión a la igualdad y dignidad humana $y$, que por ende, torne ilusoria la protección que brinda el sistema jurídico en su conjunto. La verdadera garantía de los derechos de las personas radica en su protección procesal, siendo las garantías, el medio por el cual se torna realizables y eficaces.

En cuanto al contenido y garantías del debido proceso, han tenido gran influencia los variados instrumentos y convenciones internacionales que han consagrado garantías mínimas del proceso, vale decir, presupuestos básicos sin los cuales no sería dable hablar de "debido proceso". La relevancia de esta protección judicial y de la asimilación del debido proceso a una garantía, adhiriéndonos a las reflexiones de Alex Carocca, "se encuentra reconocido en todas las declaraciones internacionales de derechos fundamentales relativas a la materia, adquiriendo un carácter supra positivo y supranacional, cuya legitimación, es sobre todo histórica, pues proviene de la abolición del proceso inquisitorial, de la tortura como medio de prueba, del sistema de prueba tasada, de la formación de la convicción del juez sobre la base actas escritas en un procedimiento fuera del control público (...) es un concepto previo a toda regulación jurídico positiva y una referencia reguladora de la interpretación del derecho vigente"186.

El derecho-garantía del debido proceso obedece por una parte al propósito de

\footnotetext{
${ }^{186}$ CAROCCA, A (1997). "El debido proceso en el ordenamiento jurídico chileno y el nuevo Código procesal”. EN Ius et Praxis vol.5, número 1. p. 439.
} 
impedir que las personas puedan ser condenadas sin antes ser escuchadas, y por otra, a la necesidad de asegurar que el orden de las actuaciones que configuran el proceso, es decir el procedimiento, satisfaga los requerimientos de justicia y racionalidad que hagan posible que tanto la pretensión que se hace valer como la correspondiente defensa se materialicen del modo más adecuado a los intereses de los litigantes, así como también a los intereses generales de la sociedad ${ }^{187}$. Se sostiene que todos los preceptos del artículo 19 número 3, como derechos procesales constitucionales, configuran los denominados derechos-Garantía ${ }^{188}$. Derechos, porque cada cual desde su propia perspectiva, puede exigir el beneficio o prestación especifica que justifica su consagración: libre acceso al tribunal, igual aplicación de la ley, defensa jurídica, intervención del juez natural, etc., y porque desde un punto de vista más general, permite demandar el juzgamiento más racional, justo y eficaz, jurídicamente posible. Entonces, derecho por su estructura social prestacional y garantía, porque su existencia no tiene otra razón de ser que asegurar o garantizar la más adecuada protección de los derechos subyacentes al proceso (vida, propiedad, integridad, etc.), y que precisamente se persigue hacer efectivos, recurriendo a los órganos que ejercen jurisdicción.

\section{ELEMENTOS DEL DEBIDO PROCESO EN CONFORMIDAD A LA NORMATIVA VIGENTE Y A LA LUZ DE LA INTERPRETACIÓN DE LOS ÓRGANOS DE PROTECCIÓN DE LOS DERECHOS HUMANOS}

El bloque de constitucionalidad de derechos fundamentales chileno hace que el espectro interpretativo, tanto para el legislador como para juez nacional, debe necesariamente ser amplio y no reduccionista, siendo sus faros orientadores: el derecho interno, el derecho internacional, y las sentencias de los tribunales internacionales. Estas últimas dotadas de carácter vinculante, que serán decisoras

\footnotetext{
${ }^{187}$ MOHOR, S y VARAS, P. Op. Cit., p. 281.

188 IBIDEM. p. 280.
} 
y determinantes, al momento de evaluar, si el Estado ha violado o no una garantía del debido proceso.

Como destaca Florabel Quispe, "La importancia del reconocimiento y aplicación efectiva del derecho al debido proceso en toda sociedad, sea en procesos judiciales o administrativos, sin lugar a dudas es de vital importancia ${ }^{189}$. Sin perjuicio, de que el debido proceso es un concepto indeterminado y dinámico, que se va adecuando a las realidades y acogiendo nuevas manifestaciones del mismo, el constituyente de 1980 como lo hemos mencionado, la doctrina, la jurisprudencia nacional y especialmente la internacional vinculante, que analizaremos en extenso en este apartado, han establecidos criterios y/o estándares, en cuanto a elementos básicos del debido proceso que serán abordados a continuación:

\subsection{El derecho a ser juzgado por un juez natural y competente dotado de independencia e imparcialidad}

La incorporación de los derechos fundamentales en el nivel constitucional cambia la relación entre juez y la ley, asignando a la jurisdicción una función de garantía del ciudadano frente a las violaciones de cualquier nivel de la legalidad por parte de los poderes públicos. En efecto, la sujeción del juez a la ley ya no es, como en el viejo paradigma positivista, sujeción a la letra de la ley, cualquiera que fuere su significado, sino sujeción a la ley en cuanto válida, es decir coherente con la Constitución ${ }^{190}$.

Para la Corte IDH la interpretación del artículo 8 de la CADH debe ser amplia, apoyándose en el texto literal de la norma y en su espíritu, además de ser apreciado de acuerdo con el artículo 29.c de la CADH, mediante el cual ninguna disposición de la misma puede interpretarse con exclusión de otros derechos y garantías inherentes al ser humano o que se deriven de la forma democrática representativa

\footnotetext{
189 QUISPE, F. (2010). El Debido Proceso en el Derecho Internacional y en el Sistema Interamericano. Valencia. Tirant lo Blanch. p. 352.

190 FERRAJOLI, L. (1999). Derechos y Garantías. La ley del más débil. Madrid. Editorial Trotta. p. 26.
} 
de gobierno ${ }^{191}$. La Sentencia del caso Blake vs Guatemala ${ }^{192}$, de 24 de enero de 1998, promueve, de la misma forma, una interpretación amplia del artículo $8 n^{\circ} 1$ de la CADH.

El derecho de toda persona a ser oída con las debidas garantías por un juez o tribunal competente, independiente e imparcial implica la posibilidad de poner a conocimiento y decisión de la autoridad pública cualquiera controversia de naturaleza procesal en la que pueden resultar afectados los derechos de las personas ${ }^{193}$. Siendo concordante con la interpretación dada mayoritariamente por la doctrina y jurisprudencia chilena al artículo $19 \mathrm{n}^{\circ} 3$ de la CPR, en cuanto a la "Igual protección de la Ley en el ejercicio de los derechos", la Corte IDH establece que: "cuando la Convención se refiere al derecho de toda persona a ser oída por un juez o tribunal competente para la determinación de sus derechos, se refiere a cualquiera autoridad pública, sea administrativa, legislativa o judicial, que a través de sus resoluciones determine derechos y obligaciones de las personas" ${ }^{\prime 194}$.

Tal idoneidad se alcanza a través de la figura del juez natural o competente, lo que se concreta en que el juez debe determinarse por la ley antes de la perpetración de los hechos, con la consecuente prohibición del juzgamiento por comisiones especiales. La Corte IDH ha sido enfática en ello, pues el artículo 8.1 de la Convención garantiza el derecho a ser juzgado por un tribunal competente [...] establecido con anterioridad a la ley, disposición que se relaciona con el concepto de juez natural, una de las garantías del debido proceso, a las que inclusive se ha

\footnotetext{
${ }^{191}$ CORTE IDH. Caso 19 comerciantes vs Colombia. Sentencia de 5 de julio de 2004. Párrs 185, 175. Párrafo 185: "el artículo 8.1 de la Convención debe interpretarse de manera amplia de modo que dicha interpretación se apoye tanto en el texto literal de esa norma como en su espíritu”. Párrafo. 175: “ Interpretado de esa manera, el mencionado texto comprende también el derecho de los familiares de la víctima a las garantías judiciales, por cuanto todo acto de desaparición forzada sustrae a la víctima de la protección de la ley y le causa graves sufrimientos, lo mismo que a su familia”.

${ }^{192}$ CORTE IDH. Caso Blake vs Guatemala, Sentencia de 24 de enero de 1998. Párrafo 96: "Este Tribunal considera que el artículo 8.1 de la Convención debe interpretarse de manera amplia de modo que dicha interpretación se apoye tanto en el texto literal de esa norma como en su espíritu, y debe ser apreciado de acuerdo con el artículo 29, inciso c) de la Convención, según el cual ninguna disposición de la misma puede interpretarse con exclusión de otros derechos y garantías inherentes al ser humano o que se deriven de la forma democrática representativa de gobierno".

${ }^{193}$ QUISPE, F. Op. Cit., p. 364.

${ }^{194}$ CORTE IDH. Caso Ivcher Bronstein vs Perú. Op. Cit.., párrafo 104: “Atendiendo a lo anterior, la Corte estima que tanto los órganos jurisdiccionales como los de otro carácter que ejerzan funciones de naturaleza materialmente jurisdiccional, tienen el deber de adoptar decisiones justas basadas en el respeto pleno a las garantías del debido proceso establecidas en el artículo 8 de la Convención Americana”.
} 
reconocido, por cierto sector de la doctrina, como un presupuesto de aquél. Esto implica que las personas tienen derecho a ser juzgadas, en general, por tribunales ordinarios, con arreglo a procedimientos legalmente establecidos ${ }^{195}$.

En concordancia con lo anterior se prohíbe el ejercicio de aquellos jueces no nombrados por ley y además de aquellos no identificables, los llamados "jueces sin rostro". La Corte IDH se ha pronunciado estableciendo "como violación al artículo 8.1 de la $\mathrm{CADH}$, la circunstancia de que los jueces intervinientes en procesos por delitos de traición a la patria hubieran sido 'sin rostro', [pues ello] determinó la imposibilidad de que el procesado conociera la identidad del juzgador y, por ende, valorara su idoneidad" 196 .

Ahora bien, no puede concluirse este apartado sin antes referirse al tema de los '"fueros" que se presentan en algunos países. El fuero originalmente ha sido establecido para proteger la integridad de la función estatal que compete a las personas a las que alcanza esta forma de inmunidad y evitar que se altere el normal desarrollo de la función pública. Esta función de garantía a favor de las partes y de la sociedad en su conjunto, más que respecto del aforado, ha sido recepcionada también por la jurisprudencia Interamericana. De esta forma, en el caso Barreto Leiva vs Venezuela, se sostuvo que "no constituye un derecho personal de los funcionarios sino que sirve al interés público, por lo que en principio, entendido en esos términos, el fuero persigue un fin compatible con la Convención. El fuero no necesariamente entra en colisión con el derecho al juez natural, si aquél se halla expresamente establecido y definido por el poder legislativo y atiende a una finalidad legítima"197.

\footnotetext{
195 IBIDEM

${ }^{196}$ CORTE IDH. Caso Lori Berenson vs Perú. Sentencia de 25 de noviembre de 2004. Párrafo 129: "respecto del procedimiento seguido ante la justicia militar. b) el juzgamiento de civiles por tribunales militares 'sin rostro' viola el derecho a ser juzgado por un juez o tribunal natural, competente, independiente e imparcial. Al no conocerse la identidad del juez se compromete la posibilidad de determinar su independencia e imparcialidad".

${ }^{197}$ CORTE IDH. Caso Barreto Leiva vs Venezuela. Sentencia de 17 de noviembre de 2009. Párrafo 98. "La Corte Interamericana ha establecido que la imparcialidad exige que el juez que interviene en una contienda particular se aproxime a los hechos de la causa careciendo, de manera subjetiva, de todo prejuicio y, asimismo, ofreciendo garantías suficientes de índole objetiva que permitan desterrar toda duda que el justiciable o la comunidad puedan albergar respecto de la ausencia de imparcialidad. La imparcialidad personal o subjetiva se presume a menos que exista prueba en contrario. Por su parte, la denominada prueba objetiva consiste en
} 
En palabras de Héctor Fix-Zamudio "el reconocimiento del derecho a un juez natural significa la eliminación de los tribunales de excepción y la prohibición de que las personas sean sustraídas del juez competente para ser sometidas a uno diferente, como los jueces militares"198.

A la luz de la Corte IDH, "el Estado al crear salas y juzgados transitorios especializados en derecho público y designar jueces que integraran los mismos, en el momento que ocurrían los hechos sub-lite, no garantizó el derecho a ser oído por jueces o tribunales establecidos con anterioridad por ley, consagrado en el artículo 8.1 de la Convención Americana" ${ }^{199}$.

La CPR al consagrar el principio de independencia judicial ${ }^{200}$, se refiere a la autonomía en relación a otros estamentos del Estado en razón de la división de poderes y la prohibición de otros organismos de ejercer funciones judiciales 2012. La imparcialidad en cambio, se refiere a la actitud que debe tener el órgano jurisdiccional al momento de tomar una decisión en un caso concreto, de manera que carezca de prejuicios o parcialidades ${ }^{203}$.

determinar si el juez cuestionado brindó elementos convincentes que permitan eliminar temores legítimos o fundadas sospechas de parcialidad sobre su persona".

198 FIX ZAMUDIO, H. (1988). En Latinoamérica: Constitución, Proceso y derechos humanos. Ciudad de México, Editorial Porrúa. p. 512.

${ }^{199}$ CORTE IDH. Caso Ivcher Bronstein vs Perú. Op. Cit., párrafo 114.

${ }^{200}$ CPR. Artículo 76: “...Ni el Presidente de la República ni el Congreso pueden, en caso alguno, ejercer funciones judiciales, avocarse causas pendientes, revisar los fundamentos o contenidos de sus resoluciones o hacer revivir proceso fenecidos".

${ }^{201}$ CORTE IDH, Caso Apitz Barbera y Otros vs Venezuela. Sentencia de 5 de agosto de 2008. Párrs 131, 55. Párrafo 131: "Los funcionarios públicos, en especial las más altas autoridades de gobierno, deben ser particularmente cuidadosos en orden a que sus declaraciones públicas no constituyan una forma de injerencia o presión lesiva de la independencia judicial o puedan inducir o sugerir acciones por parte de otras autoridades que vulneren la independencia o afecten la libertad del juzgador”. Párrafo 55: “Que el principio de separación de poderes tiene entre sus mayores objetivos garantizar la independencia de los jueces, tanto de manera institucional en relación con el poder judicial”.

${ }^{202}$ CORTE IDH. Caso Tribunal Constitucional vs Perú. Sentencia 31 de enero de 2001. Párrs 73 y 75. Párrafo 73: "Esta Corte considera que uno de los objetivos principales que tiene la separación de los poderes públicos, es la garantía de la independencia de los jueces y, para tales efectos, los diferentes sistemas políticos han ideado procedimientos estrictos, tanto para su nombramiento como para su destitución. Los Principios Básicos de las Naciones Unidas Relativos a la Independencia de la Judicatura, establecen que: 'La independencia de la judicatura será garantizada por el Estado y proclamada por la Constitución o la legislación del país. Todas las instituciones gubernamentales y de otra índole respetarán y acatarán la independencia de la judicatura'. Párrafo 75: "que para la Corte es necesario que se garantice la independencia de cualquier juez en un Estado de Derecho y, en especial, la del juez constitucional en razón de la naturaleza de los asuntos sometidos a su conocimiento". ${ }^{203}$ MEDINA, C. (2005). La Convención Americana, teoría y jurisprudencia. Santiago. Centro de Derechos Humanos. Facultad de Derecho Universidad de Chile. p. 298. 


\subsection{Publicidad de los actos jurisdiccionales}

En cuanto a la garantía de publicidad del proceso, es dable señalar que éste se debe desarrollar en unas circunstancias de lugar, tiempo y forma que permiten al público su presencia y, con ella, la observación y audiencia de los actos procesales que se realizan o, al menos, cuando se facilita su conocimiento posterior a través de registros ${ }^{204}$.

La Corte IDH ha señalado que la publicidad procesal "tiene la función de proscribir la administración de justicia secreta, someterla al escrutinio de las partes y del público y se relaciona con la necesidad de la transparencia e imparcialidad de las decisiones que se tomen. Además, es un medio por el cual se fomenta la confianza en los tribunales de justicia. La publicidad hace referencia específica al acceso a la información del proceso que tengan las partes e incluso los terceros" 205.

\subsection{El derecho a ser juzgado en un plazo razonable}

Al tenor de lo expresado por José Almagro "La presencia de un juez independiente, imparcial, natural, y con garantías de publicidad conlleva además que el juzgamiento debe ser en un plazo razonable. Es un derecho cuya invocación y participación se remonta a muchos años atrás, tanto en el ámbito académico como en su reconocimiento legal en el derecho interno e internacional. Lo anterior, dado que la tardanza en la tramitación de los procesos es una de las lacras tradicionales de la administración de justicia, aunque sean muchas las matizaciones que habría que tener en cuenta según la naturaleza de los asuntos y distribución de los mismos por demarcaciones judiciales"206. Para Miguel Revenga "Lo complejo es precisar los

\footnotetext{
204 TEDH. Caso Pretto y otros vs Italia. Sentencia de 8 de diciembre de 1983. párr. 67.

${ }^{205}$ CORTE IDH. Caso Palamara Iribarne vs. Chile. Op. Cit., Párrs 168, 202: Párrafo 168: "La publicidad del proceso tiene la función de proscribir la administración de justicia secreta, someterla al escrutinio de las partes y del público y se relaciona con la necesidad de la transparencia e imparcialidad de las decisiones que se tomen. Además, es un medio por el cual se fomenta la confianza en los tribunales de Justicia. Párrafo 202: "La publicidad hace referencia específica al acceso a la información del proceso que tengan las partes e incluso los terceros".

${ }^{206}$ ALMAGRO, J. (1984). Constitución y Proceso. Barcelona. Editorial Librería Bosh.. p. 110.
} 
límites de lo razonable o el alcance de las dilaciones que son indebidas. La razonabilidad es una noción con gran carga valorativa, por lo que no va a existir una regla universal que clarifique cuando estamos ante la superación del 'plazo razonable' o la 'dilación indebida'"207.

La Corte IDH ha dicho que este no es un concepto de fácil definición, y teniendo en cuenta que el artículo 8 de la CADH es equivalente en lo esencial al artículo 6 del CEDH, señala que comparte y toma en cuenta los tres elementos que el TEDH utilizó para precisarlo en varios fallos en los cuales se analizó este concepto. Es decir, la complejidad del asunto, la actividad procesal del interesado y la conducta de las autoridades judiciales ${ }^{208}$. La Corte IDH ha establecido "que el plazo razonable tiene como finalidad impedir que los acusados permanezcan largo tiempo bajo acusación y asegurar que esta se decida prontamente"209.

\subsection{Derecho a la presunción de inocencia}

Esta garantía constituye una posición de ventaja del ciudadano que es objeto de persecución penal. Esta ventaja consiste en atribuirle de entrada la calidad de persona inocente $y$, además, en no obligarle a hacer nada para demostrarlo ${ }^{210}$.

${ }^{207}$ REVENGA, M. (1992). Los retrasos judiciales ¿Cuándo vulnera el derecho a un proceso sin dilaciones indebidas. Colección de jurisprudencia práctica. Madrid. Tecnos. p. 14.

${ }^{208}$ CORTE IDH. Caso Suarez Rosero vs Ecuador. Sentencia 12 de noviembre de 1997. Párrs 72,74, 75. Párrafo 72: "Esta Corte comparte el criterio de la Corte Europea de Derechos Humanos, la cual ha analizado en varios fallos el concepto de plazo razonable y ha dicho que se debe tomar en cuenta tres elementos para determinar la razonabilidad del plazo en el cual se desarrolla el proceso: a) la complejidad del asunto, b) la actividad procesal del interesado y c) la conducta de las autoridades judiciales”. Párrafo 74: “Asimismo, la Corte estima que el hecho de que un tribunal ecuatoriano haya declarado culpable al señor Suárez Rosero del delito de encubrimiento no justifica que hubiese sido privado de libertad por más de tres años y diez meses, cuando la ley ecuatoriana establecía un máximo de dos años como pena para ese delito. Párrafo 75: "Por lo anteriormente expresado, la Corte declara que el Estado del Ecuador violó en perjuicio del señor Rafael Iván Suárez Rosero el derecho establecido en los artículos 7.5 y 8.1 de la Convención Americana a ser juzgado dentro de un plazo razonable o ser puesto en libertad".

${ }^{209}$ CORTE IDH. Caso Suarez Rosero vs Ecuador. Op. Cit., Párrafo.70: "El principio de "plazo razonable” al que hacen referencia los artículos 7.5 y 8.1 de la Convención Americana tiene como finalidad impedir que los acusados permanezcan largo tiempo bajo acusación y asegurar que ésta se decida prontamente. En el presente caso, el primer acto del procedimiento lo constituye la aprehensión del señor Suárez Rosero el 23 de junio de 1992 y, por lo tanto, a partir de ese momento debe comenzar a apreciarse el plazo".

${ }^{210}$ CAROCCA, A. Op. Cit., p. 426. 
Producto de esto, deben concurrir exigencias especiales para conseguir que sea despojado de esta condición.

Este derecho exige que el Estado no condene informalmente a una persona o emita juicio ante la sociedad, contribuyendo así a formar una opinión pública, mientras no se acredite conforme a la ley la responsabilidad penal de aquella ${ }^{211}$, Mismo razonamiento fue el de la corte en la sentencias del Caso Ricardo Baena y otros vs Panamá ${ }^{12}$, de 2 de febrero de 2002, y en la sentencia del caso Cantoral Benavides vs Perú ${ }^{213}$, de 3 de diciembre de 2001. En el entendido que las garantías del debido proceso no solo se deben asimilar al proceso penal, podemos advertir que en un sumario administrativo también regiría esta presunción de inocencia, lógicamente en un sentido ajeno al original, en cuanto al reproche punitivo.

A nuestro parecer, esta presunción de inocencia se aplica en la práctica en todo proceso, sea civil, laboral o de familia, en que la parte demandante, en aras del principio de impulso procesal de parte y pasividad del tribunal, debe acreditar cada uno de los fundamentos de su presentación o demanda, para que el demandado sea sentenciado a cumplir una prestación. Es decir, existiría una especie de "inocencia civil" en sentido amplio.

\subsection{Derechos de defensa propiamente tales}

211 CORTE IDH. Caso Tibi vs Ecuador. Op. Cit., Párrafo 182: “Considerados en su conjunto, los datos correspondientes al procesamiento penal del inculpado no solo no acreditan que se le hubiera tratado como corresponde a un presunto inocente; sino muestran que en todo momento se actuó, con respecto a él, como si fuere un presunto culpable, o bien, una persona cuya responsabilidad penal hubiere quedado clara $\mathrm{y}$ suficientemente acreditada”.

212 CORTE IDH. Caso Ricardo Baena y otros vs Panamá. Sentencia de 2 de febrero de 2002. Párrafo 153: “El artículo 16 de la Convención señala que: 1. Todas las personas tienen derecho a asociarse libremente con fines ideológicos, religiosos, políticos, económicos, laborales, sociales, culturales, deportivos o de cualquier otra índole. 2. El ejercicio de tal derecho sólo puede estar sujeto a las restricciones previstas por la ley que sean necesarias en una sociedad democrática, en interés de la seguridad nacional, de la seguridad o del orden público, o para proteger la salud o la moral pública o los derechos y libertades de los demás. 3. Lo dispuesto en este artículo no impide la imposición de restricciones legales, y aun la privación del ejercicio del derecho de asociación, a los miembros de las fuerzas armadas y de la policía”.

${ }^{213}$ CORTE IDH. Caso Cantoral Benavides vs Perú. Sentencia de 3 de diciembre de 2001. Párrafo 120: "El principio de la presunción de inocencia, tal y como se desprende del artículo 8.2 de la Convención, exige que una persona no pueda ser condenada mientras no exista prueba plena de su responsabilidad penal. Si obra contra ella prueba incompleta o insuficiente, no es procedente condenarla, sino absolverla”. 
Antes de analizar estos derechos, debemos indicar que en este criterio, se comprenden tanto, la defensa material y la jurídica, que se complementará su análisis en el Capítulo IV. Estos derechos de defensa se encuentra enumerados en el $n^{\circ} 2$ del artículo 8 de la CADH y en el $n^{\circ} 2$ del artículo 14 del PIDCP, que luego de establecer el derecho a ser oído ante un juzgado con ciertas características, indica que se cuentan con una serie de garantías mínimas que constituyen el derecho de defensa. La presunción de inocencia al constituir un estado de la persona reconocido por el derecho, se analizó no precisamente como un derecho de defensa, sino como un presupuesto del debido proceso. En la denominada defensa material, las garantías del debido proceso permiten a una persona poder hacer sus alegaciones y planteamientos ante un órgano que ejerce jurisdicción, en condiciones de igualdad, ya sea ejerciendo o resistiendo una acción.

\subsubsection{Notificación al demandado yl o comunicación previa al inculpado. Obligación de contar con intérprete o traductor}

Ninguna persona puede ser sentenciada sin que haya sido notificada de la acción y haya tenido posibilidad de contradecir las aseveraciones o afirmaciones del peticionante o demandante, en conformidad al procedimiento que rige. Claramente nos referimos a un requisito indispensable de la bilateralidad de la audiencia y del principio contradictorio. Tal como se preceptúa en el Código de Procedimiento Civil (CPC), Se traduce en que toda persona a cuyo respecto le pueda afectar los resultados de un juicio, debe ser necesariamente notificada ${ }^{214}$, y solo en ese momento nace la relación procesal, surge el emplazamiento y su posibilidad consecuente de realizar sus planteamiento y alegaciones, como manifestación de la bilateralidad de la audiencia, pudiendo renunciar a ella, operando en este caso, la institución procesal de la rebeldía.

En materia penal, la descripción material de la conducta imputada contiene los datos fácticos recogidos en la acusación, que constituyen la referencia indispensable para

\footnotetext{
${ }^{214}$ CPC. Artículo 38: "Las resoluciones judiciales sólo producen efecto en virtud de notificación hecha con arreglo a la ley, salvo los casos expresamente exceptuados por ella”.
} 
el ejercicio de la defensa del imputado y la consecuente consideración del juzgador en la sentencia ${ }^{215}$. La persona investigada por la comisión de un delito tiene desde el primer momento de esa investigación derecho a esa comunicación, para que pueda ejercer apropiadamente la defensa, pues de lo contrario esta se limitaría solo a ciertas etapas procesales con el consecuente perjuicio para la persona ${ }^{216}$.

En cuanto a la comunicación al demandado y lo imputado, se debe hacer alusión a la situación que se configura cuando los afectados no entienden el idioma del tribunal. Dentro de este mismo derecho a ser notificado y que se le comuniquen los cargos en su contra, y para que éste no sea ilusorio y se concrete efectivamente, se consagra, el derecho del inculpado a ser asistido gratuitamente por un traductor o interprete. Es un derecho relevante, pues supedita el real ejercicio del derecho de defensa, pues desconocer el idioma por en que será juzgado o que el juzgador no entienda el suyo propio, será un obstáculo, en la mayoría de las veces, insalvable para el justiciable.

${ }^{215}$ CORTE IDH. Caso Fermín Gutiérrez vs Guatemala. Sentencia de 20 de junio de 2005. Párrafo 67: “Al determinar el alcance de las garantías contenidas en el artículo 8.2 de la Convención, la Corte debe considerar el papel de la "acusación" en el debido proceso penal vis-à-vis el derecho de defensa. La descripción material de la conducta imputada contiene los datos fácticos recogidos en la acusación, que constituyen la referencia indispensable para el ejercicio de la defensa del imputado y la consecuente consideración del juzgador en la sentencia. De ahí que el imputado tenga derecho a conocer, a través de una descripción clara, detallada y precisa, los hechos que se le imputan. La calificación jurídica de éstos puede ser modificada durante el proceso por el órgano acusador o por el juzgador, sin que ello atente contra el derecho de defensa, cuando se mantengan sin variación los hechos mismos y se observen las garantías procesales previstas en la ley para llevar a cabo la nueva calificación. El llamado "principio de coherencia o de correlación entre acusación y sentencia" implica que la sentencia puede versar únicamente sobre hechos o circunstancias contemplados en la acusación".

${ }^{216}$ CORTE IDH. Caso Barreto Leiva vs Venezuela. Op. Cit. Párrs 29, 30. Párrafo 29: "Ahora bien, el derecho a la defensa debe necesariamente poder ejercerse desde que se señala a una persona como posible autor o partícipe de un hecho punible y sólo culmina cuando finaliza el proceso, incluyendo, en su caso, la etapa de ejecución de la pena. Sostener lo opuesto implicaría supeditar las garantías convencionales que protegen el derecho a la defensa, entre ellas el artículo 8.2.b, a que el investigado encuentre en determinada fase procesal, dejando abierta la posibilidad de que con anterioridad se afecte un ámbito de sus derechos a través de actos de autoridad que desconoce o a los que no puede controlar u oponerse con eficacia, lo cual es evidentemente contrario a la Convención. En efecto, impedir que la persona ejerza su derecho de defensa desde que se inicia la investigación en su contra y la autoridad dispone o ejecuta actos que implican afectación de derechos es potenciar los poderes investigativos del Estado en desmedro de derechos fundamentales de la persona investigada. El derecho a la defensa obliga al Estado a tratar al individuo en todo momento como un verdadero sujeto del proceso, en el más amplio sentido de este concepto, y no simplemente como objeto del mismo". Párrafo 30: "Por todo ello, el artículo 8.2.b convencional rige incluso antes de que se formule una “acusación” en sentido estricto. Para que el mencionado artículo satisfaga los fines que le son inherentes, es necesario que la notificación ocurra previamente a que el imputado rinda su primera declaración ante cualquiera autoridad pública”. 
En una realidad como la de América Latina y específicamente en nuestro país, donde existen comunidades que utilizan sus lenguas originarias (quechua, mapudungun, etc.), es indispensable la presencia de un traductor o interprete en todas las instancias, cuando así lo requieran. En caso contrario, se les está impidiendo expresarse en su lengua, y que realmente se entienda lo que quiso decir en su declaración en el marco de su defensa ${ }^{217}$.

Hasta el momento la Corte IDH no ha tenido la oportunidad de pronunciarse sobre esta materia en un caso contencioso. Sin embargo, existe una breve referencia al tema en una de sus OC, en donde la Corte IDH señaló que el derecho reconocido en el artículo 8.2 a de la CADH constituye un factor que permite superar eventuales situaciones de desigualdad en el desarrollo de un proceso ${ }^{218}$. Quispe, refuerza esta idea, al expresar que "el papel del Estado es indispensable para otorgar iguales derechos a todos los seres humanos que se encuentran bajo su jurisdicción, igualdad de derechos no solo en la teoría, sino también en la práctica. De ello depende que cualquier ciudadano al margen del lugar donde le toco nacer cuente con este derecho" 219 .

\subsubsection{Concesión al inculpado de tiempo y medios adecuados para la preparación de su defensa}

En cuanto a la concesión de tiempo no solo dice relación con el suficiente lapso

\footnotetext{
${ }^{217}$ En el caso de México, Colombia, Perú, Bolivia, Chile, Ecuador, donde existen grupos indígenas que no necesariamente hablan el idioma de la mayoría (el castellano).

${ }^{218}$ CORTE IDH. Opinión Consultiva 0C-16/99, Op. Cit. Párrs 119, 120. Párrafo 119: "Para alcanzar sus objetivos, el proceso debe reconocer y resolver los factores de desigualdad real de quienes son llevados ante la justicia. Es así como se atiende el principio de igualdad ante la ley y los tribunales y a la correlativa prohibición de discriminación. La presencia de condiciones de desigualdad real obliga a adoptar medidas de compensación que contribuyan a reducir o eliminar los obstáculos y deficiencias que impidan o reduzcan la defensa eficaz de los propios intereses. Si no existieran esos medios de compensación, ampliamente reconocidos en diversas vertientes del procedimiento, difícilmente se podría decir que quienes se encuentran en condiciones de desventaja disfrutan de un verdadero acceso a la justicia y se benefician de un debido proceso legal en condiciones de igualdad con quienes no afrontan esas desventajas". Párrafo 120: "Por ello se provee de traductor a quien desconoce el idioma en que se desarrolla el procedimiento, y también por eso mismo se atribuye al extranjero el derecho a ser informado oportunamente de que puede contar con la asistencia consular. Estos son medios para que los inculpados puedan hacer pleno uso de otros derechos que la ley reconoce a todas las personas. Aquéllos y éstos, indisolublemente vinculados entre sí, forman el conjunto de las garantías procesales y concurren a integrar el debido proceso legal”.

${ }^{219}$ QUISPE, F. Op. Cit., p. 415.
} 
para conocer la totalidad de las pruebas que obran en su contra, sino también analizarlas y poder plantear argumentos y contrapruebas que les permitan rebatirlas.

En cuanto a los medios adecuados, la Corte IDH ha señalado en concordancia con el TEDH, que "el inculpado tiene derecho a examinar a los testigos que declaran en su contra y a su favor, en las mismas condiciones, con el objeto de ejercer su defensa"220.

La Corte IDH ha considerado que "cualquiera legislación aplicada que imposibilite el derecho a interrogar a los testigos que fundamentaron la acusación contra las supuestas víctimas y prohíba el interrogatorio de agentes, tanto de la policía como del ejército, que hayan participado en las diligencias de investigación, violenta esta disposición"221. Específicamente, se ha reconocido la afectación del derecho de defensa en cuanto a la posibilidad de interrogar testigos ${ }^{222}$. De esta manera, dentro de los medios adecuados para su defensa se incorpora el derecho a interrogar los testigos presentes en el tribunal y de obtener la comparecencia de aquellos.

\footnotetext{
${ }^{220}$ CORTE IDH. Caso Castillo Petruzzi vs Perú. Sentencia de 30 de mayo de 1999. Párrafo 154: "Tal como lo ha señalado la Corte Europea, dentro de las prerrogativas que deben concederse a quienes hayan sido acusados está la de examinar los testigos en su contra y a su favor, bajo las mismas condiciones, con el objeto de ejercer su defensa”.

${ }^{221}$ IBIDEM. Párrafo 153: "La Corte considera que la legislación aplicada al caso imposibilita el derecho a interrogar a los testigos que fundamentaron la acusación contra las supuestas víctimas. Por una parte, se prohíbe el interrogatorio de agentes, tanto de la policía como del ejército, que hayan participado en las diligencias de investigación. Por otra, tal como ha sido consignado, la falta de intervención del abogado defensor hasta el momento en que declara el inculpado, hace que aquél no pueda controvertir las pruebas recabadas y asentadas en el atestado policial. "Los inculpados no tuvieron conocimiento oportuno y completo de los cargos que se le hacían; las condiciones en que actuaron los defensores fueron absolutamente inadecuadas para su eficaz desempeño y solo tuvieron acceso al expediente el día anterior al de la emisión de la sentencia de primera instancia, lo que resulto en que la presencia y actuación de los defensores fuera meramente formal y no se pudiere sostener que las víctimas contaran con una defensa adecuada".

${ }^{222}$ CORTE IDH. Caso García Asto Vs Perú. Sentencia 25 de noviembre de 2005. Párrafo 124 "La anulación del proceso penal seguido en el fuero común ante jueces sin rostro contra el señor Wilson García Asto fue hecha el 15 de enero de 2003 por la Tercera Sala Penal de la Corte Superior de Justicia de Lima, la cual revocó la decisión de 27 de noviembre de 2002 que había declarado infundado el hábeas corpus interpuesto a su favor y ordenó la remisión del expediente a la autoridad competente, dentro del término de 48 horas, para que se dispusiera el trámite de ley correspondiente (supra párr. 97.31). Sin embargo fue hasta el 10 de marzo de 2003 que el Primer Juzgado Especializado Penal en Delito de Terrorismo dictó el auto apertorio de instrucción en el nuevo juicio seguido contra el señor Wilson García Asto, en el que se dictó la medida cautelar de privación de libertad en su contra . Durante ese período de un mes y veinticinco días la presunta víctima permaneció privada de su libertad sin haber estado condenada ni procesada”.
} 


\subsubsection{El derecho a recurrir}

Este derecho es esencial, pues permite que los fallos puedan ser revisados por el superior jerárquico del tribunal que dictó la sentencia en primera instancia. Implica un estudio concienzudo, especialmente en aquellas resoluciones que traen aparejada cosa juzgada, como las sentencias definitivas, no obstante existir otro tipo de resoluciones, que también pueden ser apeladas, destacando en materia civil "el auto de prueba", y en materia penal "las medidas cautelares", como la prisión preventiva. Destacan en la legislación civil chilena, el recurso de reposición, recurso de aclaración, rectificación y enmienda, el mencionado recurso de apelación, recurso de casación en la forma y en el fondo, y en materia penal, entre otros, el recurso de apelación y el de nulidad. Se distinguen, los recursos vía retractación, que son resueltos por el mismo tribunal que los dictó ${ }^{223}$, y los vía reforma, en que el tribunal superior es el encargado de resolverlos, decidiendo si confirma o revoca lo dictaminado por el inferior ${ }^{224}$.

Para recurrir de una resolución es imprescindible poder tomar conocimiento en tiempo y forma de la resolución o decisión susceptible de ser impugnada, pues de lo contrario, este derecho a recurrir se constituiría en una formalidad o rito carente de efecto. En la jurisprudencia interamericana, tal como lo ha expresado Luis Huerta, "el ejercicio del derecho a recurrir del fallo ante el juez o tribunal superior, como es lógico suponer, implica que toda persona tiene derecho a disponer en un plazo razonable y por escrito o vía digital, de los fallos en los que se determina su responsabilidad a efecto de su posible apelación. En caso contrario no se estaría concediendo la debida revisión de la sentencia, ni acceso oportuno a las razones del fallo, impidiéndose ejercer eficazmente el derecho de defensa"225.

\footnotetext{
${ }^{223}$ CPC. Artículo 182: "Notificada una sentencia definitiva o interlocutoria a alguna de las partes no podrá el tribunal que la dictó alterarla o modificarla en manera alguna. Podrá, sin embargo, a solicitud de parte, aclarar los puntos obscuros o dudosos, salvar las omisiones y rectificar los errores de copia, de referencia o de cálculos numéricos que aparezcan de manifiesto en la misma sentencia...”

${ }^{224}$ IBIDEM. Artículo 189: "La apelación deberá interponerse en el plazo fatal de 5 días, contados desde la notificación de la parte que entabla el recurso, deberá contener los fundamentos de hecho y de derecho en que se apoya y las peticiones concretas que se formulan”.

${ }^{225}$ HUERTA, L. (2003). El debido proceso en las decisiones de la corte interamericana de derechos humanos. Comisión Andina de Juristas. Lima. p. 49. "Esto implica asimismo que las resoluciones que se emitan en
} 
A este respecto la Corte IDH, ha aclarado que "este proceso de revisión debe contar con todas las garantías que forman parte del debido proceso, para que pueda hablarse de una verdadera verificación, no bastando el mero reconocimiento teórico de medios de impugnación, sino de que éstos deben ser efectivos en la práctica. De esta manera, no basta con la existencia formal de los recursos, sino que éstos deben ser eficaces, es decir, deben dar resultados o respuestas al fin para el cual fueron concebidos"226. En el fallo del caso Castillo Pertruzzi vs Perú, se destaca la necesidad de contar con un juez natural 227.

El derecho a defenderse por medio de abogado defensor y el derecho a la asistencia Jurídica gratuita, tanto en su génesis, desarrollo institucional, naturaleza jurídica y otras manifestaciones del mismo, será ampliamente en el Capítulo IV de la presente tesis.

\section{EI DERECHO DE ACCESO A LA JUSTICIA EN CHILE}

\subsection{El derecho de concurrir ante los órganos que ejercen jurisdicción y la igual protección de la ley en el ejercicio de los derechos conforme al bloque de constitucionalidad chileno}

El Acceso a la Justicia, principio esencial de todo sistema de justicia, implica que los ciudadanos puedan ejercer sus derechos y dar solución a sus conflictos en forma eficiente y oportuna. A juicio de Sebastián Cox, "este concepto presenta una visión

\footnotetext{
distintas instancias deben contener, con exactitud y claridad, las razones por las cuales se llega a la conclusión que ellas contienen, la valoración de las pruebas y los fundamentos jurídicos y normativos que se basan”.

${ }^{226}$ CORTE IDH. Caso Herrera Ulloa Vs Costa Rica. Sentencia 2 de julio de 2004. Párrafo 161: “de acuerdo al objeto y fin de la Convención Americana, cual es la eficaz protección de los derechos humanos, se debe entender que el recurso que contempla el artículo 8.2.h. de dicho tratado debe ser un recurso ordinario eficaz mediante el cual un juez o tribunal superior procure la corrección de decisiones jurisdiccionales contrarias al derecho. Si bien los Estados tienen un margen de apreciación para regular el ejercicio de ese recurso, no pueden establecer restricciones o requisitos que infrinjan la esencia misma del derecho de recurrir del fallo. Al respecto, la Corte ha establecido que "no basta con la existencia formal de los recursos sino que éstos deben ser eficaces, es decir, deben dar resultados o respuestas al fin para el cual fueron concebidos".

${ }^{227}$ CORTE IDH. Caso Castillo Petruzzi Vs Perú. Op. Cit., Párrafo 161: "La Corte advierte que, según declaró anteriormente (supra 134), los procesos seguidos ante el fuero militar contra civiles por el delito de traición a la patria violan la garantía del juez natural establecida por el artículo 8.1 de la Convención. El derecho de recurrir del fallo, consagrado por la Convención, no se satisface con la mera existencia de un órgano de grado superior al que juzgó y condenó al inculpado, ante el que éste tenga o pueda tener acceso...”.
} 
amplia de la administración de justicia, entendiendo que las ofertas de servicios incluyen, además de la solución jurisdiccional de tutela preferentemente estatal, la promoción de los derechos, la prevención y la solución colaborativa de los conflictos, en donde participen variados sectores sociales, y no solo el estamento público y la judicatura"228.

Para lograr este objetivo se requiere que puedan obtener del Estado diversas prestaciones, dentro de las que se considera el derecho de acceder al órgano jurisdiccional o al dispositivo estatal o no estatal, destinados a la resolución de sus conflictos o tendientes a hacer efectivos sus derechos, como asimismo a un amplio catálogo de garantías mínimas reconocidas por las constituciones nacionales y convenciones o tratados internacionales.

El numerando 3 del artículo 19 de la CPR, luego de consagrar el derecho a la vida y la igualdad ante la ley, asegura "la igual protección de la ley en el ejercicio de los derechos". En el seno de la CENC, la moción original contemplaba en su inciso cuarto una consagración más directa del derecho de concurrir a tribunales, expresando que: "toda persona puede concurrir a los tribunales para hacer valer sus derechos y dispondrá de un recurso contra los actos que lo violen"229. En este sentido el comisionado Enrique Silva, autor de dicha moción, indicaba que este precepto guardaba armonía con el artículo 8 de la CADH y con el artículo 14 del PIDCP, opinión que reviste mucha importancia y efectividad en una época en que la apertura al DIDH no estaba totalmente internalizada y desarrollada ${ }^{230}$. Si bien esta moción fue rechazada ${ }^{231}$, no se discute que el derecho de concurrir a tribunales

${ }^{228}$ COX, S. (2006). Acceso a la Justicia en Realidades-Tendencias y Propuestas. Santiago Op. Cit., p. 17.

${ }^{229}$ EVANS, E. (1986). Derechos Constitucionales. Editorial Jurídica de Chile. p. 139.

${ }^{230}$ La CADH fue suscrita en San José de Costa Rica el 22 de noviembre de 1969, ratificada el 8 de octubre de 1990 bajo el gobierno del Presidente Patricio Aylwin, entrando en vigor en Chile, con la publicación en el diario oficial el 5 de enero de 1991.

${ }^{231}$ El señor Ovalle, integrante de la Comisión de estudios, en la fase de discusión, indicaba que "involucra cierto riesgo desde un punto de vista que le parece delicado, púes podría pensarse que se está consagrando el derecho a recurrir siempre personalmente a los tribunales, y cree que sería inadecuado volver a litigar en esa forma, en la que pueden intervenir inclusive personas que no son letradas. Señala que comprende que el señor Silva Bascuñán debe haber pensado al redactar este precepto, que otras disposiciones establecerán él principio pertinente en esta materia con el objeto de que los derechos sean defendidos por intermedio de letrados y que no se pueda concurrir en forma personal a los tribunales a defender o a impetrar derechos, pero estima que, en todo caso, la redacción es equívoca y podría dar lugar a que se pensara en la forma que ha expuesto. Agrega que, por otra parte, la concurrencia a los tribunales de toda persona ya está consultada al asegurarse en el inciso 
está garantizado en el enunciado de la Constitución "Igual protección en el ejercicio de los derechos", y que los temores respecto a una negación de conocimiento, juzgamiento y sentencia de los hechos denunciados por los órganos que ejercen jurisdicción, estaría subsanado por el artículo 76 de la misma Carta magna ${ }^{232}$, que consagra precisamente la obligación de los tribunales de conocer, juzgar y ejecutar lo juzgado, como asimismo con la consagración del principio de inexcusabilidad de los tribunales en el mismo precepto ${ }^{233}$, y en el artículo 10 inciso segundo del COT $^{234}$. Tal como lo sostiene Enrique Evans, que además fue integrante de la CENC, "este derecho de la igual protección de la ley en el ejercicio de los derechos fue propuesto, pues se consideraba constituirse en una consecuencia de la igualdad ante la ley y con ella se pretendía que todos quienes deben recurrir ante cualquier autoridad, incluyendo a los tribunales de diversa naturaleza, para la protección de sus derechos se encuentren en un plano de igualdad jurídica, sin que existan privilegios o fueros especiales en razón de nacionalidad, raza, sexo, condición social o situación económica y sin que sean admisibles discriminaciones arbitrarias, es decir, odiosas, injustas o irracionales"235. Con lo anterior queda de manifiesto que los demandantes, demandados, terceros y los interesados pueden hacer valer todas sus prerrogativas, acciones y defensas procesales y de fondo en un plano de absoluta igualdad jurídica.

A diferencia de la igualdad en la ley, regulada en el artículo 19 número 2 de la $\mathrm{CPR}^{236}$, a la luz de lo expresado por José Luis Cea, "esta nueva especie de igualdad

primero "la igual protección en el ejercicio de los derechos..." y en el inciso segundo, al contemplarse el derecho a la asistencia de un abogado.

${ }^{232}$ Este precepto Constitucional señala en su inciso primero "La facultad de conocer de las causas civiles y criminales, de resolverlas y hacer ejecutar lo juzgado pertenece exclusivamente a los Tribunales establecidos por ley. Ni el Presidente de la República ni el congreso pueden en caso alguno, ejercer funciones judiciales, avocarse causas pendientes, revisar los fundamentos o contenidos de sus resoluciones o hacer revivir procesos fenecidos.

${ }^{233}$ En el mismo artículo 76 la Constitución preceptúa "reclamada su intervención en forma legal y en negocios de su competencia no podrán excusarse de ejercer su autoridad, ni aún por falta de ley la contienda o asunto sometido a su jurisdicción”.

${ }^{234}$ En este cuerpo legal, el artículo referido indica "reclamada su intervención en forma legal y en negocios de su competencia, no podrán excusarse de ejercer su autoridad ni aún por falta de ley que resuelva la contienda sometida a su decisión".

${ }^{235}$ EVANS, E. Op. Cit., p. 140.

${ }^{236}$ CPR. Artículo 19 no 2 : "El Estado asegura a todos los habitantes de la República, número 2: "La igualdad ante la ley. En Chile no hay persona ni grupo privilegiado. En Chile no hay esclavos y el que pise su territorio 
se refiere a la igualdad más que nada procesal, y por ende muy cercana a la judicatura, pero no exclusiva de ésta. Cuando se la restringe al amparo judicial, entonces merece llamársela derecho a la tutela judicial efectiva, o más clásica e inexactamente derecho a la acción" ${ }^{237}$. Debe hacerse hincapié tal como lo sostiene el referido autor, en el sentido que "el derecho a la Igual protección en el ejercicio de sus derechos excede ampliamente su ejercicio ante la magistratura. No es sinónimo de igualdad solo ante la justicia en la implementación del ordenamiento jurídico"238. No se aplica entonces, solo a los tribunales como se desprendía de la Constitución de 1925, sino que es la protección y promoción de los derechos esenciales en cualquier esfera donde se encuentren amenazados o sean vulnerados, cualquiera sea el infractor, la que debe siempre entenderse procedente como tutela del ordenamiento jurídico.

La igual protección de la ley en el disfrute de los derechos no es asunto que se resuelva únicamente con reglas formales de acceso a los órganos públicos, porque presupone además, que las personas en especial la de modestos recursos o de los grupos desprotegidos, disponga en la realidad de medios adecuados para lograr que sus derechos sean legalmente cautelados.

\subsection{Tratamiento jurisprudencial del derecho de acceso a la justicia en Chile}

Con respecto a la jurisprudencia, esta ha ido evolucionando desde entenderla solo como un derecho a la acción hacía un concepto más amplio de acceso a la justicia, incorporando los elementos mencionados ya anteriormente (derecho a defensa, asistencia jurídica gratuita, derecho a ser oído, etc.), pero sin mayor claridad conceptual en cuanto a diferenciarlo del derecho a un debido proceso o del derecho a la tutela judicial ${ }^{239}$. El énfasis en los grupos en condiciones de vulnerabilidad, también es recepcionado por la judicatura constitucional, en el entendido que el

queda libre. Hombres y Mujeres son iguales ante la ley. Ni la ley ni autoridad alguna podrán establecer diferencias arbitrarias”.

${ }^{237}$ CEA, J. Op. Cit., p. 153.

${ }^{238}$ IBIDEM. p. 165.

${ }^{239}$ NASH, C; NUÑEZ, C; TRONCOSO, C. Op. Cit., p. 348. 
concepto de acceso a la justicia es omnicomprensivo de todas las facultades que permitan el ejercicio pleno de los derechos en un plano de igualdad y sin discriminación. Precisamente, este ha sido razonamiento del TC, sosteniendo que "si bien constatamos fallas a nivel general, el análisis que puede realizarse con respecto a grupos en situación de discriminación estructural presenta incluso más deficiencias. Las barreras lingüísticas y culturales, económicas y las barreras de género, son fenómenos comunes en América Latina, que inevitablemente permean el derecho de acceso a la justicia en grupos tradicionalmente discriminados o vulnerables, debido a ello, se ha establecido normativa especial en algunos casos, y en otros, la jurisprudencia y la política pública han sido las que se han utilizado para paliar los déficit encontrados"240.

En todos los análisis jurisprudenciales vinculados al derecho de acceso a la justicia, se menciona el artículo $19 \mathrm{n}^{\circ} 3$ de la CPR, como parte fundante del derecho a la justicia. En su primera aproximación a la temática, el TC dictaminó "que, por otra parte, la Constitución reconoce en su artículo $19 \mathrm{n}^{\circ} 3$, el derecho a la igual protección de la ley en el ejercicio de los derechos, lo que implica un conjunto de garantías fundamentales, entre las que pueden señalarse: el derecho fundamental de acceso a la justicia y la efectiva tutela de los derechos por parte de los tribunales, que junto con el derecho al juez natural, y al debido procedimiento, configuran el 'alma' de aquella garantía que todo ser humano posee de recurrir al juez (independiente e imparcial) en demanda de justicia, ser oído y ser resueltas sus pretensiones conforme a derecho, y hacer así posible la convivencia social en paz"241.

En otro pronunciamiento, el TC estableció que "el derecho de las personas a acceder libremente a un tribunal de justicia para la protección de sus derechos, es uno de los asegurados en el número 3 del artículo 19 de la Constitución, pues, aunque no esté designado expresamente en su texto escrito, carecería de sentido que la Carta Fundamental se hubiese esmerado en asegurar la igual protección de

\footnotetext{
${ }^{240}$ IBIDEM. p. 349.

${ }^{241}$ TC. Sentencia causa rol 248-1996, de 22 de octubre de 1996. Considerando $5^{\circ}$.
} 
la ley en el ejercicio de los derechos, el derecho a la defensa jurídica, el derecho a ser juzgado por el juez natural, el derecho a un justo y racional procedimiento, sino partiera de la base de la existencia de un derecho anterior a todos los demás y que es presupuesto básico para su vigencia, esto es, el derecho de toda persona a ser juzgada, a presentarse ante el juez, a ocurrir al juez, sin estorbos, gabelas o condiciones que se lo dificulten, retarden o impidan arbitraria o ilegítimamente ${ }^{242}$. Vinculado a lo anterior, el mismo TC ha considerado que el derecho de acceso a la justicia es una manifestación del derecho a la igual protección de la ley en el ejercicio de los derechos ${ }^{243}$.

Por su parte, las CS y CA han dado un contenido más amplio, relacionando el acceso a la justicia con diversos elementos:

a) Derecho a la acción ${ }^{244}$.

b) Derecho a ser oído ${ }^{245}$.

c) Derecho a la defensa jurídica o asistencia letrada eficaz y especializada ${ }^{246}$.

d) Derecho a la tutela judicial efectiva y a obtener una sentencia sobre el fondo del asunto $^{247}$.

e) Como un derecho vinculado al derecho a la verdad y recibir reparación de los familiares de víctimas de violaciones graves y sistemáticas de los derechos humanos ${ }^{248}$.

Entre los requisitos que deben concurrir para entender garantizado el derecho, la jurisprudencia ha mencionado que: a) No deben existir barreras de carácter económico para acceder a la justicia (Prohibición del solve et repete ${ }^{249}$ ).

\footnotetext{
${ }^{242}$ IBIDEM. Sentencia causa rol 1470-2009, de 27 de octubre de 2009. Considerando $9^{\circ}$.

243 TC. Sentencia causa rol 2042-2015, de 10 de julio de 2012. Considerando 29. "la igualdad en el ejercicio de los derechos supone el derecho a acceder a la jurisdicción para satisfacer la pretensión que sustenta un justiciable. Desde ese punto de vista, la satisfacción de esa pretensión a través del proceso no debe experimentar impedimentos u obstáculos que, en definitiva coarten el acceso a la justicia”.

${ }^{244}$ CS. Sentencia causa rol 8778-2015, de 7 de septiembre de 2015.

${ }^{245}$ IBIDEM. Sentencia causa rol 5851-2015, de 16 de junio de 2015.

${ }^{246}$ IBIDEM. Sentencia causa rol 921-2012, de 5 de abril de 2012.

${ }^{247}$ CA de SANTIAGO. Sentencia causa rol 1369-2014, de 13 de enero de 2015.

${ }^{248}$ CS. Sentencia causa rol 11.964-2014, de 12 de enero de 2015.

${ }^{249}$ TC. Sentencia causa rol 1580-2009, de 27 de enero de 2011.
} 
b) Deben eliminarse las trabas que obstaculizan el acceso al proceso, tanto para impedir que, como consecuencia de los formalismos procesales, queden ámbitos de la actividad administrativa inmunes al control judicial ${ }^{250}$. En este sentido no deben imponerse exigencias que no han sido establecidas por ley o que no se concilian con la naturaleza de los procedimientos ${ }^{251}$.

c) No deben existir barreras geográficas para acceder a la justicia 252 .

En síntesis, la jurisprudencia chilena desarrolla un concepto amplio de acceso a la justicia, vinculándolo fundamentalmente con la protección judicial y la tutela judicial efectiva. Pese a ello, no se distingue claramente el contenido de este derecho respecto de los otros, existiendo una variedad de acepciones para el mismo concepto. Lo que sí es claro, es que existe consenso en que no deben existir barreras (económicas o requisitos procesales) que hagan ilusoria la garantía del derecho de acceso a la justicia ${ }^{253}$.

\subsection{El acceso a la justicia en una nueva Constitución para Chile}

En el contexto del denominado "estallido social" ${ }^{254}$ que vivenció Chile entre octubre y diciembre del año 2019, el Presidente de la República Sebastián Piñera, anunció el día 15 de noviembre, fruto de un acuerdo con la mayoría de los partidos políticos, la realización de un plebiscito para que se decidiera la redacción de una nueva

\footnotetext{
250 TC. Sentencia causa rol 2495-2013, de 31 de julio de 2014.

${ }^{251}$ CA de SANTIAGO. Sentencia causa rol 983-2016, de 6 de diciembre de 2016.

${ }^{252}$ CA de CONCEPCION. Sentencia causa rol 3606-2014, de 25 de noviembre de 2014.

${ }^{253}$ NASH, C; NUÑEZ C; TRONCOSO, C. Op. Cit. p. 321.

${ }^{254}$ Corresponden a una serie de protestas iniciadas en Santiago, desde el 14 de octubre de 2019, cuyo punto gatillaste fue una evasión en el pago de boleto en estaciones de metro, producto aumentó de la tarifa de este transporte público. Estas manifestaciones se propagaron al resto de chile se sucedieron también tomas de carreteras, paralización de actividades, toques de queda y decretar Estados de Excepción. además actos vandálicos, como daños e incendios intencionales a la propiedad pública y privada, y una inusitada represión policial a los manifestantes. Es dable señalar que se realizó una manifestación pacífica de 1.5000.000 de personas en plaza Italia ocurrido el 25 de octubre de 2019. Las causas más de fondo de esta crisis social, podemos mencionar: la desigualdad social y económica, abusos de poder y corrupción, alto costo de la vida y sensación de victimización e inseguridad ciudadana, escasas garantías en materia de salud, educación y salud, como asimismo mantención de una Constitución de la dictadura militar. Al anuncio de 15 de noviembre de 2019 del Presidente de la República, se sumó con fecha 27 de noviembre la propuesta de una nueva agenda social.
} 
Constitución, tras los diversas protestas sociales, que si bien es cierto se basaron en otras múltiples causas, convergieron en esta necesidad de cambio constitucional. El 25 de octubre de 2020 se llevará a cabo este plebiscito, en que los chilenos tomarán la decisión sobre contar con una nueva Constitución, optando además, sobre el órgano encargado de su redacción 255 .

En la situación de agitación social del último trimestre del año 2019, se conjugaron una serie de factores, entre los que se pueden destacar los índices de inequidad en la repartición de la riqueza, la desconfianza en las instituciones y en la política, la exigibilidad de una mayor y mejor cobertura de derechos sociales. Todas estas causas trasuntaron en último término, en una disconformidad mayoritaria con la Constitución vigente de 1980, su deslegitimidad democrática y el modelo político y económico que proclama.

En cuanto a la deslegitimidad de origen, tal como ya lo hemos indicado, obedeció a un mandato del gobierno de facto a una Comisión por ella elegida, para la redacción de un nuevo texto fundamental, que no recogió el sentir de los ciudadanos, al margen del necesario consenso social que requiere una obra de tanta trascendencia para el desarrollo de una nación.

En cuanto al modelo económico, tal como lo expresa Consuelo Navarro "lo que dicha Constitución consagró fue un sistema que no representa a la sociedad y que solo beneficia a un determinado sector de ella. Plasma un modelo neoliberal, un modo de gobernanza que implica una mínima intervención del Estado y que funciona bajo una lógica de mercado, en el cual el Estado es subsidiario y las reglas que rigen nuestra vida, son definidas por aquél"256.

Este carácter subsidiario, lo relacionamos con una falta de efectividad en el acceso a la justicia, pues implica que el Estado sólo interviene para compensar las inequidades producidas por el mercado y no asegurando derechos sociales de

\footnotetext{
${ }^{255}$ En cuanto a las modalidades de conformación del cuerpo constituyente, la papeleta electoral dispondrán de dos alternativas, que corresponden en primer término a la Convención Constitucional, en que los comisionados serán elegidos por votación popular, y en segundo lugar, una convención mixta constitucional, que corresponde a una mixtura entre personas elegidas por escrutinio público y por congresista en ejercicio, en igual proporción. ${ }^{256}$ NAVARRO, C (2019). ¿Por qué cambiar la Constitución Chilena de 1980?: Aportes para un debate democrático. Santiago. Universidad Diego Portales. p. 1
} 
manera directa. Esto quiere decir que el Estado no se posiciona como primer responsable de satisfacer estos derechos y, por su parte, que la persona no es titular efectiva de éstos, ya que no puede exigir al Estado su cumplimiento, lo que constituye un obstáculo constitucional de base al acceso a la justicia ${ }^{257}$.

Más allá de la tutela judicial efectiva, y la necesidad de generar instrumentos de garantías de derechos más efectivo que el actual y reducido recurso de protección, que solo ampara alguno de ellos, resulta relevante hacer presente que una nueva Constitución debería centrarse en remover todos los obstáculos que pueden existir para acceder a la justicia, lo que si bien es cierto constituye una justa aspiración, sabemos que sin una estructura orgánica y funcional asociada, no tiene mayor sentido proclamarlo. Sostenemos que es importante centrase en los ideales de justicia para que la futura norma constitucional represente una efectiva "igual protección en el ejercicio de los derechos", propiciando una inclusión de recursos y estándares de calidad, igualitarios, universales, sin privilegios, equitativos y $\sin$ distinción del nivel socioeconómico $u$ otros factores desigualitarios 0 discriminatorios. El faro orientador de esta nueva constitución en este tópico, debe ser una justicia oportuna, rápida, empática, profesional y de alto mérito, que garantice probidad y expertiz de autoridades judiciales y auxiliares de justicia, no represiva, con inversión y reformas a las policías, mayor cobertura, moderna, sin militancia política, transparente, equitativa y democrática ${ }^{258}$.

En relación a las necesidades particulares, estimamos necesario que se aborden las situaciones específicas de cada grupo vulnerable para el ejercicio de sus derechos, como las temáticas de migrantes, NNA y reconocimiento constitucional de los pueblos originarios.

Una nueva constitución por sí sola no podrá asegurar un desarrollo económico y social de las personas que conforman una sociedad, sino va a acompañado de un

\footnotetext{
${ }^{257}$ IBIDEM. p. 3 “Proyección de este modelo es que el derecho a la propiedad se encuentre protegido de manera preferente, mientras que algunos derechos sociales no son reconocidos -como la vivienda o el agua-, y otros no se garantizan adecuadamente -como la educación, la salud y la seguridad social-. Lo anterior a pesar de las obligaciones internacionales que el Estado ha contraído en virtud de la Declaración Universal de Derechos Humanos y otros instrumentos internacionales en la materia".

${ }^{258}$ FEDERACION NACIONAL DEL ACCESO A LA JUSTICIA. http://www.fenadaj.cl/2019/12/05/cabildosfenadaj-asamblea-constituyente-y-organismo-publico-para-acceso-a-la-justicia/
} 
sistema político e instituciones sólidas que permitan estos cambios, dentro de los cuales podemos incluir el control jurídico y político de las autoridades, la optimización del sistema tributario y repartición equitativa de las cargas públicas, mecanismos anti corrupción y descentralización.

\subsection{Covid 19 y su impacto en el acceso a la justicia en Chile}

La pandemia del Covid 19 irrumpió en Chile con un primer contagio el día 3 de marzo de 2020, con dolorosas consecuencias, pérdidas de vidas humanas y el correspondiente declive social y económico. Por DS 104 se decretó por el Presidente de la República un estado de excepción constitucional por 180 días, que entre otras atribuciones, faculta decretar limitaciones a la libertad de movimiento por la autoridad militar y se flexibilizan las partidas presupuestarias de asignación de recursos para paliar la crisis. Por DS 269 de 12 de septiembre, se extendió esta medida por un lapso de 90 días. Por su parte, con fecha 2 de abril de 2020 se publicó la Ley 21.226 que establece un régimen jurídico de excepción para los procesos judiciales, en las audiencias y actuaciones judiciales y para los plazos y ejercicio de las acciones que indica, por el impacto de la enfermedad Covid 19 en Chile ${ }^{259}$. En este periodo, el Poder Judicial, se regirá fundamentalmente por una serie de principios, en conformidad con lo establecido en el Auto Acordado 53- 2020, sobre funcionamiento del Poder Judicial durante la emergencia sanitaria nacional, de 8 de abril de $2020^{260}$ :

Los principios aplicables resultan ser los siguientes:

a) Protección de la vida y la salud pública: En la determinación del funcionamiento de los tribunales de la República y los organismos anexos que colaboran en su cometido, se privilegiará siempre la vida y la salud, tanto de los funcionarios del

\footnotetext{
${ }^{259}$ LEY 21.226. Establece un Régimen Jurídico de Excepción para los procesos judiciales, en las audiencias y actuaciones judiciales y para los plazos y ejercicio de las acciones que indica, por el impacto de la enfermedad Covid 19 en Chile, de 2 de abril de 2020.

${ }^{260}$ CS. Auto Acordado 53- 2020, Funcionamiento del Poder Judicial Durante la Emergencia Sanitaria Nacional provocada por el Brote del Nuevo Corona Virus, de 8 de abril de 2020.
} 
Poder Judicial, como de los usuarios del sistema de justicia, tomando todos los resguardos instruidos por la autoridad sanitaria y utilizando como medida principal de prevención el distanciamiento social. Para ello se tendrá en especial consideración las circunstancias y contextos de cada uno, y las posibles situaciones de especial riesgo y vulnerabilidad que se presenten tanto interna como externamente.

b) Acceso a la justicia, transparencia y continuidad del servicio judicial: El estado de excepción constitucional de catástrofe no puede constituir un obstáculo al derecho de acceso a la justicia de los ciudadanos de la República y a la continuidad del servicio judicial, por lo que, en la medida que se encuentre garantizada la vida y la salud de las personas, se preferirá aquellas modalidades que maximicen la transparencia y el correcto funcionamiento del Poder Judicial, de modo que éste ejerza su mandato constitucional en las mejores condiciones posibles -con las limitaciones propias de un estado de excepción -en resguardo de los derechos y garantías de las personas.

c) Resguardo de los derechos de personas en situación de vulnerabilidad: Durante el estado de excepción constitucional de catástrofe, se deberá dar énfasis prioritario al resguardo de los derechos de las personas que se encuentran en una situación de vulnerabilidad. Constituyen, como aquellas que pertenezcan a cualquiera de los grupos de riesgo identificados por el Ministerio de Salud en sus canales oficiales, las personas privadas de libertad o sujetas al control especial de la autoridad, los adultos mayores, las mujeres, especialmente las que son víctimas de violencia de género en cualquier espacio y los NNA que de conformidad a las circunstancias especiales podrían encontrarse en peligro de sufrir cualquier tipo de violencia en el ámbito doméstico, o en situación de protección, los trabajadores exonerados y, en general, todas las personas que se encuentran en mayor riesgo en razón de la amenaza a su salud, o a sus derechos, que implica el estado de catástrofe declarado. La especial preocupación por los grupos indicados, se basa en las características de esta crisis sanitaria y a las medidas necesarias para enfrentarlas, en atención a que están expuestos a una mayor afectación de derechos, incluida su 
vida e integridad física, y por otro lado en cuanto a su acceso a los sistemas de protección, que se agrava e intensifica en las actuales circunstancias.

d) Garantía del Debido Proceso: El Poder Judicial cautelará en todas sus actuaciones guardar el debido proceso de ley y sus garantías esenciales. Este imperativo debe regir para toda la labor de los tribunales, incluso cuando emplea los mecanismos de teletrabajo, en conformidad al Auto Acordado 41- 2020 de la CS, de 18 de marzo de 2020, que regula el teletrabajo y el uso de videoconferencia en el Poder Judicial261, constituyendo precisamente el debido proceso, un límite para el desarrollo de actuaciones que se realicen mediante esta vía.

e) Utilización de medios electrónicos: Para asegurar el acceso a la justicia, el debido proceso y resguardar la salud de las personas, el Poder Judicial procurará utilizar todos los medios tecnológicos con que cuente, privilegiando su utilización flexible, actualizada y oportuna, siempre y cuando no constituya un obstáculo al ejercicio de los principios básicos que se han enunciado, y se respete plenamente los derechos de los intervinientes.

${ }^{261}$ CS. Auto Acordado 41- 2020, que regula el teletrabajo y el uso de videoconferencia en el Poder Judicial, de 18 de marzo de 2020. 


\section{CAPITULO III. ANÁLISIS DE LOS GRUPOS EN CONDICIÓN DE VULNERABILIDAD Y DE LA POBREZA COMO FACTOR DE EXCLUSIÓN Y DEPENDENCIA}

\section{ALCANCE METODOLÓGICO RELATIVO A LOS GRUPOS VULNERABLES Y CRITERIOS DE DETERMINACIÓN}

En el desarrollo del presente capítulo se analizarán en específico los grupos en condición de vulnerabilidad, enfocado en el acceso a la justicia y los obstáculos o trabas que colocan a las personas pertenecientes a ellos en una situación más dificultosa que el resto de la población, para el ejercicio de los derechos que el ordenamiento jurídico les confiere. Esta revisión se hará en mérito de las Reglas de Brasilia de Acceso a la Justica sobre Personas en Condición de Vulnerabilidad, tratados Internacionales que constituyen las fuentes de ésta, los principios aplicables, analizando sentencias de órganos de protección, como asimismo políticas públicas y buenas prácticas, y por cierto, la realidad de estos grupos en Chile en cuanto al acceso a la justicia. Así, Respecto de estos grupos, se mostrará que en algunos casos a través de la jurisprudencia y, en otros, mediante políticas púbicas y la interpretación administrativa, se ha intentado superar éstos déficit, estableciendo mecanismos para acortar las brechas en la materia.

La importancia de la determinación de estos grupos, se justifica por los avances de en materia de derechos humanos, que sitúan al objetivo de frenar las barreras suscitadas por las necesidades especiales y/o condiciones singulares de estos grupos, como la principal obligación de los Estados, para lograr un acceso a la justicia efectivo, pues éstas personas se encuentran precisamente, en una situación 
más desaventajada que el resto de la población para el ejercicio pleno de sus derechos.

Por una cuestión metodológica hemos decidido abordar en este capítulo, en primer término, el diagnóstico de los organismos internacionales respecto de estos grupos y las propuestas de las Reglas de Brasilia enfocado en un tratamiento ajustado a sus particularidades. Acto seguido, se revisarán, los grupos específicos en condición de vulnerabilidad, para culminar con las reflexiones sobre la pobreza, como una causa de vulnerabilidad en sí misma, pero también en su carácter "generalmente" transversal y agravante de algunas de estas vulnerabilidades. Para mejor comprensión, usamos el término "generalmente", pues si bien éste rasgo de la pobreza se presenta en la generalidad de los grupos vulnerables, puede ocurrir que en determinados territorios o en ciertas realidades sociales y/o económicas, la pobreza no está presente como causal transversal y agravante de la vulnerabilidad, respecto de determinados colectivos, como puede ser el caso de las Niñas, Niños y Adolescentes (NNA), de las personas migrantes o mujeres víctimas de violencia.

La condición de vulnerabilidad se asocia a la especial dificultad que enfrentar determinadas personas, en cuanto a superar una realidad de exclusión, asociándose a la imposibilidad de sortear barreras para ejercitar derechos, en atención a condiciones estructurales e inherentes a un determinado grupo ${ }^{262}$.

Siguiendo en este punto a Silvina Ribotta, debemos precisar, "que al referimos a grupos en condición de vulnerabilidad, nos centramos en algunas características especiales de éstos, que los convierten en vulnerables según determinadas condiciones sociales, jurídicas, económicas y políticas del escenario social en que se encuentren y que los condiciona negativamente en su supervivencia o les impide el ejercicio de sus derechos, libertades y acceder a la justicia en condiciones de

262 RIBOTTA, S. "Reglas de Brasilia sobre Acceso a la Justica de las Personas en Condición de Vulnerabilidad. Vulnerabilidad, Pobreza y Acceso a la Justicia”. EN Revista Electrónica Iberoamericana. Vol. 6. Número 2. p. 6. “Una persona o grupo de personas se encuentran en condición de vulnerabilidad cuando su capacidad para prevenir, resistir o sobreponerse a un impacto que les sitúe en situación de riesgo, no está desarrollada o se encuentra limitada por circunstancias diversas, para ejercitar con plenitud ante el sistema de justicia los derechos reconocidos por el ordenamiento jurídico”. 
igualdad"263. Bajo esta perspectiva, estar imposibilitado de sobreponerse a una situación de riesgo en el territorio de un Estado en que los derechos fundamentales no estén dotados de un sistema protector robusto, o que las condiciones mínimas de subsistencia no estén presentes, transforma a esta situación particular de vulnerabilidad en más gravosa, siendo más intensa y difícil de mitigar, la brecha de desigualdad material que se origina ${ }^{264}$.

Podemos distinguir diversos grupos en condición de vulnerabilidad, tales como: grupos vulnerables por razón de etnia, de género, de edad, en razón de idioma o lengua, en atención a la pobreza en que viven, en atención a la capacidad o discapacidad que presenta la persona o por su calidad de migrante o desplazado. También podemos mencionar como grupos en condición de vulnerabilidad, los derivados de su pertenencia a comunidades indígenas, por su estado de salud, por la calidad de víctima, por la exclusión cultural, política o social, y cualquier otro grupo en atención a otra característica que lo haga vulnerable.

En Chile, nos encontramos con el siguiente mapa de vulnerabilidad del Ministerio de Desarrollo Social, que refleja justamente el fenómeno de pobreza, desigualdad y de existencia de grupos vulnerables, distinguiéndose los siguientes conglomerados 265 :

a) Personas que viven en viviendas que no tienen servicios básicos. Corresponden a 1 millón 431 mil personas. (Encuesta Calificación Socioeconómica, 2017).

b) Mujeres que han sido víctimas de Violencia Intrafamiliar y que no tienen ingresos propios. Son 490 mil mujeres en esa condición (Servicio Nacional de la Mujer y

\footnotetext{
263 IBIDEM.

${ }^{264}$ En este contexto, el carácter de vulnerabilidad es relativa y temporal, vinculándose a distintas variables, incluso sociopolíticas, por lo cual nos parece acertado sostener que los grupos que están vulnerables no presentan las mismas características en todas las sociedades, ni la vulneración es la misma en tipo, grado e intensidad, sino que depende de las circunstancias históricas, sociales, económicas y de organización de la sociedad y Estado que se trate.

265 MNINISTERIO DE DESARRLLO SOCIAL. (2019). http://www.desarrollosocialyfamilia.gob.cl/ipos2019/media/IPOSPobreza_2019.pdf [consulta 30 de octubre de 2019].
} 
Equidad de Género (SERNAMEG), a partir de cifras de la Encuesta de Calificación Socioeconómica, 2019).

c) Personas que viven en campamentos o situación de hacinamiento alto o crítico, que son 43 mil familias en campamentos y casi 500 mil familias en hacinamiento (Encuesta de Calificación Socioeconómica, 2019).

d) NNA que viven en residencias bajo la protección del Servicio Nacional de Menores (SENAME).

e) Adultos y personas mayores con discapacidades, dependencia, que viven solos o institucionalizados y que pertenecen al $40 \%$ más pobre de la población. Representan aproximadamente 160 mil personas (Encuesta de Calificación Socioeconómica 2019, Servicio Nacional de la Discapacidad, (SENADIS) y Servicio Nacional del Adulto Mayor.

f) NNA entre 5 y 18 años que no asisten a ningún establecimiento educacional. Son aproximadamente 72.700 personas en esa condición (Encuesta de Calificación Socioeconómica, 2019).

g) Personas con consumo problemático de alcohol o drogas, que son 690 mil chilenos y chilenas en esa condición (Servicio Nacional para la Prevención y Rehabilitación del Consumo de Drogas y Alcohol, 2018).

h) Personas en condición de calle, 12.400 personas (Registro Social de Calle, junio 2019).

i) Personas en lista de espera con garantías de oportunidad y seguridad vencida en programa de Garantías Explicitas de Salud, que reporta a 11.087 personas en esta situación. (Ministerio de Salud 2018).

j) Personas en hogares donde uno de sus integrantes o más declara haber presenciado continuamente en el último mes tráfico de drogas, balaceras y 
violencias. Son 2 millones 360 mil personas (Encuesta de Calificación Socioeconómica, 2019).

k) Personas mayores de 18 años que están sin empleo y buscando trabajo por más de 3 meses y que no cuentan con ninguna fuente de ingreso y que pertenecen al $40 \%$ más pobre de la población, 425 mil personas (Encuesta de Calificación socioeconómica, 2019).

I) Familias en que uno o más de su integrantes presenta dependencia, moderada o severa, que no lo permite ser autovalente y que pertenece al $40 \%$ más pobre, 250 mil chilenas y chilenos en esa condición (Encuesta de Calificación Socioeconómica, 2019).

m) Persona mayor 18 años que no se encuentra estudiando y que no ha completado los 12 años de escolaridad, casi 5 millones de chilenos (Encuesta de Calificación Socioeconómica, 2019).

Los grupos en condición de vulnerabilidad son protegidos normativamente en instrumentos internacionales transversales, es decir que no se limitan a un grupo específico y además por otros de carácter particular, por ejemplo: DUDH, PIDCP y $\mathrm{CADH}$. Nacionalmente, conforme al bloque de constitucionalidad se han generado normas de protección especial en relación a cada grupo.

Por una lógica metodológica se mencionarán primeramente estos instrumentos de protección general y al analizar cada grupo, nos referiremos a aquellos de protección específica ${ }^{266}$.

Dentro de los Instrumentos generales de protección, se encuentran los siguientes:

a) DUDH, de fecha 10 de diciembre de 1948 .

\footnotetext{
${ }^{266}$ En el caso de los migrantes por ejemplo, además de los instrumentos de protección generales, se aplican: Convención Internacional sobre la Protección de todos los Trabajadores Migrantes y de sus Familiares, Convención de Viena sobre Relaciones Consulares, y Declaración de Cartagena de Refugiados, entre otros.
} 
b) $\mathrm{CADH}$, de 22 de noviembre de 1969 .

c) Declaración Americana de Derechos Humanos, de 1948.

d) PIDCP, de 16 de diciembre de 1966.

e) Pacto Internacional de Derechos Económicos, Sociales y Culturales, de 16 de diciembre de 1966.

f) Reglas de Brasilia sobre Acceso a la Justica de Personas en Condición de Vulnerabilidad en el marco de la XIV Cumbre Judicial Iberoamericana celebrada del 4 al 6 de maro de 2008.

g) Protocolo Iberoamericano de Actuación Judicial para Mejorar el Acceso a la Justicia de Personas con Discapacidad, Migrantes, Niñas. Niños, Adolescentes, Comunidades y Pueblos indígenas, en el marco de la XVII Cumbre Judicial Iberoamericana, celebrada en Santiago de Chile, del 2 al 4 de abril de 2014.

h) OC de la Corte IDH.

De las categorías de población vulnerable, en consideración a las Reglas de Brasilia, privilegiando los criterios de determinación del Protocolo Iberoamericano y Protocolo Chileno de Acceso a la Justicia para Personas en Condición de Vulnerabilidad, y en base a criterios de realidad empírica, los déficit legislativos y problemas interpretativos detectados en la experiencia chilena y latinoamericana de acceso a la justicia, se han seleccionado como grupos de análisis, los siguientes:

a) Niñas, Niños y Adolescentes

b) Personas con discapacidad

c) Personas migrantes y sujetos de protección internacional.

d) Personas, comunidades y pueblos indígenas

e) Mujeres víctimas de violencia de género. 


\section{DIAGNÓSTICOS DE ORGANISMOS INTERNACIONALES REFERENTE AL ACCESO A LA JUSTICIA DE LOS GRUPOS EN CONDICIÓN DE VULNERABILIDAD}

Tanto el Banco Interamericano de Desarrollo en conjunto con el Instituto Interamericano de Derechos Humanos de Costa Rica, PNUD y las Reglas de Brasilia, se han dedicado a describir deficiencias y plantear recomendaciones y soluciones en su caso, en relación a grupos en condición de vulnerabilidad en el acceso a la justicia.

En el Sistema Interamericano de Derechos Humanos (SIDH), el acceso a la justicia se ha comprendido fundamentalmente a partir los artículos 8.1 y 25 de la CADH. Desde el enfoque amplio ya revisado, que nos parece más adecuado, este derecho de acceso a la justicia, no es posible reducirlo a un derecho a ser oído o a interponer recursos, sino que se debe buscar compensar la desigualdad real que enfrentan estos grupos. Se exige de esta manera a los Estados no solo otorguen una serie de garantías judiciales mínimas para la determinación de derechos y obligaciones a través de instituciones y procedimientos que cumplan los requerimientos expresados en el artículo 8, sino proveer a los individuos de los medios necesarios para poder acceder a dichos procedimientos e instituciones ${ }^{267}$. Esta obligación se hace especialmente necesaria para los grupos vulnerables, y no solo restringiéndolo a lo netamente judicial, sino que abriendo el abanico a otras formas de resolución, enfocado en resultados justos y conforme a las necesidades singulares de cada grupo.

El PNUD, en su informe año 2005, al señalar como diseñar una política pública sobre acceso a la justicia, la define como "la posibilidad que debe tener toda persona de contar con una solución o remedio a sus problemas jurídicos sin importar si esas soluciones provienen de una oferta estatal o privada o si ellas son voluntarias, legales, judiciales y lo simplemente administrativas, y a condición de que asegure su oportunidad y calidad ${ }^{268}$ ". De igual forma, se aleja de la corriente institucionalista

\footnotetext{
${ }^{267}$ IBIDEM. párr. 42.

${ }^{268}$ COX, S. Op. Cit., p. 4.
} 
que se reduce a la maquinaria del ámbito público en la administración de justicia. El enfoque de acceso a la justicia que promueve el PNUD no se agota en la contemplación de aspectos cuantitativos o cualitativos de los recursos judiciales sino que entiende el acceso a la justicia como un objetivo y un medio al mismo tiempo ${ }^{269}$.

Como lo sostuvimos en el Capítulo II, Este abordaje, claramente más cabal y no fragmentario, nos hace abandonar las tesituras restrictivas de acceso a la justicia, vinculadas a la posibilidad de "golpear la puerta de un tribunal", que propugnan solo avances cuantitativos enfocados en la creación de organismos judiciales, sin hacer frente a la demanda de soluciones, que va más allá del derecho a la acción. Esta nueva mirada, engloba entre otros elementos integrantes, el debido proceso, la tutela judicial efectiva, el derecho a la defensa, la remoción de barreras de todo tipo por parte del Estado, ampliándose así el concepto, a la vindicación de derechos. De esta forma, el sistema protector de derechos hace un llamado a que los esfuerzos y actuaciones concretas de los Estados y las sociedades, se congreguen en eliminar, vencer o mitigar diversas limitaciones que se presentan en este ámbito, debiéndose no solo ofrecerse mayores canales de litigiosidad, sino que se propicie este acceso a la justicia más efectivo y menos costoso.

EI PNUD constató una deficiencia generalizada en América Latina respecto a la respuesta estatal en los diversos aspectos que abarca el acceso a la justicia, desde esta perspectiva integral ${ }^{270}$. En este sentido, existe un profundo consenso, que las herramientas con que las nuevas administraciones políticas en América Latina, se proponen reformar y modernizar este sector, deben aspirar a la promoción de una

\footnotetext{
269 PNUD (2005). Manual de políticas públicas para el acceso a la justicia. Buenos Aires. Ediciones del Instituto. p. 7. "Siendo un fin en sí mismo, se percibe como un requisito previo, como un instrumento para la transformación de las relaciones de poder que perpetúan la exclusión, la pobreza y la subordinación de grupos tales como mujeres, presos, indígenas, migrantes, discapacitados, menores, poblaciones de bajos ingresos, etcétera”.

${ }^{270}$ IBIDEM. p. 8. "En Iberoamérica, se constató la existencia de una enorme demanda sin cubrir. Quien no tiene dinero para costear un abogado y los costos de los procedimientos, no tiene defensa jurídica ni acceso a la justicia, el desconocimiento de los derechos, la casi inexistente consideración e inversión en la justicia local ( comunitaria y vecinal), dadas las dificultosas realidades de la vida en áreas rurales para una parte importante de la de la población (40\% de la población rural en América Latina) y la total descoordinación entre las entidades estatales y privadas existentes, constituyen hitos principales del mal diagnostico público y de la insatisfacción ciudadana generalizada que esta realidad arrastra”.
} 
política pública de pleno acceso a la justicia, especialmente para los sectores más pobres de la población ${ }^{271}$.

En la misma línea del PNUD, y reforzando la idea de que la reforma y modernización de la administración publica en pos de garantizar el acceso a la justicia, se define por la capacidad de construir un Estado que puede impedir la exclusión, haremos alusión al estudio del Banco Interamericano de Desarrollo y del Instituto Interamericano de Derechos Humanos de Costa Rica, realizado en 1999, que ha sido observado y complementado hasta la fecha, y que obedece a una investigación efectuada en 7 países de la región, sobre el fortalecimiento del acceso a la justicia, con la idea de influir en otros organismos de cooperación para que incorporasen en sus líneas de acción la noción de acceso desde un enfoque más equitativo, para atender a los grupos más desprotegidos, y desde una perspectiva de desarrollo, es decir que se asuma como presupuesto necesario en la elaboración de políticas públicas sobre la reforma de la justicia, a partir del entendimiento de que se trata de un derecho fundamental que no puede ser ignorado. Asume este estudio que solo en la medida en que se transforme el sistema de administración de justicia hacía uno inclusivo y de mejor calidad estaremos afianzando la credibilidad de la democracia y el bienestar de los ciudadanos ${ }^{272}$. La investigación no deja de lado un elemento finalista, en que se concibe el acceso a la justicia como un derivado de los postulados de los derechos humanos ${ }^{273}$. Además se imponen algunas consideraciones sobre la pertinencia y el sentido del acceso a la justicia para las poblaciones más desfavorecidas. La más general de etas reflexiones, apunta hacía

\footnotetext{
${ }^{271}$ THOMPSON, J. (2000). Acceso a la justicia y equidad: estudio en siete países de América Latina. Banco Interamericano de Desarrollo-Instituto Interamericano de Derechos Humanos de Costa Rica. San José de Costa Rica. 2000, p. 12.

${ }^{272}$ IBIDEM. p. 12. "La aludida investigación se centra en el interés de detectar formas adecuadas de impulsar el acceso a la justicia siguiendo la tesis argumentativa y propositiva de un acceso a la justicia que debe estar disponible por parte de los grupos que no disponen de condiciones de igualdad material y objetiva para ejercer con plenitud los derechos que el ordenamiento jurídico le reconoce, para ponderar su replicidad en otras latitudes o circunstancias. Se parte de la base al elaborar este estudio, que es válido y valioso promover el acceso a la justicia de los sectores desfavorecidos de la población, y se fundamenta en el doble soporte de que la actuación adecuada de la justicia en la resolución de conflictos es, a la vez, una exigencia del régimen democrático y una condición de primer orden para un desarrollo de los pueblos que guarde equilibrio con las necesidades de la paz social".

${ }^{273}$ IBIDEM. p. 449. "Esta convicción se extienden a comprender que la negación o postración de acceso a la justicia para un sector o grupo, es una postergación inadmisible según los principios de no discriminación que son la esencia de los derechos fundamentales”.
} 
el tema de los modelos en el objetivo de atender a las patentes necesidades de asistencia legal en este campo ${ }^{274}$.

\section{REGLAS DE BRASILIA PARA EL ACCESO A LA JUSTICIA DE PERSONAS EN CONDICIÓN DE VULNERABILIDAD}

Las Reglas de Brasilia nacen en la XIV Cumbre Judicial Iberoamericana celebrada los días 4 a 6 de marzo de 2008 en Brasilia, Brasil. Esta Cumbre agrupa a las principales redes iberoamericanas de operadores y servidores del sistema judicial, incluidos entre otros, la Asociación Iberoamericana de Magistrados, de Ministerios Públicos, la Asociación Interamericana de Defensorías Públicas, y la Unión Iberoamericana de Colegios y Agrupaciones de Abogados. En estas jornadas se estimó procedente y necesario aprobar reglas de protección respecto de personas en condición de vulnerabilidad, en atención a que son aquellas que en razón de su edad, género, estado físico o mental, o por circunstancias sociales, económicas, étnicas y culturales, encuentran especiales dificultades para ejercitar con plenitud ante el sistema judicial los derechos reconocidos por el ordenamiento jurídico. Cabe hacer presente que estas reglas vienen en complementar los postulados de la Carta de Derechos de las Personas ante la Justicia en el Espacio Judicial Iberoamericano ${ }^{275}$, declarada en la VII Cumbre Judicial Iberoamericana, celebrada celebrada en Cancún México, los días 27 a 29 de noviembre del año 2002, en especialmente en lo que respecta al apartado titulado "Una justicia que protege a los más débiles"276.

\footnotetext{
${ }^{274}$ IBIDEM. "Es transversal en cuanto a que se requiere una instancia esencialmente gratuita, con una diversidad de formas de acción, con sistemas propios diseñados o adaptados según la población que atienden, que parten de una visión global del derecho, sin perjuicio de priorizar poblaciones o temas específicos". "Se indica que dentro de los factores, salta a la vista la importancia del económico, como obstáculo y como condición, lo que trae consigo una marcada importancia de la gratuidad como nota determinante en los modelos eficaces en esta materia. La forma en que esa gratuidad se combine con otros elementos para hacer el modelo sostenible dependerá del contexto en que se desarrollen sus actividades y de las opciones abiertas por el respectivo ordenamiento jurídico".

${ }^{275}$ VII CUMBRE JUDICIAL IBEROAMERICA. (2002). Carta de Derechos de las Personas ante la Justicia en el Espacio Iberoamericano. Preámbulo: "por considerarse como un derecho fundamental de la población tener acceso a una justicia independiente, imparcial, transparente, responsable, efectiva, eficaz y equitativa”.

${ }^{276}$ IBIDEM. Artículos 23-24
} 
Las Reglas de Brasilia, constituyen estándares, no son norma jurídica, pero tienen un especial valor para cualquier proceso de reforma de justicia porque han sido elaboradas y aprobadas por los representantes de las principales instituciones del sistema judicial. Más que reflexiones pretenden establecer líneas concretas de actuación y por esa razón tiene como destinatario a los poderes públicos para el desarrollo de políticas públicas y si se transforman en ley, obligan a todos los órganos del Estado; y serán aplicables a todos los operadores de justicia.

Para ello, no sólo contemplan los problemas del acceso a la justicia, sino que establecen recomendaciones para los órganos públicos y para quienes prestan sus servicios en el sistema judicial, promoviendo desde políticas públicas hasta conductas, actitudes y procedimientos de todos los servidores y operadores del sistema judicial y de quienes intervienen de una u otra forma en su funcionamiento, tendientes a garantizar el efectivo goce y ejercicio de los derechos ${ }^{277}$.

Estas Reglas, recogen entonces, una preocupación bastante extendida respecto a que los sistemas judiciales lleguen a constituirse en reales instrumentos de defensa de los derechos de las personas, sobre todo de las más débiles. Las leyes y códigos no deberían ser por más tiempo, sólo declaraciones formales de derechos y de ilusorias garantías, vacías de contenido ${ }^{278}$.

En su exposición de motivos, que es concordante también con la concepción de acceso a la justicia amplia que defendemos, armónica con los postulados del PNUD, y de la investigación del Banco Interamericano de Desarrollo y del Instituto Interamericano de Derechos Humanos de Costa Rica, busca que este derecho de acceso a la justicia combata las relaciones asimétricas de poder y proteja a los grupos vulnerables, proclamando expresamente que "el sistema judicial se debe

\footnotetext{
${ }^{277}$ RIBOTTA, S. Op. Cit. p. 3.

${ }^{278}$ IBIDEM. "Los sistemas judiciales y toda la conformación de los Estados democráticos modernos tendrían que asumir el reto de garantizar realmente la tutela de los derechos que las leyes reconocen a sus ciudadanos, y en el caso de las personas en situación vulnerable, esa tutela de los derechos y garantías debe extremarse por cuanto se encuentran en una situación que hace mucho más difícil su ejercicio y que las coloca, invariablemente, en una situación que vulnera aún más la vulnerabilidad que ya padecen. Las declaraciones de derechos sin garantías efectivas, no tiene mayor sentido, y en nada contribuyen al fortalecimiento del Estado de Derecho. Los sistemas de justicia, deben precisamente centrase en los grupos que se cataloguen según los factores ya mencionados, en una situación de desprotección, atendiéndose siempre a sus condiciones particulares, que los sitúa en una posición más desmejorada que el resto de la población para el ejercicio pleno y cabal de sus derechos".
} 
configurar, y se está configurando, como un instrumento para la defensa efectiva de los derechos de las personas en condiciones de vulnerabilidad"279. A nuestro entender, las Reglas de Brasilia, dialogan con los postulados del PNUD, en cuanto a que el acceso a la justicia representa justamente un instrumento de transformación de las relaciones de poder, que perpetúan la exclusión, la pobreza y la dependencia de estos grupos.

En cuanto a la finalidad de estas reglas, ésta se plasma en su artículo $1^{280}$, y se orientan al efectivo acceso a la justicia de los derechos de personas, que por sus características encuentran especiales dificultades para ejercitar con plenitud ante el sistema judicial los derechos reconocidos por el ordenamiento jurídico. No se puede pensar que estas directrices están referidas solamente a la promoción de políticas públicas, sino también al trabajo cotidiano de los operadores del sistema judicial. El marco teórico que sustentan las Reglas de Brasilia, está dado por principios, derechos y obligaciones, que están contenidos en los tratados de derechos humanos, es decir, esa es la fuente que beben, para poder regular de manera operativa la ejecución de estos tratados a través de la eficacia de los derechos humanos. Se ha considerado así, como fuente para la elaboración de estas reglas, la normativa específica que protege a cada grupo ${ }^{281}$ y la jurisprudencia del sistema

\footnotetext{
${ }^{279}$ XIV CUMBRE JUDICIAL IBEROAMERICANA (2008). 100 Reglas de Brasilia. Brasilia. p. 4.

${ }^{280}$ IBIDEM. Op. Cit., p. 5. Regla 1: "Las Reglas tienen como objetivo garantizar las condiciones de acceso efectivo a la justicia de las personas en condición de vulnerabilidad, sin discriminación alguna, englobando el conjunto de políticas, medidas, facilidades y apoyos que permitan a dichas personas el pleno goce de los servicios del sistema judicial. Regla 59: "Se velará para que en toda intervención en un acto judicial se respete la dignidad de la persona en condición de vulnerabilidad, otorgándole un trato específico adecuado a las circunstancias propias de su situación”.

${ }^{281}$ A modo ejemplar, la discapacidad como situación de vulnerabilidad es regulada en este documento en mérito de la normativa protectora internacional y de los pronunciamientos de los órganos de protección, por lo cual, la presente regulación de las Reglas de Brasilia a su respecto, se está realizando en base a los principios, derechos y obligaciones contenidas en los principales instrumentos internacionales que protegen la discapacidad. Convención de las Naciones Unidas sobre los Derechos de las personas con Discapacidad, adoptada por la Asamblea General de las Naciones Unidas el 13 de diciembre de 2006 (ratificada por Chile el 29 de julio de 2008 y publicada el 17 de septiembre de 2008). Protocolo Facultativo de la convención de las Naciones Unidas sobre los Derechos de las Personas con Discapacidad, adoptado por la Asamblea General de las Naciones Unidas el 13 de diciembre de 2006 y publicada el 17 de septiembre de 2008. Convención Interamericana para Eliminación de todas las Formas de Discriminación contra las Personas con Discapacidad, adoptada por la Asamblea General de la Organización de Estados Americanos el 7 de junio de 1999 ratificada por Chile el 26 de febrero de 2002 y publicada el 20 de junio de 2002. En este sentido, se tomaron en consideración diversos tratados, y los principios de ellos emanados: Abordaje de la discapacidad desde el modelo social y de derechos, mayor protección a las personas con discapacidad, Igualdad y no discriminación, accesibilidad, respeto a la dignidad inherente, la autonomía individual incluida la libertad de tomar las propias
} 
interamericano y universal, en materia de acceso a la justicia, es decir las sentencias (y su interpretación) que se han dictado para la protección del grupo en condición de vulnerabilidad que se trate 282 .

Las Reglas de Brasilia sobre Acceso a la Justicia de las Personas en Condición de Vulnerabilidad, tienen la siguiente estructura:

Capítulo I. Preliminar.

Sección primera: Finalidad. Reglas 1-2.

Sección segunda: Beneficiarios de las reglas. Reglas 3-23

Sección tercera: Destinatarios actores del sistema de justicia. Regla 24.

Capitulo II. Efectivo acceso a la justicia para la defensa de los derechos.

Sección primera: Cultura jurídica. Reglas 26-27.

Sección segunda: Asistencia legal y defensa pública. Reglas 28-31.

Sección tercera: Derecho a intérprete. Regla 32.

Sección 4: Revisión de los procedimientos y los requisitos procesales como forma de facilitar el acceso a la justicia. Reglas 33-42.

Sección 5: Medios alternativos de resolución de conflictos. Reglas 43-47.

Sección $6^{\circ}$ : Sistema de resolución de conflictos dentro de las comunidades indígenas. Reglas 48-49.

Capítulo III. Celebración de actos judiciales.

Sección primera: Información procesal o jurisdiccional. Reglas 51-57.

Sección segunda: Comprensión de actuaciones judiciales. Reglas 58 -61.

Sección $3^{\circ}$ : Comparecencia en dependencias judiciales. Reglas 62-79.

Sección $4^{\circ}$ : Protección de la intimidad. Reglas 80-84.

Capítulo IV. Eficacia de las Reglas 85-100.

Resulta relevante hacer mención a esta estructura, pues las reglas no tienen objeto alguno, sino se convierten en obligaciones del Estado y sus órganos, en cuanto a

decisiones y la independencia de las personas, participación e inclusión efectiva en la sociedad, respeto por la diferencia y la aceptación de la discapacidad como parte de la diversidad y la condición humana, respeto a la evolución de las facultades de los niños y niñas con discapacidad y su derecho a preservar su identidad.

${ }^{282}$ CORTE IDH. Caso Ximenes López vs Brasil. Sentencia de 4 de julio de 2006. Párrafo 103: "Las personas con discapacidad a menudo son objeto de discriminación a raíz de su condición, por lo que los Estados deben adoptar las medidas de carácter legislativo, social, educativo, laboral o de cualquier otra índole, necesarias para que toda discriminación asociada con las discapacidades mentales sea eliminada, y para propiciar la plena integración de esas personas en la sociedad”. 
desarrollar políticas públicas e implementar buenas prácticas, que se deben aplicar cuando se detecta una necesidad jurídica y urge, en consecuencia, una solución a la misma, que debe ser eficiente, sostenible y replicable en el tiempo.

Las acciones que se implementan, que mayoritariamente se generan del Estado, pero también pueden provenir del ámbito privado $^{283}$, se orientan a eliminar las barreras que se presentan en relación a diversos ítems que en forma sistemática se tratan. Así, respecto de la Regla $41^{284}$ que se encuentra en la sección $4^{\circ}$, sobre la revisión de los procedimientos y los requisitos procesales, se ha establecido como buena práctica de política pública, los Centros de Conciliación para Personas con Discapacidad en Colombia ${ }^{285}$, que facilitan el acceso a la justicia a personas en situación de discapacidad, o los Tribunales de Drogas y/o Alcohol en Chile ${ }^{286}$, que propicia el acceso a la justicia en personas en condición de vulnerabilidad, especialmente debido a la pobreza y a otras variables de marginalidad y exclusión, en cuya comisión de delitos haya influido mayormente el consumo de estas sustancias, y que existan razones fundadas de la inconveniencia de someterlos a un proceso penal.

En ese mismo sentido, referente a la Regla $42^{287}$ que se refiere a la proximidad, se pueden mencionar como buena práctica de política pública, las Rondas Campesinas ${ }^{288}$ y la Justicia de $\mathrm{Paz}^{289}$, ambas en Perú, que tienen consagración constitucional en el artículo 149 de la Carta Magna, y que permite otorgar soluciones a conflictos jurídicos que se susciten en comunidades aisladas, con predominancia de población indígena. Además ésta noción de proximidad al goce de los servicios

\footnotetext{
283 FUNDACION PROBONO. http www.probono.cl [Consulta 18 de octubre de 2019] "Constituye una iniciativa de la sociedad civil con la finalidad de presentar asesoría y representación jurídica de calidad a grupos vulnerables, especialmente en relación a la variable de escasez económica”.

${ }^{284}$ XIV CUMBRE JUDICIAL IBEROAMERICANA. Op. Cit.,p. 13

${ }^{285}$ UNIVERSIDAD COOPERATIVA DE COLOMBIA. http://www.ucc.edu.co/noticias/prensa/academia/ElConsultorio-Juridico-y-Centro-de-Conciliacion-del-Campus-Medellin-se-especializa-en-la-atencion-depersonas-con-discapacidad [Consulta 18 de octubre de 2019].

${ }^{286}$ PODER JUDICIAL DE CHILE. http://www.reinsercionsocial.gob.cl/tribunales-de-tratamiento-de-drogasyo-alcohol/[ Consulta 26 de septiembre de 2019]

${ }^{287}$ XIV CUMBRE JUDICIAL IBEROAMERICANA. Op. Cit., p. 13.

${ }^{288}$ PICCOLI, E. (2019). "Las Rondas Campesinas y su reconocimiento estatal, dificultades y contradicciones de un encuentro: un enfoque antropológico sobre el caso de Cajamarca”. EN: Nueva Antropología Vol.22 número 71. México.

${ }^{289}$ GUERRA, M. (2018). Justicia de Paz en el Perú: Un Servicio de Justicia eficiente. Lima. Ediciones Universidad Católica de Lima. p. 12.
} 
del sistema de justicia, se encuentra en la App "empodérate" en Costa Rica ${ }^{290}$, que obedece al desarrollo de una aplicación para teléfonos móviles inteligentes y tabletas, que permite que NNA, puedan acceder a información sobre sus derechos y activar con un solo "click" una serie de servicios que les permite satisfacer sus necesidades de justicia. Es importante, hacer mención que la claridad en el lenguaje que se utilicen en los tribunales por sus funcionarios y jueces, como por los restantes intervinientes del sistema de justicia es fundamental para que el acceso a la justicia sea efectivo, ya que sin este elemento, la distancia socio cultural en que se encuentre la persona que acude a los servicios, impediría la proximidad que las Reglas promueven, considerando los términos técnicos que se utilizan, difíciles de comprender para las personas en general, y más aún, para los que se encuentran en una condición de desmedro. Resultan loables los esfuerzos que ha realizado el Poder Judicial En Chile, en cuanto a la creación de la Comisión de Lenguaje Claro, que nace el año 2015 por decisión del pleno de la CS, con objetivo de promover el uso de un lenguaje sencillo al interior del Poder Judicial y de establecerse como una instancia de reflexión respecto al rol que juega el lenguaje exento de un exceso de terminología técnica en el acceso a la justicia del ciudadano ${ }^{291}$.

\footnotetext{
${ }^{290}$ PODER JUDICIAL COSTA RICA. https://accesoalajusticia.poder-judicial.go.cr/index.php/noticiasninnos/671-poder-judicial-lanza-aplicacion-empoderate-dirigida-a-ninos-ninas-y-adolescentes. [Consulta 26 de septiembre de 2019].

${ }^{291}$ PODER JUDICIAL DE CHILE. (2020). Protocolo de Acceso a la Justicia de Grupos Vulnerables. Santiago. p. 19. "La Red de Lenguaje Claro es una instancia que agrupa a 7 instituciones con el propósito de trabajar de manera conjunta en la implementación de acciones orientadas a generar iniciativas, proyectos y medidas que promuevan, difundan y faciliten el uso del lenguaje claro, al interior de sus respectivas instituciones y en otros organismos del Estado. En lo que compete netamente al Poder Judicial, la utilización de lenguaje claro se extiende a las resoluciones de los tribunales, a la forma en que se dirige el debate en las audiencias, y en general todas aquellas actuaciones que implican un dialogo, que debe trasuntar en un entendimiento cabal por parte de las personas, especialmente de las más vulnerables. La preocupación del Poder Judicial por la utilización de un lenguaje claro responde a compromisos internacionales y al resultado de una participación activa en redes de cooperación judicial internacional. En dichas instancias, poderes judiciales de diversos países intercambian buena prácticas y reflexionan respecto de dificultades y soluciones en las materias de su competencia. Para el cumplimiento de su objetivo, la Comisión elabora y propone iniciativas y productos que fomenten la utilización de un lenguaje que, sin desapegarse del rigor técnico judicial, es más comprensible para los usuarios. La Comisión que se reúne periódicamente, es dirigida por un ministro de la C.S y está compuesta por miembros del poder judicial, que representan a diferentes estamentos y diversas especialidades, más la presencia de otros profesionales, como abogados externos y periodistas. Las Instituciones que conforman la Red son la Corte Suprema de Chile, la Cámara de Diputados, La Contraloría General de la República, el Consejo para la Transparencia, la Pontificia Universidad Católica de Valparaíso, la Biblioteca del Congreso Nacional y el Ministerio Secretaría General de la Presidencia. Sus objetivos son la eficiencia del uso de recursos públicos y
} 
No se debe perder de vista que entendemos por eficacia de la justicia un tema de accesibilidad, de información, de transparencia y que comienza con la amabilidad, con el trato que se brinda al justiciable, por eso las reglas no son meras reflexiones sino recomendaciones vinculantes a los poderes públicos, no solamente el judicial, como asimismo, a los jueces y a los servidores de estas instituciones. Así, la Regla $2^{292}$ se refiere al trato adecuado y conforme a las circunstancias particulares de cada grupo en condición de vulnerabilidad que deben observar los distintos operadores del sistema judicial. En Chile, la implementación de las salas Gesell293 en cuanto a posibilitar que los NNA puedan ejercer su derecho a ser oído por el tribunal con garantías de protección a su integridad física y psicológica; las entrevistas video grabadas para evitar la revictimización de este grupo ${ }^{294}$, la implementación de módulos de auto consulta para personas con discapacidad visual ${ }^{295}$, constituyen todas una manifestación de la adecuación a las circunstancias singulares de cada grupo. Tanto en Chile como en Latinoamérica, los esfuerzos son parciales y no con todo el éxito esperado, y se debe en lo ideal lograr, que el sistema de administración de justicia sea el que se adapte a la situación de una persona que pertenece a un grupo vulnerable y no al revés.

la promoción de la transparencia y acceso a la información pública. Es importante, que más instituciones del ámbito justicia, por ejemplo la Corporación de Asistencia Judicial (CAJ), Defensoría Penal Pública , Ministerio Público, puedan adherirse a esta red, o a falta de ello, puedan en forma interna, instruir por la utilización de un lenguaje entendible para todas las personas, en atención a sus condiciones singulares.

${ }^{292}$ XIV CUMBRE JUDICIAL IBEROAMERICANA. Op. Cit., Regla 2: "Se recomienda la elaboración, aprobación, implementación y fortalecimiento de políticas públicas que garanticen el acceso a la justicia de las personas en condición de vulnerabilidad. Los servidores y operadores del sistema de justicia otorgarán a las personas en condición de vulnerabilidad un trato adecuado a sus circunstancias singulares. Asimismo se recomienda priorizar actuaciones destinadas a facilitar el acceso a la justicia de aquellas personas que se encuentren en situación de mayor vulnerabilidad, ya sea por la concurrencia de varias causas o por la gran incidencia de una de ellas. Los Servidores y operadores del sistema de justicia otorgarán a las personas en condición de vulnerabilidad un trato adecuado a sus circunstancias particulares”.

${ }^{293}$ OYANEDEL, J. (2018) y ORTUZAR, H. "Sistematización de una experiencia piloto de implementación de una sala Gesell para entrevistas de niños en un Tribunal de Familia”. EN Revista Chilena de Pediatría Vol.89 n'6. p. 2.

${ }^{294}$ LEY 21.057. Que regula entrevistas grabadas en video y otras medidas de resguardo a menores de edad, víctimas de delitos sexuales, de 20 de enero de 2018. "Regula la realización de la entrevista investigativa videograbada y de la declaración judicial para prevenir la victimización secundaria de niños, niñas y adolescentes que hayan sido víctimas de delitos sexuales y otros delitos graves. Se busca evitar toda consecuencia negativa que puedan sufrir los niños, niñas y adolescentes con ocasión de su participación en el proceso penal".

${ }^{295}$ SENADIS.https://www.senadis.gob.cl/sala_prensa/d/noticias/5622/senadis-y-el-colegio-de-arquitectosfirman-convenio-que-promueve-la-inclusion-y-la-accesibilidad-de-personas-con-discapacidad. [Consulta 26 de octubre de 2019]. 
Teniendo en cuenta la importancia del presente documento para garantizar el acceso a la justicia de personas en condición de vulnerabilidad, se recomienda a todos los Estados, poderes públicos, que cada uno dentro de su respectivo ámbito de competencia promuevan reformas legislativas ${ }^{296} y$ adopten medidas que hagan efectivo el contenido de estas reglas ${ }^{297}$. Así se han dictado leyes nacionales con el objetivo de adecuar el ordenamiento jurídico interno en pos de garantizar el efectivo goce de los servicios judiciales y el ejercicio de los derechos, como asimismo se han validado protocolos de actuación local y regional, con la finalidad de establecer criterios de actuación y recomendaciones. Además se hace un llamamiento a las organizaciones internacionales y agencias de cooperación para que tengan en cuenta estas reglas en sus actividades, incorporándolas en los distintos programas y proyectos de modernización del sistema judicial en que participen ${ }^{298}$. Es dable señalar, que se incluye en su Regla 100, la constitución de una Comisión de Seguimiento ${ }^{299}$, entre cuyas finalidades está la de promover la definición, elaboración, adopción y fortalecimiento de políticas públicas que promuevan el mejoramiento de las condiciones de acceso a la justicia por parte de personas en condición de vulnerabilidad.

El mérito del instrumento en análisis está dado por constituir un ejemplo de expresa asunción de responsabilidad y toma de conciencia de los mismos operadores del

\footnotetext{
${ }^{296}$ NASH, C; NUÑEZ C; TRONCOSO, C (2017). Op. Cit., p. 333. "En este marco internacional, se dicta le ley 20066 - que reemplaza la ley 19.325 sobre violencia intrafamiliar - que fue promulgada con el propósito de dar cumplimiento a la obligación que el Estado contrajo al ratificar la Convención Belem Do Para. En este sentido, dicha ley consagra la violencia contra la mujer como como un problema de derechos humanos y establece la obligación de garantizar ciertos derechos que deberán ser cumplida a través de políticas públicas. En este sentido, se promulgó la ley 20.442 en Chile que establece normas sobre igualdad de oportunidades e inclusión social de personas con discapacidad".

${ }^{297}$ IBIDEM. "En la XVII Cumbre Judicial Iberoamericana en el año 2014 aprobó el Protocolo Iberoamericano de actuación judicial para mejorar el acceso a la justicia de personas con discapacidad, migrantes, niñas, niños y adolescentes, comunidades y pueblos indígenas. El Poder Judicial de la República de Chile en el año 2020 aprobó el Protocolo de Acceso a la Justicia de Grupos Vulnerables. Corte Suprema de Costa Rica dictó la Circular sobre Políticas para garantizar el adecuado acceso a la justicia de la población adulto mayor y personas con discapacidad”.

${ }^{298}$ XIV CUMBRE JUDICIAL IBEROAMERICANA. Op. Cit., p. 5.

${ }^{299}$ ANDREU.GUZMAN, F y COURTS, C. Op. Cit., p. 53. "La Comisión de Seguimiento de las Reglas de Brasilia, integrada en la actualidad por representantes de los Poderes Judiciales de Argentina, Costa Rica, Ecuador, España, Honduras, y Panamá, elaboró un plan marco de trabajo entre cuyos objetivos específicos se incluye fomentar el diseño de políticas públicas con alto contenido social, para mejorar el acceso a la justicia de las poblaciones en condición de vulnerabilidad fijándose, para su consecución, el "diseño de un manual de referencia para la elaboración de políticas públicas con alto contenido social”.
} 
sistema de justicia, que se traducen en estos lineamientos, pues su finalidad no es otra que la operativización concreta de los derechos humanos a través de éstas. En el Capítulo II en la Regla 25300, se instituye la obligación de promover las condiciones para una efectiva tutela de derechos. Se contempla una sección de "cultura jurídica" ${ }^{301}$, destacando las Corporaciones de Asistencia Judicial en Chile (CAJ), que contemplan una línea de servicio, que consiste en la promoción, prevención y difusión de los derechos y deberes de las personas, a través de actividades de carácter comunitario dirigidas a la población en general ${ }^{302}$. Esta línea de servicio de las CAJ, lo prestan los profesionales de los centros, a través de la participación institucional en programas de acercamiento a la comunidad, siendo las temáticas abordadas, aquellas que dicen relación con todas las materias de carácter jurídico" 303 . De esta forma se consagra la obligación del Estado de participar activamente en el diseño y ejecución de actividades de capacitación ${ }^{304}$, de la misma forma ocurre con las actividades de sensibilización en materia de género que realiza el SERNAMEG.

En la sección segunda, titulada asistencia legal y defensa publica, se trata en primer término la promoción de la asistencia técnico jurídico a la persona en condición de vulnerabilidad. En ese contexto, la Regla $28^{305}$ destaca la necesidad de la existencia de mecanismos de asistencia jurídica gratuita en diversos ámbitos, prueba de ello

\footnotetext{
${ }^{300}$ XIV CUMBRE JUDICIAL IBEROAMERICANA. Op. Cit., Regla 25: "Se promoverá las condiciones necesarias para que la tutela judicial de los derechos reconocidos por el ordenamiento sea efectiva, adoptando aquellas medidas que mejor se adapten a cada condición de vulnerabilidad.

${ }^{301}$ IBIDEM. Regla 26: "Se promoverán las actuaciones destinadas a proporcionar información básica sobre sus derechos, así como los procedimientos y requisitos para garantizar un efectivo a acceso a la justicia de las personas en condición de vulnerabilidad”.

${ }^{302}$ Estas actividades pueden ser en la modalidad de talleres, charlas, plazas de justicia, y otras, que tienen por objeto informar y educar a las personas sobre sus deberes y derechos, la forma como hacerlos valer y prevenir conflictos de connotación jurídica

${ }^{303}$ CAJ REGION METROPOLITANA. http://www.cajmetro.cl/prevencion-y-promocion-de-derechos/ [ Consulta 5 de Noviembre de 2019]

${ }^{304}$ XIV CUMBRE JUDICIAL IBEROAMERICANA. Op. Cit., Regla 27: “Que se incentivará la participación de funcionarios y operadores del sistema de justicia en la labor de diseño, divulgación y capacitación de una cultura cívica jurídica, en especial de aquellas personas que colaboran con la administración de justicia en zonas rurales y en áreas desfavorecidas de las grandes ciudades".

${ }^{305}$ IBIDEM. Regla 28: "Se constata la relevancia del asesoramiento técnico jurídico para la efectividad de los derechos de las personas en condición de vulnerabilidad, tanto en el ámbito de la asistencia legal, de la defensa para defender derechos en el proceso ante todas las jurisdicciones y en todas las instancias judiciales, como asimismo en materia de asistencia letrada al detenido”.
} 
en nuestro país, lo constituye la Defensoría Penal Mapuche ${ }^{306}$. En la regla $29^{307}$ se le otorga relevancia a los servicios que realizan instituciones estatales como la CAJ o las clínicas jurídicas, especialmente en materia migratoria ${ }^{308}$. Es relevante destacar la necesidad de garantizar una asistencia técnico jurídico de calidad y especializada, que si bien se alojó en la primera ola de acceso a la justicia, resulta a estas alturas indiscutible, que una de las herramientas principales de consecución de una igualdad de oportunidades dentro del proceso judicial, como asimismo en los otros dispositivos previstos para la resolución de conflictos, es precisamente contar con una defensa oportuna, de calidad y gratuita. Acorde con lo anterior, En la regla $31^{309}$ se hace mención a la gratuidad de los servicios, como ocurre con los Tribunales Multipuertas ${ }^{310}$ en la ciudad de Buenos Aires, Argentina o, entre otras, como la Defensoría Penal Pública en Chile (DPP). También se establece en la sección tercera de este Capítulo II, el derecho a intérprete en la Regla 32 ${ }^{311}$, en cuanto a posibilitar el acceso a la justicia a los grupos de migrantes, como ocurre con el sistema de traductor en línea ${ }^{312}$, implementado en los tribunales chilenos. En la sección 5, se instituyen los medios alternativos de resolución de conflictos, en relación a las personas en condición de vulnerabilidad, tratándolas en las Reglas 43

\footnotetext{
${ }^{306}$ DPP. http://www.dpp.cl/pag/82/245/defensa_indigena [Consulta 5 de noviembre de 2019].

307 XIV CUMBRE JUDICIAL IBEROAMERICANA. Op. Cit., Regla 29: "Se destaca la conveniencia de promover la política pública destinada a garantizar la asistencia técnico-jurídica de la persona vulnerable para la defensa de sus derechos en todos los órdenes jurisdiccionales; ya sea a través de la creación de mecanismos de asistencia letrada, consultorías jurídicas con la participación de las Universidades, casas de justicia, intervención de colegios o barras de abogados".

${ }^{308}$ PODER JUDICIAL CHILE. Protocolo de Acceso a la Justicia de Grupos Vulnerables. Op. Cit. p. 77.

${ }^{309}$ XIV CUMBRE JUDICIAL IBEROAMERICANA. Op. Cit., Regla 31: "Se promoverán acciones destinadas a garantizar la gratuidad de la asistencia técnico-jurídica de calidad a aquellas personas que se encuentran en la imposibilidad de afrontar los gastos con sus propios recursos y condiciones”.

${ }^{310}$ BUENOS AIRES CIUDAD. https://www.buenosaires.gob.ar/guiajuridicagratuita/oficina-multipuertas. [Consulta 7 de noviembre de 2019].

${ }^{311}$ XIV CUMBRE JUDICIAL IBEROMERICANA. Op. Cit., Regla 32: "Se garantiza el uso de interprete cuando el extranjero que no conozca la lengua o leguas oficiales ni, en su caso, la lengua oficial propia de la comunidad, hubiese de ser interrogado o prestar alguna declaración o cuando fuese preciso darle a conocer personalmente alguna resolución”.

${ }^{312}$ PODER JUDICIAL DE CHILE: http://colegioabogados.cl/poder-judicial-implemento-sistema-detraduccion-en-linea-para-las-audiencias/ [Consulta 7 de noviembre de 2019]. "Se realizó primera formalización con traductor en Copiapó: Proyecto se inició en 2016 con lenguaje de señas y creole. Ahora se incorporaron las lenguas de pueblos originarios: mapudungun, aimara y quechua. También, la de otros idiomas, como el inglés, francés, ruso, árabe, alemán y chino. Con la ayuda de una traducción a través de videollamadas en alta definición, los imputados que hablan idiomas distintos al castellano pueden entender qué está ocurriendo en las audiencias"
} 
y $44^{313}$, en cuanto a alternativas de solución acordes con las necesidades de las personas que conforman estos grupos. La posibilidad que tienen las personas de ser protagonistas en la resolución de sus problemáticas de carácter jurídico o en sus colisiones de interés mediante estos métodos, permite el empoderamiento ciudadano constructivista, que los hace sentirse parte de la solución y no del problema, y así evitar una lógica colonial, en que el Estado, antes el Rey o el señor feudal, expropian el conflicto a los interesados, so pretexto de la incapacidad de éstos de solucionarlos adecuadamente. Como ejemplo de estas medidas se pueden mencionar: los Centros de Mediación de las Corporaciones de Asistencia Judicial en Chile (CMED), y los ya citados Centros de Conciliación de Colombia y los Tribunales Multipuertas de Argentina, todos los cuales ofrecen este servicio, en diferentes variantes. En la sección sexta, precisamente en las Reglas 48 y $49^{314}$, se hace referencia al sistema de resolución de conflictos dentro de las comunidades indígenas ${ }^{315}$.

En este instrumento se regulan en forma específica algunas condiciones de vulnerabilidad, sin perjuicio que el carácter dinámico de las necesidades sociales ha

313 XIV CUMBRE JUDICIAL IBEROAMERICANA. Op. Cit., Regla 43: “Se impulsarán las formas alternativas de resolución de conflictos en aquellos supuestos en los que resulte apropiado, tanto antes del inicio del proceso como durante la tramitación del mismo. La mediación, la conciliación, el arbitraje y otros medios que no impliquen la resolución del conflicto por un tribunal pueden contribuir a mejorar las condiciones de acceso a la justicia de determinados grupos de personas en condición de vulnerabilidad, así como a descongestionar el funcionamiento de los servicios formales de justicia”.

314 IBIDEM. Regla 48: “Con fundamento en los instrumentos internacionales en la materia resulta conveniente estimular las formas propias de justicia en la resolución de conflictos surgidos en el ámbito de la comunidad indígena, así como propiciar la armonización de los sistemas de administración de justicia estatal e indígena basada en el principio de respeto mutuo y de conformidad con las normas internacionales de derechos humanos. Regla 49: “Además serán de aplicación las restantes medidas previstas en estas Reglas en aquellos supuestos de resolución de conflictos fuera de la comunidad indígena por parte del sistema de administración de justicia estatal, donde resulta conveniente abordar los temas relativos al peritaje cultural y al derecho de expresarse en el propio idioma”.

315 XVII CUMBRE JUDICIAL IBEROAMERICANA (2014). Protocolo Iberoamericano de Actuación Judicial para Mejorar el Acceso a la Justicia de Personas con Discapacidad, Migrantes, Niñas. Niños, Adolescentes, Comunidades y Pueblos indígenas. p.106. "De conformidad con el derecho a la libre determinación, los pueblos indígenas deben tener acceso a la justicia a nivel externo, de los Estados, e interno, a través de los sistemas consuetudinarios y tradicionales indígenas, y deben tener acceso a la justicia tanto de manera individual como colectiva. Es importante alinear la justicia ordinaria con la justicia indígena, a fin de generar un marco normativo que: "evite los solapamientos entre ambas jurisdicciones y que proporcione algunas reglas básicas de cómo debe ser la relación existente, cuáles son los límites de la jurisdicción indígena, cuál es la competencia que le corresponde a cada una de ellas y cuál debe ser la regla a aplicar si un asunto o conflicto es asumido por una jurisdicción cuando le corresponde a otra”, en el marco de la maximización de la autonomía y acceso a la justicia”. 
hecho incluir otras, como las vinculadas con las necesidades de vivienda, pues como lo hemos señalado la vulnerabilidad va a depender de factores asociados al desarrollo social y cultural, pero especialmente económico de la sociedad y de la forma del Estado, como asimismo a las incidencias en desigualdad y discriminación ${ }^{316}$.

Las Reglas de Brasilia contienen además disposiciones específicas relativas a la víctima $^{317}$, la victimización que se produce ${ }^{318}$ y a los privados de libertad ${ }^{319}$.

\section{En cuanto a la eficacia, se consagran una serie de medidas tendientes a fomentar} su efectividad, de tal manera que contribuyan de manera eficaz a la mejora de condiciones de acceso a la justicia de las personas en condición de vulnerabilidad $^{320}$.

316 XIV CUMBRE JUDICIAL IBEROAMERICANA. Op. Cit., Regla 4: "Podrán constituir causas de vulnerabilidad, entre otras, las siguientes: la edad, la discapacidad, la pertenencia a comunidades indígenas o a minorías, la victimización, la migración y el desplazamiento interno, la pobreza, el género y la privación de libertad. La concreta determinación de las personas en condición de vulnerabilidad en cada país dependerá de sus características específicas, o incluso de su nivel de desarrollo social y económico”. Estimo, que nunca es sobreabundante recalcar que se señala que podrán constituir causas de vulnerabilidad "entre otras", las que se mencionan en la regla 4, pudiéndose ampliar a otras, según los factores sociales, económicos y culturales particulares del Estado que se trate en un momento determinado, no debiéndose solamente circunscribir a las descritas.

${ }^{317}$ IBIDEM. Regla 10: "En este sentido, se considera víctima toda persona física que ha sufrido un daño ocasionado por una infracción penal, incluida tanto la lesión física o psíquica, como el sufrimiento moral y el perjuicio económico". Regla 56: "Se promoverá que las víctimas reciban información sobre los siguientes elementos del proceso jurisdiccional: Posibilidades de obtener reparación del daño sufrido, Lugar y modo y modo en que pueden presentar una denuncia o escrito en el que ejercite una acción, curso dado a su denuncia o escrito, fases relevantes del desarrollo del proceso, resoluciones que dicte el órgano jurisdiccional”.

${ }^{318}$ IBIDEM. Regla 11: "Se considera en condición de vulnerabilidad aquella víctima del delito que tenga una relevante limitación para evitar o mitigar los daños y perjuicios derivados de la infracción penal o de su contacto con el sistema de justicia, o para afrontar los riesgos de sufrir una nueva victimización. La vulnerabilidad puede proceder de sus propias características personales, o bien de las circunstancias de la infracción penal. Destacan a estos efectos, entre otras víctimas, las personas menores de edad, las víctimas de violencia doméstica o intrafamiliar, las víctimas de delitos sexuales, los adultos mayores, así como los familiares de víctimas de muerte violenta". Regla 12: "Se alentará la adopción de aquellas medidas que resulten adecuadas para mitigar los efectos negativos del delito (victimización primaria). Asimismo se procurará que el daño sufrido por la víctima del delito no se vea incrementado como consecuencia de su contacto con el sistema de justicia (victimización secundaria)”.

${ }^{319}$ IBIDEM. Regla 22: "La privación de la libertad, ordenada por autoridad pública competente, puede generar dificultades para ejercitar con plenitud ante el sistema de justicia el resto de derechos de los que es titular la persona privada de libertad, especialmente cuando concurre alguna causa de vulnerabilidad enumerada en los apartados anteriores”.

${ }^{320}$ IBIDEM. Regla 85: "La eficacia de las presentes reglas está directamente ligada al grado de colaboración entre sus destinatarios....La determinación de los órganos y entidades llamadas a colaborar depende de las circunstancias propias de cada país, por lo que los principales impulsores de las políticas públicas deben poner 
Las Reglas de Brasilia, en su Capítulo II, incluye la obligación del Estado de velar que en la realización de cualquier acto judicial que la persona reciba la información jurisdiccional o procesal necesaria ${ }^{321}$.

Se debe hacer presente que se promoverá la creación de espacios que permitan la colaboración entre los órganos del Estado, no solo implementar acciones por parte del poder judicial, y además que se pueda colaborar entre los países, en cuanto al intercambio de experiencias, analizando las causas del éxito o fracaso en cada una de ellas, fijando buenas prácticas, tal como se desprende del Manual para la Construcción de Políticas Públicas sobre Acceso a la Justicia de Personas, y especialmente del Protocolo Iberoamericano de Actuación Judicial para Mejorar el Acceso a la Justicia de Personas con Discapacidad, Migrantes, Niñas. Niños, Adolescentes, Comunidades y Pueblos indígenas, en el marco de la XVII Cumbre Judicial Iberoamericana, celebrada en Santiago de Chile en abril de 2014.

Se debe destacar el reconocimiento implícito en las Reglas de Brasilia, de que tanto el Poder Judicial, como el Ministerio Público y las Defensorías Públicas u Oficiales, y no solo los poderes políticos, tienen responsabilidades en materia de acceso a la justicia de las personas y grupos sociales en condición de vulnerabilidad. Este reconocimiento no es novedoso en materia de DIDH, pero las 100 Reglas de Brasilia, merecen como ya se ha expresado, ser elogiadas por constituir un ejemplo de expresa asunción y toma de conciencia de la existencia de esas obligaciones por parte de los operadores del sistema de justicia, que se traduce en el establecimiento de lineamientos para su operatividad concreta ${ }^{322}$.

\footnotetext{
un especial cuidado tanto para identificarlos y recabar su participación, como para mantener su colaboración dentro de todo el proceso".

${ }^{321}$ IBIDEM. Regla 51: "Se promoverán las condiciones destinadas a garantizar que la persona en condición de vulnerabilidad sea debidamente informada sobre los aspectos relevantes de su intervención en el proceso judicial, en forma adaptada a las circunstancias determinantes de su vulnerabilidad. Regla 52: "Cuando la persona vulnerable participe en una actuación, en cualquier condición será informada sobre los siguientes extremos: La naturaleza de la actuación judicial en la que va a participar, su papel dentro de dicha actuación, el tipo de apoyo que pueda recibir en relación con la concreta actuación, así como la información de que organismo o institución pueda prestarlo.

${ }^{322}$ ANDREU.GUZMAN, F y COURTS, C. Op. Cit., p. 52.
} 


\section{GRUPO VULNERABLE DE NIÑAS, NIÑOS Y ADOLESCENTES}

\subsection{Generalidades}

Un sistema adecuado de protección a los derechos de los NNA, impulsada por el Estado y una idónea legislación que permita el pleno ejercicio de ellos, cuando estos son desconocidos o derechamente trasgredidos, permite un efectivo acceso a la justicia de este grupo, en condiciones igualdad y no discriminación.

En la línea de las Reglas de Brasilia debe existir una coherencia entre lo consagrado legalmente, y las garantías que se otorguen, las que permitan al grupo vulnerable en cuestión, una defensa adecuada de derechos, pudiéndole exigir al Estado, que adecue su sistema estatal en general y de justicia en particular, y lo establezca como un instrumento de real protección, cumpliendo con los estándares de acceso a la justicia y los de debida diligencia internacionalmente validados.

En lo relativo a NNA, la CADH establece la obligación para los Estados, ensuartículo 19, de tomar medidas especiales de protección cuando se trata de niños, y esto dice relación con que los NNA se encuentran en una situación particular que requiere de la adopción de todo tipo de medidas, cualquiera sea el ente, cualquiera sea la naturaleza de esa medida, que proteja y que haga efectivos sus derechos.

Como sostiene Lovatón, "el acceso a la justicia de los niños y niñas que sufren violación de sus derechos fundamentales en América Latina, es una situación de serio divorcio entre lo consagrado en los instrumentos internacionales de derechos humanos y las legislaciones nacionales por un lado, y lo que sucede en la realidad: la gran desprotección de los derechos de los niños y niñas en el sistema de justicia, al punto que podría hablarse de la 'invisibilidad' de esta problemática en muchos países del continente" ${ }^{323}$. Esta invisibilidad, que se torna en indiferencia e

\footnotetext{
${ }^{323}$ LOVATÓN, D. Op. Cit., p. 275. "Este divorcio entre andamiaje normativo y realidad es mucho más grave si tomamos en cuenta que el principio medular que debería regir la actuación de los Estados en la protección de los derechos del niño, es el interés superior del niño”.
} 
indolencia, no solo del Estado, sino de los diversos actores de la vida social, desde el ciudadano común hasta las diversas organizaciones, se fundamenta a nuestro entender en una mirada adulto céntrica propia de una sociedad individualista y escasamente empática con las diversas limitaciones que el desarrollo evolutivo imprime a una persona, y que su equivocado abordaje puede conducir a entornos cada vez más desiguales e injustos. A modo ejemplar, cuando el juez resuelve sobre un régimen de visitas, no debe preocuparse en atender solo a la disposición horaria del adulto no custodio, sino que debe ponderar factores que dicen relación con el bienestar del niño o niña, como su vinculación con el adulto, sus intereses particulares, entre otros.

Es necesario utilizar una perspectiva de vulnerabilidad en el tratamiento proteccional. Por ello, la legislación y las políticas públicas de la niñez y adolescencia deben precisamente enfocarse en esta falta de aptitud para precaver o resistirse a las consecuencias de una transgresión. Las leyes y el Estado deben consagrar y desarrollar las medidas preventivas adecuadas en los entornos familiares y escolares para que no se produzcan situaciones de riesgo que puedan afectar la vida, supervivencia y desarrollo de los NNA, y que en caso que sus derechos fundamentales sean transgredidos, puedan lograr su restablecimiento bajo el amparo del Estado. La vulnerabilidad que presentan los NNA se agrava cuando pertenecen a otro grupo vulnerable, siendo en este caso más complejo la posibilidad de ser oídos, no ser discriminados o aspirar a un proyecto de vida en que se respete su dignidad ${ }^{324}$.

La Corte IDH al emitir la OC 17/2002 ${ }^{325}$, estableció valiosos criterios de interpretación de las normas internacionales, que los Estados miembros de la

\footnotetext{
${ }^{324}$ Además, cuando hay un niño en especial situación de vulnerabilidad, cuando pertenece a una determinada minoría, cuando está en una situación de pobreza, en una situación de desarraigo o de migración, el enfoque de la vulnerabilidad es muy pertinente, y en una sociedad como la chilena que está viviendo en los últimos años un cambio tan profundo como es la migración, este enfoque se vuelve aún más importante

${ }^{325}$ CORTE IDH. OC 17 sobre la Condición jurídica y los derechos humanos del niño de 28 de agosto de 2002. Párrs 2, 56, 57, 58, 59. 60. Párrafo 2: "Que de conformidad a la normativa contemporánea del derecho internacional de derechos humanos...los niños son titulares de derechos y no solo objeto de protección...Que la expresión 'interés superior del niño' consagrada en el artículo 3 de la Convención sobre los Derechos del Niño, implica que el desarrollo de éste y el ejercicio pleno de sus derechos deben ser considerados como
} 
Organización de Estados Americanos deben cumplir en la implementación de políticas públicas referidas o que afecten los derechos de los NNA, que en síntesis, imparten lineamientos en cuanto a mutar o transitar desde un modelo tutelar o asistencialista que se sustenta en la doctrina de la situación irregular, concibiendo al NNA como un objeto de protección, a un enfoque de derechos, que lo concibe como un sujeto de derechos, estableciendo respecto del Estado un deber inexcusable de respeto y protección a su favor.

\subsection{Normativa internacional aplicable, principios y jurisprudencia.}

criterios rectores para la elaboración de normas y la aplicación de éstas en todos los órdenes de la vida del niño. Sin embargo nuevamente la realidad dista mucho de lo consagrado en el ámbito normativo”.

Párrafo 56: "Este principio regulador de la normativa de los derechos del niño se funda en la dignidad misma del ser humano, en las características propias de los niños, y en la necesidad de propiciar el desarrollo de éstos, con pleno aprovechamiento de sus potencialidades así como en la naturaleza y alcances de la Convención sobre los Derechos del Niño".

Párrafo 57: “A este respecto, el principio 2 de la Declaración de los Derechos del Niño (1959) establece:

El niño gozará de una protección especial y dispondrá de oportunidades y servicios, dispensado todo ello por la ley y por otros medios, para que pueda desarrollarse física, mental, moral, espiritual y socialmente en forma saludable y normal, así como en condiciones de libertad y dignidad. Al promulgar leyes con este fin, la consideración fundamental a que se atenderá será el interés superior del niño.

Párrafo 58: "El principio anterior se reitera y desarrolla en el artículo 3 de la Convención sobre los Derechos del Niño, que dispone.

1. En todas las medidas concernientes a los niños que tomen las instituciones públicas o privadas de bienestar social, los tribunales, las autoridades administrativas o los órganos legislativos, una consideración primordial a que se atenderá será el interés superior del niño”.

Párrafo 59. "Este asunto se vincula con los examinados en párrafos precedentes, si se toma en cuenta que la Convención sobre Derechos del Niño alude al interés superior de éste (artículos 3, 9, 18, 20, 21, 37 y 40) como punto de referencia para asegurar la efectiva realización de todos los derechos contemplados en ese instrumento, cuya observancia permitirá al sujeto el más amplio desenvolvimiento de sus potencialidades. A este criterio han de ceñirse las acciones del Estado y de la sociedad en lo que respecta a la protección de los niños y a la promoción y preservación de sus derechos". Párrafo 60: "En el mismo sentido, conviene observar que para asegurar, en la mayor medida posible, la prevalencia del interés superior del niño, el preámbulo de la Convención sobre los Derechos del Niño establece que éste requiere “cuidados especiales”, y el artículo 19 de la Convención Americana señala que debe recibir 'medidas especiales de protección'. En ambos casos, la necesidad de adoptar esas medidas o cuidados proviene de la situación específica en la que se encuentran los niños, tomando en cuenta su debilidad, inmadurez o inexperiencia. Párrafo 61: "En conclusión, es preciso ponderar no sólo el requerimiento de medidas especiales, sino también las características particulares de la situación en la que se hallan el niño". 
a) Convención Internacional de los Derechos del Niño (CIDN) de 1989, ratificada en Chile en 1990.

b) Convención sobre Aspectos Civiles del Secuestro Internacional de Niños de 1980, ratificada por Chile en 1994.

c) Reglas Mínimas de las Naciones Unidas para la Administración de Justicia de Menores.

d) Directrices de Acción Sobre el Niño en el Sistema de Justicia Penal.

e) Protocolo para Prevenir, Reprimir y Sancionar la Trata de Personas, especialmente de Mujeres y Niños, que complementa a la Convención de Naciones Unidas contra la Delincuencia Organizada Internacional.

f) Protocolo Iberoamericano de Actuación Judicial para Mejorar el Acceso a la Justicia de Niños, Niñas y Adolescentes.

g) Reglas de Brasilia sobre Acceso a la Justicia de las Personas en Condición de Vulnerabilidad. Regla 5: "Se considera niño, niña y adolescente a toda persona menor de dieciocho años de edad, salvo que haya alcanzado antes la mayoría de edad en virtud de la legislación nacional aplicable. Todo niño, niña y adolescente debe ser objeto de una especial tutela por parte de los órganos del sistema de justicia en consideración a su desarrollo evolutivo".

De estas normas, se desprenden los siguientes principios cuya aplicación asegura un efectivo acceso a la justicia:

a) Interés superior del niño: En términos generales se considera que este principio debe ser primordial en todas las medidas relacionadas con la infancia, definiéndose como la plena efectividad de los derechos de los NNA. En este sentido, el juez al decidir la naturaleza de la medida de protección que aplique a favor de un niño vulnerado, debe ponderar los distintos factores que permitirán la restauración del o de los derechos afectados. Además, al decidir sobre cuál de los padres deberá tener el cuidado personal o custodia de un hijo, deberá considerar diversos elementos 
centrados en la idoneidad de la resolución y las repercusiones de la misma en el NNA $^{326}$.

La Jurisprudencia interamericana ha aplicado y le ha dado especial significación en algunas de sus sentencias a estos principios, prevaleciendo la concepción, de que Ios NNA tienen derechos especiales a los que corresponden deberes específicos por parte de la familia, la sociedad y el Estado, pues su condición exige una protección especial ${ }^{327}$. En Chile el caso Atala Riffo y niñas, de 24 de febrero de 2012, pone en manifiesto la importancia de la aplicación de este principio, en cuanto el aplicador del derecho, sea en el ámbito administrativo o en el judicial, deberá tomar en consideración las condiciones específicas del menor de edad y su interés superior para acordar la participación de éste, según corresponda, en la determinación de sus derechos ${ }^{328}$.

${ }^{326}$ CODIGO CIVIL. Artículo 225-2. "En el establecimiento del régimen y ejercicio del cuidado personal, se considerarán y ponderarán conjuntamente los siguientes criterios y circunstancias:

a) La vinculación afectiva entre el hijo y sus padres, y demás personas de su entorno familiar.

b) La aptitud de los padres para garantizar el bienestar del hijo y la posibilidad de procurarle un entorno adecuado, según su edad.

c) La contribución a la mantención del hijo, mientras estuvo bajo el cuidado personal del otro padre, pudiendo hacerlo.

d) La actitud de cada uno de los padres para cooperar con el otro, a fin de asegurar la máxima estabilidad al hijo y garantizar la relación directa y regular, para lo cual considerará especialmente lo dispuesto en el inciso quinto del artículo 229.

e) La dedicación efectiva que cada uno de los padres procuraba al hijo antes de la separación y, especialmente, la que pueda seguir desarrollando de acuerdo con sus posibilidades.

f) La opinión expresada por el hijo.

g) El resultado de los informes periciales que se haya ordenado practicar.

h) Los acuerdos de los padres antes y durante el respectivo juicio.

i) El domicilio de los padres.

j) Cualquier otro antecedente que sea relevante atendido el interés superior del hijo.

${ }^{327}$ CORTE IDH. Caso González y otras vs México. Sentencia de 16 de noviembre de 2009. Párrafo 408: "Esta Corte ha establecido que los niños y niñas tienen derechos especiales a los que corresponden deberes específicos por parte de la familia, la sociedad y el Estado. Además, su condición exige una protección especial que debe ser entendida como un derecho adicional y complementario a los demás derechos que la Convención reconoce a toda persona. La prevalencia del interés superior del niño debe ser entendida como la necesidad de satisfacción de todos los derechos de la infancia y la adolescencia, que obliga al Estado e irradia efectos en la interpretación de todos los demás derechos de la Convención cuando el caso se refiera a menores de edad. Asimismo, el Estado debe prestar especial atención a las necesidades y los derechos de las presuntas víctimas en consideración a su condición de niñas, como mujeres que pertenecen a u

n grupo en una situación vulnerable".

${ }^{328}$ CORTE IDH. Caso Atala Riffo y niñas vs Chile. Sentencia de 24 de febrero de 2012. Párrafo 199: "Por otra parte, la Corte reitera que los niños y las niñas ejercen sus derechos de manera progresiva a medida que desarrollan un mayor nivel de autonomía personal. En consecuencia, el aplicador del derecho, sea en el ámbito administrativo o en el judicial, deberá tomar en consideración las condiciones específicas del menor de edad y 
b) Igualdad y no discriminación: Este principio se sustenta en el sentido de un acceso a la justicia integral, en que el ejercicio de un derecho no puede estar condicionado a una determinada característica de la persona. Todo NNA es titular de derechos humanos, sin importar raza, color, sexo, género, idioma, religión, opinión política o de otra índole, origen nacional, étnico o social, posición económica, impedimentos físicos, nacimiento o cualquier otra condición del niño, de sus padres o de sus representantes legales en el ámbito jurisdiccional, que afecte de manera directa o indirecta sus intereses, debe tomarse en base al reconocimiento de sus características propias, por esto es necesario plantearse la necesidad de adecuar los procedimientos en que participan los NNA ${ }^{329}$.

Adicionalmente, debe considerarse que el derecho del niño al efectivo acceso a la justicia conlleva la obligación de las instituciones de brindar al niño o niña, un trato diferenciado y especializado. En particular, debe tenerse en cuenta que el NNA requiere en determinados casos y con respeto a su autonomía progresiva, la guía y acompañamiento de personas adultas para ejercer sus derechos, lo que variará dependiendo de su grado de desarrollo y madurez ${ }^{330}$.

La Jurisprudencia interamericana formula un llamamiento a los Estados, en cuanto a no permitir que sus autoridades realicen diferencias arbitrarias, como por ejemplo, en razón a su nacionalidad o al establecimiento de estigmas, en cuanto a asociar la condición de Niño pobre a una predisposición delictual ${ }^{331}$. Esta imposibilidad de

su interés superior para acordar la participación de éste, según corresponda, en la determinación de sus derechos. En esta ponderación se procurará el mayor acceso del menor de edad, en la medida de lo posible, al examen de su propio caso. Asimismo, la Corte considera que las niñas y los niños deben ser informados de su derecho a ser escuchados directamente o por medio de un representante, si así lo desean. Al respecto, en casos en que se presenten conflictos de intereses entre la madre y el padre, es necesario que el Estado garantice, en lo posible, que los intereses del menor de edad sean representados por alguien ajeno a dicho conflicto”.

${ }^{329}$ PODER JUDICIAL DE CHILE. Protocolo de Acceso a la Justicia de Grupos Vulnerables. p.32

${ }^{330}$ IBIDEM. "Es así como el principio de igualdad y no discriminación no solo es la obligación de ser imparcial, sino el deber que tienen los Estados respecto de tomar medidas con el objeto de concretar acciones especiales a favor de NNA, para la efectividad de sus derechos”.

${ }^{331}$ CORTE IDH. Caso Servellón García vs Honduras. Sentencia de fecha 21 de septiembre de 2006. Párrafo 112: "La Corte advierte que, en atención al principio de igualdad ante la ley y no discriminación, el Estado no puede permitir por parte de sus agentes, ni fomentar en la sociedad prácticas que reproduzcan el estigma de que niños y jóvenes pobres están condicionados a la delincuencia, o necesariamente vinculados al aumento de la inseguridad ciudadana. Esa estigmatización crea un clima propicio para que aquellos menores en situación de riesgo se encuentren ante una amenaza latente a que su vida y libertad sean ilegalmente restringidas”. 
hacer diferencias arbitraria, es representada en el fallo del caso de las Niñas Yeans Bosico vs República Dominicana, de 8 de diciembre de $2005^{332}$.

c) El Derecho a ser oído y opinar en todos los asuntos que le afectan y que sean debidamente tomadas en consideración sus opiniones: La CIDN reconoce este derecho en función de su edad y madurez, para lo que se deberá dar al niño la oportunidad de ser escuchado en todo procedimiento judicial o administrativo que le afecte, de forma directa o por medio de un representante ${ }^{333}$. El Comité de los Derechos del Niño ha desarrollado este principio, tanto en la observación General $n^{\circ} 5$, sobre las Medidas Generales de Aplicación de la Convención, como en la $n^{\circ}$ 12, dedicada exclusivamente a este derecho y a su aplicación.

Tal como se señala en el Informe Anual de Derechos Humanos en Chile del año 2019, la Observación General n 12 del Comité de Derechos del Niño, de 12 de Junio de 2006, sobre el derecho del niño a ser escuchado, establece que para que el derecho a ser oído sea real y efectivo, debe ser considerado como un proceso y

\footnotetext{
${ }^{332}$ CORTE IDH. Caso Niñas Yean y Bosico vs República Dominicana. Sentencia de fecha 8 de diciembre de 2005. Párrafo 174: "La Corte encuentra que por razones discriminatorias y contrarias a la normativa interna pertinente, el Estado dejó de otorgar la nacionalidad a las niñas, lo que constituyó una privación arbitraria de su nacionalidad, y las dejó apátridas por más de cuatro años y cuatro meses, en violación de los artículos 20 y 24 de la Convención Americana, en relación con el artículo 19 de la misma, y también en relación con el artículo 1.1 de este instrumento, en perjuicio de las niñas Dilcia Yean y Violeta Bosico”.

${ }^{333}$ CORTE IDH. Caso Atala Riffo y niñas vs Chile. Op. Cit., Párrafo 196: "La Corte resalta que los niños y las niñas son titulares de los derechos establecidos en la Convención Americana, además de contar con las medidas especiales de protección contempladas en el artículo 19 de la Convención, las cuales deben ser definidas según las circunstancias particulares de cada caso concreto. En el presente caso, el Tribunal observa que el artículo 8.1 de la Convención Americana consagra el derecho a ser oído que ostentan todas las personas, incluidos los niños y niñas, en los procesos en que se determinen sus derechos. Dicho derecho debe ser interpretado a la luz del artículo 12 de la Convención sobre los Derechos del Niño, el cual contiene adecuadas previsiones sobre el derecho a ser escuchado de las niñas y los niños, con el objeto de que la intervención del niño se ajuste a las condiciones de éste y no redunde en perjuicio de su interés genuino". Párrafo 198: "Con el fin de determinar los alcances de los términos descritos en el artículo 12 de dicha Convención, el Comité realizó una serie de especificaciones, a saber: i) no puede partir[se] de la premisa de que un niño es incapaz de expresar sus propias opiniones ii) el niño no debe tener necesariamente un conocimiento exhaustivo de todos los aspectos del asunto que lo afecta, sino una comprensión suficiente para ser capaz de formarse adecuadamente un juicio propio sobre el asunto iii) el niño puede expresar sus opiniones sin presión y puede escoger si quiere o no ejercer su derecho a ser escuchado; iv) "la realización del derecho del niño a expresar sus opiniones exige que los responsables de escuchar al niño y los padres o tutores informen al niño de los asuntos, las opciones y las posibles decisiones que pueden adoptarse y sus consecuencias; v) "la capacidad del niño [...] debe ser evaluada para tener debidamente en cuenta sus opiniones o para comunicar al niño la influencia que han tenido esas opiniones en el resultado del proceso, y vi) "los niveles de comprensión de los niños no van ligados de manera uniforme a su edad biológica", por lo que la madurez de los niños o niñas debe medirse a partir de "la capacidad [...] para expresar sus opiniones sobre las cuestiones de forma razonable e independiente”.
} 
no como un acontecimiento singular y aislado, para lo cual debe existir: i) una preparación previa por parte del responsable de escucharlo; ii) información posterior al NNA proporcionada por quien toma la decisión, especialmente acerca de cómo se tuvieron en consideración sus opiniones; y iii) en el diálogo debe generarse un contexto de confianza que permita al NNA expresarse, de manera que se produzca una conversación y no un examen unilateral ${ }^{334}$.

La Corte IDH, ha ido construyendo y desarrollando la normativa internacional, estableciendo directrices en cuanto a la conformidad convencional de las sentencias locales respecto del derecho de todo NNA a ser oído en consideración a su edad y madurez, en atención a decisiones familiares, administrativas y/o judiciales que pueden afectar su vida futura. En el caso Atala Riffo vs Chile, la opción sexual de la madre fue considerada por la CS, como fundamento denegatorio de la custodia de sus hijas, por sobre la consideración de sus opiniones, estableciéndose estándares en cuanto a la procedencia de este derecho ${ }^{335}$. En lo especifico, en la sentencia del caso Furlan y familiares vs Argentina, de 31 de agosto de 2012, se destaca por

\footnotetext{
${ }^{334}$ VALENZUELA, E y CORREA, P. (2019). "Derechos Humanos de Niños, Niñas y Adolescentes. La infancia primero: Lo prometido es deuda”. EN Informe Anual Derechos Humanos 2019. Santiago. Universidad Diego Portales. p.280. "Estas condiciones establecidas por la CIDN debieran traducirse en protocolos claros y completos, que incorporen las directrices y estándares aludidos, para los distintos operadores que están a cargo de oír al NNA".

${ }^{335}$ CORTE IDH. Caso Atala Riffo vs Chile. Op. Cit., Párrs 196, 198. Párrafo 196: "La Corte resalta que los niños y las niñas son titulares de los derechos establecidos en la Convención Americana, además de contar con las medidas especiales de protección contempladas en el artículo 19 de la Convención, las cuales deben ser definidas según las circunstancias particulares de cada caso concreto. En el presente caso, el Tribunal observa que el artículo 8.1 de la Convención Americana consagra el derecho a ser oído que ostentan todas las personas, incluidos los niños y niñas, en los procesos en que se determinen sus derechos. Dicho derecho debe ser interpretado a la luz del artículo 12 de la Convención sobre los Derechos del Niño, el cual contiene adecuadas previsiones sobre el derecho a ser escuchado de las niñas y los niños, con el objeto de que la intervención del niño se ajuste a las condiciones de éste y no redunde en perjuicio de su interés genuino". Párrafo 198: "Con el fin de determinar los alcances de los términos descritos en el artículo 12 de dicha Convención, el Comité realizó una serie de especificaciones, a saber: i) no puede partir[se] de la premisa de que un niño es incapaz de expresar sus propias opiniones ii) el niño no debe tener necesariamente un conocimiento exhaustivo de todos los aspectos del asunto que lo afecta, sino una comprensión suficiente para ser capaz de formarse adecuadamente un juicio propio sobre el asunto iii) el niño puede expresar sus opiniones sin presión y puede escoger si quiere o no ejercer su derecho a ser escuchado; iv) la realización del derecho del niño a expresar sus opiniones exige que los responsables de escuchar al niño y los padres o tutores informen al niño de los asuntos, las opciones y las posibles decisiones que pueden adoptarse y sus consecuencias; v) la capacidad del niño [...] debe ser evaluada para tener debidamente en cuenta sus opiniones o para comunicar al niño la influencia que han tenido esas opiniones en el resultado del proceso, y vi) los niveles de comprensión de los niños no van ligados de manera uniforme a su edad biológica, por lo que la madurez de los niños o niñas debe medirse a partir de la capacidad $[\ldots]$ para expresar sus opiniones sobre las cuestiones de forma razonable e independiente".
} 
contener adecuadas previsiones sobre el derecho a ser escuchado de las niñas y los niños, con el objeto de que la intervención del niño se ajuste a las condiciones de éste y no redunde en perjuicio de su interés genuino ${ }^{336}$.

d) El derecho a la vida digna, supervivencia y desarrollo: Toda persona desde su nacimiento, desde sus primeros años de vida, y en todo su desarrollo evolutivo, debe ser respetada en su dignidad y derechos. De esta manera su vida no puede ser arrebatada, bajo ninguna circunstancia, ni tampoco los valores inherentes a ella, como la libertad, el derecho a alimentarse, a la salud, a la educación, etc. La familia es el núcleo fundamental de la sociedad, de una raigambre histórica indiscutida, la que debe constituirse en el pilar de protección de todo niño que se desarrolla en su seno. Tal como lo señala la CPR "el Estado está al servicio de la persona humana y su finalidad es promover el bien común, para lo cual debe contribuir a crear las condiciones sociales que permitan a todos y a cada uno de los integrantes de la comunidad nacional su mayor realización espiritual y material posible, con pleno respeto y garantía a los derechos y garantías que la Constitución establece"337. En este sentido, es deber del Estado dar protección a la familia y propender al fortalecimiento de ésta, y de esta forma actuar, en cuanto a generar políticas públicas de vida digna a los niños y a sus familias, especialmente cuando no tienen las oportunidades para satisfacer las necesidades básicas destinadas a la

\footnotetext{
${ }^{336}$ CORTE IDH. Caso Furlan y Familiares vs Argentina. Sentencia de 31 de agosto de 2012. Párrs 228, 229, 230. Párrafo 228: "El Tribunal reitera que el artículo 8.1 de la Convención Americana consagra el derecho a ser oído que ostentan todas las personas, incluidos los niños y niñas, en los procesos en que se determinen sus derechos. Dicho derecho debe ser interpretado a la luz del artículo 12 de la Convención sobre los Derechos del Niño, el cual contiene adecuadas previsiones sobre el derecho a ser escuchado de las niñas y los niños, con el objeto de que la intervención del niño se ajuste a las condiciones de éste y no redunde en perjuicio de su interés genuino...”. Párrafo 229: “En similar sentido, el artículo 7 de la CDPD establece expresamente que los niños y las niñas con discapacidad [tienen] derecho a expresar su opinión libremente sobre todas las cuestiones que les afecten, opinión que recibirá la debida consideración teniendo en cuenta su edad y madurez, en igualdad de condiciones con los demás niños y niñas, y a recibir asistencia apropiada con arreglo a su discapacidad y edad para poder ejercer ese derecho.....”. Párrafo 230: “Asimismo, la Corte reitera que los niños y las niñas ejercen sus derechos de manera progresiva a medida que desarrollan un mayor nivel de autonomía personal. En consecuencia, el aplicador del derecho, sea en el ámbito administrativo o en el judicial, deberá tomar en consideración las condiciones específicas del menor de edad y su interés superior para acordar la participación de éste, según corresponda, en la determinación de sus derechos. En esta ponderación se procurará el mayor acceso del menor de edad, en la medida de lo posible, al examen de su propio caso....”
}

${ }^{337}$ CPR. Artículo 19 n4. 
satisfacción de derechos sociales $^{338}$. Si las familias no cubren las necesidades de sus hijos, por negligencia o intencionalmente, habiendo el Estado agotado todas las instancias de apoyo, o cuando existe grave vulneración a su integridad (física, psicológica, sexual o de otra índole), sin cumplir con las directrices administrativas o judiciales destinadas al restablecimiento de los derechos del NNA, no existiendo además redes de apoyo familiares que pudieran asumir el cuidado personal, pudiese el Estado asumir excepcionalmente la custodia en un establecimiento residencial. En el contexto residencial, se debe brindar asistencia especial de los NNA privados de su medio familiar, otorgarle un nivel de vida adecuado, y proyectado a la reinserción social del niño víctima de abandono o explotación. En caso de encontrarse institucionalizado se les debe proveer de salud, alimentación, educación, y afecto. Estas obligaciones del ámbito residencial, se hacen más patentes en los recintos encargados de cumplir las sanciones derivadas de la Responsabilidad Adolescente.

En específico, en relación con el derecho al desarrollo, el Comité de Derechos Humanos ha interpretado el término desarrollo como un concepto integral que involucra todos los aspectos de la vida del niño o niña, como son el desarrollo físico, mental, espiritual, psicológico y social de éste ${ }^{339}$. La jurisprudencia Interamericana, refuerza las ideas proyectadas en cuanto a este principio, estableciendo criterios en torno al respeto y promoción de la vida digna, supervivencia y desarrollo de este grupo vulnerable ${ }^{340}$. En este contexto, en el caso del Instituto de Reeducación del

\footnotetext{
${ }^{338}$ En Chile, se destacan los programas Chile crece Contigo, la red de jardines infantiles (JUNJI), programa de control de niño sano, subsidios únicos familiares en razón de haber hijos en una familia de escasos recursos etcétera.

${ }^{339}$ PODER JUDICIAL CHILE. Protocolo de Acceso a la Justicia de Grupos Vulnerables. Op. Cit., p. 33. “Es relevante que en casos que suponen la separación del niño de sus padres, la Corte Interamericana ha destacado la importancia de la familia en el desarrollo de la niña o niño, y hace énfasis en la obligación del Estado de adoptar medidas que promuevan la unidad familiar, con excepción de aquellos casos en que sea contraria al interés superior del niño, a su desarrollo a la intimidad y a la vida privada y familiar”.

${ }^{340}$ CORTE IDH. Caso Villagrán Morales y otros vs Guatemala. Op. Cit., Párrafo 196: "Las normas transcritas permiten precisar, en variadas direcciones, los alcances de las "medidas de protección" a que alude el artículo 19 de la Convención Americana. Entre ellas merecen ser destacadas las referentes a la no discriminación, a la asistencia especial a los niños privados de su medio familiar, a la garantía de la supervivencia y el desarrollo del niño, al derecho a un nivel de vida adecuado y a la reinserción social de todo niño víctima de abandono o explotación. Es claro para esta Corte que los actos perpetrados contra las víctimas en el presente caso, en los que se vieron involucrados agentes del Estado, contravienen estas previsiones”.
} 
Menor vs Paraguay, de 2 de abril de 2004, se ha destacado que el Comité de Derechos del Niño ha interpretado la palabra "desarrollo" de una manera amplia, holística, que abarca lo físico, mental, espiritual, moral, psicológico y social ${ }^{341}$.

Analizados los principios y la jurisprudencia que en base a estos construye y desarrolla la norma, destacamos como buenas prácticas en el ámbito latinoamericano, el Centro de Entrevistas para Personas en Condición de Vulnerabilidad Víctimas o Testigos de Delitos de República Dominicana ${ }^{342}$, Plan Piloto de Visitas en Uruguay ${ }^{343}$, sin perjuicio de las que analizaremos en el caso de Chile.

\subsection{Acceso a la Justicia en Chile de los NNA. Obstáculos estructurales y normativos}

\subsubsection{Barreras estructurales o sistémicas}

En Chile, según datos del Fondo de las Naciones Unidas para la Infancia (UNICEF), existe una población de NNA de 4.259.155 que representan un 24,2\% de la población del país. El 43,5\% de los hogares tiene un NNA como integrante ${ }^{344}$. En cuanto a situaciones de violencia, el $71 \%$ de los NNA declaran haber sido víctima

\footnotetext{
${ }^{341}$ CORTE IDH: Caso Instituto de Reeducación del Menor vs Paraguay. Sentencia de 2 de abril de 2004. Párrafo 161: "En este sentido, los artículos 6 y 27 de la Convención sobre los Derechos del Niño incluyen en el derecho a la vida la obligación del Estado de garantizar en la máxima medida posible la supervivencia y el desarrollo del niño. El Comité de Derechos del Niño ha interpretado la palabra 'desarrollo' de una manera amplia, holística, que abarca lo físico, mental, espiritual, moral, psicológico y social. Mirado así, un Estado tiene, respecto de niños privados de libertad y, por lo tanto, bajo su custodia, la obligación de, inter alia, proveerlos de asistencia de salud y de educación, para así asegurarse de que la detención a la que los niños están sujetos no destruirá sus proyectos de vida. En este sentido, las Reglas de las Naciones Unidas para la Protección de los Menores Privados de Libertad establecen que: (...) No se deberá negar a los menores privados de libertad, por razón de su condición, los derechos civiles, económicos, sociales o culturales que les correspondan de conformidad con la legislación nacional o el derecho internacional y que sean compatibles con la privación de la libertad”.

${ }^{342}$ XVII CUMBRE JUDICIAL IBEROAMERICANA. Op. Cit., p. 68.

${ }^{343}$ IBIDEM.

${ }^{344}$ UNICEF (2020). Niños, Niñas o Adolescentes en Chile. pp. 1-2.
} 
de violencia por parte de su padre, madre o algún miembro adulto de su familia. De estos, el 19,5\% señala haber recibido violencia psicológica, 25,6\% violencia física leve y el 25,9 declara haber sufrido violencia física grave ${ }^{345}$. Cerca del 70\% de nuestras niñas y niños dicen haber sufrido algún tipo de violencia por parte de su padre y/o madre. El maltrato es transversal al nivel socioeconómico de las familias ${ }^{346}$.

En cuanto a la protección de derechos, 187.825 niños se encuentran insertos en la red del SENAME ${ }^{347}$. De ellos, el 3,8\% se encuentran cuidado alternativo residencial, $5 \%$ de ellos se encuentran en cuidado alternativo familiar y un 90,7\% de los NNA con medidas de protección es atendido por un programa ambulatorio (siguen viviendo con su familia), 0,3\% de los NNA con medidas de protección se encuentran en un programa de adopción ${ }^{348}$.

Por su parte 12.039 adolescentes y jóvenes están bajo el sistema de Responsabilidad Penal Adolescente ${ }^{349}$.

A nuestro parecer, sin lugar a dudas, la principal falencia de nuestra legislación en esta materia ha sido la ausencia de políticas de prevención orientadas a evitar situaciones de vulneración. Por el contrario, los únicos esfuerzos se han instaurado, se circunscriben a la restauración de derechos y reparación de daños en sede

\footnotetext{
${ }^{345}$ IBIDEM

${ }^{346}$ IBIDEM.

${ }^{347}$ SENAME. (2019). https://www.sename.cl/web/index.php/nuestra-institucion/. [Consulta 14 de noviembre de 2019]. El Servicio Nacional de Menores (SENAME) es un organismo gubernamental centralizado, colaborador del sistema judicial y dependiente del Ministerio de Justicia y Derechos Humanos. Se encarga de la protección de derechos de niños, niñas y adolescentes, y de los jóvenes entre 14 y 17 años que han infringido la ley. Además, se ocupa de regular y controlar la adopción en Chile. Fue creado por el Decreto Ley Nº 2.465 del 10 de enero de 1979, que constituye su Ley Orgánica publicada en el Diario Oficial el 16 de enero del mismo año. Un decreto supremo del 5 de diciembre de 1979 fijó la planta y el SENAME entró en funciones el 1 de enero de 1980. El servicio lleva a cabo su gestión conforme a las instrucciones de los diversos tribunales distribuidos a lo largo del país. Todos los servicios y asistencias que se prestan en la institución, salvo las Oficinas de Protección de Derechos (OPD), están ligadas a la justicia. Los niños y adolescentes atendidos en el sistema de protección han sido derivados por los tribunales de familia. Los adolescentes en el sistema de justicia juvenil han sido derivados por los tribunales de acuerdo a la Ley de Responsabilidad Penal Adolescente. Para cumplir con su labor, el servicio cuenta con centros de atención directa y con una red de colaboradores acreditados, que postulan con proyectos a licitaciones públicas.

${ }^{348}$ UNICEF. (2020). Op. Cit., p. 5.

${ }^{349}$ IBIDEM. " $10 \%$ de ellos con salidas alternativas, 6,2\% se encuentran con medidas privativas de libertad en régimen semicerrado, $50 \%$ están con medidas de sanción en el medio libre, un 5,2\% se encuentran en régimen cerrado, $16 \%$ se encuentran con medidas de internación provisoria no privativa de libertad y un 12,5\% están con medidas de internación provisoria con privación de libertad”.
} 
judicial a aquellos NNA que se encontrasen en situación irregular. Si bien a la fecha entre los avances más sustantivos tenemos la subsecretaría de la Niñez, dependiente del Ministerio de Desarrollo Social, y la Defensoría de la Niñez, el caso en cuestión no da cuenta de adecuaciones administrativas que propendan a un correcto y eficaz desempeño de las políticas públicas en esta materia, sin reducirse a meros cambios orgánicos o de dotación de personal. Lo anterior, ligado con el reconocimiento de la legitimación en la protección y representación de los derechos de este grupo vulnerable en orden a una defensa técnica especializada.

Uno de los principales obstáculos de efectiva protección a los derechos de este grupo, estámarcadopor la percepción de la insuficiencia de la respuesta estatal, simbolizada en la crisis del SENAME. Este Servicio no ha cumplido a cabalidad su misión, y se encuentra en deuda en sus dos funciones más relevantes, correspondientes a ejecutar políticas públicas en protección, como asimismo a administrar el sistema punitivo de los adolescentes infractores.

Se han detectado deficiencias graves en las residencias o establecimientos a cargo de este organismo y de instituciones privadas colaboradoras licitadas en que ingresan niños por vulneraciones en su entorno familiar por orden de los tribunales de familia ${ }^{350}$. El ingreso a residencias o hogares de menores es considerada una medida excepcional solo cuando el ambiente familiar nuclear o extenso no dan suficientes garantías de resguardo a su integridad física y psicológica. El Instituto Nacional de Derechos Humanos, en su Informe Anual de Derechos Humanos en Chile de 2016, sostiene que resulta preocupante que se mantenga vigente la denominada ley de menores, que contiene un marco normativo obsoleto, no acorde

\footnotetext{
${ }^{350}$ LEY 16.618. Fija el Texto definitivo de la Ley de Menores, de 8 de marzo de 1967. Artículo 30: "En los casos previsto en el artículo $8^{\circ}, \mathrm{n}^{\circ} 7$ y 8 , de la ley que crea los juzgados de familia, el juez de letras de menores, mediante resolución fundada, podrá decretar las medidas que sean necesarias para proteger a los menores de edad gravemente vulnerados o amenazados en sus derechos. En particular, el juez podrá: 2) disponer el ingreso del menor de edad en un Centro de Tránsito o Distribución, hogar substituto o en un establecimiento residencial. La medida de internación en un establecimiento de protección solo procederá en aquellos casos en que, para cautelar la integridad física o psíquica del menor de edad resulte indispensable separarlo de su medio familiar o de las personas que lo tienen bajo su cuida. Esta medida tiene un carácter esencialmente temporal, no se decretará por un plazo superior a un año, y deberá ser revisada por el tribunal cada 6 meses, para lo cual solicitará los informes que procedan al encargado del centro u hogar respectivo. Sin perjuicio de ello, podrá renovarse en esos mismos términos y condiciones, mientras subsista la causal que le dio lugar. En todo caso, el tribunal podrá sustituir o dejar sin efecto la medida antes del vencimiento del plazo por el que la hubiere dispuesto".
} 
a estándares de derechos humanos y reitera la necesidad de superar las falencias de coordinación intersectorial y dar prioridad a un enfoque centrado en el sujeto ${ }^{351}$. Si bien es cierto existía en la opinión pública un manto de dudas respecto de las reales condiciones en que se encontraban los NNA en las residencias del SENAME, la visibilización de esta desprotección se hizo patente el año 2016, con el caso de la niña Lisette Villa ${ }^{352}$ de 11 años, cuyas circunstancias de fallecimiento en un centro de reparación especializada de administración directa denominado "Galvarino", ubicado en la Región Metropolitana, significaron que se destapará el conocido públicamente "caso SENAME", a pesar que hace años diversos informes hablaban de graves vulneraciones de derechos en los centros administrados y asociados al SENAME ${ }^{353}$.

En el marco de la investigación del fiscal Marcos Emilfor quién investiga las 1.313 muertes en centros del SENAME (entre 2005 y 2016) reportadas tras el deceso de Lissette, encomendó a la Policía de Investigaciones la confección de un informe criminalístico que se desarrolló por un equipo especializado, que en 2017 y 2018 investigó 240 hogares de menores ${ }^{354}$. En mérito de una investigación periodística del Centro de Investigación e Información Periodística (CIPER), los autores Nicolás Sepúlveda y Juan Guzmán constataron certezas en cuanto a que "el Estado de Chile viola sistemáticamente los derechos de los niños que están bajo su tutela". A la luz del informe aludido, esta situación se presentó en el 100\% de los centros que

\footnotetext{
${ }^{351}$ IBIDEM.

352 RADIO BIOBIO. https://www.biobiochile.cl/especial/resumen-de-noticias/2019/08/27. [Consulta 10 de julio de 2020]. "De acuerdo a la Fiscalía, ese día, después de que la niña supuestamente desobedeciera, dos educadoras de trato directo la redujeron en el suelo, sujetándole las extremidades e incluso sentándose arriba de ella una de las funcionarias, que pesaba 90 kilos. La causa de muerte fue una "asfixia por sofocación. En los días posteriores, la Directora Nacional de ese entonces, Marcela Labraña, aseguró que la niña había fallecido tras descompensarse porque no la habían ido a ver como esperaba. Por eso, una vez que se comenzaron a conocer las reales circunstancias de la muerte de L.V, Labraña fue apuntada como una posible encubridora, considerando esas declaraciones".
}

${ }^{353}$ SEPULVEDA, N; GUZMAN, J (2018). "El Brutal Informe de Policía de Investigaciones sobre abusos en el SENAME que permaneció oculto desde diciembre”. EN CIPER ACADEMICO (2018). https://ciperchile.cl/2019/07/02/el-brutal-informe-de-la-pdi-sobre-abusos-en-el-sename-que-permaneciooculto-desde-diciembre/. [Consulta 25 de julio de 2020]. "La muerte de la pequeña Lissette Villa (abril de 2016) conmovió al país y movilizó a la Fiscalía, al Poder Judicial y al Ministerio de Justicia para detener los abusos contra niños y adolescentes en hogares del SENAME, sin que eso ocurriera".

${ }^{354}$ IBIDEM. "Está fechado en diciembre de 2018, que indica que la pesadilla de los niños que el Estado debe proteger nunca paró: en 2017 la policía registró 2.071 casos de violencia y maltratos graves, incluyendo 310 agresiones de 'connotación sexual', en hogares del SENAME". 
administra el SENAME y en el $88 \%$ de los gestionados por particulares se constataron 2.071 abusos, 310 de ellos con connotación sexual ${ }^{355}$.

En concordancia con ello, el Comité de Derechos del Niño de la ONU, encargado de fiscalizar el grado de cumplimiento de los países que han suscrito la CIND, desarrolló un informe sobre Chile, publicado en julio de 2018, apuntando a la responsabilidad del Estado por las graves violaciones de los derechos enunciados en la CIDN, considerando que el sistema de protección residencial de Chile ha significado una amplia vulneración de derechos de miles de NNA bajo tutela del Estado durante un largo periodo de tiempo ${ }^{356}$. En respuesta a tal resultado, el Estado de Chile reconoce en sus declaraciones que ha fallado en proteger los derechos de los NNA chilenos y conforma una mesa en el año 2018 con más de 30 actores, la mayoría de ellos con cargos políticos relevantes, ministros, subsecretarios, senadores, diputados, entre otros, para dar inicio a un trabajo que compromete la mejora para la dignificación de los NNA residentes del SENAME, y que tuvo por nombre "Acuerdo Nacional por la Infancia". Acuerdo que aún no provoca la transformación profunda y urgente que requieren los niños, niñas y jóvenes de Chile ${ }^{357}$.

Se puede señalar que esta crisis del sistema residencial del SENAME, no se limita a la falta de recursos de dicha institución, sino que es sintomática de la escasa preocupación de la sociedad por el cumplimiento de los deberes en cuanto al reconocimiento y garantía de los derechos de este grupo. Tal como lo consignó el diario electrónico el Mostrador, en el año 2015 se conformó la Comisión investigadora SENAME II cuyo propósito era evaluar la forma en que las autoridades del gobierno han atendido las propuestas de la Cámara de Diputados, con ocasión de la aprobación del informe de la Comisión Especial Investigadora del Funcionamiento del SENAME en el año 2014 (Comisión I), y particularmente sobre

\footnotetext{
355 IBIDEM.

${ }^{356}$ COMITÉ DE DERECHOS EL NIÑO (2018). Informe de la investigación relacionada en Chile, en virtud del Artículo 13 del Protocolo Facultativo de la Convención sobre los Derechos del Niño relativo a un procedimiento de comunicación.

${ }^{357}$ DIARIO ELECTRONICO EL DESCONCIERTO. https://www.eldesconcierto.cl/2019/07/29/violencia-yexclusion-en-la-vida-de-ninos-ninas-y-adolescentes-en-residencias-del-sename-la-urgencia-de-una-politicapublica/. [Consulta de 26 de noviembre de 2019].
} 
la situación de NNA y de aquellos menores carentes de cuidado parental en Chile. Tal como se consignó en la investigación periodística aludida "después de la investigación, y de los debates originados, y tal como es percibido por la ciudadanía, el resultado fue lapidario, y a pesar de los diversos anuncios gubernamentales con supuestas medidas para superar la situación de vulneración de derechos de NNA en centros de SENAME, la situación en la actualidad lamentablemente no ha sufrido ningún cambio profundo"358.

Tras el trabajo de ambas comisiones, se han detectado los siguientes ejes deficitarios relacionados con el abordaje y respuesta del Estado respecto de la temática:

a) La incapacidad del Estado de crear condiciones mínimas para los NNA que tienen a su cargo.

b) Las graves deficiencias en el diseño, la ejecución y los programas que se implementan en el sistema de protección.

c) La inexistencia de mecanismos de coordinación intersectorial, así como la desconexión y descoordinación entre los diversos programas públicos y colaboradores.

d) La falta de rigurosidad de los funcionarios del SENAME, direcciones regionales y dirección nacional en denunciar los hechos constitutivos de delitos contra niños, niñas y adolescentes al interior de sus dependencias.

e) La discriminación a los niños, niñas y sus familias por condiciones socioeconómicas deficitarias y pobreza, privilegiando la internación en el sistema residencial por sobre modalidades ambulatorias de apoyo a las familias y sus circunstancias de vida. Dichas condiciones son utilizadas por los organismos del sistema como causa para denunciar maltrato o faltas de cuidado parental, a través de informes técnicos no periciales que emiten los mismos organismos, que sirven de plena prueba en los tribunales de familia que decretan la internación.

${ }^{358}$ IBIDEM. 
f) Graves problemas de supervisión de los centros por parte del SENAME.

Adicionalmente, a los resultados de las comisiones investigadoras, que constataron esta infracción del Estado de Chile con sus NNA. Otros informes, emanados de UNICEF, del Instituto Nacional de Derechos Humanos, del Comité de los Derechos del Niño, comparten y anuncian la falta de atención y responsabilidad estatal hacía este grupo, como una triste y real evidencia que constata que Chile ha violado sistemáticamente sus derechos humanos ${ }^{359}$. Todas estas indagaciones solo cuentan con la indiferencia de las autoridades de turno, que además son las responsables que estas situaciones no ocurran en tanto garantes principales, y también con la indolencia de la sociedad civil, que se supone debe actuar como cogarante del respeto a los derechos humanos ${ }^{360}$.

Este tipo de situaciones graves que han afectado a nuestros NNA también se han presentado en los establecimientos de cumplimiento de penas para adolescentes infractores de ley, es decir centros cerrados o semicerrados con sistemas de reinserción social, establecidos como medidas en la ley 20.084 sobre Responsabilidad Penal Adolescente.

El Instituto Nacional de Derechos Humanos, sobre el área de justicia juvenil (14\% NNA del total de atendidos por el servicio), insiste en que es necesario adecuar la ley, poniendo énfasis en la reinserción de jóvenes infractores. En este sentido se establece que el interés superior del NNA debiera constituir siempre el principio rector, y la privación de libertad solo podría ser aplicada como último recurso a la hora de dictar las órdenes de internación y que el Poder Judicial fuese responsable de la supervisión de las mismas ${ }^{361}$.

Sumado a estos ejes deficitarios detectados por las comisiones, circunscritas a la oscura realidad de los hogares de menores, nos encontramos con otras falencias que traspasan este ámbito, cuyos causas y efectos perjudícales pueden ser difíciles

\footnotetext{
${ }^{359}$ DIARIO ELECTRONICO EL DESCONCIERTO. Op .Cit., p. 3

${ }^{360}$ IBIDEM. "No se trata de casos aislados, ni cometidos por personas en particular, sino más bien por el conjunto de un sistema que se estructura desde un funcionamiento que contempla la trasgresión de los derechos humanos de los NNA como parte de su organización y modos de operar”.

${ }^{361}$ INSTITUTO NACIONAL DE DERECHOS HUMANOS (2018). Informe de Derechos Humanos 2018. p. 37.
} 
de prever, mitigar y revertir.

Los sucesos de negligencias inexcusables bajo la tutela última del Estado al interior de las antedichas residencias fallecimientos, derivadas de una inadecuada nutrición, falta de supervisión médica, escaso control de violencia interna o acoso moral o sexual, agresiones o abusos por parte de cuidadores o monitores, entre otros. Como consecuencia, el escrutinio público también es más crítico que vulneraciones producidas en otros ámbitos, igualmente graves y condenables, (bullyng escolar, abusos sexuales y violencia intrafamiliar), debido que el Estado debería tener una posición de garante en el cuidado de los NNA que están bajo su haz de protección.

En esta misma línea, en el Anuario de Derechos Humanos del año de 2018 de la Universidad de Chile, se refuerza la idea, "de que si bien los niños, niñas y adolescentes sufren una serie de menoscabos en sus derechos, los más graves, aunque no los más importantes en términos numéricos, son las vulneraciones que sufren los niños que viven en medios alternativos a su entorno familiar"362. Tal como se ha señalado, las medidas de internación en la legislación local, son de ultima ratio, o de aplicación estricta, fundada en vulneraciones graves en su entorno, ordenadas por los jueces, que en la actual legislación son los únicos que la pueden provocar. Deben hacerlo con un enfoque de protección y de derechos humanos, basados en los principios protectores, pero también, a nuestro juicio, con un criterio de realidad, en cuanto a que muchas veces la "solución" sería más dañina que el propio problema. De esta forma, el sacrificio de su derecho a la vida familiar, transformado en la regla general en situaciones de vulneraciones graves de sus derechos cometidas en el entorno familiar o social, implica la internación en lugares que no cuentan con estándares mínimos de seguridad y de respeto a su integridad física o psicológica. Ésta es la violación más grave de derechos de NNA en Chile, desde

${ }^{362}$ UNIVERSIDAD DE CHILE. (2018). Anuario de Derechos Humanos 2018. p. 16. 
el punto de vista de que en estos casos, la vulneración de derechos proviene por parte delpropio Estado 363364 .

A juicio de Alejandro Toledo González, los tipos de vulneraciones que prevalecen en los tribunales de familia, corresponden a las vinculadas con la falta de habilidades parentales de adultos responsables de NNA, que consecuentemente promueven dinámicas familiares disfuncionales, marcadas por escasas y deficientes capacidades vinculares, emocionales, nutricias, formativas, reflexivas y protectoras, por parte de los adultos responsables. Cuestión asociada además a problemas de comunicación, uso inadecuado del lenguaje, aspectos transgeneracionales no resueltos conforme a la vivencia de traumas nunca reparados en vida, concomitantes con factores de índole sociocultural educacional y sin duda, espiritual ${ }^{365}$.

En este ámbito, se debe tener presente que los tribunales de familia cuentan con una serie de organismos colaboradores del SENAME que están facultados para redactar informes previo diagnostico e intervención si fuese necesario, tanto del NNA, como de su grupo familiar o relacional. La oferta programática dependerá especialmente de la causa y gravedad de vulnerabilidad, como asimismo, del propósito de la intervención ${ }^{366}$. Si bien estos organismos colaboradores,

\footnotetext{
363 IBIDEM.

364 IBIDEM. "Tambiénsedanvulneraciones en el acceso porparte deciertos niños, fundamentalmente con algún tipo de discapacidad, o niños que están en una situación de definición de su identidad de género, a la salud en general, y en especial a la mental. Y, por cierto, lo cual es tan grave como importante, el hecho de que los niños sufren mucha violencia física y psicológica en sus propias familias”.

${ }^{365}$ Entrevista sostenida con fecha 18 de Mayo de 2020, con Alejandro Toledo González, Consejero Técnico del Tribunal de Familia de Talca, cargo que ocupa desde enero de 2010.

${ }^{366}$ Programas De Prevención Focalizada (PPF), cuyas causales de ingreso son falta de habilidades parentales y negligencias b. Programas De Reparación Y Maltrato (PRM), cuyas causales de ingreso obedecen a trasgresión a la esfera de la sexualidad y/o maltrato c. Programas de Intervención Especializadas (PIE), cuyas causales de atención se traducen en falta de habilidades parentales asociadas a consumo de drogas y alcohol de adulto a cargo y que han promovido en NNA condutales tales como: a) deserción escolar, b) conductas de desviación social, c) delincuencia precoz y consumo de drogas ilícitas en NNA. d) Oficina de Protección para la Infancia (OPD), e) Programas Municipales y dispositivos 24 Horas de falta de habilidades parentales, f) Programas PEC Especializados en Calle Falt, g) FAE PRO (Familias de Acogida), cuyas causales de ingreso corresponden a negligencia grave, falta de habilidades Parentales, adulto con consumo de drogas y alcohol, Maltrato y/o Abuso), h) Red de Hogares Protecciones, i) Red de Salud.
} 
encargados de diagnósticos, seguimiento, acompañamiento, reparación resultan muy útiles, se observan algunas falencias en su cometido ${ }^{367}$.

Existe un punto inicial que es necesario destacar, pues en nuestro país nacer y crecer en pobreza sigue siendo uno de los elementos, aunque no el único ni el exclusivo, resulta determinante respecto a la posibilidad de ejercer efectivamente los derechos de los niñosy alcanzar un pleno desarrollo como persona. La pobreza sigue afectando de un modo desproporcionadamente alto a los niños, más que a otros segmentos de la población, y es en sí misma una grave vulneración de derechos ${ }^{368}$. Además de la pobreza, ciertas formas de exclusión permanente de colectivos o grupos, afectan particularmente a la infancia. Dentro de estas manifestaciones se incluye la discriminación que afecta a los niños indígenas, la estructura patriarcal de nuestra sociedad que afecta a NNA independientemente de su sexo o identidad de género, pero particularmente se expresa en el ejercicio de la violencia dentro de las relaciones familiares y discriminación por machismo, homofobia u otras formas de intolerancia a la diversidad sexual. Otro tema emergente es la infancia migrante ${ }^{369}$.

\subsubsection{Trabas y deficiencias legislativas en el acceso a la justicia de los NNA}

Los obstáculos, también se relacionan con una legislación débil, aislada, que carece de integralidad en cuanto a la protección brindada por el SENAME, no entregando soporte legal a la creación se servicios que puedan por una lado proteger a los NNA en situación de vulnerabilidad, y asimismo, resocializar a los infractores de ley.

Urge en nuestro país la creación de un sistema integral de protección a la infancia, que se oriente a garantizar los derechos mediante un cuerpo legal sólido, que incluya mecanismos de efectiva protección a los derechos de los NNA.

\footnotetext{
${ }^{367}$ Reducido nivel de experiencia, escasa formación y experticia de post grado en profesionales, bajos niveles de remuneraciones, alto nivel de rotación, deficitarios niveles de autocuidado para profesionales interventores, limitada oferta de programas de salud mental con apoyo psiquiátrico y psicológico efectivo con orientación comunitaria especializada.

${ }^{368}$ UNIVERSIDAD DE CHILE. Anuario de Derechos Humanos 2018. Op. Cit., p. 16.

${ }^{369}$ IBIDEM. p. 18.
} 
En los últimos años, la agenda legislativa de infancia ha estado enfocada principalmente al estudio de un conjunto de proyectos de ley que fueron presentados por el ejecutivo entre los años 2015 y 2018. Dichas iniciativas tienen por objeto dotar a Chile de un sistema integral de derechos de la infancia bajo el paradigma de la $\mathrm{CIDN}^{370}$.

Dentro de estas leyes que buscan constituir un sistema de protección de la infancia, podemos mencionar la ley 21.067 que crea la Defensoría de los Derechos de la Niñez ${ }^{371}$. Esta Defensoría no defiende derechos particulares de NNA vulnerados, sino que tiene por objeto la difusión, promoción y protección de sus derechos.

370 BIBLIOTECA DEL CONGRESO NACIONAL (2018). Infancia: Agenda legislativa de los últimos años.p.1.

${ }^{371}$ Ley 21.067. Que crea la Defensoría de los Derechos de la Niñez de 29 de enero de 2018. Artículo $4^{\circ}$ : Corresponderá especialmente a la Defensoría de los Derechos de la Niñez.:

a). Difundir, promover y proteger los derechos de los niños de acuerdo a lo que establece la ley.

b) Recibir peticiones sobre asuntos que se planteen, derivadas a otro órgano que sea competente en el tema o ejercer sus atribuciones en el más breve plazo.

c) Interponer acciones y presentar querellas cuando conozca de delitos en que las víctimas sean niños.

d) Intermediar o servir de facilitador entre los niños y los órganos de la Administración del Estado o aquellas entidades que tengan por objeto la promoción o protección de derechos de los niños, cuando conozca hechos o omisiones que los puedan vulnerar.

e) Pedir antecedentes o informes a los órganos de la Administración del Estado o a aquellas entidades que tengan por objeto la promoción o protección de los derechos de los niños, cuando, dentro de su competencia, tome conocimiento de posibles vulneraciones a tales derechos por actos u omisiones de las entidades. f. Visitar los centros de privación de libertad, centros residenciales de protección o cualquier otra institución, lo que incluye a los vehículos, en los que se mantengan niños privados de libertad.

f) Deberá emitir un informe en que se registren las eventuales vulneraciones de derechos y las recomendaciones, sin perjuicio de denunciar los hechos que constituyan delitos.

g) Denunciar vulneraciones a los de los niños ante los órganos competentes, remitiendo los antecedentes que funden dicha denuncia.

h) Emitir informes y recomendaciones que tengan por objeto la promoción de derechos de los niños.

i) Observar y hacer seguimiento a la actuación de los órganos de la Administración del Estado, a entidades que tengan por objeto la promoción o protección de derechos de los niños y a organizaciones que puedan afectar con sus acciones tales derechos.

j) Actuar como amicus curiae ente los tribunales de justicia. Eso significa que puede hacer presentaciones ante los tribunales con comentarios u observaciones sobre una causa que involucre a niños. El tribunal deberá pronunciarse sobre dicha opinión en la sentencia.

k) Velar para que los responsables de formular las políticas públicas nacionales, incluidas las económicas, tengan en consideración los derechos del niño, al establecer y evaluar planes, políticas y programas.

l) Velar por la participación de los niños, para que puedan expresar su opinión y ser oídos en los asuntos que les conciernen y en la definición de las cuestiones relacionadas con el ejercicio efectivo de sus derechos humanos.

m)Promover el cumplimiento de la Convención sobre los Derechos del Niño y los demás tratados internacionales relativos a los derechos de los niños ratificados por Chile, que se encuentren vigentes, y asesorar a organismos públicos, privados, niños y sus familias sobre su aplicación.

n) Promover la adhesión o ratificación de tratados internacionales de derechos humanos de los niños.

o) Colaborar con el Instituto Nacional de Derechos Humanos en la elaboración de los informes que deba presentar a los órganos y comités especializados de la Organización de las Naciones Unidad y de la Organización de Estados Americanos, así como ante otras organizaciones internacionales. 
Además se debe incluir la ley $21.090^{372}$, que crea la Subsecretaría de la Niñez, entre cuyas funciones se encuentra asesora al Presidente de la Republica en las materias relativas a la promoción y protección integral de los niños. Asimismo tiene como función colaborar con el Ministerio de Desarrollo Social en la elaboración de políticas, coordinación de acciones y prestaciones vinculadas con los derechos de los niños ${ }^{373}$.

Junto a estas leyes aprobadas, nos encontramos con iniciativas que hasta la fecha solo son proyectos, y que en caso de aprobarse, configurarían en Chile un sistema de protección integral. El Boletín n 10.315-18 crea el Sistema de Garantías de Derechos de la Niñez, fue presentado a tramitación el año 2015 y actualmente se encuentra en segundo trámite constitucional, en la comisión especial encargada de tramitar proyectos de ley relacionados con NNA del Senado ${ }^{374}$. En septiembre de 2019 el Senado dio un paso importante, al aprobar por unanimidad la idea de legislar sobre el referido sistema de garantías. El objeto de la iniciativa es la creación de un sistema coordinado de dispositivos legales, institucionales, políticos y sociales, orientados a asegurar la efectividad de los derechos de los niños ${ }^{375}$. En este mismo sentido, lo anunció el Ministerio de Desarrollo Social ${ }^{376}$.

En cuanto a este proyecto, y como lo propugna el Ministerio de Desarrollo Social, "la Ley de Garantías de Derechos de la Niñez es una ley marco que establecerá en el país un inédito sistema de garantías y protección del ejercicio de los derechos de la infancia a través de un conjunto de normas, instituciones y políticas según lo establecido en la CIND y otros instrumentos internacionales" 377 .

p) Difundir el conocimiento de los derechos humanos, favorecer su enseñanza en todos los niveles del sistema educacional, incluyendo la formación impartida al interior de las fuerzas de Orden y Seguridad Pública.

q) Elaborar y presentar un informe con una cuenta pública anual

r) Las demás funciones y atribuciones que la ley le otorgue.

${ }^{372}$ LEY 21.090 que Crea la Subsecretaría de la Niñez de 12 de abril de 2018.

${ }^{373}$ UNIVERSIDAD DE CHILE. Anuario de Derechos Humanos 2018. Op. Cit., p. 4.

${ }^{374}$ IBIDEM.

${ }^{375}$ IBIDEN. "Este proyecto había ingresado el 24 de septiembre de 2015 a la Cámara de Diputados y durante el proceso se desarrollaron 8 audiencias públicas, en las que se recibieron 33 invitados de diversas organizaciones de la sociedad civil y expertos, quienes aportaron sus puntos de vista para enriquecer la discusión en la comisión”.

${ }^{376}$ MINISTERIODE DESARROLLO SOCIAL. http://www.desarrollosocialyfamilia.gob.cl/noticias/comisionde-familia-aprueba-por-unanimidad-la-idea-de-legislar-el-proyecto-de-ley-de-garantias-de [Consulta 10 de julio de 2020].

377 IBIDEM. 
A juicio del referido Ministerio, "la futura ley fortalecerá la protección universal, a través de la coordinación de todas las prestaciones que entrega el sistema público, rol que corresponderá al Comité Interministerial de Desarrollo Social, organismo que reúne a los ministros del área social. Entre otros temas, en la futura ley de garantías, la familia tiene un rol fundamental en el cuidado y educación de los niños, guiándoles en el ejercicio pleno de sus derechos y orientándolos conforme con su autonomía progresiva ${ }^{378}$. Esta nueva ley reconocerá al niño como sujeto de derechos, capaz de ejercerlos por sí mismo, según su edad y grado de madurez. Conforme con ello, puede actuar ante los organismos del Estado para reclamar sus derechos, en conformidad con la ley y con la orientación de sus padres cuando corresponda $^{379}$. La ley también consagra el interés superior del niño, entendido como la máxima satisfacción del conjunto de sus derechos, criterio que orienta la interpretación que se debe hacer en cada caso concreto ${ }^{380}$. A nuestro entender, la Ley de Garantías protegerá los derechos establecidos en la CIND y desarrolla normas concretas sobre algunos de esos derechos con el fin de reforzar su garantía o regular la forma de su protección, como es el caso de la protección contra la violencia, resguardo de su vida e integridad física, la libertad de expresión y el derecho a su desarrollo.

Finalmente la ley hará obligatorio que el Estado disponga en forma permanente de una política nacional de niñez y un plan de acción, para cuyos efectos fija la forma en que deben aprobarse, su plazo de duración y su contenido mínimo. Además de garantizar que desde los primeros años los NNA cuenten con los derechos esenciales que les permitan desplegar al máximo sus capacidades, esta normativa incidirá en aspectos significativos de la vida de los niños ${ }^{381}$. En efecto, en esta

\footnotetext{
${ }^{378}$ IBIDEM. "El Estado apoyará activamente a la familia en el cumplimiento de este rol, pues esta ley fortalece a la familia y a los padres, pues contiene un compromiso explícito del Estado para apoyarla en el cumplimiento de su rol como guía y orientadores de sus hijos y evidencia la voluntad del gobierno de mejorar las condiciones de vida de los niños y niñas que viven en Chile y de potenciar las capacidades de la familia para llevar adelante esta tarea".

${ }^{379}$ IBIDEM.

${ }^{380}$ IBIDEM.

${ }^{381}$ Es decir el rol que corresponde a la familia en la orientación y dirección del niño en el ejercicio de sus derechos, conforme a su edad y madurez; el rol del Estado para fortalecer a la familia, la protección universal de los derechos de los niños, el derecho a ser oídos, la proscripción de toda forma de violencia en contra de los niños, y la consagración general del interés superior del niño.
} 
normativa se espera establecer como principio general, dentro de este sistema de protección integral que se aspira implementar, que todo niño tiene derecho a asistencia jurídica gratuita para la defensa de sus derechos ${ }^{382}$.

Tal como lo anuncio el gobierno, a través del Ministerio de la Secretaría General de Gobierno, "el Congreso con fecha 5 de junio de 2020 aprobó el proyecto que crea el Servicio Nacional de Protección a la Niñez y Adolescencia, que junto con el Servicio Nacional de Reinserción Social Juvenil, terminará con el SENAME. El objetivo es separar las funciones en dos nuevos servicios, logrando una protección más efectiva de los derechos de los NNA ${ }^{383}$. Luego de un año y diez meses de tramitación, el Congreso aprobó la nueva institucionalidad, que crea un servicio público dependiente del Ministerio de Desarrollo Social y Familia y la Subsecretaría de la Niñez, encargado de proveer la oferta de protección especializada para los niños, niñas y adolescentes gravemente amenazados o vulnerados en sus derechos, con un énfasis en el bienestar e interés superior de cada niño, y un enfoque familiar que permita intervenciones integrales y eficaces. La Subsecretaria de la Niñez, Carol Brown, comentó respecto de la aprobación del proyecto, que "es un gran día porque tendremos finalmente una ley que crea un nuevo servicio de protección que termina con el SENAME"384. Sin perjuicio de ser considerado como un gran avance por el gobierno, el mismo ejecutivo con fecha 9 de julio de 2020 ingresó un veto presidencial a la ley que crea el Servicio Nacional de Protección Especializada de Niñez y Adolescencia. El argumento presidencial tendiente a dejar sin efecto la ley que el mismo había presentado como proyecto, radica en el hecho que de las modificaciones introducidas por el proyecto de ley durante la tramitación legislativa, en el texto final aprobado por el congreso nacional existen normas, que según el gobierno de turno, perjudican el interés superior de los NNA. Esta objeción

\footnotetext{
${ }^{382}$ MINISTERIO DEDESARROLLOSOCIAL. http://www.desarrollosocialyfamilia.gob.cl/noticias/comisionde-familia-aprueba-por-unanimidad-la-idea-de-legislar-el-proyecto-de-ley-de-garantias-de [Consulta 10 de julio de 2020]. "Ccabe destacar que si bien las atribuciones de los organismos de defensa técnica están otorgadas por una ley especial que autoriza su creación, el marco de ésta política pública podría haber reconocido su carácter de institucionalidades de persuasión y otras facultades conexas y complementarias para el cumplimiento de su cometido".

383 MINISTERIO SECRETARIA GENERAL DE GOBIERNO. DIRECCION DE ORGANIZACIONES SOCIALES. https://dos.gob.cl/congreso-aprobo-proyecto-de-ley-que-crea-el-servicio-nacional-de-protecciona-la-ninez-y-adolescencia-en-reemplazo-del-sename/. [Consulta 13 de julio de 2020].

${ }^{384}$ IBIDEM.
} 
o veto se basa especialmente en supeditar la creación del nuevo servicio a la aprobación de la Ley de Garantías de Derechos de la Niñez, pues a su parecer generaría un retardo injustificado en su implementación, ya que dicho proyecto lleva 5 años de tramitación ${ }^{385}$.

La Defensora de la Niñez, Patricia Muñoz, ante este veto indicó que "resulta muy lamentable que el Ejecutivo haya optado por vetar esta ley, particularmente por tener dentro de sus ámbitos, la eliminación de la norma que condicionaba el surgimiento del servicio a la Ley de Garantías, toda vez que es imprescindible que esta sea aprobada con extrema urgencia, para que guíe el comportamiento del nuevo servicio, ya que este debe tener fiscalización, pero sobre todo, mecanismos efectivos de prevención de vulneraciones y el establecimiento de claras responsabilidades en el ejercicio indelegable de la función pública que involucra la protección de los niños, niñas y adolescentes más vulnerables y vulnerados del país" 386 . Sostuvo además la Defensora, "que la creación del nuevo servicio de protección especializada debe estar necesariamente vinculado de manera directa a la Ley de Garantías, porque de otra manera no se logrará una transformación efectiva y urgente de promover los derechos de NNA, prevenir las vulneraciones a estos y, solo en aquellos casos en que la prevención no haya sido efectiva, entre en operación este nuevo servicio, que al menos erradique prácticas nocivas instaladas en el modelo de intervención de SENAME ${ }^{387}$. Reforzando los fundamentos de la Defensora, se puede señalar que la Ley de Garantías es urgente, prioritaria e indispensable, pues solo ella permite que las familias, la sociedad y el Estado puedan conducir sus acciones con la claridad de lo que involucra la relación con NNA, en tanto sujetos de derecho y no meros objetos de protección, ejecutando mecanismos eficientes de promoción de derechos, prevención de sus

385 DIARIO EL MERCURIO. https://www.emol.com/noticias/Nacional/2020/07/09/991508/Gobierno-vetaServicio-Proteccion-Ninez.[Consulta 13 de julio de 2020].

${ }^{386}$ DIARIO EL MOSTRADOR. https://www.elmostrador.cl/dia/2020/07/10/defensoria-de-la-ninez-lamentaveto-presidencial-a-proyecto-de-proteccion-chile-es-el-unico-pais-de-latinoamerica-que-no-cuenta-con-unaley-de-garantias-de-los-derechos-de-los-ninos/ [Consulta 13 de julio de 2020].

${ }^{387}$ IBIDEM. 
vulneraciones ${ }^{388}$. Agrega la Defensora que "sobre la base de sus principios y derechos consagrados, las exigencias que debe cumplir del nuevo servicio, mismo que no puede tener otro deber que el estricto y absoluto respeto de los derechos humanos de los niños, niñas, adolescentes y las familias de éstos, con quienes intervenir"389. La Defensora aseguró que "Chile es el único país de Latinoamérica que no cuenta con una Ley de Garantías de los derechos de los niños, niñas y adolescentes. La falta de este marco legal específico afecta, de manera directa, la vida y el bienestar de los NNA en nuestro país, porque impide que las políticas públicas se diseñen, implementen y evalúen con un enfoque integral, transversal y concreto, en cumplimiento de los estándares establecidos en la CIDN, por lo que seguir retrasando la urgencia de su surgimiento y la relevancia de su contenido, ahora en razón de este veto presidencial, sólo perjudica las posibilidades de atender y proteger, de manera efectiva, a los niños, niñas y adolescentes que viven en Chile"390

En Este sentido, adherimos a la visión de la Defensora, respecto del rechazo al veto presidencial, lo que realza la autonomía e independencia de su rol. Efectivamente, bajo el argumento de acelerar la puesta en marcha de un servicio, por muy importante que sea, no se puede por parte del ejecutivo restar valor a la aprobación una ley que tiene por un único fin implementar las bases de un sistema integral de protección de la niñez y adolescencia, respecto del cual deben girar las instituciones o servicios que se vayan generando para su ejecución.

En materia de Responsabilidad Penal Adolescente, el Boletín n 11.174-07 que crea el Servicio Nacional de Reinserción Social Juvenil y modifica la ley $n^{\circ} 20.084^{391}$, fue presentado el año 2017 y se encuentra en la Comisión de Constitución, Legislación, Justicia y Reglamento del Senado, en primer trámite constitucional. La iniciativa tiene por objeto crear un servicio responsable de administrar y ejecutar las medidas

\footnotetext{
${ }^{388}$ IBIDEM.

${ }^{389}$ IBIDEM.

${ }^{390}$ IBIDEM.

${ }^{391}$ LEY 20.084. Que Establece un Sistema de Responsabilidad de los Adolescentes por Infracciones a la Ley Penal, de 7 de diciembre de 2005.
} 
de la Ley $\mathrm{n}^{\circ} 20.084$, así como de implementar las políticas intersectoriales y el desarrollo de programas para la integración de los jóvenes infractores ${ }^{392}$.

A nuestro parecer, el Estado de Chile no garantiza adecuadamente el derecho de Ios NNA a contar con una defensa especializada, ya que la figura del abogado representante, en adelante, curador ad litem, reconocida en el artículo 19 de la Ley 19.968, que crea los Tribunales de Familia ${ }^{393}$, de 20 de agosto de 2004, adolece de graves problemas en términos de garantizar una debida defensa a NNA. En este contexto Valenzuela y Correa en relación a esta figura, expresan que "destaca que la regulación es sumamente abierta, algo que en la práctica favorece amplios márgenes de discrecionalidad por parte de quienes se desempeñan como curadores ad litem de los NNA en juicio, y no permite el establecimiento de estándares uniformes en la calidad de la atención" 394.

Cabe destacar que si bien las atribuciones de los organismos de defensa técnica están otorgadas por una ley especial que autoriza su creación, el marco de ésta política pública podría haber reconocido su carácter de institucionalidades de persuasión y otras facultades conexas y complementarias para el cumplimiento de su cometido.

\subsection{Políticas públicas y buenas prácticas en Chile respecto de los NNA}

\footnotetext{
392 IBIDEM. p. 5

${ }^{393}$ LEY 19.968. Que Crea los Tribunales de Familia, de 30 de agosto de 2004. Artículo 19: "Representación. En todos los asuntos de competencia de los juzgados de familia en que aparezcan involucrados intereses de niños, niñas, adolescentes, o incapaces, el juez deberá velar porque éstos se encuentren debidamente representados. El juez designará a un abogado perteneciente a la respectiva Corporación de Asistencia Judicial o a cualquier institución pública o privada que se dedique a la defensa, promoción o protección de sus derechos, en los casos en que carezcan de representante legal o cuando, por motivos fundados, el juez estime que sus intereses son independientes o contradictorios con los de aquél a quien corresponda legalmente su representación. La persona así designada será el curador ad litem del niño, niña, adolescente o incapaz, por el solo ministerio de la ley, y su representación se extenderá a todas las actuaciones judiciales, incluyendo el ejercicio de la acción penal prevista como un derecho de la víctima en el artículo 109 letra b) del Código Procesal Penal”.

${ }^{394}$ VALENZUELA, E y CORREA. P. Op. Cit., p. 285
} 
En Chile, existe una legislación aislada y programas acotados de evaluación y de restauración de derechos, que se enfocan más en la reparación que en la prevención, y que por ello, no obedecen a un sistema de acciones coordinadas e integrales, destinadas a remover las barreras de acceso a la justica respecto de este grupo vulnerable. Precisamente, en base a la carencia de un sistema integral de protección sobre la infancia, el fundamento sobre el cual se construye la política nacional, debe ser precisamente instaurar en Chile un sistema integral y efectivo de garantía de derechos a favor de los NNA, a fin de promover y proteger su ejercicio, reconociéndolos como sujetos de derechos, ya no como objetos de protección, asentando las bases de aplicación al ordenamiento interno, de la normativa internacional, así como también el trabajo integrado de los distintos sectores ${ }^{395}$.

En concordancia con los postulados del CIDN, las políticas públicas deben materializar los principios internacionales de derechos humanos, conducentes al respeto y garantía de los derechos de los NNA, y a su vez dotando de mecanismos de exigibilidad ante el Estado y de protección ante su incumplimiento, lo que a su vez se condice con el mandato del artículo $4^{\circ}$ de la CIDN ${ }^{396 " ~ y ~ c o n f o r m e ~ a l ~ a r t i ́ c u l o ~}$ $40^{397}$ del mismo cuerpo normativo protector. Sin duda, el enfoque de derechos es transversal pero en la protección e integración de un NNA se transforma en una garantía. En cuanto al enfoque de desarrollo humano nos encontramos que el concepto es compatible con el principio de participación de la CIDN e igualmente se condice con el artículo $6^{\circ}$ del mismo cuerpo normativo al enunciar el desarrollo del niño como garantía ${ }^{398}$.

\footnotetext{
395 UNIVERSIDAD DE CHILE. Anuario de Derechos Humanos 2018. Op. Cit., p. 5.

${ }^{396}$ CIDN. Artículo 4: "Los Estados Partes adoptarán todas las medidas administrativas, legislativas y de otra índole para dar efectividad a los derechos... los Estados Partes adoptarán esas medidas hasta el máximo de los recursos de que dispongan y, cuando sea necesario, dentro del marco de la cooperación internacional.

${ }^{397}$ IBIDEM. Artículo 40. $\mathrm{N}^{\circ} 1$ : "Los Estados partes reconocen el derecho de todo niño de quien se alegue que ha infringido las leyes penales o a quién se acuse o declare culpable de haber infringido esa leyes a ser tratado de manera acorde con el formento de su sentido de la dignidad y el valor, que fortalezca el respeto del niño por los derechos humanos y las libertades fundamentales de terceros y en las que se tengan en cuenta la edad del niño y la importancia de promover la reintegración del niño y de que este asuma una función constructiva en la sociedad".

${ }^{398}$ IBIDEM. Artículo 6 "1. Los Estados Partes reconocen que todo niño tiene el derecho intrínseco a la vida. 2. Los Estados partes garantizarán en la máxima medida de lo posible la supervivencia y el desarrollo del niño”.
} 
Dentro de una perspectiva de desarrollo, mancomunado con la de vulnerabilidad, se consolida el derecho a ser oído (alejado a la concepción tradicional del derecho al recurso), se debe asociar en nuestra legislación al derecho que tiene el NNA de contar con su propio abogado, especialmente cuando sus derechos sean incompatibles con sus representantes legales o aparecen gravemente vulnerados 0 amenazados.

Cabe destacar un favorable avance en la postura del Poder Judicial a favor de la designación de curador en todas las causas de protección y, también en aquellas causas contenciosas por cuidado personal y régimen de relación directa y regular ${ }^{399}$. Sin embargo, al mismo tiempo, resulta muy preocupante la manera en que se está haciendo efectiva esta exigencia, ya que no existen verdaderas condiciones para una implementación seria y de calidad de este compromiso determinado por la CS. En definitiva, la designación de un curador puede transformarse en el cumplimiento formal de un requisito sin que esto conlleve una diferencia real para los NNA vulnerados en sus derechos, ya que actualmente no hay una oferta de curadores para prestar un servicio de calidad ${ }^{400}$.

La saturación del sistema se traduce en diferencias muy relevantes en cuanto a la calidad de la atención entre un niño y otro, lo que no es justificable bajo ningún punto de vista. En definitiva, que exista un curador ad litem bajo las condiciones actuales,

\footnotetext{
${ }^{399}$ Esto se materializa mediante un acuerdo del pleno de la Corte Suprema, del 27 de marzo de 2019, en el que se establece que los jueces con competencia en familia deberán procurar como buena práctica, la designación de abogados para niños, niñas y adolescentes (Curadores que defiendan sus interés en juicio), tanto en primera como segunda instancia, bajo criterios de calidad para su selección y parámetros de desempeño

${ }^{400}$ VALENZUELA, E y CORREA, Op. Cit., p. 287. "Falta una oferta estatal adecuada para la prestación del servicio. La ley no contempló ningún tipo de financiamiento para contar con abogados y equipos especializados que cumplan esta función”400. "Así, los curadores ad litem provienen de la CAJ, programas de representación jurídica licitados por SENAME, oficinas de protección de derechos (en regiones más apartadas) y, en un número menor, de clínicas jurídicas pertenecientes a las facultades de derecho de Universidades. La mayoría de los curadores cuenta con cargas de trabajo excesivas, que no les permiten cumplir con las obligaciones mínimas del cargo. Al hacer un diagnóstico de las curadurías en la oficina regional del SENAME de la Región Metropolitana, cada curador tenía en ese momento un promedio aproximado de mil curadurías y en la oficina de curaduría de la CAJ, de la misma Región, cada curador sobrepasaba las 500 causas”. "Esto, a pesar de que el mismo programa Mi Abogado (que solo atiende a NNA en cuidados alternativos) ha definido un estándar de 60 niños por abogado y de 250 para el equipo psicosocial”.
} 
no ha impedido que sufra graves violaciones a los derechos humanos dentro del sistema de protección.

La creación del programa Mi Abogado ${ }^{401}$ al alero de la CAJ, representa sin duda un avance significativo en cuanto a estándares de actuación y financiamiento, sin embargo, es insuficiente en lo que respecta a su cobertura ${ }^{402}$. Creemos que debiera establecerse protocolos y una reglamentación bajo estándares de actuación ajustados a los instrumentos de derechos humanos, complementándose con asignación de recursos, con el objetivo que la totalidad de los NNA sujetos a medidas de protección, cuenten con un curador ad-litem que cumpla con los requisitos de experticia, y disponibilidad, tanto horaria como financiera.

Desde una perspectiva más práctica y por la importancia del hecho que los NNA puedan acceder a la justicia a través de un abogado, hemos entrevistado a la coordinadora del programa Ml Abogado Región del Maule ${ }^{403}$, de cuyas fundadas opiniones y acertadas reflexiones podemos extractar las siguientes ideas:

a) El Programa Mi Abogado surge como una respuesta a la crisis de la niñez y adolescencia en nuestro país que obligó al Estado a buscar respuesta efectiva, así mismo se publican las observaciones del Comité de Derechos del Niño de la ONU, evidenciando las falencias concretas, entre las que se deben destacar, las reiteradas vulneraciones dentro del sistema proteccional, la carencia de defensa especializada, problemas de la red de infancia, necesidad de supervisión desde la experiencia de los niños de los centros proteccionales. Es así como se construye como una política pública con independencia del gobierno de turno.

401 CAJ REGION METROPOLITANA. http://www.cajmetro.cl/programa-mi-abogado. [Consulta 12 de diciembre de 2020].

402 VALENZUELA, E y CORREA, Op. Cit., p. 287. "Es preciso aclarar que el programa representa actualmente a 2.500 NNA, número que, a fin de año, debiera aumentar a una cifra cercana a 4.000, de un universo aproximado de 100.000 NNA sujetos a medidas de protección. Se requiere con urgencia priorizar los cambios legales e institucionales que sean necesarios para que los NNA cuenten con un defensor especializado de su confianza, desde las primeras actuaciones judiciales y no solo una vez que ingresan al sistema de cuidados alternativos, residencial o familiar, como ocurre con el programa Mi Abogado”.

${ }^{403}$ Entrevista sostenida con fecha 2 de marzo de 2020, con María Paz Aliaga Saiz, Abogada, coordinadora regional Programa regional Mi Abogado, Región del Maule. 
b) Por las mismas razones que un adulto debe comparecer a cualquier juicio en que sea parte asistido por un letrado, parece del todo lógico que los NNA que han sido vulnerados en sus derechos y que producto de esa vulneración se encuentran sujetos a una medida de protección deban contar obligatoriamente con un curador ad litem que vele por sus derechos en juicio, más aún cuando este procedimiento posee una regulación diferenciada dentro de la ley que crea los tribunales de familia, elevando a categoría especial el procedimiento proteccional en sus artículos 68 y siguientes. Sin embargo, el acceso a la justicia no se encuentra garantizado más que en forma, si únicamente se designa a la figura de un abogado curador sin tener presente la especialidad que los NNA requieren.

c) El Programa Mi Abogado con objetivos y lineamientos claros, acorde a la normativa internacional en derechos de niñez y adolescencia provee de defensa jurídica especializada a los NNA, adscribiéndose a una curaduría ad litem que no se agota en lo jurídico, siendo el abogado quien encabeza la estrategia ante la magistratura, siendo la triada compuesta además por un psicólogo y un trabajador social, quienes elaboran la estrategia jurídica y la revisan cada tres meses, presentándose en su conjunto como curadores ad litem del NNA, situación que se justifica porque desde su creación, existe una política pública que respalda dicha implementación, mediante la asignación de recursos y supervisión constante de cumplimiento de objetivos, que carecen de incentivo pecuniario y metas simplemente numéricas.

d) Su rol es primordial para materializar el cambio de concepción de una justicia adulto céntrico a una que sea garante de los derechos de los NNA y los valide como tal de acuerdo a su autonomía progresiva. Lo anterior se traduce en términos prácticos en beneficios reales en sus vidas, partiendo por la materialización del derecho a ser oído en sus causas.

e) La intervención de este programa puede repercutir en poner término a institucionalizaciones de larga e incluso perpetua data, y facilitar el impulso procesal, que se materializa en solicitudes de adopción, en integraciones familiares, en poner freno a su vez a los egresos forzosos por temas administrativos, y a un sin número 
de situaciones vulneratorias que hasta hace poco parecían normales, pero que al verbalizarlas no evidencian más que el olvido del sistema hacia los NNA.

Como buena práctica de política pública en acceso a la justicia de NNA podemos mencionar dos iniciativas denominadas "salas de despedida" y "proyecto de comunicación indirecta" impulsadas por el Poder Judicial de Chile en el marco de un proyecto denominado "si yo fuera juez" ${ }^{404}$, que corresponde al principio de no discriminación y se traduce también en la obligación de juzgar con perspectiva de infancia, entendida como el reconocimiento de las características que la definen y que la distinguen de los adultos ${ }^{405}$. Buena práctica en ese sentido, las constituyen además, la implementación de las leyes que crean las salas Gesell y las entrevistas videograbadas ${ }^{406}$.

La entrevistas video grabadas, provienen a nuestro entender del derecho a ser oído, que sus opiniones sean tomadas en consideración, pero sin que se produzca una victimización secundaria, al tener que relatar a más de una persona u organismos, los hechos que al NNA le pueden producir una aflicción, angustia y en ocasiones la retractación, ante la reticencia de los operadores de otorgar credibilidad al relato, especialmente en lo relativo a atentados a su integridad o indemnidad sexual, perpetrados por parte de familiares o su entorno cercano 407 .

404 PODER JUDICIAL. Protocolo de Acceso a la Justicia de Grupos Vulnerables. Op. Cit., p. 47. "Las Salas de despedidas como proyecto se desarrollaron para propiciar que los NNA, que se encuentren presentes en las audiencias de juicio, puedan despedirse de sus familiares significativos si son condenados con privación de libertad en centros penitenciarios. Por su parte el proyecto de comunicación indirecta, tiene por objeto facilitar coordinaciones interinstitucionales para que los NNA mantengan el vínculo y la comunicación con sus adultos significativos privados de libertad”.

405 IBIDEM. p. 32.

${ }^{406}$ Entrevista sostenida con fecha 2 de maro de 2020, con María Paz Aliaga Saiz, Abogada, coordinadora regional Programa regional Mi Abogado, Región del Maule. Con un enfoque práctico desde la perspectiva del curador del programa Mi Abogado, un punto importante en cuanto al rol del curador, radica en que éste debe necesariamente junto a su triada preparar al NNA para dicha entrevista Gesell, explicar el contexto y no generar falsas expectativas, pues la mayoría de los NNA creen que será una conversación en privado con el juez, así mismo se destaca la posibilidad que tienen los curadores de acompañar in situ en la entrevista.

${ }^{407}$ En este contexto, las entrevistas video grabadas que se aplican desde la puesta en vigencia desde la ley 21.057, de 20 de enero de 2018, configuran un medio de reducir los efectos colaterales que conlleva una situación de afectación a un NNA. En Chile, un niño antes de la aplicación de esta ley, era entrevistado al menos 4 veces en instancias distintas, por un funcionario policial, del Ministerio público, por un perito psicólogo, por los jueces del tribunal, y por la defensa del imputado. 
En cuanto a la entrevistas videograbadas con la publicación de la ley $n^{\circ} 21.057$ se pretende subsanar una deuda arraigada desde la puesta en marcha de la reforma procesal penal, por una parte, en materia de protección a víctimas, a saber, la exigibilidad al ente persecutor, en virtud del principio acusatorio y como consecuencia de lo dispuesto en la propia ley orgánica del Ministerio Público, de asumir su rol de garante respecto de este interviniente y adoptar las medidas protectoras pertinentes, sin afectar la sustanciación y ritualidad del proceso, para evitar toda consecuencia negativa que puedan sufrir los niños, niñas y adolescentes con ocasión de su interacción, en calidad de víctimas, con las personas o instituciones que intervienen en el proceso penal ${ }^{408}$. No obstante lo señalado, es difícil vislumbrar la necesidad de implementar esta entrevista videograbada desde los fundamentos del proceso penal, extrapolándolo a otras áreas, como la familiar, entendiendo que aquél busca esencialmente el cumplimiento de otro fin, como lo es la resolución del conflicto jurídico-criminal.

Sin lugar a dudas la Política Nacional de Niñez y Adolescencia para el período 20152025, se esmera por saldar una deuda por parte de nuestro país, cuya legislación y políticas públicas en materia infanto juvenil hasta la fecha, no se ajustan a los tratados internacionales a los que se adscribió, y principalmente, se perciben desprovistas de un marco institucional independiente y especializado en la defensa, promoción y protección de los derechos de NNA.

En este sentido, el Estado de Chile plantea una propuesta política legislativa, que replantea el enfoque sobre la infancia, lo que se traduce en la implementación de un sistema de protección integral de derechos en el marco de la política nacional referida, de la cual ya se han aprobado algunas leyes que deberán ser puestas en marcha; otras se encuentra en revisión en el Congreso, y otras que deberán ser propuestas, debatidas e idealmente aprobadas. En este sentido destacan los

\footnotetext{
${ }^{408}$ IBIDEM. "Así, fue la victimización secundaria sufrida por los NNA, entendida como el sufrimiento que experimenta la víctima en su paso por las diferentes instancias del sistema procesal penal y por las reacciones de su entorno social, la figura que llamó la atención de aquellas organizaciones dedicadas a la reparación social, como fue el caso de la Fundación Amparo y Justicia, quien en conjunto con el Ministerio de Justicia, el Poder Judicial, el Poder Legislativo y otras instituciones, trabajaron en una mesa interinstitucional especializada que hoy forma parte del cimiento de la Ley N²1.057”.
} 
proyectos de creación de servicios independientes, tanto para el área de protección de derechos, como de integración social de adolescentes infractores, que repercutirá necesariamente en la supresión del SENAME. Además es imperioso la adecuación de la Ley de menores, que aún concibe en algunos pasajes al niño como objeto de protección, como asimismo las reformas estructurales en materia de sistemas residenciales de menores, suprimiendo los mecanismos de prestadores privados de estos servicios bajo la modalidad de licitación. Además, resulta necesario incluir de forma orgánica la representación en juicio, de forma uniforme y con cobertura nacional respecto de los NNA, concentrándose en las menos instituciones posibles (Idealmente ampliar el trabajo que realiza MI Abogado al sistema no residencial), con parámetros y formas de trabajo homogéneos.

Si bien se contempla una amplia agenda legislativa, y es indiscutible el enfoque en derechos desde la perspectiva operacional, vislumbramos vacíos de cómo efectivamente los principios rectores de esta política encuentran manifestación concreta. Esta nueva política nacional contempla objetivos estratégicos amplios, como proponer adecuación normativa, promover la gestión pública y fortalecer las condiciones familiares, comunitarias, sociales, económicas y culturales, indicando que estos objetivos se abordarán a través de lineamientos, como son la instalación del Sistema de Garantías de los Derechos de la Niñez, la definición de las orientaciones prioritarias y las condiciones transversales que orientan las acciones o procesos.

A este respecto podrían formularse dudas respecto a la metodología en la elaboración del plan de acción al que hace referencia, la urgencia necesaria en su implementación y el financiamiento de estas iniciativas, toda vez que no se aportan mayores antecedentes ni plazos para llevar a la práctica la propuesta específica. Si bien se determina un período que culmina en el año 2025 como fecha de cumplimiento del objetivo general, resultaría oportuno definir plazos y metas de ejecución de los objetivos específicos, que transforman a esta política pública en un proceso integral, y cómo ese fin particular manifiesta el principio rector. En nuestra opinión, se debe traducir a programas sociales con contenido específico, dichos 
objetivos estratégicos amplios, o bien, entregar su ejecución a un órgano del Estado definiendo su actuación.

\section{PERSONAS CON DISCAPACIDAD COMO GRUPO VULNERABLE}

\subsection{Generalidades}

En el estudio nacional de discapacidad realizado el año 2018 se constata que la cantidad de personas en situación de discapacidad en Chile es de 2.836.818, cifra cual representa el $16,7 \%$ de la población del país ${ }^{409}$.

El Preámbulo de la Convención sobre los Derechos de las Personas con Discapacidad (CDPD), establece que "la discapacidad es la interacción que se produce entre las personas con deficiencias y las barreras actitudinales y del entorno, lo que perjudica su plena y efectiva participación en la sociedad, en igualdad de condiciones que las demás" ${ }^{410}$.

Asimismo el artículo 1 de la CDPD, al distinguir o determinar las personas pertenecientes a este grupo vulnerable, señala que "persona con discapacidad es aquella que tiene deficiencias físicas, mentales, intelectuales o sensoriales, que al interactuar con el medio pueden impedir su participación plena y efectiva en la sociedad, en igualdad de condiciones" 411 .

Dentro de los significados de la discapacidad, incluimos la definición de la Organización Mundial de Salud, la cual la define como "toda restricción o ausencia debida a una deficiencia, de la capacidad de realizar una actividad en la forma o dentro del margen considerada normal para el ser humano". La discapacidad puede ser temporal o permanente, reversible o irreversible. Dentro de la definición de discapacidad, se entiende que una persona con tales restricciones, ausencias o

\footnotetext{
409 MINISTERIO DE DESARROLLO SOCIAL (2015). Encuesta del segundo estudio nacional de discapacidad. p.1.

${ }^{410}$ CDPD. Preámbulo.

${ }^{411}$ IBIDEM. Artículo 1.
} 
disminuciones, ya sean físicas, sensoriales o psíquicas, se le denomina discapacitada ${ }^{412}$.

\subsection{Normativa internacional aplicable, principios y jurisprudencia}

a) CDPD, adoptada por la Asamblea General de la ONU el 13 de diciembre de 2006, ratificada por Chile el 29 de julio de 2008 y publicada el 17 de septiembre de 2008.

b) Convención Interamericana para la Eliminación de todas las Formas de Discriminación contra las Personas con Discapacidad, adoptada por la Asamblea General de la Organización de Estados Americanos, el 7 de junio de 1999, ratificada por Chile el 26 de febrero de 2002 y publicada el 20 de junio de 2002.

c) Observación General del Comité sobre los Derechos de las Personas con Discapacidad de las Naciones Unidas.

Reglas de Brasilia sobre acceso a la justicia de las personas en condición de vulnerabilidad. Regla 7: "Se entiende por discapacidad de deficiencia física, mental o sensorial, ya sea de naturaleza permanente o temporal, que limita la capacidad de ejercer una o más actividades esenciales de la vida diaria". Regla 8: "Se procurará establecer las condiciones necesarias para garantizar la accesibilidad de las personas con discapacidad al sistema de justicia, incluyendo aquellas medidas conducentes a utilizar todos los servicios judiciales requeridos y disponer de todos los recursos que garanticen su seguridad, movilidad, comodidad, comprensión, privacidad y comunicación".

\footnotetext{
412 Distinguiendo que hay tres tipos de clasificaciones generales de discapacidad, las cuales son: discapacidad de movilidad o desplazamiento, de conducta o relación y de comunicación. Dentro de las tres ramas mencionadas anteriormente, se encuentran inmersas diversas subclasificaciones, las cuales corresponden a: discapacidad física, discapacidad sensorial, discapacidad intelectual, discapacidad psíquica, discapacidad visceral, discapacidad múltiple.
} 
La CDPD ${ }^{413}$, obliga a las partes suscriptoras a procurar, asegurar y mantener el acceso a la justicia para personas con discapacidad, así como crear mecanismos de integración para las personas que tengan estas dificultades, incluso pudiendo crear procedimientos especiales, con tal de asegurar su acceso e integración en los ámbitos del derecho y la vida jurídica y judicial en los distintos países. En sus demás articulados ampara por la libertad, la seguridad, la dignidad y su reconocimiento como persona, pudiendo actuar como entes de derecho, con capacidad jurídica y los derechos que la ley le confiere, con la ayuda que les sea necesaria; también concientizar a la población sobre los problemas de las personas con discapacidad y luchar contra los estereotipos y prácticas nocivas.

De estas normas, se desprenden los siguientes principios cuya aplicación asegura un efectivo acceso a la justicia:

a) Abordaje de la discapacidad desde el modelo social y de los derechos humanos: Un enfoque de este tipo impone la remoción de barreras en pos de la integración en la sociedad con igualdad y al fortalecimiento de su independencia, cambiando el paradigma asistencialista de la discapacidad, ya que tiene como finalidad una efectiva inclusión. De esta forma, se entrega a la sociedad la responsabilidad de reconocer y respetar la autonomía y dignidad de las personas con discapacidad, y de liberarlas de estigmas, discriminaciones y prejuicios ${ }^{414}$. Además se persigue con este principio un acceso a la justicia de las personas en condición de discapacidad en igualdad de condiciones con los demás e incluso mediante ajustes de procedimiento.

En la Jurisprudencia Interamericana, se interpreta la norma y se maximiza este principio, en el Caso Furlan y Familiares vs Argentina, al exigirse tratar la

\footnotetext{
${ }^{413}$ CDPD. Artículo 13: 1. "Los Estados Partes asegurarán que las personas con discapacidad tengan acceso a la justicia en igualdad de condiciones con las demás, incluso mediante ajustes de procedimiento y adecuados a la edad, para facilitar el desempeño de las funciones efectivas de esas personas como participantes directos e indirectos, incluida la declaración como testigos, en todos los procedimientos judiciales, con inclusión de la etapa de investigación y otras etapas preliminares. 2. A fin de asegurar que las personas con discapacidad tengan acceso efectivo a la justicia, los Estados Partes promoverán la capacitación adecuada de los que trabajan".

${ }^{414}$ PODER JUDICIAL DE CHILE. Protocolo de Acceso a la Justicia de Grupos Vulnerables. Op. Cit., p.58.
} 
discapacidad como un fenómeno en sí, que implica una responsabilidad social y estatal, de reconocimiento y preocupación activa en cuanto a barreras que deben sortear las personas que pertenecen a este grupo, destacando las arquitectónicas, económicas y actitudinales, propendiendo a su remoción ${ }^{415}$.

b) Mayor protección de los derechos de las personas con discapacidad: En este sentido sostenemos que la optimización de las normas protectoras, incluso las de derecho común, deben ser interpretadas respecto de este grupo en clave de derechos humanos, permitiendo su máximo goce y ejercicio, obligando a quienes operan con normas vinculadas al tema, a emplear siempre los estándares más altos a favor de las personas con discapacidad.

c) Igualdad y no discriminación: Busca más allá de la igualdad formal establecida en las leyes, convenciones y Constitución, tomar en cuenta las circunstancias particulares de cada persona con discapacidad a las que les aplica la ley. Tal Como se trata muy acertadamente por la Corte IDH en el caso Ximenes López vs Brasil, "las personas con discapacidad a menudo son objeto de discriminación a raíz de su

\footnotetext{
${ }^{415}$ CORTE IDH. Caso Furlan y familiares vs Argentina. Op. Cit., Párrafo 133: “Al respecto, la Corte observa que en las mencionadas convenciones se tiene en cuenta el modelo social para abordar la discapacidad, lo cual implica que la discapacidad no se define exclusivamente por la presencia de una deficiencia física, mental, intelectual o sensorial, sino que se interrelaciona con las barreras o limitaciones que socialmente existen para que las personas puedan ejercer sus derechos de manera efectiva. Los tipos de límites o barreras que comúnmente encuentran las personas con diversidad funcional en la sociedad, son, entre otras, barreras físicas o arquitectónicas, comunicativas, actitudinales o socioeconómicas”. Párrafo 196: “Asimismo, la Corte recuerda que la CDPD, anteriormente reseñada (supra párr. 137), contiene normas sobre la importancia del acceso a justicia de las personas con discapacidad 'en igualdad de condiciones con las demás' e 'incluso mediante ajustes de procedimiento y adecuados a la edad' (Preámbulo y art. 13.1). En este sentido, el Tribunal considera que en casos de personas vulnerables, como lo es una persona con discapacidad, es imperante tomar las medidas pertinentes, como por ejemplo la priorización en la atención y resolución del procedimiento por parte de las autoridades a su cargo, con el fin de evitar retrasos en la tramitación de los procesos, de manera que se garantice la pronta resolución y ejecución de los mismos”. Párrafo 278: “La Corte resalta que las violaciones declaradas en capítulos anteriores fueron cometidas en perjuicio de un niño y, posteriormente, adulto con discapacidad, lo cual implica que las reparaciones otorgadas, en el presente caso, deben seguir el modelo social para abordar la discapacidad consagrado en los diversos tratados internacionales sobre la materia (supra párrs. 133 a 135). Lo anterior implica que las medidas de reparación no se centran exclusivamente en medidas de rehabilitación de tipo médico, sino que se incluyen medidas que ayuden a la persona con discapacidad a afrontar las barreras o limitaciones impuestas, con el fin de que dicha persona pueda 'lograr y mantener la máxima independencia, capacidad física, mental, social y vocacional, y la inclusión y participación plena en todos los aspectos de la vida’”.
} 
condición, por lo que los Estados deben adoptar las medidas de carácter legislativo, social, educativo, laboral o de cualquier otra índole, necesarias para que toda discriminación asociada con las discapacidades mentales sea eliminada, y para propiciar la plena integración de esas personas en la sociedad"416. En el mismo orden de razonamiento, se debe nuevamente mencionar el caso Furlan Familiares vs Argentina ${ }^{417}$.

d) Respeto a la dignidad inherente, autonomía individual, libertad para tomar las propias decisiones e independencia de las personas con discapacidad. En este sentido, no podemos dejar de referirnos a una iniciativa reconocida a nivel internacional que se desarrolla en Chile desde 1978, que es la "TELETON", que

\footnotetext{
${ }^{416}$ Corte IDH. Caso Ximenes López vs Brasil. Op. Cit., Párrafo 103: “La Corte Interamericana considera que toda persona que se encuentre en una situación de vulnerabilidad es titular de una protección especial, en razón de los deberes especiales cuyo cumplimiento por parte del Estado es necesario para satisfacer las obligaciones generales de respeto y garantía de los derechos humanos. La Corte reitera que no basta que los Estados se abstengan de violar los derechos, sino que es imperativa la adopción de medidas positivas, determinables en función de las particulares necesidades de protección del sujeto de derecho, ya sea por su condición personal o por la situación específica en que se encuentre, como la discapacidad”
}

${ }^{417}$ CORTE IDH. Caso Furlan y familiares vs Argentina. Op. Cit., Párrs 135, 216, 267. Párrafo 135: “Asimismo, la Corte considera que las personas con discapacidad a menudo son objeto de discriminación a raíz de su condición, por lo que los Estados deben adoptar las medidas de carácter legislativo, social, educativo, laboral o de cualquier otra índole, necesarias para que toda discriminación asociada con las discapacidades sea eliminada, y para propiciar la plena integración de esas personas en la sociedad. El debido acceso a la justicia juega un rol fundamental para enfrentar dichas formas de discriminación”. Párrafo.216: “Al respecto, el Comité de Derechos Económicos Sociales y Culturales ha manifestado que 'la obligación de los Estados Partes de proteger a los miembros vulnerables de sus respectivas sociedades reviste una importancia más bien mayor que menor en momentos de gran escasez de recursos. Asimismo, manifestó la importancia de prestar apoyo suficiente a quienes en razón de su discapacidad se hayan visto privados de sus oportunidades de empleo, lo cual debe reflejar 'las necesidades especiales de asistencia y otros gastos asociados a menudo con la discapacidad, y además, en la medida de lo posible, el apoyo prestado debe abarcar también a las personas [...] que se ocupan de cuidar a personas con discapacidad [...], incluidos los familiares de estas últimas personas, [ya que] se hallan a menudo en la urgente necesidad de obtener apoyo financiero como consecuencia de su labor de ayuda'. Asimismo, el Comité de la Convención sobre los Derechos de las Personas con Discapacidad, en su primer caso, manifestó que se deben tomar en consideración las circunstancias particulares de las personas a las que se aplique una ley, puesto que los Estados no deben realizar una aplicación imparcial de la misma 'sin una justificación objetiva y razonable', por cuanto se debe tratar 'de forma diferente a personas cuya situación sea considerablemente distinta". Párrafo 267: "Al respecto, la Corte considera que el derecho a la igualdad y no discriminación abarca dos concepciones: una concepción negativa relacionada con la prohibición de diferencias de trato arbitrarias, y una concepción positiva relacionada con la obligación de los Estados de crear condiciones de igualdad real frente a grupos que han sido históricamente excluidos o que se encuentran en mayor riesgo de ser discriminados. Asimismo, la Corte ha señalado que el derecho a la integridad física, psíquica y moral, consagrado en el artículo 5.1 de la Convención Americana, no sólo implica que el Estado debe respetarlo (obligación negativa), sino que, además, requiere que el Estado adopte todas las medidas apropiadas para garantizarlo (obligación positiva), en cumplimiento de su deber general establecido en el artículo 1.1 de la Convención Americana”. 
agrupa todos los años a los canales de televisión y algunas plataformas digitales, en una actividad solidaria de recaudación de fondos por 27 horas de transmisión continua, que más allá del objetivo monetario final, para el financiamiento de sus centros de rehabilitación, que prestan atención médica, kinésica y social a miles de niños en todas las regiones del país, concientiza a toda la población, en el entendido que una persona y especialmente un niño con discapacidad, está dotado de una dignidad que debe ser reconocida, y que todas las personas y organismos deben procurar velar por su desarrollo, autonomía e independencia, dotándolo de condiciones para ello.

e) Se reconoce la personalidad y capacidad jurídica de todas las personas con discapacidad y la libertad de ellas para tomar sus propias decisiones y preferencias sin cuestionar la sabiduría en su adopción: Considera sistemas de apoyo que deben ser proporcionales y adaptados a las circunstancias de las personas con discapacidad, los que deben aplicarse durante el menor plazo posible. Asimismo, considera un sistema de salvaguardas, que impida los abusos y las sustituciones a la voluntad. La jurisprudencia Interamericana en el Caso Ximenes López vs Brasil, hace un adecuado análisis en torno al tratamiento médico que se le debe dar a una persona con discapacidad mental, respetando su condición singular en pos del favorecimiento de su autonomía e independencia ${ }^{418}$.

f) Principio de accesibilidad y participación e inclusión plenas y efectivas en la sociedad: Como corolario de los anteriores, cobra relevancia al articularse con los otros principios antedichos, pues se encuentra vinculado a la vida independiente, la no discriminación y la accesibilidad universal en actividades económicas, políticas,

\footnotetext{
418 CORTE IDH. Caso Ximenes López vs Brasil. Op. Cit., Párrafo 130: "La Corte considera que todo tratamiento de salud dirigido a personas con discapacidad mental debe tener como finalidad principal el bienestar del paciente y el respeto a su dignidad como ser humano, que se traduce en el deber de adoptar como principios orientadores del tratamiento psiquiátrico, el respeto a la intimidad y a la autonomía de las personas. El Tribunal reconoce que este último principio no es absoluto, ya que la necesidad misma del paciente puede requerir algunas veces la adopción de medidas sin contar con su consentimiento. No obstante, la discapacidad mental no debe ser entendida como una incapacidad para determinarse, y debe aplicarse la presunción de que las personas que padecen de ese tipo de discapacidades son capaces de expresar su voluntad, la que debe ser respetada por el personal médico y las autoridades. Cuando sea comprobada la imposibilidad del enfermo para consentir, corresponderá a sus familiares, representantes legales o a la autoridad competente, emitir el consentimiento en relación con el tratamiento a ser empleado".
} 
sociales y culturales, ya que en su conjunto promueven y permiten la inclusión de las personas con discapacidad en la sociedad, haciendo efectivo el ejercicio de los derechos de los cuales son titulares, constituyéndose en un valioso aporte y co constructores de la sociedad en que forman parte.

Así, tal como se sostiene y se direcciona en el Protocolo Iberoamericano de Acceso a la Justica, la accesibilidad y su relación con la discapacidad puede ser entendida en dos vertientes:

a) Como un camino para garantizar una efectiva igualdad de oportunidades en el ejercicio de los derechos.

b) Como un requisito en el diseño de cualquier entorno (físico, de las comunicaciones o de la información, incluidas las tecnologías de la información y de las comunicaciones), o en el de los bienes y servicios ${ }^{419}$.

Sin importar la forma en que sea entendida la accesibilidad, tiene como objetivo eliminar las barreras de tipo físico o actitudinal que constituyen limitaciones para las personas con discapacidad en su autonomía personal, en su interacción con el entorno, o en el ejercicio de sus derechos, obstaculizando su participación social plena y efectiva, así como una forma de vida independiente ${ }^{420}$.

De esa forma, se transitará hacia una accesibilidad universal, enfocada no solo a la supresión de barreras para los distintos tipos de discapacidad, sino a constituirse en un elemento que beneficia a todas las personas, sin importar sus diversidades funcionales. Por lo tanto, la accesibilidad universal se convierte en un presupuesto para que las personas con discapacidad puedan participar y ser incluidas en la sociedad, a no ser discriminadas, y a gozar de una igualdad de oportunidades.

\footnotetext{
${ }^{419}$ XVII CUMBRE JUDICIAL IBEROAMERICANA. Op. Cit., p.281.

${ }^{420}$ IBIDEM. Op. Cit., p.28. "Un factor de gran importancia para la eliminación de ese tipo de barreras lo ha constituido el diseño universal o el diseño para todas las personas, el cual parte de la idea de que cualquier tipo de entorno, bienes o servicios, está elaborado bajo la perspectiva integral de personas con distintas características y habilidades; tornándose en un sinónimo de pensado para todos y todas, con lo cual, la accesibilidad se dota de universalidad”.
} 
Este principio omnicomprensivo pro persona, desde un enfoque social de vulnerabilidad se encuentra recogido en la jurisprudencia interamericana ${ }^{421}$

g) Respeto a la diferencia: Implica la aceptación de la discapacidad como parte de la diversidad y condición humana, asumiendo una visión positiva e integral de ella, así exhorta a considerar a las personas con discapacidad, como titulares de derechos. Finalmente, reconoce que existe una diversidad de discapacidades y de necesidades particulares. Lo anterior, se debe relacionar con el artículo 7 de la $\mathrm{CDPD}^{422}$.

h) Respeto a la evolución de las facultades de los NNA con discapacidad, derecho a preservar su identidad: Junto con el respeto por el principio relativo al interés superior del niño o niña, es necesario respetar el derecho a ser oído y a opinar de los asuntos que le afectan a estos de acuerdo a su edad, desarrollo y tipo de discapacidad; asegurando las condiciones y medidas necesarias para que puedan desarrollar una vida plena y digna con el máximo aprovechamiento de sus

\footnotetext{
${ }^{421}$ CORTE IDH. Caso Furlan vs Familiares. Op. Cit., Párrs. 134, 300. Párrafo 134: “En este sentido, la Corte Interamericana reitera que toda persona que se encuentre en una situación de vulnerabilidad es titular de una protección especial, en razón de los deberes especiales cuyo cumplimiento por parte del Estado es necesario para satisfacer las obligaciones generales de respeto y garantía de los derechos humanos. El tribunal recuerda que no basta con que los Estados se abstengan de violar los derechos, sino que es imperativa la adopción de medidas positivas, determinables en función de las particulares necesidades de protección del sujeto de derecho, ya sea por su condición personal o por la situación específica en que se encuentre, como la discapacidad. En este sentido, es obligación de los Estados propender por la inclusión de las personas con discapacidad por medio de la igualdad de condiciones, oportunidades y participación en todas las esferas de la sociedad, con el fin de garantizar que las limitaciones anteriormente descritas sean desmanteladas. Por tanto, es necesario que los Estados promuevan prácticas de inclusión”. Párrafo 300: "La Corte recuerda que el artículo 2 de la Convención obliga a los Estados Parte a adoptar, con arreglo a sus procedimientos constitucionales y a las disposiciones de la Convención, las medidas legislativas o de otro carácter que fueren necesarias para hacer efectivos los derechos y libertades protegidos por la Convención. Es decir, los Estados no sólo tienen la obligación positiva de adoptar las medidas legislativas necesarias para garantizar el ejercicio de los derechos en ella consagrados, sino que también deben evitar promulgar aquellas leyes que impidan el libre ejercicio de estos derechos, y evitar que se supriman o modifiquen las leyes que los protegen. Por tanto, la Corte recuerda que en el marco de las obligaciones derivadas de los artículos 1.1 y 2 de la Convención, y según los estándares desarrollados en la presente Sentencia (supra párrs. 125 a 139), los Estados deben adoptar medidas para reducir las limitaciones o barreras y para dar el trato preferente apropiado a las personas con discapacidad, a fin de conseguir los objetivos de la plena participación e igualdad dentro de la sociedad para todas ellas”.
}

${ }^{422}$ CDPD. Artículo 7. 1. "Los Estados Partes tomarán todas las medidas necesarias para asegurar que todos los niños y las niñas con discapacidad gocen plenamente de todos los derechos humanos y libertades fundamentales en igualdad de condiciones con los demás niños y niñas. 2. En todas las actividades relacionadas con los niños y las niñas con discapacidad, una consideración primordial será la protección del interés superior del niño". 
potencialidades y habilidades ${ }^{423}$. La necesidad imperiosa de considerar el interés superior del NNA con discapacidad en cualquier decisión de tipo administrativa, ha sido valorada en la sentencia Furlan Familiares vs Argentina ${ }^{424}$.

Buenas Prácticas en relación a estos principios: Sin perjuicio de lo que se señalará para el caso de Chile, se pueden nombrar:

a) Plan estratégico de la rama judicial de Puerto Rico $2012-2015^{425}$.

b) Proyecto Banco Interamericano de Desarrollo con Poder Judicial de Costa Rica: A iniciativa de la comisión de accesibilidad se instauró un modelo de señalización para servicios judiciales. En este contexto se contemplan los talleres de sensibilización, promoción y respeto por los derechos de las personas con discapacidad psicosocial ${ }^{426}$.

c) Centros jurídicos y Centro de Conciliación inclusiva de Colombia para personas en situación de discapacidad ${ }^{427}$.

${ }^{423}$ PODER JUDICIAL DE CHILE. Protocolo de Acceso a la Justicia de Grupos Vulnerables. p.60.

${ }^{424}$ CORTE IDH. Caso Furlan y Familiares vs Argentina. Párrafo 126: "Por otra parte, toda decisión estatal, social o familiar que involucre alguna limitación al ejercicio de cualquier derecho de un niño o una niña, debe tomar en cuenta el principio del interés superior del niño y ajustarse rigurosamente a las disposiciones que rigen esta materia. Respecto del interés superior del niño, la Corte reitera que este principio regulador de la normativa de los derechos del niño se funda en la dignidad misma del ser humano, en las características propias de las niñas y los niños, y en la necesidad de propiciar el desarrollo de éstos, con pleno aprovechamiento de sus potencialidades. En el mismo sentido, conviene observar que para asegurar, en la mayor medida posible, la prevalencia del interés superior del niño, el preámbulo de la Convención sobre los Derechos del Niño establece que éste requiere 'cuidados especiales', y el artículo 19 de la Convención Americana señala que debe recibir 'medidas especiales de protección'. En este sentido, es preciso ponderar no sólo el requerimiento de medidas especiales, sino también las características particulares de la situación en la que se hallen el niño o la niña”.

425 PODER JUDICIAL DE PUERTO RICO. http://www.ramajudicial.pr/orientacion/informes/rama/Planestrategico-2012-2015.pdf [Consulta 15 de enero de 2020].

426 PODER JUDICIAL DE COSTA RICA. http://portal.poder-judicial.go.cr/discapacidad/psicosocial [Consulta 15 de enero de 2020].

${ }^{427}$ IBIDEM 


\subsection{Premisas y recomendaciones en base a estos principios}

Las siguientes recomendaciones, tanto para la generación de políticas públicas, como para la actuación de los tribunales contribuyen a derribar las barreras que las personas con discapacidad enfrentan cotidianamente en el ejercicio de sus derechos.

a) Observar los principios en todas las etapas del proceso en los que intervenga una persona con discapacidad, sin importar la materia del mismo ni el carácter de su participación.

b) Considerar la condición de discapacidad de las personas en la etapa de ejecución del fallo, a fin de adoptar medidas que dentro del marco de la ley, sean las más apropiadas para un cumplimiento efectivo.

d) Eliminar todo trato discriminatorio a personas con discapacidad a lo largo de las diversas etapas del procedimiento, sin importar la calidad con la que participen en él.

e) Implementar ajustes razonables para un efectivo respeto y ejercicio de los derechos de las personas con discapacidad, atendido aquellas barreras impuestas por el entorno que dificultan el ejercicio de éstos. Tal como lo expresa la CDPD "Ios ajustes razonables son modificaciones, adaptaciones necesarias y adecuadas que se requieren para garantizar que las personas con discapacidad el goce o ejercicio de todos los derechos humanos y libertades fundamentales en igualdad de condiciones. Lo ajustes razonables no deben imponer una carga desproporcionada o indebida" 428 .

f) Tener en cuenta los diversos tipos de discapacidad existente, así como las necesidades particulares de las personas con discapacidad, a fin de garantizar que

${ }^{428}$ CDPD. Artículo 2. 
los ajustes razonables logren eficazmente, tanto la igualdad de oportunidades, como el acceso a la justicia.

g) Asegurar que se estén implementando los ajustes razonables de manera adecuada, mediante comunicación directa con las personas con discapacidad. Lo anterior permitirá vencer barreras actitudinales, prejuicios y estigmas, mediante una interacción mayor entre las y los operadores de justicia y las personas con discapacidad.

En el Protocolo Argentino de acceso a la derecho autónomo previsto por la CDPD, se señala que la noción de "acceso a la justicia", de acuerdo con Francisco Bariffi, [...] es amplia y exhaustiva y puede ser analizada al menos, en tres dimensiones diferentes: legal, físico y comunicacional ${ }^{429}$.

De esta manera, tal como lo dispone el artículo 13 de la CDPD existe la obligación para las autoridades judiciales de asegurar un acceso a la justicia, lo que implica que se lleven a cabo todas las medidas necesarias para que la persona con discapacidad pueda ejercer ese derecho en igualdad de condiciones que el resto de la población, debiendo para ello realizar, incluso los ajustes al procedimiento que se requieran, y que sean adecuados a la edad.

A nuestro entender, para la generación de una política pública inclusiva e integrada a estas premisas, se debe partir del reconocimiento de todas las barreras que propician una desigualdad de las personas con discapacidad en el derecho de acceso a la justicia. Este reconocimiento es necesario para estar en posibilidad de implementar ajustes que efectivamente eliminen esas situaciones de desigualdad y discriminación, los cuales podrán ser tan variados como las necesidades del caso lo establezcan, pues en última instancia las y los jueces tienen la obligación de

\footnotetext{
${ }^{429}$ MINISTERIO DE JUSTICIA Y DERECHOS HUMANOS DE LA NACION. (2013). "Protocolo para el Acceso a la Justicia de las Personas con Discapacidad. Propuestas para un trato adecuado" EN Colección de Documentos de Política número 2, Área Justicia. Eurosocial, Programa para la Cohesión Social en América Latina, Buenos Aires. "La primera de ellas se refiere a que las personas con discapacidad puedan participar, sin importar la calidad con la que lo hagan, en los procesos judiciales por derecho propio. La segunda dimensión se relaciona con el hecho de que todas las instalaciones judiciales sean accesibles, y la tercera establece que cualquier información que se proporcione a las personas con discapacidad sea de igual forma accesible y se presente en medios alternativos de comunicación, como por ejemplo: Lengua de señas, sistema de Escritura Braille en formatos digitales, o en un texto de fácil lectura y comprensión, entre otros”.
} 
instrumentarlos atendiendo al caso en concreto, sin pretender establecer criterios generales de aplicación. Incluso, su labor de adoptar los ajustes al procedimiento debe ir más allá de lo señalado en los ordenamientos jurídicos aplicables, en atención a que deberán implementarlos aún en los casos en los que tales normas no prevean la existencia del ajuste que corresponda.

\subsection{Acceso a la justicia de las personas con discapacidad en Chile}

\subsubsection{Barreras estructurales de acceso a justicia existentes en Chile respecto de las personas en condición de discapacidad}

Cuando existe una vulneración a una persona que presenta una discapacidad, de cualquier carácter que sea, se responsabiliza a la sociedad. Sin perjuicio de esta responsabilidad genérica, existen algunas más concretas que pueden invisibilizarse tras esta generalización. Tal como lo explica Gina Basso, "cuando una persona con discapacidad se enfrenta una situación discriminatoria de cualquier naturaleza, el principal culpable señalado suele ser la sociedad en su conjunto, en la que se han plasmado los valores de un modelo economicista donde subyacen la cultura del consumo y los estereotipos de lo exitoso, perfecto y bello, entre otros factores que hoy se imponen en el mundo occidental. Sin embargo, hay medios objetivos para establecer responsabilidades más acotadas, las que corresponden a una serie de organismos públicos, cuya tarea definida por ley, es velar por los derechos e igualdad de oportunidades sociales de todas las personas con discapacidad y/o capacidades diferentes en el país"430. En Chile nos encontramos con distintas dificultades de acceso a la justicia a las personas en situación de discapacidad, que pasan por trabas de diverso tipo, incluso actitudinales por parte de los operadores

\footnotetext{
430 BASSO, G (2013). “Ley de inclusión de discapacitados: Una gran deuda del Estado de Chile”. EN CIPER ACADEMICO.https://ciperchile.cl/2013/08/08/ley-de-inclusion-de-discapacitados-una-gran-deuda-delestado-de-chile/. [Consulta 9 de febrero de 2020].
} 
del sistema y especialmente de infraestructura, que constituyen el primer obstáculo material que encuentran estas personas.

Precisamente, una de las principales barreras que enfrentan las personas en condición de discapacidad dice relación con el acceso a la infraestructura de edificios y dependencias. Actualmente se utiliza el concepto de movilidad reducida, la que afecta a personas con discapacidad física, alta dependencia, adultos mayores, mujeres embarazadas, entre otras; quienes al encontrarse con escasa movilidad e independencia, ven disminuidas sus posibilidades de salir de su domicilio o desplazarse para asistir a audiencias o tramitaciones ante tribunales, de manera autónoma y segura. Entre las principales barreras de infraestructura destacan las veredas en mal estado, falta de rebajes en cruce de calles, ramplas sin la debida pendiente, inexistencia y/o falta de mantención en ascensores, puertas angostas, falta de señalización, ausencia de salas especiales, escasa utilización de sistema braille, mobiliario inadaptado, escases de estacionamientos exclusivos, entre otros.

Para Paula Riveros, "en el caso de discapacidad mental, visual o auditiva, podemos señalar que generalmente deben ser acompañados por terceras personas, a veces los mismos agresores en materia de Violencia Intrafamiliar, resultando compleja la denuncia" 431 . Agrega que "cuando se trata de discapacidad psíquica o intelectual, el impedimento además consiste en la falta de razonamiento o entendimiento del proceso judicial, que hace que en la práctica no entiendan nada de lo ocurrido en la diligencias administrativas, judiciales o en la comparecencia o audiencia"432.

La Ley 20.422, que establece normas sobre igualdad de oportunidades e inclusión social de personas con discapacidad ${ }^{433}$, de 10 de febrero de 2010 , cuya finalidad

\footnotetext{
${ }^{431}$ Entrevista sostenida con fecha 11 de marzo de 2020 con Paula Riveros Loyola, abogada ejecutora regional séptima región del Maule, convenio CAJ-SENADIS.

432 IBIDEM.

${ }^{433}$ Con la creación de la Ley 19.284 de "Integración Social de las Personas con Discapacidad", se avanzó muchísimo en difundir y sensibilizar a la opinión pública. Se abrió la oportunidad a miles de personas, especialmente de escasos recursos, para mejorar sus condiciones de vida a través de proyectos y ayudas técnicas, entre otros legítimos beneficios que el FONADIS promovió e hizo realidad. Sin embargo, al parecer el tiempo se detuvo y no se han logrado avances significativos en estos últimos años.
} 
fue reemplazar la ley 19.284 de 14 de enero de 1994, exige que el Estado debe adecuar instrumentos y procedimientos para impedir la conductas discriminatorias y asegurar la igualdad de oportunidades. Lamentablemente, aún no contamos con los ajustes razonables necesarios para garantizar igualdad en el acceso a la justicia. En efecto, el Artículo $8^{\circ}$ de la ley en referencia, preceptúa "con el fin de garantizar el derecho a la igualdad de oportunidades de las personas con discapacidad, el Estado establecerá medidas contra la discriminación, las que consistirán en exigencias de accesibilidad, realización de ajustes necesarios y prevención de conductas de acoso. Se entiende por exigencias de accesibilidad, los requisitos que deben cumplir los bienes, entornos, productos, servicios y procedimientos, así como las condiciones de no discriminación en normas, criterios y prácticas, con arreglo al principio de accesibilidad universal” ${ }^{434}$.

En el plano local, los ajustes necesarios son las medidas de adecuación del ambiente físico, social y de actitud a las carencias específicas de las personas con discapacidad, que de forma eficaz y práctica y sin que suponga una carga desproporcionada, faciliten la accesibilidad o participación de una persona con discapacidad, en igualdad de condiciones que el resto de los ciudadanos ${ }^{435}$.

Además estos obstáculos se encuentran en personas que ejercen la profesión de abogado presentando algún tipo de discapacidad, lo que es grave, pues precisamente el ejercicio de esta profesión es la que permite facilitar el acceso a la justicia a los grupos en condición de vulnerabilidad. Desde una perspectiva de primera persona, nos hemos permitido citar extracto de entrevista sostenida con don Michael Moraga Vásquez, con la finalidad de ilustrar las barreras que debe sortear un abogado con discapacidad visual ${ }^{436}$.

\footnotetext{
${ }^{434}$ LEY 20.422. Que establece normas sobre igualdad de oportunidades e inclusión social de personas con discapacidad, de 10 de febrero de 2010. Artículo 8.

435 Conducta de acoso, es toda conducta relacionada con la discapacidad de una persona, que tenga como consecuencia atentar contra su dignidad o crear un entorno intimidatorio, hostil, degradante, humillante u ofensivo".

436 Destacado abogado no vidente que se desempeña en el ejercicio libre de la profesión, y que además, se desempeña como profesor de la Catedra de derecho de las obligaciones, en la Universidad Autónoma de Chile. "En lo que a las dificultades se refiere, mencionar primero que todo, la ausencia de traductor de lenguaje de señas en los distintos tribunales de justicia de nuestro país. En la actualidad, y gracias al acceso a la educación
} 


\subsubsection{Obstáculos o deficiencias legislativas de acceso a la justicia de las personas en condición de discapacidad}

En el marco normativo nacional, las ya citadas leyes 20.422 y la Ley 20.609 de 24 de julio de 2012, que establece medidas contra la discriminación, se esmeran en adecuarse a la normativa internacional, sin lograrlo a cabalidad. La primera que nos convoca en este tópico ${ }^{437}$, consagra normas sobre igualdad de oportunidades e inclusión social de personas con discapacidad y que establece medidas contra la discriminación.

La nueva Ley 20.422 fue sujeta a evaluación a partir de julio de 2012 a través de un estudio acucioso encargado al Departamento de Evaluación de Leyes de la Cámara de Diputados, cuyos resultados no son auspiciosos y se expresan en un extenso documento que entrega conclusiones y recomendaciones para el cumplimiento institucional en la aplicación de la norma ${ }^{438}$.

En el referido estudio de la Cámara, se diagnostica como un gran déficit para la operatividad de la ley, la ausencia de reglamentos y definiciones de responsabilidad y compromiso institucional, entre otros factores, constatando además insuficiencia presupuestaria para instalar mecanismos que fomenten la eficacia de la norma. En el sondeo de opiniones consultadas para la evaluación, se destaca un gran

\footnotetext{
que se ha ido obteniendo poco a poco, las personas con discapacidad pueden estudiar la carrera de derecho. Es así como una persona con discapacidad auditiva o visual, puede llegar a ser un profesional o técnico del área jurídica. Es aquí donde surge el primer inconveniente, ya que en nuestros tribunales de justicia, así como también en instituciones públicas como Conservador de Bienes Raíces, no existe el personal capacitado para relacionarse con un profesional que tenga dicha discapacidad”. Tampoco existe legislación sustantiva ni adjetiva impresa en sistema Braille, hecho que condiciona el acceso de las personas con discapacidad visual a las normas jurídicas. Evidentemente no, ya que si bien, como se señaló anteriormente, hay avances estructurales, no es menos cierto que aún falta en cuanto a la igualdad de oportunidades, igualdad en el acceso al conocimiento de la norma y acceso a tecnologías informáticas que hoy en día son parte importante del acceso a la justicia. No existe señalética que indique números de sala, piso y las distintas oficinas en sistema Braille.

${ }^{437}$ LEY 20.422. Artículo 1: "El objeto de esta ley es asegurar el derecho a la igualdad de oportunidades de personas con discapacidad, con el fin de obtener su plena inclusión social, asegurando el disfrute de derechos y eliminando cualquier forma de discriminación fundada en la discapacidad”.

${ }^{438}$ BASSO, G (2013). Op. Cit. p.3
} 
desconocimiento de las personas con discapacidad o sus representantes acerca de las facultades conferidas por la ley a los entes públicos, y sobre sus propios derechos y beneficios derivados de esta iniciativa legal. Este marco de desconfianza y desinformación de las personas con discapacidad, habla de su nula o escasa participación en los procesos de desarrollo de esta temática, aunque son los principales afectados. Lapidario resulta el informe, especialmente para el trabajo interministerial, ya que existe una exacerbada burocracia y se limitan las funciones del SENADIS ${ }^{439}$.

Precisamente, con la Ley 20.422 se suprime el Fondo Nacional de Discapacidad, sustituyéndolo por el SENADIS ${ }^{440}$, dotado de una institucionalidad propia, a diferencia de su predecesor, que consistía en un fondo de financiamiento para proyectos de emprendimiento para personas en situación de discapacidad. Sin perjuicio de que la promulgación de esta ley constituye un avance, adolece de defectos, entre los cuales se encuentra su escasa efectividad, la imposibilidad práctica de contar con abogado para ejercer los derechos que contempla, y las falencias procedimentales y estructurales de la sede judicial en que se ventilan estos procedimientos, que corresponden a los juzgados de policía local

Los principales organismos responsables del cumplimiento de la ley sobre discapacidad, corresponden al SENADIS, al Consejo Consultivo de la Discapacidad, Consejo Interministerial, Registro Nacional de la Discapacidad, Comisión de Medicina Preventiva e Invalidez, ministerios y municipalidades, los que han sido cuestionados en su eficiencia y eficacia para hacer operativa dicha ley.

\footnotetext{
${ }^{439}$ IBIDEM. "A modo de referencia, el estudio realizado da cuenta de dos áreas de investigación en las que participaron las instituciones públicas responsables de la implementación y aplicación de la ley. Así mismo, se evaluó la 'percepción ciudadana', apelando principalmente al nivel de información de las personas y organizaciones acerca de la ley y de los organismos del Estado relacionados con el tema”.

440 SENADIS. https://www.senadis.gob.cl/pag/2/1144/introduccion. [Consulta 17 de enero de 2020]. "El SENADIS es un Servicio Público descentralizado y desconcentrado territorialmente, que tiene por finalidad promover el derecho a la igualdad de oportunidades de las personas con discapacidad, con el fin de obtener su inclusión social, contribuyendo al pleno disfrute de sus derechos y eliminando cualquier forma de discriminación fundada en la discapacidad, a través de la coordinación del Estado”.
} 
Por su parte la ley 18.600 de 19 de febrero de 1987, que establece normas sobre deficientes mentales, se refiere a que las personas con discapacidad mental bajo los parámetros que indica ${ }^{441}$, pueden ser declaradas interdictas, y así ser protegidas, o más bien a nuestro entender, vetadas o impedidas de ejercer actos de la vida civil y así designarles curador de bienes para su representación. Esta normativa está circunscrita a la discapacidad mental y trae aparejada algunas situaciones complejas, en cuanto a que los familiares de una persona podrían solicitar la declaración de interdicción, más que para cautelar sus derechos, persiguen administrarles sus bienes libre y/o abusivamente. La Ley n 19.954 de 14 de julio de 2004, fija un procedimiento especial para declarar la interdicción de una persona y designarle curador. Si bien la letra de dicha ley no lo explicita, tal procedimiento es de tipo no contencioso o voluntario ${ }^{442}$.

\subsection{Políticas públicas y buenas prácticas de acceso a la justicia en Chile respecto de las personas en condición de discapacidad}

Sin perjuicio que las normas de protección para las personas en condición de discapacidad reiteran la consigna sobre la "igualdad de oportunidades", no se han visto reflejadas mediante una política pública coherente con el espíritu de las leyes, con formulación de reglamentos y el cumplimiento cabal de lo acordado en las convenciones internacionales a las cuales ha suscrito nuestro país.

\footnotetext{
${ }^{441}$ LEY 18.600. Establece Normas sobre Deficientes Mentales, de 19 de febrero de 1987. Artículo 2: "Para los efectos de la presente ley, se considera persona con discapacidad mental a toda aquella que, como consecuencia de una o más limitaciones síquicas, congénitas o adquiridas, previsiblemente de carácter permanente y con independencia de la causa que las hubiera originado, vea obstaculizada, en a lo menos un tercio, su capacidad educativa, laboral o de integración social”.

${ }^{442}$ LEY 19.954. Modifica la Ley 18.600, en lo relativo al Procedimiento de Interdicción de los Discapacitados Mentales, de 14 de julio de 2004. Es así, que contando con la inscripción de discapacidad en el registro pertinente, llevado por el Servicio de Registro Civil e Identificación, con una simple solicitud ante el juez de letras competente de citar al discapacitado ante su presencia para realizar una audiencia personal, se puede obtener fallo favorable. Así, la entrevista descrita solo sirve para corroborar la discapacidad y en el contexto de la misma causa debe ofrecerse un nombre para designar como curador del presunto interdicto.
} 
Las dificultades a las que se ven enfrentadas las personas en condición de vulnerabilidad por discapacidad, dependerán de las barreras que se presentan en su entorno, en virtud al déficit que se presente. Ejemplarmente, cuando la discapacidad es auditiva y las personas requieren de sistemas de apoyo a la comunicación, los tribunales deberán contar con intérprete de lengua de señas o ajustes razonables afines; de lo contrario las personas no podrán expresar, o entender lo ocurrido en audiencia, no pudiendo aclarar sus inquietudes, dado que tanto jueces, consejeros técnicos, y abogados no manejan el lenguaje de señas.

EI SENADIS ha creado el programa de acceso a la justicia para personas discapacitadas, el cual es un beneficio que se otorga a aquellas personas que en vista de su condición han sido discriminados en su acceso a la justicia. A través de este programa, las personas se pueden contactar con SENADIS en su región para que avalúe el caso, poniéndose en movimiento a especialistas para que satisfagan sus inquietudes y puedan darle una solución a sus problemas. Esto se hace con la finalidad de otorgar una defensa oportuna y de calidad a quienes han sido víctimas de discriminación o vulneración de derechos en razón de su discapacidad.

Las políticas públicas que se adopten deben ser coherentes con la premisa, que en nuestro derecho interno hemos suscrito a la CDPD, que tiene como fin "proteger y asegurar el goce pleno y en condiciones de igualdad de todos los derechos humanos y libertades fundamentales por todas las personas con discapacidad, y promover el respeto a su dignidad inherente" 443 . Precisamente, bajo este paradigma protector y en concordancia con lo preceptuado en el artículo 8 de la ley 20.422 , una de las misiones principales que tiene el Estado, específicamente el poder judicial y los servicios u oficinas de defensa jurídica, es implementar ajustes razonables, los que a la luz de la CDPD, se entenderán como las modificaciones y adaptaciones necesarias y adecuadas que no impongan una carga desproporcionada o indebida, cuando se requieran en un caso particular, para garantizar a las personas con discapacidad el goce o ejercicio, en igualdad de

${ }^{443}$ CDPD. Artículo1. 
condiciones con las demás, de todos los derechos humanos y libertades fundamentales ${ }^{444}$.

Dentro de los ajustes razonables que se deben contemplar en toda política pública de acceso a la justicia, debemos destacar:

a) Habilitación de acompañamiento durante la investigación o el testimonio de una persona de apoyo elegida por la persona con discapacidad.

b) Utilización de la comunicación alternativa y aumentativa, tales como imágenes y tablas de comunicación, para permitir a la persona expresarse plenamente.

c) Investigaciones realizadas por quienes tienen experiencia y conocimiento en la comunicación con las personas con discapacidad, en lugar de una investigación sin esta capacitación.

d) Expertos para eliminar del testimonio la información errónea, teniendo presente el tipo de discapacidad de quien declara.

e) Apoyo en la comunicación con el testigo. Asistencia [...] para la formulación de preguntas de modo que sean comprendidas por el testigo, y en el caso de los niños, teniendo en cuenta su capacidad en evolución. La posibilidad de declarar sin formalidades de vestimenta oficial, poder declarar en lugares diferentes a las cámaras, despacho del Juez o sala de audiencia oficial, incluso mediante enlaces de video. Tiempo suficiente para dar testimonio y descansos adecuados durante el proceso.

f) Provisión de información sobre los procedimientos en un lenguaje sencillo, entre otras.

g) Considerar la posibilidad de brindar un ajuste razonable en caso que una de las partes se auto identifique como persona con discapacidad o se tenga una duda fundada acerca de la existencia de una discapacidad.

En lo que a proposición de buenas prácticas se refiere, facilitaría el acceso a la justicia de este grupo, que se pudiese generalizar y que se normativizara, que cada institución pública dispusiese al menos un traductor de lengua de señas para las personas sordomudas. Otra buena práctica son los módulos de atención y consultas

${ }^{444}$ IBIDEM. Artículo 2, 
de causas que existen solo en algunos tribunales de justicia, para usuarios y abogados con discapacidad visual, siendo imperiosa su masificación. Además se estima como altamente recomendable que se contara en los tribunales, oficinas de asistencia jurídica gratuita y otros servicios análogos, con señalética que indique números de sala, piso y que los distintos estamentos contarán con sistema braille para facilitar la comunicación y la recepción por parte del juez y del resto de los operadores del sistema, de los planteamientos y pretensiones de las partes que presenten algún grado de discapacidad ${ }^{445}$.

Seguramente un avance relevante es la ejecución de Convenio CAJ- SENADIS que data del año del 2014, que proporciona un abogado a personas que por su discapacidad no pueden ejercer en condiciones de plena igualdad los derechos que el ordenamiento jurídico le confiere. La contribución principal es que las personas y sus familiares tengan prioridad de accesibilidad de atención, respecto a cualquier tema judicial o administrativo que requieran conocer, tanto presentando demandas como asesoramiento judicial o administrativo, por un profesional de manera gratuita, y oportuna ${ }^{446}$. Sin perjuicio de ello, se puede advertir que el convenio presenta algunas falencias en cuanto a cobertura, pues solo se presenta en las ciudades capitales sin extensión regional, a lo que suma, que la dotación existente es reducida y que por esta razón, se centra su intervención, en la promoción y difusión de derechos, más que en la representación judicial.

\section{PERSONAS, COMUNIDADES Y PUEBLOS INDIGENAS}

\subsection{Generalidades}

En cuanto a grupos indígenas, los problemas de acceso a la justicia, se relacionan principalmente con la falta de utilización de los estándares internacionales, en

\footnotetext{
${ }^{445}$ NASH, C; NUÑEZ, C; TRONCOSO, C. Op. Cit., p.345

${ }^{446}$ Entrevista sostenida con fecha 11 de junio con Paula Riveros Loyola, abogada ejecutora regional Séptima Región del Maule, convenio CAJ-SENADIS.
} 
relación a la interpretación y uso que se le otorga a la costumbre indígena; así como a la falta de reconocimiento de formas de resolución de conflictos propias de estas comunidades, por parte del Estado. Sin perjuicio de lo anterior, se debe destacar la presencia de otros obstáculos transversales que superan el acceso a la justicia propiamente tal, como la falta de reconocimiento constitucional y social de estas comunidades, las trabas lingüísticas, geográficas y de pobreza estructural que presentan.

Según datos de la Comisión Económica para América Latina y el Caribe, se estima que viven en Latinoamérica cerca de 45 millones de personas que se identifican como pertenecientes a comunidades indígenas, lo que representa un 8,3 de la Población total ${ }^{447}$. En Chile, la Encuesta de Calificación Socioeconómica del año 2019, arrojó que 1.585.680 personas se identifican como indígena ${ }^{448}$.

\subsection{Normativa internacional aplicable, principios y jurisprudencia}

a) Convenio $n^{\circ} 169$ de la Organización Internacional del Trabajo sobre pueblos indígenas y tribales en países independientes, firmado el 27 de junio de 1989 en Ginebra, ratificado por Chile el 15 de septiembre de 2008 y con vigencia desde 15 de Septiembre de 2009.

${ }^{447}$ COMISION ECONOMICA PARA AMERICA LATINA Y EL CARIBE. www.cepal.org/es/infografia [Consulta 21 febrero de 2020]

${ }^{448}$ CENTRO LATINOAMERICANO PARA EL DESARROLLO RURAL. https://rimisp.org/noticia/chileser-indigena-aumenta-probabilidad-de-pobreza/ [Consulta 29 de febrero de 2020]. "Que en proporción, tres de ellos vive en el mundo urbano y uno en el rural. De acuerdo a esta encuesta, un $7 \%$ de la población a nivel nacional declaró pertenecer o descender de alguno de los pueblos originarios (Aymara, Rapa Nui, Quechua, Mapuche, Atacameño, Coya, Kawésqar, Yagán y Diaguita). En la Región Metropolitana, esta cifra alcanzó el 4\%. En las regiones de La Araucanía, Arica y Parinacota, Aysén, Magallanes y Los Lagos, está proporción supera el 20\% de los habitantes "Tomando en cuenta las últimas cifras sobre pobreza, y considerando que la Araucanía tiene el porcentaje más alto de personas viviendo bajo la línea de pobreza (27\%) y que pertenecen a la etnia mapuche (29\%), El Centro Latinoamericano para el Desarrollo Rural, RIMISP, analizó cómo interactúan dichas variables y concluyo que: "En las provincias de Arauco, Malleco y Cautín, las personas que se declaran parte de los pueblos originarios son un $26 \%$; sólo un $11 \%$ de ellos habla o entiende su lengua. Después de tomar en cuenta el efecto de factores como educación, empleo, vivienda, hogar, ruralidad y condición de agricultor/a, se determinó que pertenecer a los pueblos originarios aumenta la probabilidad de ser pobre en estas provincias del sur de Chile (2,6\%). Si estas personas entienden su lengua ancestral o la hablan, la probabilidad de ser pobre aumenta a 5,6\% y 6,4\%, respectivamente" 
b) Declaración de Naciones Unidas sobre los Derechos de los pueblos indígenas, aprobada por la Asamblea General de 13 de septiembre de 2007.

c) Convención internacional sobre eliminación de todas formas de discriminación racial, adoptada en la Asamblea General de las Naciones Unidas el 21 de diciembre de 1965, suscrita por Chile el 3 de octubre de 1966 y ratificada el 20 de octubre de 1971.

d) Protocolo Iberoamericano de Actuación Judicial para Mejorar el Acceso a la Justicia de Personas con Discapacidad, Migrantes, Niñas. Niños, Adolescentes, Comunidades y Pueblos indígenas.

Las Reglas de Brasilia regulan la pertenencia a las Comunidades Indígenas como causa de vulnerabilidad en las Reglas 9 y 48.

Regla 9: "Las personas integrantes de las comunidades indígenas pueden encontrarse en condición de vulnerabilidad cuando ejercitan sus derechos ante el sistema judicial estatal. Se promoverán las condiciones destinadas a posibilitar que las personas y los pueblos indígenas puedan ejercitar con plenitud tales derechos ante dicho sistema de justicia, sin discriminación alguna que puedan fundarse en su origen o identidad indígenas. Los poderes judiciales asegurarán, que el trato que reciban por parte de los órganos de la administración de justicia sean respetuoso con su dignidad, lengua y tradiciones culturales".

Regla 48: "Con fundamento en los instrumentos internacionales en la materia, resulta conveniente estimular las formas propias de justicia en la resolución de conflictos surgidos en el ámbito de la comunidad indígena, así como propiciar la armonización de los sistemas de administración de justicia estatal e indígena basada en el principio de respeto mutuo y de conformidad con las normas internacionales de derechos humanos".

Regla 49: "Además serán de aplicación las restantes medidas previstas en estas Reglas en aquellos supuestos de resolución de conflictos fuera de la comunidad indígena por parte del sistema de administración de justicia estatal, donde resulta 
conveniente abordar los temas relativos al peritaje cultural y al derecho a expresarse en el propio idioma".

De estas normas se desprenden los siguientes principios, cuya aplicación asegura un efectivo acceso a la justicia:

a) Principio de Igualdad y no discriminación: Ningún indígena podrá recibir trato discriminatorio por su identidad étnica, idioma, género, aspecto, condiciones físicas o mentales o por su condición social. Las personas y comunidades indígenas deben ser tratadas en términos de igualdad con respecto a las personas y comunidades pertenecientes a la sociedad dominante, con plena consideración del rol que ejercen en la sociedad actual y de la importancia de preservar su identidad y sus saberes ancestrales que enriquecen nuestra sociedad ${ }^{449}$. Esto obliga al Estado a reconocer sus derechos y promover un adecuado acceso a él y a su ejercicio pleno. Lo anterior pretende incentivar la toma de medidas especiales destinadas a reducir o eliminar las condiciones que generan situaciones de discriminación. Por tanto, en ocasiones justificadas, la autoridad podrá optar por un tratamiento especializado que haga valer satisfactoriamente los derechos de las comunidades y personas indígenas ante la justicia ${ }^{450}$. La jurisprudencia Interamericana ha desarrollado un razonamiento en torno a este principio ${ }^{451}$, enfocándose además, en la no exigencia

\footnotetext{
${ }^{449}$ IBIDEM.

${ }^{450}$ Los Recursos para hacer exigibles los derechos reconocidos a los pueblos indígenas deben ser culturalmente accesibles, esto, es en cuanto a su presentación y tramitación. Deben adecuarse a las tradiciones comunitarias, a la lengua, a las formalidades propias de la cultura y ser resueltos de acuerdo con un procedimiento adecuado a los fines perseguidos. Al respecto, en el caso Fernández Ortega y otros vs México, sobre una mujer indígena que fue violada sexualmente por militares que se encontraban en el Estado de Guerrero en el marco de la lucha contra la delincuencia organizada, la Corte IDH consideró que la imposibilidad de denunciar el delito de que fue objeto y de recibir información en su idioma en los momentos iniciales "implicó, en el presente caso, un trato que no tomó en cuenta la situación de vulnerabilidad de la señora Fernández Ortega, basada en su idioma y etnicidad. Con base a lo anterior la Corte IDH considera que el Estado incumplió con su obligación de garantizar, sin discriminación, el derecho de acceso a la justicia.

${ }^{451}$ CORTE IDH. Caso López Álvarez vs Honduras. Sentencia de 1 de febrero de 2006. Párrs 170, 171. Párrafo 170: "Este Tribunal ha reiterado que el principio de derecho imperativo de protección igualitaria y efectiva de la ley y no discriminación determina que los Estados deben abstenerse de producir regulaciones discriminatorias o que tengan efectos discriminatorios en los diferentes grupos de una población al momento de ejercer sus derechos. Además, los Estados deben combatir prácticas discriminatorias y adoptar las medidas necesarias para asegurar una efectiva igualdad de todas las personas ante la ley". Párrafo 171: "Los Estados deben tomar en consideración los datos que diferencian a los miembros de pueblos indígenas de la población en general, y que conforman la identidad cultural de aquellos. La lengua es uno de los más importantes elementos de identidad de un pueblo, precisamente porque garantiza la expresión, difusión y transmisión de su cultura”.
} 
de legislación discriminatoria, por una parte ${ }^{452}$, y por otra, en cuanto a la obligación positiva del Estado de revertir prácticas discriminatorias existentes, creadas o toleradas ${ }^{453}$.

b) Principio de la Auto identificación: Es el reconocimiento por el que una persona, considerando sus costumbres, antepasados y otros aspectos culturales específicos, se percibe a sí misma como parte de un pueblo o comunidad indígena. El principio asociado a este concepto, es que dicha adscripción o identificación corresponde a un acto netamente voluntario de la persona que declara su condición indígena, y por tanto, esta no puede encontrarse supeditada a un reconocimiento o validación por parte del Estado ${ }^{454}$. La Jurisprudencia Interamericana, en el caso Xámok Kásek vs Paraguay, ha establecido que el Estado no puede desconocer la denominación o pertenencia étnica a una determinada comunidad ${ }^{455}$.

\footnotetext{
${ }^{452}$ CORTE IDH. Caso Saramaka vs Suriman. Sentencia de 28 de noviembre de 2007. Párrafo 103: “Asimismo, es improcedente el argumento del Estado en cuanto a que es discriminatorio aprobar una ley que reconozca las formas comunales de posesión de la tierra. Es un principio establecido en el derecho internacional que el trato desigual a personas en condiciones desiguales no necesariamente constituye discriminación no permitida. La legislación que reconoce dichas diferencias no es, por lo tanto, necesariamente discriminatoria. En el contexto de los integrantes de los pueblos indígenas y tribales, esta Corte ya ha expresado que es necesario la adopción de medidas especiales a fin de garantizar su supervivencia de conformidad con sus tradiciones y costumbres (supra, párrs. 78-86, 91 y 96). Por ello, es improcedente el argumento del Estado respecto de su incapacidad para crear legislación en esta área debido a la presunta complejidad de la cuestión o la posible naturaleza discriminatoria de dicha legislación”
}

453 CORTE IDH. Caso comunidad indígena Xámok Kásek vs Paraguay. Sentencia de 24 de agosto de 2010. Párrs 269, 271. Párrafo 269: "El principio de la protección igualitaria y efectiva de la ley y de la no discriminación constituye un dato sobresaliente en el sistema tutelar de los derechos humanos consagrado en varios instrumentos internacionales y desarrollado por la doctrina y jurisprudencia. En la actual etapa de la evolución del derecho internacional, el principio fundamental de igualdad y no discriminación ha ingresado en el dominio del jus cogens. Sobre él descansa el andamiaje jurídico del orden público nacional e internacional y permean todo el ordenamiento jurídico". Párrafo 271: “Además, el Tribunal ha señalado que "los Estados deben abstenerse de realizar acciones que de cualquier manera vayan dirigidas, directa o indirectamente, a crear situación

es de discriminación de jure o de facto”. Los Estados están obligados “a adoptar medidas positivas para revertir o cambiar situaciones discriminatorias existentes en sus

sociedades, en perjuicio de determinado grupo de personas. Esto implica el deber especial de protección que el Estado debe ejercer con respecto a actuaciones y prácticas de terceros que, bajo su tolerancia o aquiescencia, creen, mantengan o favorezcan las situaciones discriminatorias”.

${ }^{454}$ XVII CUMBRE JUDICIAL IBEROAMERICANA (2014). Op. Cit., p. 107.

${ }^{455}$ CORTE IDH. Caso Comunidad indígena Xácmok Kásek vs Paraguay. Op. Cit., Párrafo 37: "En primer lugar, la Corte resalta que no corresponde a este tribunal ni al Estado determinar la pertenencia étnica o el nombre de la comunidad. Como el mismo Estado reconoce, 'no puede [...] unilateralmente adjudicar o desmentir denominaciones de [las] comunidades Indígenas, por corresponder este acto a la comunidad en referencia'. La identificación de la comunidad, desde su nombre hasta su composición, es un hecho histórico 
c) Principio de la maxificación de la autonomía y acceso a la justicia considerando las especificidades de cada grupo: El acceso a la justicia será efectivo considerando las especificidades culturales, debiendo encontrarse en condiciones de ejercer el control de sus propias instituciones, ya sea jurídica, cultural o social, pudiendo ser restringidas o limitadas solo en cuanto al respeto de las normas internacionales de derechos humanos ${ }^{456}$. La optimización de este principio, justifica con plenitud la apertura de los Estados al reconocimiento de las cosmovisiones propias de cada comunidad indígena, dentro de cuyas dimensiones se contemplan sus intrínsecos mecanismos de resolución de conflictos. La Corte IDH en su jurisprudencia, ha establecido específicamente que es indispensable que los Estados otorguen una protección efectiva al grupo en referencia, que tomen en cuenta sus particularidades propias, sus características económicas y sociales, así como su situación de especial vulnerabilidad, derecho consuetudinario, valores, usos y costumbres ${ }^{457}$.

La jurisprudencia interamericana, se ha pronunciado además sobre las condiciones que deben existir para que se otorgue protección efectiva a las comunidades indígenas, debiendo considerarse por los Estados, sus características singulares, como las variables culturales, sociales, económicas e idiomáticas ${ }^{458}$. El hecho de

social que hace parte de su autonomía. Por tanto, la Corte y el Estado deben limitarse a respetar las determinaciones que en este sentido presente la Comunidad, es decir, la forma cómo ésta se auto-identifique” ${ }^{456}$ Esta capacidad de decidir sobre lo propio, se conoce como el derecho a la libre determinación de los pueblos indígenas e implica que los Estados deben tener una injerencia mínima en los sistemas consuetudinarios y tradicionales indígenas por medio de los cuales estos toman decisiones internas e imparten justicia. Para evitar los solapamientos entre justicia ordinaria y la justicia indígena, el Estado debe trabajar en un marco normativo que proporcione reglas básicas sobre resolución de conflictos, identificación de límites jurisdiccionales, competencia, entre otras Sin perjuicio de lo anterior, las personas y comunidades indígenas deben tener pleno acceso a la justicia ordinaria del Estado en el que se encuentran, tanto de manera individual como colectiva. En estas instancias la autoridad judicial deberá tener en consideración las costumbres, tradiciones y normas jurídicas del pueblo indígena involucrado.

${ }^{457}$ CORTE IDH. Caso Comunidad Xámok Kásek vs Paraguay. Op. Cit., Párr. 270.

${ }^{458}$ CORTE IDH. Caso Rosendo Cantú vs México. Sentencia de 31 de agosto de 2010. Párrs 184, 185. Párrafo 184: "Como lo ha establecido en otras ocasiones este Tribunal, y conforme al principio de no discriminación consagrado en el artículo 1.1 de la Convención Americana, para garantizar el acceso a la justicia de los miembros de comunidades indígenas, "es indispensable que los Estados otorguen una protección efectiva que tome en cuenta sus particularidades propias, sus características económicas y sociales, así como su situación de especial vulnerabilidad, su derecho consuetudinario, valores, usos y costumbres”. Además, el Tribunal ha señalado que "los Estados deben abstenerse de realizar acciones que de cualquier manera vayan dirigidas, directa o indirectamente, a crear situaciones de discriminación de jure o de facto”.

Párrafo 185: "La Corte consideró probado que la señora Rosendo Cantú no contó con un intérprete provisto por el Estado cuando requirió atención médica, ni cuando presentó su denuncia inicial, ni tampoco recibió en su idioma información sobre las actuaciones derivadas de su denuncia. Para poder poner en conocimiento de 
que las personas que pertenecen a comunidades indígenas, puedan comprender los procedimientos y actuaciones procesales, es fundamental para que puedan realmente acceder a la justicia ${ }^{459}$.

d) Principio de la protección especial a sus territorios y recursos naturales: Es uno de los derechos fundamentales para que los pueblos indígenas puedan reproducirse, mantener y desarrollar sus culturas. El concepto de territorio indígena no debe limitarse únicamente al de propiedad, sino a un sentido más amplio que comprende el hábitat que históricamente han poseído o usado para el desarrollo de sus actividades económicas y culturales. En este contexto, la conservación y resguardo de sus territorios, ante cualquier acto del Estado o particulares que pueda afectarlos, permite un acceso efectivo a la justicia en ese preciso ámbito.

La Corte IDH, en la sentencia del caso Mayagna(Sumo) Awas Tingni vs Nicaragua, de 31 de agosto de 2001, ha desarrollado este principio en base a la estrecha relación que los indígenas mantienen con la tierra, por lo cual debe de ser reconocida y comprendida como la base fundamental de sus culturas, su vida espiritual, su integridad y su supervivencia económica ${ }^{460}$. Por su parte, en la

las autoridades el delito que la había afectado y acceder a información debió recurrir a su esposo que hablaba español (...). La imposibilidad de denunciar y recibir información en su idioma en los momentos iniciales implicó, en el presente caso, un trato que no tomó en cuenta la situación de vulnerabilidad de la señora Rosendo Cantú, basada en su idioma y etnicidad, implicando un menoscabo de hecho injustificado en su derecho de acceder a la justicia. Con base en lo anterior, la Corte considera que el Estado incumplió su obligación de garantizar, sin discriminación, el derecho de acceso a la justicia en los términos de los artículos 8.1 y 25 de la Convención Americana, en relación el artículo 1.1 del mismo instrumento”.

${ }^{459}$ CORTE IDH. Caso Tiu Tojin vs Guatemala. Sentencia 26 de noviembre de 2008. Párrafo 100. "Este Tribunal considera que para garantizar el acceso a la justicia de las víctimas -en tanto miembros del pueblo indígena Maya- y que la investigación de los hechos se realice con la debida diligencia, sin obstáculos y sin discriminación, el Estado debe asegurar que aquellas puedan comprender y hacerse comprender en los procedimientos legales iniciados, facilitándoles intérpretes u otros medios eficaces para tal fin. Asimismo, el Estado deberá garantizar, en la medida de lo posible, que las víctimas del presente caso no tengan que hacer esfuerzos desmedidos o exagerados para acceder a los centros de administración de justicia encargados de la investigación del presente caso. Sin perjuicio de lo anterior, la Corte considera necesario ordenar al Estado el pago de una suma por concepto de gastos futuros, como una forma de garantizar que las víctimas puedan actuar en el proceso penal abierto ante la justicia ordinaria (infra párr. 128)”.

${ }^{460}$ CORTE IDH. Caso Mayagna(Sumo) Awas Tingni vs Nicaragua. Sentencia de 31 de agosto de 2001. Párrafo 149: "Dadas las características del presente caso, es menester hacer algunas precisiones respecto del concepto de propiedad en las comunidades indígenas. Entre los indígenas existe una tradición comunitaria sobre una forma comunal de la propiedad colectiva de la tierra, en el sentido de que la pertenencia de ésta no se centra en un individuo sino en el grupo y su comunidad. Los indígenas por el hecho de su propia existencia tienen derecho a vivir libremente en sus propios territorios; la estrecha relación que los indígenas mantienen con la tierra debe 
sentencia del caso Yakie Axa vs Paraguay, de 17 de junio de 2005, se amplía el concepto de bienes a un plano que traspasa el aspecto netamente corporal del concepto e incluye en esta expresión, los objetos inmateriales susceptibles de valor según la propia cosmovisión de cada comunidad ${ }^{461}$.

e) Participación, consulta y consentimiento frente a cualquier acción que los afecte. La consulta indígena es el derecho de los pueblos indígenas a participar en la adopción de necesidades que pueden llegar a afectar sus derechos e intereses, propiciando el goce pleno de éstos. Es fundamental para el pleno ejercicio de derechos, materializar sus propias prioridades para el desarrollo, la preservación cultural, el agua, el medio ambiente sano, entre otros ${ }^{462}$. Fluye en consecuencia, la obligación de consulta que los Estados deben adoptar, cuando una actuación estatal pudiese afectar la vida en los territorios indígenas $u$ otro aspecto cultural que se pueda ver afectado. La consulta, es un principio general del derecho internacional que posibilita la participación de las diversas comunidades en cualquier decisión legislativa o administrativa que los pueda afectar. Se encuentra íntimamente relacionado con el principio de libre determinación y protección de los territorios indígenas, ya que permite resguardar el respeto a sus derechos ${ }^{463}$. De esta forma lo ha recepcionado la jurisprudencia interamericana ${ }^{464}$.

de ser reconocida y comprendida como la base fundamental de sus culturas, su vida espiritual, su integridad y su supervivencia económica. Para las comunidades indígenas la relación con la tierra no es meramente una cuestión de posesión y producción sino un elemento material y espiritual del que deben gozar plenamente, inclusive para preservar su legado cultural y transmitirlo a las generaciones futuras”.

461 CORTE IDH. Caso Yakie Axa vs Paraguay. Sentencia de 17 de junio de 2005. Párrafo 137: "En consecuencia, la estrecha vinculación de los pueblos indígenas sobre sus territorios tradicionales y los recursos naturales ligados a su cultura que ahí se encuentren, así como los elementos incorporales que se desprendan de ellos, deben ser salvaguardados por el artículo 21 de la Convención Americana. Al respecto, en otras oportunidades, este Tribunal ha considerado que el término "bienes" utilizado en dicho artículo 21, contempla 'aquellas cosas materiales apropiables, así como todo derecho que pueda formar parte del patrimonio de una persona; dicho concepto comprende todos los muebles e inmuebles, los elementos corporales e incorporales y cualquier otro objeto inmaterial susceptible de tener un valor'”.

${ }^{462}$ XVII CUMBRE JUDICIAL IBEROAMERICANA. Op. Cit., p. 109.

${ }^{463} \mathrm{La}$ consulta, es un principio general del derecho internacional que permite que las diversas comunidades participar en cualquier decisión legislativas o administrativa que los pueda afectar. Se encuentra íntimamente relacionado con el principio de libre determinación y protección de los territorios indígenas, ya que permite resguardar el respeto a sus derechos.

${ }^{464}$ CORTE IDH. Caso Kichwa de Saroyaku vs Ecuador. Sentencia de 27 de junio de 2012. Párrafo 166: ”La obligación de consultar a las comunidades y pueblos Indígenas y tribales sobre toda medida administrativa o legislativa que afecte sus derechos reconocidos en la normatividad interna e internacional, así como la 


\subsection{Premisas básicas derivada de los principios protectores y experiencias de acceso a la justicia de comunidades indígenas en América Latina}

Una aplicación acertada de los diversos principios protectores respecto del grupo vulnerable en análisis, exigiría optimizar el respeto irrestricto a sus condiciones singulares, partiendo por un reconocimiento constitucional, y cuerpos legislativos sólidos que estén asociados a una política pública que atienda sus particularidades culturales, étnicas, lingüísticas y especialmente las relacionadas con su visión del mundo. En este sentido, sus conflictos deberían ser resueltos en concordancia con sus propios métodos de resolución, tal que no impliquen infracción a los derechos humanos o que contemplen la aplicación de sanciones o penas que tengan características de crueles, inhumanas o degradantes. Sin embargo, Tal como expresa Nash, Núñez y Troncoso, "en países como el nuestro, los intentos desde las políticas públicas, se circunscriben al dilucidar sobre el cómo facilitar la participación de las comunidades indígenas ante los tribunales nacionales, para lo cual se comienza a implementar la figura de mediadores o facilitadores interculturales" 465 .

En base a los principios protectores, debemos tener presente las siguientes premisas:

a) Que los recursos para hacer exigibles los derechos reconocidos a los pueblos indígenas deben ser culturalmente accesibles: En cuanto a su presentación y

obligación de asegurar los derechos de los pueblos indígenas a la participación en las decisiones de los asuntos que conciernan a sus intereses, está en relación directa con la obligación general de garantizar el libre y pleno ejercicio de los derechos reconocidos en la Convención (artículo 1.1). Esto implica el deber de organizar adecuadamente todo el aparato gubernamental y, en general, de todas las estructuras a través de las cuales se manifiesta el ejercicio del poder público, de manera tal que sean capaces de asegurar jurídicamente el libre y pleno ejercicio de los derechos. Lo anterior conlleva la obligación de estructurar sus normas e instituciones de tal forma que la consulta a comunidades indígenas, autóctonas, nativas o tribales pueda llevarse a cabo efectivamente, de conformidad con los estándares internacionales en la materia. De este modo, los Estados deben incorporar esos estándares dentro de los procesos de consulta previa, a modo de generar canales de diálogos sostenidos, efectivos y confiables con los pueblos indígenas en los procedimientos de consulta y participación a través de sus instituciones representativas”.

${ }^{465}$ NASH, C; NUÑEZ, C; TRONCOSO, C. Op. Cit., p. 345. "El problema, por tanto, se refiere a cómo la administración, y la administración de justicia en particular, interpretan los derechos y libertades, situación similar ocurrida en caso de mujeres”. 
tramitación deben adecuarse a las tradiciones comunitarias, a la lengua, a las formalidades propias de la cultura y ser resueltos de acuerdo con un procedimiento adecuado a los fines perseguidos. La Corte IDH, al respecto, en el caso Fernández Ortega y otros vs México, sobre una mujer indígena que fue violada sexualmente por militares que se encontraban en el Estado de Guerrero, en el marco de la lucha contra la delincuencia organizada, consideró que "la imposibilidad de denunciar el delito de que fue objeto y de recibir información en su idioma en los momentos iniciales implicó, en el presente caso, un trato que no tomó en cuenta la situación de vulnerabilidad de la señora Fernández Ortega, basada en su idioma y etnicidad. Con base a lo anterior, la Corte considera que el Estado incumplió con su obligación de garantizar, sin discriminación, el derecho de acceso a la justicia" ${ }^{466}$.

b) Derecho de los pueblos indígenas a tener un sistema de administración de justicia: Dichos Pueblos deberán tener el derecho a conservar sus costumbres e instituciones propias. Normativamente se encuentra reconocido por la mayoría de los Estados miembros de la Organización de Estados Americanos, quienes han ratificado el convenio 169 de la Organización Internacional del Trabajo, Convenio sobre Pueblos Indígenas y Tribales en Países Independientes, que les reconoce expresamente este derecho ${ }^{467}$. Este Convenio acoge el principio de maximización

\footnotetext{
${ }^{466}$ CORTE IDH. Caso Fernández Ortega vs México. Sentencia de 30 de agosto de 2010. Párrs 201 y 230. Párrafo 201: "La Corte consideró probado que la señora Fernández Ortega no contó con un intérprete provisto por el Estado a fin de presentar su denuncia y tampoco recibió en su idioma información sobre las actuaciones derivadas de su denuncia. Para poder poner en conocimiento de las autoridades el delito que la había afectado y acceder a información debió recurrir a una persona conocida que hablaba español. Por otra parte, en ocasiones posteriores que convocó a la víctima, el Estado dispuso la presencia de un intérprete y además informó que se encontraba implementando un programa de formación de intérpretes indígenas en Guerrero. La Corte valora positivamente ambas medidas adoptadas por México. Sin embargo, la imposibilidad de denunciar y recibir información en su idioma en los momentos iniciales implicó, en el presente caso, un trato que no tomó en cuenta la situación de vulnerabilidad de la señora Fernández Ortega, basada en su idioma y etnicidad, implicando un menoscabo de hecho injustificado en su derecho de acceder a la justicia. Con base en lo anterior, la Corte considera que el Estado incumplió su obligación de garantizar, sin discriminación, el derecho de acceso a la justicia en los términos de los artículos 8.1 y 25 de la Convención Americana, en relación el artículo 1.1 del mismo instrumento". Párrafo 230: "La Corte reitera que durante la investigación y el juzgamiento, el Estado debe asegurar el pleno acceso y capacidad de actuar de la víctima en todas las etapas. En un caso como el presente en el que la víctima, mujer e indígena, ha tenido que enfrentar diversos obstáculos en el acceso a la justicia, el Estado tiene el deber de continuar proporcionando los medios para que la víctima acceda y participe en las diligencias del caso, para lo cual debe asegurar la provisión de intérprete y apoyo desde una perspectiva de género, en consideración de sus circunstancias de especial vulnerabilidad. Finalmente, en caso que la señora Fernández Ortega preste su consentimiento, los resultados de los procesos deberán ser públicamente divulgados, con la finalidad de que la sociedad mexicana conozca la verdad de los hechos

${ }^{467}$ CONVENIO 169 ORGANIZACIÓN INTERNACIONAL DE TRABAJO. Artículo 8.2.
} 
de la autonomía y el acceso a la justicia según sus especificidades culturales, tal como lo sustenta el Informe del Centro de Estudios de la Justicia de las Américas ${ }^{468}$. En palabras de Lovatón, "sin duda este reconocimiento normativo es un avance para las comunidades o pueblos indígenas, aunque en los hechos habría que preguntarse hasta qué punto estos derechos son respetados y llevados a la práctica, como es el caso de la justicia indígena, ya que en muchos países donde existe pluridad de culturas, usos y costumbres, los sectores sociales indígenas siguen formando parte de los sectores históricamente discriminados y excluidos" 469 .

c) Necesidad de un reconocimiento constitucional: Las Constituciones latinoamericanas que consagran explícitamente el principio de multiculturalidad son: la Constitución de México, artículo 4; Constitución de Nicaragua, artículo 8; Constitución de Guatemala, artículo 66; Constitución de Bolivia, artículo 1; Constitución de Colombia de 1991, artículo 7; y la Constitución de Perú de 1993, artículo $2^{\circ}$ inciso $1916^{470}$. Las Constituciones que consagran el reconocimiento de los pueblos indígenas corresponden a: Constitución Argentina, artículo 75 № 17; Constitución de Bolivia, artículo 171; Constitución de Brasil, artículo 231; Constitución de Guatemala, artículo 66; Constitución de México, artículo 4; Constitución de Nicaragua, artículos 8, 89 a 91; Constitución de Paraguay, artículo 62; y Constitución de Perú, artículos 2 n 19, 48 y $89^{471 .}$

Las Cartas Fundamentales que han consagrado la protección estatal de los pueblos indígenas corresponden a: Constitución de Bolivia, artículo 171; la Constitución de Brasil, artículo 231; Constitución de Colombia, artículo 329 y 330; Constitución de

\footnotetext{
${ }^{468}$ CENTRO DE ESTUDIOS DE LA JUSTICIA DE LAS AMERICAS (2016). Informe Reforma Procesal Penal y Pueblos indígenas. Santiago. p.7. "Al respecto los artículos 8, 9 y 10 del Convenio 169...de acuerdo a las interpretaciones más extendidas, otorga a los pueblos Indígenas el derecho de administrar justicias siguiendo sus propias pautas, a la vez que atribuye a los Estados la obligación de respetar sus propias decisiones”

${ }^{469}$ LOVATÓN, D. p. 259. "En el caso de la justicia indígena, las resistencias "de hecho" que encuentra en diversos sistemas nacionales de justicia, suelen provenir de los propios actores del sistema (abogados, policías, fiscales, jueces), renuentes a reconocerles un espacio de actuación autónoma. "Con frecuencia, por ejemplo, las autoridades indígenas son acusadas penalmente de violar la ley o de usurpar las funciones de las autoridades oficiales".

${ }^{470}$ HENRIQUEZ, M. (2015). "Los pueblos indígenas y su reconocimiento constitucional pendiente”. En: Reforma Constitucional. Santiago. Editorial Lexis Nexis. p. 9

${ }^{471}$ IBIDEM.
} 
Ecuador, artículo 110; Constitución de Guatemala, artículo 66; Constitución de Honduras, artículo 173; Constitución de México, artículo 4; Constitución de Nicaragua, artículo s 89 a 91; Constitución de Panamá, artículo 199; y Constitución de Paraguay, artículo $63^{472}$.

La consagración constitucional de la promoción y desarrollo de los pueblos indígenas está contenida en la Constitución de Colombia, artículo 330; Constitución de Guatemala, artículo 66; Constitución de Honduras, artículo 173; Constitución de México, artículo 4; 10 Constitución de Nicaragua, artículos 11, 89, 90 y 180; Constitución de Panamá, artículos 122, 123, 199; y Constitución de Paraguay, artículo 63. Los derechos lingüísticos se encuentran plasmados en la Constitución de Colombia, artículo 10; Constitución de Ecuador, artículo 10; Constitución de Nicaragua, artículos 11; y Constitución de Perú, artículo 2 № 19 y $48^{473}$.

Dedican un tratamiento jurídico constitucional especial de las tierras indígenas: la Constitución Argentina, artículo 75 № 17; Constitución de Brasil, artículo 231; Constitución de Colombia, artículo 286, 310, 329 y 330; Constitución de Guatemala, artículo 67 y 68; Constitución de México, artículo 27; Constitución de Nicaragua, artículo s 89, 180 y 181; Constitución de Panamá, artículo 122 y 123; Constitución de Paraguay, artículo 63, 64 y 66; y Constitución de Perú, artículo $89^{474}$.

Por último, algunas de las Constituciones latinoamericanas mencionadas han consagrado el reconocimiento de las organizaciones sociales indígenas y de las autoridades indígenas, la validez jurídica de las normas consuetudinarias indígenas, la protección constitucional especial en materia laboral y las políticas educacionales especiales para los indígenas. En fin, es innegable el avance en el reconocimiento, casi generalizado en las Cartas Fundamentales de los Estados Latinoamericanos, como así también de los derechos de los pueblos indígenas" 475 . Sin embargo, es de esperar que estos reconocimientos no queden en el campo de los anuncios, sino que avancen acompañados de regulaciones legales y de medidas efectivas, pues a

\footnotetext{
${ }^{472}$ IBIDEM.

473 IBIDEM. p. 10

${ }^{474}$ IBIDEM.

${ }^{475}$ IBIDEM. p.4.
} 
nuestro entender algunos de estos reconocimientos, son meramente declarativos y sin reconocer una plurinacionalidad, salvo en Ecuador y Bolivia, en que claramente la idea es dar autodeterminación a los pueblos y hacerlos participes de las decisiones del Estado, así como reconocer las lenguas propias y las tradiciones de cada etnia.

d) Multiculturalidad: Precisamente, el reconocimiento de la multiculturalidad del Estado es el primer paso que los Estados deben dar a fin de asegurar en su seno la supervivencia de los pueblos indígenas, constituyendo también una forma esencial de brindar respuesta a las demandas de estos pueblos. La multiculturalidad debe ser entendida, como el conjunto variado de fenómenos sociales que derivan de la convivencia pacífica y/o coexistencia compleja de personas que se identifican con culturas diversas en un mismo territorio. El reconocimiento de la multiculturalidad supone constatar la existencia de los pueblos indígenas, con una historia y cultura particulares, esto es con identidad propia, para luego conferir valor a la legítima pretensión de permanecer, desarrollarse y evolucionar como pueblo. Finalmente, para que la multiculturalidad se configure completamente es necesaria la aceptación y valoración de la diversidad, mediante el reconocimiento de todos los factores anteriores ${ }^{476}$. En Chile se registra un proyecto de ley que se archivó y recogía la idea de un país plurinacional y multicultural ${ }^{477}$.

\subsection{Experiencias de justicia comunitaria indígena en América Andina}

\footnotetext{
${ }^{476}$ LOVATÓN, D. p.259

477 Los pueblos indígenas han instalado un punto clave en la discusión constitucional ¿Somos un país multicultural o plurinacional. Francisco Huenchumilla -senador y ex intendente de la Araucanía- presentó ante el Senado el 2018 un proyecto de "Reforma constitucional para el reconocimiento de la plurinacionalidad y de los derechos de los pueblos indígenas. En el Texto, definió el concepto como un: "Estado democrático que tiene la suficiente flexibilidad como para poseer dispositivos constitucionales que permitan la convivencia dentro del Estado de diferentes comunidades políticas y sus respectivos ordenes políticos. El Estado plurinacional es una institucionalidad política con una gran comunidad política múltiple, en la cual, las naciones internas cuentan con marcos normativos que les permiten tener una convivencia política y social. El proyecto no prosperó.
} 
Dentro de los países denominados Andinos (Venezuela, Colombia, Ecuador, Perú y Chile), los cuatro primeros presentan una justicia indígena arraigada y reconocida, las que presentan características comunes. Chile, en cambio aún siquiera consta con un reconocimiento constitucional a sus pueblos originarios. Por otro lado, hay otros mecanismos comunitarios de administración de justicia o resolución de conflictos, que se han desarrollado en el continente, primeramente, ante la Ineficacia de los sistemas estatales de justicia y, en segundo orden, porque resuelven mejor determinados conflictos familiares o vecinales. Quizás una de las experiencias emblemáticas en América del Sur, es la figura del juez de paz existente en Perú y otros países andinos" 478 .

En el estudio del Instituto de Defensa Legal/ Red Andina de Justicia de Paz y Comunitaria, se consigna que junto con la justicia indígena en Ecuador y Bolivia, los conciliadores en equidad de Colombia, los mediadores comunitarios del Ecuador 0 las Rondas Campesinas del Perú, la justicia de paz es uno de los mecanismos comunitarios de acceso a la justicia que se ha desarrollado en la región andina, estando reconocida en la Constitución del Perú de 1993, en la Constitución de Venezuela de 1999, en la Constitución de Colombia de 1991 y en la de Ecuador de 2008, aunque en este último país aún no existe legislación de desarrollo ${ }^{479}$.

El perfil del juez o jueza de paz difiere dependiendo del país o de la región ${ }^{480}$. En Perú, en la actualidad existen más de 5.000 jueces de paz en todo el territorio nacional, en especial, en las regiones alto andinas ${ }^{481}$.

La justicia de paz en la región andina comparte los siguientes rasgos comunes ${ }^{482}$ :

\footnotetext{
${ }^{478}$ LOVATÓN, D. Op. Cit., p .259.

${ }^{479}$ INSTITUTO DE DEFENSA LEGAL/RED ANDINA DE JUSTICIA DE PAZ Y COMUNITARIA (2005). La justicia de paz en los Andes. Estudio regional. Lima. p.15.

${ }^{480}$ IBIDEM. p.16. "En Venezuela y Colombia, la justicia de paz se ha instalado sobre todo en las zonas periurbanas, en tanto en el Perú es un fenómeno mayoritariamente rural”.

${ }^{481}$ CONSTITUCION DE PERU. Artículo 149: "Las autoridades de las Comunidades Campesinas y Nativas, y en su defecto las Rondas Campesinas, pueden ejercer las funciones jurisdiccionales dentro de su ámbito territorial de conformidad con el derecho consuetudinario, siempre que no violen los derechos fundamentales de la persona".

${ }^{482}$ IBIDEM. pp. 16-17.
} 
a) Un carácter lego: No es ejercida por abogados, sino que por personas que tienen un reconocimiento comunitario, tanto por su mérito como personal y ascendencia social.

b) Su naturaleza especialmente conciliadora, sin perjuicio de la existencia de matices en cada país.

c) Facultad para aplicar no sólo la ley sino también los usos y las costumbres del lugar o criterios de justicia o equidad: En este ámbito se utilizan expresiones diversas: "según su leal saber y entender" en el Perú o lo "justo comunitario" en Colombia.

d) Su cercanía geográfica y cultural a los potenciales usuarios: Los jueces de paz suelen usar el idioma predominante en el lugar y conocen los comportamientos culturales que les permite tomar decisiones acordes con el significado o cosmovisión que tenga la respectiva comunidad, respecto de un determinado hecho o conducta.

e) Su bajo costo económico: En atención a que los jueces son miembros de la misma comunidad, no recibiendo remuneración estatal en la generalidad de los casos, sumado a que las instalaciones en que ejercen sus funciones también pertenecen a la comunidad o incluso a la persona que oficia como juez.

f) La competencia habitual esté constituida por problemas vecinales o familiares: La represión de conductas antisociales menores, faltas o contravenciones, pequeños conflictos económicos y familiares, entre otros, reservándose a la justica estatal casos más graves o que trascienden a la comunidad.

g) El mayor o menor control que la comunidad suele ejercer en la designación, elección popular, y fiscalización de los jueces de paz.

Nuestra Hipótesis es que la Justicia de Paz requiere determinadas dosis de coerción estatal para hacer más eficaz y extendida su labor en la región andina. Un dato que parece corroborar esta idea es la demanda de más herramientas de coerción por parte de los jueces de paz colombianos y venezolanos, así como de los propios 
usuarios del servicio, quienes en los hechos piden mayores dosis de exigibilidad en la actuación de esta justicia ${ }^{483}$.

Otra figura similar a la justicia de paz en características pero con peculiaridades que cada contexto nacional le imprime, es la experiencia de las defensorías comunitarias en el Perú, reconocidas en el Código del Niño y del Adolescente, que son equipos formados por miembros de la propia comunidad que tras una previa capacitación y motivación de diversas instituciones (Organizaciones No Gubernamentales e Iglesias), orientan y apoyan a las personas -en especial, mujeres y niños- en sus denuncias ante el sistema de justicia en caso de violencia familiar o sexual o en sus reclamos de derechos tales como alimentos y manutención a favor de menores de edad $^{484}$.

Como se sabe, tanto el Convenio 169 de la Organización Internacional del Trabajo, como la mayor parte de las constituciones nacionales, disponen que la justicia indígena debe respetar los derechos humanos. Sin embargo, en ocasiones suelen surgir tensiones con el derecho consuetudinario de algunos pueblos o comunidades indígenas, que reclama el respeto de determinadas prácticas o costumbres que, a veces, podrían colisionar con algunos principios de derechos humanos ${ }^{485}$. No obstante ello, es importante precisar que estos últimos casos de presunta infracción de derechos, a diferencia de las estigmatizaciones de algunos sectores sociales o medios de comunicación, son excepcionales, pues las autoridades indígenas o comunitarias suelen aplicar sanciones que resultan compatibles con la dignidad de la persona. En ese sentido, con frecuencia se suele confundir equivocadamente un acto de ajusticiamiento o linchamiento con la aplicación de la justicia indígena.

\footnotetext{
483 INSTITUTO DE DEFENSA LEGAL/Red Andina de Justicia de paz y comunitaria. Op .Cit. p. 18. "Ello no quiere decir, sin embargo, que sea necesario pasar de un juez conciliador a un juez sentenciador, pues la esencia de la justicia de paz, es y debe seguir siendo la conciliación, lo que no impide, como lo demuestra la experiencia peruana, que se contemple determinadas dosis de coerción en materias tan sensibles como los alimentos o la protección contra la violencia familiar”.

${ }^{484}$ LOVATÓN, D. Op. Cit., p. 261.

485 IBIDEM. p.262. "Ese es el caso de la mujer al interior de algunas comunidades o pueblos indígenas o el de la imposición de castigos físicos en contra de las personas que han delinquido, que van desde los saludables (obligarlos a hacer castigo físico), hasta los que pueden constituir verdaderas prácticas de torturas o tratos denigrantes”.
} 
Se debe advertir, que la aplicación de estos métodos de resolución alternativa de conflictos, debe realizarse de una forma razonada a través de una oferta ordenada de los mismos. Resulta adecuado en este punto observar las reflexiones en cuanto a la ponderación de los efectos de la multiplicidad de servicios que pueden existir en esta línea, desarrollada en el estudio referido del Instituto de Defensa legal ${ }^{486}$.

\subsection{Acceso a la Justicia de las comunidades indígenas en Chile}

\subsubsection{Fenómeno del Conflicto indígena en Chile como obstáculo en el acceso a la justicia de estos grupos}

La relación de los pueblos indígenas con el Estado es compleja, entrecruzándose diversas dimensiones que deben ser abordadas en conjunto para lograr un mejor entendimiento de la situación. Antonia Rivas, en el Informe de Derechos Humanos 2019 de la Universidad Diego Portales, sostiene que "es posible constatar que cuando los últimos gobiernos han impulsado proyectos o políticas públicas que tiene relación con los pueblos indígenas, lo denominan genéricamente plan Araucanía, omitiendo así en forma simbólica las otras regiones donde habitan y viven pueblos indígenas" ${ }^{487}$. En este sentido se reduce a los conflictos del pueblo mapuche ${ }^{488}$, o

\footnotetext{
${ }^{486}$ INSTITUTO DE DEFENSA LEGAL/RED ANDINA DE JUSTICIA DE PAZ Y COMUNITARIA. Op. Cit., p. 21.

${ }^{487}$ RIVAS, A (2019). "Derechos Humanos de los pueblos indígenas en Chile”. EN: Universidad Diego Portales. Informe Anual de Derechos Humanos 2019.Santiago. p. 161

488 BIBLIOTECA NACIONAL DE CHILE. http://www.memoria chilena.gob.cl/602/w3-article-781.html.[ Consulta 19 de febrero de 2020]. "El pueblo Mapuche es uno de los pueblos originarios más notorios del país, tanto por su peso social y demográfico como por su fuerte sentido de identidad cultural que ha encontrado históricamente formas de resistencia y de adaptación a la dinámica del contacto fronterizo con españoles y chilenos. Asentados históricamente entre los ríos Itata y Tolten, en la zona centro sur del país, y emparentados lingüísticamente con sus vecinos picunches y huilliches, los mapuches presentaron una encarnizada resistencia a la dominación española durante todo el siglo xvi, hasta el punto de expulsar definitivamente a los castellanos de su territorio, luego de la gran rebelión que duró desde 1598 hasta 1602. La Guerra de Arauco se prolongó toda la primera mitad del siglo XVII, decayendo luego de la última gran rebelión mapuche de 1656, fecha desde la cual las relaciones fronterizas se distendieron y se produjeron importantes transformaciones sociales en la familia mapuche, fruto de su expansión a las pampas argentinas y la intensificación del comercio entre éstos y los criollos. Los mapuches debieron resistir durante todo el siglo XIX la intensa presión de las nuevas
} 
araucano $^{489}$ con el Estado de Chile. La misma autora expresa en relación a esta reducción que "con lo señalado no se quiere que se pierda de vista la violencia que se vive en el sur donde confluyen legítimas aspiraciones de autonomía y territorios, con actos graves de violencia que ponen en riesgo a la población general y cobran víctimas colaterales que no tienen relación con el conflicto" ${ }^{490}$. En este contexto, existe una situación relacional compleja entre miembros del pueblo mapuche, fuerzas policiales y poder judicial, en contexto de protesta social, reivindicaciones sociales y territoriales, violencia, legítima necesidad de investigar y sancionar delitos, uso desmedido de la fuerza policial y ley antiterrorista ${ }^{491}$. Esta tensión existente, con dimensiones judiciales y policiales, y de alta repercusión social, ha dado lugar a que respecto al pueblo mapuche específicamente, opere una aplicación de la ley sui generis, con garantías del debido proceso restringidas, más violencia y menos respeto por sus derechos. Es fundamental hacer presente que no se está pidiendo que se deje de investigar o de aplicar la justicia en los casos que involucran a miembros del pueblo mapuche como imputados de delitos, sino que se les apliquen las mismas leyes y tratamiento que al resto de la población, pues estimamos que existe en todos estos casos una vulneración al derecho a la igualdad ante la ley y al principio de no discriminación. Estos hechos, en los que se han

repúblicas de Chile y Argentina, que a través de respectivas campañas militares ocuparon la Región. La integración de la Araucanía al territorio chileno en 1882, provocó el derrumbe de toda una sociedad que había encontrado la manera de adaptarse a siglos de lucha y contacto fronterizo fueron confinados en territorios delimitados por el Estado, cerrándose el tránsito entre Chile y las pampas argentinas y obligándolos de esta manera a convertirse en un pueblo campesinos y a habitar tierras de mala calidad entre la zona costera y la precordillera andina, La conformación de grandes latifundios a partir del remate de llamadas tierras baldías, por parte del Estado, agravó la situación, creando una estructura agraria fuertemente desigual, a la vez que se sumaron, durante la primera mitad del siglo XX, las exacciones y estafas a comunidades mapuches, que vieron mermadas gran parte de sus tierras. El crecimiento demográfico y la contracción de las tierras comunales dio inicio a una intensa corriente de migración campo- ciudad lo que ha llevado a que hoy más de la mitad de los mapuches chilenos vivan en las ciudades. El mapudungun, su lengua, no es utilizada en gran parte de las comunidades, siendo reemplazada por el español, evidenciándose que sus formas de resolución de conflictos no son reconocidas por el Estado Chileno".

${ }^{489}$ Denominación dada por don Alonso de Ercilla y Zuñiga en su poema épico sobre la primera fase de la conquista española 'La araucana' de 1563, en que se refiere al pueblo araucano, destacando una estrofa que hace alusión a las características de este pueblo, que incluso había impedido el avance del imperio Inca.: "Chile, fértil provincia y señalada en la región Antártica famosa, de remotas naciones respetada por fuerte, principal y poderosa; la gente que produce es tan granada, tan soberbia, gallarda y belicosa, que no ha sido por rey jamás regida ni a extranjero dominio sometida".

${ }^{490}$ RIVAS, A. Op. Cit., p. 161.

${ }^{491}$ IBIDEM. 
visualizado vulneraciones a los derechos indicados, se han podido advertir en el año 2019, en situaciones de alta cobertura mediática e impacto en la opinión pública, como los casos Catrillanca ${ }^{492}$, operación huracán ${ }^{493}$ y aplicación de la ley antiterrorista ${ }^{494}$, que dejaron en evidencia discriminación, prácticas policiales abusivas y políticas criminales no amparadas por un proceso justo. Además se hace mención al caso Catriman y a la sentencia a su respecto de la CS, como asimismo a las Observaciones del Comité de la Tortura hacía Chile, en cuanto a la falta de acceso a la justicia, en relación al tratamiento policial represivo y judicial respecto de conductas catalogadas como terroristas ${ }^{495}$.

492 IBIDEM. pp.164-166. "El caso de Camilo Catrillanca marcó un punto de inflexión en el denominado conflicto mapuche, acaecido con fecha 4 de noviembre de 2018, pues un joven comunero de 25 años fue asesinado por personal de carabineros en un confuso incidente, en que se mostró en primera instancia como un enfrentamiento armado y posteriormente salió a la luz pública e incluso avalado por autoridades de gobierno de la época, que se trató de un ataque mortal unilateral y que las pruebas fueron destruidas por el mismo personal de carabineros. La excesiva militarización en la zona, la poca preparación de carabineros en el tratamiento intercultural, el uso de la ley antiterrorista en el enfrentamiento de la protesta social mapuche, la decisión política de enfrentar el problema como de seguridad pública y de pobreza y no desde la óptica de los derechos humanos de los pueblos indígenas, hacía presagiar que una tragedia así fue perfectamente posible. Nos parece que el actuar poco transparente y contradictorio de carabineros en este caso y otros confirma la existencia de un patrón de conducta que no está a la altura de lo exigible a un organismo policial en democracia y que la institución requiere en consecuencia, una revisión profunda que permita garantizar el derecho a la igualdad ante la justicia de los pueblos indígenas”.

${ }^{493}$ IBIDEM. p.166. "La operación Huracán, procedimiento policial realizado por miembros de inteligencia de carabineros que terminó con la detención de 8 comuneros mapuches acusado de ser responsables de ataques incendiarios en la Araucanía. Dicha operación resultó ser producto de un montaje realizado por miembros de la unidad de inteligencia de carabineros lo que implicó la detención y formalización de integrantes de carabineros, Esto provocó un revuelo mediático y simbólico nunca antes visto en relación al conflicto mapuche. En la operación Huracán se invocó la ley antiterrorista, se usaron interceptaciones telefónicas, que después fueron declaradas ilegales por la Corte Suprema. Además se usó un falso programa computacional denominado Antorcha que fue creado por un privado a solicitud de la unidad de inteligencia de carabineros”.

${ }^{494}$ IBIDEM. p.166-p.167 "Hemos reiterado la ineficacia de la actual ley antiterrorista específicamente al estigmatizar y discriminar al pueblo mapuche. Como lo expreso la Corte IDH la aplicación de la ley provoca también violaciones a la igualdad ante la ley, a la presunción de inocencia. Además de otros derechos consagrados en instrumentos internacionales como el 8.1 de la convención Americana sobre Derechos Humanos y los artículos 3.2 y 10 del Convenio 169 de la Organización Internacional del Trabajo. Esta ley implica que los castigos sean más severos y muchas veces son invocadas con este mismo fin sí que se cumplan con los requisitos de su configuración y son invocadas por abogados del ministerio del interior que actúan como querellantes en casos que aparecen mapuches involucrados, especialmente en caso de atentados incendiarios".

${ }^{495}$ IBIDEM. pp.168-169 "Vale la pena referirse a la resolución dictada por la Corte Suprema relativa al caso Morin Catriman y la Sentencia emanada de la Corte IDH que ordenaba al Estado de Chile cumplir con los estándares internacionales en materia de derechos humanos y dejar sin efecto la sentencia que condenó a los comuneros mapuches en el denominado caso Lonkos en que la Corte Suprema acordó que la Sentencia condenatoria había perdió efecto, sin perjuicio de la vigencia de la ley 18314. En el informe del Comité contra la tortura de 2018 (Comité sobre la Tortura. observaciones finales sobre el sexto periódico de Chile, 2 de agosto de 2018), se insta al país a garantizar que los actos de terrorismo estén definidos en la legislación nacional de 
A juicio de Miriam Henríquez, "la llamada 'cuestión indígena' se ha planteado en los últimos treinta años en Chile como un tema de real importancia, que aunque actualmente controvertido no es nuevo. Los chilenos no indígenas tienen una visión bastante reducida de las dificultades que aquejan a los indígenas, circunscribiéndolos a una situación de seguridad pública, pobreza, falta de oportunidades o escasa integración a la vida moderna" ${ }^{496}$.

Por su parte, los indígenas no sólo han cuestionado su propia situación de pobreza y marginalidad, sino que también han objetado las relaciones de dominación de la sociedad chilena basadas en la discriminación racial, en la intolerancia étnica y en la dominación de una cultura sobre las otras ${ }^{497}$.

\subsubsection{Aplicación de las formas de resolución de conflictos de las comunidades indígenas y acceso a la justicia formal Chilena}

Tal como ocurre en el contexto latinoamericano y en forma más exacerbada en Chile, nos encontramos con dificultades en cuanto a la inexistencia o precariedad de reconocimiento constitucional y legal de las formas de resolución de conflictos de las comunidades indígenas. Asimismo se ha configurado un trabado acceso a la justicia formal chilena con respeto de sus propias características. En el caso de Chile, definitivamente no existe una legislación especial sobre acceso a la justicia de comunidades indígenas. Pese a ello, existen disposiciones normativas aisladas como el artículo 54 de la Ley 19.253 que establece las normas sobre protección, fomento y desarrollo de los indígenas y crea la Corporación Nacional de Desarrollo

manera precisa y estricta, a abstenerse de aplicar la legislación antiterrorista a personas asociadas únicamente a atentados contra la propiedad en el marco de protestas en reivindicación de los derechos de los pueblos indígenas”.

${ }^{496}$ HENRIQUEZ, Miriam. (2015). “Los pueblos indígenas y su reconocimiento constitucional pendiente”. EN Reforma Constitucional. Santiago. Editorial Lexis Nexis. p. 1.

${ }^{497}$ IBIDEM. 
Indígena, de 5 de octubre de 1993, denominada ley indígena ${ }^{498}$ que leída en conjunto con las obligaciones del Estado consagradas en el convenio 169 de la Organización Internacional del Trabajo permitirían incorporar la costumbre como derecho en un juicio, así como instituciones que facilitarían considerar las particularidades de las comunidades en procedimientos judiciales, tales como la mediación intercultural y el peritaje antropológico.

Chile ha suscrito el Convenio $169^{499}$, no obstante estimamos que el artículo 9 del mismo ${ }^{500}$ no se encuentra cumpliéndose, tal como lo ilustra un fallo de la CA de Concepción ${ }^{501}$, que considera al derecho propio indígena y su aplicación judicial como contrario a la CPR.

Siguiendo a Nash, Núñez y Troncoso, en el caso de los pueblos indígenas en Chile, los mayores obstáculos para el acceso a la justicia se presentan en la aplicación de la normativa existente por parte de los operadores de justicia, que desconocen las particularidades propias de este grupo ${ }^{502}$. Podemos sostener que los déficits en el acceso a la justicia tienen que ver con deficiencias normativas y nulo reconocimiento

${ }^{498}$ LEY 19253. Que establece las normas sobre protección, fomento y desarrollo de los indígenas y crea la Corporación Nacional de Desarrollo Indígena, de 5 de octubre de 1993. Artículo 54: "La costumbre hecha valer en juicio entre indígenas pertenecientes a una misma etnia, constituirá derecho, siempre que no sea incompatible con la Constitución política de la República.

${ }^{499}$ ORGANIZACIÓN INTERNACIONAL DEL TRABAJO. Convenio 169 sobre pueblos indígenas y tribales en países independientes. 1. "En la medida en que ello sea compatible con el sistema jurídico nacional y con los derechos humanos internacionalmente reconocidos, deberán respetarse los métodos a los que los pueblos interesados recurran tradicionalmente para la represión de los delitos cometidos por sus miembros 2.Las autoridades y los tribunales llamados a pronunciarse sobre cuestiones penales deberán tener en cuenta las costumbres de dichos pueblos en la materia”.

500 IBIDEM. Artículo 9: "En la medida que ello sea compatible con el sistema judicial nacional y con los derechos humanos internacionalmente reconocidos, deberán respetarse los métodos a los que los pueblos interesados recurren tradicionalmente para la represión de los delitos cometidos por sus miembros $n^{\circ} 2$ Las autoridades y los tribunales llamados a pronunciarse sobre cuestiones penales deberán tener en cuenta las costumbres de dichos pueblos en la materia”.

${ }^{501}$ CA de CONCEPCION. Sentencia causa rol 195-2014, de 2 de mayo de 2014. Considerando 4: "Una sentencia dictada por la comunidad a la que pertenece el imputado o una sanción penal impuesta por ellos, no es compatible con nuestro sistema jurídico nacional, de manera que no tiene aplicación el artículo 9 del convenio 169 de la OIT .En efecto, el artículo 76 de la Constitución Política de la República dispone que: ' la facultad de conocer las causas civiles y criminales, de resolverlas y de hacer ejecutar lo juzgado, pertenece exclusivamente a los tribunales establecidos por ley. El artículo 19 de la Carta Fundamental, en su numeral $3^{\circ}$, al establecer la garantía de la igual protección de la ley en el ejercicio de sus derechos, expresa, en su inciso $7^{\circ}$ 'que nadie puede ser juzgado por comisiones especiales, sino por el tribunal que le señale la ley y que se halle establecido con anterioridad por ésta”.

502 NASH, C; NUÑEZ, C; TRONCOSO, C. Op. Cit., p. 345. 
constitucional, pero además, y principalmente, con problemas culturales a la hora de realizar un ejercicio hermenéutico por parte del juez que se haga cargo de la identidad cultural de las comunidades indígenas en el acceso a la justicia en condiciones de igualdad $^{503}$. Pese a ello, existen ejemplos aislados de jurisprudencia que van en el sentido contrario y que permiten afirmar que el problema no es normativo, sino hermenéutico. Uno de los casos en este ámbito lo constituye un juicio donde la utilización del peritaje antropológico para probar la costumbre fue determinante para absolver a dos imputadas que portaban hojas de coca504. Al margen de todo reconocimiento constitucional y legal, nos encontramos en la práctica, que en comunidades indígenas, especialmente del pueblo mapuche o araucano, resuelven sus conflictos en base al Az Mapu, que constituye el sistema normativo mapuche ${ }^{505}$. El Az Mapu como derecho hace prevalecer la autocomposición por sobre la pena, el dialogo por sobre la imposición del juez a través de una sentencia ${ }^{506}$. Al igual que otros sistemas sancionatorios indígenas se identifica como un sistema de justicia restaurativa, más que con el derecho penal, de carácter represivo y sancionatorio. Además no existe confianza en el Estado chileno, tal como se recoge en declaraciones de lonkos o jefes mapuches, consignadas en el texto de Mirna Villegas ${ }^{507}$.

\footnotetext{
${ }^{503}$ IBIDEM.

504 TRIBUNAL ORAL EN LO PENAL DE CALAMA. Sentencia causa rit 66-2007, de 6 de octubre de 2007. Considerando 7: "Entonces, lo que estos sentenciadores entienden, y de ahí su convicción absolutoria, es que las acusadas, no obstante realizar una conducta reprochable, lo hicieron siguiendo las formas y simbolismos propios de su cultura, lo que significa que ellas, en su conciencia y fuero interno, no tuvieron la intención de traficar las hojas de coca, sino entregársela a una persona que, como creyente, las iba a utilizar en una festividad religiosa.

505 Pervive su aplicación en ciertos sectores con mayor o menor intensidad, pero en silencio, al margen completamente del Estado, quién ignorante de las mismas, insiste en punir y criminalizar. Es más, hay una tendencia a recuperar el derecho propio, considerando ciertos sectores de la comunidad mapuche al Estado Chileno, como enemigo, debido a un comportamiento a mi parecer opresor, desde la mal llamada pacificación de la Araucanía en el siglo XIX y el no reconocimiento constitucional y/o estatal como un pueblo originario, dueño de una cultura y de una organización política.

${ }^{506}$ Más que un procedimiento se trata de un protocolo. Cada mapuche sabe que debe guardar las reglas del AZMapu. Si se produce una infracción se va a conversar con el infractor a esa familia. Se presenta alguien con autoridad de la comunidad como el Lonko, los más ancianos, aconsejan y resuelven. Con este contexto es que pueden sucederse los malowines y el derecho a maloquear cuando se ha sufrido una ofensa o a alguien de su familia. La violencia siempre ha sido un mecanismo de resolución de conflictos cuando se agotan las instancias de dialogo" ${ }^{506}$. Se privilegia la conversación, el diálogo entre familias, primando como forma de solución la reparación que la privación de derechos, incluso aceptándose la violencia como mecanismo de restauración

507 VILLEGAS, M (2014). “Sistemas sancionatorios indígenas y derecho penal. ¿Subsiste el AZ-Mapu?”. EN: Política criminal vol.9. n¹7. pp. 213-214. "Yo creo que la justicia son para cada uno. La justicia de los
} 
Es preciso destacar, que con fecha 27 de mayo de 2019 se presentó moción parlamentaria de proyecto de ley que otorga reconocimiento constitucional a los pueblos indígenas, correspondiendo al último proyecto en la materia, adscrita a una corriente de reconocimiento constitucional simple como pueblo originario, y no de categorización de Chile como un Estado plurinacional, encontrándose en tramitación legislativa ${ }^{508}$.

\subsection{Políticas públicas en materia de acceso a la justicia de personas o comunidades indígenas}

Tal como lo hemos revisado, en materia penal es donde persisten las mayores dificultades de acceso a la justicia, principalmente por una falta de reconocimiento de las formas de resolución de conflictos de las comunidades indígenas. En la posibilidad de acceder al sistema de justica formal chileno, reconociéndose las singularidades de estos grupos, es donde se ha observado un mayor avance.

En este orden de ideas, la DPP, en el marco del proceso penal formal, se encuentra realizando esfuerzos para el reconocimiento de la costumbre y los mecanismos de resolución de conflictos, a través de la Defensoría Indígena. En esta misma línea, como política pública que tiene por objetivo acortar las brechas de acceso a la justicia de la población indígena, se han creado las figuras de los mediadores o

mapuches es para los mapuches. Y las que inventaron los Winkas son para los Winkas, entonces si nos ponemos en eso, para los mapuches no es buena esta justicia, no tienes alternativa que te manden para la cárcel”. "debemos volver por lo que era antes, porque con los winkas no podemos, cuál es la mentalidad hoy día, no podemos pedirle justicia a nuestro propio enemigo, porque hoy día no es convivencia, ahora pasa a ser enemigo, ya no podemos depender de ellos, no podemos pedir que nos hagan justicia ellos, entonces aquí debemos volver a lo nuestro (dirigente Lof Yeupeco)".

${ }^{508}$ DIARIOCONSTITUCIONAL.https://www.diarioconstitucional.cl/noticias/proyectos-de-reformaconstitucional/2019/05/27/nuevo-proyecto-otorga-reconocimiento-constitucional-a-los-pueblos-indigenas. [Consulta 19 de marzo de 2020]. "El proyecto de reforma constitucional modifica el artículo $2^{\circ}$ de la Constitución, introduciéndose los siguientes inciso primeros y segundo, pasando el actual a ser el inciso tercero: La Nación Chilena, como tal, reconoce y valora la contribución de los pueblos indígenas originarios tanto a la organización del Estado como a la conformación del pueblo chileno. Es deber del Estado respetar la identidad, cultura y tradiciones de sus raíces ancestrales, no pudiendo establecerse discriminaciones arbitrarias, que se fundamenten en el orden étnico o racial de las personas”. Corresponde ahora que la iniciativa en primer trámite constitucional sea analizada por la Comisión de Constitución, Legislación, Justicia y Reglamente del Senado. 
facilitadores interculturales (que no solo operan en el ámbito de la justicia, sino también en salud o educación por ejemplo) ${ }^{509}$.

El Protocolo de atención con pertenencia cultural a usuarios y usuarias Mapuche o PAU-MAPU, en espacios de Administración de Justicia, es un conjunto breve de principios, reglas de actuación y recomendaciones dirigido a magistrados y funcionarios de municipios y del poder judicial de la macro región sur. Tiene por objetivo mejorar el acceso a la justicia de personas y grupos mapuches que acude a los distintos tribunales y juzgados regionales. A su vez, es un instrumento de información para los mismos usuarios/as mapuche con respecto a los derechos vigentes y así puedan ejercerlos adecuadamente ${ }^{510}$.

\section{PERSONAS MIGRANTES Y SUJETAS A PROTECCION INTERNACIONAL}

\subsection{Generalidades}

La migración es una característica inherente de la especie humana, lo que implica que el fenómeno migratorio se mantendrá, e incluso incrementará en las próximas décadas. De acuerdo con la División de Población del Departamento de Asuntos Económicos y Sociales de la ONU, las personas migrantes internacionales alcanzaron en 2018 la cifra de 232 millones ${ }^{511}$.

La Organización Internacional de la Migración, da cuenta además de casos especiales de migración, que podemos calificar como forzada o realizada con infracción a los derechos fundamentales, como es el caso de los migrantes

\footnotetext{
509 NASH, C; NUÑEZ, C; TRONCOSO, C. Op. Cit., p.347. “En el ámbito penal, son los encargados de colaborar en la prestación de defensa, realizando tareas como interprete/traductor, facilitar la comprensión de la cultura del imputado por parte de defensores y jueces (tradiciones, creencias, costumbres, etcétera), y realizar difusión de derechos al interior de las comunidades, entre otros. Los facilitadores están dispuestos estratégicamente en algunas de las zonas geográficas con mayor presencia de población originaria (Arica, Iquique, Calama, Cañete y Temuco), y su ámbito de trabajo es regional”.

${ }^{510}$ PODER JUDICIAL. Protocolo de Acceso a la Justicia de Grupos Vulnerables. Op. Cit. p. 114.

${ }^{511}$ XVII CUMBRE JUDICIAL IBEROAMERICANA (2014). Op. Cit., p.165.
} 
económicos o las víctimas del delito de trata de personas ${ }^{512}$. La migración es un fenómeno creciente en Chile ${ }^{513}$. El fenómeno de la migración significa un importante avance, que conlleva apertura, desarrollo e integración, pero también requiere una adecuación de nuestras instituciones, políticas e interpretación normativa ${ }^{514}$.

En Chile, de acuerdo a la información entregada por el Instituto Nacional de Estadísticas, en colaboración con el Departamento de Extranjería y Migración, los principales colectivos de las personas residentes en Chile provienen de Venezuela (30,5\%), Perú (15,8\%), Haití (12,5\%), Colombia $(10,8 \%)$ y Bolivia (8,0\%). En Chile existen 1.492.522 personas extranjeras residentes habituales, lo que implica un aumento absoluto de 242.157 personas y un aumento relativo de $19,4 \%$ respecto del año 2018, año en que la cifra estimada se situó en 1.250 .365 personas ${ }^{515}$.

\subsection{Normativa internacional aplicable, principios y jurisprudencia}

Normas internacionales aplicables:

a) Convención sobre el Estatuto de Refugiados, adoptada en Ginebra, Suiza, el 28 de julio de 1951, promulgada mediante el Decreto $n^{\circ} 287$, de 8 de junio de 1972.

\footnotetext{
512 IBIDEM. "La Organización Internacional de la Migración, define los flujos mixtos como movimientos de población complejos, que incluyen a personas refugiadas, solicitantes de asilo, desplazados internos, migrantes económicos, víctimas de trata, víctimas de tráfico, niños, niñas y adolescentes no acompañados o separados, personas que fueron objeto de violencia, comerciantes transfronterizos y personas migrantes que se desplazan por causas ambientales”.

${ }^{513}$ OBSERVATORIO JUDICIAL. (2018). La Corte, defensora del inmigrante. ¿Cómo aplica la Corte Suprema la legislación migratoria? EN Revista Radar número 2.

"Desde la década del noventa, la población migrante en Chile se ha cuadriplicado, pasando de 105.000 a 411.000 extranjeros. Entre los años 2005 a 2016 se concedieron un total de 324.932 permanencias definitivas, es decir, unos 145 permisos diarios. Lo anterior, muestra la magnitud del fenómeno migratorio, el cual ofrece una infinidad de beneficios para nuestra sociedad, pero también implica desafíos”.

${ }^{514}$ IBIDEM. "En este contexto, la Corte Suprema ha jugado un rol relevante en la gestión de la política migratoria del país. En efecto, la sala penal de la Corte ha asentado los criterios interpretativos de la normativa migratoria; especialmente en materia de expulsión. Resulta fundamental entender y analizar la jurisprudencia del Máximo Tribunal en asuntos de migración. La razón radica en que la forma como los jueces aplican la normativa migratoria establece distintos incentivos a los inmigrantes, lo cual genera verdaderas políticas migratorias".

515 INSTITUTO NACIONAL DE ESTADISTICA. (2020). Informe técnico. Estimación de personas extranjeras residentes habituales en Chile al 31 de diciembre de 2019. pp. 1-27.
} 
b) Convención sobre el Estatuto de los Apátridas de 1954 y Convención para reducir los casos de Apátrida de 1981. Chile adhirió a ambos instrumentos, con fecha 11 de abril de 2018

c) Convención de las Naciones Unidas contra la Delincuencia Organizada Transnacional y sus protocolos contra el tráfico ilícito de migrantes por tierra, mar y aire y para prevenir, reprimir y sancionar la trata de personas, especialmente mujeres y niños, promulgada mediante el Decreto $n^{\circ} 342$, de 16 de febrero de 2005.

d) Convención Internacional sobre la Protección de todos los Trabajadores Migrantes y de sus familiares de 1990, promulgada mediante el Decreto $n^{\circ} 84$ el 8 de junio de 2005.

e) Convención de Viena sobre Relaciones Consulares, promulgada mediante el Decreto $n^{\circ} 709$ de 5 de marzo de 1968

f) Declaración de Cartagena de Refugiados, adoptada en el "Coloquio sobre la Protección Internacional de los Refugiados de América Central, México y Panamá: problemas jurídicos y humanitarios", celebrado en Colombia, del 19 al 22 de noviembre de 1984.

g) OC16/99, de 1 de octubre de 1999, relativa al derecho a la información sobre la asistencia consular en el marco de las garantías del debido proceso legal, y la OC 18/03, de 17 de septiembre de 2003, relativa a la condición jurídica y los derechos de las personas migrantes indocumentadas.

h) Reglas de Brasilia sobre personas en condición de vulnerabilidad.

Regla 13: "El desplazamiento de una persona fuera del territorio del Estado de su nacionalidad puede constituir una causa de vulnerabilidad, especialmente en los supuestos de los trabajadores migratorios y sus familiares. Se considera trabajador migratorio toda persona que vaya a realizar, realice o haya realizado una actividad remunerada en un Estado del que no sea nacional. Asimismo reconocerá una protección especial a los beneficiarios del estatuto del refugiado conforme a la 
Convención sobre el Estatuto de los Refugiados de 1951, así como a los solicitantes de asilo".

Regla 14: "También pueden encontrarse en condición de vulnerabilidad los desplazados internos, entendidos como personas o grupos de personas que se han visto forzadas u obligadas a escapar o huir de su hogar o de su lugar de residencia habitual, en particular como resultado o para evitar los efectos de un conflicto armado, de situaciones de violencia generalizada, de violaciones de los derechos humanos o de catástrofes naturales o provocadas por el ser humano, y que no han cruzado una frontera estatal internacionalmente reconocida".

El inmigrante es un sujeto de tutela especial, por lo cual los principios que fluyen de la normativa protectora deben ser respetados por los jueces y por la autoridad administrativa al aplicar la normativa migratoria. Coincidiendo con el estudio del Observatorio Judicial Chileno, en muchas ocasiones la migración tiene su causa en la pobreza o inestabilidad política, por lo tanto la CS entiende que el inmigrante, como potencial sujeto de abusos, requiere un cuidado especial.

De estas normas se desprenden los siguientes principios, cuya aplicación asegura un efectivo acceso a la justicia:

a) Principio de Igualdad y no discriminación: El hecho de elegir o verse obligado por diversas circunstancias a continuar los proyectos de vida en un país diverso al de su nacimiento, de ninguna manera puede afectar la dignidad de la persona, o situarla en una posición de inferioridad, respecto de los naturales de la nación que lo acoge ${ }^{516}$.

b) Principio Pro persona: El principio pro persona es un criterio en virtud del que se debe aplicar la norma más amplia o la interpretación más extensiva, cuando se trata

\footnotetext{
${ }^{516}$ XVII CUMBRE JUDICIAL IBEROAMERICANA. Op. Cit., p.180. "La noción de igualdad se desprende directamente de la unidad de naturaleza del género humano y es inseparable de la dignidad esencial de la persona, frente a la cual es incompatible toda situación que, por considerar superior a un determinado grupo, conduzca a tratarlo con privilegio; o que, a la inversa, por considerarlo inferior, lo trate con hostilidad o de cualquier forma lo discrimine del goce de derechos que sí se reconocen a quienes no se consideran incursos en tal situación de inferioridad. No es admisible crear diferencias de tratamiento entre seres humanos que no se correspondan con su única e idéntica naturaleza”.
} 
de reconocer derechos, e inversamente, la norma más restrictiva cuando se trata de establecer restricciones a los derechos reconocidos. Idéntica decisión debe tomarse en el caso de que una norma tenga diversas interpretaciones jurídicamente aceptables $^{517}$.

c) Interés superior del NNA migrante: Significa, en términos generales, el bienestar del NNA, está basado en la dignidad del ser humano, en las características especiales de los niños, niñas y adolescentes y en la necesidad de propiciar su adecuado desarrollo ${ }^{518}$.

d) Principio de no devolución: Establece la prohibición de llevar a cabo cualquier medida que tenga como efecto devolver a una persona solicitante de asilo o refugiada a las fronteras del territorio donde su vida o libertad puedan verse amenazadas, o donde corra peligro de persecución incluyendo su intercepción, rechazo en frontera o devolución indirecta ${ }^{519}$.

e) Principio de la unidad familiar: La separación de los NNA de su núcleo familiar únicamente debe realizarse bajo una justificación clara y con una duración temporal, tan pronto lo permitan las circunstancias, han de ser devueltos a sus progenitores $^{520}$.

f) Presunción de inocencia, necesidad, proporcionalidad e idoneidad de la detención: Toda persona acusada de haber cometido un delito debe ser considerada inocente, siempre que no se establezca lo contrario, mediante una resolución judicial definitiva ${ }^{521}$. La detención de un inmigrante o refugiado debe ser una medida de última ratio, para asegurar un justo procedimiento y en su caso una devolución conforme al derecho internacional. En caso que se deba detener a una persona en situación migratoria, las condiciones de detención deben ser dignas. La

\footnotetext{
${ }^{517}$ IBIDEM. p. 182.

518 IBIDEM.

${ }^{519}$ IBIDEM. p. 184.

${ }^{520}$ IBIDEM. p. 185.

${ }^{521}$ IBIDEM. p. 187.
} 
detención del migrante, jamás puede estar fundada en motivaciones punitivas, tal como lo destaca la sentencia de la Corte IDH, Veles Loor vs Panamá522

g) Prontitud y prioridad: Adoptar las medidas necesarias para garantizar que las resoluciones judiciales y su ejecución ocurran oportunamente y sin retrasos innecesarios. Estos principios son de especial importancia, pues el tiempo que duran los procedimientos judiciales y administrativos es un factor determinante en la decisión de las personas migrantes y solicitantes de asilo de abandonar la defensa de sus derechos ${ }^{523}$.

h) Principio de confidencialidad: No se deben publicar datos personales cuando las personas migrantes y sujetas de protección internacional así lo decidan ${ }^{524}$.

i) Principio de coordinación: Comunicación constante entre las instancias competentes en los casos para evitar retrasos y lograr la correcta resolución de los mismos. Es importante reconocer que los casos de personas migrantes y sujetas de protección internacional involucran a varios países, por lo que la coordinación entre ellos es fundamental para garantizar que las personas no se queden sin un efectivo acceso a la justicia ${ }^{525}$. En casos como desapariciones, ejecuciones extrajudiciales, trata y tráfico de personas, entre otros, es imposible para las personas migrantes llevar directamente sus casos, por lo que es fundamental que se reconozca la calidad de víctimas a las familias y que cuenten con las facilidades necesarias para poder llevar los procedimientos desde sus países de origen ${ }^{526}$. Se debe tener presente que la jurisprudencia interamericana ha resuelto que se deben otorgar amplias facultades al migrante para que tenga la posibilidad de que

\footnotetext{
${ }^{522}$ CORTE IDH. Caso Velez Loor vs Panamá. Sentencia de 23 de Noviembre de 2010. Párrafo 171: “De este principio se colige que la detención de personas es por incumplimiento de las leyes migratorias nunca debe ser con fines punitivos. Así, las medidas privativas de libertad solo deberán ser utilizadas cuando fuere necesario y proporcionado en el caso en concreto a los fines mencionados supra y únicamente durante el menor tiempo posible. Para ello es necesario que los Estados dispongan de un catálogo de medidas alternativas, que puedan resultar efectivas para la consecución de los fines descritos. En consecuencia serán arbitrarias las políticas migratorias cuyo eje central es la detención obligatoria de los migrantes irregulares, sin que las autoridades competentes verifiquen en cada caso en particular, y mediante una evaluación individualizada, la posibilidad de utilizar medidas menos restrictivas que sean efectivas para alcanzar dichos fines”.
}

${ }^{523}$ XVII CUMBRE JUDICIAL IBEROAMERICANA (2014). Op. Cit., p. 189

524 IBIDEM. p. 190

${ }^{525}$ IBIDEM. p. 192

${ }^{526}$ IBIDEM. p. 12 
sea oído en las diversas instancias relativas a su proceso migratorio, y que dichas actuaciones sean coherentes, tanto en la investigación, castigo y reparación ${ }^{527}$.

j) Asistencia humanitaria y protección: Los Estados tienen la obligación de proporcionar protección y asistencia humanitaria a las personas desplazadas. Se establece la prohibición de ser castigados o perseguidos por formular la solicitud. La prohibición de desplazamientos arbitrarios, como los basados en políticas de apartheid, situaciones de conflicto armado, desastres naturales, en casos de proyectos de desarrollo a gran escala y como castigo colectivo. Además se ordena tomar de buena fe la asistencia que brinden organizaciones humanitarias tanto nacionales como internacionales ${ }^{528}$. En lo específico, en caso de calamidades, como desastres naturales o pandemias sanitarias, cualquier decisión de permanencia de una persona en territorio nacional debe apegarse aún más a este principio.

k) Acceso a la justicia considerando la situación de las personas migrantes y sujetas de protección internacional: Resulta obligatorio para cualquier impartidor de justicia asegurar una serie de prerrogativas a favor de las personas migrantes y sujetas de protección internacional, como asimismo, les corresponde verificar si dentro de cualquier otro procedimiento al que están sujetas, se les garanticen una serie de derechos. Entre estos derechos de la población migrante en cuanto al acceso a la justicia, se encuentran los siguientes:

a) El derecho a la información.

b) A la asistencia legal, a la defensa pública y derecho a un intérprete.

\footnotetext{
${ }^{527}$ CORTE IDH. Caso Nadege Dorzema y otros vs República Dominicana. Sentencia de 24 de octubre de 2012. Párrafo 199: "La Corte ha señalado que del artículo 8 de la Convención se desprende que las víctimas de violaciones de derechos humanos, o sus familiares, deben contar con amplias posibilidades de ser oídos y actuar en los respectivos procesos, tanto en la procuración del esclarecimiento de los hechos y del castigo de los responsables, como en la búsqueda de una debida reparación. En este sentido, la Corte ha señalado que en un caso de ejecución extrajudicial los derechos afectados corresponden a los familiares de la víctima fallecida, quienes son la parte interesada en la búsqueda de justicia y a quienes el Estado debe proveer recursos efectivos para garantizarles el acceso a la justicia, la investigación y, en su caso, la eventual sanción de los responsables y la reparación integral de las consecuencias de las violaciones”.
}

${ }^{528}$ IBIDEM. p. 195 
c) El derecho a asistencia consular -y a que se informe sobre ello- así como respecto de la excepción que existe en el caso de las personas que solicitan el reconocimiento de la condición de refugiado.

Estos principios, especialmente el de igualdad y no discriminación, pro persona, interés superior del niño migrante, principio de no devolución, presunción de inocencia, principio de coordinación y acceso a la justicia, han sido aplicados en Chile, en sendas sentencias de sus cortes, en que se han acogido recursos de amparo y de reclamación, respecto a dejar sin efecto resoluciones de expulsión del país aplicadas por el Ministerio del Interior y Seguridad Pública. Nuestras cortes, han puesto coto a las expulsiones del país, en base a la estrategia judicial de exigencia de una investigación penal previa en los casos de expulsiones por ingreso clandestino, y de la ponderación del germen de arraigo familiar, social y laboral, para el caso de denegación de visas especiales, temporarias o definitivas, ${ }^{529}$

La OC 18/03, ratifica los principios que deben ser atendidos por el Estado, especialmente en cuanto al derecho al debido proceso legal. En lo relativo a la existencia del derecho a una debida asistencia consular, se preceptúa que "el derecho a comunicarse con el representante consular contribuye a mejorar considerablemente sus posibilidades de defensa, y a que los actos procesales que realice se hagan con apego a la ley y con respeto a la dignidad de las personas. Por lo tanto, el derecho a la asistencia consular debe ser reconocido en el marco de las garantías mínimas para brindar a las personas extranjeras un juicio justo"530.

\subsection{Obstáculos normativos y estructurales de acceso a la justicia en Chile para personas migrantes}

\footnotetext{
${ }^{529}$ OBSERVATORIO JUDICIAL. Op. Cit., p. p 9-10.

${ }^{530}$ CORTE IDH. OC 18/2003. Op. Cit., Párrs 6, 7. Párrafo 6: “Que la obligación general de respetar y garantizar los derechos humanos vincula a los Estados, independiente de cualquier circunstancia o consideración, inclusive el estatus migratorio de las personas. Párrafo 7: “Que el derecho al debido proceso legal debe ser reconocido en el marco de las garantías mínimas que se deben brindar a todo migrante independiente de su estatus migratorio. El amplio alcance de la intangibilidad del debido proceso comprende todas las materias y todas las personas, sin discriminación alguna”.
} 
La normativa legal vigente en materia de migración fue diseñada en la lógica de incentivar una inmigración selectiva. El DL 1094531, de 19 de julio de 1974 y el respectivo reglamento de extranjería DS n 597 de 14 de junio de 1984, regulan el ingreso al país, la permanencia definitiva, el egreso, el reingreso, la expulsión y el control de los extranjeros. Esta lógica de creación de la normativa es explicada por Rodrigo Godoy y Marcel Didier, en cuanto a que "en general, estas normas otorgan amplias facultades al Ministerio del Interior para la concesión de visaciones bajo el concepto jurídico indeterminado de conveniencia o utilidad para el país y describen las causales de prohibición de ingreso, que también se hacen aplicables como causales de expulsión"532. Respecto de esta normativa, el TC ha señalado respecto de la legislación migratoria nacional, que son "el reflejo de un esquema normativo de máxima discrecionalidad que admite masivas vulneraciones de derechos o alteraciones menores, dependientes del carácter comprensivo o estricto de su innovación por las autoridades de turno"533. Esto se traduce en que dicho marco normativo faculta a las autoridades administrativas para denegar permisos de residencia y llevar a cabo expulsiones de manera expedita, sin que se contemplen procedimientos y recursos que permitan impugnar estas decisiones a través de un debido proceso ${ }^{534}$. En efecto, para determinar la medida de expulsión del país la legislación no contempla la posibilidad de que la persona presente sus descargos frente a la medida impuesta, ni que pueda presentar antecedentes favorables para regularizar su situación migratoria (por ejemplo la existencia de hijos/as en el país

\footnotetext{
${ }^{531}$ DL 1094. Establece normas sobre extranjeros en Chile, de 19 de julio de 1975.

${ }^{532}$ GODOY, R y DIDIER, M (2014). “Comentarios de la jurisprudencia de la Corte Suprema y el Tribunal Constitucional sobre derechos de las personas migrantes durante el año 2013”. EN Anuario de Derechos Humanos número 10. p. 140.

${ }^{533}$ TC. Sentencia en causa rol 2273-2013, de 4 de julio de 2013. Considerando $7^{\circ}$.

${ }^{534}$ OBSERVATORIO JUDICIAL. Op. Cit., p. 5. "Los principales actores que gestionan la política migratoria del país son tres: el Departamento de Extranjería y Migración, el Intendente Regional y la Policía de Investigaciones. El Departamento de Extranjería y Migración depende del Ministerio del Interior y su función es gestionar el otorgamiento y prórroga de visas, además de conceder el permiso de residencia definitiva. Este organismo ejerce sus potestades discrecionalmente (artículo $13^{\circ}$ ), pudiendo, por ejemplo, entregar la visa de residencia temporaria a quienes estime como útiles para el país (artículo $29^{\circ}$ ).

El Intendente Regional es el órgano encargado de resguardar la normativa migratoria en las distintas regiones del país. Por ejemplo, ante una infracción a la Ley de Migración, éste puede disponer la expulsión del extranjero. Por último, la Policía de Investigaciones controla el ingreso y salida de los extranjeros, además del cumplimiento de las obligaciones que la normativa migratoria impone, por ejemplo, ingresar al país por pasos habilitados".
} 
o un vínculo laboral estable). El recurso de reclamación ${ }^{535}$ ante la CS, resulta procedente para dejar sin efecto una expulsión de un extranjero, debiendo ejercerse en el plazo de 24 horas, lo que claramente es insuficiente en términos de la efectividad de un recurso para la protección del derecho a la libertad personal. Además se ha utilizado el recurso de amparo, conforme al artículo 21 de la CPR 536 , por constituir la expulsión del país una violación flagrante a la libertad ambulatoria y al derecho de toda persona de elegir libremente el país de su residencia conforme al artículo $19 \mathrm{n}^{\circ} 7^{537}$ de la Carta Magna y el artículo 9 del PIDCP.

Es dable señalar que al ser una autoridad administrativa la que otorga los diversos permisos o visas, su procedimiento y resolución, son regulados por la ley 19.880, que Establece las Bases de los Procedimientos Administrativos, que rigen los actos de los órganos de la administración del Estado, pudiendo además sus resoluciones

\footnotetext{
${ }^{535}$ DL 1094. Op. Cit. Artículo 89: "El extranjero cuya expulsión hubiere sido dispuesta por decreto supremo, podrá reclamar judicialmente por sí o por medio de algún miembro de su familia, ante la Corte Suprema dentro del plazo de 24 horas, contado desde que hubiere tomado conocimiento de él. Dicho recurso deberá ser fundado y la Corte Suprema procediendo breve y sumariamente fallará la reclamación dentro del plazo de 5 días, contado desde su presentación. (LEY 18.252, ART UNICO n 15) La interposición del recurso suspenderá la ejecución de la orden de expulsión, y durante su tramitación el extranjero afectado permanecerá privado de su libertad en un establecimiento carcelario o en el lugar que el Ministro del Interior o el Intendente determinen. Artículo 90.La medida de expulsión deberá ser notificada por escrito al afectado, quien podrá en dicho acto, si ello fuere procedente, manifestar su intención de recurrir en contra de la medida o conformarse con ella. En este último caso, la expulsión se llevará a efecto sin más trámite. (LEY 18.252, ART UNICO Nº 16) Transcurrido el plazo de 24 horas contado desde la notificación, en el caso de que no se haya interpuesto recurso o en el de no ser éste procedente, o transcurrido el mismo plazo desde que se haya denegado el recurso interpuesto, la autoridad a que se refiere el artículo 10 procederá a cumplir la expulsión ordenada”.

${ }^{536} \mathrm{CPR}$. Artículo 21: "Todo individuo que se hallare arrestado, detenido o preso con infracción de lo dispuesto en la Constitución o en las leyes, podrá ocurrir por sí, o por cualquiera a su nombre, a la magistratura que señale la ley, a fin de que ésta ordene se guarden las formalidades legales y adopte de inmediato las providencias que juzgue necesarias para restablecer el imperio del derecho y asegurar la debida protección del afectado.

Esa magistratura podrá ordenar que el individuo sea traído a su presencia y su decreto será precisamente obedecido por todos los encargados de las cárceles lugares de detención. Instruida de los antecedentes, decretará su libertad inmediata o hará que se reparen los defectos legales o pondrá al individuo a disposición del juez competente, procediendo en todo breve y sumariamente, y corrigiendo por sí esos defectos o dando cuenta a quien corresponda para que los corrija. El mismo recurso, y en igual forma, podrá ser deducido en favor de toda persona que ilegalmente sufra cualquiera otra privación, perturbación o amenaza en su derecho a la libertad personal y seguridad individual. La respectiva magistratura dictará en tal caso las medidas indicadas en los incisos anteriores que estime conducentes para restablecer el imperio del derecho y asegurar la debida protección del afectado".

${ }^{537}$ IBIDEM. Artículo 19 n $7^{\circ}$ : "El derecho a la libertad personal y a la seguridad individual. En consecuencia: a) Toda persona tiene derecho de residir y permanecer en cualquier lugar de la República, trasladarse de uno a otro y entrar y salir de su territorio, a condición de que se guarden las normas establecidas en la ley y salvo siempre el perjuicio de terceros”.
} 
ser impugnadas por el recurso de reclamación y el jerárquico ${ }^{538}$, los que carecen de mayor utilidad práctica, porque es la misma autoridad que deniega estos permisos, la que debería retractarse, lo que generalmente no ocurre ${ }^{539}$. En este sentido los requisitos de una persona para ingresar al país ${ }^{540}$, que pueden constituir 538 LEY 19.880. Establece Bases de los Procedimientos Administrativos que rigen los Actos de los Órganos de
la Administración del Estado, de 29 de mayo de 2003. Artículo 59: "Procedencia. El recurso de reposición se
interpondrá dentro del plazo de cinco días ante el mismo órgano que dictó el acto que se impugna; en subsidio,
podrá interponerse el recurso jerárquico. Rechazada total o parcialmente una reposición, se elevará el
expediente al superior que corresponda si junto con ésta se hubiere interpuesto subsidiariamente recurso
jerárquico. Cuando no se deduzca reposición, el recurso jerárquico se interpondrá para ante el superior
jerárquico de quien hubiere dictado el acto impugnado, dentro de los 5 días siguientes a su notificación. No
procederá recurso jerárquico contra los actos del Presidente de la República, de los Ministros de Estado, de los
alcaldes y los jefes superiores de los servicios públicos descentralizados. En estos casos, el recurso de reposición
agotará la vía administrativa. La autoridad llamada a pronunciarse sobre los recursos a que se refieren los incisos
anteriores tendrá un plazo no superior a 30 días para resolverlos. Si se ha deducido recurso jerárquico, la
autoridad llamada a resolverlo deberá oír previamente al órgano recurrido el que podrá formular sus descargos
por cualquier medio, escrito o electrónico. La resolución que acoja el recurso podrá modificar, reemplazar o
dejar sin efecto el acto impugnado”.
539 Una persona al ser expulsada del país, sin perjuicio del recurso de reclamación ante la CS en un plazo de 24
horas, solo podrá ejercer vía administrativa, este recurso de reposición con subsidio jerárquico ante la respectiva
gobernación o intendencia, no otorgándosele en la tramitación, la posibilidad de refutar la causal invocada ni
de probar el arraigo social o la no investigación penal previa, según corresponda.

${ }^{540}$ DL 1094. Artículo 15: "Se prohíbe el ingreso al país de los siguientes extranjeros: 1.- Los que propaguen o fomenten de palabra o por escrito o por cualquier otro medio, doctrinas que tiendan a destruir o alterar por la violencia, el orden social del país o su sistema de gobierno, los que estén sindicados o tengan reputación de ser agitadores o activistas de tales doctrinas y, en general, los que ejecuten hechos que las leyes chilenas califiquen de delito contra la seguridad exterior, la soberanía nacional, la seguridad interior o el orden público del país y los que realicen actos contrarios a los intereses de Chile o constituyan un peligro para el Estado; 2. - Los que se dediquen al comercio o tráfico ilícito de drogas o armas, al contrabando, a la trata de blancas y, en general, los que ejecuten actos contrarios a la moral o a las buenas costumbres; 3.- Los condenados o actuales procesados por delitos comunes que la ley chilena califique de crímenes y los prófugos de la justicia por delitos no políticos; 4.- Los que no tengan o no puedan ejercer profesión u oficio, o carezcan de recursos que les permitan vivir en Chile sin constituir carga social; 5.- Los que sufran enfermedades respecto de las cuales la autoridad sanitaria chilena determine que constituyen causal de impedimento para ingresar al territorio nacional; 6.- Los que hayan sido expulsados u obligados al abandono del país por decreto supremo sin que previamente se haya derogado el respectivo decreto; (LEY 18.252 ART UNICO $\mathrm{N}^{\circ} 2$ a) y b) 7.- Los que no cumplan con los requisitos de ingreso establecidos en este decreto ley y su reglamento, sin perjuicio de lo dispuesto en el $\mathrm{N}^{\circ} 4$ del artículo siguiente y en los artículos 35 y 83, y 8.- Los que habiendo incurrido en la comisión de los delitos tipificados en el inciso primero del artículo 68 y en el artículo 69, y a su respecto hubieren prescrito las acciones penales o las penas correspondientes, en su caso, encontrándose fuera del territorio nacional. (LEY 18.252 ART UNICO $\mathrm{N}^{\circ} 2$ c) 4”.

Artículo 16: "Podrá impedirse el ingreso al territorio nacional de los siguientes extranjeros: 1.- Los condenados o actualmente procesados por delitos comunes que la ley chilena califique de simples delitos; 2.- Los que hayan salido de Chile por disposición del Gobierno, y no estén comprendidos en el $\mathrm{N}^{\circ} 6$ del artículo anterior; 3.- Los expulsados de otro país por autoridad competente, y 4.- Los menores de 18 años que viajen a Chile sin ser acompañados de su padre, madre o guardador y carezcan de autorización escrita de uno de ellos o del Tribunal competente, debidamente refrendada por autoridad chilena. Las prohibiciones de este artículo y del anterior, serán aplicadas por las autoridades señaladas en el artículo 10 de este decreto ley”.

Artículo 17: "Los extranjeros que hubieren ingresado al país no obstante encontrarse comprendidos en alguna de las prohibiciones señaladas en el artículo 15 o que durante su residencia incurran en alguno de los actos u omisiones señaladas en los números 1, 2 y 4 del artículo indicado, podrán ser expulsados del territorio nacional”. 
causal de expulsión en caso de incumplimiento como en la causales de los números 1, 2 y 4 del artículo 15, las diversas visas que se pueden otorgar, requisitos y su 


\section{duración ${ }^{541}$, su carácter y posibilidad de mutarse ${ }^{542}$ hasta obtener la residencia definitiva, las causales específicas de expulsión ${ }^{543}$ y sus sanciones, se encuentran}

${ }^{541}$ En una revisión del DL, se pueden observar que en el párrafo $4^{\circ}$, articulo 18 a 40 bis, se regulan las siguientes visas o permisos a que pueda optar un extranjero para residir en Chile:

a) Residentes oficiales. Artículo 19: "Se considerarán residentes oficiales los miembros del Cuerpo Diplomático y Consular acreditados ante el Gobierno y los de organizaciones internacionales reconocidos por Chile, a quienes se concederán visaciones diplomáticas u oficiales. Se otorgará este mismo tipo de visaciones a los miembros de sus familias que vivan con ellos, al personal administrativo y al de servicio y a las demás personas que determine el reglamento que dictará el Ministerio de Relaciones Exteriores”.

Artículo 20: "Los residentes ofi ciales podrán permanecer en Chile en esta calidad hasta el término de las misiones oficiales que desempeñen en el país, circunstancia que, la representación diplomática, consular o el organismo nacional o internacional ante el cual se encontraban acreditados, estarán obligados a comunicar al Ministerio de Relaciones Exteriores, dentro del plazo de 15 días, contado desde el término de la misión”. Artículo 21: "Los residentes oficiales, con exclusión del personal administrativo o de servicio, podrán solicitar, al término de sus respectivas misiones, permanencia definitiva. El personal administrativo o de servicio, podrá solicitar al término de sus funciones, visación de residente sujeto a contrato o de residente temporario y, en cas os de que esas funciones terminen después de un año de residencia en Chile, la permanencia definitiva".

b) Residente sujeto a contrato: Artículo 23: "Se otorgarán visaciones de residente sujeto a contrato a los extranjeros que viajen al país con el objeto de dar cumplimiento a un contrato de trabajo. La misma visación se podrá otorgar a los extranjeros que se encuentren en el territorio nacional y se radiquen en el país para dar cumplimiento a un contrato de trabajo. Igual visación será otorgada a los miembros de sus familias que determine el reglamento. La visación sujeta a contrato podrá tener una vigencia de hasta dos años y podrá ser prorrogada por períodos iguales. Si no se especifica plazo en el pasaporte, se entenderá que su vigencia es la máxima. El residente sujeto a contrato podrá solicitar su permanencia definitiva al cumplir dos años de residencia”.

Artículo 24: "El contrato de trabajo que se acompañe para obtener esta visación deberá contener una cláusula por la que el empleador o patrón se comprometa a pagar el pasaje de regreso del trabajador y demás personas que estipule el contrato. Las formalidades y características del contrato serán señaladas en el reglamento”.

c) Visación de residente estudiante. Artículo 27: "Se otorgará visación de residente estudiante al extranjero que viaje a Chile con el objeto de estudiar en establecimientos del Estado o particulares reconocidos por éste, o en centros u organismos de estudios superiores o especializados. Igualmente podrá otorgarse a los extranjeros que, encontrándose en el país, acrediten haberse matriculado en alguno de estos establecimientos. Dicha visación tendrá una vigencia máxima de un año y podrá ser renovada por períodos iguales, en forma sucesiva y gratuita. Para obtener las prórrogas de estas visaciones el extranjero deberá acreditar su condición de estudiante mediante los correspondientes certificados de matrícula y de asistencia. El residente estudiante no podrá desarrollar actividades remuneradas dentro del país, si no es autorizado previamente por el Ministerio del Interior”.

Artículo 28: "El residente estudiante que tenga más de un año de residencia en Chile, podrá solicitar otra de las visas establecidas en este decreto ley. El extranjero que sea titular de visación residente estudiante podrá solicitar la permanencia definitiva, al término de sus estudios".

d) Visación de residente temporario. Artículo 29: "Se otorgará visación de residente temporario al extranjero que tenga el propósito de radicarse en Chile, siempre que acredite vínculos de familia o intereses en el país cuya residencia sea estimada útil o ventajosa, visación que se hará extensiva a los miembros de su familia que vivan con él. Se podrá conceder también ésta visación a los ex residentes que, a lo menos, hubieren permanecido un año en el país y a los que hubiesen tenido anteriormente permanencia definitiva y ésta hubiere caducado, de acuerdo con el artículo 43".

Artículo 30: "La visación de residente temporario tendrá una vigencia máxima de un año y podrá prorrogarse por una sola vez, por igual período. Si no se especifica plazo en el respectivo pasaporte, se entenderá que su vigencia es la máxima”. 
previstas en el referido D.L, bajo la lógica de una regulación que mira a la migración como un hecho irregular y no como un derecho humano, y en que el arraigo de la persona en el país es evaluado arbitrariamente por la autoridad administrativa, no mirando siempre la integración y contribución del extranjero al país, ni menos los principios emanados de los instrumentos de protección internacional y las normas

Artículo 31: "El titular de visación de residente temporario que completare un año de residencia en tal calidad, podrá solicitar su permanencia definitiva y si completare dos años de residencia en Chile, estará obligado a solicitarla. En caso de no hacerlo, deberá abandonar el país”.

e) Visación de asilado político o refugiado. Artículo 34: "Se podrá conceder visación de residente con asilo político a los extranjeros que, en resguardo de su seguridad personal y en razón de las circunstancias políticas predominantes en el país de su residencia, se vean forzados a recurrir ante alguna misión diplomática chilena solicitando asilo. Una vez que se conceda el asilo diplomático, en el carácter de provisorio, se calificarán los antecedentes y circunstancias del caso, por el Ministerio de Relaciones Exteriores y por el Ministerio del Interior y se dispondrá el otorgamiento o el rechazo de la visación. En caso de disponerse su otorgamiento, el asilo diplomático concedido se confirmará con el carácter de definitivo y se estampará la visación en el pasaporte, salvoconducto u otro documento análogo que presente el extranjero o en el que se le otorgue. Esta visación se hará extensiva a los miembros de la familia del asilado político que hubieren obtenido, junto con él, asilo diplomático".

Artículo 34 bis: "Se considerará como refugiado a quien se encuentre en alguna de las situaciones previstas en las Convenciones internacionales vigentes en Chile. El refugiado tendrá derecho a que se le otorgue la correspondiente visación de residencia".

Artículo 35: "Se podrá conceder, asimismo, visación de residente con asilo político, a los extranjeros que, por las mismas situaciones expresadas en el artículo anterior, se vean forzados a abandonar su país de residencia e ingresen al territorio nacional irregularmente. En este caso estarán obligados a presentarse ante la autoridad señalada en el artículo 10 e invocar que se les acuerde este beneficio, debiendo formalizar por escrito la petición dentro de 10 días, contados desde la presentación ante la mencionada autoridad".

f) Visación de residente definitivo. Artículo 41: "La permanencia definitiva es el permiso concedido a los extranjeros para radicarse indefinidamente en el país y desarrollar cualquier clase de actividades, sin otras limitaciones que las que establezcan las disposiciones legales y reglamentarias. Este permiso se otorgará por resolución del Ministerio del Interior”.

Artículo 42: "Los plazos de residencia en el país para obtener la permanencia definitiva deberán ser ininterrumpidos. Se entenderá que no ha habido interrupción cuando los períodos de ausencia no superen los ciento ochenta días dentro del año, contados hacia atrás desde la fecha de vencimiento de la visación de residencia”.

542 OBSERVATORIO JUDICIAL. Op. Cit., p.5.

${ }^{543}$ DECRETO LEY 1094. Artículo 69: "Los extranjeros que ingresen al país, o intenten egresar de él clandestinamente, serán sancionados con la pena de presidio menor en su grado máximo). Si lo hicieren por lugares no habilitados, la pena será de presidio menor en sus grados mínimo a máximo. Si entraren al país existiendo a su respecto causal de impedimento o prohibición de ingreso, serán sancionados con la pena de presidio menor en su grado máximo a presidio mayor en su grado mínimo. Una vez cumplida la pena impuesta en los casos precedentemente señalados, los extranjeros serán expulsados del territorio nacional”.

Artículo 71: "Los extranjeros que continuaren residiendo en el país después de haberse vencido sus plazos de residencia legal, serán sancionados con multa de 1 a 20 sueldos vitales, sin perjuicio de que pueda disponerse su abandono obligado del país o su expulsión”.

Artículo 72: "Los extranjeros que durante su permanencia en el país no dieren cumplimiento oportuno a la obligación de registrarse, de obtener cédula de identidad, de comunicar a la autoridad, cuando corresponda, el cambio de domicilio o actividades, serán sancionados con multas de 1 a 20 sueldos vitales, sin perjuicio de disponerse en caso de infracciones graves o reiteradas a las disposiciones de este decreto ley, el abandono del país o su expulsión”. 
básicas del debido proceso legal, sin la cautela e intervención del juez, salvo cuando la medida de expulsión ya se encuentra decretada. Frente a los déficits que presenta la normativa específica en materia de extranjería, a no exigir un procedimiento judicial en caso de expulsión, los/las inmigrantes, tal como se ha esbozado, utilizan las normas supletorias (normas administrativas), cuya sede son los respectivos organismos que dependen del poder ejecutivo y no del judicial ${ }^{544}$.

Sin embargo, estas normas administrativas, tampoco responden a las necesidades específicas de este grupo de la población, pues además de no existir un debido proceso administrativo (pues se omite la fase de contradicción al momento de tomar decisiones), toda la tramitación administrativa es: a) altamente burocrática (excesivo plazos de espera); b) formalista; y; c) onerosa, por cuanto se deben realizar diversos pagos para la notarización de documentos, solicitud de certificados, entre otros. El plazo estimado para la resolución de la invalidación de una orden de expulsión o de la reconsideración de un permiso de residencia es aproximadamente de 1 año 6 meses, lo que excede con creces el plazo razonable para tomar una determinación sobre derechos, tales como la libertad personal o la protección de la familia.

Las deficiencias de la legislación migratoria no solo están dadas por sus falencias en materia de acceso a la justicia en el sentido que hemos descrito, sino también en general, por tratarse de una normativa que no está construida bajo un enfoque de derechos humanos, sino de seguridad nacional, lo que implica una visión y tratamiento de la realidad migratoria como un fenómeno de peligro y, por tanto, de riesgo para la nación ${ }^{545}$.

A mayor abundamiento, la orden de expulsión debe ceñirse a ciertas garantías de la ley 19.880 , lo que no se configura en la generalidad de los casos. A saber, es

\footnotetext{
${ }^{544}$ Los Gobernadores e Intendentes son nombrados por el Presidente de la República y son los representantes de éste en la región.

${ }^{545}$ Debemos señalar que los diversos elementos integrantes del debido proceso, latamente desarrollados en el capítulo II de nuestra tesis, son obviados y desconocidos por la legislación migratoria y por la vía administrativa, constituyendo una traba u obstáculo para el acceso de la justicia de este grupo, en cuanto a la regularización de su situación migratoria, y que como tales les corresponde, pues independiente de su origen nacional y de las razones de su desplazamiento migratorio, deben ser tratados en condiciones de igualdad y sin discriminación, en cuanto al reconocimiento y garantía de sus prerrogativas, especialmente en su capacidad de discernir el país de su residencia y el libre desarrollo de sus planes de vida.
} 
recurrente la infracción principio de contradictoriedad establecida en el artículo $10^{546}$ de la misma ley, y no estando presentes las etapas del procedimiento administrativo, conforme al artículo $18^{547}$, obviándose este modo, las instancias de iniciación, instrucción y fiscalización.

La legislación nacional no contempla el derecho a la defensa jurídica en materia migratoria, pues al no consagrarse el principio contradictorio, no se concibe la posibilidad de ser asistido el ciudadano extranjero por abogado, salvo la interposición del recurso extraordinario, en caso que lo solicitado en la vía administrativa no sea acogido, principalmente en los supuestos de expulsión ${ }^{548}$. Bien es sabido que por las condiciones de vulnerabilidad y desprotección, agravadas por la pobreza y la exclusión que se encuentra la persona migrante, la posibilidad de procurarse asesoría y representación de abogado particular pagado se hace dificultoso y en la mayoría de los casos, inalcanzable ${ }^{549}$. En este sentido, agregar que el migrante también se puede encontrar en la necesidad de que un conflicto de relevancia jurídica no asociado directamente con su calidad migratoria, sea solucionado y por ende un derecho común sea

\footnotetext{
${ }^{546}$ LEY 19880. Op. Cit., Artículo 10: "Principio de contradictoriedad. Los interesados podrán, en cualquier momento del procedimiento, aducir alegaciones y aportar documentos u otros elementos de juicio. Los interesados podrán, en todo momento, alegar defectos de tramitación, especialmente los que supongan paralización, infracción de los plazos señalados o la omisión de trámites que pueden ser subsanados antes de la resolución definitiva del asunto. Dichas alegaciones podrán dar lugar, si hubiere razones para ello, a la exigencia de la correspondiente responsabilidad disciplinaria. Los interesados podrán, en todo caso, actuar asistidos de asesor cuando lo consideren conveniente en defensa de sus intereses. En cualquier caso, el órgano instructor adoptará las medidas necesarias para lograr el pleno respeto a los principios de contradicción y de igualdad de los interesados en el procedimiento".

${ }^{547}$ IBIDEM. Artículo 18: "Definición. El procedimiento administrativo es una sucesión de actos trámite vinculados entre sí, emanados de la Administración y, en su caso, de particulares interesados, que tiene por finalidad producir un acto administrativo terminal. El procedimiento administrativo consta de las siguientes etapas: iniciación, instrucción y finalización”.

${ }^{548}$ En esta vía administrativa, si bien no se exige la asistencia letrada, es altamente recomendable la comparecencia a través de abogado, especialmente por la imposibilidad del migrante de representarse personalmente y por la dificultad de entender los procedimientos e incluso en algunos casos, el idioma

${ }^{549}$ En general los servicios de asistencia jurídica gratuita en Chile, se circunscriben en lo que dice relación con la representación en tribunales y no ante órganos administrativos, como es el caso de los procedimientos administrativos migratorios que se tramitan ante las gobernaciones e intendencias. De hecho, las CAJ a través de sus Centro Jurídico y Social no se avocan a estas materias, existiendo solo una oficina especializada de Derechos Humanos en la ciudad de Santiago, que ejerce acciones administrativas, pero solo circunscritos a casos de esta ciudad. También Existen experiencias de Universidades en esta materia, pero tampoco de carácter territorial generalizado.
} 
reconocido, satisfaciendo una necesidad jurídica determinada, debiéndose en estos casos asegurar también el acceso a la justicia ${ }^{550}$.

Considerando la legislación en la materia, la jurisprudencia mediante la aplicación de tratados internacionales sobre derechos humanos ha intentado limitar la arbitrariedad y acortar la brecha que existe para los migrantes para acceder a la justicia y buscar la garantía de sus derechos. Esta manifestación se da tanto en la jurisprudencia constitucional como en la jurisprudencia de los tribunales superiores de justicia (CS y CA). En armonía con la lógica crítica de la regulación nacional en la materia, que ya hemos mencionado, destaca particularmente una sentencia del TC del año 2016, la cual estableció respecto de la legislación migratoria que "se trata de una norma pre-constitucional elaborada en 1975 y que refleja un esquema normativo de máxima discrecionalidad que admite masivas vulneraciones de derechos o alteraciones menores, dependientes del carácter compasivo o estricto de su invocación por las autoridades de turno"551. En relación al acceso a la justicia es relevante destacar que esta sentencia sostiene que "el deber estatal de residir es una cuestión sometida al derecho interno de cada Estado, pero cumpliendo las obligaciones propias del derecho Internacional. Lo anterior exige un particular cuidado en el ejercicio de la potestad administrativa y legislativa de cada Estado, con un examen de las limitaciones propias de los derechos fundamentales invocados"552. En este sentido, esto supone que la actuación de la autoridad administrativa debe garantizar los estándares de acceso a la justica que emanan del derecho Internacional.

\subsection{Políticas públicas y buenas prácticas de acceso a la justicia en Chile respecto de la población inmigrante}

\footnotetext{
${ }^{550}$ Por ejemplo, una mujer extranjera que no recibe aporte económico del progenitor de sus hijos para su manutención, debe ser amparada por el estado, con el objeto de concurrir debidamente representada ante un tribunal y exigir que se fije una pensión de alimentos suficientes para satisfacer las necesidades de todo orden que presenten sus hijos. En este caso la atención de las CAJ es universal, por lo cual su atención está garantizada, no obstante encontrarse los profesionales de este servicio con barreras, tales como el idioma o la no comprensión de los procedimientos en Chile.

${ }^{551}$ TC. Sentencia causa rol 2273-2016 de 4 de julio de 2016. Considerando $7^{\circ}$.

${ }^{552}$ IBIDEM. Considerando 11.
} 
Por mandato del DL 1094 vigente, la posibilidad de un extranjero de regularizar la situación migratoria y oponerse a los decretos de expulsión o de rechazo de visas de permanencia, se tramita ante entes meramente administrativos, no existiendo normativa legal que ampare los derechos en esta instancia administrativa. Ante este vacío, la jurisprudencia, la reglamentación administrativa (normas infralegales) y las políticas públicas, han debido desarrollar mecanismos para acortar la brecha de acceso a la justicia de la población migrante en Chile, reconociendo, por una parte, los derechos de la población migrante y, por otra, garantizando el derecho a un debido proceso.

Así, por ejemplo, respecto del reconocimiento de derechos, la administración ha dictado circulares y oficios interpretativos de la legislación migratoria y otros cuerpos normativos, para garantizar derechos sociales, tales como salud y educación ${ }^{553}$. Destacan en el ámbito de acceso a la justicia, la circular n 30.722 de 10 de septiembre del año 2014, del Departamento de Extranjería y Migración que "elimina la aplicación de sanciones migratorias a NNA" y el oficio n`575 de 10 de agosto del año 2015, de la Fiscalía Nacional que "imparte criterios de actuación en los delitos de trata de personas y tráfico ilícito de migrantes".

Es del caso indicar, que en el más reciente instructivo general sobre una política migratoria en Chile, de 6 de noviembre de 2018, establece lineamientos e instrucciones para la implementación y desarrollo de ésta, instituyendo como uno de los ejes, precisamente, el acceso a la justicia en condiciones de igualdad ${ }^{554}$. En aplicación de este instructivo, por ejemplo, y con el fin de avanzar hacia la garantía del debido proceso, las Intendencias deberán seguir realizando, de oficio, audiencias públicas para que los(as) migrantes puedan ser oídos en los procedimientos de expulsión. Estas audiencias, si bien no tienen regulación legal,

\footnotetext{
${ }^{553}$ NASH, C; NUÑEZ, C; TRONCOSO, C. Op. Cit., p.330. "Resolución exenta n 1914 'Aprueba convenio de colaboración celebrado entre los ministerios de salud e interior'. Oficio ordinario $n^{\circ}$ 07/1008 'instruye sobre el ingreso, permanencia y ejercicio de los derechos de los alumnos inmigrantes en los establecimientos educacionales que cuentan con reconocimiento oficial', entre otros".

${ }^{554}$ IBIDEM. "El gobierno procurará que las y los migrantes, en condición de igualdad con la población nacional, cuenten con asistencia y representación pata los procedimientos en que sean parte, incluido en los casos que se encuentren privados de libertad. A su vez, el gobierno deberá velar por informar oportunamente a las y los migrantes de sus derechos y proveerá los mecanismos que le permiten comprender los procedimientos judiciales y administrativos en los que participen”.
} 
se han desarrollado desde el año 2015 como una medida administrativa por parte de este organismo, para darle oportunidad a los(as) migrantes de presentar antecedentes favorables para regularizar su situación migratoria y dejar sin efecto la órdenes de expulsión del país.

Como parte de las políticas públicas, destaca en el ámbito del derecho a defensa, la existencia de una unidad de DPP en materia migratoria en cuanto a la comisión de delitos ${ }^{555}$, existiendo aún déficit en la asistencia jurídica en lo relativo a la regularización, permanencia y oposición a expulsión, entre otras. Esta debilidad en cuanto a la defensa jurídica gratuita estatal, radica en que la asistencia especializada solo se ofrece por las clínicas jurídicas de algunas Universidades y por la oficina de derechos humanos de la CAJ, que solo tienen presencia en la Región Metropolitana. Además se debe considerar el Protocolo Intersectorial de Atención a Víctimas de Trata de Personas, que establece la coordinación de las instituciones que prestan asistencia de diversa índole a víctimas del delito de trata de personas a objeto de garantizar el efectivo ejercicio de los derechos de las víctimas.

En atención a las múltiples deficiencias de la actual regulación y por una decisión de gobierno de normar el ingreso de extranjeros a territorio nacional y establecer procedimientos claros en cuanto a su permanencia y eventual expulsión, se presentó un proyecto ley por el ejecutivo con fecha 4 de junio de $2013^{556}$, que con fecha 20 de mayo de 2020, en su segundo trámite constitucional, fue despachada desde la Comisión de Derechos Humanos del Senado y pasó a su símil de hacienda, última instancia que revisará el texto antes de ser vista en sala ${ }^{557}$. Este proyecto suprime la criminalización de la permanencia irregular y establece un sistema de obtención de visa temporal solo fuera de Chile. Si bien fija un

\footnotetext{
${ }^{555}$ DPP. www.dpp.cl/pag/169/381/defensa_de_personas_extranjeras_y_migrantes>. [Consulta 14 de febrero de 2020].

${ }^{556}$ Boletín 8970-06. Proyecto de ley sobre migración y extranjería, de 20 de mayo de 2013. "El Estado aún no asume su deber de establecer una institucionalidad, además de declarar que el actual proyecto no representa un avance significativo en el respeto de los derechos fundamentales de los y las migrantes, ni garantiza adecuadamente el principio de reunificación familiar y las garantías del debido proceso de las personas migrantes ante la decisión de expulsión o rechazo de visas de residencia”.

${ }^{557}$ El ejecutivo además le puso urgencia de discusión inmediata, es decir 6 días para der despachada Por otra parte, ha sido considerado por el bloque opositor y por asociaciones de inmigrantes como un intento de frenar el fenómeno migratorio y el legítimo derecho de otros nacionales de residir en el país.
} 
procedimiento de expulsión más expedito, en que se otorga un plazo de 7 días para poder reclamar la expulsión, consagrando expresamente un derecho de reclamación por vía administrativa, continua primando la ausencia de la concesión de medios adecuados para la defensa, y lo más relevante, que el proceso sigue siendo administrativo y no judicial, con las garantías debidas.

Es preciso mencionar, que desde octubre de 2018, ante la falta de condiciones dignas de trabajo, vivienda y acceso a servicios básicos por una parte de la población migrante en nuestro país, el gobierno ha impulsado un "Plan humanitario de regreso ordenado" 558 , medida que permite el retorno de personas extranjeras, que de forma voluntaria manifiesten su intención de regresar a su país, ya sea de manera individual o en grupos familiares. El programa consiste en facilitar a través de aviones financiados por el gobierno de Chile, el traslado a su país de origen a ciudadanos que así lo soliciten, previa evaluación de requisitos y estableciendo una prohibición de ingreso al país en un tiempo determinado (9 años). Este plan que en principio puede ser considerado positivo, por su carácter humanitario, y obedecer a una lógica de responsabilidad del Estado, sostenemos que la prohibición de reingreso al país por un plazo de tiempo importante, presenta la infracción al derecho de elegir su lugar de residencia y de la libertad ambulatoria que le permite ingresar y salir libremente de él cuando lo estime conveniente. En esta línea de razonamiento, un fallo de la CA de Santiago, de 10 de junio de 2020, acogió un recurso de amparo presentado en el marco del plan humanitario, por un grupo de ciudadanos colombianos, que debido a las condiciones que se encontraban en Chile, especialmente por la crisis sanitaria del Covid 19, se les estaba exigiendo la firma de declaración de no retornar al país por un plazo de 9 años, lo que la Corte consideró una exigencia ilegal y arbitraria.

Por su parte, nos parece altamente discriminatorio y arbitrario, por establecer limitaciones para connacionales de un país determinado, el Decreto $n^{\circ} 42.386^{559}$,

\footnotetext{
${ }^{558}$ SECRETARIA GENERAL DE GOBIERNO. https://www.chileatiende.gob.cl/fichas/56635-planhumanitario-de-regreso-ordenado. [Consulta 22 de febrero de 2020]. "Pueden postular a este beneficio los extranjeros que habiten en Chile, sin importar su situación migratoria, a excepción de personas provenientes de países limítrofes. Se dará prioridad a los grupos familiares con hijos e hijas, y personas con problemas de salud. El grupo familiar deberá retornar de forma conjunta”.

${ }^{559}$ DECRETO 43.286, de 20 de junio de 2019.
} 
emanado del Ministerio del Interior y Seguridad Pública, publicado en el diario oficial el 22 de junio de 2019, que estableció como requisito para el ingreso al país de todo ciudadano venezolano, con fines de recreo, deportivos, religiosos u otros similares, la obtención de "visa consular de turismo simple", con derecho a ingreso y permanencia en Chile, en tal calidad, por un período máximo de 90 días, estando prohibido residir, realizar actividades remuneradas o con fines migratorios. Se fundamenta el Decreto en el alto flujo migratorio de aquel país y que al parecer del gobierno era necesario establecer para este grupo y no para otros, una barrera legal de entrada, pues a partir de esa fecha solo ingresan a Chile ciudadanos de esa nacionalidad, para fines turísticos o afines, por un plazo máximo definido, no pudiendo trabajar ni establecerse en nuestro país con fines migratorios.

\subsection{Alcances de la jurisprudencia migratoria en Chile}

Al no existir un recurso judicial específico en materia migratoria (salvo el referido con el plazo de 24 horas) se han utilizado las acciones de reclamación y amparo constitucional frente a la vulneración de derechos, las que tienen ciertas diferencias, principalmente, en cuanto a tribunal competente y plazos de interposición ${ }^{560}$. Así, por ejemplo, en el contexto de acciones de amparo, la jurisprudencia ha dejado sin efecto órdenes de expulsión, donde no se garantiza un debido proceso ${ }^{561}$.

De esta manera, la jurisprudencia nacional entiende que los migrantes, frente a órdenes de expulsión, deben tener derecho de acceso a la justicia, más allá de buenas prácticas de las intendencias en los términos ya descritos, sino que implica

\footnotetext{
${ }^{560}$ En cuanto al recurso de reclamación solo procede ante la CS y tiene un plazo limitado para su interposición, mientras que el recurso de amparo, se interpone ante las CA, siendo susceptible de ser apelada antes la CS, y no se encuentra sujeta a un plazo para su presentación.

561 CA de COPIAPO. Sentencia causa rol 290-2015, de 20 de octubre de 2015. En el mismo sentido: CA de Santiago Sentencia causa rol 2083-2015 de 4 de diciembre de 2015. “Así las cosas, la medida de expulsión se funda en la existencia de un debido proceso, en que la persona tuvo derecho a ser oída, a contar con defensa letrada, a presentar pruebas y a ejercer los medios de impugnación que procedan. Sin embargo, en ese caso ninguno de estos supuestos se da, ya que según los documentos acompañados por la recurrida, la denuncia se efectuó el mismo día que la intendencia regional se desistió de ella, lo que no permitió la existencia de un proceso previo tramitado conforme a los estándares nacionales e internacionales de debido proceso”.
} 
en todos los casos y a todo evento o circunstancia, el derecho de ser oídos, contar con defensa letrada, presentar pruebas y ejercer medios de impugnación.

No obstante, el déficit legislativo detectado en el acto y procedimiento administrativo de expulsión y los escasos avances en la materia, analizaremos a continuación, algunas sentencias de nuestras Cortes, que permitirá visualizar una evolución respecto de la temática migratoria, en cuanto a un abordaje desde una perspectiva de protección especial a los inmigrantes como grupo vulnerable.

La CS entiende que el inmigrante, como potencial sujeto de abusos, requiere un cuidado especial. Este presupuesto es la base que sustenta la jurisprudencia migratoria y por eso la corte pone tanto énfasis en las condiciones del inmigrante ${ }^{562}$.

En relación a las ordenes o decretos de expulsión, los recursos de amparo y reclamación que se promovieron ante nuestras Cortes, se basaron en denegación a visas de residencia, o porque de oficio, a juicio de la autoridad administrativa, el extranjero ha incurrido en ciertas causas que motivan su expulsión, dentro de las que destacan, el ingreso al país, no obstante estar bajo las prohibiciones del artículo $15^{563}$ del DL 1094, o que durante su residencia haya incurrido en actos u omisiones también previstos en aquél artículo564.

Durante el período 2016-2017, de un total de 137 casos, en 92 oportunidades la CS ministros declaró ilegal el decreto de expulsión, versus 45 veces que desecharon la pretensión del extranjero. Por tanto, en el $67,15 \%$ de las veces la CS falló a favor del inmigrante ${ }^{565}$. La CS, en general, resuelve a favor del inmigrante y esta tendencia va en aumento. Recordemos que la normativa migratoria establece que si un extranjero ingresa ilícitamente al territorio nacional o incurre en las causales

\footnotetext{
562 OBSERVATORIO JUDICIAL. Op. Cit., p.7

563 A modo ejemplar, condenados por delitos comunes en su país, los que sufran enfermedades respecto de las cuales la autoridad sanitaria chilena que constituyen casual de impedimento para ingresar al territorio nacional.

564 Dentro de estas hipótesis, se encuentra dedicarse al comercio o tráfico ilícito de drogas o armas, al contrabando, al tráfico ilegal de migrantes y trata de personas y, en general, los que ejecuten actos contrarios a la moral y a las buenas costumbres, como asimismo los que no tengan o no puedan ejercer profesión u oficio, o carezcan de recursos que les permitan vivir en Chile sin constituir una carga social.

${ }^{565}$ OBSERVATORIO JUDICIAL. Op. Cit., p. 8. "Otro dato resulta de comparar el número de recursos de amparo acogidos por las CA, en comparación con la CS. Durante el año 2016 y 2017 las cortes de apelaciones acogieron un total de 71 recursos de amparo; en término porcentuales se traduce en un 51,8\% de recursos acogidos. Mientras que, la CS en el mismo período resolvió a favor del inmigrante en el 67,15\% de las ocasiones
} 
de expulsión legales, es obligación de la autoridad administrativa disponer la expulsión. Como ya se ha adelantado, La CS ha puesto coto a este imperativo legal mediante dos estrategias jurisprudenciales: el "germen de arraigo" y la exigencia de una investigación penal ${ }^{566}$.

Al avocarse a la tarea de rechazar o acoger un amparo o una reclamación, la CS analiza cuál es la situación familiar y laboral del inmigrante en situación irregular. En la medida que éste cuente con un núcleo familiar en Chile (hijos, cónyuge o conviviente) y/o acredite algún vínculo laboral estable, se ha ordenado anular el decreto de expulsión.

${ }^{566}$ IBIDEM. p.9 
Bajo este razonamiento, situaciones como convivir con un ciudadano chileno ${ }^{567}$; estar embarazada ${ }^{568}$; tener hijos menores nacidos en chile ${ }^{569}$; vivir con su familia ${ }^{570 ;}$ contar con una fuente de ingresos que permita subsistir en el territorio nacional ${ }^{571}$; o tener un trabajo estable son condiciones ${ }^{572}$, a juicio de la alta magistratura nacional, hacen desaparecer el sustento fáctico y jurídico que justifica el decreto de expulsión. En concepto de la CS, el interés superior del Niño migrante y la unidad Familiar son principios jurídicos que prevalecen sobre la normativa migratoria. En efecto, se sostiene en el estudio del Observatorio Judicial, que "en consecuencia, si existe un germen de arraigo (razona la CS), entonces el decreto de expulsión debe tener una fundamentación más allá de las normas formales. En este sentido se reconoce que en el caso concurren los supuestos que habilitan a la administración para expulsar al inmigrante, sin embargo, la existencia de un germen de arraigo es una circunstancia que permite dejar sin efecto la normativa migratoria, ya que hay bienes jurídicos más importantes que serían vulnerados (por ejemplo, integridad del niño) si se llevase a efecto el decreto de expulsión"573.

Existen casos donde el inmigrante no cuenta con un germen de arraigo, ya sea por carecer de algún vínculo familiar o laboral en el país. Para hacer frente a estas circunstancias, nuestro máximo tribunal ha construido una jurisprudencia que se puede calificar de "novedosa", que consiste en condicionar la potestad sancionatoria de expulsión a la existencia de un juicio penal, donde se acredite el efectivo ingreso clandestino de un inmigrante, cuando se le está aplicando esa causal de expulsión ${ }^{574}$. Se debe tener presente que actualmente, ante el ingreso clandestino de un inmigrante, el Intendente Regional realiza la respectiva denuncia para iniciar un proceso penal e Inmediatamente después se desiste de la acción, aparejando

\footnotetext{
567 CS. Sentencia causa rol n 19144-2017, de 22 de mayo de 2017.

568 IBIDEM. Sentencia causa rol n 11650-2017, de 10 de abril de 2017.

569 IBIDEM. Sentencia causa rol n 7007-2017, de 7 de marzo de 2017.

570 IBIDEM. Sentencia causa rol n 65406-2016, de 15 de septiembre de 2016.

571 IBIDEM. Sentencia causa rol n 101756-2016, de 4 de enero de 2017.

572 IBIDEM. Sentencia causa rol n 16034-2016, de 1 de marzo de 2016.

573 OBSERVATORIO JUDICIAL. Op. Cit., pp. 10-11. "Respecto al germen de arraigo dado por la existencia de un vínculo laboral, la Corte no invoca norma o principio jurídico que prime sobre la Ley de Migración. En estos casos la segunda sala se limita únicamente a decir que la existencia de una relación laboral es signo de un germen de arraigo, que por sí sólo permite soslayar la sanción de expulsión”.

574 IBIDEM.
} 
dos consecuencias. La primera, que corresponde a la extinción de la responsabilidad penal del inmigrante, y la segunda, que habilita a la administración a dictar el decreto de expulsión, lo que vulnera el debido proceso y atenta contra el acceso a la justicia de este grupo. Precisamente, la jurisprudencia elaborada por la CS consiste en negar el segundo efecto del desistimiento de la acción penal, a saber, expulsar al inmigrante clandestino. La Excelentísima corte, sostiene que el Ministerio del Interior (y la Intendencia Regional) que es el único que puede iniciar un proceso punitivo, al desistirse de acción penal, impide se investigue la efectividad del ingreso clandestino al país. Luego al no estar acreditado el ingreso clandestino es improcedente expulsar al inmigrante ${ }^{575}$. Con esta interpretación, a nuestro entender, se asegura el derecho del migrante de mantenerse en el país ${ }^{576}$.

Para finalizar, haremos referencia a una sentencia de la CA de Talca, rol 149-2020, de 4 de agosto del año 2020, caratulada "Sarai Perches Ferrabus y otros con Departamento de Extranjería y Migración del Ministerio del Interior" en el que tuvimos la posibilidad de intervenir como abogado patrocinante, alegando el recurso ante la ilustrísima CA. En esta sentencia, se acoge un recurso amparo presentado por una familia venezolana, dejándose sin efecto resoluciones administrativas de la Gobernación, las cuales denegaban visas temporarias para los integrantes de la familia, no obstante cumplirse el requisito para su procedencia, establecido en el artículo 29 del DL 1.094, consistente en acreditar la existencia de vínculos de familia e intereses en Chile, como asimismo la ventaja o utilidad de su permanencia. Las resoluciones impugnadas no se hicieron cargo de las fundamentaciones de arraigo social y laboral, solo señalándose como fundamento la aplicación del Decreto 43.286 de 22 de junio de 2019, que fue aplicado sin efectuar una interpretación adecuada del mismo. Esta sentencia de la Corte de Talca, aplica los principios protectores en forma acertada, destacando entre otros, el interés superior del niño

\footnotetext{
575 CS. Sentencia causa rol n 37160- 2017, de 21 de agosto de 2017. Sentencia causa rol 38.057-2017 de 21 de misma fecha.

576 OBSERVATORIO JUDICIAL. Op. Cit., p.11. “A juicio del ministro de la CS, Lamberto Cisterna: “en ausencia de sentencia penal que establezca, más allá de toda duda razonable, el ingreso clandestino, se entiende que todo decreto de expulsión es ilegal y arbitrario, pues la ley faculta a la autoridad para desistirse y el razonamiento de la Corte es que en ese caso se deja sin bases el hecho. Si la autoridad no permite que eso se investigue, queda sin bases la expulsión y por eso le damos la razón.
} 
migrante y a la protección de la unidad familiar. Para una mayor claridad, me he permitido reproducir algunos párrafos de la parte considerativa y resolutiva del referido fallo. El considerando sexto desarrolla la idea de la arbitrariedad del acto administrativo y carencia de fundamento que motivan la resolución. Se expresa "que de un análisis de las resoluciones administrativas impugnadas se advierte la carencia de toda motivación, en atención a que no se precisan razones fundadas por las cuales se desestima la solicitud del clan familiar al que pertenecen los recurrentes, salvo el de señalar que no contaban con visto bueno de turismo, exigencia que solo comenzó a regir en territorio nacional a partir del 22 de junio del año pasado, en circunstancia que el ingreso a la República de Chile de todos los integrantes, del cual los integrantes forman una sola familia, fue anterior a esa fecha $y$, por ende, no les resulta aplicable la normativa que a este respecto contempla el Decreto $\mathrm{n}^{\circ} 42.386$ emanado del Ministerio del Interior y Seguridad Pública, publicado en el Diario Oficial el 22 de junio de 2019, que estableció como requisito para el ingreso al país de todo ciudadano venezolano, con fines de recreo, deportivos, religiosos u otros similares, la obtención de visa consular de turismo simple, con derecho de ingreso y permanencia en Chile, en tal calidad, por un periodo máximo de 90 días. El propio decreto expresamente señala en su acápite final, que lo dispuesto allí comenzaría a regir a contar de la total tramitación de dicho decreto, el cual debe entenderse afinado con la publicación precitada"577.

En el considerando séptimo se recepciona la teoría del germen de arraigo y la protección a los principios aludidos. E expresa que "en este orden de ideas, los recurrentes Nerio Enrique González Higuera y Sarai Katherine Perche Ferrabus,

\footnotetext{
${ }^{577}$ Precisamente en el considerando octavo se refuerza este razonamiento al señalar “que todo lo antes expuesto se infiere claramente que la decisión del organismo estatal recurrido en orden a expulsar del territorio nacional a todos los recurrentes constituye un acto ilegal que vulnera derechos fundamentales como acontece con la libertad ambulatoria y la seguridad individual, consagradas en el artículo $19 \mathrm{n}^{\circ} 7$ de la CPR, en atención a que se está afectando derechos humanos que deben ser reconocidos y protegidos a la brevedad y en todo momento, como lo exige el artículo $5^{\circ}$ de nuestra Carta Fundamental. En concordancia con ésta última normativa, el PIDCP y la $\mathrm{CADH}$, tratados internacionales ratificados por Chile y, por consiguiente, obligatorios, en su artículo 9 del PIDCP consagra el derecho de todo individuo a la libertad y seguridad individual; donde toda persona que se halle legalmente en el territorio de un Estado tiene derecho a circular libremente en él su residencia. En el caso puntual de los recurrentes ellos ingresaron legalmente a Chile y han permanecido en esa calidad desde hace más de un año a la fecha, por lo que su situación jurídica debe mantenerse inalterable, al no haber incurrido en dicho lapso en ningún acto contrario a derecho”.
} 
no registran antecedentes penales pretéritos, tanto en su país de origen ni tampoco durante todo el tiempo que han permanecido en la República de Chile, que se justifiquen en la expulsión del territorio nacional, sino que por el contrario, de los documentos allegados se estima que cuentan con arraigo laboral y social, y además uno de sus integrantes, Adonay de 10 años de edad, está cursando estudios regulares en la escuela sargento $2^{\circ}$ Daniel Rebolledo de Talca. Cabe consignar que respecto del menor Adonay González Perche, que también forma parte de la familia referida, mediante resolución exenta $n^{\circ} 4.447$ de 8 de noviembre de 2019, se le otorgó visa temporaria por un año, lapso que aún no ha transcurrido y, sin embargo, sin que exista ningún hecho sobreviviente, se ha librado en contra de sus padres la decisión de expulsión del país por parte del Departamento de Extranjería y Migración del Ministerio del Interior y Seguridad Pública, vulnerando con ello gravemente el derecho de todo menor de edad de vivir con sus padres cuando existan razones graves para ello" 578 .

Como corolario de todo lo razonado por este fallo, la corte resuelve en su considerando décimo "que atento a todo lo antes esgrimido, no cabe más que considerar ilegal el acto por el cual el Departamento de Extranjería y Migración dispuso la expulsión de la familia, por lo que es menester dictar las medidas conducentes para reestablecer el imperio del derecho y asegurar la debida protección de los afectados, razón por la cual se dejará sin efecto la medida de expulsión de todos los recurrentes y de cualquiera otra decisión, que fundada en el decreto $n^{\circ}$ 42.386, publicada en el Diario Oficial de 22 de junio de 2019, los obligue hacer abandono del país".

\footnotetext{
${ }^{578}$ En concordancia con en ello la cláusula novena expresa: “Que a mayor abundamiento, es importante hacer presente que el artículo $1^{\circ}$ del texto constitucional, reconoce a la familia como el núcleo fundamental de la sociedad, por lo que cualquier acto contrario a dicho principio debe ser erradicado absolutamente, más aún cuando el cumplimiento del decreto de expulsión en que se sustenta la acción de amparo interpuesta, en los términos expedidos, significa alejar injustificadamente a uno de sus miembros, transgrediendo con ello el principio universal del interés superior del NNA, más aún en época de pandemia mundial, como acontece con el Covid 19. A este respecto, el artículo 9 de la CIDN, del cual nuestro país es parte, en el artículo $9 \mathrm{n}^{\circ} 1$ dispone que los Estados velarán para que el niño no sea requerido de sus padres contra la voluntad de éstos”.
} 


\section{MUJERES VÍCTIMAS DE VIOLENCIA DE GÉNERO}

\subsection{Aspectos Preliminares}

Pareciera un contrasentido aseverar que las mujeres forman parte de un grupo minoritario y pese vulnerable, y que los actos de violencia que sufren tengan por el Estado un tratamiento diferenciado. Deberían en principio, ser tratados como cualquier tipo de violencia, sin embargo el carácter discriminatorio y sexista que reviste la violencia contra ellas, como un elemento estructural dentro de la sociedad, la configura como una situación que debe ser observada, regulada jurídicamente y protegida de forma especial ${ }^{579}$.

Lamentablemente la violencia de género, que tiene su base en las ideas, normas y comportamientos que la sociedad ha establecido para cada sexo, como asimismo el valor y significado que les asigna, el que claramente sitúa al hombre en una situación asimétrica de superioridad, en variados ámbitos, en el espectro universal, regional y por supuesto en Chile, (marido es considerado jefe de la sociedad conyugal, enfoque sexista en el aula, disparidad en la tasa de empleabilidad laboral, escala remuneracional y un largo listado de etcéteras), perpetúan las desigualdades y discriminación. La Convención sobre la Eliminación de Todas las Formas de Discriminación contra la Mujer (CEDAW), define a la discriminación contra las mujeres como "toda distinción, exclusión o restricción basada en el sexo que tenga por objeto o resultado menoscabar o anular el reconocimiento, goce o ejercicio por la mujer, independientemente de su estado civil, sobre la base de la igualdad del hombre y la mujer, de los derechos humanos y las libertades fundamentales en las esferas política, económica, social, cultural y civil o en cualquier otra esfera"580. Por su parte, violencia contra de las mujeres, es considerada según la Convención Interamericana para Prevenir, Sancionar y Erradicar la Violencia contra la Mujer,

\footnotetext{
${ }^{579}$ A mayor abundamiento, cuando los actos de violencia ocurren debido a condiciones biológicas de la víctima y las consecuencias sociales culturalmente atribuidas a ellas, dichos actos deben ser tratados y combatidos con especial ahínco.

${ }^{580}$ CEDAW. Artículo 1.
} 
como "cualquiera acción o conducta basada en su género, que cause muerte, sufrimiento físico, sexual, psicológico y económico o cualquier tipo de daño ya sea que tenga lugar dentro de la familia o en cualquier relación interpersonal que ocurra en la comunidad y sea perpetrada por cualquier persona y/o que sea perpetrada 0 tolerada por el estado o sus agentes, donde quiera que ocurra, tanto en el ámbito público o privado" 581 . Lo anterior traspasa a la concepción de violencia contra la mujer, que establece nuestra legislación, y que solo contempla la violencia producida en el ámbito de las relaciones de familia, por el cónyuge, ex cónyuge, conviviente o ex conviviente o respecto de aquellas que tienen un hijo en común con el agresor.

Desde hace varias décadas el sistema de protección de los derechos humanos y la comunidad internacional han afirmado que la violencia contra las mujeres tiene en su base la discriminación que las afecta y constituye una violación a los derechos humanos, partiendo de la dignidad intrínseca de las personas, pudiendo afectar la igualdad, la libertad, la vida, la integridad, la salud, y el acceso a la justicia, cuando el Estado no responde a los requerimientos de las víctimas, requiriéndose un acceso real que permita a las mujeres víctimas de violencia solicitar a la administración de justicia, una pronta, oportuna y eficaz solución a la situación que les afectan.

En los últimos años ha habido un avance, aunque aún insuficiente, en el terreno normativo a favor de la consagración de los derechos de las mujeres, tanto en el ámbito de los tratados internacionales como de la legislación local. Sin embargo, diversos estudios coinciden en constatar que en el sistema de justicia estatal y en la sociedad en general, persisten prácticas discriminatorias, tanto en el ámbito doméstico como sexual ${ }^{582}$.

Tal como lo sostienen Arbeláez y Ruíz, "la situación de falta de oportunidades para el logro de la equidad es la que conduce al surgimiento de fenómenos sociales de vulnerabilidad y discriminación. De ahí que se haya visto un aumento en el

\footnotetext{
581 CONVENCION INTERAMERICANA PARA PREVENIR, SANCIONAR Y ERRADICAR LA VIOLENCIA CONTRA LA MUJER. Artículo 1.

${ }^{582}$ LOVATÓN, D. Op. Cit., p. 266.
} 
porcentaje de mujeres con disminución progresiva de recursos no solo económicos, sino también en cuanto a redes de participación socio laboral y de protección judicial"583.

Es necesario que el Estado asegure el derecho de la mujer víctima a denunciar la violencia que las afecta, a que los hechos sean investigados y que los agresores reciban la sanción correspondiente, velando por la prevención y la reparación, pues solo bajo el cumplimiento de esos presupuestos, se garantizará respecto de ellas, un efectivo acceso a la justicia, y con ello, se establecerán mecanismos de compensación a la situación de discriminación y asimetría en que se encuentran ${ }^{584}$. La superación de esta realidad, puede lograrse con medidas legislativas, con actividades nacionales y de cooperación internacional en diversas esferas, tales como el desarrollo económico y social, la atención a la maternidad, a la salud y al apoyo social, pero por sobre todo con la educación, tanto en el ámbito escolar, como en los propios hogares, en pos de forjar desde la infancia, cambios de paradigmas sociales y relacionales, en torno a repudiar la violencia de género y su normalización.

\subsection{Normativa internacional aplicable y obstáculos al acceso a la justicia de las mujeres víctimas de violencia}

En este escenario es inevitable reconocer que en América Latina, las normas nacionales e internacionales llaman la atención de los Estados, pero no logran ser un canal adecuado y completo de protección, pues tal como se sostiene por el Comité de la CEDAW "las mujeres siguen siendo objeto de importantes actos y

\footnotetext{
583 ARBELAEZ DE TOBON, L y RUIZ, E. Op. Cit., p. 14.

${ }^{584}$ La violencia y todas las formas de acoso y explotaciones sexuales, en particular las derivadas de prejuicios culturales, son incompatibles con la dignidad y la vida de la persona humana y deben ser eliminadas.
} 
conductas discriminatorias, subrayando que la discriminación viola los principios de igualdad de derechos y del respeto de la dignidad humana" 585 .

En el concierto internacional, Chile participa del SUDH y del SIDH reconociendo y aprobando como vinculantes, sus principios y normas en materia de igualdad y no discriminación, que de suyo debe observar de manera integral y dialéctica el juez. Se ha incorporado a su vez al bloque de constitucionalidad, las normativas internacionales atingente ya referidas, principalmente la CEDAW, aprobada por la Asamblea General de la ONU en 1979 y ratificada por Chile el 7 de diciembre de 1989, y la Convención Interamericana para Prevenir, Sancionar y Erradicar la violencia contra la mujer de 6 de septiembre de 1994, conocida como Convención Belem do pará, ratificada por Chile el 15 de noviembre de 1996.

La propia Asamblea General de la ONU, al establecer menciones y deberes especiales en relación a mujeres víctimas de violencia enfatiza la necesidad de adoptar medidas que contribuyen a garantizar el efectivo acceso a la justicia en condiciones de igualdad. La Declaración de reunión de alto nivel de la Asamblea General sobre el Estado de Derecho, en resolución de 24 de septiembre de 2012, es del siguiente tenor "reconocemos la importancia de lograr que las mujeres, sobre la base de la igualdad del hombre y la mujer, disfruten plenamente de los beneficios del Estado de Derecho; nos comprometemos a utilizar las leyes para defender la igualdad de sus derechos y conseguir su participación plena y en pie de igualdad, incluso en las instituciones de gobernanza y el sistema judicial, y renovamos el compromiso de establecer marcos jurídicos y legislativos adecuados para prevenir y combatir todas las formas de discriminación y violencia contra la mujer y asegurar su empoderamiento y pleno acceso a la justicia"586.

En este ámbito, el acceso a la justicia efectivo, exige el diagnóstico y remoción de barreras de género que se van presentando, y que la estructura social y del Estado debe remover. Los obstáculos en el acceso a la justicia, principian con el no

${ }^{585}$ COMITÉ CEDAW. (2004). Recomendación General número 25 sobre medidas especiales de carácter temporal.

${ }^{586}$ ORGANIZACIÓN DE NACIONES UNIDAS (2012). Resolución de 24 de septiembre de 2012. Declaración de reunión de alto nivel de la Asamblea General sobre el Estado de Derecho. 
reconocimiento de una situación desventajada de la mujer en diversos ámbitos ${ }^{587}$. En el sistema de justicia, las mujeres son víctimas de prejuicios y estereotipos de género negativos que sesgan la toma de decisiones al fallar, además de promover situaciones de múltiple discriminación y la revictimización. Otra barrera de género de trascendencia es la mencionada ausencia de servicios jurídicos especializados para mujeres ${ }^{588}$.

En lo referente a la esencialidad del derecho de acceso a la justicia para asegurar el pleno ejercicio de sus derechos, resulta pertinente examinar la recomendación General $n^{\circ} 33$ de 3 de agosto de 2015 del Comité CEDAW, sobre el Acceso de las Mujeres a la Justicia. En el apartado I denominado Introducción y Ámbito, se enumeran 13 puntos que se traducen en premisas sobre el fenómeno de la violencia contra las mujeres y la discriminación que se presenta a su respecto, como asimismo, recomendaciones e instrucciones concretas para los Estados en cuanto a la propiciar un pleno y efectivo goce y ejercicio de sus derechos.

Los puntos centrales de esta recomendación, son los que se tratan a continuación ${ }^{589}$ :

a) El derecho de acceso de las mujeres a la justicia es esencial para la realización de todos los derechos protegidos en virtud de la CEDAW. Es un elemento fundamental del Estado de Derecho y la buena gobernanza, junto con la independencia, la imparcialidad, la integridad y la credibilidad de la judicatura, la lucha contra la impunidad y la corrupción, y la participación en pie de igualdad de la mujer en la judicatura y otros mecanismos de aplicación de la ley.

\footnotetext{
${ }^{587}$ ARBELAEZ DE TOBON, L y RUIZ, E. Op.Cit.p.20. "El análisis de los obstáculos de acceso a la justicia desde la perspectiva de género permite tomar en cuenta cómo los factores económicos, geográficos, sociales y culturales, afectan de manera diferenciada a mujeres y hombres, confirmando que en la mayoría de los casos las mujeres se encuentran en situación de desventaja, pese a la existencia de tratados específicos como la Convención de Belem Do Pará y la CEDAW que reconocen su derecho a acceder a recursos judiciales idóneos y efectivos"

${ }_{588}$ IBIDEM.

${ }^{589}$ COMITÉ CEDAW. (2015). Recomendación General número 33 sobre el acceso de las mujeres a la justicia.
} 
b) El derecho de acceso a la justicia es pluridimensional. Abarca la justiciabilidad, la disponibilidad, el acceso, la buena calidad, el suministro de recursos jurídicos para las víctimas y la rendición de cuentas de los sistemas de justicia.

c) Las obligaciones específicas del Estado en cuanto a promover un efectivo acceso a la justicia, abarcan la protección de los derechos de la mujer contra todas las formas de discriminación a fines de empoderarlas como individuos y titulares de derechos. El acceso efectivo a la justicia optimiza el potencial de emancipación y de transformación del derecho.

d) Los obstáculos y restricciones que impiden a la mujer realizar su derecho de acceso a la justicia en pie de igualdad, incluyen una falta de protección jurisdiccional efectiva de los Estados partes en relación con todas las dimensiones del acceso a la justicia. Esos obstáculos se producen en un contexto estructural de discriminación y desigualdad, debido a factores como los estereotipos de género, las leyes discriminatorias, los procedimientos interseccionales o compuestos de discriminación, las prácticas y los requisitos en materia probatoria, y al hecho de que no ha asegurado sistemáticamente que los mecanismos judiciales son física, económica, social y culturalmente accesibles a todas las mujeres. Todos estos obstáculos constituyen violaciones persistentes de los derechos humanos de las mujeres.

e) Se deben reformar y mejorar los procedimientos y la calidad de la justicia para las mujeres a todos los niveles de los sistemas de justicia, incluidos los mecanismos especializados y cuasi judiciales ${ }^{590}$.

f) El ámbito del derecho de acceso a la justicia incluye también los sistemas de justicia plural. El término "sistemas de justicia plural" se refiere a la coexistencia, dentro de un Estado parte, de las leyes estatales, los reglamentos, los procedimientos y las decisiones, por una parte, y las leyes y prácticas comunitarias,

\footnotetext{
590 Los mecanismos cuasi judiciales comprenden todas las acciones de los órganos o dependencias administrativas públicas, similares a los que realiza la judicatura, que tienen efectos jurídicos y pueden afectar a los derechos, deberes y prerrogativas jurídicos.
} 
religiosas, consuetudinarias o indígenas, por la otra. Por lo tanto, los sistemas de justicia plural incluyen múltiples fuentes de derecho, ya sea oficiales u oficiosas, estatales, no estatales y mixtas, que pueden encontrar las mujeres cuando procuran ejercer su derecho de acceso a la justicia.

g) Los tratados y declaraciones internacionales y regionales de derechos humanos y la mayoría de las constituciones nacionales contienen garantías relativas a la igualdad de sexo y/o género ante la ley y una obligación de asegurar que todos saquen provecho de la protección de la ley en condiciones de igualdad ${ }^{591}$.

h) En virtud del párrafo a) del artículo 5 de la Convención, los Estados partes tienen la obligación de exponer y eliminar los obstáculos sociales y culturales subyacentes, incluidos los estereotipos de género, que impiden a las mujeres el ejercicio y la defensa de sus derechos e impiden su acceso a recursos efectivos.

i) La discriminación contra la mujer, sobre la base de los estereotipos de género, la estigmatización, las normas culturales dañinas y patriarcales y la violencia basada en el género, que afectan particularmente a las mujeres, tienen efectos adversos sobre la capacidad de éstas para obtener acceso a la justicia en pie de igualdad con los hombres. Además, la discriminación contra la mujer se ve agravada por factores interseccionales que afectan a algunas mujeres en diferente grado o de diferente forma que a los hombres y otras mujeres. Las causas de la discriminación interseccional o compuesta pueden incluir la etnia y la raza, la condición de minoría o indígena, el color, la situación socioeconómica y/o las castas, el idioma, la religión o las creencias, la opinión política, el origen nacional, el estado civil y/o maternal, la

\footnotetext{
${ }^{591} \mathrm{El}$ artículo 15 de la Convención dispone que hombres y mujeres deben gozar de igualdad ante la ley y deben beneficiarse de igual protección de la ley. El artículo 2 estipula que los Estados partes deben adoptar todas las medidas necesarias para garantizar la igualdad sustantiva entre hombres y mujeres en todas las esferas de la vida, incluso mediante el establecimiento de tribunales nacionales competentes y otras instituciones públicas que garanticen la protección efectiva de la mujer contra todo acto de discriminación. El contenido y ámbito de esa disposición se detallan en la recomendación general $n^{\circ} 28$ sobre las obligaciones básicas de los Estados partes en virtud del artículo 2 de la Convención. El artículo 3 de la Convención menciona la necesidad de contar con medidas apropiadas para asegurar que la mujer pueda ejercer y disfrutar de sus derechos humanos y libertades fundamentales en pie de igualdad con los hombres.
} 
localización urbana o rural, el estado de salud, la discapacidad, la propiedad de los bienes y el hecho de ser mujeres lesbianas, bisexuales, intersexuales.

j) Otros factores que entorpecen el acceso de las mujeres a la justicia incluyen el analfabetismo, la trata de mujeres, los conflictos armados, la búsqueda de asilo, los desplazamientos internos, la apátrida, las migraciones, las mujeres que encabezan hogares, la viudez, las que viven con el VIH/SIDA, la privación de libertad, la penalización de la prostitución, el alejamiento geográfico y la estigmatización de las mujeres que luchan por sus derechos.

k) El Comité ha documentado muchos ejemplos de los efectos negativos de las formas de discriminación sobre el acceso a la justicia, incluidos los recursos ineficaces para mujeres que pertenecen a esos grupos, que suelen no denunciar la violación de sus derechos a las autoridades por temor a ser humilladas, estigmatizadas, arrestadas, deportadas, torturadas o sometidas a otras formas de violencia contra ellas, incluso por los oficiales encargados de hacer cumplir la ley. Se ha observado también que, cuando las mujeres de esos subgrupos plantean reclamaciones, las autoridades con frecuencia no actúan con la debida diligencia para investigar, enjuiciar y castigar a los perpetradores y/o aplicar medidas correctivas.

l) Además de las que figuran en los artículos 2 c), 3, 5 a) y 15 de la Convención, los Estados partes tienen otras obligaciones basadas en los tratados para asegurar que todas las mujeres tengan acceso a la educación y la información sobre sus derechos y sobre los recursos disponibles, y sobre cómo acceder a ellos, y a sistemas competentes y sensibles a las cuestiones de género para resolver las controversias, así como acceso en igualdad de condiciones a recursos eficaces y oportunos.

m) Las opiniones y recomendaciones del Comité sobre las medidas necesarias para superar los obstáculos con que tropiezan las mujeres cuando tratan de obtener acceso a la justicia se basan en la experiencia adquirida durante la consideración de los informes de los Estados partes, sus análisis de comunicaciones individuales y su realización de encuestas con arreglo al Protocolo Facultativo de la Convención. 
Además, se hace referencia a la labor sobre el acceso a la justicia que realizan otros mecanismos de derechos humanos de las naciones unidas, las instituciones nacionales de derechos humanos, las organizaciones de la sociedad civil, incluidas las asociaciones de mujeres de base comunitaria y las investigaciones académicas.

Por su parte, en la Conferencia Mundial de Derechos Humanos de la ONU ${ }^{592}$, los Estados aprobaron la Declaración y Programa de Acción de Viena ${ }^{593}$, constituyendo un hito en la historia de los esfuerzos encaminados a lograr la observancia de la Declaración Universal de los Derechos Humanos (DUDH); reforzando principios como el de la universalidad de los derechos y la obligación de los Estados de acatarlos y por primera vez, se proclaman de manera incuestionable los derechos de las mujeres como derechos humanos.

Se pueden extraer los siguientes postulados, en base la preocupación profunda por las diversas formas de discriminación y violencia a que siguen expuestas las mujeres en todo el mundo:

a) Artículo 14: "Los derechos de las mujeres son derechos humanos".

b) Artículo 18: "Los derechos humanos de la mujer y de la niña son inalienables, integrante e indivisible de los derechos humanos universales, la plena participación, en condiciones de igualdad, de la mujer en la vida política, civil, económica, social y cultural en los planos nacional, regional e internacional y la erradicación de todas las formas de discriminación basadas en el sexo son objetivos prioritarios de la comunidad internacional".

\footnotetext{
592 Se llevó a cabo el 25 de junio de 1993 los 7.000 participantes de diferentes estados miembros de las naciones unidas, en la conferencia superaron importantes diferencias para elaborar un documento final conviviente que pusiera de relieve el carácter indivisible e interdependiente de los derechos económicos, sociales y culturales, civiles y políticos, que se refuerzan mutuamente para todos los seres humanos que habitan el planeta.

${ }^{593}$ La Declaración de Viena Condenó la grave situación de los derechos humanos en muchas partes del mundo como la tortura y los tratos o penas crueles, inhumanas o degradantes, las ejecuciones sumarias o arbitrarias, las desapariciones y las detenciones arbitrarias, Señaló en especial todas las formas de racismo, de discriminación racial y apartheid, ocupación y dominio extranjero y xenofobia. Subrayo la pobreza, el hambre, la intolerancia religiosa, el terrorismo y la incapacidad de mantener el imperio de la ley y colocó la vigencia de los derechos humanos como un tema central en el debate mundial sobre la paz, la seguridad y el desarrollo.
} 
c) Artículo 24: "Estamos decididos a adoptar las medidas que sean necesarias para eliminar todas las formas de discriminación contra las mujeres y las niñas, y suprimir todos los obstáculos a la igualdad de género y al adelanto y potencialización del papel de la mujer".

Dichos postulados, revisten especial relevancia, cuando se trata del tema de igualdad y no discriminación contra las mujeres y las poblaciones en situación de vulnerabilidad. En esencia, con un nivel de obligatoriedad para los Estados, al asumir como propios y prioritarios estos derechos y sus requerimientos de garantía, se da el fundamento para el logro real del desarrollo, la paz y la consolidación de la democracia.

En misma línea del Programa de Viena, a nivel regional, destaca la Estrategia de Montevideo que se ha convertido en una apuesta política específica, en la cual participó el Estado de Chile, para el logro de la igualdad de género en el año $2030^{594}$. Las medidas en ella incluidas requieren el compromiso y participación de los ministerios sectoriales, las entidades de planificación y presupuesto, los organismos descentralizados, los parlamentos y el poder judicial, ente otros actores ${ }^{595}$.

Algunas de las medidas establecidas en la Estrategia de Montevideo van dirigidas al poder judicial, relativas al marco normativo sobre igualdad y no discriminación, en cuanto a eliminar todas las barreras legales e institucionales para el acceso efectivo e igualitario de las mujeres a la justicia, sin discriminación, garantizando la participación, la transparencia, la independencia y la atención oportuna y de calidad, con personal especializado y reparación integral del daño en caso de violación de sus derechos a efectos de poner fin a la impunidad ${ }^{596}$. En materia institucional, sobre políticas multidimensionales e integrales de igualdad, se impulsan medidas tendientes a asegurar que los procesos de transversalización de la igualdad de

\footnotetext{
594 COMIISON ECONOMICA PARA LATINA Y EL CARIBE (2017). Estrategia de Montevideo para la implementación de la Agenda Regional de Género en el Marco del Desarrollo Sostenible hacía el 2030. marzo 2017.pp. 13-14.

595 IBIDEM. "Por lo tanto, es un instrumento cuyo alcance compromete a toda la estructura estatal y que reconoce el liderazgo de los mecanismos para el adelanto de las mujeres”.

${ }^{596}$ IBIDEM. p. 28
} 
género permeen toda la estructura del Estado ${ }^{597}$. Adicionalmente, se orientan a la construcción y fortalecimiento de capacidades estatales en gestión pública ${ }^{598}$.

Una de las principales y más graves constataciones del informe de la CIDH "Acceso a la justicia para las mujeres víctimas de violencia en las Américas" de 20 de Enero de 2007, consiste en que pese al reconocimiento formal de los Estados, la violencia contra la mujeres es un desafío prioritario y forma parte de la agenda pública, aún existe una brecha entre lo que consagran las leyes y políticas públicas y lo que sucede en realidad, un patrón de impunidad.

El informe CIDH constata también que "la ineficacia de los sistemas de justicia para juzgar y sancionar a los perpetradores de actos de violencia contra las mujeres...si bien existen carencias estructurales en el ámbito económico y de recursos humanos para procesar casos con celeridad y eficacia, en casos de violencia contra las mujeres (la violencia se ve afectada por la existencia de patrones socioculturales discriminatorios)" 599 . En ocasiones es el mismo sistema judicial es el que influye negativamente en la dificultad de las pertenecientes a este grupo para ejercer sus derechos con plenitud ${ }^{600}$.

La CIDH ha verificado una serie de obstáculos que dificultan la interposición de denuncias de actos de violencia. Entre las razones expuestas para este problema, se encuentran la victimización secundaria que pueden sufrir las víctimas al intentar denunciar los hechos perpetrados, la falta de protecciones y garantías judiciales para proteger la dignidad y la seguridad de las víctimas y de los testigos durante el proceso ${ }^{601}$. Tal como se expresa en la Recomendación General nº 33, la condición

\footnotetext{
${ }^{597}$ ARBELAEZ DE TOBON, L y RUIZ, E. Op. Cit., p. 21.

${ }^{598}$ IBIDEM. p. 30. "La desigualdad y la discriminación de género empeoran o tal vez se vuelven más notorias, cuando las mujeres experimentan violaciones de derechos humanos (la experiencia inicial de la desigualdad de género) y luego les son negados los recursos legales eficaces para tratar esas mismas violaciones (la segunda experiencia de la desigualdad de género y la discriminación)". "La doble necesidad de abordar la persistencia de la desigualdad de género y el acceso a la justicia es hoy más relevante con la creciente conciencia sobre el peso que la desigualdad y la discriminación de las mujeres tienen para el desarrollo y la democracia”.

${ }^{599}$ CIDH (2007). Acceso a la justicia para las mujeres víctimas de violencia en las Américas. Párr. 8.

${ }^{600}$ LOVATÓN, D. Op. Cit., p. 269

${ }^{601} \mathrm{CIDH}$. Acceso a la justicia para las mujeres víctimas de violencia en las Américas. Párr. 12.
} 
de mujer agravada por otras circunstancias de vulnerabilidad transforma en más dificultoso el acceso efectivo a la justicia ${ }^{602}$.

\subsection{Recomendaciones de la CIDH sobre la remoción de trabas en el acceso a la justicia por parte de los Estados}

Ante estas constataciones sobre la muy preocupante situación de las mujeres que sufren violencia y que enfrentan grandes obstáculos para acceder a la justicia, la CIDH formula a la luz de su referido informe, un conjunto de recomendaciones a los Estados ${ }^{603}$.

Los Estados deben:

a) Diseñar una política estatal integral, respaldada con recursos públicos adicionales para garantizar que las víctimas de violencia tengan un acceso adecuado a la justicia y que los actos de violencia se prevengan, investiguen, sancionen y reparen en forma adecuada ${ }^{604}$.

b) Exhortar a los Estados a crear las condiciones necesarias para que las mujeres puedan usar el sistema de administración de justicia para remediar los actos de violencia sufridos y recibir un trato digno por parte de los funcionarios al acudir a las diversas instancias judiciales ${ }^{605}$.

c) La protección jurídica de los derechos de la mujer sobre la base de la igualdad con los hombres y garantizar por conducto de los tribunales nacionales competentes

\footnotetext{
${ }^{602} \mathrm{La}$ CIDH ha observado que la violencia, la discriminación y las dificultades para acceder a la justicia, afectan en forma diferenciada a las mujeres indígenas y afrodescendientes, debido a que están particularmente expuestas al menoscabo de sus derechos por causa del racismo. Asimismo ha constatado que los obstáculos que enfrentan....pueden ser particularmente críticos porque sufren de varias formas de discriminación combinadas, por ser mujeres, por su origen étnico o racial y/o por su condición socio-económica.

${ }^{603}$ LOVATÓN, D. p.270.

${ }^{604} \mathrm{CIDH}$. Acceso a la justicia para las mujeres víctimas de violencia en las Américas. Op. Cit., párr. 19.

${ }^{605}$ IBIDEM párr. 296.
} 
y de otras instituciones públicas, la protección efectiva de la mujer contra todo acto de discriminación ${ }^{606}$.

d) Que el Estado cuente con una legislación que permita sancionar ciertos hechos, que estos se investiguen como delitos cuando corresponda y que las investigaciones no sean formales o ritos procesales, sino exhaustivas, serias e imparciales ${ }^{607}$. Se vincula esta obligación impuesta al Estado, con el hecho que el aludido informe define acceso a la justicia como "el acceso de jure y facto a instancias y recursos judiciales de protección frente a actos de violencia, de conformidad con los parámetros internacionales de derechos humanos"608.

Entre las medidas concretas que se sugieren a los Estados por parte de la $\mathrm{CIDH}$, se pueden mencionar ${ }^{609}$ :

a) En los casos de violencia familiar, luego de la sentencia, podría introducirse una modificación legislativa a fin de establecer la obligación de los jueces de llevar a cabo "audiencias de seguimiento" de lo dispuesto en la sentencia y las obligaciones y compromisos del agresor.

b) Otra medida que los algunos Estados podrían implementar para mejorar la protección del sistema de justicia a favor de los derechos de las mujeres, en especial frente a casos de violencia sexual o violencia familiar, sería de terminar de proscribir, en los pocos países que aún lo mantienen, el eximente de responsabilidad penal cuando el violador contrae matrimonio con la víctima.

c) Asimismo, que los Estados no contemplen en sus legislaciones procesales penales la figura del desistimiento en casos de violencia sexual o violencia familiar, por la precariedad de la protección a la víctima y por la vulnerabilidad de ésta.

\footnotetext{
${ }^{606}$ LOVATÓN, D. Op. Cit., p. 270

${ }^{607} \mathrm{CIDH}$. Acceso a la justicia para las mujeres víctimas de violencia en las Américas. Op. Cit., párr 5.

${ }^{608}$ LOVATÓN, D. Op. Cit., pp. 270-271.

${ }^{609}$ IBIDEM.
} 
d) Necesidad de fortalecer los servicios de peritaje médico y psicológico en los casos de violencia sexual y violencia familiar, dadas las dificultades probatorias en este tipo de delitos, constatándose que son notorias las exigencias que plantean los fiscales para llevar a juicio un caso, existiendo un estándar mayor de prueba para decidir llevar estos casos a juicio.

e) Propiciar la creación y fortalecimiento de fiscalías especializadas en violencia sexual y violencia familiar. Sobre el particular, hay fiscalías especializadas en Honduras, Ecuador, Guatemala o Chile.

f) Propiciar la creación y fortalecimiento de unidades especiales de protección de las víctimas de violencia sexual y violencia familiar.

g) Los Estados también podrán adoptar medidas para amortiguar la "victimización secundaria" de las víctimas de violencia sexual, cuando deciden ponerse en contacto con el sistema de justicia, dentro de las cuales se consideran las siguientes:

g1) La reducción de tiempos de espera para la atención de la víctima.

g2) Trato digno en el sistema judicial, a favor de la víctima.

g3) Entrevistas adecuadamente realizadas.

g4) Medidas especiales para la comparecencia en juicio, cuando la víctima se encuentra en un estado de especial vulnerabilidad.

Además, las Reglas de Brasilia regulan el género como condición de vulnerabilidad ${ }^{610}$, proponiendo medidas concretas en su regla 20: "Se impulsarán

\footnotetext{
${ }^{610}$ XIV CUMBRE JUDICIAL IBEROAMERICANA. Op. Cit., Regla 17: “La discriminación que la mujer sufre en determinados ámbitos supone un obstáculo para el acceso a la justicia, que se ve agravado en aquellos casos en los que concurra alguna otra causa de vulnerabilidad".

Regla 18: "Se entiende por discriminación contra la mujer toda distinción, exclusión o restricción basada en el sexo que tenga por objeto o resultado menoscabar o anular el reconocimiento, goce o ejercicio por la mujer, independiente de su estado civil, sobre la base de la igualdad del hombre y la mujer de los derechos humanos y las libertades fundamentales en las esferas política, económica, social, cultural, civil o en cualquier otra esfera.
} 
las medidas necesarias para eliminar la discriminación contra la mujer en el acceso al sistema de justicia para la tutela de sus derechos e intereses legítimos, logrando la igualdad efectiva de condiciones. Se prestará una especial atención en los supuestos de violencia contra la mujer, estableciendo mecanismos eficaces destinados a la protección de sus bienes jurídicos, al acceso a los procesos judiciales y a su tramitación ágil y oportuna"611.

\subsection{Acceso a la justica de la mujer víctima de violencia en Chile}

\subsubsection{Panorama de la violencia contra la mujer en Chile y el déficit legislativo en cuanto a su protección}

En nuestro país, la institución familiar se constituye como una de las principales sostenedoras y reproductoras de la estructura patriarcal. Lógica cultural que además genera una serie de dispositivos psicológicos y subjetivos que hacen que los sujetos encuentren en la violencia un medio legítimo de resolución de conflictos, y que refuerzan la desigualdad en las relaciones de poder, donde uno de los miembros, en este caso hombres, llegan a considerar "que la mujer le pertenece, o ellos son responsables de su disciplinamiento cuando ellas se han desviado de la norma".

En relación a las estadísticas, la tendencia histórica de los últimos 10 años indica que sobre el $80 \%$ de las víctimas de Violencia intrafamiliar son mujeres. Casos Policiales por Delitos de Violencia Intrafamiliar y \% de víctimas mujeres 2008- 2020.

Regla 19: "Se considera violencia contra la mujer cualquiera acción o conducta basada en su género que cause muerte, daño o sufrimiento físico, sexual o psicológico a la mujer, tanto en el ámbito público como privado mediante el empleo de la violencia física y psíquica”.

${ }^{611}$ IBIDEM. Op. Cit. Regla 20. 


\begin{tabular}{|c|c|c|c|}
\hline AÑO & $\begin{array}{c}\text { CASOS VIOLENCIA } \\
\text { INTRAFAMILIAR }\end{array}$ & MUJERES & \% MUJERES \\
\hline 2008 & 125.281 & 104.492 & $83,4 \%$ \\
\hline 2009 & 139.492 & 115.485 & $82,7 \%$ \\
\hline 2010 & 135.711 & 111.220 & $81,9 \%$ \\
\hline 2011 & 153.424 & 125.300 & $81,6 \%$ \\
\hline 2012 & 143.411 & 116.290 & $81,0 \%$ \\
\hline 2013 & 138.892 & 112.636 & $81,0 \%$ \\
\hline 2014 & 129.742 & 104.522 & $80,5 \%$ \\
\hline 2015 & 120.255 & 96.710 & $80,4 \%$ \\
\hline 2016 & 114.867 & 92.367 & $80,4 \%$ \\
\hline 2017 & 113.529 & 90.953 & $80,1 \%$ \\
\hline $2018^{\star}$ & 27.845 & 22.325 & $80,1 \%$ \\
\hline
\end{tabular}

En cuanto a las estadísticas de los homicidios a mujeres o femicidios, las cifras varían, si emanan del gobierno, o de instancias privadas no gubernamentales, como la Red Chilena de Violencia hacia las Mujeres ${ }^{612:}$

\begin{tabular}{|c|c|c|c|}
\hline AÑO & RED CHILENA & SERNAMEG & FRUSTRADOS* \\
\hline 2008 & 59 & 59 & \\
\hline 2009 & 52 & 55 & \\
\hline 2010 & 65 & 49 & \\
\hline 2011 & 47 & 40 & 87 \\
\hline
\end{tabular}

${ }^{612}$ RED CHILENA CONTRA LA VIOLENCIA HACIA LAS MUJERES. (2018). Dossier Informativo. www.nomasviolenciacontramujer.cl. [Consulta 13 de abril de 2020]. 


\begin{tabular}{|c|c|c|c|}
\hline 2012 & 45 & 34 & 82 \\
\hline 2013 & 56 & 40 & 76 \\
\hline 2014 & 58 & 40 & 103 \\
\hline 2015 & 58 & 45 & 112 \\
\hline 2016 & 52 & 34 & 129 \\
\hline 2017 & 66 & 43 & 115 \\
\hline $2018^{\star \star}$ & 31 & 20 & 68 \\
\hline
\end{tabular}

\begin{tabular}{|c|c|c|c|}
\hline $\begin{array}{c}\text { RANGO } \\
\text { ETARIO }\end{array}$ & FEMICIDIOS & MIGRANTES & CHILENAS \\
\hline $0-18$ & 5 & 0 & 5 \\
\hline $19-55$ & 21 & 4 & 17 \\
\hline $56->$ & 3 & 0 & 3 \\
\hline Desconocido & 2 & 0 & 2 \\
\hline Total & 31 & 4 & 27 \\
\hline
\end{tabular}

Cabe destacar que existen situaciones conexas al femicidio que permanecen invisibles, desconectadas de este concepto, tales son el suicidio femicida, mujeres que se quitan la vida porque ya no soportan la violencia, y el castigo femicida, asesinatos a personas con vínculo familiar o afectivo directo con la mujer agredida de modo de castigarla o dañarla psíquicamente ${ }^{613}$. Además existen críticas respecto

${ }^{613}$ IBIDEM. p. 4. 
de la forma en que los medios de comunicación informan estos cruentos crímenes ${ }^{614}$.

Chile en cumplimiento parcial de las normas internacionales ya mencionadas, a las que ha adherido, creó una ley de violencia intrafamiliar ${ }^{615}$, que tipifica actos de violencia cometidos entre miembros de un grupo familiar, incluyendo entre otros, como víctimas, a las mujeres siempre que tengan una relación familiar determinada con el agresor ${ }^{616}$, estableciendo distintos énfasis, pero limitándolo a la protección de la violencia en el ámbito de la familia, y no como en el espectro internacional, que se protege a la mujer ante actos de violencia suscitados en y por su condición de tal, en diversos ámbitos de la vida comunitaria. A mayor abundamiento, en nuestro país rige la ley 20.066 de Violencia Intrafamiliar, de 7 de octubre de 2005, que por lo demás no solo protege a la mujer sino a todo integrante de la familia que sufra un daño físico o psíquico por otro integrante de este núcleo. Se establecen

\footnotetext{
${ }^{614}$ Los medios de comunicación han instalado estos crímenes como casos puntuales, cuyos victimarios son "hombres psicópatas" y las víctimas hijas de "madres despreocupadas". La falta de comprensión de la violencia contra las mujeres invisibiliza el machismo que hay detrás de esta violencia, en la que los hombres someten, dominan y se apropian de los cuerpos de mujeres de distintas edades, condiciones sociales, culturales o étnicas. Los poderes del Estado encargados de proteger a las mujeres, investigar los crímenes y castigar a los femicidas no cumplen con su labor. Prueba de ello es que de las 18 mujeres víctimas de femicidio hasta mayo de este año, un tercio había realizado denuncia previa por agresión. Los medios de comunicación, por su parte, persisten en transmitir toda clase de detalles morbosos y sensacionalistas sobre casos específicos sin entregar ninguna noción ni crítica al ejercicio de poder que implican estos asesinatos.

${ }^{615}$ LEY 20.066. Establece Ley de Violencia Intrafamiliar, de 7 de octubre de 2005.

${ }^{616}$ IBIDEM. Artículo 5: "Violencia intrafamiliar. Será constitutivo de violencia intrafamiliar todo maltrato que afecte la vida o la integridad física o psíquica de quién tenga o haya tenido la calidad de cónyuge del ofensor o una relación de convivencia con él; o sea pariente por consanguinidad o por afinidad en toda la línea recta o en la colateral hasta el tercer grado inclusive, del ofensor, de su cónyuge o de su actual conviviente. También habrá violencia intrafamiliar cuando la conducta referida en el inciso precedente ocurra entre los padres de un hijo común o recaiga sobre persona menor de edad, adulto mayor o discapacitada que se encuentre bajo el cuidado o dependencia de cualquiera de los integrantes del grupo familiar”
} 
factores de riesgo ${ }^{617}$ que permiten al juez aplicar medidas cautelares ${ }^{618}$ por un plazo

de 180 días prorrogables. Dentro de las medidas cautelares se encuentra el tratamiento psicológico del agresor, cuyo fin teórico es que pueda entender el fenómeno de la violencia intrafamiliar, comprender la ilicitud de su conducta, controlar impulsos y cambiar en definitiva patrones de violencia física y psíquica. Lamentablemente no presenta un efecto práctico relevante, pues tiene el carácter

${ }^{617}$ IBIDEM. Artículo $7^{\circ}$.- Situación de riesgo. Cuando exista una situación de riesgo inminente para una o más personas de sufrir un maltrato constitutivo de violencia intrafamiliar, aun cuando éste no se haya llevado a cabo, el tribunal, con el solo mérito de la denuncia, deberá adoptar las medidas de protección o cautelares que correspondan. Se presumirá que existe una situación de riesgo inminente como la descrita en el inciso anterior cuando haya precedido intimidación de causar daño por parte del ofensor o cuando concurran además, respecto de éste, circunstancias o antecedentes tales como: drogadicción, alcoholismo, una o más denuncias por violencia intrafamiliar, condena previa por violencia intrafamiliar, procesos pendientes o condenas previas por crimen o simple delito contra las personas o por alguno de los delitos establecidos en los párrafos 5 y 6 del Título VII, del Libro Segundo del Código Penal o por infracción a la ley n¹7.798, o antecedentes psiquiátricos o psicológicos que denoten características de personalidad violenta. Asimismo, se presumirá que hay una situación de riesgo inminente, cuando el denunciado oponga, de manera violenta, su negativa a aceptar el término de una relación afectiva que ha mantenido recientemente con la víctima. Ley 20480. Además, el tribunal cautelará especialmente los casos en que la víctima esté embarazada, se trate de una persona con discapacidad o tenga una condición que la haga vulnerable. Se considerará especialmente como situación de riesgo inminente el hecho de que un adulto mayor, dueño o poseedor, a cualquier título, de un inmueble que ocupa para residir, sea expulsado de él, relegado a sectores

secundarios o se le restrinja o limite su desplazamiento al interior de ese bien raíz, por algunos de los parientes señalados en el artículo $5^{\circ}$.

${ }^{618}$ IBIDEM. Artículo 92: "Medidas cautelares en protección de la víctima. El juez de familia deberá dar protección a la víctima y al grupo familiar. Cautelará, además, su subsistencia económica e integridad patrimonial. Para tal efecto, en el ejercicio de su potestad cautelar y sin perjuicio de otras medidas que estime pertinentes, podrá adoptar una o más de las siguientes:

1. Prohibir al ofensor acercarse a la víctima y prohibir o restringir la presencia de aquél en el hogar común y en el domicilio, lugar de estudios o de trabajo de ésta, así como en cualquier otro lugar en que la víctima permanezca, concurra o visite habitualmente. Si ambos trabajan o estudian en el mismo lugar, se oficiará al empleador o director del establecimiento para que adopte las medidas de resguardo necesarias.

2. Asegurar la entrega material de los efectos personales de la víctima que optare por no regresar al hogar común.

3. Fijar alimentos provisorios.

4. Determinar un régimen provisorio de cuidado personal de los niños, niñas o adolescentes en conformidad al artículo 225 del Código Civil, y

establecer la forma en que se mantendrá una relación directa y regular entre los progenitores y sus hijos.

5. Decretar la prohibición de celebrar actos o contratos.

6.- Prohibir el porte y tenencia de cualquier arma de fuego, municiones y cartuchos; disponer la retención de los mismos, y prohibir la adquisición o almacenaje de los objetos singularizados en el artículo $2^{\circ}$ de la ley №17.798, sobre Control de Armas. De ello se informará, según corresponda, a la Dirección General de Movilización, a la Comandancia

de Guarnición o al Director del Servicio respectivo para los fines legales y reglamentarios pertinentes. Con todo, el imputado podrá solicitar ser excluido de estas medidas en caso de demostrar que sus actividades industriales, comerciales o mineras requieren de alguno de esos elementos.

7. Decretar la reserva de la identidad del tercero denunciante.

8. Establecer medidas de protección para adultos mayores o personas afectadas por alguna incapacidad o discapacidad. 
de voluntario, y el juez por mandato legal, carece de facultades de obligar a la persona a seguir un determinado tratamiento bajo ciertos lineamientos y objetivos.

Esta legislación, dista de todos los lineamientos normativos internacionales, pues si bien en su artículo 1 señala que el objeto de la ley es "prevenir, sancionar, erradicar la violencia intrafamiliar y otorgar protección a las víctimas de las misma", solo tipifica aquellos actos cometidos por el cónyuge, ex cónyuge, conviviente, ex conviviente, o aquellos cometidos por aquel que tiene con la mujer, un hijo(a) en común sin necesidad de relación de convivencia619. De esta forma deja sin regulación ni sanción los hechos cometidos por razón de género, por personas que no pertenecen al círculo familiar de la mujer víctima, tales como actos de agresiones en la vía pública o en ámbitos laborales y/o educacionales ${ }^{620}$, lo que no ha estado exento de críticas.

Fija esta ley además, específicamente los deberes del Estado en esta materia, el rol del SERNAMEG ${ }^{621}$, las situaciones de riesgo, las medidas cautelares, que aparte de resguardar su integridad pueden asegurar su patrimonio y/o subsistencia, y contempla sanciones cuando esta violencia constituye delito, siendo más altas y gravosas que si el delito se cometiere sin mediar relación familiar ${ }^{622}$. Además, no nos parece adecuado por ser discriminatoria y atentatoria a la dignidad e integridad de la mujer la consagración de la figura del maltrato habitual ${ }^{623}$, que parte de la

${ }^{619}$ De este modo se deja sin investigación, reparación o sanción especial, aquellas agresiones psicológicas o físicas cometidas contra la mujer debido a su condición de tal, en otras esferas, como la del pololeo o noviazgo, o en otros ámbitos de la vida social, laboral etcétera.

${ }^{620}$ En este sentido, han sido recurrentes los casos de violencia extrema, con resultado de muerte incluso, en contexto diversos a los familiares, en que la sanción a los responsable no ha considerado la vulnerabilidad por razón de género de la víctima. https://www.latercera.com/reportajes/noticia/columna-mercedes-duccifernanda-gabriela/739371/[Consulta 17 de abril de 2020].

621 SERNAMEG. www.sernameg.gob.cl. [Consulta 29 de abril de 2020]. "Servicio Nacional de la Mujer y Equidad de Género, cuya misión es fortalecer las autonomías y ejercicio pleno de derechos y deberes de la diversidad de las mujeres, a través de la implementación y ejecución de políticas y planes y programas de igualdad y equidad de género, considerando el enfoque territorial, y aportando al cambio cultural que se requiere para alcanzar una sociedad más igualitaria entre mujeres y hombres en el país”.

${ }^{622}$ CODIGO PENAL. Artículo 400: "Si los hechos a que se refieren los artículos anteriores de este párrafo se ejecutan en contra de alguna de las personas que menciona el artículo $5^{\circ}$ de la ley sobre violencia intrafamiliar, o con cualquiera de las circunstancias segunda, tercera o cuarta del $n^{\circ} 1$ del artículo 391 de este Código, las penas se aumentarán en un grado”.

623 IBIDEM. Artículo 14: "Delito de maltrato habitual. El ejercicio habitual de violencia física o psíquica respecto de alguna de las personas referidas en el artículo $5^{\circ}$ de esta ley se sancionará con la pena de presidio menor en su grado mínimo a medio, salvo que el hecho sea constitutivo de un delito de mayor gravedad, caso 
perniciosa premisa, que la mujer debe ser agredida física o psicológicamente más de una vez para que pueda obtener reparación y que el agresor sea sancionado. En cuanto al delito de maltrato habitual, Javiera Canales, ha indicado que "los problemas que enfrentan las víctimas son resultado, en primer lugar, de la inexistencia de regulación específica sobre violencia en contra de las mujeres ${ }^{624}$. De hecho, el propio TC le recordó su labor de investigación al Ministerio Público al dictaminar que "debe proceder a investigar los hechos delictivos con la mayor celeridad y prontitud para que dicha investigación sea, en la medida de lo posible, exitosa"625.

Por otra parte, las sanciones que contempla esta ley ${ }^{626}$ son a nuestro juicio de baja entidad y escasamente efectivas para la protección de la mujer, contemplando multas a beneficio fiscal y medidas accesorias temporales (máximo dos años),

en el cual se aplicará sólo la pena asignada por la ley a éste. Para apreciar la habitualidad, se atenderá al número de actos ejecutados, así como a la proximidad temporal de los mismos, con independencia de que dicha violencia se haya ejercido sobre la misma o diferente víctima. Para estos efectos, no se considerarán los hechos anteriores respecto de los cuales haya recaído sentencia penal absolutoria o condenatoria.

${ }^{624}$ CANALES. J (2020). "El peregrinaje de las víctimas de violencia de género para acceder a la justicia en tiempos de Covid 19”. EN CIPER ACADEMICO. https://ciperchile.cl/2020/05/02/el-peregrinaje-de-lasvictimas-de-violencia-de-genero-para-acceder-a-la-justicia-en-tiempos-de-covid-19/. [Consulta 4 de julio de 2020]. pp. 1-2.

${ }^{625}$ Requerimiento del Juzgado de Familia de Pudahuel para que se dirima la contienda de competencia entre dicho tribunal y el Ministerio Público respecto de la causa RIT F-2758-2008, seguida por violencia intrafamiliar, caratulada Moncada con Segovia [2009] ROL No 1.320-2009 CC. (Tribunal Constitucional), p.4. ${ }^{626}$ LEY 20.066. Establece Ley de Violencia Intrafamiliar. Artículo 8. "Sanciones. Se castigará el maltrato constitutivo de violencia intrafamiliar, atendida su gravedad, con una multa de media a quince unidades tributarias mensuales a beneficio del gobierno regional del domicilio del denunciante o demandante, para ser destinada a los centros de atención de víctimas de violencia intrafamiliar existentes en la región respectiva y que sean de financiamiento público o privado. El condenado deberá acreditar el pago de la multa dentro de los cinco días siguientes a la fecha de la notificación de la sentencia, a menos que el juez, por motivos fundados, prorrogue dicho término hasta por quince días. En caso de incumplimiento el tribunal remitirá los antecedentes al Ministerio Público, conforme a lo dispuesto en el artículo 240 del Código de Procedimiento Civil.

Artículo $9^{\circ}$.- Medidas accesorias. Además de lo dispuesto en el artículo precedente, el juez deberá aplicar en la sentencia una o más de las siguientes medidas accesorias:

a) Obligación de abandonar el ofensor el hogar que comparte con la víctima.

b) Prohibición de acercarse a la víctima o a su domicilio, lugar de trabajo o estudio, así como a cualquier otro lugar al que ésta concurra o visite habitualmente. Si ambos trabajan o estudian en el mismo lugar, se oficiará al empleador o director del establecimiento para que adopte las medidas de resguardo necesarias.

c) Prohibición de porte y tenencia y, en su caso, el comiso, de armas de fuego. De ello se informará, según corresponda, a la Dirección General de Movilización, a la Comandancia de Guarnición o al director de Servicio respectivo, para los fines legales y reglamentarios que correspondan.

d) La asistencia obligatoria a programas terapéuticos o de orientación familiar. Las instituciones que desarrollen dichos programas darán cuenta al respectivo tribunal del tratamiento que deba seguir el agresor, de su inicio y término.

e) Obligación de presentarse regularmente ante la unidad policial que determine el juez. 
consistentes en abandono del hogar común por parte del victimario, no acercamiento del agresor a la víctima y prohibición de portar armas, conjuntamente con una mácula en certificado de antecedentes del agresor. En caso que el hecho de violencia sea constitutivo de delito se aumentará en un grado la sanción.

Sin perjuicio de las debilidades normativas existente en la protección de la mujer, hubo un avance importante en el tratamiento de la figura del femicidio, ajustándose más cabalmente a la normativa internacional, promulgándose la Ley 21.212 que modifica el Código Penal, el Código Procesal Penal y la Ley 18.216 en materia de tipificación del Femicidio, de 4 de marzo de 2020, conocida como "ley Gabriela", que declara como femicidio al asesinato de cualquier mujer "con motivo de odio, menosprecio, o abuso por causa de género, con independencia de existir un vínculo afectivo, a diferencia de la tipificación anterior, reducida a la relación matrimonial o de convivencia con el agresor"627. La ley Gabriela pretende dar justicia póstuma a esas mujeres asesinadas por razones de género, con penas más severas contra el agresor. En sentido contrario, cuando la violencia no concluye con la muerte de la mujer, generando un daño físico o psíquico a la sobreviviente, para que sea considerada una acción de Violencia Intrafamiliar, originando sanciones mayores y active las medidas de auxilio a su favor, debe necesariamente existir el vínculo familiar afectivo previo exigido en la ley 20.066. A mayor abundamiento, no nos parece razonable, que un juez pueda condenar esa conducta culmine del eslabón de la violencia (dar muerte a la mujer), pero prescinda de un reproche penal diferenciado, cuando se trata de amenazas, malos tratos habituales o lesiones por razones de género (que por lo demás, podrían eventualmente desencadenar en un femicidio), debido a que la ley 20.066 solo le entrega una protección especial cuando el hecho que produce un daño físico, psicológico, económico o de otra índole, se suscite solo dentro del seno familiar. Necesitamos prevenir la muerte de

\footnotetext{
${ }^{627}$ LEY 21.212. Modifica el Código Penal, el Código Procesal Penal y la Ley 18.216 en materia de Tipificación del femicidio, de 4 de marzo de 2020. Artículos 1 y 2. En este contexto señalar que con esta ley surgida de un hecho de connotación pública, consistente en el novio de una joven menor de edad, la asesino a ella y a su madre, se apertura la sanción a conductas que no involucran convivencia de la víctima con el agresor, como es la relación de noviazgo. También se tipifica a partir de esta ley como femicidio cualquier asesinato a su mujer, por su condición de tal, incluso no habiendo relación sentimental alguna entre agresor y víctima.
} 
una mujer, para que la justicia no llegue tarde a ella, siendo la legislación actual aún insuficiente. Existe un desafío pendiente en cuanto a replantear el ámbito de aplicación de la ley de violencia intrafamiliar en Chile, o más concretamente, mutarla y ampliarla, a una legislación específica en materia de violencia contra la mujer.

\subsubsection{Ruta crítica en cuanto a la denuncia, investigación, sanción y reparación de los actos de violencia hacía la mujer}

Ahora bien, en el acceso a la justicia de este grupo, sumado al sombrío escenario legislativo descrito, existe una "ruta crítica" relacionada con los diversos problemas a los que se enfrentan las mujeres a la hora de denunciar casos de violencia, existiendo dificultades en relación a la primera declaración que hace la víctima ${ }^{628}$ y en cómo se operativiza esa denuncia por el funcionario administrativo policial que la recibe (generalmente, carabineros), en cuanto a una correcta contención y coordinación con tribunal o fiscalía para la activación de las medidas de protección urgentes en pos de resguardar la vida e integridad de la mujer.

Esta ruta comienza en la generalidad de los casos, incluso antes de la denuncia, con un temor genuino a denunciar por los estigmas que conlleva y por las consecuencias negativas en torno a la reacción del agresor y a la desestructuración familiar e impacto económico que pudiese traer aparejada. Este temor se acrecienta con la percepción de la víctima, de escasa seguridad a su propia integridad y a la de su familia, que le otorga el sistema judicial en su conjunto, posterior a la denuncia que se realice. Es innegable que existe actualmente una mayor concientización sobre la importancia de denunciar cualquier acto que constituya violencia de género,

\footnotetext{
${ }^{628}$ La pauta unificada de riesgo aplicada en Chile desde 2017, utilizada por todos los funcionarios que pueden recibir una denuncia, entre los que se encuentran principalmente: carabineros, funcionarios de policías o tribunales, busca unificar los criterios con los cuales las policías evalúan los distintos niveles de riesgo en los que se encuentran las mujeres que se presentan en las comisarías y cuarteles de la PDI para hacer una denuncia. Esto permitirá actuar con mayor eficiencia y prontitud en las derivaciones y medidas de protección que se puedan otorgar, y es un gran avance para generar parámetros comunes entre todas las instituciones que interactúan en la prevención de la violencia y protección de las víctimas.
} 
lo cual derivó en un aumento del $13 \%$ en las denuncias por violencia intrafamiliar ${ }^{629}$ entre 2018 y 2019. Sin embargo, estas denuncias terminan incrementando la larga lista de investigaciones archivadas por falta de pruebas y por no cumplir con el "estándar" que se requiere. Sin ir más lejos, el año 2019 el mismo Ministerio Público reveló que más del 53\% de las causas por violencia intrafamiliar las archivaron, siendo la cifra evidentemente desalentadora ${ }^{630}$.

La razón de esta gran cantidad de archivos y escasas medidas cautelares o de protección aplicadas, es resultado de falta de compromiso con las víctimas sobrevivientes de violencia de género y los estereotipos judiciales a la hora de investigar. Muchas veces los funcionarios públicos que reciben estas denuncias no tienen la capacitación suficiente, se exceden en sus facultades, califican jurídicamente los hechos cuando no corresponde y hacen preguntas fuera de lugar a las víctimas ${ }^{631}$. En concordancia con lo que se ha sostenido, una vez vencidas las barreras psicológicas previas al acto denunciar, un siguiente obstáculo se refiere carencia de capacitación y por ende, de idoneidad, de los funcionarios pertinentes, para redactar un parte o denuncia con detalle y bien informada, que incluya la recomendación de medidas cautelares de protección. Se requiere en forma urgente una función de acogida que no ponga duda en los relatos de las mujeres, sin culpabilizarlas, en que se les informe correctamente de los pasos a seguir ${ }^{632}$.

Recalcando las falencias en torno a la recepción de denuncia, el Observatorio de Equidad de Género en Salud de Chile, ha sostenido que "esto se traduce, en la falta de criterios de los operadores en cuanto a las tomas de denuncia, sin perjuicio del

\footnotetext{
${ }^{629}$ MINISTERIO PÚBLICO. (2019). Boletín Institucional de Fiscalía de Chile año 2019.

${ }^{630}$ Hace algunos días, el Fiscal Nacional Jorge Abott instruyó a todos los persecutores del país a solicitar medidas cautelares, incluso antes de la formalización, para dar mayor protección a las víctimas. Esto, sin embargo, no es ningún gesto de buena voluntad, pues ya está estipulado desde 2005 en el artículo 15 de la Ley sobre Violencia Intrafamiliar. En la práctica, además, este artículo no se aplica. En ese mismo anuncio, el fiscal Abott explicó que las cautelares aplicaban para "aquellos casos que estén en flagrancia”. Es decir, para aquellos agresores que son sorprendidos en el acto mismo de la agresión o hasta doce horas posteriores. La norma de 2005 no establece este requisito. Por tanto, el Fiscal Nacional, en su acto de querer proteger a las víctimas, lo que hizo fue obstaculizar e interpretar restrictivamente la normativa vigente. Con esto, además, mostró que desconoce los tiempos que demora una víctima en denunciar: hasta siete años, según estadísticas del Ministerio de la Mujer.

${ }^{631}$ CANALES, J. Op. Cit., p. 2. Por ejemplo: “¿le pegó?, ¿La amenazó de muerte?, ¿Le hizo algo de verdad?”, bajo la falsa premisa que la violencia psicológica no fuese suficiente para constituir delito de maltrato habitual”.

${ }^{632}$ CIDH. (2007). Acceso a la justicia para las mujeres víctimas de violencia en las Américas. Párr.8.
} 
avance que ha significado la utilización de la pauta unificada de riesgo y consentimiento informado, para que los antecedentes pasen a SERNAMEG y sea contactada por este organismo para atención psico-socio-jurídica ${ }^{633}$. Una vez ingresadas a esta ruta, existen una serie de problemas que se relacionan con el sector salud, con la falta de motivaciones y recursos en el sistema para realizar los informes psicológicos que en ocasión los jueces exigen a las mujeres en sus procesos; insensibilidad en los médicos tratantes que no dejan plasmados en los informes los casos de Violencia Intrafamiliar ( resistencia de ser llamados a declarar ente tribunal), y que los servicios de salud no están siendo aprovechados como puertas de entrada a la ruta ${ }^{634}$.

En cuanto al poder judicial, los problemas que se constatan, entre otros, son los siguientes: la falta de comprensión del fenómeno, con una naturalización de la violencia de género, atenuación de las sanciones, deslegitimación de las mujeres, descalificaciones de las dimensiones subjetivas y emocionales. Esto sumado, a que algunos jueces, no comprenden la variación de declaraciones, atribución de intencionalidad a la falta de declaración de las denunciantes, dificultades de los actores del sistema de justicia para coordinarse con SERNAMEG, como asimismo falta de flexibilidad y de apertura, reconocimiento solo entre pares; adicionándose, que en las mujeres hay un gran desconocimiento de las etapas del proceso judicial, sus tiempos y consecuencias ${ }^{635}$.

A la luz del estudio del Observatorio de Equidad de Género y Salud, se ha concluido que "las limitaciones de la institucionalidad para sancionar la violencia contra la las mujeres han generado un contexto de gran impunidad, que tiene su base en las definiciones de violencia que contiene la ley, en la insuficiencia de los recursos asignados y en la débil capacitación de las personas que operan el sistema" ${ }^{636}$.

\footnotetext{
${ }^{633}$ OBSERVATORIO DE EQUIDAD DE GÉNERO Y SALUD. (2018). Violencia de Género en Chile. p. 30

${ }^{634}$ LOVATÓN, D. Op. Cit., p .253.

${ }^{635}$ IBIDEM. p.254.

${ }^{636}$ OBSERVATORIO DE EQUIDAD DE GÉNERO Y SALUD. (2018). Op. Cit. p. 30
} 
Dentro de esta esta ruta crítica podemos mencionar los siguientes elementos obstaculizantes:

a) Disparidad de criterios en cuanto a la derivación policial a sede penal o familiar, pues los procedimientos y posibles sanciones son diferentes, no siendo aconsejable que en Chile existan dos jurisdicciones encargadas de la sanción de la Violencia intrafamiliar ${ }^{637}$. Es dable señalar que nuestra legislación contempla actos de Violencia Intrafamiliar que no son constitutivos de delito, es decir, cuando no deja una secuela física que se pueda asimilar al delito de lesiones conforme a la legislación penal, y otros que constituyen delito ${ }^{638}$, lo que ha a nuestro parecer dificulta su tratamiento integral en una sola sede judicial. En este sentido, los insultos y denostaciones no constituyen delitos y son procesados por la justicia de familia, en que las sanciones aplicables son de baja entidad y con escasos efectos reparatorios para las víctimas y disuasivos respecto del agresor.

b) La falta de tratamientos específicos de Violencia Intrafamiliar, tanto para la víctima como para el victimario, revela que el Estado no está dando una respuesta integral a este fenómeno.

c) Las sanciones en nuestro país no aparecen del todo adecuadas, eficientes y eficaces para la protección y reparación de la mujer639.

Tal como se expresa en el Informe Anual de Derechos humanos de la Universidad Diego Portales año 2019, en el capítulo titulado "Acceso a la justicia y violencia contra la mujer" 640 , para facilitar el acceso a la justicia a las mujeres cuando respecto de ellas se ejerce violencia, se formulan una serie de sugerencias:

\footnotetext{
${ }^{637}$ Las declaraciones de incompetencia entre ambas sedes conllevan una desprotección para la víctima. En general no se hace un seguimiento de las medidas accesorias ni de las medidas adoptadas que traen aparejadas hechos más graves.

${ }^{638}$ LEY 20.066. Artículo 6: "Los actos de violencia intrafamiliar que no constituyan delito serán de conocimiento de los juzgados de familia y se sujetarán al procedimiento de la ley 19.968”.

${ }^{639}$ IBIDEM. Artículo 8 y 9, establecen una pena principal de multo a beneficio fiscal, y como accesoria, abandono del hogar común por parte del agresor, prohibición de acercamiento a la víctima, prohibición de tenencia de armas e ingreso a un programa terapéutico respecto del agresor. Además el artículo 7 de esta ley y artículo 92 de la ley 19.968, establecen medidas cautelares durante la secuela del procedimiento.

${ }^{640}$ UNIVERSIDAD DIEGO PORTALES (2019). Informe Derechos Humanos 2019. p. 211.
} 
a) Se recomienda un control efectivo de las medidas cautelares como de las condiciones de la suspensión condicional con el fin de brindar una mayor protección a la víctima.

b) En el ámbito de jurisdicción de familia se recomienda regular normativamente la comparecencia letrada en juicio, dado que en la mayoría de las ocasiones la partes acuden personalmente y desconociendo sus derechos.

c) Incrementar el número de programas de reparación para mujeres víctimas de violencia.

d) Necesidad de desarrollar a lo largo del país programas de rehabilitación de hombres agresores.

e) Fomentar la regulación de los temas conexos de manutención, relación directa y regular por parte de los jueces en la resolución de los problemas de Violencia Intrafamiliar.

f) Insistir en el inicio de un dialogo entre el Ministerio de Educación y las instituciones de educación superior para incluir en las mallas cursos sobre violencia doméstica, de manera que más profesionales puedan acercarse al tema

g) Que se deben tomar en cuenta por parte del Estado y las autoridades, en toda decisión y consideración, las experiencias y expectativas de mujeres y hombres.

\subsection{Jurisprudencia y políticas públicas de acceso a la justica de las mujeres víctimas de violencia de género en Chile}

Se entiende por parte de la judicatura, que el problema es de políticas públicas, en tanto reconocen los deberes del Estado de actuar según la normativa internacional y reconocen la labor del SERNAMEG al realizar asistencia jurídica especializada. Desde la perspectiva de una justicia procesal, la normativa recogida en la síntesis precedente, tiene una lectura influenciada por el artículo $19 n^{\circ} 3$ de la CPR, el cual 
instituye la racionalidad y justicia en los procedimientos que sigan los tribunales competentes para obtener sentencias idóneas. La importancia de la coordinación de tribunal y servicio, se constata en sentencia de CA de Punta Arenas ${ }^{641}$, en que se reconoce la necesidad de la implementación de políticas públicas para superar el fenómeno de la violencia contra la mujer y la importancia de una defensa especializada en el tema.

En otras ocasiones, las sentencias de los tribunales, se constituyen en un obstáculo. Por ejemplo, en una sentencia de la CA de la Serena, dicho tribunal confirmó la utilización de la atenuante de arrebato u obcecación en un caso de femicidio frustrado, debido al arrebato que le habría producido a la pareja de la víctima el conocimiento de una infidelidad ${ }^{642}$.

Tal como lo sostiene el Observatorio de Equidad de Género y Salud, a lo que adherimos, "es necesario la aplicación de políticas públicas con perspectiva de género, lo que supone un diagnóstico del(os) problema(s) donde se reconoce que existen necesidades diferenciadas atendiendo a la adscripción de género, como en

\footnotetext{
${ }^{641}$ CA de PUNTA ARENAS. Sentencia causa rol 28-2012 de 4 de mayo de 2012. Considerando 2: “Así, bajo su potestad jerárquica normativa y conforme a ella, se ha entregado el conocimiento de esas delicadas materias a la judicatura especial integrada con asesores especialistas y funcionando con redes de apoyo como las que aporta SERNAMEG de manera de asegurar la efectiva comprensión del conflicto, cuyos contenidos vienen traspasados por las emociones de los involucrados, entre otros componentes".

${ }^{642}$ CA de LA SERENA. Sentencia causa rol 159-2016 de 31 de mayo de 2016, considerando $7^{\circ}$ : "Que en cuanto al quebrantamiento del principio de razón suficiente por parte de los jueces penales alegada por el recurrente, esta Corte no puede sino acudir al considerando noveno de la sentencia, allí el Tribunal a quo señala el contexto en que ocurrieron los hechos que dieron lugar al delito: "Así, la dinámica de ocurrencia de la agresión, se consolidó con la valoración integrada del relato de la afectada por el delito, Karol Pizarro Chacana, quien de manera conteste con lo referido por su cónyuge y acusado Olmos Barraza, indicó que el día de ocurrencia de los hechos, estuvo marcado por un contexto de develación de una infidelidad de parte de doña Karol Pizarro. Ella reconoció que previo al arribo de carabineros a su casa, recibieron una llamada telefónica, no recuerda bien si a su teléfono al de su marido, pero en definitiva quien contestó el llamado fue el acusado, reconociendo la declarante que quien llamaba era un varón y era su amante. A las preguntas de la defensa, ahondando sobre este aspecto, le respondió la víctima, que tanto el día 25 de junio de ese año, como el día anterior a los hechos, el 27 de julio, se habían recibido llamados de ese sujeto, ante lo cual su esposo le habría interrogado si era capaz de engañarlo, a lo que ella respondió negando esa posibilidad.” Así las cosas, la llegada de carabineros no puede ser tomada en cuenta de manera aislada por los sentenciadores del juicio, sino dentro del contexto que estaban viviendo víctima y acusado, esto es, la develación n directa a Olmos por parte del amante de su cónyuge de que la víctima le era infiel, hechos que el tribunal que recibió la prueba estima probados y que le sirvieron de base para configurar la atenuante del $11 \mathrm{~N}^{\circ} 5$ del Código Penal, tal como se expresa en el considerando décimo catorce; Además, en el considerando décimo octavo el Tribunal del juicio reafirmó este contexto en que ocurrieron los hechos al indicar que considerando los dichos de la víctima ,que efectivamente la concurrencia de un factor emocional de infidelidad e inminente ruptura de su vínculo, fue el elemento gatillante de este hecho"
} 
el impacto que tendrían las acciones, medidas, políticas del Estado orientadas a la solución de la problemática"643.

En nuestro país, El SERNAMEG, tiene como una de sus iniciativas centrales, contribuir a la autonomía física de las mujeres con la erradicación de toda forma de violencia, tanto en lo público como lo privado, a través de la prevención, atención, protección y reparación del daño psicosocial, además de promover el acceso a la justicia de las víctimas mediante un sistema especializado de atención para estos fines.

Dentro de las políticas públicas tendientes a este fin, se pueden considerar, entre otras, las siguientes ${ }^{644}$ :

a) Creación de centros especializados de atención para mujeres víctimas de violencia. En cuanto a la atención integral de mujeres víctimas de violencia de género, tanto en el plano psicológico, social, y por cierto legal, con la finalidad de ser representada en las audiencias ante los juzgados de familia y penal, son cubiertas parcialmente con 109 Centros de la Mujer en todo el país ${ }^{645}$.

b) Realización de campañas mediáticas de sensibilización.

c) Énfasis en la primera respuesta del sistema con respecto a casos de femicidio.

d) Asistencia telefónica y a través de medios tecnológicos.

e) Mecanismos de intervención para proteger a las víctimas de violencia de género.

f) Capacitaciones y formación de monitores en prevención de Violencia.

Todas estas situaciones mencionadas son un reflejo de los retos que el país enfrenta, no solo para el logro del disfrute de un trabajo igualitario y libre de violencia y discriminación en el sistema judicial, sino también para conseguir el eficaz

\footnotetext{
${ }^{643}$ OBSERVATORIO DE EQUIDAD DE GÉNERO Y SALUD. Op. Cit., p.33. “Dichas políticas deben ser desde una perspectiva intersectorial, nacional e integral; la ausencia de una política de esas características vulnera las convenciones internacionales en la materia, y deben propender al mejoramiento del acceso a la justicia de mujeres víctimas de violencia”.

${ }^{644}$ NASH, C; NUÑEZ, C; TRONCOSO, C. Op. Cit., p. 336

645 SERNAMEG. www.sernameg.gob.cl. [Consulta 10 de mayo de 2020].
} 
desarrollo de las políticas y acciones dirigidas a garantizar la no discriminación de todas las chilenas en el acceso a la justicia.

En palabras de Canales, "en lo inmediato, amerita la creación de una ley corta que incorpore y persiga las violencias en contra de las mujeres más allá de las relaciones institucionalizadas, entendiendo que este fenómeno le ocurre a las mujeres por el hecho de serlo y que puede ocurrir en cualquier tipo de relación, formal o informal. Además, es imprescindible que el Ministerio Público no siga interpretando restrictivamente la normativa y de la debida celeridad a las denuncias para evitar el peregrinaje de una víctima de violencia de un órgano estatal a otro"646.

\subsection{El peregrinaje de las víctimas de violencia de género para acceder a la justicia en tiempos de Covid 19}

En atención a los tiempos de la pandemia Covid 19, uno de los focos de preocupación de la comunidad y por cierto del Estado, la ha constituido la situación de las mujeres víctimas de violencia dentro de los hogares. En el entendido, que debido a las medidas de confinamiento que fueron establecidas en el país, como asimismo la modalidad del teletrabajo, y los altos índices de cesantía por el declive económico que se ha experimentado, se ha constatado que la permanencia del hombre en el hogar fuese más habitual, y por consiguiente, en algunos de ellos, los rasgos violentos y los patrones culturales asimétricos se acrecentaron, y consecuencialmente, la violencia en todas sus dimensiones (física, psicológica, sexual, económica etc.). Lo descrito ha provocado en las mujeres una situación de mayor indefensión, por la imposibilidad de denunciar, de obtener protección, y en general, se han visto impedidas de acceder a la justicia.

Con la pandemia, y como se observa en las situaciones de crisis, se produce un proceso psicológico de encapsulamiento, que se relaciona con la teoría modular de la mente. La mente desarrolla mecanismos apropiados para tareas particulares,

${ }^{646}$ CANALES. J (2020). Op. Cit. p. 3. 
como la elección entre alternativas, categorías, ítems y juzgar calidad de hábitat. Así las cosas, se daría un fenómeno de encapsulamiento de Violencia Intrafamiliar. Lo importante en esta situación de crisis sería sobrevivir, lo que nos lleva a presumir que superada la situación de pandemia habría un aumento de denuncias

En Chile, la víctima de violencia de género tarda hasta siete años en denunciar a su agresor. El sistema judicial no reconoce lo difícil que es dar ese paso, siendo atingente proponer un proceso breve e idóneo para sobrevivientes de violencia de género, que tenga énfasis en la protección de la vida y no en el resguardo de lo familiar 647 .

El SERNAMEG ha dado a conocer en el mes de abril de 2020, una serie de mecanismos para realizar denuncias por violencia de género en contexto de pandemia, en que un número importante de ciudades se encontraban en confinamiento o con medidas de restricción parcial a la libertad de desplazamiento. En este sentido, se puede destacar la buena práctica originada en España, Mascarilla 19, que se aplica en Chile, traduciéndose en un convenio suscrito entre SERNAMEG y algunas farmacias, que permite que una mujer ingrese en ese establecimiento previamente señalizado y pida este producto, ante lo cual el funcionario dependiente, activará un operativo de protección, dando cuenta a las policías, fiscalía y al mismo SERNAMEG, para que se implementen medidas urgentes de resguardo a la integridad de la mujer violentada. Además se pueden mencionar mecanismos de denuncia silenciosa, como el "chat web", la denuncia a través del trámite fácil de la oficina judicial del Poder Judicial, y el número de teléfono 1455, todos los que hacen activar este protocolo de protección, evitando la retractación, debido a la complejidad emocional que resulta acercarse a la unidad policial y verbalizar su situación de riesgo, previniéndose además, una potencial persecución del agresor a la unidad policial o los cuestionamientos administrativos o policiales ante la denuncia.

${ }^{647}$ IBIDEM. 
En cuanto al aumento perceptual y no porcentual o numérico de denuncias evidenciado durante la pandemia, Canales sostiene que "si bien las restricciones impuestas por la pandemia limitan el derecho a la libertad de tránsito y pueden explicar que las denuncias por delitos de violencia de género hayan disminuido con respecto al año pasado, esta crisis sanitaria dejará en evidencia las dificultades que enfrentan quienes se atreven a denunciar a sus agresores frente a un sistema judicial, que no las acoge con la celeridad requerida" 648 .

Ahora bien, ¿qué pasa con las víctimas que no alcanzaron a denunciar mientras el delito estuvo flagrante?, ¿seguirán esperando mientras la agresión aumenta por estar confinadas junto a su agresor por el Covid 19?. No hay respuesta para esta interrogante, pero lo más grave es la situación que afecta a quienes no son debidamente representadas, que concurren a denunciar en más de una ocasión y no obtienen respuesta satisfactoria.

Especialmente en el marco de las actuales medidas extraordinarias de limitación de la libertad ambulatoria, recalcamos que es urgente crear un proceso especial para víctimas sobrevivientes de violencia de género, en el que se establezca un estándar probatorio aterrizado, de acuerdo a las características de este tipo de delitos, con procedimientos más breves e idóneos para la concesión de medidas cautelares en la sede de derecho que corresponda, poniendo énfasis en la protección integral de nuestras mujeres.

\footnotetext{
${ }^{648}$ IBIDEM. "Las denuncias habrían disminuido en un 20\% ante el Ministerio Público y en un 59\% ante Carabineros. Ver por ejemplo "Denuncias por violencia intrafamiliar disminuyen en un 59\% durante cuarentena, publicado en El Dínamo el 7 de abril y Fiscal Nacional rinde Cuenta Pública 2020 vía streaming por medidas de prevención del Coronavirus”, publicado por el departamento de prensa de la Fiscalía el 23 de abril.
} 


\section{LA POBREZA COMO CAUSA DE VULNERABILIDAD}

\subsection{Aspectos estadísticos y preliminares de la Pobreza}

América Latina es el continente de la desigualdad y exclusión. No es el más pobre del mundo, pero concentra abusos en las diferencias de pobres y ricos" 649 . La pobreza genera múltiples efectos perniciosos de diversa entidad ${ }^{650}$. Se ha constatado a nivel latinoamericano un aumento de los niveles de pobreza en la población que presenta otras condiciones de vulnerabilidad ${ }^{651}$.

Según datos recientes, Chile es el segundo país con menor "índice pobreza" en Latinoamérica, reportando en un 11,7\% (equivalente a 2.046.404 de personas en situación de pobreza), con una importante disminución de la tasa durante los últimos años, de $29,1 \%$ a $11,7 \%$ entre 2006 a $2015^{652}$. Sin embargo, el $72 \%$ de la riqueza se concentra en el quintil más rico de la población traducido en un índice Gini de 0,73 sobre el 0,53 del indicador general o media 653

EI PNUD propone al menos 3 perspectivas para medir la pobreza: en el ingreso, en la satisfacción de las necesidades básicas y en la capacidad para funcionar socialmente ${ }^{654}$. En el caso de ingreso traza una línea de pobreza en los dos dólares americanos por día para América Latina ${ }^{655}$.

\subsection{Pobreza, vulnerabilidad y desigualdad}

\footnotetext{
${ }^{649}$ ARBELAEZ DE TOBON, L y RUIZ, E. Op.Cit.p.18.

${ }^{650}$ IBIDEM. "Sabemos que la pobreza produce exclusión y marginación, sufrimientos, hambre, desnutrición y enfermedades, limita las libertades y oportunidades sociales, impide el acceso a la educación y cultura, condena a vivir en hábitat inadecuados, en condiciones insalubres de vida e inseguridad en el entorno, ocasiona o profundiza discapacidades, provoca violencia y conflictos armados, excluye de la participación democrática y ciudadana que aumenta gravemente la vulnerabilidad, pero también mata"

${ }^{651}$ IBIDEM. "Por ello, se ha constatado un aumento en el porcentaje de mujeres, niños o personas en situación de discapacidad, con disminución progresiva de recursos no solo económicos, sino también en cuanto a redes de participación sociolaboral y de protección judicial”

652 IBIDEM. p. 14.

653 IBIDEM.

654 PROGRAMA DE NACIONES UNIDAS (2017). Informe sobre desarrollo humano. Nueva York. p. 18.

655 IBIDEM.
} 
Tal como se expresó al iniciar este capítulo, la pobreza se analizará en forma separada a los grupos en condición de vulnerabilidad ya revisados, no obstante que al tenor de las Reglas de Brasilia, constituye por sí un grupo en condición de vulnerabilidad $^{656}$. Sin embargo, por el carácter agravante que a nuestro juicio reviste la pobreza en relación a algunos grupos en condición de vulnerabilidad en el acceso a la justica, dependiendo del contexto relacional y social determinado, bien merece un tratamiento previo y específico, pues la condición de pobreza intensificaría los efectos perniciosos que provocan otras vulnerabilidades, como la calidad de migrante, de perteneciente a una comunidad indígena, etcétera.

Se entiende de este modo que el concepto es bastante amplio, abarcando las distintas formas de vulneración social, ya que la pobreza no es la única forma de vulneración existente, no pudiéndonos permitir ser simplistas y sostener que solo son pobres los individuos que no cuentan con los recursos necesarios de alimentación, educación, salud y vivienda, en pos de satisfacer sus necesidades más básicas. Como lo explica Ribotta, "la pobreza es un eje transversal que se interrelaciona con las demás condiciones de vulnerabilidad y cuando concurre con otra u otras condiciones de vulnerabilidad, se genera una situación de extrema necesidad"657. Para la misma autora, pobreza es "ausencia de capacidades para generar capacidades mínimas aceptables, no es solo falta de recursos económicos, sino la carencia de la facultad de convertirlo en capacidad de funcionamiento"658. La pobreza es una condición que se presenta siempre de manera coyuntural y temporal, aunque según los escenarios sociales, lo profundo de los niveles que se desarrolla la pobreza, el tipo de Estado de Derecho que vivan esos seres humanos

\footnotetext{
${ }^{656}$ XIV CUMBRE JUDICIAL IBEROAMERICANA. Op. Cit., Regla 15: La pobreza constituye una causal de exclusión social, tanto en el plano económico como en los planos social y cultural y supone un serio obstáculo para el acceso a la justicia especialmente en aquellas personas que conviven con otra causal de vulnerabilidad. Regla 16: Se promoverá la cultura y alfabetización jurídica de las personas en situación de pobreza, así como las condiciones para mejorar su efectivo acceso a la justicia.

${ }^{657}$ RIBOTTA, S. Op. Cit., p. 16. “De este modo, los pobres son vulnerables en razón de la pobreza que viven y de la capacidad e incapacidad económica para satisfacer las necesidades básicas y sociales de los seres humanos, especialmente las vinculadas a la salud, alimentación, vivienda, educación, trabajo y acceso al agua potable”.

${ }^{658}$ IBIDEM. p. 16. "Lo más relevante es la pobreza de acceso y disposición de recursos materiales de ingresos y bienes en el sentido de satisfactores que se traduce en carencias de poder económico y de poder social y político que imposibilite a la persona satisfacer sus necesidades básicas, desarrollar sus capacidades básicas y ejercitar su libertad real”.
} 
y el tipo de modelo social y económico que detente, la pobreza se vivirá como una situación de coyuntura económica, de movilidad de clase social o una situación imposible de escapar ${ }^{659}$. En este sentido se sostiene que tanto la pobreza como la desigualdad dependerá de lo profundo que sea la brecha entre ambos polos relevantes de la desigualdad, particularmente de cuan bajo sea el límite inferior y si es suficiente para cubrir las necesidades básicas según el escenario social, económico, político, geográfico, cultural e histórico en que se sitúan las personas ${ }^{660}$.

\subsection{La Pobreza como una cuestión de derechos humanos. Ser pobre y vulnerable como obstáculo en el ejercicio de los derechos}

Las Reglas de Brasilia establecen que la pobreza es una causal de exclusión social en diversos planos, y asimismo constituye un obstáculo para el acceso a la justicia, al tenor de sus reglas 15 y $16^{661}$, después de incluirla dentro de las causas de vulnerabilidad, en la Regla 3.

La Jurisprudencia interamericana, se ha detenido en el análisis de la pobreza, como un elemento integrante y causante de una violación de derechos humanos. De este modo, la pobreza es una cuestión de derechos humanos que origina consecuencias jurídicas vinculantes para los Estados y la sociedad civil. La jurisprudencia interamericana resaltó la idea de asimilar el hambre, la pobreza, la indigencia, hasta la exclusión social, como una forma de tortura, trato cruel, inhumano y degradante 662 .

\footnotetext{
659 IBIDEM. p. 19

${ }^{660}$ IBIDEM. "La pobreza no se detiene en determinar si unos tienen más o menos recursos para hacer frente al desarrollo de sus planes de vida, sino que esta desigualdad y pobreza sea tal que impide que las personas que menos tienen puedan ejercer en igualdad de condiciones el desarrollo de sus capacidades básicas, y por lo tanto, vivir los planes de vida que libremente han escogido".

${ }^{661}$ XIV CUMBRE JUDICIAL IBEROAMERICANA. Regla 15: La pobreza constituye una causal de exclusión social, tanto en el plano económico como en los planos social y cultural y supone un serio obstáculo para el acceso a la justicia especialmente en aquellas personas que conviven con otra causal de vulnerabilidad. Regla 16: Se promoverá la cultura y alfabetización jurídica de las personas en situación de pobreza, así como las condiciones para mejorar su efectivo acceso a la justicia.

${ }^{662}$ CORTE IDH. Caso Loayza Tamayo vs Perú. Sentencia de 17 de septiembre de 1997. Párrafo 57: "La infracción del derecho a la integridad física y psíquica de las personas es una clase de violación que tiene diversas connotaciones de grado y que abarca desde la tortura hasta otro tipo de vejámenes o tratos crueles, inhumanos o degradantes cuyas secuelas físicas y psíquicas varían de intensidad según los factores endógenos y exógenos que deberán ser demostrados en cada situación concreta. La Corte Europea de Derechos Humanos
} 
En ligazón estricta a lo jurídico, tal como lo sostiene Almela, "pobre es la persona que carece de recursos suficientes para sufragar en su oportunidad los gastos de diversa índole que se causen con motivo del juicio o la gestión de que se trate, sin desatender sus necesidades vitales, entendiéndose por tales las suyas propias y las de su familia que viva a sus expensas" 663 .

El costo de los procesos es una limitante para que las personas en situación de pobreza puedan acceder a la justicia664. A tal problema se suma el descontento de la existencia de mecanismos de asistencia jurídica gratuita ${ }^{665}$.

Dentro de las medidas tendientes a erradicar la pobreza por parte de los Estados, destacan ${ }^{666}$ :

a) Nivel estructural: Mediante la obligación de erradicar la pobreza como fenómeno multidimensional a través de políticas tendientes a remover las asimetrías estructurales.

b) Nivel individual: Las obligaciones se condensan en la exigencia de dispensar un tratamiento diferenciado a los pobres, brindándoles mayor protección, tal tratamiento parte de considerar la pobreza como una condición jurídica que condiciona el abordaje, desarrollo y solución de un caso.

\footnotetext{
ha manifestado que, aún en la ausencia de lesiones, los sufrimientos en el plano físico y moral, acompañados de turbaciones psíquicas durante los interrogatorios, pueden ser considerados como tratos inhumanos. El carácter degradante se expresa en un sentimiento de miedo, ansias e inferioridad con el fin de humillar, degradar y de romper la resistencia física y moral de la víctima (cf. Case of Ireland v. the United Kingdom, Judgment of 18 January 1978, Series A no. 25. párr. 167). Dicha situación es agravada por la vulnerabilidad de una persona ilegalmente detenida (cf. Case Ribitsch v. Austria, Judgment of 4 December 1995, Series A no. 336, párr. 36). Todo uso de la fuerza que no sea estrictamente necesario por el propio comportamiento de la persona detenida constituye un atentado a la dignidad humana (cf. Ibid., párr. 38) en violación del artículo 5 de la Convención Americana. Las necesidades de la investigación y las dificultades innegables del combate al terrorismo no deben acarrear restricciones a la protección de la integridad física de la persona”.

${ }^{663}$ ALMELA, C. Op. Cit., p.7. “Aquellas personas que viven en una situación de pobreza, tienen más dificultad que el resto de personas para obtener la satisfacción de sus necesidades jurídicas. Cuando las necesidades básicas no están cubiertas, el nivel de insatisfacción en relación a sus necesidades jurídicas es mayor”

${ }^{664}$ ARBELAEZ DE TOBON, L y RUIZ, E. Op. Cit. p. 27. "La pobreza es uno de los principales factores que dificultan el acceso a la justicia, ya que el costo que entrañan los procesos judiciales para aquellas personas que viven en condiciones de pobreza o extrema, es muy alto, y en ocasiones este grupo poblacional debe priorizar otros derechos esenciales para la existencia, como vida o la alimentación”.

${ }^{665}$ RIBOTTA, S. Op. Cit., p. 23. "La tutela jurídica diferenciada de los pobres como sujetos vulnerables implica que las obligaciones de respeto, de garantía, de adoptar medidas legislativas -o de otro carácter- y la prohibición de discriminación se intensifican y particularizan ente la pobreza y los pobres por acción de los Estados” ${ }^{666}$ IBIDEM.
} 


\section{4. ¿Quiénes se consideran pobres en Chile? Relevancia de esta distinción en materia de acceso a la justicia y asistencia jurídica gratuita}

La pobreza debe ser considerada bajo un concepto amplio y susceptible de interpretaciones en base a diversos criterios. En este orden de ideas, Pablo Andrade y Alicia Puyana, expresan que "la pobreza no es un concepto unitario y univoco, sino que una situación susceptible de distintas interpretaciones determinadas por los factores de análisis considerados como relevantes, primando en Chile un enfoque de pobreza medible en base a los ingresos del grupo familiar, estando precedido de otros enfoques de conceptualización y medición de la pobreza"667. Bajo esta premisa, la forma de calificar la pobreza en Chile, que nos permite determinar quiénes son pobres, nos lleva a describir el enfoque del Ministerio de Planificación Nacional, actual Ministerio de Desarrollo Social, desde 1990 hasta la fecha, con algunas variantes, como la inclusión del Registro Social de Hogares (RSH), constituido en mecanismo de medición desde el año 2017. Este enfoque actual está basado en los ingresos ${ }^{668}$ y traza líneas de pobreza o indigencia,

${ }^{667}$ ANDRADE, P y PUYANA, A. (2010). La Pobreza en América Latina ¿Una dimensión olvidada de la integración económica regional?. Santiago. Clacso Libros. p.27. “a) Enfoque Neoliberal: Surge en los comienzos de los años 1970, debido a las metodologías y conceptos del Banco Mundial. Se definió la pobreza en un sentido absoluto como la insatisfacción de necesidades básicas sobre un patrón mínimo. El principal parámetro que utilizaba lo constituían las condiciones de vivienda (tipo de vivienda, eliminación de excretas, grado de hacinamiento y equipamiento hogar). En Chile, a través de las agencias políticas sociales del gobierno militar, Oficina de Planificación Nacional y Secretaría de Desarrollo Social se adoptó este enfoque.

b) Enfoques de las estrategias de sobrevivencia: Los sectores de resistencia al gobierno militar chileno, organizaciones de base, parte de la iglesia católica en la denominado "opción preferencial por los pobres” y agencias de cooperación internacional, lo adoptaron en las décadas de los 1980. Esta definía la pobreza como la exclusión política, social y espacial, poniendo de este modo, mayor atención a las condiciones de vida de los sectores populares y sus estrategias para enfrentar la pobreza más que en las rentas o ingresos.

c) Enfoque de los organismos internacionales: Este enfoque se basa en una interpretación de la realidad latinoamericana en algunos casos y en la del mundo en vías de desarrollo en otros. Fue desarrollada por las agencias de la ONU, Organización Internacional del Trabajo, PNUD, y posee la objetividad de las que carecen otros enfoques. Define la pobreza como la insatisfacción de las necesidades básicas, medida según los indicadores de ingreso en relación al costo de una canasta básica de alimentos que cubre los requerimientos nutricionales mínimos recomendados por la Organización de las Naciones Unidas para la alimentación y la Agricultura, y la Organización Mundial de Salud.

d) Enfoque Crítico: Se construye desde la teoría de la marginalidad y de los enfoques de los organismos internacionales. Define la pobreza como la insatisfacción de necesidades básicas, producto de una distribución del ingreso inequitativa, además de la marginalidad y privación de los beneficios del desarrollo”.

${ }^{668}$ El criterio para medir la pobreza es en base a los ingresos que se generan en un grupo familiar (divididos por el número de miembros del mismo, ingreso percápita familiar) que pueda cubrir una canasta básica de alimentos y cubrir necesidades básicas de salud, educación, vivienda; es decir se considera pobre la persona perteneciente a un grupo familiar, que no puede generar una determinada cantidad de dinero, que les posibilite 
elaboradas en torno al costo de canastas alimentarias mensuales per cápita y al ingreso de los hogares, midiendo la pobreza y determinando los beneficiarios de ciertas prestaciones del Estado, mediante la aplicación de "fichas, encuestas o cartolas" ubicando a la población en tramos porcentuales, siendo los quintiles, deciles o porcentajes más bajos, los considerados pobres o indigentes, según el caso. Es relevante, tal como se realiza actualmente con el $\mathrm{RSH}$, incluir una mirada multidimensional en la medición, del que carecían sistemas anteriores, que no solo determine la pobreza en base a los ingresos, sino que atienda a otros factores, que dicen relación con la vulnerabilidad que presentan las estructuras familiares, tales como la presencia de enfermedades catastróficas o la existencia de personas en situación de discapacidad dentro del grupo familiar.

El RSH es una base de datos que contiene información de las personas y los hogares que han solicitado su incorporación ${ }^{669}$, y está constituido por los datos aportados, tanto por las familias como por las distintas instituciones del Estado, permitiendo entregar a la ciudadanía un instrumento transparente y sencillo, que refleja la realidad socioeconómica de los hogares de Chile ${ }^{670}$.

La calificación socioeconómica que se hace para obtener este registro, es el rango porcentual en que se ubican los hogares de acuerdo a los ingresos efectivos que perciben, número de personas que componen el hogar y sus características ${ }^{671}$ y dependiendo de esta calificación van a condicionarse los beneficios que puedan

cubrir una determinada canasta básica, que se fija mensualmente según la variación del Índice de precios al consumidor. El criterio basado en la renta del individuo si bien es practico al momento de determinar quien cumple con dicho requisito, evitando el abuso y haciendo más expedito el otorgamiento de un beneficio determinado, tiene el grave inconveniente de dejar fuera de optar a éstos, a personas que si bien tienen un ingreso superior al establecido, son tan o más pobres que las personas que entraron a gozar del beneficio, en atención a sus necesidades sociales y familiares particulares.

${ }^{669}$ Las personas deben solicitar en sus municipios la incorporación a este registro.

${ }^{670}$ MINISTERIO DE DESARROLLO SOCIAL. http://www.registrosocial.gob.cl/ [Consulta 2 de abril de 2020]. "Este instrumento perfecciona las deficiencias de la FPS, está constituido con datos aportados por el usuario interesado en ser calificado, y las bases de datos administrativas que posee el Estado, lo cual permite ubicar finalmente a cada hogar en un tramo de ingreso o vulnerabilidad socioeconómica.

${ }^{671}$ IBIDEM. "Una vez establecido el tramo de calificación socioeconómica sobre la base del promedio de ingresos per cápita corregido por el índice de necesidades, el sistema evalúa la coherencia del tramo determinado con la tenencia de bienes raíces y/o vehículos de los integrantes del hogar y acceso a planes de salud y/o establecimientos educacionales de alto valor, relacionando la variante económica con la social. Existiendo menores de edad en el hogar, también verifica el nivel de ingreso de padres o madres cuando éstos no forman parte del hogar, en base a los cuales el tramo de calificación socioeconómico podría ser modificado". 
optar y los énfasis que las políticas públicas deben considerar para la satisfacción de las necesidades de tipo social que se puedan detectar ${ }^{672}$.

Extrapolando estos enfoques a materia de asistencia jurídica, se debe considerar como fundamento el texto constitucional, que asegura el asesoramiento y defensa gratuita a toda persona que no pueda procurársela por sí mismo ${ }^{673}$. Se insta asegurar, por mandato constitucional en Chile, la posibilidad de acceder a la asistencia letrada gratuita, no dependiendo únicamente del monto de recursos económicos personales que disponga, sino de la posibilidad o imposibilidad de la persona de costear un abogado, independiente del nivel de ingresos que tenga, basándose en estos parámetros de mediciones, pero otorgando una cierta libertad dentro de estos márgenes, a los prestadores estatales de la asistencia jurídica gratuita, para la focalización o determinación de sus potenciales usuarios, , tal como se expondrá.

\subsection{Población pobre como beneficiaria de la asistencia jurídica gratuita por parte del Estado}

\subsubsection{Mecanismos de focalización o de determinación de usuarios por parte de los servicios de Asistencia Jurídica Gratuita}

Las obligaciones en torno a promover y asegurar el acceso a la justicia, en concordancia con la regla $24^{674}$ de las Reglas de Brasilia, vinculan a los tres poderes

\footnotetext{
${ }^{672}$ Así en los dos primeros tramos, del 0 al 40\%, se encuentran los hogares de menores ingresos o mayor vulnerabilidad y del 81 al $100 \%$ se sitúan los hogares con mayores ingresos o menor vulnerabilidad. La aplicación de la cartola que ubica a las personas en un tramo determinado, le permite optar a beneficios, como subsidio único familiar, ingreso familiar de emergencia para aliviar pandemia Covid 19, subsidio de agua potable y alcantarillado, optar a atención de salud y jurídica gratuita etcétera.

${ }^{673}$ En principio no podrán procurársela por sí mismos, los que están insertos dentro de los tramos de pobreza que los hace vulnerables, considerando sus ingresos y los otros factores que los categorizan en este tramo.

${ }^{674}$ XIV CUMBRE JUDICIAL IBEROAMERICANA.. Regla 24: "Serán destinatarios del contenido de las presentes Reglas: a) Los responsables del diseño, implementación y evaluación de políticas públicas dentro del sistema judicial; b) Los Jueces, Fiscales, Defensores Públicos, Procuradores y demás servidores que laboren en el sistema de Administración de Justicia de conformidad con la legislación interna de cada país; c) Los Abogados y otros profesionales del Derecho, así como los Colegios y Agrupaciones de Abogados; d) Las
} 
del Estado, exigiendo un rol activo a los servicios de justicia, y no solo a los tribunales, en pos de remover obstáculos estructurales y asegurar el real ejercicio de los derechos por parte de todos los habitantes del territorio del Estado que se trate, sin ninguna distinción.

En el otorgamiento del derecho de asistencia jurídica gratuita por parte de los Estados, en general, se recurren a criterios socio-económicos, diversos a la pobreza o indigencia ya descritos, ampliándose a grupos desprotegidos o derechamente vulnerables, sin que por definición estadística o porcentual pertenezcan estrictamente a la categoría de "pobres".

Las leyes 17.995 y 18.632, que establecen el marco jurídico de funcionamiento de las CAJ existentes en Chile ${ }^{675}$, preceptúan que su finalidad es "prestar asistencia jurídica y judicial gratuita a personas de escasos recursos". De igual manera, los estatutos de las CAJ establecen que éstas tienen “...por objeto proporcionar asistencia judicial y/o jurídica gratuita a personas de escasos recursos"676. La población objetivo de las CAJ no se encuentra especificada en su marco legal, más allá de señalar que se refiere a personas de escasos recursos, lo que ha generado que cada una de ellas, lleve a cabo un trabajo propio para determinar los criterios de focalización de sus servicios, a través de la caracterización de la condición de pobreza o escasos recursos, así como para realizar la calificación socioeconómica de los usuarios ${ }^{677}$. Se ha hecho la distinción en cuanto a que la atención de orientación e información es universal y es la línea de representación judicial la que requiere un mecanismo de focalización, en atención a que solo algunas personas pueden optar al beneficio de la asistencia jurídica gratuita, en este caso.

Por otra parte, desde el año 2011, las CAJ llevaron a cabo diagnósticos de sus mecanismos de calificación socioeconómica vigentes, para focalizar o seleccionar

\footnotetext{
personas que desempeñan sus funciones en las instituciones de Ombudsman. e) Policías y servicios penitenciarios. f) Y, con carácter general, todos los operadores del sistema judicial y quienes intervienen de una u otra forma en su funcionamiento”.

${ }^{675}$ Existen 4 Corporaciones de Asistencia Judicial, Corporación de Asistencia Judicial Tarapacá, con sede en Iquique. Corporación de Asistencia Judicial de Valparaíso, con domicilio en Valparaíso, Corporación de Asistencia Judicial Bío Bío, con sede en Concepción y Corporación de Asistencia Judicial Región Metropolitana, con domicilio en Santiago, las cuales gozan de personalidad jurídica propia.

${ }^{676}$ DECRETO CON FUERZA DE LEY 995 de 21 de septiembre de 1981. Artículo 3 a).

${ }^{677}$ ORDINARIO Nº 685 MINISTERIO DE JUSTICIA. Mecanismo de Focalización Socioeconómica para la atención en la Línea Judicial de las Corporaciones de Asistencia Judicial. p.1.
} 
sus usuarios, constatándose que existen diferencias en los métodos utilizados, basándose en los enfoques de medición para la pobreza en general ya revisados, presentando matices, tanto en cuanto a los criterios, como en los procedimientos de calificación.

Si bien, el RSH constituye en esencia el mecanismo de focalización de las CAJ, para determinar el ingreso al servicio, la experiencia adquirida por los operadores del servicio de asistencia jurídica gratuita ha demostrado la necesidad de mantener vigente un instrumento subsidiario de calificación socioeconómica para aquellas personas que no están inscritas en el RSH, o cuya información se encuentra desactualizada o que la misma se considere no fidedigna. En base a lo anterior, la mesa técnica del Ministerio de Justicia, construyó la aplicación de una Entrevista de Primera Atención, la cual además de registrar los datos de caracterización del usuario/a, permite efectuar una calificación socioeconómica, a través de los conceptos de ingreso autónomo, ingreso autónomo per cápita del hogar y especialmente la capacidad de pago ${ }^{678}$.

De esta forma, podrán ser usuarios de las CAJ en forma automática, los usuarios que según el RSH formen parte de un hogar cuya calificación se encuentra dentro del $\vee$ decil o 50\% más vulnerable, quienes ingresarán directamente al servicio de patrocinio judicial de las CAJ. En este sentido varía del 40\% que constata el RSH para considerar a una persona dentro de la población más vulnerable desde una perspectiva socioeconómica. En atención a lo señalado, se adoptarán mecanismos de focalización o de determinación de usuarios, distinguiéndose la focalización de un usuario por ingreso automático, sin necesidad de una calificación socio económico previo y las que requieren de esta calificación socioeconómica para discernir su entrada al servicio, en mérito de la capacidad de pago ${ }^{679}$. Tal como fluye

\footnotetext{
678 IBIDEM. “ La capacidad de pago, se define para estos efectos, como los medios económicos disponibles que tiene una persona para obtener asesoría jurídica con el fin de ejercer sus derechos ante los tribunales de justicia "Para establecer la capacidad de pago de una persona, se deberá identificar el ingreso monetario de la familia, entendiéndose por éste, el ingreso autónomo más las transferencias que recibe el hogar por parte del Estado, al que se restará el nivel de gastos del grupo familiar, los cuales se definen como el valor de los bienes y servicios de consumo adquiridos por un hogar para la satisfacción directas de las necesidades no suntuarias de sus miembros”.

${ }^{679}$ Se entiende que deben ser calificados los que se encuentran del sexto al décimo decil de la población en adelante, es decir el 50\% menos vulnerable. Los que se encuentran dentro del 20\% menos desfavorecido, no
} 
del Mecanismo de Focalización Socioeconómica para la Atención en la Línea Judicial de las CAJ elaborado por el Ministerio de Justicia, se les aplicará la calificación socioeconómica a todos aquellos usuarios que no se encuentren registrados en el $\mathrm{RSH}$ al momento de solicitar el patrocinio judicial y asimismo se aplicará a los usuarios que no ingresen en forma automática, es decir, aquellos usuarios que pertenezcan a un hogar cuyo tramo de calificación los ubique sobre el $v$ decil y hasta el viii decil inclusive (50 a $80 \%$ menos vulnerable) ${ }^{680}$.

En cuanto al ingreso automático al servicio, independiente del ingreso económico, se consideran dos criterios, tanto de vulnerabilidad, como por aplicación de leyes:

a) Por criterio de vulnerabilidad: Corresponde a los usuarios, que por su condición, se consideran que están en una situación de vulnerabilidad acreditada, como en los siguientes casos, más allá de su nivel de pobreza o de disposición económica. En este criterio se incluyen:

a1) Beneficiario del sistema intersectorial de protección social: Se acredita esta calidad con un carnet otorgado por el Ministerio de Desarrollo Social, para que puedan gozar de diversos servicios estatales, dentro del que se encuentra la asistencia jurídica gratuita.

a2) Representación de víctimas de delitos violentos. Se consideran vulnerables, por ser víctimas de delitos de alta connotación social, que les haya generado un daño, tanto físico como psicológico. Permite su ingreso automático a la línea de representación judicial, como asimismo a los Centros de Atención a Víctimas de las

\footnotetext{
se será calificado y no podrá ingresar al servicio, salvo la línea de orientación e información que es de ingreso universal.

${ }^{680}$ IBIDEM. p .6. “A mayor abundamiento, para los efectos de determinar el ingreso del usuario a patrocinio judicial en función de la calificación socioeconómica efectuada, se considerará el ingreso autónomo per cápita y la capacidad de pago del usuario, atendiendo los siguientes criterios de corte". "Casos de ingreso automático: a) Aquellos usuarios que presenten un ingreso autónomo per cápita del hogar igual o inferior a 3 U.F, ingresarán directamente a la línea judicial. b) Respecto de aquellos usuarios pertenecientes a un grupo familiar que presente un ingreso autónomo per cápita entre 3 U.F a 12 U.F, se evaluará la capacidad de pago. Si esta es inferior o igual a 2,5 U.F, será beneficiario de patrocinio judicial. Si la capacidad de pago es superior, el usuario quedará excluido del servicio de patrocinio judicial c) Aquellos usuarios que presenten un ingreso autónomo per cápita superior a 12 UF, por regla general quedarán excluidos del servicio de patrocinio judicial de la CAJ, con excepción de aquellos que declaren gastos de salud originados por enfermedad de alto costo, a los cuales se les aplicará criterio de capacidad de pago, ingresando al servicio si es igual o inferior a 2,5 U.F. La UF es una medida reajustable crediticia y comercial que sirve de marco referencial en leyes y decretos para dar un valor de referencia a determinados bienes, servicios o transacciones. Valor UF a 30 de abril de 2020 \$28.690 pesos”.
} 
CAJ, que tienen por finalidad la representación judicial a través de presentación de querella en el juicio criminal, contemplando además el acompañamiento psicológico y social.

a3) Representación de víctimas de violencia Intrafamiliar: En este contexto, se debe indicar que el Estado a través de la ley 20.066 otorga a las víctimas de violencia intrafamiliar determinadas garantías a fin de velar por su bienestar físico y psíquico. En este sentido, la violencia intrafamiliar es un fenómeno en que las mujeres, NNA y adultos mayores, son los grupos más vulnerables, por lo que adoptar medidas conducentes a garantizar la vida, integridad personal y seguridad de los miembros de la familia, se traduce entre otras acciones, en el deber de adoptar políticas orientadas a prevenir la violencia intrafamiliar, en especial respecto de estos grupos, y a procurarles asistencia jurídica gratuita. En ese sentido, los usuarios que sean víctimas de violencia intrafamiliar, ingresan de forma automática a la línea de patrocinio judicial.

a4) Beneficiarios del Programa de Reparación y Atención Integral de Salud: E Estado de Chile reconoce como víctimas a familiares de detenidos desaparecidos y ejecutados políticos en la época de dictadura militar (1973-1990), siendo beneficiarios de pensiones de reparación, becas de estudios, atención en salud física y mental, y otros beneficios, entre los que se encuentra la asistencia jurídica estatal gratuita ${ }^{681}$.

a5) Personas con discapacidad: El Estado debe adoptar las acciones para velar que las personas con alguna discapacidad, sin perjuicio de estar en una situación de pobreza o no, puedan tener un tratamiento diferenciado en este ítem y optar a la asistencia jurídica gratuita del Estado. Lo anterior, debido a que son personas que deben invertir muchos recursos en la discapacidad que les afecta y por tanto no siempre tendrá los recursos para proporcionarse un abogado particular ${ }^{682}$.

${ }^{681}$ LEY 19.123. Crea la Corporación Nacional de Reparación y Reconciliación, Establece pensión de reparación y otorga otros beneficios en favor de personas que señala, de 8 de febrero de 1992. LEY 19.980. Modifica la ley 19,123, Ley de Reparación, ampliando o estableciendo beneficios en favor de las personas que indica, de 9 de noviembre de 2004. Ley 20.405. Que crea el Instituto Nacional de Derechos Humanos, de 10 de diciembre de 2009.

${ }^{682}$ Por otra parte y en cuanto a la acreditación de la discapacidad, está queda sujeta al criterio profesional y en aquellos casos donde existe una duda razonable se podrá requerir a la persona, de manera excepcional la acreditación de su condición de discapacidad, mediante el certificado otorgado por el COMPIN, con el objetivo 
b) Por aplicación de leyes: Corresponde a los usuarios que por ley ingresan automáticamente a la línea de patrocinio judicial, entre los que se encuentran:

b1) Personas indígenas solo en materia de dominio y distribución de tierras según el artículo 57 de la Ley 19.253 de 5 de octubre de 1993, que establece normas sobre protección, fomento y desarrollo de los indígenas y crea la Corporación Nacional de Desarrollo Indígena ${ }^{683}$.

b2) Curador ad litem de un menor de edad ${ }^{684}$.

b3) Juntas de Vecinos y demás organizaciones comunitarias ${ }^{685}$.

b4) Personas privadas de libertad ${ }^{686}$.

En materia de defensa penal se establece la atención de un defensor en forma gratuita hasta un cierto nivel de ingreso autónomo del imputado ${ }^{687}$.

En forma ilustrativa, podemos mencionar que en España, en conformidad a la ley 1/1996 de 10 de enero de 1996 sobre asistencia jurídica gratuita ${ }^{688}$, en relación al

de facilitar a las personas con capacidades diferentes el acceso a la justicia y evitar las burocratización que pudiera generarse producto de la exigencia de acreditación y que finalmente, por medio de los antecedentes presentados del usuario y el criterio profesional se resuelva de forma inmediata el ingreso o exclusión del servicio.

${ }^{683}$ Se analizará este artículo en el análisis del grupo respectivo.

${ }^{684}$ LEY 19968. Crea los Tribunales de Familia, de 30 de agosto de 2004. Artículo 19. "En todos los asuntos de competencia de los juzgados de familia en que aparezcan involucrados intereses de niños, niñas, adolescentes, o incapaces, el juez deberá velar por que estos se encuentren debidamente representados. El juez designará a un abogado perteneciente a la respectiva Corporación de Asistencia Judicial o a cualquier institución pública o privada que se dedique a la defensa, promoción o protección de sus derechos, en los casos en que carezcan de representante legal o cuando, por motivos fundados, el juez estime que sus intereses son independientes o contradictorios con los de aquel que corresponda legalmente su representación. La persona así designada será el curador ad-litem del niño, niña, adolescente o incapaz, por el solo ministerio de la ley y su representación se extenderá a todas las actuaciones judiciales...”.

${ }^{685}$ LEY 19.418, Establece normas sobre juntas de vecinos y demás Organizaciones comunitarias, de 20 de marzo de 1997. Artículo 28: "Asimismo, estas organizaciones gozarán, por el solo ministerio de la ley, de privilegio de pobreza. Pagarán rebajados, en el 50\%, los derechos arancelarios que correspondan a notarios, conservadores y archiveros por actuaciones no incluidas en el privilegio anteriormente citado. Las donaciones y asignaciones testamentarias que se hagan a favor de las juntas de vecinos y de las demás organizaciones comunitarias estarán excedentes de todo impuesto y del trámite de insinuación”.

${ }^{686}$ CPC. Artículo 135: "Se estimará como presunción legal de pobreza la circunstancia de encontrarse preso el que solicita el privilegio, sea por sentencia condenatoria, sea durante la substanciación del juicio criminal”.

${ }^{687}$ DPP. http://www.dpp.cl/pag/92/256/aranceles_y_tramos. [Consulta 3de abril de 2020]. "Se establece que la gratuidad del servicio si el imputado registra como ingreso igual o menos de 13,5 UTM. En la línea superior a ese rango comienza el copago, que puede llegar a un pago íntegro del servicio si la persona percibe más 120 Unidades Tributarias Mensuales (UTM). Cada prestación procesal tiene un valor dependiendo de la complejidad del caso y el tiempo empleado, según una tabla de valores emanado de un decreto económico del Defensor Nacional Penal Público. Así nos encontramos que una gestión de salida alternativa tiene un costo de 26,79 UTM, la gestión y representación de una causa que termine en juicio abreviado tiene un valor de 36,71 UTM y la gestión y representación en un juicio oral tiene un valor de 87,36 UTM".

${ }^{688}$ LEY 1 /1996 de Asistencia Jurídica Gratuita, de 10 de enero de 1996. Artículo 1. 
artículo 119 de la Constitución, se consagra que se otorgará el derecho a la asistencia jurídica a personas naturales y jurídicas. Se establece para las primeras, como inicial criterio de clasificación y procedencia, que acrediten insuficiencia de recursos para litigar ${ }^{689}$, sin perjuicio que tal como lo indica el inciso final del artículo 1 de la referida norma, "en la aplicación de esta ley deberán tomarse en consideración las necesidades específicas de las personas que se encuentran en situación de vulnerabilidad"690.

En concreto, en conformidad a la normativa española, tendrán derecho a la asistencia jurídica gratuita:

a) Los ciudadanos españoles, los nacionales de los demás Estados de la Unión Europea y los extranjeros que residan en España, cuando acrediten insuficiencia de recursos para litigar.

b) Las entidades gestoras y servicios comunes de la seguridad social.

c) Las siguientes personas jurídicas cuando acrediten insuficiencias de recursos para litigar, como asociaciones de utilidad pública y fundaciones inscritas en el registro administrativo correspondiente ${ }^{691}$.

d) En el orden jurisdiccional penal: Tendrán derecho a la asistencia letrada y a la defensa y representación gratuita, todos los ciudadanos, aunque sean extranjeros, que acrediten insuficiencia de recursos para litigar, aun cuando no residan legalmente en territorio español

e) En el orden contencioso administrativo: Los ciudadanos extranjeros que acrediten insuficiencia de recursos para litigar, aun cuando no residan legalmente en territorio español, tendrán derecho a la asistencia letrada y a la defensa y representación gratuita en todos aquellos procesos relativos a su solicitud de asilo y ley de extranjería (incluida vía administrativa previa).

${ }^{689}$ MINISTERIO DE JUSTICIA DE ESPAÑA. https://www.mjusticia.gob.es/cs/Satellite/Portal/es/serviciosciudadano/tramites-gestiones-personales/asistencia-juridica-gratuita. [Consulta 3 de abril de 2020].

${ }^{690}$ LEY 1 /1996 de Asistencia Jurídica Gratuita, de 10 de enero de 1996. Artículos 2 y 3

${ }^{691}$ En caso de personas jurídicas, es necesario que se trate de asociaciones declaradas de utilidad pública o de fundaciones inscritas en el registro administrativo correspondiente y que su base imponible en el impuesto sobre sociedades sea inferior a la cantidad equivalente triple del Indicador Público de Renta de Efectos Múltiples, en cómputo anual. 
f) Víctimas de violencia grave: Con independencia de la existencia de recursos para litigar, se reconoce el derecho de asistencia jurídica, que se les prestará de inmediato, a la víctimas de violencia de género, de terrorismo y de tratas de seres humanos en aquellos procesos que tengan vinculación, deriven o sean consecuencia de su condición de víctimas, así como a los menores de edad y las personas con discapacidad psíquica, cuando sean víctimas de situaciones de abuso o maltrato.

g) Afectados por accidentes profesionales, viales o afines: Se reconoce el derecho de asistencia jurídica gratuita a quienes a causa de un accidente acrediten secuelas permanentes que les impidan totalmente la realización de las tareas de su ocupación laboral o profesional habitual y requieran la ayuda de otras personas para realizar las actividades más esenciales de la vida diaria, cuando el objeto del litigio sea la reclamación de indemnización por los daños personales y morales sufridos ${ }^{692}$.

Tanto en Chile, como en España, la intención del Estado es ampliar su capacidad estatal en cuanto a la existencia de servicios jurídicos gratuitos e integrales para la protección de los derechos sociales organizados por el Estado.

\subsubsection{Privilegio de Pobreza}

En nuestro país se consagra el privilegio de pobreza, que se encuentra regulado por el $\mathrm{CPC}^{693}$ y el $\mathrm{COT}^{694}$, que habilita para litigar sin costos. A nuestro juicio, más que privilegio o beneficio, es propiamente un derecho de asistencia jurídica gratuita reconocido por el Estado y los tribunales, que está dado para las personas que están en situación no necesariamente de pobreza, sino de indisponibilidad de

\footnotetext{
${ }^{692}$ MINISTERIO DE JUSTICIA DE ESPAÑA. https://www.mjusticia.gob.es/cs/Satellite/Portal/es/serviciosciudadano/tramites-gestiones-personales/asistencia-juridica-gratuita. [Consulta 3 de abril de 2020].

${ }^{693}$ CPC. Título XIII. Artículos 129-137.

${ }^{694}$ COT. Título XVII. Artículos 591-602.
} 
recursos para desarrollar sus planes de vida, ejercer sus libertades y derechos, específicamente, pagar abogado o cubrir los costos del proceso ${ }^{695}$.

Como bien lo expresa Benito Mauriz este derecho a litigar sin costos o "privilegio" se ha definido "como un derecho que tienen las personas pobres, consistente en obtener asistencia jurídica y los gastos derivadas de la misma -en sentido ampliosin necesidad de pagar por ello"696. EI COT en su artículo 591 se refiere al alcance extensión del Privilegio de pobreza ${ }^{697}$. Además el mismo cuerpo normativo se refiere a las prestaciones cubiertas ${ }^{698}$, y a la obligación de reintegro en caso de sentencia favorable 699 .

Gómez Colomer, lo entiende como "un derecho subjetivo que conceden las leyes procesales, consistentes en la excepción de los gastos que el proceso origina, a aquel que va a ser parte, o que ya lo es, cuyos recursos económicos acredite ser insuficientes, de acuerdo con los baremos que aquellos establecen, para

695 "Pues bien, el derecho a recibir ayuda económica del Estado para costear la asesoría y defensa jurídica supone un grado o nivel relativo de pobreza, no absoluto. En efecto, significa, por una parte que la ley debe ayudar al indigente, es decir, a quien no tiene medios suficientes para preparar y sostener su acción o los recursos procesales, pero también quiere decir, por otro lado, que dicha facultad se debe otorgar igualmente a quienes, disponiendo de algunos recursos, carecen de estos en cantidad adecuada, por lo cual tampoco pueden contar con medios para pagar un abogado, receptor o gastos notariales". "No se trata, es suma, de ayudar solo a desvalidos o menesterosos, carentes absolutamente del dinero con el cual sufragar su asesoría o defensa jurídica, sino que, además, a quienes, por necesidades inevitables de índole familiar, social o personal se hallan en posición vulnerable para defender su dignidad y derechos esenciales amenazados o vulnerados. En el fondo, la Constitución reitera aquí el principio de isinomia o igualdad, aplicándolo en el campo de la asesoría y defensa jurídica”.

${ }^{696}$ MAURIZ, B. (1999). El privilegio de pobreza en la asistencia legal en Chile. Ponencia Asistencia Legal en PUC. Santiago.

${ }^{697}$ CPC. Artículo 591 inciso 1: "El privilegio de pobreza, salvo en los casos que se conceda por el solo ministerio de la ley, será declarado por sentencia judicial y deberá pedirse al tribunal a quién le corresponde conocer en única o primera instancia del asunto en que haya de tener efecto". inciso segundo: "Los que lo obtuvieren usaran papeles simples en sus solicitudes y actuaciones y tendrán derecho para gratuitamente servidos por los funcionarios del orden judicial, y a los abogados ,procuradores y funcionarios subalternos designados para prestar servicios a los litigantes pobres”; Inciso tercero: "Salvo que la ley expresamente ordene otra cosa quedarán también exentos al pago de las multas establecidos para los litigantes, pero si procedieren con notoria malicia, podrá el tribunal imponer la multa correspondiente, conmutando en arresto de un día por un vigésimo de sueldo vital”.

${ }^{698}$ COT. Artículo 602: “Tiene derecho a la gratuidad de ciertas escrituras y certificados relativos al derecho de familia, otorgados por notarios y oficiales civiles. Además los escritos y las sanciones que dieren origen el reconocimiento o legitimación de hijos, estarán exentos de todo impuesto”.

${ }^{699}$ CPC. Artículo 594: "Pero si el litigante pobre obtuviere en el juicio, será obligado a destinar una décima parte del valor líquido que resultare a su favor para el pago de los honorarios y derechos causados, distribuyéndose esta suma a prorrata entre todos los interesados, sino alcanzaren a ser íntegramente cubiertos de lo que se les adeudare”. 
sufragarlos"700. El privilegio de pobreza entones, es un derecho público consistente en un conjunto de beneficios pecuniarios, ya sea otorgado por ley o por el juez respectivo, permite que aquellos que no cuenten con lo necesario para solventar los gastos de un litigio, puedan acudir a los tribunales de justicia para interponer sus pretensiones u oponerse a ella ${ }^{701}$.

Si bien, el CPC se refiere en el título XIII al "Privilegio de Pobreza", y en el COT se refiere en el título XVII a "de la asistencia judicial y del privilegio de pobreza", cuando se desarrollan la normas a través de los correspondientes articulados, alude a criterios en función de esta indisponibilidad, y deja a la regulación de los prestadores del servicio el establecimiento de los criterios de indisponibilidad, o al juez, quién tendrá además la posibilidad de aplicar los parámetros objetivos que señala la ley ${ }^{702}$. Tal como lo preceptúa la normativa procesal chilena, se contempla un privilegio de pobreza judicial ${ }^{703}$, que debe solicitarse por la parte interesada al juez que conoce del asunto, en cualquier estado del proceso y aun antes de la iniciación del juicio, debiendo invocar alguna causal que lo haga procedente ${ }^{704}$.

Para justificar la existencia de estos requisitos, se sostiene que tiene como fin evitar hasta donde sea posible, que los que obtengan este privilegio promuevan demandas frívolas, maliciosas o temerarias ${ }^{705}$, y en caso de proceder con esta

\footnotetext{
${ }^{700}$ GOMEZ COLOMER, J. (1981). El beneficio de Pobreza (La solución española al problema del acceso gratito a la justicia). Barcelona. Editorial José Bosch S.A. p. 39.

${ }^{701}$ Así el privilegio de pobreza está compuesta por dos vocablos, dígase, privilegio y pobreza. Privilegio, entendiendo un derecho que compete a uno por ley en la que se concede a un particular un exención de que no gozan otras En cuanto a pobreza, entendemos estrechez, necesidad, carencia de lo necesario para el sustento de la vida, pero como se ha indicado, a nuestro parecer en función de la normativa y su espíritu, más que pobreza absoluta se requiere una indisponibilidad de recursos para un fin específico.

${ }^{702}$ COT. Artículo 600: "Las personas patrocinadas por las Corporaciones de Asistencia Judicial o alguna de las entidades públicas o privadas destinadas a prestar asistencia jurídica y judicial gratuita gozarán por el solo ministerio de ley de los beneficios establecidos en los incisos segundo y tercero del artículo 591 y no regirán para ellas las consignaciones que las leyes exigen para interponer recursos ante autoridades judiciales o administrativas. En los asuntos y gestiones que patrocinen las entidades referidas, los procuradores del número y receptores de turno y los demás funcionarios del orden judicial o administrativo, prestarán sus servicios gratuitamente. Lo anterior se entiende sin perjuicio de lo dispuesto en el artículo 594 de este Código”.

${ }^{703}$ CPC. Artículos 130, 131,132, 134.

${ }^{704}$ IBIDEM. Artículo 132: "Si la parte citada no se opone dentro de tercero día a la concesión del privilegio, se rendirá la información y se resolverá con el mérito de ella y de los demás antecedentes acompañados, o que el tribunal mande agregar. Si hay oposición se tramitará el incidente en conformidad a la regla general. La apelación de la sentencia que acepte el privilegio de pobreza se concederá solo en el efecto devolutivo".

${ }^{705} \mathrm{El}$ privilegio de pobreza es dado para reestablecer la igualdad jurídica, la que se turbaría en sentido opuesto si se diera acceso a causas injustas y sin razón, la que a la vez iría en detrimento de la justicia y de la protección al derecho que precisamente se ha querido garantizar
} 
finalidad, pueden ser sancionados al pago de $\operatorname{costas}^{706}$. El privilegio de pobreza judicial, es esencialmente revocable, ya que puede dejarse sin efecto después de otorgado, si se prueban circunstancias que habrían bastado para negarlo. En sentido contrario, puede ser otorgado después de rechazado, si se prueba un cambio de fortuna o circunstancias que autoricen su concesión ${ }^{707}$. Consideramos que la declaración judicial del privilegio de pobreza, no hace sino entrabar el acceso a la justicia de las personas de escasos recursos, toda vez que se le exige para obtener el derecho de litigar sin costos, cumplir con una serie de requisitos y trámites que no hacen sino obstaculizar el derecho a obtener la tutela de sus derechos o la resolución de sus conflictos ${ }^{708}$. A la luz de estos antecedentes, el privilegio de pobreza también plantea dificultades para asegurar el acceso a la justicia de los más necesitados y dar cumplimiento a lo previsto por la CPR y la CADH, toda vez que se exige al interesado no solo conocer la existencia de este beneficio, sino además, la presentación por escrito ante el tribunal, y acreditar su condición de precariedad económica. Tal como fluye del Informe Anual de Derechos Humanos 2017 de la Universidad Diego Portales, "la pobreza legal de amplios sectores de la sociedad, vinculada primariamente al desconocimiento de los derechos y procedimientos judiciales básicos, torna más utópica la solicitud correcta y formal de este privilegio ante el juez"709.

Esta situación no concuerda con el espíritu de las normas internacionales de derechos humanos que exigen la provisión por parte del Estado de recursos

\footnotetext{
${ }^{706}$ COT. Artículo 600 inciso $3^{\circ}$. "Las personas que gocen de privilegio de pobreza no serán condenadas al pago de costas, a menos que el tribunal respectivo, en resolución fundada, declare que han obrado como litigantes temerarios o maliciosos".

${ }^{707}$ CPC. Artículo 136: "Podrá dejarse sin efecto el privilegio después de otorgado, siempre que se justifiquen las circunstancias que hubieren bastado para denegarlo. Podrá también otorgarse el privilegio después de rechazado, si se prueba un cambio de fortuna o de circunstancias que autoricen esta concesión”.

${ }^{708}$ Además de la situación de relativa pobreza, que no le permite sufragar los honorarios de abogado y los costos del proceso, debe tener un legítimo derecho para litigar. El solicitante deberá litigar en el proceso fundadamente, demostrando previamente la razón que la asiste para litigar. Pero, no se requiere su conocimiento acabado de la causa, pues si así fuera el tribunal prejuzgaría sobre el estado en cuestión

${ }^{709}$ UNIVERSIDAD DIEGO PORTALES. (2017). “Acceso a la Justicia en Chile”. p. 204. “En la práctica esto resulta a todas luces inviable, pues las personas, y no solo los más pobres, apenas conocen sus derechos fundamentales y como ejercerlos, entonces suponer que quién carece de recursos económicos están en condiciones reales de solicitar este beneficio, parece al menos ingenuo, amén del tiempo que la tramitación de ésta petición puedan tomar”.
} 
efectivos para recurrir al sistema judicial en busca su protección y tutela de los derechos de las personas. En efecto, la Corte IDH ha entendido que "la posibilidad real de interponer un recurso que sea sencillo y rápido. Cualquier norma o medida que impida o dificulte hacer uso del recurso de que se trata constituye una violación del acceso a la justicia"710. Aparte de este privilegio de pobreza judicial, siguiendo la terminología la ley, existe una manifestación del mismo, que es por el solo ministerio de la ley, y que es concedido a los interesados en el momento que requieren los servicios de las instituciones que por ley están facultadas para operar con él ${ }^{711}$.

\footnotetext{
${ }^{710}$ CORTE IDH. Caso Cantos Vs Argentina. Op. Cit., Párrafo 77. "Por tanto, la Corte, por unanimidad, declara que: el Estado violó el derecho de acceso a la justicia consagrado en los artículos 8.1 y 25 de la Convención Americana sobre Derechos Humanos, en relación con el artículo 1.1 de la misma, en perjuicio del señor José María Cantos, en los términos de los párrafos 54, 55 y 56 de la presente Sentencia. y en consecuencia, por unanimidad, decide que: 1. el Estado debe de abstenerse de cobrar al señor José María Cantos la tasa de justicia y la multa por falta de pago oportuno de la misma. 2. el Estado debe fijar en un monto razonable los honorarios regulados en el caso 1099 de la Corte Suprema de Justicia de la Nación Argentina, en los términos de los párrafos 70.b. y 74. 3. el Estado debe asumir el pago de los honorarios y costas correspondientes a todos los peritos y abogados del Estado y de la Provincia de Santiago del Estero, bajo las condiciones establecidas en el punto anterior. 4. el Estado debe levantar los embargos, la inhibición general y demás medidas que hayan sido decretadas sobre los bienes y las actividades comerciales del señor José María Cantos para garantizar el pago de la tasa de justicia y de los honorarios regulados. 5. El Estado debe pagar a los representantes de la víctima la cantidad total de US\$15.000,00 (quince mil dólares de los Estados Unidos de América) por concepto de gastos causados en el proceso internacional ante el sistema interamericano de protección de los derechos humanos, de conformidad con lo expuesto en los párrafos 73 y 74 de la presente Sentencia. 6. desestima por no ser procedentes las demás pretensiones de la demanda. 7. el Estado debe rendir a la Corte Interamericana de Derechos Humanos un informe sobre las medidas tomadas para dar cumplimiento la presente Sentencia cada seis meses a partir de la notificación de la misma. 8. supervisará el cumplimiento de esta Sentencia y dará por concluido el presente caso una vez que el Estado haya dado cabal aplicación a lo dispuesto en el presente fallo".

${ }^{711}$ COT. Artículo 600: "Las personas patrocinadas por las corporaciones de asistencia judicial o algunas de las entidades públicas o privadas destinadas a prestar asistencia jurídica y judicial gratuita gozarán por el solo ministerio de la ley de los beneficios establecidos en los inciso segundo y tercero del artículo 591 y no regirán para ellos las consignaciones que las leyes exigen para interponer recursos ante la autoridad judicial o administrativa”.
} 


\section{CAPÍTULO IV. DERECHO FUNDAMENTAL A LA ASISTENCIA JURÍDICA GRATUITA. DESCRIPCIONES, EVOLUCIÓN Y DESARROLLO CONSTITUCIONAL}

\section{DERECHO A LA DEFENSA}

\subsection{Defensa material}

La asistencia jurídica gratuita, es un elemento esencial dentro del acceso a la justicia, asociándose a una garantía del debido proceso, y a la obligación positiva del Estado de brindar los medios para que las personas puedan a través de esta asistencia jurídica ejercer los derechos que el ordenamiento jurídico les confiere.

Para entender la asistencia jurídica gratuita como derecho, debemos referirnos al derecho a la defensa como su presupuesto básico.

De esta manera, se concibe una defensa material y otra jurídica. La defensa material se refiere al derecho que tiene toda persona de contar con los medios adecuados para poder presentar alegaciones en el proceso; esto implica la existencia de un derecho a la acción para su operatividad y eficacia.

El TC ha señalado que "el derecho a defensa se expresa en el principio de bilateralidad de la audiencia. Nadie puede ser condenado sin ser oído, ya sea en juicios penales y civiles. El demandado debe contar con los medios necesarios para presentar adecuada y eficazmente sus alegaciones, lo que presupone el conocimiento oportuno de la acción"712.

La defensa material no solo está constituida por las herramientas destinadas a repeler una agresión injusta y asociada al demandado o imputado, sino actualmente se vincula a un derecho subjetivo que faculta la actuación de un sujeto, y extendida a todas las partes intervinientes en cualquier clase de proceso. En este sentido amplio, la facultad de ejercer una acción, a través de una demanda, de cualquier

712 TC. Sentencia causa rol número 1994, de 21 de septiembre de 2012. Considerando 25. 
naturaleza que ésta sea, sería también una manifestación del derecho a la defensa ${ }^{713}$. Sostenemos que la defensa material es definida adecuadamente en Chile, en el Código Procesal Penal (CPP) ${ }^{714}$.

\subsection{Defensa jurídica o técnica. Concepto y ámbito de aplicación}

La garantía de la defensa en general, confiere un conjunto de facultades y atribuciones, las que no solo pueden ser ejercidas personalmente por la parte, lo que se denomina autodefensa, sino que por regla general deben ser ejercidas por un abogado, es decir, por un profesional universitario investido por el órgano público competente de la facultad de defender los derechos de las personas ante la autoridad, sea o no judicial, y en general, de proveer a la pacífica convivencia humana mediante el conocimiento y aplicación del derecho ${ }^{715}$, dando lugar a la denominada defensa técnica.

Tanto la autodefensa como la defensa técnica son un complemento, pero esta última hace eficaz la autodefensa, cuando esta se contempla, y al tenor de lo expresado por Giovanni Leone "el defensor participa en el proceso para la integración técnica de las partes"716.

La defensa jurídica tiene una larga raigambre histórica ${ }^{717}$. El derecho a defensa jurídica es conceptualizado de una manera muy acabada por el profesor Evans, quién lo define como "el derecho a solicitar y obtener la intervención del abogado

\footnotetext{
${ }^{713}$ Precisamente, el derecho a formular los planteamientos y alegaciones que considere oportunos, así como a intervenir en todas las actuaciones judiciales y en las demás actuaciones del procedimiento, aplicable a todos los otros ámbitos, se refiere a lo que conocemos como defensa material.

${ }^{714}$ CPP. Artículo 8.

715 PEREIRA, H. (1996). Curso de Derecho Procesal. Santiago. Editorial Jurídica Conosur. p. 465.

${ }^{716}$ LEONE, G. (1989). Tratado de Derecho Procesal Penal (traducción de Santiago Sentís Melendo). Buenos Aires. Ediciones Jurídicas Euro- América. p. 466.

${ }^{717}$ IBIDEM. “Así en Grecia, la profesión de abogado se confunde con la del político, es por ello que los grandes políticos se encargaban también de la defensa de los derechos particulares antes los tribunales. En Roma, la defensa de los derechos privados corresponde a los patronos, sobre los esclavos. Luego aparecen los oradores cumpliendo funciones similares a la de los abogados y más tarde los advocatos o jurisconsultos, los que tenían como misión esencial la de dirigir las causas a su cuidado. Bajo el imperio romano la distinción entre orador y abogado desaparece, entendiéndose por este último a todo aquel que se ocupa de los intereses ajenos ante los tribunales”.
} 
para la defensa de los derechos de las personas, intervención que debe admitirse no solo en los tribunales de justicia, sino en cualquier otro órgano jurisdiccional o ante cualquier autoridad"718. Tal como lo indicamos en lo concerniente a la defensa material, el derecho a la defensa jurídica se ha vinculado generalmente a la prerrogativa que tiene todo imputado por un delito de ser representado por abogado en materia penal ${ }^{719}$. Sin perjuicio de su consagración penal como un derecho inalienable del imputado de un delito, su reconocimiento más que legal y estrictamente penal, es constitucional y convencional, pues se debe considerar el artículo $19 \mathrm{n}^{\circ} 3$ inciso segundo de la CPR y el artículo 8 d) de la CADH, como asimismo el artículo $14 \mathrm{c}$ ) del PIDCP, los cuales reconocen y garantizan la asistencia de abogado para ejercer derechos e intereses legítimos. La defensa jurídica es más amplia que la defensa judicial. En efecto, aquella se materializa no solo ante el poder judicial, sino que de frente a cualquier órgano que ejerza jurisdicción, sea o no un magistrado, y también, de cara a autoridades públicas carentes de potestad jurisdiccional ${ }^{720}$.

\footnotetext{
${ }^{718}$ EVANS, E. Op. Cit. p. 27.

${ }^{719}$ NOGUEIRA, H. El Debido Proceso en la Constitución y en el sistema interamericano. Op. Cit., p. 43. “El derecho de defensa garantizado a través de asistencia letrada tiene su máximo grado de aplicación en el proceso penal, aun cuando ella ampara a todos los que comparecen ante cualquier jurisdicción, sin perjuicio de que las normas procesales permitan, en virtud de la simplicidad del procedimiento, la comparecencia personal, ya que la asistencia letrada tiene por finalidad asegurar la igualdad de armas de las partes y el principio de contradicción”. En este orden de ideas, el derecho a defensa implica además el derecho del imputado a una defensa técnica o jurídica, de comunicarse libremente con su abogado defensor, sin que dicha comunicación pueda ser obstaculizada, intervenida o impedida, lo que implicaría una afectación del derecho, el que quedaría restringido o vulnerado. Dicho derecho a defensa técnica está garantizado por el CPP en su artículo $8^{\circ}$, inciso $1^{\circ}$, que determina que "El imputado tendrá derecho a ser defendido por un letrado desde a primera actuación del procedimiento dirigido en su contra”. Asimismo, el artículo 7 inciso $2^{\circ}$ de este cuerpo normativo preceptúa: "se entenderá por primera actuación del procedimiento cualquier diligencia o gestión, sea de investigación, de carácter cautelar o de otra especie, que se realizare por o ante un tribunal con competencia en lo criminal, el ministerio público o la policía, en la que se atribuyere a una persona responsabilidad en un hecho punible”. El Código del ramo reitera dentro de los derechos del imputado, en su artículo 93: "que desde la primera actuación del procedimiento y hasta la completa ejecución de la sentencia que se dictare, el imputado tiene derecho a designar libremente uno o más defensores de su confianza, debiendo nombrarse un defensor penal publico si no lo tuviere, como asimismo, determina Ser asistido por un abogado desde los actos iniciales de la investigación. Además se establece en materia penal, que la ausencia del defensor en cualquier diligencia en que la ley exigiere expresamente su participación acarreara la nulidad de la misma”.

${ }^{720}$ Más todavía, para invocar y obtener el reconocimiento del derecho a defensa en estudio, no es menester que ello se haga dentro de un proceso ceñido a los trámites, requisitos y otros elementos característicos del procedimiento que ha de seguirse ante ellos, siendo también aplicable en el derecho administrativo, en especial el de índole sancionatorio, cuanto el proceso justo y con un procedimiento racional reclame que sea respetado con la cualidad de garantía suprema de la defensa técnica, para precaver toda arbitrariedad, preventivamente o ex post.
} 


\subsection{Rasgos característicos de la defensa jurídica o técnica}

La defensa jurídica como derecho fundamental, presenta determinadas características que deben estar presentes para que cumpla los estándares exigidos por el DIDH, los que se condensan en las siguientes características:

a) Irrenunciabilidad: Significa que la parte procesal no podría voluntariamente decidir que no se le otorgue la posibilidad de defenderse en un proceso en que se discuten cuestiones en la que tengan interés. Para mayor precisión el derecho debe estar a disposición del ciudadano, no obstante poder voluntariamente descartarlo, sin perjuicio de su posibilidad inalienable de solicitarlo nuevamente, aceptando bajo su responsabilidad lo acontecido en la secuela del proceso. Además, puede limitarse esta garantía para la protección de otros derechos fundamentales en busca del justo equilibrio en el conflicto de intereses.

b) Inalienabilidad: En complemento con la característica anterior, se traduce en que no puede ser objeto de disposición voluntaria por su titular, serle substraído o traspasado a terceras personas, ya que la defensa no es un privilegio ni una concesión querida por la humanidad, sino que es un verdadero derecho originario del hombre.

c) Objetividad y subjetividad del derecho: El carácter subjetivo del derecho a la defensa procesal se traduce en un derecho personal de obtener una prestación. Además tiene un ámbito propiamente objetivo, como una garantía fundamental necesaria para la validez del juicio, independiente de la voluntad de la parte. Cuando se dice que la defensa es una exigencia del proceso, no se está señalando una esfera distinta a la que se reconoce como garantía de la actuación de las partes, sino que corroborando que su violación afecta a la validez del proceso, ya sea que provenga del propio procedimiento, por no contar con los trámites necesarios y oportunos para ejercerla; o del juez, al no permitir indebidamente su ejercicio a uno o más de los contendientes. Esta circunstancia se corresponde perfectamente con la dimensión objetiva de los derechos fundamentales que se precisa por la doctrina 
constitucionalista, y la teoría general del derecho, configurando una "doble función"721.

d) Integralidad: La defensa es un concepto global, compuesto por la defensa material, la autodefensa en ciertos casos, y por la defensa formal o técnica. En este sentido, la acepción defensa no es necesariamente el correlativo de la acusación ${ }^{722}$.

\section{DEFENSA JURÍDICA O TÉCNICA COMO ELEMENTO DEL DEBIDO PROCESO}

\subsection{Fundamentación de la defensa jurídica como garantía del debido proceso}

Las razones que justifican la existencia de la defensa letrada derivan en forma directa del carácter eminente y crecientemente técnico del proceso y de los temas sustantivos en él tratados. El fundamento de la institución del defensor radica en que las facultades otorgadas por el derecho a la defensa requieren de conocimientos técnicos que las personas en general desconocen, lo que se convierte en un elemento de exclusión para la persona común en relación a la justicia.

Resulta relevante considerar la argumentación en torno al equilibrio procesal, ya que la intervención del letrado, permite restablecer la igualdad de las partes. De esta forma, adhiriéndonos a lo expresado por Emilio Pfeiffer, "la garantía de la defensa jurídica está motivada principalmente por el principio de igualdad, pues sabido es que sin el auxilio del letrado todas las garantías de un proceso justo pueden quedar malogradas"723. Lo anterior se refuerza en las reflexiones de Piero Calamandrei, quién eleva a un carácter esencial la labor del abogado en un esquema de división

\footnotetext{
${ }^{721}$ CRUZ, P. Op. Cit., p. 523. "Por un lado como derechos subjetivos de los ciudadanos, y por el otro, como garantía de derecho objetivo, rescatándose de esta última un valor aceptado por la comunidad”.

${ }^{722}$ CAROCCA, A. Op. Cit., p. 417.

723 PFEIFFER, E. (1997). Derecho Constitucional. Tomo I. Santiago. Editorial Jurídica de Chile. p. 213.
} 
de poderes, catalogando su función, como de naturaleza pública ${ }^{724}$.

En este sentido, si el derecho a la defensa jurídica tiene rango constitucional y el defensor letrado no puede ser impedido, limitado o perturbado en su función, asimismo, bajo el presupuesto que el abogado contribuye a la paz social mediante el conocimiento de la aplicación del derecho; y que el ejercicio de la acción exige el patrocinio de éste; es de toda consecuencia sostener que la actividad jurisdiccional es correlativa al deber de contar con un defensor técnico, constituyéndose de esta manera su presencia en un requisito de validez del proceso.

\subsection{Defensa personal y análisis de la compatibilidad con la defensa técnica}

La exigencia de una defensa jurídica con las indudables ventajas comparativas que posee frente a la autodefensa, no significa que esta última sea descartada de plano, en los ordenamientos jurídicos nacionales e internacionales ${ }^{725}$. La reflexión anterior, se fundamenta en razón a que las normas legales deben interpretarse siempre en el sentido más favorable a la efectividad de los derechos de las personas y, en virtud de ello, al establecerse excepciones a la intervención del abogado en ciertos procesos, no se está obligando a las partes a que actúen personalmente, sino otorgándoseles la facultad de elegir entre la autodefensa y la defensa letrada y técnica, siendo ambas alternativas idóneas para realizar en tales casos actos procesales de carácter válido ${ }^{726}$.

\footnotetext{
${ }^{724}$ CALAMANDREI, P. (1960). Demasiados Abogados. Buenos Aires. Ediciones Jurídicas Europa- América. p. p 22-23. "porque el ejercicio jurisdiccional por parte del Estado, como complemento y punto de equilibrio con las otras funciones derivadas de un esquema de división de poderes, la función de abogado se eleva, comenzándose a sentir que el resultado del proceso también es de interés público, y no solo como un duelo legalizado entre dos antagonistas procesales, pues en todo proceso se encuentra en juego la aplicación de la ley, es decir el respeto a la voluntad colectiva". "Pero, el carácter público de la función ejercitada por los abogados no es opuesta con su condición económica de profesionales privados, entendiéndose entonces, como el ejercicio privado de funciones públicas”.

${ }^{725}$ En determinadas circunstancias, el inculpado, a través de sus propios actos, incluyendo la declaración que rinda sobre los hechos que se atribuyen, puede enfrentar y refutar la acusación en su contra.

${ }^{726}$ NOGUEIRA, H. El debido proceso en la Constitución y en el sistema interamericano. Op. Cit., p. 113. “así el derecho a la asistencia del abogado permanece intacto en tales supuestos, lo que conlleva en principio, el
} 
Es dable señalar el inculpado tiene derecho de defenderse personalmente o de ser asistido por un defensor de su elección y que si no lo hiciere, a la luz de la CADH, tiene el derecho irrenunciable de ser asistido por un defensor proporcionado por el Estado, remunerado o no, según la legislación interna. En estos términos, un inculpado puede defenderse personalmente, aunque es necesario entender que esto es válido solamente si la legislación interna se lo permite ${ }^{727}$.

En el Derecho Internacional de los Derechos Humanos, en el caso Hill vs España, se negó por el Estado a uno de los imputados el derecho a defenderse personalmente, porque la legislación vigente solo permitía al acusado defenderse con el apoyo de un abogado. El Comité de Derechos Humanos consideró que este requisito establecido por la legislación era incompatible con el derecho a la autodefensa $^{728}$.

La jurisprudencia sobre casos de esta índole tiende a considerar el derecho a defenderse personalmente no tanto como un elemento importante del debido proceso, sino más bien como un mal menor. Un ejemplo de este enfoque es el caso de un reo a quien se le denegó el permiso para asistir a una audiencia ante un tribunal de alzada, porque el defensor de oficio que lo representaba opinó que el recurso carecía de méritos y renunció a participar de la audiencia. Ante esto el Comité concluyó que el Estado tenía el deber de asignar a otro defensor de oficio o haberle permitido al autor que se defendiera él mismo en la vista del recurso de

derecho del afectado pobre, a que se le provea asistencia de abogado gratuita, si así este lo considera conveniente para la mejor defensa de sus derechos o intereses legítimos”.

${ }^{727}$ CORTE IDH. OC 11/90. Excepciones al agotamiento de los recursos internos. Op. Cit., Párrafo 25: "Los literales d) y e) del artículo 8.2 expresan que el inculpado tiene derecho de defenderse personalmente o de ser asistido por un defensor de su elección y que si no lo hiciere tiene el derecho irrenunciable de ser asistido por un defensor proporcionado por el Estado, remunerado o no según la legislación interna. En estos términos, un inculpado puede defenderse personalmente, aunque es necesario entender que esto es válido solamente si la legislación interna se lo permite. Cuando no quiere o no puede hacer su defensa personalmente, tiene derecho de ser asistido por un defensor de su elección. Pero en los casos en los cuales no se defiende a si mismo o no nombra defensor dentro del plazo establecido por la ley, tiene el derecho de que el Estado le proporcione uno, que será remunerado o no según lo establezca la legislación interna. Es así como la Convención garantiza el derecho de asistencia legal en procedimientos penales. Pero como no ordena que la asistencia legal, cuando se requiera, sea gratuita, un indigente se vería discriminado por razón de su situación económica si, requiriendo asistencia legal, el Estado no se la provee gratuitamente”.

${ }^{728}$ COMITÉ DE DERECHOS HUMANOS. Caso Hill y Hill vs España. Dictamen de 2 de abril de 1997. Párrafo. 14.2. 
apelación ${ }^{729}$. Así, el derecho reconocido en el artículo 8.2 d) de la CADH se refiere a dos posibilidades de defensa del inculpado, esto es, que la puede ejercer el mismo y aquella que supone la asistencia de un defensor de su elección.

\section{LA DEFENSA JURÍDICA EN LA CONTITUCIÓN Y LEGISLACIÓN CHILENA. DEBATE EN LA CENC Y APLICACIÓN DEL DERECHO DE DEFENSA}

\subsection{Debate en torno a la defensa jurídica en la CENC y su proyección constitucional}

La CPR en el artículo 19 número 3 inciso segundo asegura a todos las personas el derecho a la defensa jurídica: "Toda persona tiene derecho a la defensa jurídica en la forma que la ley señale y ninguna autoridad o individuo podrá impedir, restringir o perturbar la debida intervención del letrado si hubiera sido requerida". Este precepto quedó de esta manera después de un arduo debate en el seno de la CENC, donde se discutió, entre otros puntos, el ámbito de aplicación de la defensa jurídica, la significación del uso de los vocablos "impedir, restringir o perturbar", los alcances de cuándo se considera requerida la intervención del letrado en la forma que establece la ley, entre otras precisiones.

Es importante realizar una interpretación lo más adecuada posible, a cada fragmento del precepto, basado en lo que se debatió y consignó en las actas oficiales de la Comisión, por los distintos catedráticos que formaron parte de ella, pues en estos antecedentes encontramos el espíritu de la norma, como de igual manera la proyección del precepto y una interpretación fiel a su espíritu, tanto por la justicia ordinaria y/o constitucional ${ }^{730}$.

\footnotetext{
${ }^{729}$ IBIDEM. Caso Reid (Carlton) vs Jamaica. Observación de 20 de julio de 1990. Párrafo. 11.4.

${ }^{730}$ Podemos afirmar que su naturaleza jurídica es de una igualdad. De esta manera, este derecho pretende otorgar a todas las personas iguales posibilidades, ya sea para ejercer determinados derechos como para defenderlos, independiente de cualquier condición particular que presenten.
} 
La moción al interior de la CENC, impulsada por el comisionado Silva, fue del siguiente tenor: "toda persona tiene derecho a recurrir a asesoramiento de abogado y ninguna autoridad o individuo podrá impedir o perturbar la debida intervención del letrado". El autor expresó "que su proposición ya estaba realmente anunciada en un debate que se originó en esta Comisión, en presencia del ex Ministro de Justicia señor Gonzalo Prieto, oportunidad en la que se manifestó que la Constitución sería tan respetuosa de la profesión de abogado que elevaría a rango constitucional el derecho y, por lo tanto la obligación, cuando corresponda, de la intervención de los abogados, la que debe tener mucha amplitud en todo el panorama del ejercicio de los derechos y el castigo de las infracciones, no sólo en el aspecto puramente judicial, sino en toda la vastedad de lo jurídico, o sea, en todo aquello atingente a la vivencia del derecho formulado en la norma, en cuanto a su ejercicio y a sus sanciones"731. Otro integrante, Jorge Ovalle sostenía "que no se trata de una deformación profesional ni de dignificar la carrera universitaria de abogados sino de reforzar la protección de los derechos, para que esta protección sea defendida adecuadamente, eficazmente por quien debe prepararse para ello, por qué no considera posible esa debida protección si el desarrollo de la defensa no es llevado por quien sea apto para esa labor, por lo cual dicho precepto cuenta con su aceptación"732. Los integrantes de la CENC, consensuaron en que la intervención del letrado va más allá de la sola defensa en juicio, demandando dicha garantía una atención integral, una orientación previa y durante todo el proceso.

Cuando se hace referencia a "la forma que la ley señale", se debe hacer presente en este sentido, que será precisamente la ley la encargada de determinar la forma o manera en que las personas verán cumplida la garantía en cuestión.

En relación a los vocablos impedir, restringir o perturbar, el comisionado Evans estimaba que era necesario sustituir el término "perturbar" de la propuesta del autor

\footnotetext{
${ }^{731}$ EVANS, E. Op. Cit., p. 167

732 IBIDEM. "El señor Silva Bascuñán afirmó “Que la intervención del letrado que se quiere consagrar es toda la asistencia jurídica en la vivencia de la ley: no sólo en relación al proceso, sino en relación con todas las consultas, a toda la labor propia del abogado, a la actividad administrativa”.
} 
de la moción ${ }^{733}$. En este sentido, Silva argumentó, lo que fue aprobado por la Comisión, que debía mantenerse la voz "perturbar", que es más adecuada”734.

Por otra parte, sobre la expresión debida intervención, quedó constancia de su sentido y alcance en el acta oficial respectiva, lográndose un consenso previo debate $^{735}$. El mismo comisionado Silva argumentó que "esa defensa se reconoce, pero en la forma que señale la ley, se remite la disposición constitucional, por ende, a las normas que establezca el legislador, trazando una reserva legal fuerte, pero que en definitiva tiene que respetar la esencia del derecho, encontrándose tales normas en el Código de Procedimiento Civil y en el Código de Procedimiento Penal, especialmente" $" 36$.

El texto Constitucional en lo relativo a la defensa jurídica hace una alusión especial a la defensa jurídica que deben recibir los integrantes de las Fuerzas Armadas y de Orden y Seguridad Pública, probablemente debido al rol que cumplían en la época histórica en que se gestaba la nueva Constitución. Dicha preceptiva es del siguiente tenor: "tratándose de los integrantes de las Fuerzas Armadas y de Orden y

\footnotetext{
${ }^{733}$ CEA, J. Op. Cit., p.155

${ }^{734}$ IBIDEM. "En todo caso, le agradaría más incluir los dos términos: "restringir o perturbar", por cuanto el vocablo "perturbar" atañe más a una cuestión práctica, pues es en el hecho, no en el derecho, donde se altera la intervención del letrado".

${ }^{735}$ IBIDEM. "señor Ovalle (...) está de acuerdo en que la redacción de este precepto, como la de otros exclusivamente reglamentarios, adolece, por el afán de quitarle reglamentariedad, de vicios y defectos que perturban su claridad. Y por eso la redacción de este inciso puede llamar la atención. Porque bien podría entenderse que la referencia a la autoridad comprende al legislador. No es su opinión, pero podría entenderse así, pues no está dicho que el legislador tiene la facultad de regular los derechos del abogado. Cree que, de todas maneras, se subentiende que la expresión debida implica que el legislador será quien regulara la participación del abogado en el proceso". "El señor Silva Bascuñán deja constancia que era necesario agregar la palabra debida en este inciso y que la entiende en el sentido indicado por el señor Ovalle y que nunca le ha cabido duda de ninguna especie. Explica que en ningún instante ha afirmado que en este inciso la palabra autoridad este referida al legislador. Su exposición anterior estaba dirigida a evitar que se mencionara a cada momento al legislador en este capítulo"

${ }^{736}$ IBIIDEM. “Además la Constitución, señala que haya sido 'requerida' la debida intervención del letrado, lo que significa la intervención del letrado debe ser respetada, pero solamente si hubiere sido requerida. No dice la disposición quien debe pedir dicha intervención, de lo que se deduce que la Constitución deja abierta la posibilidad de cualquier sujeto capaz pueda defender a un tercero, o al imputado, abriendo así, como es razonable entenderlo, la acción popular o pública en defensa, especialmente, de la dignidad y de los derechos humanos". "Entender la disposición en términos distintos, culminantes en que la intervención del letrado debe ser respetada nada más que si la requiere el querellante o el inculpado, llevaría a la condicionalidad de un derecho que no puede quedar en tal precariedad. Se violaría con esa hermenéutica, además, el derecho a la justicia jurídica, consagrado en el artículo 19 N² 26 de la Constitución”.
} 
Seguridad pública, este derecho se regirá en lo concerniente a lo administrativo y disciplinario, por las normas pertinentes a sus respectivos estatutos" ${ }^{137}$. Tal norma es nueva, pues no existía en constituciones chilenas anteriores, estableciendo a nuestro parecer una desigualdad, por lo que se ha planteado duda con respecto a si configura una discriminación, o sea, una diferencia injusta, la cual puede constituir según el caso, un privilegio o un perjuicio. En el fallo del caso Palamara Iribarne vs Chile, de 22 de noviembre de 2005, se cuestionó la existencia de una jurisdicción diferenciada de carácter militar en Chile, de esa misma forma, una defensa categorizada también debería ser cuestionada, teniendo siempre presente la urgencia de la reforma de la anacrónica justicia militar en Chile ${ }^{738}$.

\subsection{Exigencia de patrocinio de abogado en la legislación chilena}

Se previene como exigencia en el ordenamiento jurídico nacional, que en la primera presentación, tanto de una demanda o contestación, en cualquier ámbito jurídico, conste patrocinio de abogado, siendo la excepción, los casos en que se permita recurrir ante el órgano jurisdiccional sin el patrocinio de un abogado. Así, la ley que establece las normas sobre comparecencia en juicio, dispone que "ninguna persona, salvo en los casos de excepción contemplados en este artículo o cuando la ley exija la intervención personal de parte, podrá comparecer en los asuntos y ante los tribunales, sino representada por abogado habilitado para el ejercicio de la profesión"739. En igual sentido, consagra que "la primera presentación de cada parte o interesado en asuntos contenciosos o no contenciosos ante cualquier tribunal de la república, sea ordinario, arbitral o especial, deberá ser patrocinado por un

\footnotetext{
${ }^{737}$ La disposición es clara, no obstante los reparos que pudieren hacerse en torno a la igualdad ante la ley y la garantía de defensa jurídica en el ámbito militar.

${ }^{738}$ En Chile, el Código de Justicia Militar de 19 de diciembre de 1944, es aplicable a funcionarios de las fuerzas armadas, cuando cometan delitos en el ejercicio de sus funciones. El procedimiento contemplado es de tipo inquisitivo, considerándose una fase de sumario y otro plenario, en que se contempla la figura del fiscal, quién investiga, acusa y dicta condena, sea absolutoria o condenatoria, recurrible ante la Corte Marcial.

${ }^{739}$ LEY 18.120. Establece Normas sobre Comparecencia en Juicio, de 18 de mayo de 1982. Artículo 2 inciso $1^{\circ}$.
} 
abogado habilitado para el ejercicio de la profesión"740. El mismo CPC, preceptúa que "toda persona que deba comparecer en juicio a su nombre o como representante legal de otra, deberá hacerlo en la forma que determine la ley"741. El patrocino ha sido definido, como un "contrato celebrado entre el cliente y el abogado, por medio del cual aquel encomienda a éste la defensa de sus derechos en un juicio o asunto" ${ }^{742}$. A nuestro entender, el patrocinio radica en un acto por el cual una persona encomienda a un abogado la defensa de sus derechos en juicio. A la luz del artículo 520 del COT "los abogados son personas revestidas por la autoridad competente de la facultad de defender ante los tribunales de justicia los derechos de las partes litigantes" 743 . Para poder ser abogado en Chile se requieren una serie de requisitos ${ }^{744}$. Este título en Chile se otorga por la CS, siendo el único título profesional que no se expide directamente por las Universidades que imparten la carrera de pregrado ${ }^{745}$. El abogado cuenta con una serie de facultades, las cuales distarán dependiendo de las exigencias legales del Estado ${ }^{746}$.

\footnotetext{
${ }^{740}$ IBIDEM. Artículo 1 inciso 1.

${ }^{741}$ CPC. Artículo 4.

${ }^{742}$ CORREA, J (2005). Curso de Derecho Procesal Tomo I. Santiago. Ediciones Jurídicas de Santiago. p. 104

${ }^{743}$ COT. Artículo 520.

${ }^{744}$ IBIDEM. Artículo 523: "Para poder ser abogado se requiere:

$1^{\circ}$ Tener 20 años de edad.

$2^{\circ}$ Tener el grado de licenciado en Ciencias Jurídicas otorgado por alguna universidad, en conformidad a la ley. $3^{\circ}$ No haber sido condenado ni estar actualmente acusado por crimen o simple delito que merezca pena aflictiva. $4^{\circ}$ Antecedentes de Buena Conducta.

$5^{\circ}$ Haber cumplido satisfactoriamente una práctica profesionalmente por seis meses en las Corporaciones de Asistencia Judicial a que se refiere la ley n 17.995 , circunstancia que deberá acreditarse por el Director General de la respectiva Corporación. Las Corporaciones de Asistencia Judicial, para este efecto, podrán celebrar convenios con el Ministerio Público y con la Defensoría Penal Pública. Un Reglamento determinará los requisitos, formas y requisitos para que dicha práctica sea aprobada,

${ }^{745}$ IBIDEM. Artículo 521: "El título de abogado será otorgado en audiencia pública por la Corte Suprema reunida en tribunal pleno, previa comprobación y declaración de que el candidato reúne los requisitos establecidos en los artículos 523 y 526.

${ }^{746}$ CPC. Artículo 7: "El poder para litigar se entenderá conferido para todo el juicio en que se presente, y aun cuando no exprese las facultades que se conceden, autorizará al procurador para tomar parte, del mismo modo que podría hacerlo el poderdante, en todos los trámites e incidentes del juicio y en todas las cuestiones que por vía de reconvención se promuevan, hasta la ejecución completa de la sentencia, o salvo que la ley exija intervención personal de la parte misma. Las cláusulas en que se nieguen o en que se limiten las facultades expresadas, son nulas. Podrá, asimismo, el procurador delegar el poder obligando al mandante, a menos que se le haya negado esta facultad. Sin embargo, no se entenderán concedidas al procurador, sin expresa mención, las facultades de desistirse en primera instancia de la acción deducida, aceptar la demanda contraria, absolver posiciones, renunciar los recursos o los términos legales, transigir, comprometer, otorgar a los árbitros facultades de arbitradores, aprobar convenios y percibir.
} 
En nuestra realidad procesal, y en coherencia con la aceptación limitada de la autodefensa, existen casos específicos en que se puede solicitar autorización al tribunal, ya que por razones de naturaleza o cuantía, se permite comparecer y defenderse personalmente ${ }^{747}$. Recordaremos que existen una serie de casos particulares en que no se requiere contar con patrocinio de abogado ${ }^{748}$, y además, que no obstante el carácter inalienable e irrenunciable de la defensa jurídica, si la parte es debidamente notificada, y emplazada, renunciando a su derecho de defensa técnica, quedará en una situación de "rebeldía", afectándole los resultados del proceso, salvo en los casos que se autoriza por ley la comparecencia personal ${ }^{749}$.

En el ámbito procesal, para que una persona tenga capacidad para comparecer en juicio, debe reunir la capacidad de goce, de ejercicio y el "Ius Postulandi", condición está última que se entrega exclusivamente a determinadas personas, que son precisamente las que señala la ley ${ }^{750}$. Así, no es lo mismo hablar de comparecencia en sentido amplio, como la posibilidad de presentarse físicamente en un proceso, que concebirlo en sentido estricto, caso en el cual nos referimos a la posibilidad de apersonarse en el proceso y hacer peticiones al órgano jurisdiccional, ya sean éstas acciones, defensas o simples solicitudes.

\section{DERECHO A LA DEFENSA JURÍDICA EN EL DERECHO INTERNACIONAL DE DERECHOS HUMANOS}

\footnotetext{
${ }^{747}$ LEY 18.120. Que Establece Normas sobre Comparecencia en Juicio.. Artículo 2 inciso $3^{\circ}$.

${ }^{748}$ IBIDEM. Artículo 2 inciso $9^{\circ}, 10^{\circ}, 11^{\circ}$. "Estos casos se condensan en: a) En aquellos departamentos en que hay menos de 4 abogados en ejercicio; b) Manifestaciones mineras; c) Asuntos que conozcan Alcaldes o Jueces de Policía Local salvo regulación de perjuicios de cuantía superior a 2 U.T.M; d) Causas electorales; e) Recursos de amparo y protección; f) Denuncias criminales; g) Solicitudes aisladas de mero trámite (copias, desarchivos, certificados, etcétera.).

${ }^{749}$ En este ámbito, a modo ejemplar, se puede indicar que en un procedimiento por una acción de arrendamiento, el arrendatario de una finca que no ha pagado las rentas, es notificado y apercibido de contar con abogado, no haciéndolo, el juicio seguirá adelante, pero se verá vedado, de ejercer las alegaciones dentro de su derecho de defensa.

${ }^{750}$ Bajo esta lógica, un profesor puede acudir al órgano jurisdiccional demandando de divorcio contra su cónyuge, o solicitando una indemnización de perjuicios producto del incumplimiento de un contrato, pero para "participar en un juicio conduciendo jurídicamente una causa o representando a otro", debe necesariamente contar con abogado".
} 
El artículo $14 \mathrm{c}$ ) del PICP, consagra el derecho a la defensa en los siguientes términos: "El derecho de ser asistido por un defensor a su elección, a comunicarse con él y preparar su defensa. La persona debe ser informada que puede elegir un defensor o a que se le nombre en defensor de oficio gratuito". El artículo 6.3.c del CEDH, establece por su parte que "todo acusado tiene derecho a defenderse por sí mismo o ser asistido por un defensor de su elección".

A su vez, el artículo 8 de CADH bajo el título de las garantías judiciales, se refiere la letra d), al "derecho del inculpado a defenderse personalmente o de ser asistido por un defensor de su elección, y de comunicarse libre y privadamente con su defensor".

Sobre el derecho de defensa y asistencia letrada eficaz, la Corte IDH se ha pronunciado no solo respecto del derecho de contar con la asistencia de un abogado, sino que con la facultad de poder a través de él ejercer actuaciones relevantes para la protección de sus intereses ${ }^{751}$, como la revisión del expediente, la aportación de pruebas y el derecho a interrogar a los testigos. Asimismo se ha referido al derecho de elegir a su defensor, tal como lo profundizaremos en el Capítulo V. En este orden de ideas, en la sentencia del caso Castillo Petruzzi vs Perú, de 30 de mayo de 1999, se determinó que se violó el derecho a elegir abogado y el derecho de la defensa a interrogar testigos, pues los imputados involucrados en el caso no tuvieron asistencia letrada desde su detención, cuando la tuvieron ésta les fue designada de oficio sin permitírseles elegir libremente a sus abogados y además, esta defensa se vio seriamente limitada en su actuar, contaron con escasa posibilidad de presentación de prueba de descargo, no tuvieron conocimiento

\footnotetext{
${ }^{751}$ CORTE IDH, Castillo Petruzzi y otros vs Perú, Op. Cit., Párrafo 221: "En efecto, el proceso se siguió ante un órgano jurisdiccional que no puede ser considerado juez natural para hechos e inculpados que ahora nos ocupan; en este procesamiento actuaron jueces y fiscales 'sin rostro'; los inculpados no dispusieron de un defensor de su elección desde el momento mismo de la detención; y los defensores que finalmente les asistieron no contaron con la posibilidad de entrevistarse a solas con sus defensores, conocer oportunamente el expediente, aportar pruebas de descargo, contradecir las de cargo y preparar adecuadamente los alegatos. Evidentemente no nos encontramos ante un procesamiento que satisfaga las exigencias mínimas del "debido proceso legal”.
} 
oportuno y completo de los cargos que se les imputaban, hubo obstáculos para entrevistarse privadamente con los abogados, etcétera ${ }^{752}$.

Similares restricciones a la defensa y al rol de los abogados fueron constatados por la Corte IDH en relación a las limitaciones que imponía la etapa sumaria en la causa penal en el Caso Palamara Iribarne vs Chile, en tanto el secreto de las actuaciones propias de la etapa sumaria impidieron que el defensor pudiera estar presente en las declaraciones del imputado e implicó la necesidad de solicitar diligencias probatorias sin conocimiento del sumario ni de los fundamentos de los cargos, todo lo cual minó el verdadero derecho a defensa del imputado ${ }^{753}$. El caso de la comunidad Yakie Axa vs Paraguay, la sentencia de 17 de junio de 2005, resulta relevante en cuanto a ampliar la dimensión de cobertura de la función del abogado, pues en relación con la denuncia penal que tuvieron que enfrentar los miembros de la comunidad, se detalla que el hecho de que se hayan realizado diligencias probatorias como declaraciones de testigos, levantamientos de datos de las personas acusadas como de viviendas, inspecciones en el lugar de los hechos, decomisos, además de medidas provisionales a favor de la parte denunciante sin que los miembros de comunidad fueran oídos y participaran a través de un abogado de su elección, pese a haberlo pedido, resulta violatorio al artículo 8 de la Convención Americana ${ }^{754}$.

\footnotetext{
752 ONU. (1990). Principios Básicos sobre la Función de los Abogados relativo a las salvaguardias especiales en asuntos penales, aprobados por el Octavo Congreso de las Naciones Unidas sobre Prevención del Delito y Tratamiento del Delincuente. La Habana.

${ }^{753}$ Corte IDH, Caso Palamara vs Chile. Op. Cit., Párrafo 175: "El artículo 9 de la Convención dispone que nadie puede ser condenado por acciones u omisiones que en el momento de cometerse no fueran delictivos según el derecho aplicable. Tampoco se puede imponer pena más grave que la aplicable en el momento de la comisión del delito. Si con posterioridad a la comisión del delito la ley dispone la imposición de una pena más leve, el delincuente se beneficiará de ello. Cuando la Corte se pronuncie sobre las alegadas violaciones al artículo 8 de la Convención, tomará en consideración los referidos alegatos de los representantes sobre la violación al artículo 9 de dicho tratado".

${ }^{754}$ Corte IDH. Caso comunidad indígena yakye Axa vs Paraguay. Sentencia de 17 de junio de 2015. Párrs 115 y 116. Párrafo 115: "Como ha quedado demostrado, el proceso penal en contra de miembros innominados de la Comunidad Yakye Axa inició el 16 de marzo de 1999 con la denuncia que presentó el representante legal de la firma Livestock Capital Group Inc. El 22 de marzo de 1999 el Juez dio apertura al sumario. El 3 de mayo de 1999 los líderes de la Comunidad, reconocidos como tales por el INDI, designaron abogado a fin de que los representara en el proceso penal referido, lo cual fue aceptado en un inicio por el Juez de la causa. No obstante, frente a la oposición de la parte actora, el Juez revocó su providencia anterior e impidió la expedición de fotocopias al letrado de la Comunidad. Los días 5 y 11 de septiembre de 2000 el abogado de la Comunidad volvió a solicitar la intervención en el proceso penal y solicitó se expidan fotocopias de lo actuado hasta esa fecha. El 11 de septiembre del mismo año el Juez declaró "no ha lugar” la solicitud de intervención. El 15 de
} 
Como bien lo expresa Sergio García Ramírez "la defensa del justiciable se refiere a que la función misma de defensa y también al ejercicio de ésta a través de distintos medios, destacando la presencia y actuación del defensor, que contribuye a integrar la personalidad procesal del justiciable"755. En sentencia de 7 de septiembre de 2004, en el caso Tibi vs Ecuador se refleja la ineficacia de un acto de nombramiento meramente formal ${ }^{756}$.

\section{DERECHO A LA ASISTENCIA JURÍDICA GRATUITA. APROXIMACIÓN A UN CONCEPTO Y SU RELACIÓN CON EL ACCESO A LA JUSTICIA}

El acceso a la justicia claramente es un concepto omnicomprensivo de otros derechos particulares, que se enmarcan en los avances de derechos humanos ya analizados, siendo el derecho de la asistencia jurídica gratuita, una parte integrante y esencial de éste. Se concibe la asistencia jurídica gratuita, tanto como garantía del debido proceso y la tutela judicial, como asimismo una obligación positiva del Estado en cuanto a la remoción de obstáculos de diversa índole que impide el goce y ejercicio de derechos, especialmente por las personas que pertenecen a los grupos vulnerables.

septiembre de 2000 el abogado de la Comunidad interpuso un recurso de apelación contra la providencia que denegó su participación, recurso que fue rechazado por el Juez el 18 de septiembre de 2000”. Párrafo 116: "Durante el referido proceso penal se llevaron a cabo varias diligencias probatorias, entre ellas, declaraciones de testigos, levantamientos de datos de los miembros de la Comunidad, inspecciones en el lugar de los hechos. De igual forma, se otorgaron medidas provisionales a favor de la parte actora, consistentes en la prohibición de ingreso de los miembros de la Comunidad al territorio de la Estancia Loma Verde; se decomisaron varios cajones de apicultura pertenecientes a la Comunidad, y se ordenó el levantamiento de las viviendas de la Comunidad. Todas estas gestiones se llevaron a cabo sin que los miembros de la Comunidad Yakye Axa fueran oídos y participaran a través de un abogado de su elección”.

${ }^{755}$ GARCIA, S (2006). Anuario de Derecho Constitucional Latinoamericano, Ciudad de México. Publicaciones \& Fomento editorial. p.1138.

${ }^{756}$ Corte IDH. Caso Tibi vs Ecuador. Op. Cit., Párrs 195 y 196. Párrafo 195: “A su vez, la Corte observa que el señor Tibi, como detenido extranjero, no fue notificado de su derecho de comunicarse con un funcionario consular de su país con el fin de procurar la asistencia reconocida en el artículo 36.1.b de la Convención de Viena sobre Relaciones Consulares (supra párr. 90.17). En este sentido, la Corte señaló que el derecho individual del nacional de solicitar asistencia consular a su país "debe ser reconocido y considerado en el marco de las garantías mínimas para brindar a los extranjeros la oportunidad de preparar adecuadamente su defensa y contar con un juicio justo. La inobservancia de este derecho afectó el derecho a la defensa, el cual forma parte de las garantías del debido proceso legal”. Párrafo 196: "De lo expuesto, la Corte concluye que el Estado violó los artículos 8.2.d y 8.2.e de la Convención Americana, en perjuicio del señor Daniel Tibi”. 
Dentro de la clasificación de los derechos fundamentales, el derecho a la asistencia jurídica lo podemos situar dentro de los derechos de prestación, pues permite reclamar un beneficio, desde un prisma instrumental, constituyendo un medio que permite reestablecer el ejercicio de aquellos derechos que hubiesen sido desconocidos o vulnerados. También se puede considerar en este enfoque, que la asistencia jurídica gratuita como derecho requiere siempre una acción positiva estatal en cuanto a crear las condiciones adecuadas de base, ideando políticas e institucionalidad, removiendo las trabas que impidan hacer efectivos los derechos consagrados.

Desde éste prisma estatal, la asistencia jurídica gratuita es una función que tiene por objeto poner al alcance de la comunidad y concretamente de los actores más necesitados, los instrumentos que se encuentran a disposición de los abogados para acceder integralmente al sistema legal en general. Por consiguiente, siguiendo el razonamiento de Luis Bates, se alude al "conjunto de medidas tomadas para asegurar que la operatividad del sistema legal no varié debido al nivel de ingresos del individuo"757.

Dentro de los criterios clasificatorios, también se puede concebir la asistencia jurídica gratuita como un derecho de seguridad jurídica, integrante de las garantías procesales del debido proceso que benefician al individuo, produciendo tranquilidad, certeza, saber a qué atenerse y con una proyección de trascendencia social, no solo circunscrita al proceso, sino que a los efectos que el ejercicio de este derecho puede tener en los planes y calidad de vida de las personas ${ }^{758}$. Se dice además que la asistencia jurídica gratuita consiste en ayudar al individuo relativamente pobre en la tramitación judicial, tanto evitándole gastos propios de la litis, cuanto dirigiéndole e informándole sobre la forma de hacer valer sus derechos en juicio ${ }^{759}$. Desde una

\footnotetext{
${ }^{757}$ BATES, L. (1978). Reflexiones sobre el problema de la asistencia legal en Chile. Departamento de práctica y asistencia legal. Pontificia Universidad Católica de Chile. Santiago. p. 13.

${ }^{758} \mathrm{CPR}$. Artículo 1 inciso $4^{\circ}$ : "El Estado está al servicio de la persona humana y su finalidad es promover el bien común, para lo cual debe contribuir a crear las condiciones sociales que permitan a todos y cada uno de los integrantes de la comunidad nacional su mayor realización espiritual y material posible, con pleno respeto a los derechos y garantías que esta Constitución establece”.

${ }^{759}$ BATES, L. Op. Cit., p. 13.
} 
perspectiva de derecho-deber, se conceptualiza, siguiendo a Gómez Colomer, como "un derecho público subjetivo, de carácter estrictamente procesal por su finalidad, estructura y rango constitucional, en virtud de la cual la parte procesal, actual o futura, que acredite insuficiencia de recursos para ejercer su derecho de acción, que litigie por derechos propios y tengan posibilidades de éxito en el proceso, viene eximida totalmente o en una parte, de abonar los gastos que el proceso origine, los de asesoramiento previo y los honorarios a que tienen derecho, por profesionales o funcionarios que en él intervienen"760.

La mayoría de las conceptualizaciones coinciden en calificar a la asistencia jurídica gratuita como un derecho de carácter prestacional, en que el potencial beneficiario se encuentra en condiciones de exigir al Estado una acción positiva, que consiste en obtener gratuidad en el servicio judicial y de justicia en general, no solamente restringida a la asesoría y representación de un abogado ${ }^{761}$, tal como nos referimos al tratar el privilegio de pobreza, que es el instrumento que permite concretar la asistencia jurídica gratuita. Además existe coincidencia en cuanto a que la población pobre, de escasos recursos, notoriamente menesterosa, o que se ha determinado su incapacidad de proporcionarse los servicios de un abogado particular o hacerse cargo de los costos del proceso, bajo criterios objetivos, tiene derecho a la gratuidad de la asistencia jurídica ${ }^{762}$.

La asistencia judicial, al tenor de lo expuesto por Mario Cassarino, es "un conjunto de normas legales destinadas a facilitar a las personas pobres o de escasos recursos el ejercicio de sus derechos ante los tribunales de Justicia" ${ }^{163}$. Sostenemos, que la asistencia judicial es más reducida que la asistencia jurídica gratuita en cuanto a su campo de aplicación, pues representa solo una de las manifestaciones de la asistencia jurídica gratuita, consistiendo exclusivamente en la representación

\footnotetext{
760 GOMEZ, J. (1998). Derecho Jurisdiccional Parte General. Valencia. p. 265.

${ }^{761}$ COT. Artículo 591 inciso 2: "Los que lo obtuvieren usarán papel simple en su solicitudes y actuaciones y tendrán derecho para ser gratuitamente servidos por los funcionarios del orden judicial, y por los abogados, procuradores y oficiales subalternos designado para prestar servicios a los litigantes pobres”.

762 IBIDEM. Artículo 595: “Corresponde a los jueces de letras designar cada mes y por turno, entre los no exentos, un abogado que defienda las causas civiles y otro que defienda a las causas del trabajo de las personas que hubieren obtenido o debieran gozar del mencionado privilegio...”.

763 CASSARINO, M. (2004). Manual de Derecho Procesal. Santiago. Editorial jurídica de Chile. p. 187.
} 
de personas o grupos de personas ante un órgano jurisdiccional, abogando por el reconocimiento de una pretensión de carácter legal, ya sea en asuntos de carácter contencioso, judicial, no contencioso o penal, caso este último, en el que se pretenderá la adecuada sanción del delincuente o la declaración de inocencia del procesado.

Dentro de la asistencia jurídica gratuita en Chile, además de la judicial, encontramos la asistencia administrativa, que consiste en abogar ante los órganos de la administración, para el reconocimiento de determinados derechos o intereses. Además se menciona la asistencia a grupos o comunidades en pos de intereses difusos, la asistencia en educación legal, con el fin de lograr el empoderamiento de los ciudadanos en nociones cívicas y la asistencia a sindicatos u organizaciones ${ }^{764}$.

En el vasto espectro de la asistencia jurídica gratuita se debe mencionar la importancia del asesoramiento, pues desde los debates de la CENC se ha consensuado que es en la etapa previa de ilustración o consejo, donde se puede definir el derrotero o resultado de un pleito, en cuanto a la elección de estrategias jurídicas y procesales más idóneas. En muchas ocasiones una asesoría oportuna y de calidad puede evitar un juicio y aclarar dudas del usuario, que podrá dilucidar sus incertidumbres o contar con herramientas para poder resolverlo a través de métodos alternativos de resolución de conflictos ${ }^{765}$.

\section{CARACTERÍSTICAS DEL DERECHO DE ASISTENCIA JURÍDICA GRATUITA EN CHILE}

\footnotetext{
${ }^{764}$ En Chile, la asistencia relativa al área administrativa o en otros ámbitos afines, no ha tenido la atención necesaria del legislador y de las políticas públicas ideadas por el ejecutivo, circunscribiéndose los esfuerzos públicos a la orientación e información, difusión de derechos y representación, de casos que potencialmente se pueden presentar ante los tribunales de justicia.

${ }^{765}$ CEA, J. Op. Cit., p. 162. "En ella se estudian los antecedentes que llevan o no a plantear una acción, o la defensa correcta, sea en sede judicial o de otra naturaleza. La asesoría es, por ende, la etapa previa a la defensa. Fácil es comprender que ella resulta, casi siempre, decisiva para el éxito o fracaso de la fase siguiente, es decir, la que se desenvuelve ya en el proceso propiamente tal o en la gestión pública de que se trate”.
} 
Sin lugar a dudas la fundamentalidad del derecho a la asistencia jurídica gratuita deriva de su naturaleza jurídica instrumental, configurándose como un mecanismo idóneo para la concreción y ejercicio del resto de los derechos conferidos por el ordenamiento jurídico. El carácter instrumental del derecho a la asistencia jurídica gratuita, se justifica en que precisamente permite que el acceso a la justicia, el debido proceso y el derecho a la defensa, sean una posibilidad concreta para las personas, independiente de pertenecer a un determinado grupo vulnerable o de carecer de recursos económicos.

Las características de este derecho son las siguientes:

a) Es un derecho constitucional de la persona: Consagrado en el artículo $19 n^{\circ} 3$ inciso $3^{\circ}$ de la CPR, que requiere que el Estado desarrolle las actuaciones necesarias para que el ejercicio de estos derechos sea real y efectivo. Así configurado, es un derecho que tiene una doble dimensión, puesto que además de ser garantía de los derechos de los particulares, sirve también a los intereses generales de la justicia, puesto que tiende a asegurar los principios de contradicción e igualdad entre las partes, y a facilitar así al órgano judicial la búsqueda de una sentencia ajustada a derecho.

b) Es un derecho procesal, por su finalidad y estructura: Se encuentra preordenado a la producción de efectos meramente procesales, nunca sustantivos ${ }^{766}$.

c) Es un derecho social de contenido prestacional: Es un derecho social, en tanto que su origen obedece al reconocimiento de una necesidad concreta que interesa a personas claramente especificadas, esto es, a aquellas que por su situación económica se ven incapacitadas para acceder a ciertos servicios, como es la administración de justicia y los servicios de asesoría y defensoría en juicio; y, asimismo, presenta un carácter marcadamente prestacional en cuanto implica una acción positiva del Estado para proveer ciertos bienes y servicios que por razones económicas, de escasez de recursos, no pueden ser adquiridos a través del

${ }^{766}$ RODRIGUEZ, N. Op. Cit., p. 46. 
mercado ${ }^{767}$. De esta forma no basta una simple abstención u omisión por parte del Estado, sino que es necesario que este derecho sea otorgado a través de los poderes públicos o mediante los particulares subsidiados por el Estado ${ }^{768}$.

Al tenor de las reflexiones de Patricia canales y Virginie Loiseau, se destaca la evolución desde una noción de obligación honorífica de la asistencia jurídica gratuita ${ }^{769}$, hacía una responsabilidad que le pesa al Estado. En base a este mismo razonamiento, la judicatura constitucional chilena, expulsó del ordenamiento jurídico la expresión "gratuitamente" del artículo 595 del COT, en cuanto a la carga constitucional de los abogados de defender a los "notoriamente menesterosos", explicando justamente la evolución desde un cargo honorífico a una obligación estatal ${ }^{770}$. El carácter social prestacional de este derecho se constata también en la $\mathrm{CE}^{771}$.

d) Es un derecho de configuración legal: Debido a que la CPR delega a la ley, la potestad y obligación de arbitrar asesoría y defensa jurídica a quién carece de los medios para procurársela por sí mismo.

El Derecho de asistencia jurídica gratuita no se trata pues de un derecho absoluto e ilimitado sino de un derecho cuyo contenido y concretas condiciones de ejercicio corresponde delimitarlos al legislador ${ }^{772}$. El legislador cuenta con un amplio margen

\footnotetext{
${ }^{767}$ MAQUEO, M. (2011). Elementos económicos y constitucionales en el análisis de la asistencia jurídica gratuita. Tesis Doctoral. Universidad de Salamanca. p. 286.

${ }^{768}$ IBIDEM. "En atención a situaciones tanto de interés público como de interés privado, el Estado debe brindar efectivamente una prestación que, en este caso, consiste en otorgar los servicios jurídicos y técnicos necesarios, así como la exención de cuotas o cobros, para entablar y defenderse en un posible litigio en igualdad de condiciones que su contraparte".

${ }^{769}$ CANALES, P y LOISEAU, V (2004). La Asistencia Jurídica gratuita en la legislación de Chile, Alemania, España, Francia, Italia y Suecia. Biblioteca del Congreso Nacional de Chile. p. 36. "Que sobre el punto cabe tener presente que en Europa, en países tales como España, Italia o Francia, se dejó en poder de los abogados la representación y defensa en juicio de los litigantes de escasos recursos, bajo el supuesto que se trataba de una obligación honorifica”.

${ }^{770}$ TC. Sentencia causa rol 1254-08. Op. Cit., Considerandos 31-41.

${ }^{771}$ Un claro ejemplo de ello lo constituye el estado de la cuestión en España, país en que el acceso gratuito a la justicia se encuentra consagrado en el artículo 119 de la Carta Fundamental, de forma tal que la defensa gratuita de las personas de escasos recursos deja de conceptualizarse como una labor altruista u honorifica de los abogados y pasa a ser un derecho de carácter social, que impone una obligación del Estado para su adecuado aseguramiento.

${ }^{772}$ MAQUEO, M. Op. Cit. P. 299. “Ciertamente el carácter de derecho de configuración legal que preceptúa el artículo 119 constitucional deviene de su propia naturaleza de derecho social y más específicamente de su carácter prestacional, pues este tipo de derechos presentan una estructura distinta de los tradicionales derechos
} 
de discrecionalidad para delimitar y, en su caso, fijar el alcance de la prestación que la propia Constitución garantiza, respecto de los derechos sociales, y concretamente en lo concerniente a la asistencia jurídica gratuita, debiéndose respetar en el desarrollo legislativo, el objetivo de la norma constitucional en referencia, y el cumplimento de los principios constitucionales generales de igualdad, no discriminación y respeto a la dignidad humana, que trasuntarán en un acceso a la justicia respetuoso de las garantías procesales de debido proceso, incluida lógicamente la asistencia jurídica gratuita.

Esta libertad de acción posibilita que el legislador pueda crear los instrumentos e institucionalidad necesaria para prestar este servicio, confiriéndole las facultades de autonomía o administración de recursos que se determinen, como asimismo fijar los requisitos objetivos, tanto por criterios económicos o de vulnerabilidad, respecto de los que deben tener este derecho-beneficio, reconociéndoles la carencia de medios que señala la Constitución.

Derecho de configuración legal también en la normativa española, puesto que la CE no proclama la gratuidad de la administración de justicia, sino un derecho a la gratuidad de la justicia, en los casos y en la forma que el legislador determine ${ }^{773}$. En Chile, a diferencia de la normativa española, son las propias instituciones de asistencia jurídica gratuita las que deben interpretar la norma constitucional, pues sus estatutos solo se refieren en forma amplia a que sus beneficiarios deben contar con escasos recursos ${ }^{774}$. El TC ha dictaminado en este sentido "que, como puede apreciarse, así como se consagra el derecho a la asistencia jurídica gratuita, le corresponde al Estado, a través del legislador, establecer medios efectivos que

de libertad e igualdad. No se hacen ya efectivos por el hecho de que se respeten o amparen sino que se requiere de antemano, y en cualquier caso más que en los derechos fundamentales tradicionales, acciones del Estado tendientes a realizar el programa contenido en ellos".

${ }^{773}$ MAQUEO, M. Op. Cit., p. 298.

${ }^{774}$ MINISTERIO DE JUSTICIA. Oficio 685 de 2 de febrero de 2018. En relación a la ley 17.995 y Decreto Supremo 995 de 16 de julio de 1981. 
permitan una adecuada defensa de aquellas personas que carezcan de bienes suficientes para litigar"775.

Nos inclinamos en sostener que la asistencia jurídica gratuita en Chile no tiene solo un desarrollo o una configuración legal, sino que es mixta, pues se distingue en relación a las materias de asistencia jurídica en que recae la prestación. En este sentido, en materia penal, la Ley 19.718 recoge el mandamiento constitucional, y regula materias funcionales del derecho, como los beneficiarios, la duración de la asistencia, contenido material del derecho, entre otros, y aspectos orgánicos, relativos a la organización y funcionamiento de la Defensoría, tanto la netamente pública como la pública licitada. En cambio, en materia civil, que las principales prestadoras son las CAJ, sus leyes y decreto solo se refieren a aspectos de organización, abordando en forma muy somera las finalidades y beneficiarios ${ }^{776}$.

e) Instrumentalidad: Hemos indicado que la fundamentalidad del derecho se sustenta en esta característica, significa que la asistencia jurídica gratuita sirve de concreción y garantía de ejercicio de los derechos fundamentales a la tutela judicial, a la igualdad de armas procesales y a la defensa letrada. La asistencia Jurídica gratuita es un derecho que se debe otorgar a quien carece de medios para procurarse un abogado por sus propios medios, a efectos de que nadie quede privado del acceso a la justicia por falta de recursos económicos o por su situación de vulnerabilidad 777 .

\footnotetext{
775 TC. Sentencia causa rol 1254-08, de 29 de julio de 2009. "En tal sentido, la ley n ${ }^{\circ}$ 19.718, de 19 de marzo de 2001, instauró en materia criminal la DPP, de modo tal que esta defensa se efectúa a través de una institución estatal, por si misma o vía licitación a privados, a quienes se remunera por sus servicios profesionales en conformidad a las bases respectivas. Por su lado, décadas antes, en el ámbito civil -bajo las estructura de la CAJ- la legislación estableció una práctica profesional, en virtud de la cual se obliga a todo Egresado de Derecho a atender gratuitamente a aquellas personas que son beneficiarias del denominado privilegio de pobreza”.

${ }^{776}$ LEY 17.995. Crea las Corporaciones de Asistencia Judicial, de 8 de agosto de 1981. Artículo 2: "Dichas Corporaciones gozarán de personalidad jurídica, tendrán patrimonio propio y no perseguirán fines de lucro. Su finalidad será prestar asistencia jurídica y judicial gratuita a personas de escasos recursos...". "Son las resoluciones, oficios y circulares de menor jerarquía de sus directivos, los que regulan materias tan relevantes como: beneficiarios del servicio, criterios de focalización socioeconómica por vulnerabilidad, líneas de atención, contenido material del derecho, forma de solicitar este derecho, etcétera.”.

${ }^{777}$ MAQUEO, M. Op. Cit .p. 293. "Así pues, como puede observarse, tanto el derecho a la jurisdicción como la propia asistencia jurídica gratuita tienen un objetivo en común, consistente en evitar un posible estado de indefensión, y con ello promover la materialización efectiva de otros derechos”.
} 
En España, relación a la asistencia jurídica gratuita y a la tutela judicial efectiva, ha sostenido el TCE, que "ambos presentan como último fundamento el derecho generalizado a la defensa de todos los derechos consagrados por el orden jurídico $y$, por ende, se les reconoce un carácter inminentemente instrumental"778. Precisamente, en el ámbito constitucional español se torna imprescindible la asistencia jurídica gratuita como un condicionante de la tutela judicial efectiva ${ }^{779}$. En este punto María Maqueo, sostiene que "el artículo 24 y el artículo 119 de la CE se constituyen en realidades imprescindibles, para las que la asistencia jurídica es un instrumento más, de singular importancia, con miras al cumplimiento de los fines pretendidos por el derecho a la tutela judicial efectiva y el derecho a la defensa y asistencia del letrado, cuyo corolario no es otra cosa que el derecho de acceso a la Justicia"780. Esta reflexión es de total aplicación en el derecho chileno, en cuanto a que para concebir la asistencia jurídica gratuita como derecho, un aspecto fundamental radica en el derecho a la defensa y orientación letrada otorgada por el Estado, en todo el proceso, así como el recurso jurisdiccional legalmente pertinente.

Ahora bien, no obstante la estrecha relación que presentan la igual protección en el ejercicio de los derechos y la asistencia jurídica gratuita, no debe perderse de vista que se trata de dos derechos que si bien coexisten entre sí y se relacionan en varios aspectos, especialmente por referirse al mismo "fenómeno social con relevancia jurídica", como lo es el proceso jurisdiccional, presentan un contenido material

\footnotetext{
${ }^{778}$ IBIDEM. “Así pues, como ha puesto de manifiesto el Tribunal Constitucional en sus sentencias 16/1994, de 20 de enero; 117/1998, de 2 de junio; 183/2001, de 17 de septiembre; 95/2003, de 22 de mayo; y 9/2008, de 21 de enero, fundamentalmente, la gratuidad de la justicia es instrumento y concreción de los derechos fundamentales a la tutela judicial efectiva y a la asistencia letrada, por lo que no se trata solo de un derecho que garantice los intereses de los particulares, sino también los intereses generales de la justicia en tanto que tiende a asegurar los principios de contradicción e igualdad procesal entre las partes y a facilitar así al órgano judicial, la búsqueda de una sentencia ajustada a derecho, aunque sin dudas su finalidad inmediata radica en permitir el acceso a la justicia, para interponer pretensiones u oponerse a ellas, a quienes no tienen medios económicos suficientes para ello y, más ampliamente, trata de asegurar que ninguna persona quede procesalmente indefensa por carecer de recursos para litigar".

${ }^{779}$ MARTIN, L. (2009). "El derecho a la asistencia jurídica gratuita. Barcelona. Bosh .p.38. "Si el artículo 24 de la Constitución instituye como derecho fundamental el acceso libre a los tribunales de justicia como fórmula de materialización del derecho a la tutela judicial efectiva, difícilmente podría llevarse a cabo por parte de quienes no tienen recursos suficientes para abonar los costes de una abogado, de un procurador o de otros profesionales, cuya participación en el proceso se hace preceptiva por exigencia legal o, en su caso, necesaria por la dificultad del proceso o por la complejidad del caso litigioso".

${ }^{780}$ MAQUEO, M. Op. Cit., p. 295.
} 
propio y, hasta cierto punto, independiente ${ }^{781}$. Si en el contexto constitucional chileno, el igual ejercicio en los derechos convertido en un real acceso a la justicia, involucra todos los aspectos relativos al debido ejercicio del derecho a la jurisdicción, la asistencia jurídica gratuita se limita a sortear el obstáculo económico que supone la litigación y, en un sentido extenso, la resolución de los conflictos jurídicos.

f) Gratuidad de la Asistencia Jurídica: La asistencia jurídica debe sentar sus bases en el concepto de gratuidad. Es de este modo que se cumple de manera favorable con el acceso al sistema de justicia, en sentido amplio y no restringido, en cuanto a acceder a cualquier instancia estatal, comunitaria, centralizada o descentralizada, que tenga por objeto resolver un conflicto de relevancia jurídica o con sus facultades afectar o limitar un derecho. La relevancia en este punto radica en la determinación de la forma cómo se hace realidad el principio de gratuidad, con la finalidad de dar respuesta a la consecuente problemática, existiendo tres tesis al respecto ${ }^{782}$.

\section{FUNDAMENTOS Y MODELOS DE ASISTENCIA JURÍDICA GRATUITA}

\footnotetext{
${ }^{781}$ IBIDEM. "Tan es así que mientras la tutela judicial efectiva se dirige sin excepción a cualquier persona y hace referencia en un sentido extenso a evitar cualquier obstáculo que impida el libre acceso a la jurisdicción y a la impartición de justicia (como la dilación en el proceso, la rigurosidad de los presupuestos procesales, la independencia e imparcialidad de los juzgadores, entre otros), la asistencia jurídica gratuita se reduce a un sector específico de la población, como son aquellas personas que carecen de recursos suficientes para litigar y que, sólo por disposición legal, se extiende la asesoría jurídica previa al juicio".

${ }^{782}$ NAVARRETE, C. (2008). La Gratuidad como base de la Administración de Justicia y sus Excepciones: La asistencia Judicial. Santiago Chile. Editorial Santiago. p.p 24-25. "Primera Tesis: Administrando gratuitamente justicia. Los que se encuentran a favor de esta tesis se fundan en el hecho que es el Estado quien otorga asistencia jurídica, por lo tanto, no puede en el desempeño de un deber recibir utilidad de ninguna especie. Segunda Tesis: Administración de justicia retribuida. Se argumenta esta tesis, que no se puede poner en duda que las costas ocasionadas en un litigio deben ser de cargo de las partes, ya que cada uno debe responder del propio hecho y de las consecuencias del mismo, porque el juicio o la sentencia que le pone término aprovecha directamente solo a la parte que resulta victoriosa. La justicia es actualmente gratuita por que los litigantes nada tienen que pagar a los jueces. $3^{\circ}$ Tesis: Sistema mixto o intermedio. Se basa en el hecho que tanto el Estado como los particulares interesados deben concurrir al mantenimiento de la administración de Justicia”.
} 


\subsection{Motivos que justifican la Existencia de un sistema de Asistencia Jurídica Gratuita tutelado por el Estado}

El fundamento de la existencia de una asistencia jurídica estatal gratuita, es el hacer accesible la justicia a los pobres, pero no necesariamente en un sentido de pobreza pura, como se ha hecho al analizar las líneas de pobreza a través de los diversos enfoques, sino a aquel que se encuentra en una situación de falta capacidad para contratar los servicios de un abogado. Esta incapacidad es ponderada y definida, por criterios establecidos en la ley, o en disposiciones reglamentarias 0 apreciaciones subjetivas, a juicio del juez o de comisiones, según corresponda.

De esta forma se busca mitigar ciertas manifestaciones externas de diferencia social y así contrarrestar los perjuicios e ideas en torno a que el abandono gubernativo había hecho germinar y propagar la indefensión jurídica en los grupos más desposeídos.

En Chile, las motivaciones de contar con asistencia jurídica gratuita evolucionan desde un enfoque de la caridad hacía la consideración como un derecho constitucional ${ }^{783}$. Tomando en consideración el aspecto económico, se ha entendido que los ciudadanos tienen ciertos derechos establecidos por el ordenamiento jurídico, que en caso de encontrarse en una situación de precariedad no pueden ser ejercidos en forma plena ${ }^{784}$. Se entiende de mejor manera esta razón económica, tal como lo expresa Cassarino, en el sentido que "ser titular de un derecho y carecer de los medios económicos para hacerlos valer, equivale a no poseerlo"785.

\footnotetext{
${ }^{783}$ BATES, L. Op. Cit., p. 47. "En Chile no están muy claros los motivos de la asistencia jurídica gratuita, aunque en sus inicios tenía una clara orientación hacia la caridad y la ayuda a los más pobres, como resabio del derecho medieval e indiano, más con el tiempo se ha ido vinculando comúnmente a las garantías de igualdad ante la ley y la igualdad en el ejercicio de los derechos, presentando así, características mixtas, derivadas de la caridad y derecho público, pero lejos aún de aproximarse a la motivación de bienestar económico social".

${ }^{784}$ CASSARINO, M. Op. Cit., p. 193. "El pago de los honorarios profesionales a los abogados que, en nuestra terminología jurídica, denominaremos costas personales, y el pago de los tributos y derechos arancelarios de los oficiales subalternos de la administración de justicia, que llamamos costas procesales”.

${ }^{785}$ IBIDEM.
} 
A nuestro entender, de la escasez por parte importante de la población de medios económicos para ejercer los derechos, es que el legislador consciente de esta situación de abierta injusticia, ha establecido normas legales e instituciones que vienen a auxiliar a este litigante. Por una parte, y como primera motivación de la génesis de esta asistencia, se colige el hecho que el principio de igualdad ante la ley significa que no deben haber personas ni grupos privilegiados, entendiéndose por ello que no deben haber diferencias de ningún tipo, menos tratándose de personas en situación de pobreza. Como segundo fundamento, basándonos en el principio romano que sostiene "nadie puede hacerse justicia por sí mismo", está el hecho que el hombre no tiene la capacidad para resolver conflictos con sus pares, en términos simples no son buenos jueces. En definitiva, los Estados crean y mantienen sistemas de asesorías jurídicas gratuitas, con el fin de defender los derechos de los particulares que se encentran vulnerables socialmente y además con la finalidad de mantener el orden jurídico social.

\subsection{Modelos de Asistencia Jurídica Gratuita}

Siguiendo a Robert Rhudy, los modelos de asistencia jurídica gratuita dicen relación con los sistemas, enfoques o mecanismos que hayan sido elaborados para proporcionar servicios de asistencia jurídica a personas y grupo de bajos ingresos ( $u$ otras causas o asuntos en situación desventajosa) en los Estados, y se diferencian en cuanto a sus formas de financiamiento y como prestan el servicio ofrecido $^{786}$.

Es necesario advertir previamente, que si bien los modelos de asistencia jurídica presentes en el derecho comparado se refieren principalmente a la asesoría y defensa prestada a personas que carecen de medios económicos suficientes, ello no significa que no traten o puedan tratar asuntos concernientes a personas con

\footnotetext{
786 RHUDY, R (1999). “Acceso a la justicia: modelos de asistencia jurídica”. EN BIEBESHEIMER, C y CORDOVEZ, C. La justicia más allá de nuestras fronteras. Experiencia de reformas útiles para América Latina y el Caribe. Washington DC. Banco Interamericano de Desarrollo. p. 67.
} 
una buena posición económica que en una situación especialmente desventajosa o vulnerable requieran la intervención del Estado, ya que no pueden atenderse adecuadamente por medio de mecanismos del mercado privado ${ }^{787}$.

En el derecho comparado se pueden apreciar al menos tres modelos de asistencia jurídica gratuita, los cuales son: el sistema de defensa oficial o modelo estratégico de servicio social ("staff system"), el sistema judicial o modelo de servicio ("judicare system"), y el sistema mixto.

a) Sistema de defensa oficial o "modelo estratégico de servicio social", conocido como "staff system": Este modelo que impera en Estados Unidos, se caracteriza principalmente por organizarse en uno o varios órganos compuestos por abogados asalariados encargados de la defensa jurídica (de ahí viene el nombre de Staff y servicio social, a quienes se le remunera independientemente del número de casos que patrocinan).

En Estados Unidos, es el sistema oficial de defensa de los indigentes, y cada vez más Estados comienzan a usarlo para la asistencia de personas de escasos recursos ${ }^{788}$. Se argumenta que este sistema es beneficioso ya que tiende a una mayor especialización, y que por encontrarse estructurado como un servicio público genera un mayor acercamiento a la población, ya sea por su ubicación física o por la facilidad en transmitir sus funciones ${ }^{789}$.

A su vez, este modelo puede subclasificarse en dos vertientes, según cómo se estructure la relación del abogado patrocinante con el Estado. Así, se puede hablar de un sistema de defensa de oficio, cuando el letrado dedicado a la práctica privada es llamado a intervenir de acuerdo a las disposiciones de la defensa pública, y defensa oficial, cuando es funcionario de planta del servicio de Defensoría Pública. En este sentido en Chile, los abogados licitados de la DPP, constituirían defensa de oficio, y la CAJ y la DPP no licitada, serían casos de defensa oficial.

\footnotetext{
${ }^{787}$ IBIDEM. p. 68.

788 IBIDEM.

${ }^{789}$ IBIDEM
} 
b) Sistema judicial o "modelo de servicio", conocido como "judicare system": Es el sistema vigente en países como Italia y España, que entrega a los abogados privados la defensa (estrictamente judicial) de las personas que carecen de recursos (mediante un proceso de acreditación al igual que el caso del privilegio de pobreza chileno), por medio de una especie de obligación honorífica ${ }^{790}$. Se subclasifica este sistema en relación con la administración y estructura de la asistencia prestada por los abogados ajenos a la administración pública. Puede hablarse de un subsistema con programa de certificación o cupones conocido como judicare en sentido estricto y uno basado en abogados de turno o por día. Este sistema de judicare en sentido estricto consiste básicamente en la derivación de causas de personas que califican para la asistencia jurídica gratuita, a un abogado privado que participa en el programa o que es seleccionado con total libertad por el solicitante, y a quien se le pagará una vez prestado su servicio, mediante fondos públicos. El segundo subsistema, por turno o días en cambio, generalmente se administra por el tribunal o por la entidad local de asistencia jurídica gratuita, que establece un sistema de turno para que abogados privados proporcionen orientación y representación a personas de escasos recursos, quienes pueden ser remunerados por esos organismos o no, imponiéndose con matices un deber honorífico sobre ellos.

Más allá de esta subclasificación del judicare, este sistema en general puede presentar ventajas en cuanto a la elección del defensor y a una posible mayor rapidez en la entrega de la defensa. Sin embargo, los problemas son variados, como por ejemplo, que a causa de su estructura solo se limita a la defensa en juicio, pero no en los trámites anteriores a la demanda y a su preparación. Como debilidad se puede agregar, que cuando presenta carácter de obligatorio genera visos de inconstitucionalidad, al considerarse que constituye una carga indebida solo asociada a la profesión de abogado y que genera pérdidas de recursos económicos para el profesional, al tener que gestionar tiempo y capacidades en causas, gratuitamente o bajo los salarios fijados por el Estado.

${ }^{790}$ CANALES, P y LOISEAU, V. Op. Cit., pp.2-3. 
Para Rudhy, además, "este modelo no es muy eficiente para promover una reforma legislativa o defender causas de política pública, ni para prestar asistencia en cuestiones que atañen particularmente a las personas de bajos ingresos, poblaciones indígenas y con otras minorías en situación desventajosa, además de que los abogados privados no residen en comunidades de bajos ingresos ni en zonas rurales"791. Es dable consignar que este sistema es el que sigue nuestro país con el sistema del abogado de turno.

c) Modelo intermedio o mixto ${ }^{792}$ : Este modelo se encuentra presente en los ordenamientos jurídicos de Suecia, Holanda y Gran Bretaña, entre otros. Como su nombre lo señala, presenta características de los dos sistemas anteriores, y para muchos, representa el mejor modelo ${ }^{793}$.

Reiteramos que en Chile se sigue un modelo mixto, pues nos encontramos con los 3 esquemas, dependiendo de las materias, de organismos y de las modalidades en que se presta la asistencia jurídica gratuita ${ }^{794}$.

\section{EVOLUCIÓN HISTÓRICA, LEGAL Y CONSTITUCIONAL DE LA ASISTENCIA JURÍDICA GRATUITA}

\subsection{Evolución histórica de la Asistencia Jurídica Gratuita}

\footnotetext{
${ }^{791}$ RHUDY. Op. Cit. p. 81

${ }^{792}$ CANALES, P y LOISEAU, V (2004). Op. Cit., p. 1.

793 IBIDEM. p.63.

${ }^{794}$ A mayor abundamiento, en Chile se constatan características de un sistema de judicare en la institución del abogado de turno, pues en forma honorifica ciertos abogados deben brindar este servicio por un sistema de turnos, a requerimiento del juez, a aquellas personas que cuenten con un beneficio de asistencia jurídica, denominado privilegio de pobreza, sin perjuicio que la gratuidad de sus servicios se suprimió por una sentencia de TC el año 2009, tal como se analizará. Por su parte, Staff System o sistema de defensa oficial y de oficio, lo constatamos en materia penal a través de la DPP y la DPP licitada respectivamente, y a través de las CAJ, que obedecen a un servicio estatal de prestación de servicios de asistencia jurídica gratuita a cargo y costa del Estado.
} 
En un principio las diferencias que se suscitaban entre los hombres se regularon por la ley del más fuerte, es decir por la fuerza física o intelectual. Sin embargo, las sociedades nacientes se vieron en la necesidad de establecer formas más adecuadas para resolver sus controversias, entregándole esta responsabilidad a terceros ajenos a la controversia, naciendo así el juez y el proceso. Junto a la sociedad se generan además como consecuencia, los conflictos sociales y dentro de ellos, emerge el problema de la asistencia jurídica gratuita. A través del tiempo, en forma permanente, ha sido constante la existencia de personas privadas de recursos suficientes para defender sus derechos, y como la ignorancia existe, generalmente en razón directa de la pobreza, surge y se acrecentó la necesidad de contar una persona al corriente del derecho para asistirlos. Precisamente, dentro de la historia de la humanidad la asistencia a los postergados para que tuvieran una defensa ha estado presente en diversas épocas y contextos. En la antigua Grecia y en el Derecho Romano existen diversas mutaciones en cuanto a su contenido y forma de otorgarlo, tal como lo desarrolla la profesora y abogada chilena, Solange Doyharcabal795. Por su parte, en el derecho español, existe una raigambre histórica

${ }^{795}$ DOHYHARCABAL, S (1983). “Asistencia Jurídica en el derecho romano”, EN Revista Chilena de Historia del Derecho. número 9. pp. 35-42. "En Atenas encontramos la creación de abogados para pobres: La más importante obra de Dracón fue haber redactado normas escritas, fijando así el Derecho. Al estar las normas jurídicas escritas, implica que ante un mismo caso se aplicara una misma norma, evitando de este modo arbitrariedades. Así cuando la escritura no lo ha fijado, cuando su texto no es invariable, hay oportunidades para interpretaciones más injustas. Otra obra de Dracón fue dotar al Estado del poder judicial. En Roma se observa la institución del Patronato Cuyo origen es básicamente aristocrático. En virtud de esta institución se establecía que ningún ciudadano de la clase ínfima debía quedar sin defensor. La sociedad romana estaba conformada por el patrono quien era el dueño, señor de la tierra y de los poderes públicos y por otro lado estaba el cultivador de la tierra. El patrón tenía su familia natural y junto a ella se encontraba una especie de familia, compuesta por estos hombres débiles que pasaron a transformarse en servidores y que se les llamo colentes o clientes. Entre ellos existía un verdadero contrato cuyos efectos fueron determinados por las leyes. Sucedía que entre los derechos primordiales reconocidos al cliente estaba el ser defendido en justicia por su patrono, lo que explica que los defensores hayan sido en un principio de origen patricio. Cuando los patricios comenzaron a perder sus privilegios, los patrones al verse en la situación de estar frente a la perdida de sus derechos, ya no se vieron obligados a prestar asistencia judicial a sus colentes. Sin embargo, lo continuaron haciendo, pero ya no, por el contrato que los unía, sino en razón de ser un medio de influencia y supremacía honorifica. Esto porque, los clientes comprendieron que sus derechos podía ser defendidos por personas más hábiles que sus antiguos patronos. Posteriormente al ser privado de su mayor privilegio, el de la defensa judicial, el Patrono se tuvo que transformar en un verdadero abogado, adecuándose de este modo a la nueva realidad. A pesar de esto no osó en cobrar remuneración, ya que su orgullo se hubiera visto humillado. Sin embargo, se estableció un acuerdo tácito entre él y su cliente en que se le haría una donación por sus servicios, denominada honorarium, xenium, solatium o palmarium (la palma del abogado que triunfa). Después de una evolución que contempló la consagración de la abogacía y del rol del abogado como una profesión y no una afición. En el Bajo Imperio, el emperador Diocleciano se siguió preocupando de la necesidad de asistencia gratuita, se reglamentaron las costas judiciales, se rebajaron de ciertas personas, etcétera. Finalmente Constantino, fuertemente influenciado por el 
en que destaca el carácter de una imposición de dios que es asumida por los abogados, con la finalidad de asistir a los menesterosos, permitiéndonos seguir en este punto al profesor chileno Antonio Dougnac, quién revisa las normas que se consagran desde el fuero juzgo a la Novísima Recopilación ${ }^{796}$.

\subsection{Desarrollo histórico y legal de la Asistencia Jurídica Gratuita en Chile}

Tal como lo señala Dougnac, "en Chile existieron abogados de pobres desde 1567, año de la fundación de la primera Real Audiencia en Concepción. En los años siguientes se pierde el rastro de ellos. Para la segunda Audiencia de Chile creada en 1609, cuya sede fue Santiago, se contemplaba la existencia de este funcionario. Incluso a fines del siglo XVII, hubo dos abogados de pobres, a los que se les remuneraba con el producido de las multas o penas de cámara"797. Otra manifestación de la asistencia jurídica gratuita a los pobres es la dictación del Auto

cristianismo, reitero a los pobres la defensa gratuita disponiendo que para evitar injurias de los poderosos sus pleitos se vieran en primera instancia ante el mismo emperador, y sancionaba al abogado que se negaba a aceptar la designación de oficio, borrándolo de las listas”.

796 DOUGNAC, A. (1978). "Notas históricas en torno a la asistencia jurídica gratuita y la práctica forense en Chile”. EN Revista de Derecho Procesal Universidad de Chile. año 3. número 5. pp.26-28. En este acápite hace referencia a los principales cuerpos legales hispánicos hasta 1806. a) Fuero juzgo (año 696 a 701): Dejó a los pobres bajo la protección de los Obispos por medio de procuradores 'para que no desfallezca la verdad por el poderío'. En el caso de que un pobre accionare contra un rico, debía hacerse representar por un procurador tanto o más adinerado que su adversario, y si era rico el que litigaba contra el pobre, debía aquel hacerse representar por un procurador pobre. b) Siete Partidas (1256-1263) de Alfonso X: Estableció que los que fueran demandados por los pobres, debían responder ante el Rey, además se dispuso que los jueces podían obligar a los abogados a defender gratuitamente a viudas, huérfanos y otros menesterosos. c) Nueva Recopilación, o denominada Recopilación de Leyes de Castilla de Felipe II en el año 1567, en se ordenaba a los abogados que defendieran a los pobres “de gracia y por amor a Dios”. d) Leyes de Indias 1680, Recopilación de las Leyes de los Reinos de las Indias. Se establecía que debían dedicarse dos días a la semana para la vista de los juicios de los pobres, que después se redujo al día sábado. e) Novísima Recopilación: Bajo el imperio de Carlos IV en 1806, en el Título XXII del Libro V contienen disposiciones minuciosas sobre la participación de los abogados legos o asalariados en la causa de los pobres “de gracia y por amor a Dios” (Ley 13), obligándose a los abogados de los pobres a estar presente los días sábados en las audiencias para dar cuenta de sus procesos y ver lo que les llevaren los procuradores (Ley 14), sin perjuicio de otras disposiciones sobre los derechos de los fiscales y escribanos y sobre el uso y sellos de los pobre.

${ }^{797}$ IBIDEM. p.29. 
Acordado de la Real Audiencia de 20 de diciembre de 1784 que estableció un turno entre todos los abogados inscritos en la audiencia para defender a los pobres ${ }^{798}$.

Tratándose de los indígenas estos tenían un status especial, tanto es así que la Recopilación de Las Leyes de las Indias de 1680 contemplaba la existencia de un abogado pagado con las penas de cámara y otros recursos, para que los defendiera en los asuntos que tuviesen con los españoles (léase individuos de raza blanca), este funcionario era el procurador general de naturales ${ }^{799}$. Nuestro país, luego de su Declaración de Independencia de 12 de febrero de 1818, mantuvo las disposiciones españolas que se encontraban vigentes a ese entonces, que consistían en normas de las Siete Partidas (1255-1263), de la Novísima Recopilación (1527-1567) y a las disposiciones contenidas en las Leyes de Indias (1680). Si bien antes de la independencia, era la Real Audiencia la que otorgaba el privilegio de pobreza, finalmente quedó entregado el conocimiento de tal solicitud a la CA o al Juez de primera instancia correspondiente. Después del hito independentista, y durante los primeros gobiernos republicanos, solo se establecieron algunas disposiciones aisladas tendientes a proteger a los pobres ${ }^{800}$. Hasta dicha fecha la preocupación del Estado en cuanto a proporcionar bienestar jurídico a los indigentes se había traducido solo en la dictación de medidas que regulaban la concesión de beneficio de privilegio de pobreza, no recordándose ninguna iniciativa tendiente a fomentar la creación de un servicio especial que cumpliera con tan importante labor ${ }^{801 .}$

\footnotetext{
${ }^{798}$ IBIDEM.

799 IBIDEM. "Dicho cargo fue suprimido en 1761, sin embargo, en 1866 se restableció el cargo de protector de indígenas para que los auxiliase particularmente, en los juicios sobre nulidad o validez de contratos de compraventa y arrendamiento".

${ }^{800}$ Entre estas disposiciones encontramos el decreto de 13 de julio de 1839 que establecía que era la CA la que debía nombrar abogados y procuradores encargados de la defensa de los pobres, el decreto de 8 de octubre de 1863, se ordenaba en virtud de este decreto que las declaratorias de pobreza, se debían tramitar y resolver por el juez de primera instancia que debiera conocer de la causa.

${ }^{801}$ Los jueces de letras tenían la tuición de las personas pobres y desvalidas que se hallen en el caso de entablar ante ellos cualesquiera reclamación judicial. Además les corresponde otorgar privilegio de pobreza a las personas que no puedan costear una defensa judicial y designar mensualmente y por turno a los abogados, procuradores y demás personas que deben servirlos gratuitamente.
} 


\subsection{Análisis histórico Constitucional del derecho a la Asistencia Jurídica Gratuita en Chile}

a) Reglamento Constitucional de 1812: Es considerado como la primera constitución del pueblo chileno. Radica la función judicial en los tribunales y jueces ordinarios, recayendo en el gobierno la obligación de velar por los deberes de los magistrados sin perturbar sus funciones. No contiene norma alguna sobre asistencia jurídica letrada ${ }^{802}$.

b) Constitución de 1818: Se denominó proyecto de Constitución provisoria para el Estado de Chile. El punto más relevante en relación a la justicia y los pobres es el establecimiento de un juzgado de paz que se aproxima bastante a lo que entendemos por conciliación, pues estaba destinado a llamar a los litigantes a un avenimiento, y solo en caso de fracaso de éste, se tramitaría el juicio. Si bien es cierto no dice relación con las personas de escasos recursos exclusivamente, se entiende que constituyó un elemento importante para que éstos pudieran tener acceso a una respuesta satisfactoria a sus necesidades jurídicas, que de otra forma no podrían obtener por carecer de recursos para contratar un abogado. El artículo 25 preceptuaba: "deberá establecerse un juzgado de paz, y en el ínterin lo será todo juez de primera instancia, que antes de darle curso, llamará a las partes y tratará de reducirlas a una transacción o compromiso extrajudicial; y poniéndose constancia de no haber tenido efecto ésta diligencia, solo correrá la demanda" ${ }^{803}$.

c) Constitución de 1822: En el Capítulo III "De los jueces de paz" se repite el sistema de llamado a conciliación obligatorio, con la diferencia que ya no era los jueces de instancia los llamados a conocer, si no que era un tribunal especial denominado Tribunal de la Concordia. Sus disposiciones representaron un progreso evidente del derecho público chileno, consagrando la igualdad de todos los chilenos ante la ley y el establecimiento de algunas garantías individuales ${ }^{804}$.

\footnotetext{
${ }^{802}$ GARCIA HUIDOBRO. C. (2012). "El Reglamento Constitucional Provisorio de 1812: Reflexiones para un Bicentenario”. EN: Revista Chilena de Derecho. Vol. 39 n¹. p. 236.

${ }^{803}$ PROYECTO DE CONSTITUCIÓN PROVISORIA PARA EL ESTADO DE CHILE. Artículo 25. Es dable señalar que estos jueces de Paz nunca fueron creados y la conciliación en el juicio ordinario, de general aplicación, como en los especiales es de exclusiva responsabilidad del juez, tal como lo señala el artículo 262 del CPC en la actualidad.

${ }^{804}$ CONSTITUCION DE 1822. Artículos 190-191.
} 
d) Constitución de 1823: Conocida como la Constitución moralista, por el tenor regulador de conductas sociales que lo hacía ver como un manual de buenas costumbres en variados pasajes constitucionales. Se reforzó la idea de la conciliación destinado en título XV para los jueces de conciliación en sus artículos 167 a 175, en que se establece la conciliación como obligatoria, ya que ninguna persona puede presentarse a los tribunales ordinarios con demanda judicial, sin haber ocurrido a los de conciliación.

e) Constitución de 1828: Fue redactada con un marcado tinte liberal. Esta constitución en su Capítulo III organizó los derechos Individuales, bajo el título "de los derechos imprescriptibles e inviolables del hombre" 805 . Se reconocieron derechos, tales como la libertad, la privacidad, propiedad, opinión, etc. Así, se estableció por primera vez en una carta constitucional chilena, un señalamiento explícito de los derechos fundamentales. Sin embargo, constituyó solo una declaración de intenciones que debía inspirar al resto de las garantías, y no se consagró expresamente la garantía de acceso a la justicia, ni menos aún, la asistencia jurídica gratuita.

f) Constitución de 1833: Esta Constitución si bien marca un hito histórico en lo político e institucional, al imponer un régimen presidencialista impersonal y fuerte, que fuera más allá de los caudillismos que asolaban en la época post independentista, en lo netamente relativo a la asistencia letrada gratuita no es demasiado lo que se puede consignar. Aún no existía signo alguno de reconocimiento constitucional al derecho a la defensa judicial que fuera más allá de la garantía de la necesidad del juzgamiento legal. A pesar de esto, durante la vigencia de esta Constitución, que se extendió por 92 años, sí se vieron avances en el plano legal, como la dictación el 15 de octubre de 1875, de la Ley de Organización y Atribuciones de los Tribunales, que estableció el privilegio de pobreza y el sistema de abogados de turno, pero careciendo de un reconocimiento en espectro constitucional.

g) Constitución de 1925: Dictada bajo el gobierno de Arturo Alessandri, se constituyó en una reacción al régimen parlamentario que irrumpió en el país después del golpe de Estado que terminó con el mandato del presidente José Manuel Balmaceda. En esta Carta se organizaron de manera numérica por primera vez las garantías constitucionales. Además de este avance se consagra constitucionalmente el recurso

${ }^{805}$ CONSTITUCION DE 1828. Artículo 10. 
de amparo en su artículo 16, como un mecanismo de acceso a la justicia inmediata y absolutamente desformalizado, para remediar situaciones irregulares de afectación de la libertad personal.

Es dable y pertinente hacer mención al artículo 11 y 12 que establecen bases de garantías que fueron consolidadas posteriormente ${ }^{806}$. Se suscitaron algunas reformas constitucionales relevantes durante la vigencia de esta Constitución, en cuanto a la asistencia jurídica gratuita. En primer término, el proyecto constitucional de 1965, que añadía lo siguiente al artículo $10 n^{\circ} 1$, consagrando la igualdad ante la ley "corresponde al Estado otorgar asistencia jurídica a quienes, para hacer efectivos los derechos que las leyes le reconocen, no puede procurársela por sí mismo'"807. Debido a los debates legislativos posteriores, esta positiva reforma no se concretó. La reforma constitucional de 1971, el denominado estatuto de garantías, fue dictada de conformidad con una recomendación previa de la ONU ${ }^{808}$ constituyendo un esfuerzo por organizar un sistema de derechos mediante la asistencia legal, modificando en esa parte la Constitución de $1925^{809}$.

Al mismo tiempo desde el área administrativa, durante la vigencia de esta Carta se dictaron decretos y/o reglamentos, que abordaron tópicos operativos relacionados con la asistencia jurídica gratuita, como la creación del Colegio de Abogados, en cuya responsabilidad recayó la tutela de crear y mantener consultorios jurídicos de pobres, que fueron los encargados de brindar atención jurídica gratuita a personas de escasos recursos, hasta la creación de las CAJ, como asimismo, el

${ }^{806}$ CONSTITUCION DE 1925. Artículo 11: "Nadie puede ser condenado, sino es juzgado legalmente y en virtud de una ley promulgada antes del hecho sobre que recae el juicio". Artículo 12: "Nadie puede ser juzgado por comisiones especiales, sino por el tribunal que le señale la ley y que se halle establecido por anterioridad por ésta”.

${ }^{807}$ NAVARRETE, C. Op. Cit., p. 54.

${ }^{808}$ La ONU había formulado una recomendación a los gobiernos de cada Estado en orden a ser apoyadas en sus esfuerzos para obtener la organización y desarrollo de sistemas adecuados de asistencia jurídica para la protección de los derechos de individuo.

${ }^{809}$ CONSTITUCION POLITICA DE 1925. Artículo 17 nº 10: "El Estado deberá remover los obstáculos que limiten en el hecho, la libertad e igualdad de las personas u grupos y garantizará y promoverá su acceso a todos los niveles de educación y cultura y a los servicios necesarios para conseguir esos objetivos, a través de los sistemas e instituciones que señala la ley”. 
establecimiento de prácticas gratuitas por parte de los egresados de las escuelas de derecho y otras directrices relevantes ${ }^{810}$.

El 8 de septiembre de 1928 se dicta el Decreto $n^{\circ} 1.280$ que fija el texto definitivo de la Ley 4.409 que rige la organización de los servicios de asistencia judicial. Así, en su artículo 12 letra ñ), se le impuso Consejos de los Colegios de Abogados la obligación crear y mantener consultorios jurídicos gratuitos para pobres y vigilar la correcta actuación de los abogados llamados por ley a asistir a las personas que gozan del privilegio de pobreza ${ }^{811}$.

Con la dictación de la Ley $n^{\circ}$ 5520, de fecha 26 de diciembre de 1934, que modificó la Ley 4.409 , se marca una etapa de progreso en estos servicios, dándose un paso definitivo en la asistencia judicial. Esta ley en síntesis estableció lo siguiente:

${ }^{810}$ NAVARRETE, C. Op. Cit., pp. 56-57. “Mediante el Decreto nº 6392 del Ministerio de Educación de 31 de diciembre de 1929, se estableció la obligación de los estudiantes de derecho de efectuar una práctica profesional para optar al título de abogado, ingresando a los consultorios dependientes del colegio de abogados. Por decreto n406 se crea el 'Colegio de Abogados', que tenía por objeto agrupar y organizar a todos los miembros del foro. En 1928, la ley 4409 fortaleció a este organismo, otorgándole facultades tendientes a la creación y administración de consultorios jurídicos, que pudiesen concretar la prerrogativa constitucional. En 1929, el decreto ${ }^{\circ} 6392$ intentó cubrir la creciente necesidad de hacer efectivo el principio de la gratuidad de la justicia, estableciendo para estos efectos una sección de práctica forense dependiente del colegio general. Sin embargo, dicha sección no tuvo el funcionamiento esperado producto de la falta de recursos económicos del Consejo General. En el año 1932 se marca el inicio de sus servicios, así el Colegio de Abogados de Santiago el 1 de agosto abre el primer consultorio jurídico gratuito para pobres. Para poder dar inicio a esta gran empresa el colegio de abogados de Santiago contó con la ayuda económica del gobierno, que en sus inicios fue de \$5000 escudos. Dicho consultorio contaba con 2 secciones jurídicas, una que tenía cargo la atención de asuntos civiles y del trabajo y otra, los asuntos criminales y administrativos. Cada sección estaba a cargo de un abogado jefe que recibía su remuneración del colegio. En este servicio colaboraban abogados que en forma voluntaria ofrecían sus servicios profesionales, y también estudiantes de derecho de cuarto y quinto año de las Universidades de Chile y Católica. Durante este mismo año, para lograr una mayor eficacia en su labor se nombraron dos procuradores rentados y se crea una sub sección de asistencia social a cargo de una visitadora social titulada. Tomando como ejemplo lo realizado por el colegio de abogados de Santiago, se crea un consultorio gratuito en Valparaíso, dependiente del centro de derecho de la escuela de derecho de la Universidad de Chile y financiado en cierta medida por el colegio de abogados de esa ciudad. Es en el año 1934 cuando se vieron los primeros frutos de esta institución, gracias a la colaboración de 72 candidatos a abogados que concurrieron a este servicio a cumplir con la práctica forense, en el consultorio de la ciudad de Santiago”.

${ }^{811}$ NAVARRETE, C. Op. Cit., p. 56. “Además se crean 2 consultorios gratuitos dependientes de los colegios de abogados de Cautín y de Talca cada uno con un abogado jefe. Posteriormente se van creando otros consultorios en diversas ciudades del país. Ya en el año 1945, se habían instalado oficinas en diez de los once departamentos que componen la jurisdicción del Consejo General del colegio de abogados”. 
a) Faculta a los consultorios jurídicos creados por el Colegio de Abogados, que se extendían en algunas provincias del país para aplicar medidas de control sobre los abogados de turno.

b) Concede privilegio de pobreza por el solo ministerio de la ley a las personas que fueren patrocinada por estos servicios.

c) Contiene medidas concretas sobre práctica forense obligatoria.

d) Exime a los abogados del consultorio de la obligación de pagar patente respecto de los asuntos que en ellos tramiten

En las normativas constitucionales, legales y reglamentarias mencionadas, se basó toda la estructura de asistencia judicial desde antes de la mitad del siglo XX en Chile, siendo los Consejos provinciales del Colegio de Abogados los encargados de crear y sostener este consultorio de asistencia gratuita y fiscalizar la labor de estos abogados. Consecuente con ello, para que los pobres tuvieran una defensa efectiva y eficaz, el Consejo General del Colegio de Abogados creó el servicio de asistencia judicial en su jurisdicción y en los diversos Consejos Provinciales. Es del todo evidente que constituía un derecho en su efectividad bastante precario, en atención a que descansaba en los aportes que hacían en gran parte, de forma gratuita y desinteresada, los abogados de un determinado territorio, con una escasa dotación profesional de planta, recursos insuficientes y disminuida cobertura territorial.

Es dable expresar, que el acta constitucional número 3 de 1976 que precedió a la Constitución de 1980, y que fue fruto del trabajo de la CENC, que fue publicada como DL 1552 el 3 de septiembre de 1976, instituyó en su artículo 1 n 3 inciso $2^{\circ}$ y $3^{\circ}$ que: "toda persona tiene derecho a defensa jurídica y ninguna autoridad o individuo podrá impedir, restringir o perturbar la debida intervención del letrado si hubiera sido requerida. La ley arbitrará los medios para otorgar asesoramiento y defensa jurídica a quienes no puedan procurárselo por sí mismos"112.

${ }^{812}$ ACTA CONSTITUCIONAL n ${ }^{\circ} 3$ de 1976 . Artículo 1 incisos $1^{\circ}, 2^{\circ}, 3^{\circ}$. 


\section{ASISTENCIA JURÍDICA GRATUITA. PERÍOdO DE GESTACIÓN Y DESARROLLO CONFORME AL BLOQUE DE CONSTITUCIONALIDAD VINCULANTE PARA CHILE}

\subsection{Periodo formativo de la Constitución de 1980. Comisión de Estudios para una Nueva Constitución}

En la CPR queda establecido de manera definitiva el principio de la igualdad ante la ley, y con él, la garantía del acceso a la justicia para todas las personas, como asimismo, las garantías mínimas del debido proceso, dentro de las cuales se encuentra la defensa jurídica propiamente tal y la asistencia Jurídica gratuita. La actual redacción constitucional respecto de la asistencia jurídica gratuita es la siguiente: "la ley arbitrará los medios para otorgar asesoramiento y defensa jurídica a quienes no puedan procurárselos por sí mismo" ${ }^{\text {"13. }}$.

Esta moción fue presentada a la CENC, por el comisionado Silva, siendo el texto de su propuesta original, el siguiente: "corresponderá al Estado otorgar asistencia jurídica a quienes para hacer efectivo los derechos que las leyes les reconocen, no puedan prestárselas por sí mismos"814.

En el seno de la CENC, el debate originado respecto de esta moción, se suscitó en la sesión 103. Silva sostuvo "que la expresión corresponde al Estado otorgar asistencia jurídica está formulada en los mismos términos en que había sido ya aprobada en la tramitación de algunas reformas constitucionales y le parece que fue en la primera de las presentadas en el año 1965, que quedó pendiente en el senado en segundo trámite constitucional, donde estaba colocado este inciso en los

\footnotetext{
${ }^{813}$ CPR. Artículo 19 número 3, inciso 3º.

${ }^{814}$ EVANS, E. Op. Cit., p. 139.
} 
términos mencionados" 815 . Evans "manifiesta que no le agrada la redacción 'corresponde al Estado otorgar asistencia jurídica...', porque estima que el día de mañana puede dar margen a que sostenga que la asistencia judicial que hoy brindan el Consejo General del Colegio de Abogados y los Consejos provinciales de la orden, como su fiscalización y su funcionamiento deban ser realizados por el Estado a través de un servicio público, tentativa que ya tuvo lugar antes y durante el régimen de la unidad popular" ${ }^{116}$. Los temores del comisionado Evans se relacionaban con una posible politización en la concesión del beneficio, siendo a su juicio más razonable dejarlo al libre juego del desarrollo comunitario ${ }^{817}$.

Para Enrique Ortuzar, presidente de la Comisión, "hay una razón que le parece fundamental, y es la que dio el señor Evans, en el sentido de que sería extraordinariamente grave que en una materia tan delicada pudiera la autoridad administrativa arbitrar estos medios y, con carácter obligatorio, para la asistencia jurídica a quienes no puedan procurárselas por sí mismos"818. En cambio, no cree que haya ningún inconveniente para que con la redacción propuesta por Evans, puedan el día de mañana por propia iniciativa, organismos particulares, organizaciones intermedias, crear sistemas de asistencia jurídica como los que existen actualmente, pero que no tendrían naturalmente el carácter de obligatorios, sino de voluntarios para quienes deseen hacer uso de los mismos ${ }^{819}$.

En cuanto a lo refutado por Evans y Ortuzar, el comisionado Silva fundamentó la pertinencia de la expresión Estado, indicando que "en cuanto concierne a la

\footnotetext{
${ }^{815}$ IBIDEM.

${ }^{816}$ IBIDEM.

817 ACTAS OFICIALES, Sesión 103, p. 5. "Recuerda al respecto que el señor Silva Bascuñán debe tener presente los esfuerzos que debió desplegar para convencer a algunos estatistas de la asistencia judicial, de la inconveniencia de privar al colegio de abogados de la tuición sobre esta importante tarea colectiva, y de entregarla a un servicio público que, evidentemente, sería politizado el día de mañana, desconociéndose los objetivos o finalidades para los cuales se iba a prestar la asistencia judicial y discriminándose acerca de a quienes y por qué razón les sería prestada o denegada. Agrega que no consignaría ese inciso en la Constitución porque, al hacerlo, se está facilitando, aunque no se desee, no se exprese, ni se pretenda, la estatización de esta asistencia, motivo por el que prefiere dejar entregada esta materia al libre juego de una comunidad que se va a mover soberanamente, ya que es posible que sea el Estado, el Colegio de Abogados u otras entidades los que establezcan organismos de asistencia jurídica y parece aconsejable no señalarlo como un deber del Estado, sino dejarlo al libre juego del desarrollo comunitario".

${ }^{818}$ CEA, J. Op. Cit., p. 161

${ }^{819}$ IBIDEM.
} 
expresión corresponde al Estado otorgar asistencia jurídica... del inciso tercero, concuerda con el señor Evans y la sugerencia que ha formulado, y agrega que en todo momento ha sostenido, como presidente del Colegio de Abogados, que éste desarrolla la función de defender a las personas desprovistas de recursos, en virtud de un delegación del estado, puesto que dicha entidad es una persona jurídica de derecho público que está realizando una función propia del Estado, por lo que en principio, no observa ningún inconveniente o contradicción con la constitucionalidad al preceptuar que corresponde al Estado prestar la asistencia jurídica a quien no esté en condiciones de proporcionársela por sí mismo"820. Añadió el autor de la moción que "prefiere la sustitución propuesta por el señor Evans, por cuanto existe inclinación en muchas mentalidades, incluso ilustradas, a confundir el Estado con el gobierno, y a pesar que cada vez que se otorgan atribuciones al Estado, se están concediendo a quienes accidentalmente, en forma transitoria, se encuentran en un momento histórico a cargo de la instrumentación jurídica gubernamental, que integra a su vez, el Estado"821.

Es importante destacar que la CENC, después del debate correspondiente, acordó que sería la ley y no el Estado quien arbitraría los medios. Lo anterior en la actualidad se concretiza con lo regulado por las leyes que crean los servicios de asistencia jurídica gratuita. No hubo objeción que el articulado constitucional contemplará la defensa y el asesoramiento, a quienes no puedan procurársela por sí mismo y la frase ilativa "para hacer efectivo los derechos que las leyes le reconocen". Es preciso indicar, que el Consejo de Estado fue el organismo que revisó el ante proyecto de esta Comisión optó por eliminarla, sin dar ninguna justificación al respecto, como fue la tónica de la revisión de este Consejo a las propuestas de la CENC. Si bien la doctrina no se ha esmerado en pronunciarse sobre los motivos de esta supresión, estos parecieran apuntar a la escasa expertiz técnica jurídica de los integrantes del Consejo de Estado. A nuestro juicio esta

\footnotetext{
${ }^{820}$ EVANS, E. Op. Cit., p. 164. "Insiste en que no advierte ninguna contradicción, en principio, en este aspecto con relación a la práctica y la continuación del régimen actual que entrega al Colegio de Abogados, persona jurídica de derecho público, la realización de un servicio de asistencia judicial, porque forma parte integrante del Estado, si acaso se concibe en toda amplitud de su ordenamiento jurídico”.

${ }^{821}$ IBIDEM. p.165.
} 
supresión le resta operatividad al precepto, pues guardaba armonía con la urgencia de efectividad de las normas formalmente declaradas, no obstante que en mérito de una interpretación en clave de derechos humanos y acorde al bloque de constitucionalidad, indiscutiblemente la preceptiva orienta la asistencia jurídica gratuita del Estado hacía la efectividad de los derechos que las leyes reconocen y de esta forma debería ser interpretada.

Por último es dable consignar que el actual precepto después de la discusión dentro de la CENC, indica que la ley arbitrará los medios para otorgar asesoramiento y defensa jurídica a quienes no pueden procurárselos por sí mismos, siendo que la moción original se refería a que correspondería al Estado otorgar asistencia jurídica gratuita a quienes, para hacer efectivos los derechos que las leyes les reconocen, no puedan prestárselos por sí mismos. Para entender los alcances de la inclusión de las frases "defensa y asesoramiento", debemos mencionar, que según el diccionario de la Real Academia de la Lengua Española, asesorar es dar consejo o dictamen; tomar consejo del letrado asesor, o consultar su dictamen; dicho de una persona, tomar consejo de otro, o ilustrarse con su parecer. En este sentido, el comisionado Sergio Diez enfatizó la relevancia de incluir las frases "defensa y asesoramiento" 822 . Silva, recepcionando las sugerencias de los otros integrantes, propuso que el numerando en estudio consignará los conceptos de asistencia y asesoramiento, a lo que el Evans respondió que "es necesario la expresión defensa que ya se recoge en el inciso segundo del artículo en referencia, y tiene la impresión que el concepto defensa es más completo y que permitiría una intervención más amplia del letrado, porque asistir y asesorar son términos sinónimos según el diccionario. En cambio, el concepto defensa implica una actividad activa del abogado, que requiere compenetrarse de los antecedentes; entrevistarse y estar en contacto con su defendido y hacer valer los derechos de éste"823. A su vez Diez,

\footnotetext{
${ }^{822}$ ACTAS CONSTITUCIONALES. Sesión 103. p. 4. “...la asistencia puede interpretarse como un consejo, recomendación o informe que se entrega a una persona para que haga valer sus derechos. Este asesoramiento corresponde a una intervención anticipada y de calidad de parte del letrado, cuya finalidad es dar a conocer a quien se siente lesionado en sus derechos, las distintas alternativas que el sistema judicial le presenta; pero no sólo derechos; pero no solo cuando exista un bien jurídico lesionado, sino que este asesoramiento también abarca el consejo especializado ante algún requerimiento distinto a la antesala de un litigio”.

${ }^{823}$ IBIDEM.
} 
sostiene que "el concepto de defensa requiere asumir la representación del defendido. Por eso le agrada esta expresión, ya que lo importante es que el defendido pueda ser representado por el abogado" ${ }^{24}$. Finalmente Diez se pronuncia en el sentido siguiente: "existen muchos casos de asistencia en que solo se dan consejos, como los de jurisdicción voluntaria y adopción; pero hay muchos otros que son de defensa, en que se asume el patrocinio y la representación del ofendido"825. En conclusión, se aprecia que la intención de la CENC era establecer por parte del letrado una intervención de carácter integral.

\subsection{Regulación normativa de la Asistencia Jurídica Gratuita conforme al bloque de constitucionalidad chileno}

En base a este tópico se pretende analizar cómo se encuentra configurada la obligación del Estado de asegurar el derecho a la defensa jurídica a todas las personas, en el DIDH y en el derecho constitucional chileno, entendiendo que forma parte de un todo indisoluble de acuerdo a la teoría ampliamente adherida, que acepta la idea del bloque de constitucionalidad y la supremacía constitucional.

Las normas que específicamente consagran este derecho son los artículos $11 n^{0} 1$ de la Declaración Americana de Derechos Humanos, artículo 14.3.d) del PIDCP, y el artículo 8.2.e) de la CADH.

a) Declaración Americana de Derechos Humanos: Artículo $11 \mathrm{n}^{\circ}$ 1: "Toda persona acusada de un delito tiene derecho a que se presuma su inocencia mientras no se pruebe su culpabilidad, conforme a la ley y en juicio público en el que se le hayan asegurado todas las garantías necesarias para su defensa.

b) PIDCP: Artículo $14 \mathrm{n}^{\circ}$ 3: "Durante el proceso, toda persona acusada de un delito tendrá derecho, en plena igualdad, a las siguientes garantías mínimas: A hallarse presente en el proceso y a defenderse personalmente o ser asistida por un defensor de su

\footnotetext{
${ }^{824}$ IBIDEM.

${ }^{825}$ ACTAS CONSTITUCIONALES. Sesión 103. p.5.
} 
elección; a ser informada, si no tuviera defensor, del derecho que le asiste a tenerlo, $y$, siempre que el interés de la justicia lo exija, a que se le nombre defensor de oficio, gratuitamente, si careciere de medios suficientes para pagarlo".

c) $\mathrm{CADH}$. Artículo 8. "Garantías Judiciales. $n^{\circ}$ 2: Toda persona inculpada de delito tiene derecho a que se presuma su inocencia mientras no se establezca legalmente su culpabilidad. Durante el proceso, toda persona tiene derecho, en plena igualdad, a las siguientes garantías mínimas: e) Derecho irrenunciable de ser asistido por un defensor proporcionado por el Estado, remunerado o no según la legislación interna, si el inculpado no se defendiere por sí mismo ni nombrare defensor dentro del plazo establecido por la ley".

d) CEDH: Si bien, se entiende que no es obligatorio para nuestro país, por haberse acogido las interpretaciones que se han hecho del mismo por los órganos de protección regionales, se hará mención al articulado correspondiente.

Artículo 6. $\mathrm{n}^{\circ}$ 3: "Todo acusado tiene, como mínimo, los siguientes derechos: A defenderse por sí mismo o a ser asistido por un defensor de su elección y, si carece de medios para pagarlo, a poder ser asistido gratuitamente por un abogado de oficio, cuando los intereses de la justicia así lo exijan".

\section{CRÍTICAS A LA ASISTENCIA JURÍDICA GRATUITA EN CHILE}

Sin perjuicio que el análisis de falencias se desarrollará en el Capítulo VI, al analizar en particular cada una de las instituciones o servicios de asistencia jurídica gratuita en Chile, especialmente las CAJ y abogado de turno, mencionaremos a continuación algunas críticas generales que se han formulado a la concesión de este derecho-beneficio.

a) Soledad de la Asistencia Legal: Las instituciones de la asistencia jurídica gratuita adolecen de un carácter atomizado o solitario que se traduce en la existencia de un 
grupo de instituciones que funciona casi totalmente de manera independiente ${ }^{826}$. En nuestro país el problema reside básicamente en la falta de mecanismos de evaluación del trabajo realizado, lo que hace dificultoso detectar las deficiencias y virtudes de una u otra institución, impidiendo a su vez la creación de planes de integración entre todas ellas ${ }^{827}$.

b) Pasividad de los servicios: La pasividad de los servicios de asistencia jurídica gratuita presenta diversas formas de expresión, dentro de las cuales consideramos las siguientes:

b1) En su actuar limitan su atención solamente a las personas que concurren por sus propios medios a sus oficinas, por lo tanto, en la medida que un potencial usuario desconozca la existencia de los consultorios jurídicos, no habrá ayuda de ningún tipo para ese caso, pues no se contempla el acercamiento de las centros de atención a las personas, dentro del sistema general de asistencia jurídica gratuita, así como tampoco la relación con otras instituciones vinculadas con la atención de personas de escasos recursos, tales como municipalidades, escuelas, carabineros, iglesias, etc. Además esta característica de pasividad, se refleja en un tratamiento rutinario o poco creativo que se da en los casos que se reciben, puesto que se limitan a aquellos problemas o materias que los clientes consideran susceptibles de ser tratadas por los abogados, es decir, los requerimientos de asesoramiento legal dependen de las expectativas que los clientes tienen del rol y función de los abogados.

b2) Falta de participación del usuario en las decisiones y seguimiento de sus casos: Esta pasividad se debería en parte a que el sistema de asistencia jurídica gratuita está diseñado para ser pasivo. Un crecimiento de demandas terminaría por colapsar

\footnotetext{
${ }^{826}$ No tienen comunicación entre ellos, ni dentro del país, ni en el hemisferio. Esto debido a que no existen programas de cooperación o coordinación que tiendan a un trabajo en conjunto o planificaciones globales que naturalmente propendan al mejoramiento del acceso a la justicia.

${ }^{827}$ Ejemplo de este carácter atomizado lo constituyen las CAJ, que como se dirá, existen 4 CAJ en el país. Cada uno tiene sus consultorios jurídicos separados, algunas veces coincidiendo en las comunas beneficiadas, cada uno se propone sus propias metas, elabora sus programas de asistencia, etcétera.
} 
el sistema, debido a que no cuenta con la capacidad física ni profesional para encarar una mayor afluencia de público. Pese a esto, creemos necesario superar esta pasividad aunando esfuerzos tendientes a difundir la existencia de servicios gratuitos, investigar los posibles problemas legales que aquejan a las personas, y buscar vías de participación de los beneficiarios reales o potenciales, que aumente el conocimiento de los procesos legales y burocráticos, promoviendo la idea de que son sujetos de derecho y no entes pasivos de caridad ${ }^{828}$. En todo caso nada de esto será posible si no se cuenta con un mayor financiamiento.

c) Inexistencia de un adecuado sistema de difusión: La divulgación del derecho y de las instituciones que proporcionan asistencia legal gratuita en nuestro país no es comparable en cantidad y calidad, con la promoción de servicio de otros ejes relevantes del servicio social, como la salud, previsión y educación, derivado de la pasividad que caracteriza a estos organismos de asistencia jurídica gratuita y el escaso interés en la difusión a nivel masivo de las funciones que realizan. La legislación chilena solo establece la presunción de que "la ley es conocida por todos", pero como muy bien sabemos esta suposición de conocimiento de las leyes no se materializa, porque la mayoría no recibe la información, y además, porque aquellos pocos que la reciben, no la entienden adecuadamente, y por lo tanto, malamente pueden traducirla a su favor, en cuanto a ejercicio real y efectivo de las prerrogativas que se les confiere por el ordenamiento jurídico ${ }^{829}$ Estamos ciertos que el no implementar políticas de difusión constituyen negligencia de estas instituciones, ya que se desaprovecha la optimización de un servicio instaurado con inversión de recursos y esfuerzos provenientes no solo del Estado, sino que de la población toda. La información masiva influiría positivamente en la concurrencia de los individuos interesados en solucionar sus problemas. Sin sistemas de difusión, es poco probable que las personas se enteren de la existencia de dichas entidades,

\footnotetext{
${ }^{828}$ BATES, L. Reflexiones sobre el problema de la asistencia legal en Chile. Op. Cit., p.26

829 En este ámbito, de nada sirve consagrar en la ley la creación de órganos y mecanismos que otorguen asesoramiento a las personas de escasos recursos, si ellos, los beneficiados, ignoran su existencia.
} 
su ubicación, el servicio que prestan, quienes son beneficiarios, requisitos que se exigen para su atención, etcétera.

d) Falta de recursos: Las instituciones de asistencia jurídica gratuita carecen de recursos económicos necesarios para otorgar una mayor y mejor cobertura asistencial. Ello se debe, por una parte, a la falta de conciencia pública sobre la importancia que la asistencia jurídica gratuita puede tener en la calidad de vida de las personas pobres y, por la otra, la creencia generalizada de que la única fuente de financiamiento se encuentra en el presupuesto de la nación. El Estado ha incluido restringidamente dentro de las políticas sociales el ámbito de la justicia, y si bien, los gobiernos de los años 1990 a la fecha (retorno a la democracia), han destacado el retraso del área judicial, lo cierto es que nada parece ser suficiente para paliar las deficiencias existentes.

e) Materia poco estudiada: La asistencia jurídica gratuita se constituye en una materia insuficientemente estudiada en Chile. Estudios, investigaciones y publicaciones son escasas. Por consiguiente aparece como uno de los problemas más desconocidos de nuestro medio, ya que muchos de los aspectos que lo componen no se solucionan, debido a la falta de conocimiento y ausencia de ideas creativas.

f) Insuficiencia de la labor específica de las Universidades como instituciones que forman a los futuros abogados: La forma como los futuros abogados aprenden el derecho, durante su paso por las escuelas de derecho, determina su competencia profesional. En el ámbito de la asistencia jurídica gratuita, la labor de las Universidades no está bien enfocada, ya que los estudiantes terminan su formación académica sin contar con una experiencia práctica importante, que les permita realizar la tramitación judicial que requiere todo juicio y aplicar los conocimientos teóricos al caso concreto con un sentido social, incluyendo la etapa de asesoría al interesado. De hecho, muchas Universidades no contemplan dentro de su malla curricular la enseñanza clínica, por considerarlo una forma inferior de educación, entendiendo la labor académica solo cómo la enseñanza de las normas legales y la manipulación de la doctrina, con exclusión de los hechos. Pero es necesario tener 
conciencia del peligro que significa formar abogados sin entrenamiento y sin experiencia, pues difícilmente estarán en condiciones de enfrentar las exigencias que implica el ejercicio de la abogacía y el compromiso ético con las personas que deban representar. La enseñanza práctica proporciona al estudiante hábitos, destrezas y criterios que se relacionan con su capacidad ético profesional y con sus habilidades profesionales y de litigación, tanto escrita y predominante oral, por la inclusión de procedimientos de este carácter en la mayoría de las competencias jurisdiccionales. A nuestro parecer, sin esta formación práctica se genera una desvinculación del estudiante, futuro abogado, con la realidad jurídica, atentando contra su cabal formación y rol que deberá desempeñar en la sociedad.

El Estado al asumir el compromiso del asesoramiento y defensa jurídica con los más necesitados, lo hace como vía para disminuir las limitantes de la igualdad, pero no se puede olvidar que un derecho no es una limosna. Por lo mismo, se debe prestar un servicio digno, integral y eficiente. En fin, la gratuidad no puede dar paso a la mediocridad. 


\section{CAPÍTULO V. CONFORMIDAD CONSTITUCIONAL Y CONVENCIONAL DE LA ASISTENCIA JURÍDICA GRATUITA EN CHILE}

\section{ESTÁNDARES DE ASISTENCIA JURÍDICA GRATUITA CONFORME AL BLOQUE DE CONSTITUCIONALIDAD}

En el apartado 5 del Capítulo I de la presente tesis nos esmeraremos constatar la conformidad entre la ley chilena y la norma protectora internacional, respecto del aseguramiento del derecho a la asistencia jurídica gratuita, desde la perspectiva del bloque de constitucionalidad de derechos fundamentales que rige en nuestro país,

Tal como lo señala Daniel O' Donnell, quien fuera Alto Comisionado de la ONU para los Derechos Humanos, la garantía de asistencia letrada gratuita figura entre los elementos esenciales del debido proceso que están comprendidos en el derecho a ser oído con las debidas garantías del artículo 8 de la $\mathrm{CADH}^{830}$.

Si bien las normas nacionales e internacionales son claras en cuanto a la existencia de la garantía de asistencia jurídica gratuita y la obligación correlativa del Estado en cuanto a brindarla, existen ciertas interrogantes respecto de la interpretación y aplicación que surgen a su respecto.

Justamente, estas respuestas son las que configuran los estándares de asistencia jurídica gratuita a los que adhiere Chile, en virtud de su texto constitucional y a su bloque de constitucionalidad, las que nos esmeraremos en dilucidar, y de esta forma corroborar si existe en materia de asistencia jurídica gratuita en Chile armonía con las exigencias del derecho constitucional y convencional.

a) Existencia o no de requisitos para ejercer este derecho y alcance de la carencia de medios económicos e irrenunciabilidad: Los tratados internacionales reconocen la obligación del Estado a asegurar defensa jurídica a todas las personas sin

830 O’DONELL, D (2007). Derecho internacional de derechos humanos. Normativa, Jurisprudencia y doctrinas de los Sistemas universal e interamericano. Oficina México del alto comisionado de derechos humanos. p. 406. 
discriminación, lo que en algunas ocasiones se traducirá en el otorgamiento concreto de defensa de oficio o prestada a nombre del Estado, debiéndonos preguntar bajo qué condiciones se produce este otorgamiento.

Ante esta interrogante, los instrumentos internacionales entregan diversas respuestas. Tanto el PIDCP como el CEDH reconocen la circunstancia del menoscabo económico como requisito, exigiendo además que lo requiera el interés de la justicia. La CADH en cambio no menciona estos criterios, y así el artículo 8 consagra el "derecho Irrenunciable" a recibir la asistencia letrada por parte del Estado.

Como bien se observa, la CADH acorde a su redacción resulta ser más garantista, por cuanto establece este derecho como irrenunciable, al señalar que se configura la exigencia de esta prerrogativa, "si el inculpado no se defendiere por sí mismo ni nombrare defensor dentro del plazo establecido por ley". La CADH no hace mención ni condiciona la asistencia de un abogado de oficio a la situación económica del acusado, permitiendo de esta forma ejercitar este derecho cuando lo requiera y así lo considere. De todas formas, si bien la jurisprudencia interamericana no ha tenido la oportunidad de definir el término irrenunciable, es importante tener en cuenta que a la luz de la OC 11/90 "las circunstancias de un procedimiento particular, su significación, su carácter y su contexto en un sistema legal particular son factores que fundamentan la determinación de si la representación legal es o no necesaria para el debido proceso" ${ }^{331}$. Es decir, este carácter de irrenunciable no será a todo evento, lo que guarda relación con el derecho de defenderse personalmente y con el alcance del deber correlativo del Estado de entregarle esta asistencia jurídica gratuita, la que puede limitarse por las circunstancias de un procedimiento particular, su carácter, contexto, etcétera. En el derecho chileno se presenta en consecuencia

\footnotetext{
${ }^{831}$ CORTE IDH. OC 11-90. Op. Cit., Párrafo 28: “ En materias que conciernen con la determinación de [los] derechos y obligaciones de orden civil, laboral, fiscal o de cualquier otro carácter el artículo 8 no especifica garantías mínimas, como lo hace en el numeral 2 al referirse a materias penales. Sin embargo, el concepto de debidas garantías se aplica también a esos órdenes y, por ende, en ese tipo de materias el individuo tiene derecho también al debido proceso que se aplica en materia penal. Cabe señalar aquí que las circunstancias de un procedimiento particular, su significación, su carácter y su contexto en un sistema legal particular, son factores que fundamentan la determinación de si la representación legal es o no necesaria para el debido proceso”.
} 
que una persona puede solicitar obrar con privilegio de pobreza y beneficiarse gratuitamente del servicio de abogados y otros funcionarios, pero será la ley quién determinará si en un caso concreto atendiendo a su materia, es o no indispensable contar con abogado, siendo irrenunciable como se ha dicho, en materia penal ${ }^{832}$. Conforme con la $\mathrm{CADH}$ al tratarse de un derecho irrenunciable, el Estado está obligado de proveer un abogado de oficio a todo imputado que lo necesita en todo el territorio bajo su jurisdicción. Esto se hace aún más necesario en los lugares de difícil acceso, donde no existen profesionales o estos son escasos, no disponiéndose de recursos económicos suficientes para que el individuo pueda ejercer su derecho de defensa contando con un abogado ${ }^{833}$.

O' Donnell expresa que "las disposiciones de los instrumentos internacionales relativas a este derecho presentan diferencias significativas. EI PIDCP establece dos requisitos para el goce de este derecho, por una parte que el acusado carezca de medios para sufragar los honorarios de un defensor, y por otro, que el 'interés de la justicia' exija el nombramiento de un defensor gratuito (inciso d del párrafo 3 del art.14)" "834. Ninguna de estas condiciones figura en la disposición correspondiente de la CADH que reconoce el derecho irrenunciable de ser asistido por un defensor proporcionado por el Estado, remunerado o no según la legislación interna, si el inculpado no se defendiere por sí mismo ni nombrare defensor dentro del plazo establecido por la ley (inciso e, párrafo 2 del art.8).

En cuanto a la existencia de recursos económicos como condicionante para la gratuidad de la asistencia jurídica en Chile, en caso de la concesión del privilegio de pobreza judicial, será el juez el que ponderará su concesión en base a determinados factores y en el caso, del privilegio de pobreza legal, será la ley quién establecerá los casos en que opera en forma automática. Tal como se ha indicado, tanto las CAJ y la DPP, determinarán internamente según criterios de focalización propias si

\footnotetext{
832 Desde la perspectiva de las garantías judiciales penales, este derecho se caracteriza por ser irrenunciable cuando el inculpado no se defendiere por sí mismo ni nombrare defensor dentro del plazo establecido por la ley, en cuyo caso tiene el derecho de que el Estado proporcione uno.

${ }^{833}$ QUISPE. F. Op. Cit., p. 349.

${ }^{834}$ O’DONNELL, D. Op. Cit., p. 410.
} 
una persona puede ser atendida gratuitamente por el servicio de asistencia jurídica ${ }^{835}$. Además al no existir ley que indique que materias debe cubrir cada servicio, se podría pensar que su cobertura será universal, pero esta situación quizás ideal, es impracticable, porque se debe ponderar en atención con la disponibilidad de recursos humanos y financieros, cuantía o valor de la cosa disputada, etcétera. En este sentido se faculta a las propias instituciones regular y establecer materias de exclusión, como ocurre en las CAJ con materias específicas, especialmente las relativas a los instrumentos bancarios, juicios particionales y liquidaciones de sociedades, entre otras.

En este ámbito, resultan muy necesarias las reflexiones de Osvaldo Gozaíni en cuanto a la procedencia del derecho a ser oído, que se vincula al derecho a tener abogado, lo que justifica su carácter de irrenunciable. Considera el autor "vulnerado el derecho a ser oído cuando la persona no tiene representante legal que lo asista, ni el Estado se lo proporciona en condiciones suficientes para salvaguardar el ejercicio efectivo de la defensa" ${ }^{836}$. De este modo la CADH garantiza el derecho al

\footnotetext{
835 También puede ocurrir que una persona no teniendo recursos, es notificada de una demanda y no concurre a instituciones que brindan la asistencia jurídica gratuita, en representación y con recursos del Estado, existiendo en ese caso una renuncia expresa a su derecho, debiéndose continuar el proceso en su rebeldía. En cambio en materia penal es un requisito de validez del proceso la comparecencia con abogado defensor, y en caso que la persona asista sin abogado, independiente de su situación económica, el juez debe asignarle un defensor del Estado, sin perjuicio del derecho de repetición que tiene en este caso, la Defensoría Penal Pública contra esta persona.
}

${ }^{836}$ GOZAINI, O. (2017). El Debido Proceso. Estándares de la Corte Interamericana de Derechos Humanos. Buenos Aires. Rubinzal - Culzoni Editores. pp. 293-294. Cita oportunamente, el caso Benedict Jacobs vs Grenada, en que los peticionarios argumentaron ante la CIDH, que no existe asistencia letrada efectiva para acciones constitucionales ante los tribunales de Grenada y que esto constituye una violación del señor Jacobs a un juicio imparcial consagrado en el artículo 8 de la Convención. Sobre la base de la información que tuvo ante sí, la Comisión se manifiesta satisfecha de que una acción constitucional que involucre cuestiones legales de la naturaleza que plantea el sr. Jacobs en su petición, como el derecho al debido proceso y a la pertinencia de sus condiciones carcelarias, son procesal y sustantivamente complejas y no pueden ser planteadas o presentadas efectivamente por el recluso sin contar con representación letrada. En este caso el Sr Jacobs es indigente $\mathrm{y}$ no puede por otros medios obtener representación letrada para emprender acciones constitucionales". Se expresó también en este informe, que el requisito de una audiencia imparcial en el tribunal superior debe ser congruente con los principios del 8.2. En consecuencia, cuando un condenado procura una revisión constitucional de irregularidades en un juicio penal y carece de medios para obtener asistencia letrada a efectos de emprender una acción constitucional, y cuando los intereses de la justicia, así lo requieran, el Estado debe otorgar asistencia letrada, para garantir suficientemente el derecho a ser oído". "En este ámbito se destaca que se refiere al 'interés de la justicia' que no es una expresión que ocupa la Convención, pero se debe entender en lo especifico, en el carácter del proceso en cuestión, según lo que se desprende del párrafo 28 de la OC 11/90 
abogado en procedimientos penales a todo evento, pero como no ordena que la asistencia legal cuando se requiera sea gratuita, un indigente se vería discriminado por razón de su situación económica si requiriendo asistencia legal, el Estado no se la provee gratuitamente. Lo dicho, se expresa en la referida OC 11/90, expresando que "hay que entender por consiguiente que el artículo 8 exige la asistencia legal solamente cuando esta es necesaria e imperiosa para que se pueda hablar de debidas garantías y que el Estado no lo provea gratuitamente cuando se trata de un indigente, no podrá argüir en su favor luego que dicho proceso existe pero no fue agotado".

En la citada OC 11/90, se expresa que "puede que en un caso el Estado otorgue asistencia legal gratuita, pero no los costos que sean necesarios para que el proceso sea el debido que ordena el artículo 8"837. Además, la Corte IDH, señaló que el artículo 8 exige asistencia legal solamente cuando esta es necesaria ${ }^{838}$. Se concluye en esta OC que "aun en aquellos casos en los cuales un acusado se ve obligado a defenderse a sí mismo porque no puede pagar asistencia legal, podría presentarse una violación del artículo 8 de la Convención si se puede probar que esa circunstancia afectó al debido proceso a que tiene derecho bajo dicho artículo"839.

${ }^{837}$ CORTE IDH. OC 11/90. Op. Cit., Párrafo 29: “Naturalmente que no es la ausencia de asistencia legal lo único que puede impedir que un indigente agote los recursos internos. Puede suceder, incluso, que el Estado provea asistencia legal gratuita, pero no los costos que sean necesarios para que el proceso sea el debido que ordena el artículo 8. En estos casos también la excepción es aplicable. Aquí, de nuevo, hay que tener presentes las circunstancias de cada caso y de cada sistema legal particular.

${ }^{838}$ IBIDEM. Párrafo 28: "En materias que conciernen con la determinación de [los] derechos y obligaciones de orden civil, laboral, fiscal o de cualquier otro carácter el artículo 8 no especifica garantías mínimas, como lo hace en el numeral 2 al referirse a materias penales. Sin embargo, el concepto de debidas garantías se aplica también a esos órdenes y, por ende, en ese tipo de materias el individuo tiene derecho también al debido proceso que se aplica en materia penal. Cabe señalar aquí que las circunstancias de un procedimiento particular, su significación, su carácter y su contexto en un sistema legal particular, son factores que fundamentan la determinación de si la representación legal es o no necesaria para el debido proceso”.

${ }^{839}$ IBIDEM. Párrafo 27: "En materias que conciernen con la determinación de [los] derechos y obligaciones de orden civil, laboral, fiscal o de cualquier otro carácter el artículo 8 no especifica garantías mínimas, como lo hace en el numeral 2 al referirse a materias penales. Sin embargo, el concepto de debidas garantías se aplica también a esos órdenes y, por ende, en ese tipo de materias el individuo tiene derecho también al debido proceso que se aplica en materia penal. Cabe señalar aquí que las circunstancias de un procedimiento particular, su significación, su carácter y su contexto en un sistema legal particular, son factores que fundamentan la determinación de si la representación legal es o no necesaria para el debido proceso”. 
En el caso de la comunidad Yakye Axa vs Paraguay, en relación con la denuncia que tuvieron que enfrentar los miembros de la comunidad indígena referenciada, se detalla que el hecho de que se hayan realizado diligencias probatorias como declaraciones de testigos, levantamientos de datos de las personas acusadas, inspecciones en el lugar de los hechos, decomisos de bienes de las personas acusadas, el levantamiento de las viviendas de la comunidad además de otorgamiento de medidas provisionales a favor de la parte denunciante sin que los miembros de la comunidad Yakye Axa fueran oídos y participaran a través de un abogado de sus elección (a pesar de sus reiteradas peticiones en este sentido), resulta violatorio del artículo 8 de la $\mathrm{CADH}$. Además, los miembros de la comunidad no pudieron presentar pruebas de descargo ni interrogar a los testigos propuestos por la contraparte" ${ }^{840}$. Los autores Diana Montero y Alonso Salazar ${ }^{841}$, comentan en esta línea argumentativa la referida sentencia.

${ }^{840}$ Corte IDH. Caso Comunidad Indígena Yakye Axa Vs. Paraguay. Sentencia de 17 de junio 2005, Párrs. 115, 116. Párrafo 115: "Como ha quedado demostrado, el proceso penal en contra de miembros innominados de la Comunidad Yakye Axa inició el 16 de marzo de 1999 con la denuncia que presentó el representante legal de la firma Livestock Capital Group Inc (supra párr. 50.79). El 22 de marzo de 1999 el Juez dio apertura al sumario. El 3 de mayo de 1999 los líderes de la Comunidad, reconocidos como tales por el INDI, designaron abogado a fin de que los representara en el proceso penal referido, lo cual fue aceptado en un inicio por el Juez de la causa. No obstante, frente a la oposición de la parte actora, el Juez revocó su providencia anterior e impidió la expedición de fotocopias al letrado de la Comunidad (supra párr. 50.81). Los días 5 y 11 de septiembre de 2000 el abogado de la Comunidad volvió a solicitar la intervención en el proceso penal y solicitó se expidan fotocopias de lo actuado hasta esa fecha. El 11 de septiembre del mismo año el Juez declaró "no ha lugar” la solicitud de intervención. El 15 de septiembre de 2000 el abogado de la Comunidad interpuso un recurso de apelación contra la providencia que denegó su participación, recurso que fue rechazado por el Juez el 18 de septiembre de 2000 (supra párr. 50.86)”. Párrafo 116: “Durante el referido proceso penal se llevaron a cabo varias diligencias probatorias, entre ellas, declaraciones de testigos, levantamientos de datos de los miembros de la Comunidad, inspecciones en el lugar de los hechos (supra párrs. 50.80, 50.82 y 50.83). De igual forma, se otorgaron medidas provisionales a favor de la parte actora, consistentes en la prohibición de ingreso de los miembros de la Comunidad al territorio de la Estancia Loma Verde (supra párr. 50.85); se decomisaron varios cajones de apicultura pertenecientes a la Comunidad (supra párr. 50.84), y se ordenó el levantamiento de las viviendas de la Comunidad (supra párr. 50.87). Todas estas gestiones se llevaron a cabo sin que los miembros de la Comunidad Yakye Axa fueran oídos y participaran a través de un abogado de su elección. Asimismo, los miembros de la Comunidad no pudieron presentar pruebas de descargo ni interrogar a los testigos propuestos por la contraparte. Esta indefensión de los miembros de la Comunidad se prolongó hasta el 14 de septiembre de 2001, cuando el Juez aceptó la participación del INDI como representante de la Comunidad Yakye Axa (supra párr. 50.88). De acuerdo con el expediente obrante en el presente caso, la causa penal no prosiguió más allá del sumario”.

${ }^{841}$ MONTERO, D; SALAZAR, A (2013). Derecho de Defensa en la Jurisprudencia de la Corte Interamericana de Derechos Humanos. San José de Costa Rica, Editorial Isolma. p.118. 
Respecto del derecho de hacerse representar ante el órgano competente en pos de ejercitar sus derechos laborales a favor de un migrante, la irrenunciabilidad de este derecho resulta esencial, pues de lo contrario se le pone en una situación de vulnerabilidad y discriminación con respecto a trabajadores nacionales ${ }^{842}$.

En este orden de ideas, la OC 18/03 acentúa el papel que debe jugar el principio de igualdad de armas en todo proceso, con miras a atenuar los factores de desigualdad real que puedan obstaculizar el goce y ejercicio efectivo de los derechos de los litigantes $^{843}$. Por su parte, la Corte IDH en la OC $16 / 99$ ha dejado sentado con claridad el principio de igualdad de armas, destacando que "la presencia de condiciones de desigualdad real obliga a los Estados a adoptar medidas de compensación que contribuyan a reducir o eliminar los obstáculos y deficiencias que impidan o reduzcan la defensa eficaz de los propios intereses. Esto es así, pues de no existir esos medios de compensación en los procedimientos, las personas que se encuentran en una situación de desventaja o vulnerabilidad, no podrían hacer uso en condiciones de igualdad a las garantías del debido y acceder a la justicia"844. De lo ampliamente razonado en este punto, y de la exigencia de requisitos para optar a la asistencia jurídica gratuita otorgada por el Estado, se desprenden dos interpretaciones en cuanto al alcance de la obligación estatal y a la irrenunciabildad de este derecho, según lo resuelto por la propia Corte IDH. La primera permitiría

\footnotetext{
${ }^{842}$ IBIDEM.

${ }^{843}$ CORTE IDH. OC 18/03. Voto razonado de don Sergio García Ramírez. Párrafo 38: "El debido proceso, en los extremos que interesan para el objeto de la OC-18/2003, entraña, por una parte, la mayor igualdad -equilibrio, "igualdad de armas"-- entre los litigantes, particularmente importante cuando en un extremo de la contienda se halla el vulnerable trabajador migrante y en el otro el empleador dotado de derechos suficientes y eficientes, una igualdad que sólo se consigue --en la mayoría de los casos, que reflejan la verdadera dimensión del problema colectivo-- cuando el poder público incorpora, a través de leyes y criterios de interpretación y aplicación, los elementos de compensación o corrección a los que antes me referí; y por otra parte, el cumplimiento claro y fluido del deber que tiene el Estado de brindar el servicio de justicia, sin distinción y mucho menos discriminación, que entrañaría, de entrada, la derrota del justiciable débil”.

${ }^{844}$ CORTE IDH. OC 16/99. Párrafo 119: "Para alcanzar sus objetivos, el proceso debe reconocer y resolver los factores de desigualdad real de quienes son llevados ante la justicia. Es así como se atiende el principio de igualdad ante la ley y los tribunales y a la correlativa prohibición de discriminación. La presencia de condiciones de desigualdad real obliga a adoptar medidas de compensación que contribuyan a reducir o eliminar los obstáculos y deficiencias que impidan o reduzcan la defensa eficaz de los propios intereses. Si no existieran esos medios de compensación, ampliamente reconocidos en diversas vertientes del procedimiento, difícilmente se podría decir que quienes se encuentran en condiciones de desventaja disfrutan de un verdadero acceso a la justicia y se benefician de un debido proceso legal en condiciones de igualdad con quienes no afrontan esas desventajas".
} 
eximir al Estado de la obligación de otorgar asistencia jurídica gratuita, cuando tanto factores externos como internos del procedimiento permitan concluir que esa defensa no es necesaria para respetar el debido proceso. La segunda regla, es que esas mismas circunstancias pueden hacer exigible al Estado el otorgamiento de defensa aunque no concurra el requisito del menoscabo económico.

A la luz de las reflexiones de O'Donnell, colegimos que "tradicionalmente se ha entendido que el Estado es quien desarrolla la actividad estatal de asistencia jurídica gratuita como un servicio destinado exclusivamente a los pobres, pero lo cierto es que esa labor pública corresponde al cumplimiento de una obligación estatal de asegurar el derecho a la defensa y debido proceso, en términos de igualdad y no discriminación" ${ }^{\prime 45}$.

Otro requisito para otorgar defensa a través del Estado consiste en que lo exija "el interés de la justicia". Este término no ha sido definido por la jurisprudencia universal ni europea que los han acuñado en sus textos, pero si se desprende de la lectura normativa y se ha expresado en algunos casos jurisprudenciales, en cuanto que la asistencia jurídica gratuita se exige por el interés de la justicia. Debido a esta necesidad por el interés de justicia, parece razonable también extender esta interpretación para el caso de penas privativas de libertad (debido a la gravedad de la intervención en el cuerpo del sujeto).

La jurisprudencia del Comité de Derechos Humanos arroja luz sobre los criterios que permitan determinar cuando la representación es necesaria para el interés de la justicia. Se establece claramente que la asistencia letrada gratuita es imprescindible en toda etapa de los procesos por los delitos castigados con la pena de muerte ${ }^{846}$. Por ende, no se reconoce en este interés por la justicia el derecho a un defensor de oficio para infracciones castigadas con multa ${ }^{847}$. EI TEDH, no obstante la exigencia de "no tener los medios para pagarlo" considera que esta

${ }^{845}$ O’DONELL. Op. Cit., p.410.

${ }^{846}$ COMITÉ DE DERECHOS HUMANOS. Caso Taylor Vs Jamaica Sentencia de 2 de abril de 1998. Párrafo 7. 5: "El derecho a un defensor de oficio para entablar un recurso de inconstitucionalidad, contra de una sentencia, después de haber agotado las instancias de apelación”.

${ }^{847}$ O’DONELL. D. Op. Cit., p. 411. 
garantía es mucho más amplia que la garantía del abogado defensor de oficio, por cuanto es obligatoria ante cualquier infracción al margen de la gravedad y poco o nada tienen que ver con los recursos económicos del imputado para contar con este derecho" 848 . Es más, según este tribunal es un derecho que va más allá del proceso o de las audiencias, e incluso abarca las relaciones entre el abogado y su defendido respecto de todas las declaraciones ${ }^{849}$.

b) Amplitud procesal de la asistencia letrada del Estado: A la luz de la CADH, se trata de un derecho irrenunciable, pero reconocido en ese carácter, solo para los procesos penales. Sin perjuicio de lo anterior, ello no significa que su importancia sea menos trascendente en procesos de otra naturaleza, como bien determinó la jurisprudencia internacional de los derechos humanos y la jurisprudencia del derecho interno ${ }^{850}$. Es menester recordar el pronunciamiento de la Corte IDH en su OC 11/90 en que se establece que las debidas de garantías del numeral 2 del artículo 8, entre las cuales se contempla el derecho irrenunciable de ser asistido por un defensor proporcionado por el Estado, se aplica a los otros ordenes que establece el numeral 1, es decir, orden civil, laboral, fiscal, o de cualquier otro carácter ${ }^{851}$. Bajo esta perspectiva, el concepto de debidas garantías se aplica

\section{${ }^{848}$ IBIDEM.}

849 TEDH. Caso Poitrimol contra Francia, sentencia del 23 de noviembre de 1993. Esta sentencia deja clara la importancia de este derecho, elemento fundamental del proceso justo. Asimismo, señala que un acusado no pierde tal beneficio solo por el hecho de no estar presente en los debates.

${ }^{850}$ QUISPE. F. Op. Cit., p.426: “ El TCE, en la STC 47/87, y posteriormente en la STC 105/1996 del 11 de junio señaló que "entre las garantías que integran el derecho a un proceso justo, se incluye el derecho a la defensa y a la asistencia letrada que el artículo 24.2 de la Constitución reconoce no solo para el proceso penal sino también, con las oportunas especialidades, para el resto de los procesos, y cuya finalidad, al igual que todas las demás garantías que conforman el derecho en el que se integran, es el de asegurar la efectiva realización de los principios de contradicción e igualdad de las partes que imponen a los órganos judiciales el deber positivo de evitar desequilibrios entre la respectiva posición procesal de las partes, o limitaciones en la defensa que pueden inferir a alguna de ellas un resultado de indefensión, prohibido en todo caso en el artículo 24.1 CE”. Este Tribunal en consonancia con la doctrina del TEDH, sustentada entre otras en las sentencias de los casos Airey y Pakelli, ha señalado que, desde la perspectiva constitucional, la denegación de la asistencia letrada no conlleva si más una vulneración del artículo 24.2 CE. Y dado que la valoración de la necesidad o no del abogado de oficio depende de diversos aspectos, además de ser una obligación del juez o tribunal, no se debe perder de vista que siempre las normas legales deben interpretarse en el sentido más favorable a la efectividad de los derechos fundamentales (pro homine)".

${ }^{851}$ Sin perjuicio, que en letra de la norma, en materias que conciernen con la determinación de [los] derechos y obligaciones de orden civil, laboral, fiscal o de cualquier otro carácter el artículo 8, no especifica garantías mínimas, como lo hace en el numeral 2 al referirse a materias penales. 
también a esos órdenes y, por ende, en ese tipo de materias el individuo tiene derecho también al debido proceso que se aplica en materia penal, incluida por cierto, la asistencia jurídica gratuita.

Todos los instrumentos coinciden que en su aspecto literal se trata de un derecho que se puede ejercer solo en asuntos penales, no obstante la práctica a través de la jurisprudencia, fundamentalmente europea, que se ha extrapolado al continente americano, ha ampliado el ámbito de aplicación de este derecho más allá de su expresión litera|852. Tal como lo expresa Revenga, "aunque el artículo 6.1 del CEDH no impone la asistencia gratuita de letrado en los procesos civiles, puede obligar ello a los Estados, cuando sea imprescindible para un acceso efectivo al juez, bien porque la ley prescriba la asistencia del letrado o bien por razón de la complejidad del proceso o de la causa" ${ }^{\prime 35}$.

Es dable recalcar que las primeras partes de la CADH, el PIDCP y el CEDH establecen normas generales del debido proceso aplicables a todo tipo de procedimientos, mientras que las segundas agregan una serie de garantías específicas para los acusados en un proceso penal, entre las que se encuentra el derecho a recibir defensa de oficio, gratuita o no, bajo ciertas circunstancias.

Lamentablemente en Chile existe una identificación del derecho de asistencia jurídica gratuita a los casos netamente judiciales, y no obstante esfuerzos de cobertura de las instituciones respectivas sigue siendo necesario una aplicación más amplia en temas administrativos y en la justicia de policía local, que entre otros aspectos, tiene competencia en accidentes de tránsito y conflictos vecinales o comunitarios ${ }^{854}$.

\footnotetext{
852 TEDH. Caso Airey vs Irlanda. Sentencia de 9 de octubre de 1979. "Se obliga al Estado a proporcionar este derecho cuando sea imprescindible para un proceso justo. El TEDH señala que si bien el articulo 6.1 no garantiza la asistencia jurídica para los procesos civiles, si garantiza un derecho efectivo de acceso a los tribunales en tales causas".

853 REVENGA SANCHEZ, M. (2013) "El Derecho a la asistencia jurídica gratuita en la Jurisprudencia del Tribunal Europeo de Derechos Humanos” en http://info5.juridicas.unam.mx/ libros/6/2562/35.pdf (Consulta 25 de enero de 2019).

${ }^{854}$ En nuestro país la cobertura de este derecho no solo se circunscribe a la materia penal, sino que también se extiende a materia civil, familia y laboral. De hecho el privilegio de pobreza, la institución del abogado de tuno,
} 
c) Gratuidad de la asistencia jurídica: Sin perjuicio de ya haber sido tratada como característica la asistencia jurídica en el capítulo anterior, la gratuidad de la asistencia jurídica es un problema que se presenta a raíz de la lectura de los tratados Internacionales, radicando precisamente en la modalidad gratuita o pagada de cómo se prestará la asistencia jurídica por el Estado. Tanto el PIDCP como el CEDH señalan expresamente que esta será gratuita cuando el acusado carezca de medios suficientes para pagar los servicios de un abogado y cuando el interés de la justicia lo exija. Por otro lado la CADH no toma posición sobre la gratuidad, ya que entrega esa definición a los Estados, al reconocer la prestación de ese servicio "remunerado o no según la legislación interna". En este sentido es aclaratoria la reflexión de Quispe, en cuanto a que "la realidad económica en América Latina impide, en gran medida, el cumplimiento por parte del Estado de modo efectivo de este derecho. A contrario sensus, se hace imprescindible brindar este derecho, justamente porque en ocasiones, no cabe ni la mínima posibilidad de que la persona pueda contar con un abogado por su cuenta, debido a que es ya difícil el acceso material a la justicia por parte de estas personas"855.

En Chile, conforme a la normativa constitucional analizada, la asistencia jurídica es gratuita, cuando la persona no tiene los medios para procurársela por sí mismo ${ }^{856}$. Además, está configurada la existencia de servicios de asistencia jurídica estatal, como las CAJ, DPP y el abogado de turno. Este último circunscrito a favor de los que gozan o debieren gozar del privilegio de pobreza.

d) Defensa personal y asistencia letrada: Tal como lo hemos revisado, la defensa personal no es incompatible con la defensa jurídica y técnica, solo cuando las normas procesales la permitan, en virtud de la simplicidad del procedimiento, y a nuestro parecer, de forma complementaria y a elección del afectado, pues la

y la CAJ, cubren todas estas temáticas, salvo materias y procedimientos excluidos, por su significación, contexto legal, etcétera.

${ }^{855}$ QUISPE, F. Op. Cit., p. 430

$856 \mathrm{Tal}$, como se ha señalado las personas pueden solicitar un privilegio de pobreza ante un juez, que le permite servirse de abogados y funcionarios que el Estado les designa. Además existe un privilegio de pobreza legal para personas que se encuentren en una determinada situación de vulnerabilidad, no solo de carácter económica. 
asistencia letrada tiene por finalidad asegurar la igualdad de armas de las partes y el principio de contradicción ${ }^{857}$.

e) Derecho a ser informado de la asistencia jurídica gratuita del Estado: Esta prerrogativa de la defensa jurídica gratuita también incluye la facultad de ser informado de este derecho, y la obligación del Estado de asegurarla en términos de igualdad y no discriminación, lo que tiene sentido en atención a una mirada integral de las garantías del debido proceso.

En palabras de O' Donnell, "es claro cómo se puede observar que desde la perspectiva de la asistencia letrada, durante distintas etapas del proceso, cualquier persona acusada, no solo tiene derecho de representación, sino que tiene derecho a ser informado de su derecho de asistencia letrada" ${ }^{558}$. En opinión del mismo autor "así, todas las personas detenidas tienen derecho a la asistencia de un abogado, siendo la autoridad competente quién les informará de ese derecho prontamente, después de su arresto y les facilitará medios para ejercerlo. Además, en caso de no contar con un abogado de su elección, la autoridad judicial le nombrará uno, aun sin costo alguno, si no cuenta con medios para pagarlo" ${ }^{859}$. En nuestro país, si bien es cierto, en materia civil o de policía local, el tribunal no le informa en la primera resolución a la persona que debe contar con abogado, es una exigencia del Estado a favor del ciudadano, que este último pueda informarse de sus derechos procesales, y entre éstos se encuentra el derecho de que se le proporcione un abogado en forma gratuita en caso de no contar con los medios de contratación de un abogado particular, con la finalidad de que comparezca representado al proceso ${ }^{860}$.

\footnotetext{
${ }^{857}$ NOGUEIRA, H. El Debido Proceso en la Constitución y el Sistema Interamericano de Derechos Humanos. Op. Cit., p. 111.

${ }^{858}$ O’DONELL. D. Op. Cit., p. 409.

859 IBIDEM. p.110.

${ }^{860}$ En materia laboral y familia, los tribunales como buena práctica y sopena de continuar el juicio en su rebeldía, han incluido en su primera resolución, la orden que intima a las partes a constituir patrocinio y poder con abogado, con la advertencia de que si no tienen los recursos para proporcionárselo, puede recurrir a uno, suministrado por el Estado ${ }^{860}$.
} 
f) Posibilidad de elección del defensor de oficio: En términos generales, el Derecho Internacional de los Derechos Humanos ha establecido que la elección del letrado es un derecho comprendido dentro del derecho a la defensa. Pero cabe preguntarse si ese derecho existe en el caso de la asistencia jurídica gratuita prestada por el Estado, entendiendo que hay existencia de recursos limitados y que esa defensa opera cuando las personas no queden proveerlas por sí mismos. Desde la perspectiva de las garantías judiciales, en cuanto a la posibilidad de que el inculpado cuente con el patrocinio letrado de un defensor de su elección, la Corte IDH, en el citado caso Castillo Petruzzi vs Perú ha destacado la importancia de la comunicación libre y privada entre ambos ${ }^{861}$. Mismo razonamiento ha quedado expresado en el fallo del caso Suarez Rosero vs Ecuador, de 12 de noviembre de $1997^{862}$. Desde la perspectiva de O' Donnell, el derecho a tener un defensor de oficio no comprende el derecho a elegir el defensor que se le asigna ${ }^{863}$. La jurisprudencia interamericana ha dictaminado existir infracción al derecho irrenunciable a contar con defensor proporcionado por el Estado, cuando se persiste en la designación de

${ }^{861}$ CORTE IDH. Caso Castillo Pettruzzi vs Perú. Op. Cit., Párrs 146 y 148. Párrafo 146: "La Corte considera, tal y como ha quedado demostrado, que de conformidad con la legislación vigente en el Perú, las víctimas no pudieron contar con asistencia legal desde la fecha de su detención hasta su declaración ante la DINCOTE, cuando se les nombró un defensor de oficio. Por otra parte, cuando los detenidos tuvieron la asistencia de los abogados de su elección, la actuación de éstos se vio limitada (supra 141)”. Párrafo 148: Sin embargo, en casos en que, como en el presente, ha quedado demostrado que los abogados defensores tuvieron obstáculos para entrevistarse privadamente con sus defendidos, la Corte ha declarado que hay violación del artículo 8.2.d de la Convención”.

${ }^{862}$ CORTE IDH .Caso Suarez Rosero vs Ecuador. Op. Cit., Párrafo 83: "Debido a su incomunicación durante los primeros 36 días de su detención, el señor Suárez Rosero no tuvo la posibilidad de preparar debidamente su defensa, ya que no pudo contar con el patrocinio letrado de un defensor público y, una vez que pudo obtener un abogado de su elección, no tuvo posibilidad de comunicarse en forma libre y privada con él. Por ende, la Corte considera que el Ecuador violó el artículo 8.2.c, 8.2.d y 8.2.e de la Convención Americana”.

${ }^{863}$ CORTE IDH. Caso Kelly Vs Jamaica. Informe 15 de septiembre de 1987. Párrafo 5. 10: "En cuanto a la cuestión de la defensa del autor, en particular ante el Tribunal de Apelación, el Comité recuerda que es evidente que se debe prestar asistencia jurídica a un preso condenado a la pena de muerte. Esto se aplica a todas las etapas del procedimiento judicial. En el caso del autor resulta claro que se le asignó un abogado de oficio para la apelación. De lo que se trata es de saber si su abogado tenía derecho a abandonar la apelación sin haber consultado previamente al autor. La solicitud del autor de autorización para apelar ante el Tribunal de Apelación, de 23 de febrero de 1983, indica que éste no deseaba estar presente durante la vista de la apelación, pero que deseaba que se le asignara un abogado de oficio con ese fin. Posteriormente, y sin haber consultado antes con el autor, el abogado estimó que no había fundamentos para la apelación, dejando efectivamente así al autor sin representación legal. El Comité opina que aunque el apartado d) del párrafo 3) del artículo 14 no da derecho al acusado a elegir el defensor que se le asigna de oficio, se han de adoptar medidas para conseguir que el defensor, una vez asignado, lleve a cabo una representación eficaz en interés de la justicia. Esto supone que el abogado debe consultar al acusado cuando éste tenga la intención de desistir de un recurso y de informarle en el caso de que el recurso que pretenda interponer carezca de fundamento”. 
abogado defensor, no obstante el acusado haber manifestado su falta de voluntad en mantener la representación ${ }^{864}$. La jurisprudencia interamericana además, se ha manifestado sobre la posibilidad de que un defensor represente a más de un representado y su posible cuestionamiento de procedencia ${ }^{865}$.

En Chile no existe una norma legal o un procedimiento establecido que le permita a la persona elegir al abogado que lo asista gratuitamente a cargo del Estado. No obstante ello, puede solicitar en casos fundados la sustitución del abogado proporcionado por el juez o respecto del abogado perteneciente de la institución de asistencia jurídica gratuita que acuda. En el caso de haber sido designado por el juez, como en caso del abogado de turno, aunque es discutible, estimamos que se puede solicitar fundadamente al juez el cambio de la persona del defensor, en atención a que este derecho debe ser otorgado con estándares de calidad, y si existe una objeción fundamentada a ese respecto, y el tribunal cuenta con alternativas de designación en este sentido, no se vislumbra óbice constitucional y procesal para que lo procesa.

En caso de un abogado integrante de alguna institución de asistencia jurídica gratuita, a nuestro parecer resulta factible solicitar directamente ante las autoridades de la Institución una modificación de la persona del abogado, siempre que existan motivos fundados, quedando esta decisión al arbitrio del jefe del servicio. Estos motivos fundados, se pueden deber a una falta de imparcialidad del abogado por tener un vínculo de amistad o parentesco con la contraparte o en caso que el abogado haya evidenciado desidia en la tramitación de caso, debiéndose en este

\footnotetext{
${ }^{864}$ O’DONELL, Op. Cit., p. 411. "No obstante, puede producirse una violación de este derecho de ejercer el derecho a la defensa jurídica, cuando el tribunal continúa acreditando a un defensor de oficio, a pesar de que el acusado ha indicado que no lo acepta como su representante, ni le ha dado instrucciones y ha hecho lo necesario para obtener los servicios de otro defensor”.

865 “La Corte Interamericana considera que la prohibición de que un defensor asista a más de un inculpado, si bien limita las alternativas en cuanto a la elección del defensor, no significa en sí una violación del artículo 8.2.d de la Convención”. De esta forma, la jurisprudencia interamericana ha sido más consistente en este punto, señalando que la regla del derecho interno que establece que a cada acusado corresponderá un defensor diferente (lo que implica una imposibilidad de elección cuando hay escasez de personal), y a falta de defensor de confianza producto de la suspensión a un abogado del ejercicio de su profesión, no vulneran la CADH.
} 
último evento aperturarse un sumario o investigación administrativa si es constatada esta negligencia.

Sin existir un pronunciamiento oficial al respecto, y como postura nuestra, sostenemos que sería procedente solicitar a la Contraloría General de la República que calificase la actuación del abogado, que en determinados casos es funcionario público, con la finalidad de solicitar un cambio en la persona del prestador, sin perjuicio del ejercicio de recursos por incumplimiento de estándares, conforme a lo que se expresará en el apartado 2.2 del presente capítulo.

La posibilidad de solicitar al juez el cambio de abogado propiamente no está contemplada, salvo que se decrete el "abandono de la defensa", por incumplimiento de las obligaciones asociadas al patrocinio, que pudiesen provocar la indefensión del afectado.

g) Comienzo de la asistencia jurídica gratuita: Otro tema resuelto por la jurisprudencia consiste en determinar cuándo comienza la obligación de otorgar asistencia jurídica gratuita. La CADH y el PIDCP señalan literalmente que esta asistencia opera durante el proceso. Sin embargo parece razonable ampliar la asesoría letrada a momentos anteriores al inicio judicial del procedimiento. Por su parte el Comité ha resuelto que un acusado tiene derecho a asistencia letrada durante las audiencias preliminares ${ }^{866}$ y a lo largo de los interrogatorios ${ }^{867}$. Si bien la Corte IDH no ha solucionado este problema, se ha argumentado que "sin duda, el acceso a un abogado debe darse desde las primeras actividades iniciadas en contra del sujeto por cualquier autoridad, aun cuando estas no sean de carácter judicial" ${ }^{868}$. Esto es indiciario de la ampliación de la asistencia jurídica gratuita a asuntos y diligencias previas a la actuación del juez, lo que se coincide también con un adecuado respeto y garantía del debido proceso.

\footnotetext{
${ }^{866}$ O’DONELL, D. Op. Cit., p.407.

${ }^{867}$ IBIDEM.

868 MEDINA, C; NASH, C (2003). Manual de Derecho Internacional de los Derechos Humanos para Defensores Penales Públicos. Parte I. Doctrina. Santiago, Centro de Documentación Defensoría Penal Pública, 2003. p. 94.
} 
Como lo sostiene Quispe, "es indispensable para garantizar el derecho de defensa en asuntos penales que el individuo cuente con este derecho desde el primer momento de su detención, a efectos de que su primera declaración sea con la presencia de su abogado y el representante del ministerio público, para evitar que su declaración sea alterada y pueda gravar o comprometer su situación jurídica"869. Además a juicio de los autores Montero y Salazar, "es preciso determinar que el derecho a la defensa surge desde el momento en que se ordena investigar a una persona, por lo que el investigado debe tener acceso a la defensa técnica desde ese mismo momento, sobre todo en la diligencia en la que se recibe su declaración. Impedir a éste contar con la asistencia de su abogado defensor es limitar severamente el derecho a la defensa lo que ocasiona desequilibrio procesal y deja al individuo sin tutela frente al ejercicio del poder punitivo" ${ }^{870}$. El derecho a la defensa surge desde el momento en que se ordena investigar una persona o la autoridad dispone o ejecuta actos que implican afectación de derechos, el investigado debe tener acceso a la defensa técnica desde ese mismo momento, sobre todo en la diligencia en la que se recibe su declaración. Lo contrario sería limitar severamente el derecho a la defensa, lo que ocasiona desequilibrio procesal y deja al individuo sin tutela frente al ejercicio del poder punitivo ${ }^{871}$.

En Chile, la calidad de imputado y el reconocimiento de sus derechos surge desde la primera actuación del procedimiento en su contra, sea ésta judicial, de investigación, cautelar o policial ${ }^{872}$. Además, en las otras materias diversas a la penal, la consagración constitucional del asesoramiento, y las líneas de atención de las diversas instituciones de asistencia jurídica gratuita consagran este derecho aún antes del inicio del proceso.

\footnotetext{
${ }^{869}$ QUISPE. Op. Cit., p. 430.

${ }^{870}$ MONTERO, D; SALAZAR, A. Op. Cit., p. 118

${ }^{871}$ IBIDEM.

${ }^{872}$ CPP. Artículo 7: "Calidad de imputado. Las facultades, derechos y garantías que la Constitución política de la República, este Código y otras leyes reconocen al imputado, podrán hacerse valer por la persona a quién se atribuyere participación en un hecho punible desde la primera actuación del procedimiento dirigido en su contra y hasta la completa ejecución de la sentencia. Para este efecto, se entenderá por primera actuación del procedimiento cualquiera diligencia o gestión, sea de investigación, de carácter cautela o de otra especie, que se realizaré por o ante un tribunal con competencia en lo criminal, el ministerio público o la policía, en la que se atribuyere a una persona responsabilidad en un hecho punible”.
} 
h) Duración de la asistencia letrada: Según el Comité y la $\mathrm{CIDH}$, el derecho a la asistencia letrada es aplicable, en principio, a todas las etapas del proceso. En un caso, el Comité señaló que la asistencia letrada procede en la apelación, pero eso no significa necesariamente que el defensor está obligado a presentar ese recurso. Cuando se decide por parte del profesional que no hay mérito, lo correcto sería informar al acusado de esta situación y así ofrecer la asesoría de otro abogado ${ }^{873}$.

Al tenor de lo expresado por O'Donnell, "el derecho a la defensa obliga al Estado a tratar al individuo en todo momento como como un verdadero sujeto del proceso, en el más amplio sentido de este concepto, y no simplemente como objeto del mismo"874. La Corte IDH ha resaltado que el derecho a la defensa necesariamente debe poder ejercerse desde que se señala a una persona como posible autor o partícipe de un hecho punible y solo culmina cuando finaliza el proceso, incluyendo en algunos casos la etapa de ejecución de la pena"875. En Chile por considerarse la asistencia jurídica gratuita inherente al derecho a la defensa se entiende concedida en toda la secuela del juicio, hasta la ejecución completa de la sentencia, salvo que cambien las circunstancias que se tuvieron en vista respecto del beneficiario, en relación al momento de otorgarla ${ }^{876}$.

i) Adecuación y calidad de la asistencia jurídica gratuita del Estado: La asistencia jurídica gratuita no se satisface por el simple nombramiento o designación del abogado de oficio, ya que el derecho debe ser una asistencia jurídica gratuita que tenga efectividad, a obtener una defensa jurídica en el pleno y completo sentido de

\footnotetext{
${ }^{873}$ Ante esta situación, lo que se esperaría del derecho interno, si es que pretende asegurar lo anterior, es que se diseñen sistemas que garanticen el respeto a los derechos de los justiciables cuando los defensores decidan no perseverar.

${ }^{874}$ O’DONELL, Op. Cit., 411.

${ }^{875}$ IBIDEM. "Se debe garantizar la efectividad y eficacia de este derecho desde el momento en que la ley imponga su asistencia, así como en todas las diligencias hasta la obtención de una sentencia firme”.

${ }^{876}$ CPC. Artículo 7: "El poder para litigar se entenderá conferido por todo el juicio en que se presente, y aún cuando no exprese las facultades que se conceden, facultarán al procurador, para tomar parte, del mismo modo que podría hacerlo el poderdante, en todos los trámites e incidentes del juicio y en todas las cuestiones que por vía de reconvención se promuevan, hasta la ejecución completa de la sentencia definitiva, salvo lo dispuesto en el artículo $4^{\circ}$ o salvo que la ley exija intervención personal de la parte misma....”.
} 
la expresión, que no se obtiene con la pasividad del letrado designado o nombrado, ya que si este último no desarrolla su función, se produce indefensión y el derecho a la asistencia del profesional idóneo que establece la Constitución, se convierte en palabras vacías, quitándole fuerza normativa a este derecho y garantía constituciona| $^{877}$. EI TEDH, en el caso Ártico vs Italia, de 13 de mayo de 1980, y en el caso Pakelli vs Alemania, de 25 de abril de 1983, determinó la existencia de responsabilidad del Estado por vulneración del derecho a la defensa ${ }^{878}$.

Como bien lo expresa Nogueira, "en todo caso, la ausencia de asistencia letrada gratuita efectiva para que provoque indefensión material debe producir algún perjuicio a la parte afectada" $" 77$. En cuanto a la permanencia de este derecho en caso de perjuicio, por no contar con la defensa jurídica estatal debida, agrega el mismo autor, que "así el derecho a la asistencia del abogado permanece intacto en tales supuestos, lo que conlleva en principio el derecho del afectado pobre, a que se le provea asistencia de abogado gratuita, si así este lo considera conveniente para la mejor defensa de sus derechos o intereses legítimos" 880 .

En nuestro país, tal como se expresó en lo concerniente a la defensa jurídica como derecho, existen procedimientos en que no es necesario la competencia por abogado, por ejemplo, cuando la persona lo solicite, cuando el valor de la coda disputada sea exiguo, o cuando en la ciudad donde se encuentre el juzgado respectivo cuente con 4 o menor número de abogados, o el juez lo considere procedente por algunas causales específicas ${ }^{881}$.

\footnotetext{
${ }^{877}$ Así, el derecho de carácter prestacional a la defensa jurídica y asistencia de un letrado idóneo gratuito, no se satisface con la mera designación o nombramiento del abogado si hay ausencia de asistencia jurídica efectiva, en cuyo caso se lesiona el derecho constitucional, produciendo como consecuencia la consabida indefensión.

${ }^{878}$ NOGUEIRA. El debido proceso en la Constitución y en el sistema interamericano, Op. Cit., p. 111

${ }^{879}$ IBIDEM. "a su vez, las normas legales deben interpretarse siempre en el sentido más favorable a la efectividad de los derechos de las personas y, en virtud de ello, al establecerse excepciones a la intervención del abogado en ciertos procesos, no se está obligando a las partes a que actúen personalmente, sino otorgándoseles la facultad de elegir entre la autodefensa y la defensa letrada y técnica, siendo ambas alternativas idóneas para realizar en tales casos actos procesales de carácter valido”.

${ }^{880}$ IBIDEM. p. 112.

${ }^{881}$ LEY 18120. Establece Normas sobre Comparecencia en Juicio. Artículo 2 inciso $1^{\text {o: }}$ "Ninguna persona, salvo en los casos de excepción contemplados en este artículo, o cuando la ley exija intervención personal de la parte, podrá comparecer en los asuntos y ante los tribunales a que se refiere el inciso primero del artículo anterior, sino representada por un abogado habilitado para el ejercicio de la profesión, por procurador del número, por estudiante inscrito en...”. Inciso tercero: “Para la iniciación y secuela del juicio podrá, sin embargo, solicitarse autorización para comparecer y defenderse personalmente. El juez, podrá concederla atendida la
} 
La Corte IDH, en el caso Caso Hilaire Constantine y Benjamín y otros contra Trinidad Tobago, en sentencia 21 de junio de 2002, concluyó que en la práctica no se encontraba a disposición de los inculpados la asistencia legal adecuada para que presenten acciones constitucionales de manera efectiva, sosteniendo que "si bien de manera formal se halla consagrado en el ordenamiento jurídico del Estado, el derecho a intentar una acción constitucional, en este caso se impidió el empleo de este recurso en cuanto el Estado no proporcionó a los inculpados asistencia jurídica gratuita, a fin de que pudieran ejercitarlo efectivamente, y de esta forma constituyó un recurso ilusorio para aquellos" 882 .

Es importante el reconocimiento de este derecho para lograr una adecuada defensa, pero es también importante, más allá de los cuestionamientos que se han desarrollado a la designación meramente formal, que la labor del defensor de oficio sea real, efectiva y honesta ${ }^{883}$, y no una mera formalidad en cuanto a carencia de funcionalidad, debiendo el abogado designado de oficio actuar de manera diligente con el fin de proteger las garantías procesales del acusado, evitando que sus

\footnotetext{
naturaleza y cuantía del litigio o las circunstancias que se hicieren valer, sin perjuicio de exigir la intervención de abogados, siempre que la corrección del procedimiento así lo aconsejaré.”. Inciso octavo: "Las obligaciones consignadas en el primer inciso del artículo 1 y de este artículo, no regirán en aquellos departamentos en que el número de abogados en el ejercicio de la profesión sea inferior a cuatro, hecho que determinará la Corte de Apelaciones correspondiente". Inciso $10^{\circ}$ : No regirán tampoco respecto de los asuntos de que conozcan los jueces de subdelegación y de distrito; los alcaldes, los jueces de policía local, salvo en los asuntos de regulación de daños y perjuicios de cuantía superior a dos Unidades Tributarias Mensuales.....en los recursos de amparo y protección, respecto del denunciante en materia criminal, en las solicitudes que aisladamente se pidan copias , desarchivos y certificaciones, ni respecto de los martilleros, peritos, depositarios, interventores, secuestres y demás personas que desempeñen funciones análogas, cuando sus presentaciones tuvieren por único objeto llevar a efecto la misión que el tribunal les ha confiada o dar cuenta de ella”

${ }^{882}$ CORTE IDH. Caso Hilaire, Constantine y Benjamín y otros contra Trinidad Tobago, sentencia 21 de junio de 2002. Párrafo 152.b: "Igualmente, este Tribunal estima que existen pruebas suficientes para concluir que, en la práctica, no se encuentra a la disposición de los inculpados de homicidio intencional, la asistencia legal adecuada para que presenten acciones constitucionales de manera efectiva. Si bien de manera formal, se halla consagrado en el ordenamiento jurídico del Estado, el derecho a intentar una acción constitucional, en el caso de George Constantine, Wilson Prince, Mervyn Edmund, Martin Reid, Gangadeen Tahaloo, Noel Seepersad, Natasha De Leon, Phillip Chotalal, Wilberforce Bernard, Amir Mowlah y Mervyn Parris se impidió el empleo de este recurso en cuanto el Estado no proporcionó a los inculpados asistencia jurídica a fin de que pudieran ejercitarlo efectivamente, y de esta forma constituyó un recurso ilusorio para aquéllos. Con ello resultaron violados los artículos 8 y 25 de la Convención en relación con el artículo 1.1 de ésta.

${ }^{883}$ El defensor de oficio debe ser honesto consigo mismo y con la institución de la que depende, ya que el acusado no cuenta con otra defensa y es él quien tiene que ejercer ese papel como fuera contratado y pagado por el acusado.
} 
derechos se vean lesionados, de lo contrario, esta designación sería equivalente a no contar con defensa técnica ${ }^{884}$. En este contexto, se refuerza la necesidad que el rol del abogado designado por el Estado produzca reales efectos en pro del ejercicio de los derechos ${ }^{885}$. El defensor de oficio, lamentablemente, en ocasiones desempeña una labor formal, dada la cantidad de casos en los que tiene que participar, pues para efectos formales basta su presencia y firma en el documento que se le requiera ${ }^{886}$.

Esta situación se observa en el caso Tibi vs Ecuador ya citado, según el cual se desprende que "el señor Tibi fue detenido el 27 de septiembre de 1995 y al día siguiente prestó declaración ante el fiscal sin la presencia de su abogado defensor. El 4 de octubre del mismo año, el juez, en el auto apertorio del proceso mediante el cual declara abierta la etapa del sumario, le designó un abogado de oficio, y posteriormente se constató que este no visitó a la presunta víctima ni intervino en su defensa. Así, pese a existir una defensa de oficio y habérsela asignado, esta fue inexistente en la defensa, dejando en la más absoluta indefensión al acusado, que tampoco pudo contratar un abogado particular por falta de recursos económicos" 887 . En el ámbito universal, la jurisprudencia del Comité ha resuelto en reiteradas ocasiones que el Estado no tiene responsabilidad por las actuaciones del defensor

\footnotetext{
${ }^{884}$ CORTE IDH. Caso Barreto Leiva Vs Venezuela, Op. Cit., Párrafo 61: “La acusación puede ser enfrentada y refutada por el inculpado a través de sus propios actos, entre ellos la declaración que rinda sobre los hechos que se le atribuyen, y por medio de la defensa técnica, ejercida por un profesional del Derecho, quien asesora al investigado sobre sus deberes y derechos y ejecuta, inter alia, un control crítico y de legalidad en la producción de pruebas".

${ }^{885}$ QUISPE, F. Op. Cit., pp. 430-431. "No se trata de una figura decorativa en un proceso para cumplir una formalidad, sino de una figura activa en la defensa de los derechos del procesado. De no ser efectiva dicha defensa, no cumple su objetivo, que no es otro que el logro de un juicio justo".

${ }^{886}$ La desprofesionalización y la escasez de recursos hace que la institución del abogado de turno y las Corporaciones de Asistencia Judicial pierda la calidad requerida, pues en caso de esta última, en muchas ocasiones las causas son tramitadas por alumnos en práctica, sin perjuicio de los avances que se han constatado en materia laboral y de familia.

${ }^{887}$ CORTE IDH. Caso Tibi vs Ecuador. Op. Cit., Párrs 194, 165 f). Párrafo 194: “Como se demostró, en el auto cabeza del proceso que declaró abierta la etapa de sumario, dictado el 4 de octubre de 1995, el Juez designó un abogado de oficio para el señor Daniel Tibi y los otros sindicados. Ese abogado no visitó a la presunta víctima ni intervino en su defensa. Si bien el señor Tibi logró comunicarse posteriormente con un abogado particular, no pudo contratar sus servicios por falta de recursos económicos. Esta situación hizo que durante el primer mes de detención no contara con asistencia de un abogado (supra párr. 90.19), lo que le impidió disponer de una defensa adecuada”. Párrafo 165 f): "En consecuencia, no contó con la asistencia de un abogado durante el primer mes".
} 
privado, ya que no es un agente del Estado. Pero es importante tener presente que al aplicar la teoría sobre la responsabilidad por omisión de los agentes estatales, si se vulnerará el pacto, cuando el incumplimiento de los deberes profesionales del defensor sea manifiesta y el Estado no tome medidas correctivas ${ }^{888}$. Tal como lo consigna O 'Donnell, "la jurisprudencia del Comité de Derechos Humanos reconoce el derecho del imputado a una 'representación eficaz' conforme al interés de la justicia, pero también reconoce la presunción de que la actuación de un defensor ha sido adecuada"889. La negativa del defensor de no aceptar las sugerencias del acusado sobre garantías de defensa no constituye vulneración de una defensa adecuada, pero la jurisprudencia en un caso si lo consideró una violación al pacto, cuando el abogado no se hizo cargo de una indicación de la víctima que señalaba que las pruebas del proceso habían sido obtenidas mediante maltratos" ${ }^{890}$. Se puede aseverar que la jurisprudencia universal ha establecido una especie de presunción de buena actuar profesional del abogador defensor estatal ${ }^{891}$, lo que no desconoce, que en casos donde la aplicación del proceso mismo implica violación de otros derechos humanos, el abogado no puede pasar por alto esas situaciones, más aún si es designado por el Estado.

j) Denegación de este derecho, cuando no se proporciona por el Estado debido a que no es considerada obligatoria procesalmente la comparecencia de abogado: Adhiriendo a las reflexiones de O 'Donnell consideramos que "se vulnera este derecho a la asistencia letrada cuando se deniega un abogado de oficio para quien carece de medios económicos, con el solo argumento de que el proceso respectivo no requiere intervención obligatoria de abogado, pero tampoco ésta negación implica automáticamente vulneración del derecho a asistencia judicial gratuita, ya que la Constitución concede protección a los derechos concretos y reales de las personas, lo que obliga a examinar la posible vulneración del derecho atendiendo al contenido y finalidad del mismo que se considere afectado, lo que permite

\footnotetext{
${ }^{888}$ O’DONELL, D. Op. Cit., p. 413

${ }^{889}$ IBIDEM.

890 IBIDEM.

${ }^{891}$ IBIDEM. "El comité ha declarado que en ausencia de una prueba clara de negligencia profesional por parte del abogado, no corresponde al Comité cuestionar el juicio profesional de este último”.
} 
discernir si dicha violación se ha o no producido efectivamente, más allá de la mera apariencia formal" ${ }^{892}$.

k) Derecho a la asistencia letrada es concurrente con el derecho de la otra parte a un proceso sin dilaciones indebidas: El interés de la otra parte también debe ser protegido adecuadamente, debiendo evaluarse en cada caso concreto la situación específica, a fin de evitar que la petición de asistencia judicial no sea solo una maniobra dilatoria para prolongar una situación jurídica que aparece desde el inicio del proceso como insostenible ${ }^{893}$.

\section{INCUMPLIMIENTO DEL DEBER DE ASISTENCIA JURÍDICA GRATUITA DEL ESTADO Y VÍAS IDONEAS EN POS DE SU REESTABLECIMIENTO}

La asistencia jurídica gratuita brindada por el Estado debe cumplir con ciertas exigencias o con los estándares indicados en el punto anterior, por lo cual si esta no se otorga o se configuran infracciones a estos estándares, se generan determinadas consecuencias o sanciones para el Estado o para los que en su representación deben otorgar la prestación, por lo cual los eventuales incumplimientos, responsables particulares y sanción aplicable si procediese, deben obedecer a un detallado análisis casuístico.

\subsection{Situaciones de incumplimiento del deber de Asistencia Jurídica Gratuita estatal}

Se pueden advertir las siguientes hipótesis, sin ser taxativas, en que el derecho de asistencia jurídica gratuita no es posible ejercerse por las personas a quienes les

\footnotetext{
892 IBIDEM. p. 414.

${ }^{893}$ IBIDEM.
} 
corresponde legal y constitucionalmente, con cumplimiento a los estándares recientemente desarrollados:

a) No otorgamiento del privilegio de pobreza judicial por el juez en conformidad a lo establecido en el artículo 129 del CPC.

b) Omisión de nombramiento de abogado de turno por el juez respectivo, no obstante cumplir con los requisitos del artículo 595 y 597 del COT.

c) No reconocimiento del privilegio de pobreza legal, como es el caso del artículo 135 del CPC y artículo 600 del COT.

d) Negación por parte de una CAJ o DPP, de ingresar a una persona en forma ilegal y arbitraria, no existiendo fundamento para denegarla. Por ejemplo, cuando una CAJ se rehúsa atender a una persona, sin perjuicio de que la persona haya acreditado escasez de recursos o que sea de ingreso automático, según los mecanismos de focalización, o aduciendo que la contraparte es atendida por la misma institución.

e) Que la atención del Abogado de turno o de la institución estatal específica, como las CAJ o DPP, no cumpla con los estándares de calidad exigida, siendo deficiente e incluso negligente.

f) Que el instrumento creado por el Estado para otorgar asistencia jurídica gratuita no tenga cobertura en ciertas materias, no comprenda la etapa previa de asesoramiento o no se extienda en toda la secuela del juicio.

Reiterando que no son taxativas estas hipótesis de incumplimiento, constituyen las situaciones más comunes que se pueden configurar. En estos casos proceden las siguientes herramientas judiciales tendientes a subsanar estas afectaciones al derecho de asistencia jurídica gratuita. 


\subsection{Vías idóneas ante un no otorgamiento de asistencia jurídica gratuita o que este derecho no cumpla con los estándares constitucionales y convencionales}

\subsubsection{Recurso de apelación}

En caso de no otorgamiento del privilegio de pobreza por parte del juez o no reconocimiento del privilegio de pobreza legal, la parte afectada puede presentar un recurso de apelación conforme al artículo 194 del CPC, siendo en este caso la CA quien puede revisar la resolución y otorgar el privilegio, rechazado por el tribunal primera instancia ${ }^{894}$.

\subsubsection{Recurso de Nulidad}

La nulidad procesal se define como la sanción mediante la cual se priva a un acto o actuación del proceso, o a éste en su conjunto, de los efectos normales previstos por la ley, cuando en su ejecución no se han guardado las formas prescritas por aquella ${ }^{895}$.

En caso de no reconocimiento o no otorgamiento de privilegio de pobreza o no designación de abogado de turno, la parte está habilitada para presentar un recurso de nulidad. También procedería, en el caso de que la asistencia jurídica gratuita otorgada a una persona en la secuela del procedimiento no se haya extendido a determinadas materias o no se haya conferido por todo el proceso. Asimismo, procede el recurso en cuestión si dicha asistencia no tuvo la calidad requerida o no fue oportuna, o se le exigieron requisitos no previstos, como asimismo si se excluyó

\footnotetext{
${ }^{894}$ CPC. Artículo 194 n² 2.

895 CORREA, J (2005). Op. Cit., p. 117. “El destacado procesalista Hugo Alsina, lo señala claramente, en el sentido de que la formula sería: donde hay indefensión han nulidad; si no hay indefensión, no hay nulidad”.
} 
su atención por una causal no legal, o si está defensa no se suministró en forma gratuita.

Como bien lo señala Jorge Correa, "la finalidad genérica de los actos del proceso confluye en la preservación de una garantía constitucional que asegure entre otras la adecuada defensa en el proceso" ${ }^{\prime 96}$. Por ello, con la nulidad procesal se busca resguardar el debido proceso y todo proceso debe estar formado por un núcleo indestructible que es el principio de contradicción, igualdad de armas, y si la asistencia jurídica gratuita no está garantizada o no cumple estándares mínimos, ese proceso estaría viciado y sería aplicable la nulidad. La nulidad procesal podrá ser declarada, de oficio o a petición de parte, en los casos que la ley expresamente lo disponga y en todos aquellos en que exista un vicio que irrogue a alguna de las partes un perjuicio solo reparable con la declaración de nulidad ${ }^{897}$. Solo podrá impetrarse dentro de 5 días, contados desde que aparezca o se acredite que quién deba reclamar de la nulidad tuvo conocimiento del vicio, a menos que se trate de la incompetencia absoluta del tribunal.

Además, se debe tener presente que el juez puede de oficio declarar la nulidad, si advierte que una de las partes debe abandonar el proceso por carecer de medios, habiendo pedido el privilegio de pobreza, o haber dejado constancia que le han negado la atención en algún organismo de asistencia jurídica gratuita ${ }^{898}$.

Específicamente en materia penal si en el curso del proceso, no se le otorga a una persona la defensa jurídica por parte del Estado, sea gratuitamente o con el copago que corresponda, o esta no sea de calidad, o que se le haya impedido ejercer al defensor los derecho que la ley otorga, se puede solicitar la nulidad del juicio y de

\footnotetext{
${ }^{896}$ IBIDEM

${ }^{897}$ CPC. Artículo 83: "La parte que ha originado el vicio o concurrido a su materialización o que ha convalidado tácita o expresamente el acto nulo, no podrá demandar la nulidad. La declaración de nulidad de un acto no importa la nulidad de todo lo obrado. El tribunal que declara la nulidad deberá establecer precisamente cuales actos quedan nulos en razón de su conexión con el acto anulado después de su publicación”.

${ }^{898}$ IBIDEM. Artículo 84 inciso $3^{\circ}$ : "El Juez podrá corregir de oficio los errores que observe en la tramitación del proceso. Podrá asimismo tomar las medidas que tiendan a evitar la nulidad de los actos de procedimiento. No podrá, sin embargo subsanar las actuaciones viciadas en razón de haberse realizado éstas fuera del plazo fatal indicado por la ley".
} 
la sentencia ${ }^{899}$, sin perjuicio de ser procedente recurso de protección. Nogueira ejemplifica adecuadamente a través del análisis de la sentencia rol n²08-2004, de 30 de abril de 2004, pronunciada por la CA de Temuco, la procedencia de un recurso de nulidad, por la falta de calidad y eficiencia que puede tener una defensa jurídica gratuita, ocasionado por no proporcionar el tribunal respectivo al abogado designado por el Estado los medios para realizar una defensa de calidad 900 .

${ }^{899}$ CPP. Artículo 374: "Motivos absolutos de nulidad. El juicio y la sentencia serán siempre anulados. b) cuando la audiencia del juicio oral hubiere tenido lugar en ausencia de alguna de las personas cuya presencia continuada exigen, bajo sanción de nulidad, los artículos 284 y 286. c) Cuando al defensor se le hubieren impedido ejercer los derechos que la ley exigen".

900 NOGUEIRA, H. El Debido proceso en la Constitución y en el sistema interamericano. Op. Cit., pp. 414418. "Hace referencia en su texto a una sentencia rol n ${ }^{\circ} 208-2004$ de 30 de abril de 2004, pronunciada por la Ilustrísima Corte de Apelaciones de Temuco, primera sala, integrada por los ministros señores Víctor Reyes Hernández, Julio Cesar Grandón Castro y Fernando Carreño Orrego constituye un buen ejemplo pedagógico de aplicación de las normas sobre derecho a la defensa eficaz, conjugando adecuadamente el derecho interno e internacional de los derechos humanos. En este caso existió una falta de preparación del defensor penal público designado para defender al imputado de autos de un delito de homicidio, por el exiguo plazo que se le dio a la defensa del imputado para lograr una defensa eficaz. El fallo es el siguiente: Considerando $1^{\circ}$ : Que el fundamento del recurso de nulidad planteado por la defensa del imputado es la causal contemplada en el literal c) del artículo 374 del Código Procesal Penal, motivo absoluto de nulidad, y que permite que el juicio oral y la sentencia sean anulados cuando al defensor se le hubiere impedido ejercer las facultades que la ley le otorga. Sostiene la recurrente que a ella se le designo defensor del acusado al comienzo de la audiencia de juicio oral, dándosele un tiempo de cuatro horas para interiorizarse del caso, llevándose a cabo el juicio oral transcurridas que fueron aquellas cuatro horas concedidas por el tribunal. El imputado había confiado su defensa desde un comienzo del proceso al abogado señor Miguel Concha Coronado, con el cual aquel había sostenido reiteradas reuniones de análisis acerca de los alcances, debilidades de la acusación y estrategias de defensa, y después de meses de estudios habían acordado la forma más eficaz de enfrentar el juicio oral. La noche antes del juicio oral el mencionado abogado defensor a raíz de un accidente que había sufrido días antes, y ante la gravedad de la lesión sufrida, obtuvo una licencia médica por siete días, de los cuales tres estuvo hospitalizado. Frente a este hecho, es decir, el impedimento que sufrió el profesional letrado Concha Coronado, de concurrir a la audiencia del juicio oral, el defensor Jefe de la Defensoría Penal Pública de Angol, señora Solange Sufan Arias, a las 10,00 horas se presentó al Tribunal Oral en lo Penal de esa ciudad solicitando la suspensión del juicio oral del imputado que se iniciaba, resolviendo los jueces que tal petición se resolvería en la misma audiencia, y así fue como enseguida el Juez Presidente de ese tribunal, don Waldemar Koch Salazar, mediante resolución escrita le comunico que a ella se le designaba abogado defensor del imputado y que debía asumir inmediato la defensa en la audiencia que se llevaría a efecto dentro de cuatro horas más, suspendiéndose la audiencia a las 11,30 horas reanudándose a las 15,30 horas. Argumenta la recurrente que ante tal resolución interpuso un recurso de nulidad pues esa decisión significaba un grave quebrantamiento del derecho de defensa adecuada que tenía el imputado, y no dándose lugar a la suspensión de la audiencia el recurso aquel fue rechazado indicándose en el que el tiempo racional y prudente para aquella profesional, atendidas su experiencia y condiciones, para interiorizarse del caso era de cuatro horas. Este tiempo no fue aceptado por la defensora ni esta aceptada por el imputado, siendo impuesta por el Tribunal esa calidad, ya que la complejidad del caso, tratabase de un homicidio, simple para el ministerio público, y calificado para la querellante, tiempo que no era suficiente, racional ni prudente, para ejercer todas las facultades que la ley le otorga a la defensa, incurriéndose en la causal del articulo 374 letra c) del Código Procesal Penal. Termina señalando la recurrente que la actitud del Tribunal Oral en lo Penal de Angol además conculco el Pacto Internacional de Derechos Civiles y Políticos en su artículo 14 punto 3 letra b); la Convención Americana de Derechos Humanos, articulo 8 N²; y la Constitución Política de la Republica, articulo 19 Nº3. Sostiene que el derecho de defensa abarca la defensa material, en relación con la posibilidad de formular los planteamientos y alegaciones que considere oportunos, así como 
su derecho a intervenir en todas las actuaciones judiciales y en las demás actuaciones del procedimiento (art. $8^{\circ} \mathrm{del}$ Código Procesal Penal); y también el derecho de defensa técnica que consiste en el derecho a la defensa jurídica y la prohibición de que alguna autoridad o individuo impida, restrinja o perturbe la debida intervención del letrado si ella hubiere sido requerida desde la primera actuación del procedimiento y hasta la completa ejecución de la sentencia (arts. $8^{\circ}$ inc.193 b) y 102 inc. 1 del Código Procesal Penal). Considerando $2^{\circ}$ : Que los antecedentes que se tienen la vista y de lo expuesto por los intervinientes en la audiencia de la vista del recurso aparece que los hechos relacionados en el recurso son efectivos en cuanto a que en primera instancia la defensa del imputado fue entregada al abogado Miguel Concha Coronado, que este profesional sufrió un accidente días antes de la realización de la audiencia del juicio oral y que el día anterior a ella se le otorgó una licencia médica, que el día de la audiencia aquella la Jefa de la Defensoría Penal Pública de Angol hizo presente esta circunstancia al Tribunal respectivo quien resolviendo la petición de suspensión de la audiencia la negó y designó como defensora del imputado a esa profesional dándole un plazo de cuatro horas para imponerse de los antecedentes y defender al acusado en la audiencia respectiva, que el caso sometido a la decisión del tribunal era un delito de homicidio, como se dijo, simple para el Ministerio Publico, y calificado para el querellante particular, que había un gran número de testigos que interrogar y contrainterrogar, y peritos que debían declarar. Considerando $3^{\circ}$ : Que se ha señalado por esta misma Corte que hay consenso en la jurisprudencia y la doctrina que el proceso penal es el conjunto de normas y actuaciones a través de las cuales se hace efectivo el poder sancionador del Estado, mediante la amenaza concreta de aplicación de una pena a los responsables de actos constitutivos de delitos, dando garantías de igualdad de condiciones a las partes, acusadora y acusada, para presentar y discutir su caso ante un juez imparcial, a fin de legitimar ante la sociedad la decisión de fuerza que toma el Estado, si el proceso termina en una condena (Causa Rol № 665-2003, sentencia del 15 de diciembre de 2003, ministro redactor señor Héctor Toro Carrasco). Este sistema, mediante el cual se permite el funcionamiento del poder penal estatal, es el conjunto de elementos que intervienen en la creación, aplicación y ejecución de las normas penales y constituye un complejo sistema de garantías que tiene el ciudadano frente al poder penal del Estado, garantías que parten desde la Constitución Política de la Republica cuando en su artículo $19 \mathrm{~N}^{\circ} 3$, inc. $5^{\circ}$ señala que "Toda sentencia de un órgano que ejerza jurisdicción debe fundarse en un proceso previo legalmente tramitado. Corresponderá al legislador establecer siempre las garantías de un racional y justo procedimiento", y la garantía de la defensa procesal, elevada a la categoría de derecho humano por la Carta Fundamental, se encuentra en este cuerpo legal establecida en su artículo $19 N^{\circ} 3$,inc.2. Toda persona tiene derecho a defensa jurídica en la forma que la ley señale y ninguna autoridad o individuo podrá impedir, restringir o perturbar la debida intervención del letrado si hubiese sido requerida y el inciso $3^{\circ}$ expone que la Ley arbitrara los medios para otorgar asesoramiento y defensa jurídica a quienes no puedan procurárselos por sí mismos. Considerando $4^{\circ}$ : Que el fundamento del recurso de nulidad entablado por la defensoría penal pública de Angol es, en síntesis, el derecho a la defensa que tiene todo imputado y que parte por el derecho mismo a ser oído y a intervenir en el juicio, pues es interesado en los resultados del juicio y puede intervenir en la decisión jurisdiccional que de ser condenatoria afectará algunos de los bienes jurídicos que no obstante su calidad de imputado tiene, como ser su libertad personal, su patrimonio, etcétera.; asimismo, tiene derecho a contradecir las alegaciones del ente acusador, a formular sus propias alegaciones destinadas a desvirtuar los cargos formulados en la acusación, a presentar sus pruebas, y a tener un defensor técnico y jurídico. Toda esta normativa, que arranca desde la Constitución Política de la República, como se expuso en el motivo precedente, tiene acogida, también, en nuestro sistema procesal penal cuando en los artículos 8 inc. 112, 93 b), 102 inc. 1231, 232, 237, 269, 283, y 286, reglan el ejercicio del derecho de defensa y el asesoramiento que el imputado debe tener de un letrado, de un abogado, profesional que por su experiencia y conocimientos permite presumir, por lo menos, la realización de una defesa eficaz. Sin embargo, esta defensa para que sea eficaz no solo requiere de un profesional competente, sino que aquél debe tener un conocimiento acabado y profundo de los hechos que se le imputan al acusado, de las circunstancias que rodearon el hecho punible y las personales propias del acusado. Considerando $5^{\circ}$ : Que de acuerdo con lo expuesto precedentemente y relacionado con los hechos en que se funda el recurso de nulidad deducido, se infiere que a pesar de la idoneidad, experiencia y calidad profesional que detenta la defensora Solange Sufán Arias (Considerando 3 de la resolución que rechazo el incidente de nulidad planteado por aquella defensora) no podía siquiera presumirse que tendría el cabal, agotado, profundo y acabado conocimiento de los hechos y de sus circunstancias y de las propias del inculpado, no siendo por lo tanto racional ni prudente las 4 horas que el Tribunal oral en lo penal de Angol le otorgara para que se hiciera cargo de la defensa, El abogado jefe de una defensoría local, cuyo es el caso de autos, respecto de la abogado señora Solange Sufan Arias, también puede ser abogado defensor si se hubiera autodesignado en el proceso, lo que no consta, pero si adquirió tal calidad 


\subsubsection{Recurso de protección}

\section{Estos derechos derivados del debido proceso son de carácter instrumental, constituyen derechos y garantías para la protección de otros derechos, que son los}

que fundamentalmente se busca proteger y subyacen en el proceso (vida, libertad, etc.), por eso no tendrían protección directa.

En un proceso entran en juego todos los derechos-garantías, dentro de los cuales se encuentra la asistencia jurídica gratuita, cuyo incumplimiento de estándares o requisitos de procedencia, proviene normalmente de las propias resoluciones judiciales que se adoptan para poner en ejecución las leyes adjetivas o bien las

desde el momento mismo en que el tribunal la designó como defensora al inicio de la audiencia de juicio oral, pues el imputado en ese momento carecía de defensor produciéndose la situación de abandono de la defensa normada en el artículo 286 del Código procesal penal y el Tribunal debía cumplir con aquella obligación que también establece el artículo 106 del mismo cuerpo legal procesal ,ya que es requisito de validez del juicio oral la presencia ininterrumpida del defensor durante toda la audiencia. Sin embargo como aquí se trata de la sustitución de un defensor penal público por otro no se da la situación del inciso final del artículo 286, que impide suspender la audiencia por ausencia del defensor elegido por el imputado, caso en el cual, el tribunal debe designar de inmediato un defensor pena público y concederle a éste un tiempo prudente para interiorizarse del caso y propender a una adecuada y eficaz defensa del imputado. Que en consecuencia, en el procedente caso nos encontramos en una situación de abandono de hecho de la defensa que regulan los artículos 106 inciso segundo y 286 inciso $2^{\circ}$, ambos del Código Procesal Penal, en que junto con designar defensor público de reemplazo no existe impedimento para que el tribunal pudiere suspender la audiencia del juicio oral en el tiempo mínimo necesario de acuerdo al motivo de la suspensión, es una de las facultades que le confiere el artículo 283 inciso primero del cuerpo legal citado . De modo tal que ha existido una falta de preparación de la defensora penal público designada para defender al imputado de autos, de un delito de homicidio existiendo un gran número de personas que deben testificar ,el interrogatorio de peritos y pruebas documentales sobre las que se podrá abrir debate, una carpeta de antecedentes de más de 200 fojas ,la presencia en el juicio de un querellante particular que en su acusación alega la existencia de agravantes en perjuicio del acusado, todo lo cual lleva a resolver a estos sentenciadores que el plazo de 4 horas que se le concedió a la defensa no es un periodo prudente, es insuficiente ,para que se hubiere interiorizado del caso y lograr así una defensa real y eficaz. Prudente, es decir o hacer lo que es conveniente para un momento y el plazo que se le dio a la defensa del imputado para lograr una defensa eficaz, no fue el conveniente para ella, considerando las circunstancias referidas en el párrafo anterior, de ahí entonces, el resolver el tribunal en la forma que lo hizo ,impidió al defensor poder ejercer las facultades que la ley le otorga incurriendo en la causal de nulidad absoluta contenida en el artículo 74 c) del Código Procesal Penal, conculcándose las garantías constitucionales y los derechos contenidos en los tratados internacionales suscritos, aprobados y vigentes en nuestro país,por lo que deberá, en consecuencia, anularse el juicio oral y la sentencia dictada en los antecedentes, debiendo quedar el proceso en estado de realizarse un nuevo juicio oral ante el tribunal no inhabilitado que corresponda. Por estas consideraciones y visto lo dispuesto en los artículos 372,374 letra c, 378, 384 y 386 del CPP, se acoge en todas sus partes el recurso de nulidad deducido a fojas 24, y en consecuencia se anulará el juicio oral y la sentencia de 16 de marzo de 2004, quedando el proceso en estado de fijarse nueva audiencia para la realización de un nuevo juicio oral ante un tribunal no inhabilitado que corresponda". 
sustantivas. En tales casos, los afectados habrán de protegerse mediante interposición de recursos ordinarios o extraordinarios que se establezcan en el ordenamiento jurídico procesal (apelación, nulidad, etcétera) ${ }^{901}$. En lo específico, si la falta de asistencia jurídica gratuita repercutiera en una privación o restricción de libertad, sería procedente el recurso de amparo ${ }^{902}$. Fundamentando esta idea, los profesores Mohor y Varas, quienes son considerados los precursores de esta teoría, que como lo veremos, ha tenido recepción en la judicatura chilena, sostienen que "se es cauteloso respecto de la procedencia del recurso de protección en contra de resoluciones judiciales, debido a que es excepcional y procede más que todo respecto de actuaciones de la administración o particulares, por lo que permitir el recurso de protección en forma general por infracción a las garantías del 19 n 3 por parte del juzgador, significaría su aplicación indiscriminada en relación a las resoluciones judiciales" 903 .

No obstante que la generalidad de los autores es del parecer que no procede el recurso de protección, coincidiendo con los profesores citados, podría a nuestro entender ser procedente para salvaguardar el derecho a la asistencia jurídica gratuita, en caso de un desconocimiento, privación o amenaza del ejercicio del mismo por parte de la autoridad administrativa o judicial. Se respalda esta tesitura en el entendido "que la violación de otros derechos del 19 n 3 durante el proceso, puede ser considerada como un acto u omisión arbitraria o ilegal, que en relación de causa-efecto provoque una amenaza, perturbación, privación en el legítimo

\footnotetext{
${ }^{901}$ MOHOR, S; VARAS, P. Op. Cit. p. 292.

${ }^{902} \mathrm{CPR}$. Artículo 21: "Todo individuo que se hallare arrestado, detenido o preso con infracción de lo dispuesto en la constitución o en las leyes, podrá ocurrir por sí, o por cualquiera a su nombre, a la magistratura que señale la ley, a fin de que ésta ordene se guarden las formalidades legales y adopte de inmediato las providencias que juzgue necesarias para restablecer el imperio del derecho y asegurar la debida protección del afectado. Esta magistratura podrá ordenar que el individuo sea traído a su presencia y su decreto será precisamente obedecido por todos los encargados de las cárceles o lugares de detención. Instruida de los antecedentes, decretará su libertad inmediata o hará que se reparen los defectos legales o pondrá al individuo a disposición del juez competente, procediendo en todo breve y sumariamente, y corriendo por sí esos defectos o dando cuenta a quien corresponda para que los corrija. El mismo recurso, y en igual forma, podrá ser deducido en favor de toda persona que ilegalmente sufra cualquiera otra privación, perturbación, o amenaza en su derecho a la libertad personal y seguridad individual. La respectiva magistratura dictará en tal caso las medidas indicadas en los incisos anteriores que estime conducentes para restablecer el imperio del derecho y asegurar la debida protección del afectado".
}

${ }^{903}$ MOHOR, S; VARAS, P. Op. Cit., p. 292. 
ejercicio de alguno de los derechos subyacentes que se ventilan en el juicio"904. De esta forma, si la resolución que transgreda por acción u omisión de conceder legal, constitucional y convencionalmente la asistencia jurídica gratuita, pasa a constituir comportamiento arbitrario e ilegal a partir del cual se derivan los efectos que constitucionalmente harán procedente el recurso de protección, pero no para obtener directamente la protección del derecho-garantía afectado, sino para la debida salvaguarda del derecho subyacente, materia del proceso ${ }^{905}$.

Cuando, el derecho subyacente está dentro del catálogo del artículo 20 de la CPR, que enumera expresamente los derechos cautelados por el referido recurso, no habría dificultad en su análisis; pero si el derecho subyacente no se encuentra en el catálogo, se debe hacer un estudio más detenido. Aparentemente en esta hipótesis, la posibilidad de interposición de un recurso de protección frente a la eventualidad de una transgresión de alguno de los derechos-garantía por obra de una resolución judicial, con la finalidad de obtener la protección directa del derecho subyacente e indirecta del derecho-garantía, parece quedar en entredicho ${ }^{906}$. Sin embargo, la apertura a su procedencia se vincula con lo dispuesto en el artículo $19 \mathrm{n}^{\circ} 24$, inciso $1^{\circ 907}$ de la CPR, en que se asegura el derecho de propiedad sobre toda clase de bienes, mencionando expresamente entre ellos, a los bienes incorporales o derechos. De esta manera resultaría jurídicamente posible sostener la procedencia del recurso de protección, aún dentro de la hipótesis que nos ocupa, sobre la base de argumentar que la violación de algunos de los derechos del artículo 19 n³, entre ellos la asistencia jurídica gratuita, por medio de una resolución judicial, implicaría afectar a la libertad para adquirir el dominio que se tiene del derecho subyacente no protegido directamente por el recurso de protección. Extrapolando este análisis normativo a la realidad práctica, sería aplicable este recurso en caso que una

\footnotetext{
904 IBIDEM .p. 293.

${ }^{905}$ Entendemos en la situación de una persona que requiere la asistencia de un abogado para que lo defienda en un juicio civil de indemnización de perjuicios por una negligencia médica, su derecho a la asistencia jurídica gratuita viene relacionado con el derecho subsecuente, que es su vida e integridad física y/o psicológica consagrada en el artículo $19 \mathrm{n}^{\circ} 1$ de la CPR, obteniéndose la protección directa del derecho subyacente y la protección indirecta del derecho-garantía.

${ }^{906}$ MOHOR, S; VARAS, P. Op. Cit., p.293.

${ }^{907}$ CPR. Artículo 19 n 24 inc. $1^{\text {o: }}$ "El derecho de propiedad en sus diversas especies sobre toda clase de bienes corporales o incorporales”.
} 
resolución judicial violara algún precepto del 19 n 3 (igualdad ante la justicia, debido proceso, asistencia jurídica gratuita), y afectará con ella, arbitraria e ilegalmente otro derecho, como el derecho a obtener o conservar una jubilación ${ }^{908}$. Este mismo razonamiento procedería si una municipalidad privara a una persona de su empleo sin haber realizado un sumario administrativo, privándolo del derecho a la propiedad de conservar su grado administrativo ${ }^{909}$. En lo netamente relativo a la asistencia jurídica gratuita es viable la presentación de este recurso cuando se niega el derecho a ser asistido por un abogado a costo del Estado, o cuando se imponen trabas de cualquier tipo, especialmente de carácter económico para obtenerlo. En el curso del proceso si existe alguna violación de estándares nos inclinamos en pensar que serían procedentes los recursos ordinarios procesales indicados.

La CS ha acogido un recurso de protección presentado por una ciudadana, quien sostuvo que la CAJ de Valparaíso habría obrado arbitraria e legalmente, por no brindarle asistencia jurídica gratuita durante la tramitación de la causa rol de ingreso 226-2018 ante el $2^{\circ}$ juzgado civil de Viña del Mar, sobre terminación de contrato de arrendamiento y restitución del inmueble arrendado por el actor, hecho que lo privaría de su derecho a la integridad física y psíquica, y a la igual protección de sus derechos. Al acogerse el recurso, se ordenó por la CS que la CAJ debía obligatoriamente brindar el servicio, no obstante que justificó su no otorgamiento por el hecho de que la contraparte estaba siendo atendida por la misma institución. En aras de lo que ya hemos razonado, y tal como lo destaca el Diario Constitucional, "resulta relevante este fallo debido a que el derecho a la asistencia jurídica gratuita, no está contemplada dentro del catálogo de aquellos que son protegidos por el recurso de protección"1910. Con esta interpretación de la CS, cualquier privación,

\footnotetext{
${ }^{908}$ CS. Sentencia causa rol 24.847, de 26 de enero de 1995. “Como el recurso de protección no procede respecto del derecho a la seguridad social, del cual el derecho a la jubilación es solo una de sus múltiples manifestaciones, su interposición debería fundarse en que, al comprometerse por la acción judicial el derecho a obtener una jubilación, con ello se estaría afectando el derecho de dominio sobre la jubilación o pensión, o bien, según sea el caso, la libertad para adquirir su dominio"

${ }^{909}$ CS. Sentencia causa rol 24.470, de 31 de enero de 1995.

${ }^{910}$ DIARIOCONSTITUCIONAL.https://www.diarioconstitucional.cl/noticias/asuntos-de-interespublico/2019/01/11/cs-acoge-proteccion-contra-corporacion-de-asistencia-judicial-de-valparaiso/ [Consulta 15 de mayo de 2020]. "En fallo dividido, la Corte Suprema acogió recurso de protección y ordenó a la Corporación de Asistencia Judicial de Valparaíso arbitrar las medidas necesarias para otorgar asesoría jurídica a recurrente en juicio de arrendamiento. La sentencia sostiene que útil resulta recordar que la Corporación de
} 
perturbación u amenaza a este derecho, habilitaría al afectado a recurrir a la CA para que esta ordene el restablecimiento del derecho exigiendo que se tomen las providencias para otorgar efectivamente el servicio. En este sentido, si la asistencia jurídica gratuita no fuera de calidad, no abarcará todas las etapas del proceso o no fuese gratuita, podría ser procedente el recurso de protección y de este forma obtener la asistencia jurídica gratuita denegada. Para mayor precisión se hará alusión al considerando quinto de la sentencia ${ }^{911}$.

Por los efectos vinculantes a la CAJ, y por las falencias estructurales que presenta esta institución, asociadas en gran parte a falta de inyección de recursos humanos y financieros, estimamos que este fallo no es del todo acertado, pues la exclusión de ciertas materias, o la obligatoriedad de atender a las dos partes de un proceso por parte del organismo se justifica en atención a que el ofrecimiento formal de una línea de atención en relación a una determinada materia o respecto de la ampliación

Asistencia Judicial de Valparaíso forma parte de los servicios de asistencia jurídica gratuita creados por la Ley № 17.995 y, más allá de poseer personalidad satisfacción de una necesidad pública de carácter general, consistente en el ejercicio del derecho a defensa jurídica asegurado en el numeral $3^{\circ}$, inciso $2^{\circ}$, del artículo 19 de la Constitución Política de la República. La resolución agrega que de esta manera, en la consecución de tal objetivo resulta exigible, respecto del órgano recurrido, el cumplimiento del deber de coordinación contemplado en el artículo 37 bis de la Ley $\mathrm{N}^{\circ} 19.880$, relacionado con el principio de eficacia dispuesto en los artículos 9 y 13 del mismo cuerpo normativo. Ello implica, en el caso concreto, que ante la imposibilidad de prestar asistencia letrada para la defensa del actor en juicio, la recurrida debió arbitrar los medios necesarios para proveer tal servicio, sea mediante la provisión de recursos humanos internos, o a través del señalamiento de otra u otras entidades que pudiesen brindar la prestación requerida por el peticionario. A continuación, el fallo señala que no habiéndose satisfecho la obligación referida en el motivo precedente, debe concluirse que la conducta de la Corporación de Asistencia Judicial de Valparaíso es ilegal, resultando tal omisión, además, apta para amenazar el derecho del actor a la integridad física y psíquica, dadas las perniciosas consecuencias que de la ausencia de asistencia letrada en juicio pudieren derivarse. Por tanto, concluye que se revoca la sentencia apelada de dos de agosto de dos mil dieciocho, y en su lugar se declara que se acoge el recurso de protección interpuesto en contra de la Corporación de Asistencia Judicial de Valparaíso, ordenándose a la recurrida adoptar las medidas necesarias para representar en juicio al recurrente o, en su defecto, indicarle con claridad él o los organismos que pudieren hacerlo, coordinándose con ellos hasta que asuman la representación del acto. Decisión adoptada con los votos en contra del ministro Prado y del abogado Matus. El Ministro Prado estuvo por confirmar la sentencia apelada teniendo en consideración que no existe norma alguna que imponga a la corporación recurrida la obligación de prestar a todo evento sus servicios a quien así lo requiera, pudiendo no hacerlo por diversas razones, como la ausencia de calificación socioeconómica, la inviabilidad jurídica de la pretensión del peticionario, o la existencia de defensa incompatible, tal como ha ocurrido en el caso concreto. Y por su parte, el abogado Matus fue de parecer de confirmar el laudo en alzada, teniendo para ello especialmente en cuenta que la garantía directamente afectada por los hechos denunciados es aquella contemplada en el artículo 19 №3 inciso $3^{\circ}$ de la Carta Fundamental, no encontrándose ella comprendida en el catálogo de su artículo 20, sin que sea posible, por lo demás, omitir tal limitación so pretexto de concurrencia de alguna difusa amenaza a otro u otros derechos".

${ }^{911}$ CS. Sentencia causa rol 19.253-2019, de 2 de enero de 2019. Considerando quinto. 
de cobertura de usuarios, podría desnaturalizar el mandato constitucional y convencional vinculado a la prestación de este servicio con características de eficacia ${ }^{912}$. Hacer presente que este fallo de la CS revocó o dejó sin efecto la sentencia de la CA de Valparaíso que había desestimado el recurso de protección, en atención a que "del mérito de los antecedentes no existe arbitrariedad o ilegalidad de parte de la recurrida, toda vez que representado a una de las partes en el juicio, se vio imposibilitado de atender el requerimiento del recurrente, en consecuencia, al no acceder a la petición no ha vulnerado disposición legal alguna, ajustándose a la normativa vigente de defensa incompatible en relación con causas civiles, por lo que la presente acción será rechazada"13.

\subsubsection{Acción de Indemnización de perjuicios}

Esta alternativa legal siempre está disponible cuando por un acto u omisión, doloso o negligente se provoca un daño, material o moral a una persona, que se traduce en perjuicios que deben ser reparados por el que cometió el acto o incurrió en la omisión, debiendo existir una relación entre éstos y el perjuicio ${ }^{914}$.

En caso de la asistencia jurídica gratuita, la institución, CAJ o DPP, o abogado de turno, incluso el juez que no otorga o reconoce, debiendo hacerla, puede producir un grave perjuicio en contra del afectado. No obstante ello, es más probable que el perjuicio se produzca por una deficiente o dolosa actuación u omisión del abogado asignado, responsabilizando a la institución que lo contrata. En el caso de los estudiantes postulantes al título de abogado que realizan su práctica profesional en las CAJ, sino están lo suficientemente supervisados por los abogados del servicio,

\footnotetext{
${ }^{912}$ Existen consultorios de la CAJ, en que solo se contempla en dotación un solo abogado, por lo cual atender a dos partes de un proceso, resulta impracticable. En los consultorios, en que efectivamente existe más de un abogado, no existen en ocasiones, las garantías de infraestructura que puedan asegurar la confidencialidad de los documentos y expedientes.

${ }^{913}$ CA de VALPARAISO. Sentencia causa rol 5262-2018, de 2 de agosto de 2018.

${ }^{914}$ CODIGO CIVIL. Artículo 2314: "El que ha cometido un delito o cuasidelito que ha inferido daño a otro, es obligado a la indemnización, sin perjuicio de la pena que le impongan las leyes por el delito o cuasidelito”.
} 
pueden incurrir en ciertas acciones u omisiones negligentes que lleguen a significar que la persona no obtenga los resultados esperados y que en derecho le correspondían ${ }^{915}$.

El dolo o negligencia de los prestadores de la asistencia jurídica gratuita que implique que este derecho social prestacional no sea brindado, no cumpliéndose con los estándares exigidos, se pueden deber a diversas causas. No obstante ello, la jurisprudencia es escasa, y encontramos más casos de mala praxis de la abogacía realizada por abogados particulares que han generado indemnizaciones de perjuicios, que las de abogados pertenecientes a las instituciones de asistencia jurídica gratuita o abogados de turno. De hecho, después de una extensa revisión, solo se ha detectado un caso, en que la CA de Santiago en sentencia de 8 de junio de 2018, ratificó sentencia del 21ํJuzgado Civil de Santiago, de 12 de julio de 2017, que condena a la CAJ de la Región Metropolitana, por su actual negligente, que dicen relación entre otras conductas, con la no presentación de una lista de testigos en el término probatorio, en conformidad a la exigencia del artículo 319 del CPC, que desencadenó en una sentencia desfavorable para el usuario. Tal como lo informó el Diario Constitucional "en fallo unánime, la CA de Santiago confirmó la sentencia que condenó a la CAJ Metropolitana por su actuar negligente en la representación de un paciente que demandó al Hospital San Borja Arriarán, condenando a la institución a pagar a título de indemnización de perjuicios al afectado la suma de $\$ 15.000 .000$ de pesos. La sentencia del Tribunal de alzada ratificó los fundamentos en relación a la falta de servicio de la CAJ Metropolitana en

\footnotetext{
915 Casos de negligencia inexcusable, se pueden configurar, si dentro del plazo legal, no se presenta una demanda compensación económica en el marco de un divorcio por culpa, en que la mujer representada, solicita una cantidad de dinero en contra de su cónyuge en reparación porque durante los años de convivencia matrimonial se dedicó al cuidado de los hijos y a las labores del hogar, y por esas circunstancias no pudo desarrollar una actividad remunerada o lo hizo en menor medida de lo que podía o quería, dando como resultado que no se puede obtener indemnización alguna. De mayor gravedad son los efectos que se pueden ocasionar en materia penal, en que un imputado podría demandar al abogado defensor que realizó una intervención meramente formal no gestionando acciones y estrategias en pro de su defensa. También puede ocurrir actos delictivos por parte de un abogado que sin perjuicio de la responsabilidad penal puede acarrear responsabilidad civil. Por ejemplo, obtener una indemnización por un atropello de un niño, cobrar el abogado la indemnización por las facultades inherentes al mandato, y posteriormente no restituir el dinero a la familia del fallecido.
} 
la defensa judicial del representado"916. El mismo medio de información reportó que "la resolución sostiene que los hechos no controvertidos fijados en el motivo noveno de la sentencia en análisis, así como la existencia del acto dañoso consistente en la no presentación de la lista de testigos por parte de la postulante de la demandada y la deficiencia en la confección de los libelos de casación y apelación, al no especificar norma reguladora de la prueba, actos que fueron calificados como constitutivos del obrar negligente de la demandada en la tramitación de una demanda de indemnización de perjuicios seguida en contra del Servicio de Salud Metropolitano Central, lo que se extiende a su relación de causalidad con la dictación de una sentencia desfavorable, precisamente por la falta de prueba para acreditar la falta de servicio alegada, realidad fáctica que por los motivos señalados no admiten modificación alguna, dice el fallo del tribunal de alzada"917. La suma indemnizatoria decretada obedece a que se llegó a la convicción, que debido a negligencias en la tramitación de una causa, el derecho constitucional no se otorgó en definitiva, afectándole esta circunstancia directamente a la usuaria privada de recursos económicos, pues la acción civil, por la cual recurrió al organismo prestador, no prosperó, por una causa ajena a la voluntad del interesado, e imputable en este caso a la $\mathrm{CAJ}^{918}$. Esta Sentencia que condena a la CAJ, confirmó la sentencia dictada por el tribunal de primera instancia que había condenado al pago de la misma cantidad ${ }^{919}$.

A nuestro entender el razonamiento del tribunal de primera instancia, y de las cortes fue acertado, porque efectivamente se pudo probar la existencia del actuar

\footnotetext{
${ }^{916}$ DIARIOCONSTITUCIONAL.https://www.diarioconstitucional.cl/noticias/asuntos-de-interespublico/2018/06/11/corte-de-santiago-confirma-sentencia-que-acogio-demanda-por-negligente-defensajudicial/. [Consulta de 18 de mayo de 2020].

${ }^{917}$ IBIDEM. "Luego agrega que por ello es que cumplidas las exigencias de la responsabilidad extracontractual por falta de servicio señaladas en los motivos décimo quinto a vigésimo, ambos inclusive, del fallo en alzada, no cabía sino acoger la demanda de autos".

${ }^{918}$ CA de SANTIAGO. Sentencia causa rol 10.530-2017, de 8 de junio de 2018. "Esta sentencia que acoge la demanda contra el actuar de la Corporación de Asistencia Judicial, a través de su abogado y postulante, obliga a la Corporación de Asistencia Judicial Región Metropolitana, por \$15.000.000 de pesos, en atención a los daños ocasionados al demandante, que por el actual negligente aludido no pudo prosperar en su demanda de indemnización de perjuicios contra un establecimiento hospitalario por la responsabilidad que le cabía en una negligencia, por un erróneo diagnóstico de enfermedad”.

${ }^{919} 21^{\circ}$ Juzgado Civil de Santiago. Sentencia en causa 13.189-2015, de 12 de julio de 2017.
} 
negligente en forma precisa, como asimismo los efectos perniciosos vinculados a ella, y la relación causal, en que se conjuga la responsabilidad concreta del estudiante que no presentó los documentos en los plazos indicados ni fundamentó el recurso que procedía, pero también del abogado que no lo supervisó, debiendo hacerlo.

Según las normas generales de derecho civil, la institución condenada a pagar una indemnización civil por negligencia de uno de sus integrantes o incluso postulantes en caso de las CAJ, puede ejercer el derecho de repetición, iniciando un juicio de cobro de pesos respecto del directamente implicado, sin perjuicio de la responsabilidad institucional que le cabe como persona jurídica. En efecto, no obstante, de las responsabilidades institucionales y personales que pudiesen acreditarse en un caso concreto, claramente existe una responsabilidad última del Estado en cuanto de no generar una conversión total del sistema de asistencia jurídica gratuita, especialmente en lo que dice relación con la generación de una estructura organizativa adecuada, profesionalización del servicio y de incorporación recursos económicos suficientes, para garantizar una dotación de abogados y profesionales colaboradores optimas y que puedan satisfacer la demanda existente proveniente de las necesidades jurídicas de la población.

\section{PROYECTOS POR UNA NUEVA INSTITUCIONALIDAD DE LA ASISTENCIA JURÍDICA GRATUITA EN CHILE}

Desde hace muchos años que las autoridades de turno se han interesado en el mejoramiento de la asistencia jurídica y judicial en el país. Para el logro de este objetivo han planteado diferentes proyectos que tienen por finalidad hacer efectiva esta garantía constitucional. Es dable señalar que la actual institucionalidad consistente en las DPP, CAJ y abogado de turno, que serán analizadas en el Capítulo VI, han sido objeto de constante revisión, especialmente las dos últimas. Así, se han venido discutiendo sobre cuál es la mejor forma de llevar a cabo esta 
labor, y no obstante que los resultados no han sido a nuestro entender los esperados, el Estado ha mantenido la preocupación de cumplir con su deber de garantizar los derechos de las personas, sea que el mismo desarrolle esta función o a través de terceros. Estos proyectos tienen por finalidad satisfacer una necesidad nacional, en el sentido que es de urgencia para la población contar con un sistema de asistencia jurídica gratuita que preste un servicio adecuado, eficaz y profesional. Mediante el mensaje $\mathrm{n}^{\circ}$ 117- 325 de 4 de noviembre de 1992, bajo el gobierno de Patricio Aylwin, se envió al Senado un proyecto de ley para crear el Servicio Nacional de Asistencia Jurídica, que después de la modificación del proyecto en 1995, pasó a llamarse Corporaciones Regionales de Asistencia Jurídica ${ }^{920 .}$

De este proyecto, tal como lo desarrolla Marianela Barriga, se pueden destacar determinadas características ${ }^{921}$ :

a) Crea un Servicio Nacional de Asistencia Jurídica encargado de planificar, programar, coordinar, promover, fiscalizar y proporcionar asistencia jurídica, y no sólo judicial en todo el país;

b) Preceptúa que este servicio tendrá una Dirección Nacional, con responsabilidad por los aspectos organizativos del sistema, encargada de las directrices de funcionamiento, y Direcciones Regionales, de carácter más operativo.

c) Suprime las CAJ creadas por leyes $n^{\circ} 17.995$ y 18.632, pasando a ser el servicio el continuador legal de las mismas.

\footnotetext{
920 El mensaje presidencial hace presente en primer término que es absolutamente necesario generar oportunidades y medios para que los ciudadanos puedan resolver su conflicto conforme a derecho. Asimismo se sostiene la idea de que de este modo se hace efectiva la existencia de un real y auténtico Estado de Derecho y régimen democrático. Así estamos frente a una convivencia civilizada cuando la población tiene mecanismos formales que les permitan resolver sus disputas y aseguren la igualdad ante la ley, otorgando una adecuada asistencia jurídica gratuita, evitando una situación de desventaja de una parte frente a la otra. Es por esta razón que la propia Constitución en su artículo 19 número $3^{\circ}$ otorga el derecho a defensa jurídica como uno de los derechos fundamentales de toda persona, reconociéndose de este modo la importante y urgente responsabilidad del Estado para dar efectividad práctica a dicha garantía

${ }^{921}$ BARRIGA, M (2016). La defensa de los pobres; Instituciones que amparan el ejercicio de sus derechos. Concepción. Universidad Católica de Concepción. pp. 46-47.
} 
d) Consagra a este nuevo organismo como un servicio público funcionalmente descentralizado, con personalidad jurídica y patrimonio propio, y sometido a la supervigilancia del Presidente de la República, a través del Ministerio de Justicia.

e) Se amplía el rango de posibles beneficiarios al incluir a personas jurídicas que no persiguen fines de lucro y tengan su domicilio en Chile, contemplándose además la posibilidad de asistencia jurídica no judicial.

Entre las funciones del organismo que la ley se proponía crear, se podían destacar las siguientes ${ }^{922}$ :

a1) Ejecutar directamente acciones de asistencia jurídica a través de consultorios jurídicos gratuitos, cuando esto no sea posible, el servicio podrá suscribir convenios con cualquier órgano de la administración del Estado y otras entidades, así como con personas naturales o jurídicas privadas.

a2) Informar, educar y asesorar a la población en materias legales de interés general con el objeto de prevenir eventuales conflictos jurídicos o procurar solución a los ya existentes.

a3) proporcionar a los egresados de derecho, postulantes a obtener el título de abogado, la práctica requerida en conformidad a la ley.

En cada región habrá una Dirección Regional, a cargo de un Director, tendrán amplias facultades de organización y operación, dependiendo de la misma los consultorios jurídicos gratuitos que se establezcan en cada región.

Cumpliendo con el trámite de formación de ley, este proyecto fue presentado ante la Comisión de Constitución, Legislación y Reglamento del Senado, donde se produjo la discusión legal de cada uno de los preceptos, decidiéndose la modificación del proyecto original, por estimarse que no era necesario conservar la estructura de una Dirección Nacional, sino generar solo corporaciones con cobertura regional y dotadas de autonomía ${ }^{923}$. El proyecto de ley enmendado

\footnotetext{
${ }^{922}$ IBIDEM. pp 47-48.

${ }^{923}$ BATES, L. Op. Cit., p.35.
} 
mediante moción parlamentaria constaba de 19 artículos permanentes agrupados en seis títulos, y de cinco artículos transitorios. Entre los principales objetivos del proyecto propuesto por la Comisión cuya aprobación se pretende, encontramos los siguientes ${ }^{924}$ :

a) Crear Corporaciones de Asistencia Jurídica en cada una de las regiones del país, con personalidad jurídica y patrimonio propio, que sustituyan las actuales CAJ.

b) Establecer que las referidas corporaciones tendrán como función primordial brindar asistencia jurídica a personas de escasos recursos, tanto directamente como a través de terceros.

c) Precisar que la función principal de las corporaciones será prestar asistencia jurídica y no solo judicial, por cuanto las necesidades de asesoría legal de las personas de escasos recursos alcanzan no solamente a situaciones de conflicto judicial, sino que también a una serie de actos extrajudiciales.

d) Establecer que en caso que se produzca un conflicto jurídico entre dos o más personas con derecho a privilegio de pobreza, la Corporación Regional de Asistencia Jurídica respectiva deberá adoptar las medidas necesarias para que todas ellas sean atendidas adecuadamente.

Sin embargo, luego del arduo trabajo realizado por la Comisión, y de las múltiples discusiones y opiniones al respecto, el proyecto no tuvo mayor desarrollo y no alcanzó a convertirse en ley. Bajo la presidencia de la republica de Ricardo Lagos, mediante oficio $n^{\circ} 20.659$ de 22 de agosto de 2002, el Senado accedió a la proposición de la Cámara de Diputados en orden a disponer el archivo del proyecto de ley que crea las Corporaciones Regionales de Asistencia Judicial ${ }^{925}$.

\footnotetext{
924 IBIDEM.

${ }^{925}$ Así llega a su fin el mayor proyecto ideado y creado en estos últimos 30 años en nuestro país, tendiente a crear un sistema cierto que viniera a llenar el vacío existente en la materia de asistencia jurídica gratuita, cumpliendo de este modo con el anhelo de convertir la garantía constitucional consagrada en el artículo 19 n³, en una garantía real y efectiva beneficiando a quienes más lo necesitan.
} 
En el Informe Anual del año 2017, de la Universidad Diego Portales se analizó un proyecto del año 2006, que pretendía generar un sistema mixto, de defensa oficial, como de abogados subsidiados por el Estado, el que tampoco logró su aprobación como ley de la República ${ }^{926}$. La Presidenta de la República, Michelle Bachelet, al referirse a la implementación de la reforma laboral, en la cuenta pública de 21 de mayo de 2009, aludió a la presentación de un proyecto de asistencia jurídica proporcionada por el Estado, que traspasará lo laboral, el que finalmente no se concretó 927 .

Con fecha 18 de diciembre de 2011, el presidente Piñera anunció la presentación de una iniciativa de ley, que sería ingresada a discusión parlamentaria el próximo semestre, establece el Servicio Nacional de Asistencia Jurídica como sucesor de los actuales organismos. Junto con ello concluiría la práctica profesional de los estudiantes de derecho bajo la tutela del Estado ${ }^{928}$. Este proyecto comenzó a ser elaborado en mayo de 2010, por un equipo liderado por el ex Ministro de Justica Felipe Bulnes ${ }^{929}$. Justamente uno de los énfasis de esta iniciativa de ley radicaba en la supresión de las CAJ y la eliminación de la exigencia de práctica profesional en esta entidad de los egresados de derecho de las diversas Universidades que imparten la carrera de Derecho ${ }^{930}$. Se estimaba adecuado establecer un proceso de transición de la actual institucionalidad a la fórmula legal y orgánica proyectada,

\footnotetext{
${ }^{926}$ UNIVERSIDAD DIEGO PORTALES. (2017). “Acceso a la justicia en Chile”. Op. Cit., p. 198. "Vale la pena consignar que a partir del año 2006 el Ministerio de Justicia se encuentra abocado el estudio y diseño de una institucionalidad destinada a prestar defensa y asesoramiento a quienes no puedan procurárselo por sí mismo. En efecto, se trata un proyecto de ley que crea un servicio público, descentralizado y desconcentrado denominado 'Defensoría y Asesoría Legal', que se estructura sobre la base de una Dirección nacional y de direcciones regionales, además de un Consejo Nacional de Asistencia Jurídica. Este nuevo sistema contempla un sistema mixto de prestación de servicios, a través de profesionales de la institución y de externos, los que se podrán ser contratados por medio de distintas modalidades, como por ejemplo, licitaciones públicas, convenios directos, entre otros".

927 IBIDEM. "Más aun, aseguraremos que los trabajadores cuenten con asesoría legal especializada y profesional. Por eso, prontamente ingresare al Congreso Nacional un Proyecto de ley que crea un Servicio Público y Nacional de Asesoría Jurídica, el que brindara asesoría de calidad para los trabajadores, pero también a las familias que no cuentan con medios para procurárselas por sí mismos”.

928 TAGLE, A (2020). https://www.elmercurio.com/legal/movil/detalle.aspx?Id=900807\&Path=/0D/BE/. [Consulta de 16 de mayo de 2020].

929 IBIDEM.

${ }^{930}$ IBIDEM.
} 
para lograr que el nuevo servicio fuese del todo profesionalizado y especializado ${ }^{931}$. Este proyecto, planteaba que tanto la asesoría como la representación y patrocinio judicial bajo este nuevo servicio, serán otorgadas respecto de aquellas materias que son de competencia de los juzgados de familia, del trabajo y letras (que no se refieren a procedimientos contenciosos en materias comerciales y mineras). Así también incluyen temas penales y civiles de juzgados de garantía, materias de tribunales de juicio oral en lo penal, y defensa de derechos humanos (sobre personas que habiten en Chile) ${ }^{932}$.

A juicio de Alicia Tagle, "uno de los aspectos más innovadores del Servicio Nacional de Asistencia Jurídica es que las causas de aquellas materias que determine su director, junto con el Consejo Nacional que lo asesorará, podrán ser asumidas por prestadores externos, a quienes se accederá mediante un sistema de vouchers" Tal como lo desarrolló el proyecto, no obstante la arista de prestadores externos, el Servicio Nacional de Asistencia Jurídica contaría con una Dirección Nacional, al mando de un Director Nacional, cuyo nombramiento dependerá del sistema de alta dirección pública, y Direcciones Regionales (una en cada región del país, a excepción de la región metropolitana, que contará con dos) ${ }^{934}$.

Ante la no aprobación del referido proyecto, en materia de asistencia jurídica gratuita podemos constatar que el único proyecto que sigue vigente es precisamente una modificación del artículo 523 del COT, en cuanto a los requisitos para ser abogado, pero que en ningún caso alude a que estas prácticas estarán a cargo de las

\footnotetext{
${ }^{931}$ IBIDEM. "El objetivo a corto plazo, antes dela aprobación e implementación de la ley que se proyecta es preparar a las actuales instituciones de asistencia jurídica gratuita, especialmente Corporación de Asistencia Judicial, para su fin y hacer una transición al nuevo mecanismo, ciento por ciento profesionalizado y especializado. Gran parte de la calidad es la profesionalización, acompañado de una buena plataforma en materia de gestión; de la incorporación de mecanismos y procedimientos de control y evaluación”.

932 IBIDEM.

${ }^{933}$ IBIDEM. p. 2. "Para ello existirá un registro de abogados (creado y administrado por el servicio), que deberán haber rendido un examen habilitante sobre el área de especialidad en que prestarán asesoría y acreditado sus plataformas administrativas y tecnológicas de trabajo. Sin embargo, al igual que los prestadores que dependan de la institución, estarán sometidos al control y evaluación de ésta”.

${ }^{934}$ IBIDEM. p.p. 2-3. El Director Nacional será asesorado por un Consejo nacional, compuesto por el ministro de justicia -quién lo presidirá-, de hacienda y de desarrollo social. Además por un abogado especializado en litigación y asistencia judicial, representante del colegio de abogados con mayor cantidad de afiliados, y un académico con trayectoria universitaria de mínimo cinco años en derecho civil o laboral, representante de Consejo de rectores y Universidades autónomas”.
} 
Universidades o que los servicios de asistencia jurídica gratuita serán completamente profesionalizados, como se ha aspirado, por lo cual no se puede considerar en base a lo que hemos revisado, como un esfuerzo serio de reforma en cuanto a la manera de otorgar mecanismos idóneos de que posibiliten el ejercicio de derechos, cumpliendo con estándares de calidad y adecuación. En estricto rigor, este proyecto se circunscribe que las CAJ, además de realizar convenios con DPP o Ministerio Público para la realización de las prácticas profesionales, podrá hacerlo con otras instituciones públicas y privadas $^{935}$. Aunque la ley no está aprobada, existen ciertos convenios vigentes entre la CAJ y algunos organismos, entre los que destaca el suscrito con el SERNAMEG y Servicio Nacional del Consumidor, por lo cual su concreción legislativa avala una buena práctica interinstitucional. Este proyecto también establece la posibilidad de que los funcionarios públicos puedan convalidar su experiencia judicial para efectos de cumplir con el requisito legal habilitante para prestar el juramento respectivo y desempeñarse como abogado ${ }^{936}$.

Estos proyectos de ley y anteproyectos, se refirieron a reformas al "por mayor", que tenían por objeto una modificación al sistema institucional de asistencia jurídica gratuita en forma íntegra, configurando un cambio o giro institucional y orgánico, los que como hemos consignado, no han tenido mayor avance.

\footnotetext{
935 INFORME DE LA COMISION DE CONSTITUCION, LEGISLACION, JUSTICIA Y REGLAMENTO de 29 de mayo de 2018, recaído en proyecto de ley refundido que modifica el Código Orgánico de Tribunales en materia de práctica profesional para obtener el título de abogado. El proyecto que se encuentra en segundo trámite constitucional, a los requisito $1^{\circ}, 2^{\circ}, 3^{\circ}, 4^{\circ}$ del artículo 523 , modifica el $5^{\circ}$, adicionando como requisito para ser abogado "Haber cumplido satisfactoriamente una práctica profesional por 6 meses en las Corporaciones de Asistencia Judicial a que se refiere la ley 17.995 y n 18.632, circunstancia que deberá acreditarse por el Director General de la respectiva Corporación. Las Corporaciones de asistencia judicial, para este efecto, podrán celebrar convenios con el Ministerio Público y otros organismos, servicios e instituciones que, con arreglo a la ley o sus estatutos, presten asesoría jurídica y judicial gratuita. Tales Convenios se celebrarán previo acuerdo del Consejo directivo de la respectiva corporación.

${ }^{936}$ IBIDEM. Modifica el artículo $523 \mathrm{n}^{\circ}$ 5, inciso $3^{\circ}$, en los siguientes términos: "La obligación establecida en el $n^{\circ} 5$ se entenderá cumplida por los postulantes que sean funcionarios o empleados del poder judicial por el hecho de haber desempeñado sus funciones durante cinco años, en las primeras cinco categorías del escalafón personal de empleados u oficiales de secretaría. Asimismo, los funcionarios o empleados del Ministerio Público, la Defensoría Penal Pública y las Corporaciones de Asistencia Judicial, que postulen al título de abogado podrán solicitar se tenga cumplida la misma exigencia siempre que reúnan los siguientes requisitos:

-Haber servido a lo menos 5 años en la Institución.

-Haber desempeñado funciones de orientación jurídica o de asistencia judicial por 6 meses dentro de dicho periodo. Para acreditar esta circunstancia el postulante deberá acompañar un certificado suscrito por el jefe del servicio en que se acredite el cumplimiento de estas labores, señalando la unidad y fecha en que fueron ejercidas. -Observar una buena conducta funcionaria”.
} 
Sin embargo, las reformas exitosas han sido las "al por menor", focalizándose en áreas especializadas, en lo penal, laboral, y en derecho de familia. Un factor diferenciador tras estas reformas ha sido su carácter auxiliar a reformas sistémicas a la justicia en temáticas especializadas, las cuales, al cambiar la dinámica del ejercicio profesional en litigio, por exigir con mayor intensidad la presencia del letrado en audiencias orales, tornaba antiética la mantención de la representación judicial por medio de estudiantes de derecho, rotativos, inexpertos y sobrecargados de causas ${ }^{937}$. Tal como lo expresa Pablo Fuenzalida, "desde un punto de vista constitucional se corregía un problema de igualdad de armas ante la persecución penal a cargo del Ministerio Público y la defensa de empleadores representados por abogados laboralistas, que ahora enfrentaban a un par simétrico" ${ }^{938}$. A juicio de este mismo autor, "las reformas 'al por menor' enseñan que estas mejoras resultan efectivas por tratarse de consecuencias necesarias para la puesta en marcha de cambios sistémicos al escenario en el cual se ejerce como abogado litigante. De seguirse una estrategia incremental o gradualista similar, se requeriría reformar la asistencia jurídica gratuita de la mano de las reformas procesales pendientes, lo cual prácticamente se reduce a la reforma procesal civil”939.

Una de las modificaciones más recientes se enfocó en la asistencia jurídica gratuita en la justicia de familia y laboral que involucraban a las CAJ. Una de las principales modificaciones a los procesos de familia realizada a través de la Ley no 19.968 que crea los tribunales de familia, de 30 de agosto de 2004, fue establecer como regla general la comparecencia personal en los nuevos tribunales, inspirada en la idea de conseguir una justicia más accesible al ciudadano común, lo que se traducía

\footnotetext{
${ }^{937}$ La reforma procesal penal y la reforma laboral en Chile, exige un sistema profesionalizado de ella, prueba de ella de ella es la Defensoría Penal y la Defensoría Laboral, en su caso.

${ }^{938}$ FUENZALIDA,P.(2019).https://www.elmercurio.com/Legal/Noticias/AnalisisJuridico/2019/11/06/Acceso-a-la-justicia-y-nueva-agenda-social.aspx. [Consulta 14 de mayo de 2020].

${ }^{939}$ IBIDEM. "En familia se fue avanzando del descalabro de la comparecencia personal hacia la representación con mayor presencia profesional y supervisión de los postulantes, aumentando las jornadas laborales de los abogados de las corporaciones de asistencia judicial, así como al permitirles representar ambas partes en conflicto jurídico”.
} 
evidentemente en el abandono de la exigencia de asistencia letrada para los justiciables ${ }^{940}$.

Del estudio de las actas de la Ley 20.286, de 15 de septiembre de 2008, que introduce modificaciones orgánicas y procedimentales a la Ley 19.968, tuvo por objeto subsanar los nudos críticos que generó la no inclusión de la defensa letrada como requisito, retomándose con esta ley la comparecencia letrada obligatoria ${ }^{941}$. Específicamente, este cuerpo normativo introduce un nuevo artículo 18 a la Ley no 19.968, que invierte la regla de comparecencia en los tribunales de familia. A partir de la presente modificación, la regla general en procedimientos ordinarios será la comparecencia letrada obligatoria, a menos que el juez por motivos fundados permita la comparecencia personal. Así, por ejemplo, en caso de renuncia del abogado patrocinante o de abandono de hecho de la defensa, el tribunal deberá designar de oficio a otro que la asuma, a menos que la parte lo reemplace por uno de su confianza.

De acuerdo al mensaje del ejecutivo, las razones de la mutación de una defensa no letrada a técnica en la litigación de familia apuntan a mejorar tres materias: a) un mayor aseguramiento del acceso a la justicia de los ciudadanos, b) el perfeccionamiento de los procedimientos de los tribunales de familia, c) una mayor eficacia en la administración de justicia (al producirse filtros previos de causas que llegan finalmente al conocimiento de los jueces).

Tal como lo advierte Correa, "Al mismo tiempo, el inciso segundo del nuevo artículo 18 establece, como un elemento inseparable de la regla anterior, que las partes podrán ser patrocinadas y representadas en juicio por las CAJ. La redacción de este inciso es muy importante para el desarrollo del sistema, ya que comienza señalando que 'ambas partes' podrán ser defendidas por esta Corporación, lo que no ocurría antes de esta modificación, puesto que cuando una de las partes era representada

\footnotetext{
940 UNIVERSIDAD DIEGO PORTALES. “Acceso a la justicia en Chile”.Op. Cit. p. 195

${ }^{941}$ BIBLIOTECA DEL CONGRESO NACIONAL. Historia de la ley n 20.286. www.bcn.cl/histley/lfd/hdl20.286/HL20286.pdf [Consulta 24 de mayo de 2020]. "Más allá de los cuestionamientos teóricos a esta norma, en los primeros años de aplicación del nuevo sistema se apreciaron serios problemas tanto en la eficiente defensa de los derechos de los recurrentes, como en la gestión de los tribunales y, el desarrollo del procedimiento”.
} 
por ese organismo la otra parte no podía serlo, todo por aquello que no se puede representar a ambas partes al mismo tiempo"942.

Esta norma de la comparecencia letrada en materia de familia, impacta decididamente en la asistencia jurídica gratuita, ya que esa forma de comparecencia se traducirá en una mayor actividad del Estado para satisfacer el derecho a la defensa de aquellas personas que no cuentan con abogados. Además, la normativa que reformula positivamente la reciente reforma, se hace cargo de los deberes constitucionales dirigidos al Estado asegurando una defensa profesional a través de CAJ.

Dentro de las reformas al "por menor", también debemos considerar la Ley $\mathrm{n}^{\circ}$ 20.087, de 3 de enero de 2006, que sustituye el procedimiento laboral contemplado en el Capítulo $V$ del Código del Trabajo, modificando esta manera el procedimiento laboral, cuya puesta en marcha se inició en forma gradual el 31 de marzo del $2008^{943}$.

El informe de Derechos Humanos 2017 de la Universidad Diego Portales pone en relevancia a la profesionalización de la defensa en materia laboral, pues "la nueva estructura procedimental exige que la litigación esté a cargo de abogados habilitados para el ejercicio de la profesión, eliminando con ello la participación de los postulantes, lo que obligó a las autoridades a buscar algún mecanismo de asistencia jurídica letrada" ${ }^{94}$.

\footnotetext{
${ }^{942}$ CORREA, J. (2009). Derecho Procesal de Familia. Santiago. Editorial Thompson Reuters Puntolex. p. 39. ${ }^{943}$ La puesta en marcha gradual de esta reforma contempló 5 etapas. La primera, siendo la primera la que incluyó las regiones II Y XII y la última etapa que contempló las regiones IX,X,XI y XV a iniciarse el 30 de octubre de 2009.

${ }^{944}$ UNIVERSIDAD DIEGO PORTALES. (2017). “Acceso a la justicia en Chile”. Op.Cit.p.197. "En efecto, la senadora Soledad Alvear, junto con los diputados Eduardo Safirio y Patricio Vallespín, presentaron en agosto de 2006 un proyecto de ley para crear la figura del defensor laboral, iniciativa que contó con el respaldo de la CUT. Sin defensa para los trabajadores vamos a tener un pie cojo, señaló en su oportunidad la senadora, refiriéndose a la necesidad de garantizar a los trabajadores una defensa profesional gratuita que asegure el ejercicio y respeto de los derechos laborales. Esta preocupación que fue bien recepcionada por el gobierno, se materializó a través del programa de Defensa Laboral del Ministerio de Justicia, con profesionales de la Corporación de Asistencia Judicial”. "La misión de este programa será entregar defensa jurídica profesional y especializada a los trabajadores que no tengan recurso económicos. Se trata de una figura similar a la del defensor penal, pero que se instala orgánicamente al alera de las CAJ y supone la contratación de profesionales especializados y distribuidos territorialmente”.
} 
Las Oficinas de Defensa Laboral (ODL) han podido cumplir los objetivos trazados y se ha consolidado como una institución que representa de buena forma a los trabajadores, en los diversos juicios en que han de representar los intereses de los que cumplan con los requisitos para ser atendidos, lo que dice relación con sus ingresos. La decisión gubernamental de entregar a las CAJ la representación de los trabajadores no ha estado exenta de críticas, como se ha expresado en el Informe aludido recientemente, pues "la creación de la figura de defensores para la nueva judicatura laboral parece necesaria y acertada, pero la modalidad empleada, programa ad hoc, monitoreado por el Ministerio de Justicia con abogados dependientes de la CAJ, pone en evidencia la ausencia de un sistema de asistencia jurídica gratuita que integre y articule todas las áreas en que se deben prestar estos servicios" 945 .

A través de este análisis podemos observar que el Estado chileno ha presentado a lo largo de los años una constante preocupación por el fortalecimiento del sistema jurídico, sobre todo en cuanto a la asistencia jurídica gratuita. Sin embargo estos esfuerzos parecen no ser muy fructíferos, ya que durante aproximadamente 30 años se han discutido proyectos que pretenden mejorar y dar mayor calidad al acceso a la justicia para las personas, continuando con una institucionalidad que prosigue presentando falencias estructurales y de funcionamiento.

Es importante fortalecer áreas que impliquen el perfeccionamiento de los profesionales que realizan sus funciones en estas instituciones, las necesidades sociales evolucionan y con ello se crean nuevas soluciones jurídicas, que los abogados y auxiliares de justicia deben conocer ${ }^{946}$.

La nueva agenda social anunciada por el gobierno del presidente Sebastián Piñera, con fecha 22 de octubre de 2019, en el contexto del denominado "estallido social",

\footnotetext{
945 IBIDEM. p. 197.

946 "El Estado chileno debe tomar conciencia y tratar con seriedad el tema del acceso efectivo a la justicia a través de una reforma sustancial al actual sistema, con el objetivo de fortalecer aquellos aspectos que podrán dar un mejor servicio a la comunidad, como entregar mayor información a los usuarios, aumentar el número de abogados en las CAJ para una mejor distribución de causas y mejorar los canales de comunicación entre usuarios y abogados".
} 
al que hicimos referencia en el apartado 7.3 del Capítulo I de este trabajo, incluyó, la asistencia jurídica gratuita pero acotada a lo políticamente sostenible, las víctimas de la delincuencia. Al tenor de lo expuesto por Fuenzalida "los incentivos que impone la actual coyuntura por soluciones inmediatas dificultan pensar sobre el acceso a la justicia como una política social de largo aliento, pero una nueva postergación puede terminar por incubar un nuevo quiste que a futuro nos lleve a experimentar otro estado de ebullición (...) El veredicto sobre si Chile cambió o no lo entregará la historia, no así aquel relativo al devenir del acceso a la justicia y su necesario complemento, la asistencia jurídica"947. En este contexto de convulsión, se entendió por parte del gobierno que no era el momento de hacer reformas macros en asistencia jurídica gratuita, pues no respondía a las necesidades sociales insatisfechas reclamadas por el movimiento social, considerando que supuestamente estas necesidades están cubiertas por la actual institucionalidad, solo avocándose a la seguridad ciudadana, con la promesa de implementación de una Defensoría de Víctimas, lo que aún no se concreta, estando pendiente su implementación desde la modificación de la Ley 20.516, de 11 de julio de 2011, que generó una reforma constitucional que establece la obligación de otorgar defensa penal y asesoría jurídica a las personas naturales que han sido víctimas de delitos y que no pueden procurárselas por sí mismas ${ }^{948}$.

A nuestro juicio habría sido una gran posibilidad haber tomado el anuncio presidencial como una oportunidad para corregir los diversos problemas asociados con la asistencia jurídica gratuita, entre ellos, la desprofesionalización y escases de recursos, que se evidencian desde sus orígenes.

El acceso a la justicia en nuestro país sigue siendo una garantía constitucional que tiene desafíos pendientes. No obstante, no transitamos por la avenida de quienes

\footnotetext{
${ }^{947}$ FUENZALIDA,P.(2019).https://www.elmercurio.com/Legal/Noticias/Analisis-

Juridico/2019/11/06/Acceso-a-la-justicia-y-nueva-agenda-social.aspx. [Consulta 14 de mayo de 2020].

${ }^{948}$ LEY 20.516. Reforma Constitucional que establece la obligación de otorgar defensa penal y asesoría jurídica a las personas naturales que han sido víctimas de delitos y que no pueden procurársela por sí mismas. Artículo 1: "La ley señalará los casos y establecerá la forma en que las personas naturales víctimas de delitos dispondrán de asesoría y defensa jurídicas, a efecto de ejercer la acción penal reconocida por esta Constitución y las leyes".
} 
consideran que es una garantía que solo está en el papel. Al contrario, valoramos todos los esfuerzos que se han hecho a nivel estatal para remover los obstáculos especialmente económicos, con el objeto de garantizar el acceso a la justicia mediante la asistencia jurídica gratuita procurada por el Estado, en condiciones de igualdad y no discriminación. Sin perjuicio de esta valoración, sostenemos que resulta necesario que se retomen los esfuerzos tendientes a una mayor profesionalización del sistema en las causas civiles y de familia, ampliándose la cobertura a temáticas como policía local o del consumidor, y que esto vaya asociado a la dotación de recursos. Asimismo estimamos de relevancia el aporte de los estudiantes egresados de la carrera de Derecho, pues sin un sistema unificado, dotado de recursos humanos y financieros, continúan siendo la única alternativa de dar cobertura y cumplimiento al mandato constitucional. La profesionalización es absolutamente necesaria, pero debe ser suficiente en número y especialización, para que cumpla sus objetivos a cabalidad.

Lamentablemente nos hemos quedado solo en las buenas intenciones de los gobiernos de turno y en los hechos, instituciones que a nuestro juicio deben tarde 0 temprano reformarse. El Estado de Chile si bien cumple con algunos estándares mínimos en la materia, el sistema existente está lejos de remover los obstáculos económicos que limitan o impiden el acceso a la justicia de los más pobres ${ }^{949}$.

Como pudimos ver han pasado prácticamente 3 decenios desde los primeros esbozos de proyectos que pretendían en un principio crear un sistema de asesoría jurídica nacional y posteriormente mejorar los servicios existentes, sin embargo, se ha insinuado y se profundizará en el Capítulo VI, que las instituciones de asistencia judicial presentan un carácter atomizado o solitario, que se traduce en la existencia de un grupo de instituciones que funciona de manera independiente sin objetivos comunes y sin el respaldo estatal requerido. Lamentablemente, no existen programas de cooperación o coordinación que tiendan a un trabajo en conjunto o

\footnotetext{
${ }^{949}$ UNIVERSIDAD DIEGO PORTALES. UNIVERSIDAD DIEGO PORTALES. (2017). “Acceso a la justicia en Chile”. Op. Cit., p. 177.
} 
planificaciones globales que naturalmente propendan al mejoramiento del acceso a la justicia.

\section{CONSTRUCCIÓN DE UNA POLÍTICA PÚBLICA QUE AYUDE A LA CREACIÓN DE UN SERVICIO DE ASISTENCIA JURÍDICA INTEGRAL}

\subsection{Obligaciones positivas del Estado en Asistencia Jurídica Gratuita}

Una reforma a los sistemas de justicia no solo pasa por la dictación de nuevos códigos y la creación de nuevas instituciones que posibiliten la viabilidad de éstos, sino que requiere la construcción de una política pública que haga efectivo el acceso de las personas marginadas de él, ya sea por ignorancia de sus derechos, condición socio-económica desmedrada, por vulneración e incluso por ubicación geográfica aislada. Por esta razón, es necesario dar una mirada crítica al actual sistema mediante el cual estas personas vulnerables acceden a la justicia, analizarlo y fortalecerlo a través de políticas públicas de asistencia jurídica gratuita, instando a la participación activa de la ciudadanía, con el fin de hacer más justo e igualitario el acceso a nuestro sistema de justicia.

Desde una perspectiva amplia, el gobierno, a través del Ministerio de Justicia, pretende otorgar al público un servicio prestador de asistencia jurídica gratuita coherente, accesible, cercano a las personas, justo e igualitario, en que los individuos puedan hacer valer sus derechos, ofreciéndoles las mismas condiciones de eficacia y agilidad, ya sea que cuenten con recursos económicos para solventar esta asesoría o no ${ }^{950}$.

\footnotetext{
${ }^{950}$ En este mismo sentido, el CPP, adopta todas las medidas normativas necesarias para que las personas que carecen de recursos y, por tanto, no puedan designar abogado pagado de su confianza, reciban la asesoría de un defensor penal público.
} 
El rol del Estado en esa materia es la de asegurar a los ciudadanos la posibilidad de acceder efectivamente a un servicio de calidad que les permita conocer y ejercer oportuna y adecuadamente sus derechos, prevenir conflictos jurídicos y resolverlos en condiciones de equilibrio e igualdad. Para el cumplimiento de este rol estatal, la asistencia jurídica gratuita debe emprender las siguientes líneas de acción:

a) Entregar información acerca de los derechos de las personas y orientación para su ejercicio.

b) Prestar servicios para resolver conflictos en instancias prejudiciales de mediación, negociación, arbitraje y conciliación.

c) Educar y difundir los derechos de las personas, desarrollar redes sociales locales y estrategias de trabajo comunitario que facilitan la prevención de conflictos y la intervención intersectorial.

d) Representar y patrocinar.

e) Ejercer todas las acciones tendientes a facilitar y asegurar la prevención o solución de conflictos jurídicos y un expedito, eficiente y oportuno acceso a la justicia.

f) Participar en el ámbito de la elaboración de propuestas para mejorar el acceso a la Justicia de las personas.

\subsection{Principios orientadores de un ideal de Asistencia Jurídica Gratuita para lograr un efectivo acceso a la justicia}

Tal como lo hemos señalado, la desigual situación en que se encuentra gran parte de la población de nuestro país para ejercer sus derechos, ya sea por razones socioeconómicas, culturales, étnicas, de género, etcétera, realza la importancia de la asistencia jurídica gratuita como única vía para dar cumplimiento a la igualdad ante la justicia asegurada a todos los ciudadanos en la CPR. Esta aspiración de igualdad 
es la principal preocupación de la asistencia jurídica gratuita, y hacia la superación de su marginación se enfocan todos sus esfuerzos, que deben traducirse en los siguientes principios orientadores:

a) Dar un real acceso a la justicia de todos los ciudadanos, especialmente a aquellos que no pueden procurársela por sí misma, es y seguirá siendo la misión fundamental de la asistencia jurídica gratuita. Dicha misión implica que el servicio deberá promover la accesibilidad de las personas al mismo, y desde éste hacía la justicia, la integralidad, oportunidad y eficacia de las respuestas, la participación, empoderamiento y promoción de relaciones de confianza entre las personas.

b) Accesibilidad como principio rector: La igualdad asegurada en nuestra Carta Fundamental, reconoce a toda persona idénticas posibilidades de acceder a la justicia, pero esta igualdad tan anhelada queda solo en un concepto jurídico normativo, si la asistencia jurídica gratuita no contempla acciones que permitan que efectivamente toda persona cualquiera sea su sexo, edad, etnia o condición pueda conocer y ejercer sus derechos, los de su grupo familiar o comunidad, y de protegerlos. Se debe destacar la accesibilidad a la atención de profesionales, aludiendo a la accesibilidad o inmediación, es decir, la posibilidad de toda persona de tener contacto directo con un profesional competente. Pero no sólo estamos hablando de una accesibilidad física o presencial, sino que también horaria. Para facilitar el acceso físico se pueden implementar consultorios móviles o ubicados cerca de donde habitan o circulan habitualmente las personas, y tomar medidas para promover flujos de atención que faciliten la entrevista de los usuarios con los profesionales. Como buena práctica, se debe destacar, que en la emergencia sanitaria provocada por el Covid 19, la atención usuaria se ha hecho en forma remota, tanto en las CAJ como en la DPP. En lo concreto, en lo que dice relación con la CAJ Región Metropolitana, los funcionarios en atención al alto flujo de usuarios y peligro de contagios, por decisión de su Dirección General, desde el 23 de marzo de 2020, se encuentran desempeñando funciones bajo la modalidad de teletrabajo, lo que implica que la atención con cada usuario que requiere asesoría jurídica se hace mediante video llamada y el contacto posterior se realiza por este 
medio o por otros análogos, como comunicación por correo electrónicos o entrevista telefónica. Es dable señalar que la constitución de patrocinio judicial, representación en el proceso y presentaciones de escritos, se realiza vía digital en conformidad a la Ley de tramitación electrónica vigente en Chile desde 2016. La asistencia a audiencias, se desarrolla virtualmente mediante videoconferencias, en conformidad al Auto Acordado 53-2020, dictado por la CS con fecha 9 de abril de 2020.

Se distinguen dos etapas en que la asistencia jurídica gratuita puede actuar, es decir, antes de que el conflicto jurídico aparezca y una vez que éste se manifiesta. La intervención previa a que el conflicto se suscite, se relaciona con que gran parte de los problemas jurídicos atendidos por las actuales instituciones que prestan asistencia jurídica gratuita, pueden ser prevenidos, si se interviene precozmente, anticipándose a su generación. Por lo tanto, es de suma importancia en esta etapa, la difusión y promoción de los derechos que permitan prevenir conflictos sociojurídicos. Una vez que el conflicto se manifiesta, la intervención oportuna evita llegar a etapas más desarrolladas del conflicto y previene que éste se complique. Por esta razón, se hace hincapié en la necesidad de ofrecer un fácil acceso a los profesionales y por ende su intervención inmediata.

c) Respuestas integrales: Los problemas de las personas son multicausales, por lo que teniendo en cuenta dicha complejidad podremos abordarlo eficazmente. Esto involucra trabajo en equipo desde distintas miradas y disciplinas, tanto en el diagnóstico de los problemas, como en el diseño e implementación de la estrategia de intervención. También para lograrlo se necesita de la vinculación con otros servicios, instituciones y organizaciones que desde su mirada aporten una manera distinta y eficaz de entender y enfrentar los problemas. En este sentido, se considera esencial la interdisciplinariedad para otorgar respuestas más integrales, de mayor eficacia y calidad.

d) Promoción de relaciones de confianza y colaboración: Constituye un desafío para la asistencia jurídica gratuita, el promover relaciones de confianza y colaboración entre las personas y los profesionales, y entre las diversas instituciones que directa e indirectamente coadyuvan y propician el otorgamiento de esta prestación con 
estándares de calidad. Asimismo, busca relevar las relaciones que las personas tienen con otros, reforzando los vínculos sociales y el sentido de pertenencia, potenciando de esta manera la capacidad de auto regulación fomentando la responsabilidad de las relaciones sociales que se establecen.

\subsection{Participación y empoderamiento en una política pública de Asistencia Jurídica Gratuita}

Es necesaria la promoción constante de la participación protagónica de las personas en la prevención y/o superación de los conflictos jurídicos-sociales que les afectan, transitando paulatinamente desde un rol secundario y pasivo, de mero receptor de acciones y servicios, a un rol activo en el enfrentamiento de sus problemas, definiendo e implementando acciones para el goce y ejercicio de sus derechos.

El empoderamiento es el resultado de la interacción entre las personas y el servicio, que potencia el desarrollo de un conjunto de destrezas, habilidades y conocimientos del usuario, y fomenta el empleo de sus espacios y organizaciones, con miras a la construcción de relaciones más justas e igualitarias.

La participación es necesaria los siguientes ámbitos de la asistencia jurídica gratuita:

a) Respecto del usuario. El servicio debe incorporar a las personas, motivarlas y permitirles apropiarse de los procesos. La participación de los usuarios debe involucrar la definición de sus necesidades y problemas, y también la forma como resolverlos. Para esto se requiere:

a1) La creación de canales adecuados que le permitan al usuario conocer sus derechos, ejercer y resolver sus conflictos. En este sentido en Chile, un avance lo ha constituido la implementación por parte del Poder Judicial, de la Oficina Judicial Virtual, a través de su sitio web www.pjud.cl, que permite a toda persona y no solo 
a los abogados, en forma digital, realizar presentaciones y/o demandas, revisar los expedientes virtuales, sin necesidad de aproximarse al tribunal. Esto, necesariamente, debe ir acompañado de una educación cívica y participación de los medios de comunicación, con la finalidad de que las personas sean instruidas en la utilización de la plataforma, pues de lo contrario, su escaso o inadecuado uso se pudiese transformar en un nuevo obstáculo ${ }^{951}$.

a2) Que las personas tengan poder para decidir sobre la forma o procedimiento de resolución de conflictos, que le sea más adecuada a sus necesidades, esto es, participación activa en su caso.

a3) Incorporar al usuario en el proceso de resolución de su problema.

a4) Fomentar la comparecencia personal de los usuarios en tramites determinados en que la presencia del abogado no es imprescindible, debidamente asesorados por profesionales, y de otras formas de actuación judicial que ofrezcan mayores posibilidades de intervención directa de los usuarios en tribunales ${ }^{952}$.

a5) En la evaluación de la gestión de la asistencia jurídica gratuita.

b) Respecto del servicio:

b1) A nivel organizacional. Los equipos locales deben tener la facultad de planificar y ejecutar el desarrollo de las distintas líneas de acción, a partir de su realidad local. El diseño metodológico del trabajo de asistencia jurídica gratuita debe ser participativo, en el que se potencie el trabajo en equipo, el que permite que los problemas de los usuarios sean tratados en forma integral e interdisciplinaria.

\footnotetext{
${ }^{951}$ Este año la Oficina Judicial Virtual, a la cual se puede acceder con la clave única proporcionada gratuitamente por el Registro Civil e Identificación, ha incorporado una opción de "trámite fácil”, ante lo cual, completando digitalmente algunos datos sencillos, se puede acudir virtualmente al tribunal, para realizar una petición. En materia de familia, el trámite fácil implementado en la OJV del Poder Judicial permite solicitar una liquidación de una deuda alimenticia, o solicitar un apremio en caso de incumplimiento de la obligación por parte del alimentante. En materias civil, laboral o penal, se pueden solicitar desarchivos de causas por esta vía.

${ }^{952}$ En este sentido, los sistemas de mediación obligatoria en materia de familia, constituyen un claro ejemplo de empoderamiento del propio afectado o interesado en la resolución de un conflicto de relevancia jurídica.
} 
Potenciar las capacidades individuales de cada miembro del equipo, permitiéndole incorporarse activamente al desarrollo de los objetivos propuestos.

b2) A nivel institucional. En este punto, la participación se manifiesta mediante la definición de políticas públicas en temas de justicia, esto es, aporte en el ámbito legislativo, en su evaluación y propuestas a la organización jurisdiccional y presencia en la cultura nacional. Todo esto, sirviéndose de la opinión pública, de la difusión de derechos, la prevención de conflictos sociales, las acciones de interés público y la labor formadora de ciudadanos; elevando el nivel de vida de los más desprotegidos, fin último de la asistencia jurídica.

\section{CARACTERÍSTICAS Y FUNCIONES DE UNA ASISTENCIA JURÍDICA GRATUITA COHERENTE CON LOS ESTÁNDARES DE DERECHOS HUMANOS}

\subsection{Valores de una moderna Asistencia Jurídica Gratuita}

El sistema de asistencia jurídica debe tener una estructura desconcentrada territorialmente, tanto en su gestión como en su administración. Esta desconcentración permite cumplir con su principio rector "la accesibilidad", ya que facilita la presencia institucional en las distintas zonas del territorio, haciendo posible la respuesta oportuna y eficaz acorde con la realidad local. La asistencia jurídica debe prestarse con transparencia, lo que se vincula con la publicidad y el ajuste a estándares de probidad que deben observar los servidores públicos en el ejercicio de sus funciones. En relación a la transparencia, una entidad prestadora de asistencia jurídica gratuita debe ser clara y contar con procedimientos preestablecidos y públicamente conocidos, en cuanto a la selección de personal, definición de funciones y perfil de cada cargo, carrera funcionaria, evaluación por desempeño, como asimismo, condiciones, causales y derechos emanados del término de la relación laboral. Además se debe contar con la dotación de profesionales y personal de apoyo necesario para asesorar debidamente a sus 
usuarios. La formación profesional, teórica y práctica, es imprescindible para el desempeño de la labor encomendada y el buen funcionamiento del sistema. Las entidades que brindan este servicio y por consiguiente las personas que las hacen operativas, deben interiorizarse de la realidad de los sujetos beneficiarios del servicio y enfocar las estrategias de acción a la satisfacción de sus necesidades, siendo flexibles y contando con la capacidad organizacional y de recursos humanos suficientes y adecuados, que les permitan adaptarse a los desafíos de diversa índole que se presenten. En el punto de la flexibilidad, la pandemia del Covid 19 y sus múltiples efectos, claramente ha constituido un punto de inflexión para medir la capacidad de adaptación en pos del cumplimiento del mandato constitucional y de los objetivos institucionales.

\subsection{Funciones del sistema de Asistencia Jurídica Gratuita}

Las principales funciones del sistema de asistencia jurídica gratuita se relacionan con la prevención y la resolución.

a) Prevención: En este sentido, las líneas de acción están constituidas por la orientación, información, conocimiento y difusión de los derechos de las personas y de la forma como ejercerlos, y están dirigidos a precaver los conflictos sociojurídicos, tanto en el ámbito individual como colectivo. Para este fin nos parece que la asistencia jurídica debe crear y utilizar todos los medios de que disponga, es decir, programas a través de los medios de comunicación masiva, entrega de folletos y libros educativos, como asimismo, charlas y foros que desarrollen en poblaciones, escuelas públicas, liceos industriales, etc.

b) Resolución: En este punto se contemplan las distintas formas de resolución de conflictos.

b1) La asistencia jurídica gratuita debe ofrecer al público formas de solución de conflictos que ellos elijan y que partiendo de sus necesidades ayuden a la paz 
social. Es así como durante los últimos años se han desarrollados por las CAJ, mecanismos alternativos no litigiosos de resolución de conflictos ${ }^{953}$.

b2) La asistencia jurídica gratuita debe cooperar con la resolución de conflictos por la vía jurisdiccional, que requiere de representación y asistencia en juicio, tanto en el caso de particulares como en el de grupos o colectividades. Esta forma de resolución de conflictos requiere por parte del profesional, empatía para situarse en la posición de usuario y ver desde su óptica las necesidades del mismo. Por lo tanto, el mayor protagonismo del usuario es fundamental para lograrlo.

\subsection{Revisión y propuestas de Asistencia Jurídica Gratuita}

La asistencia jurídica gratuita es una función pública del Estado, que hoy en la actualidad traspasa el ámbito individual y se sitúa en el público, asumiendo la representación de los intereses de toda la colectividad, en que se involucran derechos fundamentales que les afectan a la sociedad en su conjunto, para la defensa de los derechos humanos, y el logro de la paz social.

Desde esta perspectiva, las acciones se orientan en contra de la discriminación de grupos marginados y a mantener relaciones de poder equilibradas.

Se consideran formas de intervención eficaces las siguientes:

a) Propuestas legislativas de asistencia jurídica gratuita. Tienden a la protección de los derechos fundamentales, recogiendo la visión que tienen las personas pobres y pertenecientes a grupos en condición de las leyes e instituciones y abogando por su interés al momento de evaluar dichas leyes e instituciones.

b) Aplicación e interpretación judicial amplia de las normas jurídicas y de los tratados internacionales mediante la intervención por la vía jurisdiccional.

\footnotetext{
953 Se contemplan, entre ellos, la mediación, la negociación y la conciliación, que presentan un mayor índice de cumplimiento de acuerdos, economizan recursos a las partes y descongestionan los tribunales.
} 
c) Generación de opinión y debate, incorporando la opinión pública en la representación de intereses sociales. Evaluación de las actuaciones de los poderes públicos y de particulares, como apoyo a la defensa de las personas y contribución a las políticas públicas.

d) La necesidad de contar con un servicio de asistencia jurídica integral se ha acrecentado en nuestro país, debido a la gran cantidad de personas que requieren hoy día de ella. Por lo tanto, es un imperativo del Estado fortalecer las políticas públicas de asistencia jurídica gratuita que permitan la realización de acciones que representen las reales necesidades locales y regionales, para propender o generar un real acceso a la justicia. 


\section{CAPÍtUlO VI. POLITICAS PÚBLICAS, NECESIDADES JURÍDICAS DE LA POBLACIÓN E INSTITUCIONALIDAD DE LA ASISTENCIA JURÍDICA GRATUITA EN CHILE}

\section{POLÍTICAS PÚBLICAS Y BUENAS PRÁCTICAS EN AMÉRICA LATINA Y EN CHILE EN MATERIA DE ACCESO A LA JUSTICIA Y ASISTENCIA JURÍDICA GRATUITA}

En concordancia con la concepción amplia e integral de acceso a la justicia, la oferta de servicios de asistencia jurídica gratuita implica no solo la existencia y disponibilidad de mecanismos estatales de índole jurisdiccional, sino la consideración de dispositivos de resolución alternativas de conflictos, como asimismo la inclusión de prestadores privados en su consecución. A este respecto, a la luz de lo expresado en el Informe Anual de Derechos Humanos de la Universidad Diego Portales del año 2017, "una concepción amplia de acceso a la justica, va más allá de la sola provisión de procedimientos e instancias judiciales de resolución de conflictos. Supone además integrar dentro de la oferta estatal, además del acceso a un proceso judicial, mecanismos alternativos de resolución de conflictos, dispositivos de información y orientación legal y el uso de tecnologías de la información, por mencionar algunas formas de expandir el derecho de acceso a la justicia. Implica también dejar de circunscribirlo a la provisión de asistencia 
jurídica gratuita por parte del Estado y utilizar para su evaluación una mirada comprensiva de las distintas dimensiones que este comprende" 954.

En cuanto a una conceptualización de políticas públicas, Manuel Tamayo, expresa que "son el conjunto de objetivos, decisiones y acciones que lleva a cabo un gobierno para solucionar los problemas que en un momento determinado, los ciudadanos y el propio gobierno consideran prioritarios" ${ }^{\prime 255}$. Desde este punto de vista, las políticas públicas se pueden entender como un proceso que se inicia cuando un gobierno o un directivo público detecta la existencia de un problema que, por su importancia, merece su atención y termina con la evaluación de los resultados que han tenido las acciones emprendidas para eliminar, mitigar o variar ese problema. Por su parte, Almela las ha definido como "acciones que desarrolla un órgano del Estado para dar respuesta a unas demandas sociales"956. Bajo esta lógica, cuando surge una necesidad social, el Estado como responsable de satisfacer y garantizar estas necesidades, debe adoptar aquellas medidas adecuadas para darle respuesta.

A diferencia de las políticas públicas, y en una lógica de género a especie, las buenas prácticas de políticas públicas en acceso a la justicia, son acciones concretas circunscritas en tiempo y espacio, que tienen por características ser innovadoras, efectivas, sostenibles y replicables. Su objetivo ha de ser la eliminación de barreras a la población en condición de vulnerabilidad para poder acceder a la justicia en condiciones de igualdad ${ }^{957}$.

A juicio de Almela, y como lo hemos sostenido en el desarrollo de nuestra tesis, "las limitantes de acceso a la justicia, que los Estados democráticos se han esmerado en vencer o mitigar a través de las reformas procesales, no han repercutido en aminorar las dificultades en el ejercicio de los derechos, especialmente de los grupos vulnerables, centrándose los esfuerzos estatales en la eliminación de las trabas socioeconómicas, relacionados con la asistencia jurídica, siendo estas

\footnotetext{
${ }^{954}$ UNIVERSIDAD DIEGO PORTALES. (2017). “Acceso a la justicia en Chile”. Op. Cit., p.380.

955 TAMAYO, M. (1997). “El Análisis de las Políticas Públicas”, EN Bañón y Carrillo. (1997): “La Nueva Administración Pública”. Madrid. Alianza Editorial. pp.281-312

${ }^{956}$ ALMELA, C. Op. Cit., p. 1.

${ }^{957}$ IBIDEM. p. 12.
} 
acciones, aún insuficientes, para lograr un efectivo acceso y una asistencia jurídica concordante con los estándares de constitucionalidad y convencionalidad ${ }^{958}$.

Las carencias que se desprenden en todos los ámbitos de acceso a la justicia deben ser analizadas desde la óptica de las necesidades jurídicas de la población, y como lo ha sostenido el PNUD, se requieren generar los mecanismos necesarios para la efectiva realización de los derechos ${ }^{959}$. Resulta imprescindible de esta forma plantear la emergencia de las políticas públicas de acceso a la justicia provenientes de una construcción institucional basada en las necesidades jurídicas de la población. EI PNUD, establece como premisa la obligación estatal de crear una oferta de servicios de justicia que se adapte a las necesidades jurídicas de la población. En efecto, la posición del programa en este punto, consiste en que "se debe crear una oferta de servicios de justicia que se adapte a las necesidades presentes de la sociedad y las singulares condiciones de cada grupo de vulnerabilidad, según corresponda, requiriéndose configurar un mecanismo de diagnóstico capaz de identificar tanto los niveles de incidencia de una problemática jurídica determinada, como las características específicas que presenta o los condicionamientos socioeconómicos que la rodean"960. Se entrega relevancia a la detección de necesidades jurídicas en la población, y especialmente de las no resueltas. En este orden, resulta imprescindible la verificación de las necesidades que se encuentran resueltas por el sistema de justicia instaurado, y el estudio de los mecanismos formales de resolución, como asimismo, aquellas que no pueden ser satisfechas $^{961}$. Sobre las carencias identificadas se trata de impulsar reformas

\footnotetext{
${ }_{958}$ IBIDEM. "Un examen acerca del panorama nacional muestra que pese, a la enorme cantidad de reformas procesales que nuestro ordenamiento jurídico ha experimentado en estos últimos años, el acceso a la justicia sigue siendo una asignatura pendiente. Desde el retorno a la democracia, todos los gobiernos que han estado en el poder, cualquiera sea su color político, si bien han desarrollado iniciativas y proyectos de distinto tipo, no han podido aminorar los problemas de acceso a la justicia de ciudadanos que buscan resolver conflictos simples y cotidianos. Los esfuerzos se han centrado en mejorar los mecanismos de asistencia jurídica gratuita para eliminar las barreras socioeconómicas que limitan el ejercicio de este derecho, uno de los estándares exigidos internacionalmente, pero no se ven cambios legales o institucionales que permitan concluir que estos obstáculos hayan disminuido de manera significativa”.

${ }_{959}$ PNUD. Manual de políticas Públicas para el desarrollo. Op. Cit. p. 15.

${ }_{960}^{9}$ IBIDEM.p.9.

${ }^{961}$ IBIDEM. "el diagnóstico se plantea como un proceso único que se desarrolla en dos fases consecutivas en el tiempo. La primera de ella se avoca a la identificación de las necesidades jurídicas de la población, mientras que la segunda trata de valorar cuáles de esas necesidades legales son, en la práctica, resueltas por el sistema de justicia instaurado. En este segundo momento del proceso de diagnóstico se realiza un estudio de los
} 
capaces de aumentar la oferta de servicios jurídicos en la medida necesaria para hacer frente a este déficit, lo que implica aprovechar e incorporar a los actores no estatales, que de hecho, desempeñan labores en materia de acceso a la justicia ${ }^{962}$.

Agrega el PNUD, que "además de las cuestiones pecuniarias existen una variedad de situaciones que deben ser tratadas más allá de costos del servicio, y se traducen en las barreras de acceso descritas. Así, emerge la necesidad de generar mecanismos específicos, o adaptar los existentes para que la población pueda sentirse protegida y sienta como propios los mecanismos de protección de los derechos" $"$.

Adhiriéndonos al análisis del PNUD, en cuanto a la detección de necesidades jurídicas de la población, como presupuesto de implementación de políticas públicas de acceso a la justicia, estimamos que toda política pública debe necesariamente identificar la naturaleza de los distintos servicios jurídicos que deben ser puestos a disposición de sus operadores, y de esta forma ajustarse a ciertas líneas u orientaciones, cuando se haga una reforma o se elabore una política en acceso a la justicia o de asistencia jurídica gratuita, mediante intervenciones de tratamiento de las necesidades de sectores desprotegidos y de la regulación integradora de las necesidades del sector y la intervención en cuestiones de índole estructural (es decir, afrontando las carencias que los sistemas de nuestra región presentan en las necesidades asociadas a la pobreza y a la exclusión social). Los Estados deben necesariamente atender a las singularidades de cada grupo vulnerable, y coherente con esa obligación, los ordenamientos jurídicos deben dar una respuesta a las necesidades reales y concretas de la población ${ }^{964}$.

mecanismos formales e informales de prestación de servicios. Las necesidades jurídicas identificadas en el diagnóstico que no pueden ser absorbidas y tratadas por los mecanismos jurídicos vigentes, es decir, las necesidades jurídicas insatisfechas de la población se configuran como indicadores del vacío institucional que debe ser cubierto”.

962 IBIDEM.

963 IBIDEM.

${ }^{964}$ IBIDEM. p.162. "Es imprescindible partir de un ordenamiento jurídico en que los derechos respondan a las necesidades reales de la población, que incorporen las especificidades necesarias para satisfacer la heterogeneidad social, desde un punto de vista de universalidad subjetiva, coherente con la obligación del Estado de prestar especial atención a los grupos vulnerables y a los obstáculos de acceso a la justicia a los que se enfrentan para garantizar que la gente realmente acceda a los mecanismos previstos”. 
En una perspectiva de evolución histórica, originariamente el acceso a la justicia en general y la asistencia jurídica gratuita en particular, solo se contempló dentro del sistema judicial penal, cuando estaba amenazada la libertad personal. Se justifica claramente que hoy también se intensifica en esa área, pues es donde el sistema punitivo estatal muestra su mayor capacidad de injerencia en la esfera de los derechos y libertades de los individuos, pero también se ha ampliado progresivamente a las necesidades jurídicas relacionadas con la vivienda, los conflictos vecinales, con las deudas entre particulares o ante entidades bancarias, problemas de regularización y registro de propiedades, el derecho de familia y el derecho laboral ${ }^{965}$. Se ha constatado una constante insatisfacción de las necesidades jurídicas en diversas clases de conflictos y materias ${ }^{966}$. El estado de la cuestión en Chile, en mérito del Informe Anual 2017 de Derechos Humanos de la Universidad Diego Portales, explicita que "entre los conflictos que más se repiten cabe destacar los conflictos cotidianos, lo que se ha denominado pequeñas causas, como problemas por productos defectuosos, cobro de bajos montos de dinero o conflictos de convivencia vecinal, para cuyos involucrados el acceso a la justicia se ve distante y gravoso, principalmente por el tiempo y dinero que ello demanda y porque los procedimientos judiciales, por lo general, no son sensibles o no recogen las particularidades de este tipo de asuntos" $" 967$.

Desde aproximadamente el año 2014 que el acceso a la justicia de grupos vulnerables ha sido una preocupación constante para el Poder Judicial, donde el fin que quieren lograr es una mayor cercanía de la ciudadanía y un acceso inclusivo, en que cada grupo, ya latamente desarrollado en el Capítulo III, los cuales presentan dificultades especiales que no le permiten obtener una real posibilidad de resolver

\footnotetext{
${ }^{965}$ La razón de brindar cobertura a las necesidades reales, se aprecia en el derecho administrativo, pues el trato con el Estado, en ocasiones, se torna burocrático, y los grupos desposeídos necesitan recurrir a estas decisiones cuando la consideran injustas o arbitrarias, con asesoramiento y representación jurídica, sino se ven gravemente limitados, sobre todo si la instancia revisora es la propia administración.

966 “Actualmente existen diversos tipos de conflictos entre las personas de nuestra sociedad donde el Estado no da una respuesta coherente, o simplemente se retarda en dar una respuesta eficiente, expedita y alcanzable”

${ }^{967}$ UNIVERSIDAD DIEGO PORTALES. (2017). “Acceso a la justicia en Chile”. Op. Cit., p. 364.
} 
sus conflictos de relevancia jurídica, obtener sentencias adecuadas, y en definitiva, ejercer sus derechos y acceder efectivamente a la justicia ${ }^{968}$.

Ya es de nuestro conocimiento que toda política pública y buena práctica debe necesariamente basarse en las necesidades reales que no han sido absorbidas por el sistema de justica, cobrando importancia lo que destaca el Protocolo sobre Grupos en Condición de Vulnerabilidad del Poder Judicial chileno ${ }^{969}$.

Las Políticas públicas en Chile en lo relativo al acceso a la justicia en general y a la asistencia jurídica gratuita en particular, han tenido por objeto garantizar este acceso a la justica en condiciones de igualdad y, en ese sentido, cumplir con la obligación de remover las distintas barreras y obstáculos que se presentan. Entendemos así, un concepto amplio de políticas públicas que incorpora diversas fuentes para su generación, dentro de las que se incluyen, las políticas del ejecutivo, del legislativo y la influencia del sistema interamericano en su creación e implementación, cuando dispone de medidas de reparación vinculadas con ésta temática ${ }^{970}$.

En el caso de las políticas públicas en Chile, su mayor énfasis está vinculado con reducir los costos económicos para acceder a la justicia, siendo parte de la institucionalidad, las CAJ, DPP, y el abogado de turno ${ }^{971}$.

\footnotetext{
968 PODER JUDICIAL. Protocolo de Acceso a la Justicia de Grupos Vulnerables. Op. Cit., p. 1. "En este contexto el presente protocolo cumple el propósito de adaptar a la realidad social y jurídica de nuestro país el Protocolo Iberoamericano de Actuación Judicial para mejorar el acceso a la justicia de personas con discapacidad, migrantes, niñas, niños, adolescentes, comunidades y pueblos indígenas que surgió de la XVII Cumbre Judicial Iberoamericana, de manera de contribuir al desarrollo del acceso a la justicia de personas en situación de vulnerabilidad en nuestro país y de fortalecer la capacidad institucional de darles una efectiva atención y respuesta. Dentro de los grupos que se encuentran insertos en este tema, cabe decir que son; las personas con problemas de lenguaje, los que poseen alguna discapacidad intelectual, inmigrantes, pueblos originarios, entre otros. Todos estos esfuerzos se consolidaron en la elaboración del Protocolo de Acceso a la Justica de Grupos Vulnerables del año 2020, del Poder Judicial de Chile”.

969 IBIDEM. p.8. “...determinar el estado actual de una determinada cuestión para poder desarrollar, partiendo de él, una adecuada política institucional que sirva para solucionar el problema. Cuando se habla de acceso a la justicia, en su variable de necesidad jurídica, es importante conocer con claridad las necesidades que existen en la población usuaria, y a las que el sistema no da solución ya que solo así, la política pública que se desarrolle, responderá a éstas y aportará soluciones adecuadas y eficaces. Lo que esperan las personas frente a sus necesidades jurídicas, es obtener una respuesta que dé solución. Cuando esta respuesta no se recibe se está ante necesidades jurídicas insatisfechas"

${ }^{970}$ NASH, C; NUÑEZ, C; TRONCOSO, C. Op. Cit., p.321.

${ }^{971}$ IBIDEM
} 
En este escenario, las políticas públicas de acceso a la justicia del Estado de Chile se han circunscrito fundamentalmente a la asistencia jurídica gratuita, dejando relegado otros relevantes, tales como la facilitación del acceso a la justicia a través de mecanismos no judiciales, la capacitación a los operadores de justica, la educación o información a la ciudadanía, el favorecimiento de coordinación institucional y propiciar la creación de redes nacionales y regionales, que si bien se han instaurado como buena práctica de algún órgano del Estado, específicamente dentro del poder judicial. No aparecen respaldados por una estructura institucional, consagración legal, financiamiento permanente y proyección temporal, como las que gozan las instituciones de asistencia jurídica gratuita.

\section{NECESIDADES JURÍDICAS DE LA POBLACIÓN EN CHILE}

A juicio de Nash, Núñez y Troncoso, "las necesidades jurídicas, para conocerlas hay que obtener información que demuestre el nivel de insatisfacción y frustración de la población en general, así como de los sectores más desfavorecidos"972. Para conseguir aquel parámetro, se debe armonizar lo que perciben los usuarios por una parte, y por otra, lo que estiman los operadores del sistema de justicia ${ }^{973}$. Es básico tener antecedentes suficientes sobre la situación real, de lo contrario, la política pública que se formule no resultará adecuada ${ }^{974}$. Tal como lo destacan los referidos Nash, Núñez y Troncoso, "una vez identificado el problema, detectada la necesidad jurídica a la hay que atender, el paso siguiente es brindar una solución apropiada que dé respuesta a la demanda planteada"975.

\footnotetext{
972 IBIDEM. "Para ello hay que escuchar a las personas usuarias exponiendo las necesidades desde su perspectiva y hacer un contraste con la percepción del personal que administra justicia y de quienes se desempeñan en cualquier ámbito relacionado con el quehacer del sistema judicial, ya que es posible que la información que se obtenga, sea diversa y resulta fundamental para completar una imagen real de las necesidades jurídicas".

973 IBIDEM. p. 322.

${ }^{974}$ IBIDEM. "Hay que averiguar, en primer lugar, lo que hace falta, es decir, las necesidades que tienen los colectivos que se encuentran en situación de vulnerabilidad para vencer o superar las barreras existentes y una vez detectadas estas necesidades, hay que analizar todos los medios de que se dispone para corregir la situación".

${ }^{975}$ IBIDEM. p. 11.
} 
La posibilidad de llegar al sistema judicial para reclamar derechos implica un conocimiento de los mismos y de los medios para ejercerlos o lograr su reconocimiento, esto es, una ciudadanía legalmente empoderada, que dispongan la posibilidad de obtener un pronunciamiento judicial justo, en el cual las resoluciones se dicten en un tiempo razonable y sean respetuosas de los demás derechos y salvaguardas constitucionales, entre ellas, en particular, las garantías del debido proceso legal y específicamente la asistencia jurídica gratuita por parte del Estado. Por problemas jurídicos, entenderemos aquellas situaciones que refieren a la existencia de un derecho que se encuentra en conflicto producto de la colisión de intereses entre dos o más partes, o situaciones en que la gente tiene la percepción de que sus derechos son o podrían ser privados o vulnerados, por particulares o incluso el mismo Estado. En cuanto al concepto de necesidad jurídica insatisfecha, puede abordarse desde un enfoque subjetivo o interno, por el cual, las personas definen si su necesidad jurídica (ya identificada) fue satisfecha o no. Desde una perspectiva objetiva u externa, es posible considerar como necesidades jurídicas insatisfechas, aquellas que no fueron llevadas al sistema de justica ni cuentan con representación abogados ni mediadores.

Cristian Riego y Ricardo Lillo, en relación con el cumplimiento de estándares en materia de acceso a la justicia, han destacado que no es solo relevante detectar las necesidades jurídicas de la población, sino que la determinación de la vía más adecuada para satisfacerlas ${ }^{976}$. Ello implica analizar los estudios que se han realizado en esta materia, para lo cual en este acápite se registran los datos más importantes de investigaciones efectuadas en dos períodos, uno inmediatamente después del regreso a la democracia en Chile, es decir, durante la década de los noventa y, el otro, en los últimos cinco años ${ }^{977}$. Estos estudios tendieron a diagnosticar las necesidades jurídicas de la población en sentido amplio, donde los objetivos de estos sondeos se concentran en el dimensionamiento de las

\footnotetext{
${ }^{976}$ RIEGO C; LILLO, R (2015) “¿Que se ha dicho sobre el funcionamiento de la justicia civil en Chile? Aportes para la reforma”. EN Revista Chilena de derecho privado. Santiago. número 25. p.13. "en cuanto a la evaluación del cumplimiento de los estándares internacionales en materia de acceso a la justicia en Chile exige, primero que todo, conocer cuáles son las necesidades legales que tiene la ciudadanía, qué problemas son los más frecuentes y qué caminos seguir para resolverlos”.

977 IBIDEM.
} 
necesidades jurídicas de la población, su caracterización y segmentación a nivel de población residente en Chile, a la vez, en la estimación y caracterización de las necesidades jurídicas insatisfechas, identificando las brechas o barreras de acceso a justicia que enfrenta la población, en particular en cuanto a los más vulnerables. Estos resultados se traducen en las investigaciones de Jorge Correa ${ }^{978}$ y Luis Barros $^{979}$ realizadas en 1993 y 1997 respectivamente, y en la Encuesta Nacional de Necesidades Jurídicas y Acceso a la Justicia del año $2016^{980}$.

Todos los datos extraídos fueron puestos en una escala de significación estadística, así mismo fueron tomando cada uno un nivel de importancia mayor o menor ${ }^{981}$. Los objetivos de los 3 diagnósticos fue identificar la cantidad, perfil y características de las necesidades jurídicas de la población, distinguiendo entre otros, por nivel socioeconómico, como asimismo identificar el comportamiento de la población frente a sus necesidades jurídicas, considerando el tipo de instancias, procesos o actores a los que recurren y sus relaciones con ellos. También se analizó la incidencia de los factores socioeconómicos en el acceso a justicia ${ }^{982}$.

Las investigaciones de 1993 y 1997 daban cuenta que la opinión respecto de la justicia era mayoritariamente negativa, 82,8\% en 1993 y 88\% en 1997, resultando como motivos, entre otros, la lentitud, la ineficiencia y el carácter discriminatorio de la justicia en contra de los pobres ${ }^{983}$.

Tal como fluye del Informe Anual Derechos Humanos del año 2017 de la Universidad Diego Portales, "en relación a las necesidades legales, el estudio de 1993, muestra que fuera de los problemas de carácter penal (que sumaban el

\footnotetext{
${ }_{978}$ BARROS, L; CORREA, J (1993). Justicia y marginalidad, percepción de los pobres. Corporación de promoción universitaria. Santiago.

${ }^{979}$ BARROS, L. (1997). Opiniones de los sectores urbanos en torno a la justicia. Corporación de promoción universitaria, Santiago.

${ }^{980}$ GFK ADIMARK S.A (2016). Encuesta nacional de necesidades jurídicas y acceso a justicia. Santiago.

${ }^{981}$ En los tres estudios mencionados, fueron encuestados hombres y mujeres de 18 años y más, siendo alrededor de quinientas muestras en los estudio de 1993 y 1997 y cuatro mil muestras en el año 2014, siendo los dos primeros enfocados en ámbito urbano de la Región Metropolitana y el segundo en la realidad rural y urbana de todo el país.

${ }^{982}$ UNIVERSIDAD DIEGO PORTALES. (2017). “Acceso a la justicia en Chile”. Op. Cit., 370.

983 IBIDEM. Todos los datos extraídos fueron puestos en una escala de significación estadística, así mismo fueron tomando cada uno un nivel de importancia mayor o menor.
} 
$46,8 \%)$, los problemas de tipo civil constituyeron el segundo grupo más importante con un $24,5 \%{ }^{984}$. Por su parte, los asuntos laborales representaban el $16,2 \%$, siendo los más destacados la falta contrato y/o pago de imposiciones cuando se trabaja de forma dependiente, con un $22 \%$ de ese total, y el despido injustificado y sin desahucio, con un 17\%. Finalmente, los temas de familia ocupaban un $12,5 \%$ del total de problemas legales, y dentro de esta materia los principales eran la custodia de los hijos $(10,7 \%)$, y las pensiones alimenticias $(11,9 \%)$, considerados dentro del universo estadístico completo ${ }^{985}$.

En cuanto a la vía o vías de resolución de las necesidades jurídicas, la investigación de 1993, se refirió a las gestiones realizadas por las personas conducentes a satisfacer estas necesidades, en materia penal y civil ${ }^{986}$. En la investigación realizada en 1997 se observa que los problemas civiles pasaron a constituir la mayor prevalencia con porcentajes muy superiores a los del estudio anterior, así por ejemplo un 49,3\% de los encuestados dijo tener problemas como consumidores y un $47 \%$ dijo ser acreedor de deudas impagas ${ }^{987}$. Estas investigaciones reflejan una percepción negativa de la ciudadanía respecto del sistema de justicia ${ }^{988}$.

La Encuesta Nacional de Necesidades Jurídicas y Acceso a Justicia realizado en 2016 por la empresa de encuestas GFK Adimark, constituyó un estudio de percepción ciudadana mandatado por el Ministerio de Justicia, que indagó respecto del porcentaje de personas que han tenido una necesidad jurídica y que han

\footnotetext{
${ }^{984}$ Dentro de esta área, aquellos más relevantes eran los préstamos de dinero sin devolución (20,7\%) y el engaño al comprar productos o contratar servicios (15,7\%).

985 IBIDEM. p. 366.

${ }^{986}$ IBIDEM. "En relación con los caminos seguidos para resolver estas necesidades, en la investigación de 1993, en los casos penales el 44,8\% manifestó no haber hecho denuncia alguna ; en materia de familia, especialmente solicitud de pensión de alimentos, el 46,9\% de los que tenían esta necesidad habían realizado gestiones tendientes a la satisfacción de esta necesidad mediante el ingreso a la justicia formal; por último aquellas necesidades civiles de carácter estrictamente civil tenían una tasa de denuncia o presentación a tribunales inferiores al 10\%”.

${ }^{987}$ BARROS, L. Op .Cit., pp. 366-368.

${ }^{988}$ RIEGO C; LILLO, R. Op. Cit., p. 23. "estas investigaciones de carácter empírico fueron realizadas en la década de 1990, los que, en general, dieron cuenta de la mala percepción y desconfianza de la ciudadanía hacía el sistema de justicia, fundamentalmente porque este no era accesible ni respondía a las necesidades legales de las y los ciudadanos”.
} 
requerido una orientación o patrocinio judicial de abogado ${ }^{989}$. En este estudio se detectaron necesidades en el ámbito civil, trabajo, familia, salud y educación ${ }^{990}$.

Cuadro 1: Población con necesidades jurídicas en el año 2016, total población (4.000, total de encuestados).

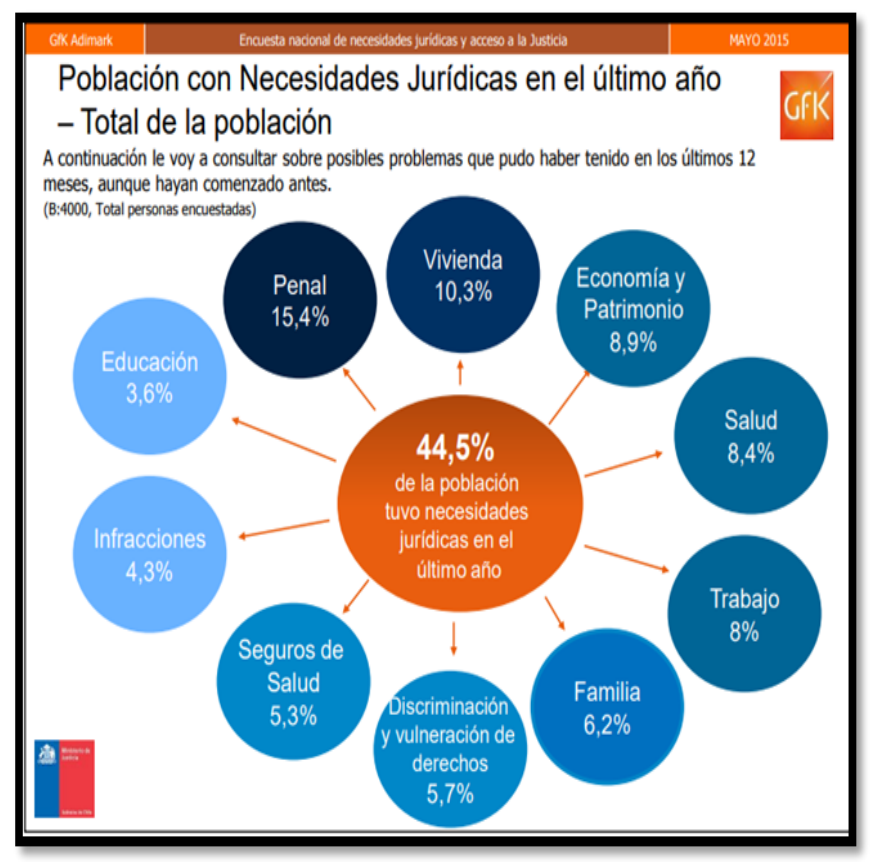

Las necesidades jurídicas no se presentan de manera homogénea dentro de la población, sino que existen niveles de reconocimiento de necesidades jurídicas diferenciados en los distintos perfiles sociales ${ }^{991}$ :

${ }^{989}$ GFK ADIMARK S.A (2016). Op. Cit., p. 30. "Los datos muestran que, del total de encuestados, el 44,5\% declaró que tuvo algún tipo de necesidad jurídica en el último año. Esta cifra es relevante si se piensa que al menos 4 de cada 10 personas en Chile se encuentran en esta situación y que pueden haber requerido información legal, asesoría jurídica o representación judicial. Incluso podría tratarse de personas que de haber tenido la oportunidad estarían dispuestas a acudir a mecanismos negociados de resolución de conflictos. En síntesis, es posible sostener que alrededor de un $50 \%$ de los encuestados tiene o ha tenido una necesidad legal, según la definición antes señalada, que esos requerimientos en promedio tienen una duración de un año y medio y que poco más de un tercio de las personas consultadas (34\%) acude al sistema de justicia formal en busca de una solución. Lo más grave es que, cualquiera sea el camino seguido, un $62 \%$ de los encuestados sostiene que el problema o situación no se ha resuelto".

${ }_{990}$ IBIDEM. “Además del ámbito penal, que ocupó un 34,6 \% del total de las necesidades legales declaradas por los encuestados, las principales necesidades jurídicas en materia civil se dan en temas de vivienda (22,5\%), economía y patrimonio (20\%) y salud (18,9\%). Le siguen los problemas sobre temas de trabajo (17,9\%), familia (14\%), discriminación y vulneración de derechos (12,8\%), seguros de salud (11,8\%) y educación $(8,1 \%)$. Por supuesto que un individuo podía declarar más de una necesidad legal insatisfecha y en diversas materias".

${ }^{991}$ GFK ADIMARK S.A (2016). Op. Cit., p. 38. 
a) Territorio: En la zona norte del país la necesidad jurídica es mayor.

b) Zona de residencia: Se constata mayor cantidad de necesidades en zonas urbanas.

c) Edad: Dentro de los rangos etareos, los adultos jóvenes es quién tiene una mayor necesidad jurídica.

d) Grupo socioeconómico: Los grupos socioeconómicos tienen mayores o menores necesidades jurídicas, dependiendo de los recursos que poseen para hacer frente a aquellas, lo que se relaciona con la pobreza, sus dimensiones y consecuencias, latamente desarrollada en esta tesis.

e) Escolaridad: Reducidos niveles de escolaridad muestran una mayor necesidad jurídica, en atención a que precisamente en este ítem se cimientan y desarrollan las brechas de desigualdad existentes.

f) Grupos originarios: Se detectó que los pueblos y comunidades indígenas constituyen un colectivo con necesidades jurídicas asociadas a temáticas particulares derivadas de la necesidad de reconocimiento legal y social, pero también debido a su vinculación a la falta de oportunidades de desarrollo, a la marginalidad y a la pobreza.

g) Actividad laboral: La población empleada presenta necesidades jurídicas relacionadas con el propio escenario en que forjan su vinculación con el empleador, con las consecuentes vulneraciones respecto de las cuales pueden verse afectadas $^{992}$. La población desempleada, por su parte, presenta necesidades jurídicas vinculadas a la falta de empleo, la pobreza, y a la búsqueda de la remoción de barreras u obstáculos socioeconómicos por parte del Estado.

En base a este panorama de necesidades detectadas y siguiendo las pautas del nuevo enfoque de acceso a la justicia, que implica dar respuesta a las demandas por hacer efectivo los derechos, especialmente por los grupos más desfavorecidos, exige que la oferta de servicios jurídicos no tuviesen costo, suministrado principalmente por instituciones públicas y también privadas de interés público. Es

\footnotetext{
992 No pago de remuneraciones, escasa tutela de derechos fundamentales en el ámbito laborales, despido injustificado, etcétera.
} 
dable señalar que la oferta privada no subsidiada por el Estado al estar mediada por el pago del particular se constituye como fuente de inequidad para el acceso.

La preocupación sobre la efectiva implementación de acciones tendiente a la satisfacción de necesidades jurídicas y frente a los datos antes presentados, surgen interrogantes respecto de las acciones tomadas por el Estado chileno para hacer frente a este conjunto de necesidades legales insatisfechas. En efecto, no se han llevado a cabo reformas legales destinadas a paliar el déficit en la oferta estatal, ya sea a través de modificaciones procesales funcionales u orgánicas, ni se han introducido cambios en la provisión de mecanismos de asistencia jurídica gratuita, área típicamente abordada cuando se intenta mejorar los niveles de acceso a la justicia. Una mirada global muestra que la justicia civil se mantiene prácticamente igual, conservándose los mismos procedimientos y modelos orgánicos sin distinción respecto al tipo de conflicto que se conocen. En efecto, de acuerdo a la normativa vigente, los juzgados de policía local son los que deberían resolver los conflictos vecinales o de baja complejidad, lo que dista de la realidad ${ }^{993}$. La falta de incorporación en forma generalizada de los métodos de resolución alternativa de conflictos, impide en gran medida una satisfacción de las necesidades civiles, especialmente en el ámbito de policía local. A mayor abundamiento, pese al auge que en los últimos años han experimentado los mecanismos de resolución de conflictos, por ejemplo en materia de familia994 o daños en salud, ${ }^{995}$ estos mecanismos no han sido incluidos en forma integrad en la legislación.

993 UNIVERSIDAD DIEGO PORTALES. (2017). “Acceso a la justicia en Chile Op. Cit., pp. 374-375. “Dichos tribunales dependen de los municipios y no directamente del poder judicial, en que prima la falta de información, la manera en que la prueba es rendida ente un delegado del juez, que no es la óptima, sin la debida inmediación y garantías que proporcionan un juicio oral, en la práctica hace que si se requiera de un profesional a cargo. El problema es que sumado a los honorarios de un abogado, más las notificaciones, considerando el tiempo invertido en tramitar un caso, resulta que el beneficio esperado no supera de ninguna manera los costos asociados. Esto termina, entones, por desincentivar el acceso a la justicia de policía local por parte de los ciudadanos comunes y corrientes".

994 LEY 19.968. Crea los tribunales de familia. Artículo 106: "Mediación previa, voluntaria y prohibida. Las causas relativas al derecho de alimentos, cuidado personal y al derecho de los padres e hijos e hijas que vivan separados a mantener una relación directa y regular, aun cuando se deban tratar en el marco de una acción de divorcio o separación judicial, deberán someterse a un procedimiento de mediación previo a la interposición de la demanda, el que se regirá por las normas de esta ley y su reglamento.

${ }^{995}$ LEY 19.966. Que establece un régimen de garantías en salud, de 3 de septiembre de 2004. Artículo 43: "El ejercicio de las acciones jurisdiccionales contra los prestadores institucionales públicos que forman las redes asistenciales definidas por el artículo 16 bis del decreto ley $\mathrm{N}^{\circ} 2.763$, de 1979, o sus funcionarios, para obtener 
En todos tipos de juicios civiles, con excepción de la conciliación judicial que existe en nuestro ordenamiento jurídico en ciertos procedimientos, la mediación, la negociación u otras fórmulas autocompositivas, no se contemplan en ninguna etapa del proceso judicial ni en forma previa a este, salvo por medio de instancias voluntarias y extrajudiciales, como la mediación financiera que ofrece el Servicio Nacional del Consumidor ${ }^{996}$.

Han existido algunas alternativas diversas en cuanto a la solución de conflictos como las Unidades de Justicia Vecinal, que fueron diseñadas siguiendo la experiencia norteamericana y Argentina de los tribunales Multipuertas ${ }^{997}$. Si bien el modelo de las Unidades de Justicia Vecinal era perfectible, sin embargo, el trabajo y la experiencia acumulada en los cinco años de funcionamiento de estas unidades no fueron suficientes para convencer al ejecutivo de mantenerlas e incluso ampliarlas. En marzo del año 2017 el Ministerio de Justicia puso término al proyecto piloto de las Unidades de Justicia Vecinal.

A nuestro parecer, la reforma a la justicia civil del año 2005, requiere ser aprobada con urgencia, por su impacto en la forma en que se administraría la justicia civil en Chile, mutándose desde un prisma pasivo y escrito, a uno ágil y oral, ${ }^{998}$ materializado a través de un proyecto de CPC, el cual tampoco ha prosperado y continúa en tramitación ${ }^{999}$.

\footnotetext{
la reparación de los daños ocasionados en el cumplimiento de sus funciones de otorgamiento de prestaciones de carácter asistencial, requiere que el interesado, previamente, haya sometido su reclamo a un procedimiento de mediación ante el Consejo de Defensa del Estado, el que podrá designar como mediador a uno de sus funcionarios, a otro en comisión de servicio o a un profesional que reúna los requisitos del artículo 54. En el caso de los prestadores privados, los interesados deberán someterse a un procedimiento de mediación ante mediadores acreditados por la Superintendencia de Salud, conforme a esta ley y el reglamento, procedimiento que será de cargo de las partes. Las partes deberán designar de común acuerdo al mediador y, a falta de acuerdo, la mediación se entenderá fracasada”.

${ }^{996}$ LEY 20.555. Modifica ley n¹9.496, sobre protección de los derechos de los consumidores, para dotar de atribuciones en materias financieras, entre otras, al Servicio Nacional del Consumidor.

${ }^{997}$ RIEGO C; LILLO, R. Op. Cit., p. 22

998 Proyecto ingresado el 13 de marzo de 2012 a la Cámara de Diputados, boletín 8197-2012.

999 Sin perjuicio que su aprobación significaría avance, ha sido criticado por parte de la doctrina y del foro, fundamentándose que salvo el caso del procedimiento monitorio, la propuesta no regula procedimientos simples, rápidos y amigables para aquellos casos cotidianos que reemplacen a los actualmente vigentes, los que resultan muy costosos en términos de tiempos, costos de oportunidad y valor monetario, más aun tomando en consideración la exigencia de representación profesional en todas las circunstancias.
} 


\section{INSTITUCIONALIDAD DE LA ASISTENCIA JURÍDICA GRATUITA EN CHILE. ASPECTOS PRELIMINARES Y AUSENCIA DE UNA PERSPECTIVA ENFOCADA EN LOS GRUPOS EN CONDICION DE VULNERABILIDAD}

Desde la óptica de la asistencia jurídica, la oferta estatal sigue intacta. Se mantienen las CAJ, con los mismos objetivos, idéntica orgánica y la misma distribución territorial desde su creación. En lo medular no han sufrido cambios estructurales, pese a varios anteproyectos y proyectos de ley que han intentado modificarlas. Con todo, es justo reconocer que en algunas áreas han diversificado sus servicios, incorporando por ejemplo, desde hace ya un par de décadas, mecanismos alternativos de resolución de controversias. Se mantienen incólumes, aunque con dudas acerca de su eficacia, las figuras del abogado de turno y el privilegio de pobreza. La DPP, con sus variantes pública y licitada, han contribuido a generar un sistema moderno que conjuga los diversos modelos de asistencia jurídica con una inyección importante de recursos asociados.

Todas estas instituciones, desde un punto de vista orgánico, conforman la oferta de asistencia jurídica gratuita en Chile, las que se analizará en los próximos apartados específicamente, sin perjuicio de hacer presente que algunos tópicos ya han sido tratados en forma tangencial respecto de las instituciones respectivas.

Hemos desarrollado en el transcurso de esta tesis, un análisis pormenorizado a los grupos en condición de vulnerabilidad, defendiendo la tesis que el acceso a la justicia debe ser concebido en un sentido amplio e integral. En este sentido, se ha instado en dejar atrás la primera ola de acceso a la justicia, que asimilaba este derecho a la ayuda legal de pobres, llamando a concebirlo en cambio, como un instrumento para transformar la relación que perpetúan la exclusión, la marginalidad y la pobreza en relación a estos grupos. El acceso a la justicia, si bien no se restringe solo a la asistencia jurídica proporcionada por el Estado, por cierto la incluye, con la finalidad de que los derechos sean ejercidos y que las declaraciones jurídicas, puedan transformarse en reales instrumentos de protección. Para lograr resultados justos y poder efectivamente lograr la concreción de los derechos consagrados, la 
asistencia del abogado es fundamental, debiendo ser proporcionada por el Estado, cuando no se puedan procurar por los medios particulares de las personas. La asistencia jurídica, bajo este enfoque amplio y no meramente institucional, debe conformarse al segundo avance de derechos humanos, en cuanto a que el Estado debe remover todo tipos de obstáculos o trabas en el acceso a la justicia y al tercer avance de derechos humanos, en tanto que las políticas públicas y la institucionalidad creada al efecto, debe guardar armonía y ajustarse con las condiciones singulares de cada grupo vulnerable, que los sitúan precisamente, en una condición de especial dificultad para el ejercicio de los derechos en igualdad y no discriminación.

Así entonces, la asistencia jurídica gratuita que requiere un NNA, debe ser proporcionada en atención a la edad y madurez que tenga, entendiendo que el acceso a la justicia para un niño involucra que debe ser oído, y que su vida digna, supervivencia y desarrollo sea cautelada. En caso de un miembro de comunidad indígena, migrante, persona en situación de discapacidad o mujer víctima de violencia, también debe enfocarse la asistencia jurídica gratuita en los factores que la hacen vulnerable, y en las barreras o trabas que debe enfrentar.

En el desarrollo de nuestro trabajo hemos constatado que existe una preocupación por estos grupos, y un enfoque diferenciado en diversas aristas del acceso a la justicia, esfuerzo que en materia de asistencia jurídica gratuita estimamos como todavía insuficientes. Si bien existen centros especializados en grupos vulnerables, como los Centros de la Mujer del SERNAMEG, convenio SENADIS- CAJ, programa MI Abogado de la CAJ, Defensoría Penal Indígena, estos se instalan como una oficina más dentro de la institucionalidad existente, siendo necesario un abordaje más completo y a su vez específico, creando servicios de asistencia jurídica gratuita especializada protectora de cada grupo, dotado de estructura propia y con más recursos asociados. En este sentido se evidencian falencias en la escasa cobertura del convenio CAJ SENADIS, Programa MI Abogado, solo enfocado al ámbito residencial, y especialmente en la defensa a migrantes, que es muy reducida y escasamente visibilizada. 


\section{ABOGADO DE TURNO}

La institución del abogado turno viene precedida de una raigambre histórica medieval ${ }^{1000}$, que se desarrolló en la etapa colonial ${ }^{1001}$ y se afianzó en la legalidad y codificación de la República de Chile.

En cuanto a una evolución histórica, tal como lo describe Héctor Humeres "puede apreciarse que la institución del abogado de turno tiene antecedentes históricos en el derecho español medieval, e incluso romano, y de allí se consagró en normas internas de la república, a partir de 1837, y especialmente en la Ley de Organización y Atribuciones de los Tribunales de 1875, trasladándose luego, en términos similares, al COT de 1943, que actualmente rige en Chile, habiendo a la fecha sufrido solo modificaciones de carácter formal"1002. El COT preceptúa que "corresponderá a los jueces de letras designar cada mes y por turno, entre los no exentos, un abogado que defienda las causas civiles y otro que defienda las causas del trabajo de las personas que hubieren obtenido o debieran gozar del respectivo privilegio. Con todo, cuando las necesidades lo requieran, y el número de abogados en ejercicio lo permita, la Corte de Apelaciones respectiva podrá disponer que los jueces de letras designen dos o más abogados de cada turno, estableciéndose la forma en que se deban distribuir las causas entre los abogados designados"1003.

Se establece además en el COT, "que es obligación de los abogados defender gratuitamente hasta su turno la causa de pobres que se encomiendan en

\footnotetext{
${ }^{1000}$ HUMERES, H. “El Abogado de Turno: Un trabajo forzado”. EN Sentencias destacadas. Una mirada desde la perspectiva de las políticas públicas. Santiago. Libertad y Desarrollo. p. 39. "Por su parte, en lo relativo a Chile, se estima que hubo abogados de "pobres" desde el año 1567, y ya en las Ordenanzas de Felipe II para la Segunda Audiencia de Chile se les contemplaba; ello aparece recogido posteriormente en la Real Audiencia, la que mediante un auto acordado de 1784 estableció un turno entre todos los abogados inscritos en la Audiencia, aumentándose su número”.

${ }^{1001}$ IBIDEM. p.39. “Asimismo de acuerdo a lo consignado por los historiadores, la institución pasó en esencia de las VII Partidas de Alfonso X el sabio a textos jurídicos posteriores, y es así como en la ordenanza de abogados de 1495 de los Reyes Católicos, incluidas en la Recopilación de Leyes de Castilla de 1567, se ordenaba que los abogados defendieran a los pobres 'de gracia y amor a dios'”

1002 IBIDEM.

${ }^{1003}$ COT. Artículo 595 inciso $1^{\circ}$. Artículo 597.
} 
conformidad a los preceptos de este título. Los abogados podrán excepcionarse de esta obligación por motivos justificados que serán calificados por el juez que conozca de la causa en que aquel deba cumplir la obligación, el que resolverá esta materia de preferencia y proveerá simultáneamente la designación del reemplazante. El abogado que no cumpliere esta obligación será sancionado con suspensión del ejercicio de la profesión hasta por seis meses, por el tribunal que conozca de la causa en que se hubiere producido el incumplimiento. De la resolución que imponga la sanción se podrá reclamar, dentro de tercero día, ante el tribunal superior jerárquico del que la dictó"1004.

Se han esgrimido diversas razones para explicar los fundamentos de esta figura del abogado de turno ${ }^{1005}$. Esta institución ha sido objeto de un sin número de críticas provenientes desde diversos frentes. Se ha sostenido la inconstitucionalidad de la figura, en cuanto a la exigencia de la gratuidad de la labor de este abogado, toda vez que supone la violación de un conjunto de garantías constitucionales, como la igualdad ante la ley y la igual repartición de las cargas públicas ${ }^{1006}$. Otras críticas apuntan a la disparidad de la carga de trabajo que debe asumir el abogado de turno (puede tratarse de una o varias causas y en distintos estados de tramitación) y a la falta de criterios claros para la designación del turno, el que habitualmente recae en abogados recién egresados sin mayor experiencia profesional ${ }^{1007}$.

Además de la gratuidad que establece el artículo 595 del COT que es el punto trascendental para determinar si constituye una carga arbitraria y que afectaría la igualdad ante la ley, que se analizará en el desarrollo de este título, existen algunos problemas adicionales que la figura del abogado de turno genera para la garantía del acceso efectivo a la justicia. En primer término, se trata de una institución que

\footnotetext{
1004 IBIDEM. Artículo 598.

${ }^{1005}$ UNIVERSIDAD DIEGO PORTALES. (2017). “Acceso a la justicia en Chile” Op. Cit., p. 199 “Algunos sostienen que se trata de una suerte de retribución que los abogados deben hacer al Estado dado que éste les otorga el título de abogado y no la Universidad donde cursaron sus estudios. Otros sostienen que la profesión de abogado es una función pública que nace de sentimientos humanitarios y de justicia, por tanto estos profesionales deben ayudar a las personas de escasos recursos. Finalmente, otros tantos consideran que el turno es una de las formas que la ley establece para cumplir con el mandato constitucional de proveer de asistencia jurídica a los que no pueden procurársela por sí mismos (Artículo 19 n 3 , inciso $\left.3^{\circ}\right)^{\prime}$.

1006 IBIDEM.

1007 IBIDEM.
} 
no opera en forma uniforme en todo el país, carece de procedimientos y criterios comunes para la designación de los abogados, razón por la cual genera desigualdades tanto para los abogados como para los usuarios. En segundo lugar, se trata de una institución que no contempla instancias de seguimiento y evaluación de las gestiones realizadas, lo que opera como un desincentivo para brindar una buena atención a los beneficiados. En relación con este último punto, cabe señalar que las cortes no tienen facultades para monitorear el trabajo de los abogados ni sancionarlos en caso de desempeño deficiente de sus funciones. Solo pueden sancionarlos sino cumplieren con la obligación de defender gratuitamente las causas asignadas por el turno ${ }^{1008}$.

EI TC ha clarificado que la Institución misma de los abogados de turno, es legítima y constitucional, de acuerdo a su interpretación de la Carta Fundamental. Para llegar a dicha afirmación analiza su desarrollo histórico, concluyendo que ha sido concebida como un "deber que se impone a los abogados de atender gratuitamente a los pobres, lo que constituye una labor filantrópica de los abogados, a quienes se les otorga el monopolio de la defensa judicial en el contexto de una verdadera función pública de colaboradores de la administración de justicia, y que además, se enmarca en la particular circunstancia de que el título de abogado es otorgado por la Corte Suprema"1009. Para el TC la existencia legal de los abogados de turno es válida en términos constitucionales, ya que con ellas se cumple una finalidad establecida en la propia CPR, consistente en que el Estado asegure a través de la ley los medios para que las personas puedan recibir defensa jurídica cuando no puedan proveerla por sí mismos, en virtud de que los abogados son colaboradores de la justicia, puesto que entre otras razones, en muchos casos solo a través de su trabajo se puede asegurar la igualdad ante la justicia y la defensa técnica de todas las personas ${ }^{1010}$.

No obstante los aspectos revisados, la principal discusión respecto de la constitucionalidad de la institución del abogado de turno en nuestro país ha radicado

\footnotetext{
1008 UNIVERSIDAD DIEGO PORTALES. (2017). “Acceso a la justicia en Chile”. Op. Cit., p. 203.

1009 TC. Sentencia Causa rol 755-2007, de 31 de marzo de 2008. considerando 22.

1010 IBIDEM. p.23.
} 
en la gratuidad. En ese sentido el TC se ha pronunciado sobre la inaplicabilidad por inconstitucionalidad del precepto legal en referencia, como asimismo de la inconstitucionalidad del mismo, al conocer y pronunciarse sobre requerimientos presentados por el Colegio de Abogados de Chile ${ }^{1011}$. Al ser presentado este requerimiento, diputados presentaron un informe al TC pidiendo el rechazo de la solicitud de inconstitucionalidad ${ }^{1012 .}$

Tanto en la sentencia de inaplicabilidad como de inconstitucionalidad del fragmento que instituye "la gratuidad", se han mencionado una serie de infracciones a derechos constitucionales, pues ha resultado vencido el estándar de presunción de constitucionalidad que ostenta toda norma jurídica, como asimismo, se ha constatado la imposibilidad del TC de interpretarlo de una forma armónica con el texto constitucional ${ }^{1013}$.

\begin{abstract}
${ }^{1011}$ El primero de los requerimientos de inaplicabilidad, fue presentado con fecha 22 de marzo de 2007 por el presidente de Colegio de abogados de Chile, don Sergio Urrejola Monckeberg, en causa rol 755-2007, cuya sentencia de 31 de marzo de 2008, declaró inaplicable el precepto en cuanto a la expresión "gratuitamente", dejando incólume el desarrollo del artículo. El requerimiento presentado el 6 de agosto de 2008, por el presidente del colegio de abogados de Chile, don Enrique Barros Bourie, en causa rol 1254-2008, declaró inconstitucional el precepto en cuanto a la expresión "gratuitamente”, expulsándolo del ordenamiento jurídico, dejando incólume el desarrollo del artículo.
\end{abstract}

1012 HUMERES, H. Op. Cit., p.49: "Es del caso consignar que, con fecha 26 de noviembre del año 2008, 33 Diputados de la República, interpusieron una serie de excepciones de previo y especial pronunciamiento, y solicitaron formalmente el rechazo de la acción de inconstitucionalidad presentada por el Colegio de Abogados. En lo medular, dicha presentación, al solicitar el rechazo de la acción interpuesta, señaló que la inaplicabilidad decretada en el fallo del recurso objeto de este comentario no obligaba al Tribunal Constitucional a declarar a su vez la inconstitucionalidad de la norma que había sido objeto de reproche; que de acogerse el aludido recurso, se estaría rompiendo la presunción de constitucionalidad y el carácter abstracto de la acción; y que la declaración de inconstitucionalidad implicaba legislar y generar vacíos y contradicciones. Asimismo, impugnó los argumentos del requerimiento, indicando que si bien el abogado de turno es una carga pública, ella no reviste los caracteres de única ni excesiva, que no contraría derechos fundamentales ni afecta la igualdad ante la ley ni la libertad de trabajo".

1013 TC. Sentencia causa rol 1254-2008, de 29 de julio de 2009. Considerando 18. “Que tal como lo ha señalado reiteradamente esta magistratura 'el respeto hacía la labor que desarrolla el legislador obliga al Tribunal Constitucional, en su función de contralor de la constitucionalidad de la ley, a buscar al menos, alguna interpretación del precepto cuestionado que permita armonizarlo con la Carta Fundamental y solo en el evento de no ser ello posible, unido a la necesidad de cautelar integralmente la plena vigencia de los principios de supremacía constitucional, igualdad ante la ley y certeza jurídica, resultará procedente y necesaria la declaración de inconstitucionalidad. Como ha precisado la doctrina, la denominada 'presunción de constitucionalidad' impone a quién sostiene que el texto de la ley es inconstitucional, la carga de argumentar convincentemente que 
Precisamente con la finalidad de lograr una certeza e igualdad jurídica, se ha entendido que al establecerse obligatoriamente la gratuidad de la labor del abogado designado por el juez, se han infringido las siguientes garantías constitucionales:

a) Igualdad ante la ley. En el entendido que la diferenciación que se hace si bien es objetiva y razonable en cuanto al fin perseguido que es brindar asistencia jurídica gratuita, como asimismo el instrumento consistente en imponer una carga, al imponerse gratuitamente transforma el medio en gravoso, en consideración que el fin perseguido no exige al abogado que deba desempeñarse sin retribución alguna, pues la obligación recae en el Estado y no en el abogado. En lo relativo a la igualdad y no discriminación, la sentencia del TC expresa "que de todo lo señalado se desprende que la gratuidad de turno establecida en el artículo 595 del COT, considerada en abstracto, infringe objetivamente la igualdad ante la ley y en particular la prohibición de discriminar arbitrariamente, en los términos que reconoce y ampara el artículo 19 n² de la Carta Fundamental y así se declarará" ${ }^{1014}$.

b) Igualdad ante las cargas públicas ${ }^{1015}$. Esta vulneración consiste en que la carga personal impuesta a los abogados no sería justificable sin remuneración, al existir otras cargas en el sistema legal chileno que si son retribuidas pecuniariamente. En cuanto a lo desproporcional y arbitrario de la disposición en comento, el TC sentenció "que no escapa a esta magistratura la circunstancia que incluso en deberes de carácter cívico, como son el servicio militar y la integración de vocales de mesas electorales, el legislador (Leyes $n^{\circ} 20.045$ y 20.592, ambas de 2005) ha establecido mecanismos de compensación pecuniaria -bajo la forma de asignación o bono- que permitan, en parte, hacerse cargo de los gastos en que se debe incurrir para poder ejecutar las mismas de manera eficiente"1016. Reforzando esta idea, se expresó "que, de este modo, la carga del turno que se impone excepcionalmente a

se da una incompatibilidad entre la norma que ese texto expresa y el sistema de normas que el texto constitucional consagra”.

1014 IBIDEM. Considerando 66.

${ }^{1015}$ CPR. Artículo 19 n 20: "La igual repartición de los tributos en proporción a las rentas o en la progresión o forma que fije la ley, y la igual repartición de las demás cargas públicas. En ningún caso la ley podrá establecer tributos manifiestamente desproporcionados o injustos...”

1016 TC. Sentencia causa 755-2007, de 30 de Maro de 2008 Considerando 54. 
los abogados debe ser debidamente retribuido, derecho fundamental que nuestra Carta Suprema prevé incluso en estados de excepción constitucional, al respecto que reconoce el derecho de ser indemnizado respecto de las limitaciones que se impongan al derecho de propiedad"1017. En cuanto a la prestación de servicios públicos a través de particulares, se puede desarrollar sin que bajo ninguna circunstancia implique un detrimento económico para quién lo lleve a cabo ${ }^{1018}$. De esta forma, el Estado puede cumplir sus obligaciones a través de los particulares, en conformidad al principio de subsidiariedad o supletoriedad, pero sin que ello importe un detrimento patrimonial.

c) Libertad de Trabajo con una justa retribución ${ }^{1019}$. En este sentido, el TC reconoce el derecho a una justa retribución por todo trabajo, aunque se imponga bajo la forma excepcional de una carga ${ }^{1020}$. Agrega, "que de no ser así, como en el caso del turno gratuito, la carga se transformaría en una verdadera práctica forzada de trabajo"1021. Esta norma puede atentar la dignidad del hombre, en cuanto al goce y ejercicio de sus derechos laborales ${ }^{1022}$. Que la carga exista y esté legitimada, pero que no pueda ser gratuita, nos abre dos debates. El primero dirigido a si es lícito que el abogado le cobre al Estado, y en caso de ser afirmativo, la forma como cobra el abogado que cumple con el turno, y el segundo, en cuanto a la legitimización del abogado para cobrarle a los destinatarios del beneficio por el servicio prestado.

\footnotetext{
1017 IBIDEM. Considerando 55.

1018 TC. Sentencia causa rol 1254-2008, de 29 de julio de 2008, Considerando 77.

${ }^{1019}$ CPR. Artículo 19 n 16: “Toda persona tiene derecho a la libre contratación y a la libre elección del trabajo con una justa retribución”.

1020 TC. Sentencia causa rol 755-2007, de 31 de marzo de 2008. Considerando 60: “Que la Carta Fundamental reconoce y ampara el derecho a una justa retribución por todo trabajo, aunque se imponga bajo la forma excepcional de una carga, lo que, por lo demás se vincula ni más ni menos que con la dignidad de la persona humana a que alude el artículo 1 de la Constitución política...”

${ }^{1021}$ IBIDEM. Sentencia causa rol 1254-2008, 29 de julio de 2008. Considerando 79: "Que la eventual infracción se produciría como consecuencia de que la norma privaría a los abogados afectados por el turno del derecho a desarrollar libremente un trabajo y a obtener una justa retribución por el servicio prestado, lo que transformaría la carga en una verdadera práctica forzada de un trabajo. De este modo se sostiene, la carta fundamental no puede autorizar un impedimento absoluto por parte del profesional para obtener una legítima retribución patrimonial”.

${ }^{1022}$ HUMERES, H. Op. Cit., p. 55. "Pero en todo caso, y tal como asevera la doctrina nacional, el legislador no podría bajo sanción de inconstitucionalidad dictar normas que atentaren contra la igualdad y la dignidad del hombre en materia laboral. De acuerdo con ello, las normas legales que se contraponen contra dichos principios, deberían entenderse viciadas por inconstitucionalidad”.
} 
En cuanto al primer debate, podemos señalar que a la luz de lo expuesto y especialmente los razonamientos del TC, claramente que el abogado está facultado para cobrar legítimamente por el trabajo prestado, pues de lo contrario sería un atentado contra su dignidad y los derechos inherentes a ésta, como la igualdad ante la ley y la libertad de trabajo con una justa retribución, aunque proceda de una carga. Es dable señalar además, que después de 11 años de dictada la sentencia de inconstitucionalidad, no existe una postura clara por parte de la doctrina y no ha existido la posibilidad de que las cortes de justicia, se hayan pronunciado por este punto. La única vía idónea de exigir el pago de los servicios prestados, sería que el abogado designado por el turno demande al Estado a través de una acción de cobro de pesos, que se ciñe al procedimiento ordinario civil, regulado en el CPC, constituyendo un juicio de lato conocimiento y que se puede prolongar por un largo tiempo. Esta propuesta de solución, a nuestro juicio, resultaría una doble carga para el abogado, pues a la inicial, de asumir la defensa impuesta, se sumaría la de presentar y sostener una demanda contra el Estado con todo lo que ello significa, desgaste emocional, pago de receptores y otros costos, con la contingencia incierta de ganancia o pérdida que impera ante todo juicio, y teniendo como contraparte al Estado. La razón por la cual no ha existido pronunciamiento se puede deber al carácter excepcional que reviste el turno ante la imposibilidad de ser asistido por las CAJ o clínicas jurídicas de las Universidades en su caso, lo que se da actualmente en pocas ocasiones, debido a la amplia cobertura nacional especialmente de la primera.

En cuanto al segundo debate, en cuanto a la posibilidad de cobrar el abogado por el servicio a la persona beneficiaria, estimamos tajantemente que infringiría el derecho constitucional de asistencia jurídica gratuita, de carácter instrumental y al servicio del acceso a la justicia, convirtiéndose este en ilusorio, pues impondría una obligación de pago por el ejercicio legítimo de un derecho constitucional, por parte de la persona amparada por el privilegio de pobreza, desvirtuándolo en su letra y espíritu. 
Podemos concluir, que para ser efectiva, esta institución requiere de profundas mejoras en orden a su objetivo, gestión y retribución. De no ser así, por las razones antes mencionadas, más valdría la pena pensar en su eliminación, lo cual resulta coherente con la propuesta del Ejecutivo de crear un sistema de asistencia jurídica profesional de defensa y asesoría legal para los más pobres ${ }^{1023 .}$

\section{DEFENSORÍA PENAL PÚBLICA}

\subsection{La Asistencia Jurídica Gratuita en el sistema procesal penal chileno. El derecho a la defensa en el nuevo sistema de justicia penal}

Uno de los cambios más importantes que se introducen con la reforma procesal penal vigente en Chile desde el año 1999, es el amplio reconocimiento que se hace del derecho de defensa de todo imputado, consecuente con el mandato constitucional e internacional de asegurar a todas las personas un justo y debido proceso.

En el nuevo sistema de justicia criminal, junto con reforzar la persecución penal, para lo cual se crea el Ministerio Público, al que se le concede la titularidad de la acción penal pública, el ejercicio de los derechos y garantías del imputado se regula en términos muy distintos a los del anterior sistema. El antiguo esquema procesal penal, estaba inspirado en el principio de presunción de culpabilidad y en que la investigación y la sanción se monopolizaba en un solo órgano, que lo constituía el juez del crimen, siendo el imputado tratado como un objeto del jus puniendi estatal, más que un sujeto de derechos.

Tal como lo preceptúa el Código Procesal Penal (CPP), "las facultades, derechos y garantías que la Constitución Política de la Republica, este Código u otras leyes reconocen al imputado podrán hacerse valer por la persona a quien se le atribuyere

${ }^{1023}$ UNIVERSIDAD DIEGO PORTALES. (2017). “Acceso a la justicia en Chile”. Op. Cit., p.203. 
participación en un hecho punible desde la primera actuación del procedimiento dirigido en su contra y hasta la completa ejecución de la sentencia"1024. Pues bien, consecuente con el momento en que reconoce su derecho a hacer valer todas sus alegaciones y argumentaciones, el nuevo sistema admite que el imputado tendrá derecho a designar libremente uno o más defensores de su confianza ${ }^{1025}$. Por ello, tanto el imputado que disponga de dinero para contratar un abogado, o el que carezca de medios u opte por un defensor penal público, podrá hacerlo desde la primera actuación del procedimiento, entendiendo por tal “...cualquier diligencia o gestión, sea de investigación, de carácter cautelar o de otra especie, que se realizare por o ante un tribunal con competencia criminal, el Ministerio Público o la policía, en la que se atribuyera a una persona responsabilidad en un hecho punible"1026.

En este orden de ideas, en caso de que ese imputado no haya contratado un abogado, procede la designación de un defensor penal público, la que puede ser solicitada por el Ministerio Público, por el Juez ${ }^{1027}$ y si se encuentra privado de libertad, por cualquier persona ${ }^{1028}$. De acuerdo a la ley de la DPP, hasta la primera audiencia judicial intervendrá siempre el defensor local, quien será designado para asistir al imputado hasta el término de la primera audiencia judicial, de acuerdo a

\footnotetext{
${ }^{1024} \mathrm{CPP}$. Artículo 7 inciso $1^{\circ}$ : "Usualmente los que realizan esta primera actuación contra un imputado, son los organismos especializados de persecución penal -Policía y Ministerio Público- quienes realizan esta primera actuación del procedimiento, ya que comienzan al recibir la denuncia o requerimiento”.

1025 IBIDEM. Artículo 8 inciso $1^{\circ}$ : “Ámbito de la defensa. El imputado tendrá derecho a ser defendido por un letrado desde la primera actuación del procedimiento dirigido en su contra. Todo imputado que carezca de abogado tendrá derecho irrenunciable a que el Estado le proporcione uno. La designación del abogado la efectuará el juez antes de que tenga lugar la primera actuación judicial del procedimiento que requiera la presencia de dicho imputado"

${ }^{1026}$ IBIDEM. Artículo 7 inciso $2^{\circ}$ : "Para este efecto, se entenderá por primera actuación del procedimiento cualquiera diligencia o gestión, sea de investigación, de carácter cautelar o de otra especie, que se realizare por o ante un tribunal con competencia en lo criminal, el ministerio público o la policía, en la que se atribuyere a una persona responsabilidad en un hecho punible”.

${ }^{1027}$ IBIDEM. Artículo 102 inciso 1: "Derecho a designar libremente a un defensor. Desde la primera actuación del procedimiento y hasta la completa ejecución de la sentencia que se dictare, el imputado tendrá derecho a designar libremente uno o más defensores de su confianza. Si no lo tuviere, el juez procederá a hacerlo, en los términos que señale la ley respectiva. En todo caso, la designación del defensor deberá tener lugar antes de la realización de la primera audiencia a que fuere citado el imputado".

${ }^{1028}$ IBIDEM. Artículo 102 inciso $2^{\circ}$ : “Si el imputado se encontrare privado de libertad, cualquier persona podrá proponer para aquél un defensor determinado, o bien solicitar se le nombre uno. Conocerá de dicha petición el juez de garantía competente o aquél correspondiente al lugar en que el imputado se encontrare”.
} 
las normas internas sobre distribución de causas en la defensoría local respectiva ${ }^{1029}$.

Tal como preceptúa el CPP, "el abogado designado por el imputado, ya sea de confianza o perteneciente al sistema de Defensoría Penal Pública, debe ejercer desde el momento de su nominación todos los derechos y facultades que la ley le concede al imputado"1030. Por ende, no existe ninguna posibilidad de que diligencias a las que deba ser citado expresamente el imputado, pueda asistir sin abogado, salvo los casos excepcionales en que el juez de garantía autorice expresamente, a instancias del propio imputado, pero no contra su voluntad ${ }^{1031}$.

Por otra parte, para la validez de ciertas audiencias es imprescindible la presencia tanto del imputado como de su defensor, transformándose en un requisito de validez de la actuación. En tal situación se encuentran las audiencias en que se solicite la prisión del imputado ${ }^{1032}$, aquella en que se solicite la aprobación de la suspensión condicional del procedimiento y la de preparación del juicio oral ${ }^{1033}$.

\footnotetext{
${ }^{1029}$ Solo si después de esta primera audiencia judicial, el Ministerio Publico decide seguir adelante con el caso, procederá la designación de un defensor penal público privado, contratado mediante el sistema de licitación o de convenio, teniendo el imputado derecho a elegir uno de la nómina preparada por la Defensoría Regional ${ }^{1030}$ CPP. Artículo 104. "Derechos y facultades del defensor. El defensor podrá ejercer todos los derechos y facultades que la ley reconoce al imputado, a menos que expresamente se reservare su ejercicio a este último en forma personal”.

1031 IBIDEM. Artículo 102 inciso $4^{\circ}$. "Si el imputado prefiriere defenderse personalmente, el tribunal lo autorizará sólo cuando ello no perjudicare la eficacia de la defensa; en caso contrario, le designará defensor letrado, sin perjuicio del derecho del imputado a formular planteamientos y alegaciones por sí mismo, según lo dispuesto en el artículo $8^{\circ}$.

1032 IBIDEM. Artículo 142 inciso $3^{\circ}$ : "La presencia del imputado y su defensor constituye un requisito de validez de la audiencia en que se resolviere la solicitud de prisión preventiva".

1033 DEL RIO, C; ROJAS, F (2009) De la Reforma Procesal Penal. Santiago. Lexis Nexis. p.447. "Si no compareciere el defensor penal público del imputado a alguna de estas audiencias, el tribunal deberá evaluar la situación, pudiendo adoptar las siguientes determinaciones: postergar la realización de la audiencia para una nueva fecha, lo que deberá hacer cuando la no comparecencia del defensor sea debidamente justificada o cuando una determinación distinta perjudique seriamente los derechos del imputado; o, proceder a requerir el nombramiento de un nuevo defensor público al imputado, caso en el cual procederá a realizar inmediatamente la audiencia, salvo que se trate de la preparación del juicio oral, la cual deberá suspender hasta por 3 días a objeto de permitir que el defensor se interiorice del caso". "Si la no comparecencia del defensor se produce en la audiencia del juicio oral, no será posible postergar su realización, debiendo designarse inmediatamente un defensor público que reemplace al de confianza o público que no compareció, concediéndosele a este un plazo prudente para interiorizarse del caso”.
} 
Ahora bien, de lo antes dicho, se desprende que en el proceso penal vigente, el derecho a la defensa ocupa un lugar central, acogiendo por ende ampliamente el principio de prohibición de la indefensión, como manifestación del derecho1034 1035.

\subsection{Defensoría Penal Pública. Ley que la crea, funcionamiento y organización}

Con el advenimiento de la nueva justicia procesal penal, la DPP viene en reemplazar a la institución de la defensa de oficio, propia del proceso penal y establecido siempre en favor del sujeto pasivo del mismo.

Desde este punto de vista sostenemos que tal como ocurría con la defensa de oficio $^{1036}$ que regía en el anterior sistema, la defensa penal púbica puede ser confundida con la asistencia jurídica gratuita, ya que concurren ambas simultáneamente, cuando se trata de un imputado o acusado en el proceso penal que carece de recursos, y que por tanto tiene derecho a un defensor penal público, y además gratuito, situación bastante frecuente en este tipo proceso.

Sin embargo, la asistencia jurídica gratuita es un concepto mucho más amplio que no se limita al proceso penal ni a una sola de sus partes, como sí lo hace la defensa penal pública. Además su naturaleza jurídica es distinta, pues la asistencia jurídica gratuita es un mecanismo para proporcionar esta asistencia a la persona que carece de recursos para obtenerla por sí misma y su fundamento es el deber de asistencia social que corresponde al Estado. La defensa penal pública es en estricto rigor un mecanismo para proveer de defensa letrada al sujeto pasivo del proceso penal y cuyo fundamento es evitar que dicho proceso pueda realizarse sin que esta parte

\footnotetext{
1034 CPP. Artículo 317. "Incapacidad para ser perito. No podrán desempeñar las funciones de peritos las personas a quienes la ley reconociere la facultad de abstenerse de prestar declaración testimonial”.

1035 Por lo tanto, la falta de designación y de comparecencia de un defensor penal público, una vez que pasa a ser obligatoria su presencia, acarrean la nulidad de tales actuaciones. Esto se desprende de lo señalado en el artículo 103 del CPP, "la ausencia del defensor en cualquier actuación en que la ley exigiere expresamente su participación acarreara la nulidad de la misma.

1036 Defensa era ejercida por los Consultorios Jurídico Sociales (CJS) de las CAJ, generalmente con la intervención de estudiantes, postulantes al título de abogado.
} 
pueda desarrollar debidamente las alegaciones y pruebas en beneficio de sus intereses, por ende, cuando la parte no nombra defensor, ya sea porque no puede o no quiere, le debe ser designado uno con cargo del Estado.

La DPP tiene por finalidad proporciona defensa penal a los imputados o acusados por crimen, simple delito o falta que sean de competencia de un Juzgado de Garantía o de un Tribunal Oral en lo Penal y las cortes respectivas, en su caso. Así, aunque al definir los beneficiarios, la ley omitió la precisión, lo cierto es que ésta ha de entenderse a la luz de la finalidad de la institución, no pudiendo por ende, ser considerados como beneficiarios de la defensa penal pública, quienes sean imputados o acusados por delitos de que corresponda conocer a un tribunal militar o, en su caso, a un juzgado del crimen.

Si bien se ha destacado, se debe destacar en este punto, que en materia penal, a la luz del mandato constitucional, a diferencia de la generalidad de los casos, la única exigencia que se formula al beneficiario es que carezca de abogado y no, como ya se ha dicho, que carezca de medios para contratar o procurarse uno por sí mismo ${ }^{1037}$. Este detalle no es de menor importancia, pues significa un cambio total en la forma de enfrentar el tema; la defensa penal pública ya no es entendida como una labor meramente asistencial, sino que por el contrario, aparece como un derecho, una garantía de todo ciudadano, independiente de sus recursos o medios económicos y aún de la posibilidad real de que pueda procurarse esa defensa por sus propios medios. La defensa penal pública aparece como la materialización de un deber del Estado y, respecto de las personas, como un derecho y no como una gracia o dispensa.

Es importante enfatizar, que por ley se establecen límites a la actuación de la defensoría, en cuanto a la materia, y a los tribunales en que deben desenvolverse.

\footnotetext{
${ }^{1037}$ En este sentido, se consagra como un derecho a favor de todo imputado, sin perjuicio de hacer presente, que al contar con recursos económicos, puede optar a los servicios de la Defensoría Penal Pública, a través de un copago fijado por el mismo servicio. De otro lado, debe igualmente evidenciarse que la labor de la Defensoría se extiende a brindar asistencia a todo aquel que carezca de abogado, independientemente de que pudiere contar con los recursos necesarios para financiarlo. No se establecen, en esta materia, distingos entre las personas, en razón de la capacidad económica de cada una.
} 
En efecto, como bien lo tratan los profesores Rodrigo Medina, Carlos Dorn y Luis Morales, "se delimita así la labor de la defensoría; en primer lugar, por la materia de que puede conocer, sólo respecto de asuntos penales, y en segundo lugar, en razón de los tribunales llamados a conocer de éstas, quedan por tanto excluidos aquellos asuntos sometidos a tribunales civiles, laborales, de menores, pero también los asuntos penales de que conocen los tribunales militares, y aquellos de que deban continuar conociendo los tribunales del crimen" ${ }^{1038}$.

La Ley $n^{\circ} 19.718$ que crea la institución de la DPP, se inicia mediante un mensaje en el boletín n² 2365-07 de fecha 13 de julio de 1999, que crea un servicio público descentralizado, dotado de personería jurídica y patrimonio propio, que debe relacionarse con el Presidente de la República a través del Ministerio de Justicia. Su dirección superior está a cargo de un funcionario de exclusiva confianza del Presidente de la República, denominado Defensor Nacional ${ }^{1039}$.

A diferencia de lo que acontece con el Ministerio Público, que es un organismo autónomo, para el caso de la DPP, se optó por someterla derechamente a la super vigilancia del Presidente de la República a través del Ministerio de Justicia. De igual modo, y a diferencia del Ministerio Público, la DPP no es una institución jerarquizada, sin perjuicio del sistema de control y responsabilidad que la misma ley establece. La DPP se organiza en una Defensoría Nacional y en Defensorías Regionales, éstas últimas se organizan a través de defensorías locales, sin perjuicio de los abogados e instituciones con quienes celebren convenio para la prestación del servicio de defensa penal ${ }^{1040}$.

${ }^{1038}$ MEDINA, R; MORALES, L; DORN, C (2007). Manual de derecho procesal penal. Santiago. Lexis Nexis. p. 76.

1039 A nivel regional, las atribuciones del servicio están a cargo de los defensores Regionales, debiendo existir uno por cada región, con excepción de la Metropolitana, en la que habrá dos. A su vez, se crean defensorías locales como unidades operativas en las que se desempeña la defensoría en la región. Estas solo existirán en aquellas ciudades cuya población exceda a 50.000 habitantes y, aun cuando no se cumpla con este mínimo, cuando se trate de una capital de región.

${ }^{1040} \mathrm{El}$ personal de la Defensoría estará regido por las disposiciones de la ley que la crea, $\mathrm{n}^{\circ} 19.718$ y las normas del estatuto administrativo, $n^{\circ} 18334$. Dentro de las funciones exclusivas del Defensor Nacional, es entre otras, dirigir, organizar y administrar la defensoría, controlarla y velar por el cumplimiento de sus objetivos y fijar, con carácter general, los estándares básicos que deben cumplir en el procedimiento penal quienes presten servicios de defensa penal pública. Dentro de las funciones que el Defensor Regional, que se requieren previa 
En cuanto a la organización de la DPP, se contará con las siguientes unidades administrativas: recursos humanos, informática, administración y finanzas, estudios, evaluación, control y reclamaciones ${ }^{1041}$.

Precisamente, la DPP incluye Defensorías Regionales que es la encargada de la administración de los medios y recursos necesarios para la prestación de la defensa penal pública en la región o extensión geográfica que corresponda, en aquellas regiones en que exista más de una defensoría regional a los imputados o acusados por crímenes, simples delitos o faltas que sean de competencia de juzgados de garantía, tribunales orales en lo penal y las cortes respectivas, cuando les corresponda conocer de estos mismos asuntos, y que carezcan de abogados para que suma se defensa ${ }^{1042}$.

Es la forma en que se desconcentra la DPP, y debe existir una por cada región, salvo en la Región Metropolitana, en que existen dos. Medina, Morales y Dorn refuerzan estas ideas de desconcentración y descentralización, al sostener que "cada defensoría regional, cuenta con defensores locales con coberturas en los distintos juzgados, y los defensores locales deberán asumir la defensa de todo imputado que carezca de abogado en la primera actuación del procedimiento dirigido en su contra y, en todo caso, con anterioridad a la realización de la primera audiencia judicial a que fuere citado"1043. Se considera relevante el accionar del Defensor Local, en términos de rol y permanencia temporal ${ }^{1044}$. Claramente, los

audiencia del consejo, fijar, oyendo al consejo, los criterios de actuación de la defensoría para el cumplimiento de los objetivos establecidos en la ley. En el caso del Defensor Regional, deben distinguirse aquí aquellas atribuciones que el Defensor Nacional ejercita por sí solo, y que por tal razón denominaremos exclusivas y aquellas en que debe proceder previa audiencia del Consejo de Licitaciones de la defensa penal pública, que es el cuerpo técnico colegiado encargado de cumplir las funciones relacionadas con el sistema de las licitaciones de la defensa penal pública que le encomienda la ley

${ }^{1041}$ MEDINA, R; MORALES, L; DORN, C. Op. Cit., p. 80.

1042 DEL RIO, C; ROJAS, F (2009) De la Reforma Procesal Penal. Santiago. Lexis Nexis. p.32. "La función de evaluación deberá considerar el estudio, diseño, y ejecución de los programas de fiscalización y evaluación permanente respecto de las personas naturales y jurídicas que presten servicios de defensa penal pública”.

1043 MEDINA, R; MORALES, L; DORN. C. Op. Cit., p. 80.

1044 IBIDEM. "asimismo, deberá asumir la defensa del imputado o acusado siempre que, falte abogado defensor, por cualquier causa, en cualquier etapa del procedimiento. Deberá mantener esta defensa hasta que la asuma el defensor que designare el imputado o acusado, salvo en los casos en que éste fuere autorizado por el tribunal para defenderse personalmente". 
Defensores Locales deben ejercer sus funciones con transparencia de manera de permitir a los defendidos el conocimiento de los derechos que les confiere la ley, así como los procedimientos, contenidos y fundamentos de las actividades que emprendan en el cumplimiento de sus funciones ${ }^{1045}$.

Otra función de la defensoría es designar a los letrados o instituciones licitantes con convenio vigente a quienes les corresponda asumir las defensas en casos determinados, para ir configurando un sistema de defensa, en que las prestación no solo la realiza la DPP a través de su personal de planta, sino también por abogados que licitan a través de un proceso estandarizado de adjudicación, una "cartera" de defendidos para prestarles este servicio, bajo las condiciones establecidas por ley. Se sigue de esta forma, un modelo mixto que recoge características del judicare system y el staff system, que se establece a través de un sistema de defensa netamente estatal a cargo de abogados de la DPP, en conjunto con un sistema de licitación a cargo de la misma DPP, que encomienda a abogados privados la defensa de los derechos de los imputados, que son denominados defensores penales públicos licitados, contemplando además los aludidos convenios directos que celebra el Defensor Nacional con abogados privados para la prestación del servicio de defensa.

Con la finalidad de hacer posible esta forma de DPP licitada, la ley creó un Consejo Nacional de la DPP, integrado por los ministros y académicos ${ }^{1046}$

Es dable señalar, que podrán participar en la licitación, las personas naturales que cuenten con el título de abogado y cumplan con los demás requisitos para el ejercicio profesional, y las personas jurídicas, públicas o privadas, con o sin fines de lucro, que cuenten con profesionales que cumplan los requisitos para el ejercicio

\footnotetext{
1045 Precisamente a los defensores locales les corresponde asumir la defensa de los imputados que carezcan de abogado en la primera actuación del procedimiento dirigido en su contra y, en todo caso, con anterioridad a la realización de la primera audiencia judicial que fuere citado. Asimismo, les corresponderá asumir la defensa, respecto de aquellos casos que no alcancen a ser cubiertos por la licitación del servicio.

1046 Entre las funciones de este Consejo, se encuentran, las de proponer al Defensor Nacional el monto de los fondos por licitar, a nivel nacional y regional; aprobar las bases de las licitaciones a nivel regional, a propuesta de la Defensoría Regional; la de convocar y establecer las bases de la licitación a nivel regional para la contratación de los futuros defensores, etcétera.
} 
profesional de abogado ${ }^{1047}$. Los criterios para la resolución de la adjudicación, son Ios siguientes: a) Costos del servicio b) Permanencia y habitualidad en el ejercicio de la profesión en la región respectiva. c) Número y dedicación de abogados disponibles en el caso de personas jurídicas. d) Experiencia y calificación de los profesionales que postulen. e) Apoyo administrativo de los postulantes ${ }^{1048}$. La decisión del concurso será pública y fundada procediendo la reclamación ${ }^{1049}$.

La ley contempla estrictos mecanismos de control, reclamos y sanciones en relación a los profesionales que presten defensa, entre los cuales hay requerimientos e informes periódicos, inspecciones de oficio y todo un sistema de reclamos de los beneficiarios que pueden traducirse en sanciones consistentes en multas, según lo establecido en los contratos respectivos o en la terminación del contrato.

Como establece la Ley 19.718 que crea la DPP "la Defensoría Regional, elaborará una nómina de los abogados que, en virtud del proceso de licitación, deban asumir la defensa penal pública de los imputados o acusados en la región respectiva. Para estos efectos, todos los abogados se individualizarán con sus propios nombres $\mathrm{y}$, según proceda, se señalará su pertenencia a una persona jurídica licitada"1050.

${ }^{1047}$ LEY 19.718. Crea la Defensoría Penal Pública, de 27 de febrero de 2001. Artículo 44: "Los postulantes a la licitación deberán señalar específicamente el porcentaje del total de caso al que postulan y el precio de sus servicios. La licitación será resuelta a nivel regional por un Comité de Adjudicación Regional, integrado por un representante del Ministerio de Justicia, por el Defensor Nacional y el Defensor Regional o un representante de aquellos, un académico de la región y un juez con competencia en lo penal”.

${ }^{1048}$ IBIDEM. Artículo 46. "Si la persona natural o jurídica que postula a la licitación se encontraré prestando el servicio de defensa penal pública o lo hubiere prestado con anterioridad, se considerarán, además, las eventuales sanciones que se le hubieren aplicado y el número de personas que hubiere solicitado el cambio de defensor”.

${ }^{1049}$ Cualquier reclamación interpuesta por algunos de los participantes será conocida y resuelta por el Comité de Adjudicación Regional. Contra su resolución, solo procederá la apelación ante el Consejo de Licitaciones de la Defensa Penal Pública. La labor de adjudicación se realizará por el plazo que el Consejo señale, el que no podrá ser superior a seis meses, al cabo del cual deberá llamarse nuevamente a licitación por el total de casos o por el porcentaje no cubierto, según corresponda. Los contratos a que dé lugar una licitación serán suscritos por el Defensor Nacional. El pago de los fondos licitados se efectuará en la forma que establezca el reglamento. En cada uno de estos deberá retenerse, a título de garantía, un porcentaje del mismo, el cual será determinado en las bases de la licitación. Además de este fondo de reserva, el Consejo deberá exigir al abogado o a la persona jurídica respectiva una boleta bancaria de garantía, o cualquier otra caución que estime suficiente con el objeto de asegurar la adecuada prestación de los servicios licitados. Si se abriere proceso administrativo del cual pudiere resultar la aplicación, a la persona natural o jurídica que preste servicios de defensa penal pública, de alguna de las sanciones previstas en la misma ley, las garantías solo se entregaran o devolverán, según proceda, en la parte que exceda el monto que pudiere ser condenado a pagar a título de sanción.

${ }^{1050}$ IBIDEM. Artículo 51. 
Esta nómina deberá ser actualizada permanentemente y remitida a la o las defensorías locales, Juzgados de Garantía, Tribunal Oral en lo Penal y CA de la región respectiva. El imputado o acusado elegirá de esta nómina al abogado que, estando disponible, asumirá su defensa.

En cuanto a la solicitud de cambio del defensor, la misma Ley 19.718 preceptúa que "con todo, el imputado o acusado, en su caso, tendrá derecho a solicitar en cualquier momento, con fundamento plausible, el cambio de su defensor penal público, petición sobre la cual se pronunciará el Defensor Regional. El reemplazante será designado por el imputado o acusado en la misma forma ya indicada" ${ }^{1051}$.

Los defensores penales públicos y licitados ejercerán sus funciones con transparencia, de manera de permitir a los defendidos el conocimiento de los derechos que les confiere la ley, así como los procedimientos, contenidos y fundamentos de las actividades que emprendan en el cumplimiento de sus funciones. Designado el defensor penal público no podrá excusarse de asumir la representación del imputado o acusado. En cuanto a la supervisión y control, tan relevante para el fiel cumplimiento de las funciones propias de la defensa, como se ha expresado en la Ley 19.718 "el desempeño de los defensores locales y de los abogados que prestan defensa penal pública será controlado a través de Inspecciones, auditorías externas, informes, reclamaciones"1052. Los defensores están sujetos a responsabilidad administrativa, de acuerdo con las disposiciones del estatuto administrativo para funciones públicos; responsabilidad civil y penal, por los ilícitos en que incurran en el cumplimiento de sus funciones ${ }^{1053}$.

\footnotetext{
1051 IBIDEM. Artículo 53.

1052 IBIDEM. Artículo 56.

1053 IBIDEM. Artículo 69. "Las personas naturales y jurídicas que presenten servicios de defensa penal pública, sea en virtud de un proceso de licitación o de un convenio directo, estarán afectos a responsabilidad civil y penal, en su caso, y además incurrirán en responsabilidad en los siguientes casos: a) Cuando la defensa no fuere satisfactoria, de acuerdo con los estándares básicos, definidos por el Defensor Nacional, que deben cumplir en el procedimiento penal quienes presten servicios de defensa penal pública) Cuando no hicieren entrega oportuna de los informes semestrales o del informe final, o consignaren en ellos datos falsos, y c) Cuando incurrieren en incumplimientos del contrato celebrado”.
} 
Dentro de las sanciones que pueden aplicarse a los defensores penales públicos y públicos licitados, se encuentran las multas, que se aplicarán, en caso de defensa no satisfactoria y omisión en la entrega de los informes, directamente por el Defensor Regional ${ }^{1054}$.

\subsection{Apreciaciones sobre la calidad y adecuación der servicio brindado por la DPP y encuestas de percepción ciudadana}

A nuestro parecer, el modelo de asistencia jurídica en la defensa penal se perfila a cumplir con estándares de defensa, destacando la amplia dotación de recursos, y la adecuada organización del servicio, como asimismo el carácter profesional de sus prestadores. Justamente, se trata de un servicio profesionalizado, en que la prestación penal pública recae solo en abogados, en que existe una partida presupuestaria importante en la mantención del servicio, incluyéndose un sistema mixto de prestaciones tanto públicas y privadas, que redunda en que el imperativo constitucional y legal de contar con abogado desde la primera actuación del procedimiento se haga efectivo.

Se contemplan efectivos mecanismos de control, con el objeto de que las prestaciones numéricamente consideradas, puedan satisfacer el universo de imputados que requieran la prestación. Indiscutiblemente es un punto a favor, que no se limite la atención solo a la población más vulnerable desde un punto de vista socioeconómico, como ocurre con las CAJ o los abogados de turno, en temas diversos a lo penal, pues permite a personas que percibiendo un ingreso superior a ciertos estándares establecidos ya revisados en el Capítulo III, puedan optar al

\footnotetext{
${ }^{1054}$ En la misma resolución, se dispondrá se impute al valor de la multa de la multa la suma que se encontrare retenida a título de garantía, y si ella no fuere suficiente se señalará el incremento del porcentaje a retener de las cantidades que se devengaren a favor del prestador del servicio hasta el entero pago de la pensión. De la resolución del Defensor Regional se podrá apelar, dentro del plazo de cinco días de notificada, ante el Defensor Nacional, quién resolverá en los diez días siguientes. La terminación del contrato se dispondrá por el Consejo, a requerimiento del Defensor Regional, en caso de incumplimiento del contrato.
} 
servicio especializado que ofrece la DPP con su variante de DPP licitada. También son valoradas, las experiencias de defensorías penales especializadas. Entre estas, destaca la Defensoría Juvenil que atiende al grupo etareo que le afecta la Ley 20.084, sobre responsabilidad penal adolescente. Asimismo, se contempla, la Defensoría Penal Indígena, para la atención judicial que se adecúe a las singularidades de este grupo y la Defensoría Penitenciaria, encargada de representar a las personas que ya están condenadas por un delito, para el adecuado ejercicio de los beneficios carcelarios y de la orientación de temas jurídicos diversos a lo penal.

Como toda institución, también no está exenta de críticas, dentro de las que se incluyen, la escasa preparación de los defensores en relación a las audiencias de control de detención, reducida accesibilidad de los imputados libres y privados de libertad a concertar citas con su defensor, etcétera.

Sin perjuicio de estas apreciaciones un tanto genéricas, hemos decidido destacar un estudio denominado "percepción del servicio de la DPP", encomendado por esta institución al Centro de Estudios de la Pontificia Universidad Católica de Chile, que oficiando como auditor externo, nos otorgará datos objetivos sobre la percepción ciudadana respecto de esta institución ${ }^{1055}$. Este estudio se basa en una muestra de 1.202 encuestados en la zona urbana de doce comunas de Santiago. Es necesario destacar, que solo el $44 \%$ de la población ha oído hablar de la DPP, por lo cual podemos señalar que es un organismo relativamente conocido por la población en general. En cuanto a la función de la DPP, del universo muestral que la conoce, un $82,9 \%$ sabe que su función es garantizar a toda persona imputada de un delito que se le designe un defensor y sea representado judicialmente. De las 1.202 personas encuestadas, 107 habían tenido contacto personal o por un familiar con la DPP en los últimos 5 años, es decir un 8,9\% de los encuestados. El 60,5\% de ellos, se había acercado derechamente para la representación de un abogado, y el resto

\footnotetext{
1055 BRAVO, D; ORDENES, C. Percepción del servicio de la Defensoría Penal Pública. Santiago. Centro U.C

Encuestas y estudios longitudinales. pp 38-44.
} 
porcentual, se divide en aquellos cuyo fin era consultar sobre el seguimiento de una causa, búsqueda de información, etcétera.

En una escala de calificación, en que 1 es la calificación menor y 7 la mayor, las personas que fueron atendidas por la DPP, directamente o que lo fue un familiar, evalúan los siguientes ítems con las consecuentes calificaciones.

Calidad profesional del abogado: 5,2

Trato al imputado: 5,2

Información: 5,0

Ubicación y comodidad de oficinas: 5,5

Rapidez con que son resueltos los casos: 4,5

Evaluación general: 5,1

\section{CORPORACIÓN DE ASISTENCIA JUDICIAL. GENESIS, DIMENSIÓN INSTITUCIONAL, ESTRUCTURA Y ORGANIZACIÓN}

\subsection{Orígenes}

Una primera forma que ha tenido la legislación chilena de avocarse al problema de la defensa jurídica de aquellas personas que no acceden a los servicios de un abogado particular, es a través de la institución de los abogados de turno (y el complemento del privilegio de pobreza $)^{1056}$. Superada esta fase, el Estado responde a esta necesidad de defensa jurídica a través de las CAJ en materias civiles,

\footnotetext{
${ }^{1056}$ Lo que caracteriza principalmente a este modelo es que se trata de una carga honorífica impuesta a algunos intervinientes en el sistema de justicia, especialmente los abogados, quienes entregan una especie de beneficio a personas de escasos recursos. Esa configuración básica de la asistencia jurídica gratuita (de carga y beneficio) impide mecanismos de control efectivos sobre las obligaciones impuestas y la obtención efectiva de los privilegios, y ha sido objeto de un juicio de inconstitucionalidad al no establecer una retribución por la carga pública impuesta.
} 
laborales, familia y de la línea de Solución Colaborativa de Conflictos (SCC). Las CAJ son entidades de derecho público, con personalidad jurídica y patrimonio propio, y sin fines de lucro ${ }^{1057}$. En cuanto a su distribución, las CAJ se encuentran desplegadas a lo largo de Chile, existiendo 4, distribuidas en zonas territoriales: Metropolitana (CAJ Región Metropolitana), Valparaíso (CAJ VAL, Bío Bío (CAJ Bío Bío) y de Tarapacá (CAJ Tarapacá), cada una, con jurisdicción sobre varias regiones ${ }^{1058}$.

A pesar de que actualmente existe un concepto claro de esta institución y dónde se ubican estos organismos en el ordenamiento jurídico nacional, es imperativo remontarnos a sus primeros años de funcionamiento y distribución territorial ${ }^{1059}$. Fue así como el 8 de septiembre de 1928, con la dictación de la Ley $n^{\circ} 4.409$, se mandataba a los Consejos de los Colegios de Abogados, crear y mantener consultorios jurídicos gratuitos para pobres y vigilar la correcta actuación de los abogados llamados por la ley a asistir a personas que gozan del privilegio de pobreza ${ }^{1060}$. Años más tarde, al eliminarse la agremiación obligatoria, en virtud de la dictación del DL $n^{\circ} 3621$, los colegios fueron transformados en asociaciones gremiales de derecho privado y de libre inscripción. Posteriormente, los consultorios crecieron y gracias al mayor financiamiento otorgado por la Ley no 7.291 y a través de los Consejos provinciales del Colegio de Abogados el servicio se extendió al resto de las provincias ${ }^{1061}$. El 29 de marzo de 1935, se dicta el DS n ${ }^{\circ} 1.260$, que fija

${ }^{1057}$ LEY 17.995. Que concede personalidad jurídica a los servicios de asistencia jurídica gratuita que se indican en las regiones que se señalan, de 8 de mayo de 1981. Artículo 2 inciso $1^{\circ}$. LEY no 18.632. Crea Corporación de Asistencia Judicial de las regiones de Tarapacá y Antofagasta y le concede personalidad jurídica, de 24 de julio de 1987. artículo 1 inciso $2^{\circ}$

${ }^{1058}$ La CAJ Región Metropolitana de Santiago tendrá competencia sobre las regiones Metropolitana, Sexta, Séptima y Duodécima Regiones (artículo 2 Decreto 995 de 1981, del Ministerio de Justicia), y por último, la CAJ de Tarapacá y Antofagasta será competente en las Primera, Décimo Quinta y Segunda Regiones. En el caso de las corporaciones de la Región Metropolitana, de la Región de Valparaíso y la del Bío Bío, su nacimiento se debe a la Ley N ${ }^{\circ} 17.995$, de 16 de diciembre de 1982. Por su parte, la corporación de Tarapacá y Antofagasta fue establecida unos años después, por medio de la Ley n ${ }^{\circ}$ 18.632, de 24 de julio de 1987.

${ }^{1059}$ AYLWIN, M (1988). Justicia y Sectores de bajos ingresos. Santiago Editorial Jurídica Conosur. p. 178-179. "El origen de las CAJ, se remonta a la primera década del siglo XX, como una institución que se creó para cumplir la tarea de brindar asistencia jurídica y judicial gratuita a la personas de escasos recursos y proporcionar los medios necesarios para que los egresados de derecho puedan efectuar su práctica profesional, pudiendo así optar al título profesional de abogado, que hasta ese instante era ejercida por las asociaciones de abogados y más recientemente por el Colegio de Abogados de Chile, quienes cumplían dicha tarea”

${ }^{1060}$ LEY 4.409 de 8 de septiembre de 1928. Orgánica del Colegio de Abogados. Artículo 12 letra ñ.

${ }^{1061}$ DL 3621. Fija normas sobre Colegio Profesionales, de 3 de febrero de 1981. 
el texto definitivo de la Ley 4.409, creando los servicios de asistencia jurídica para pobres $^{1062}$. Se fue consolidando de esta manera, con diversas reformas, el derecho a la asistencia jurídica gratuita, como un deber correlativo del Estado, en cuanto a entregar asistencia jurídica social gratuita a las personas de escasos recursos económicos, a través de las Leyes n 17.995 y n $18.632^{1063}$, del año 1981 y 1987 respectivamente, las que dan existencia legal a las 4 CAJ en el País:

\subsection{Finalidades y objetivos de las CAJ}

Revisado el origen de la institución, cabe preguntarse cuál es la finalidad y los objetivos de las CAJ, interrogantes que se plantean año tras año, desde su creación e implementación en nuestro país. Es por ello que las finalidades de estos organismos serán las de prestar asistencia jurídica y judicial gratuita a personas de escasos recursos y proporcionar los medios para efectuar la práctica necesaria para el ejercicio de la profesión a los postulantes a obtener el título de abogado.

A pesar de haber sido creadas con posterioridad a la dictación de la CPR, la primera finalidad de las CAJ no está planteada en términos de cumplimiento de una obligación estatal emanada de la Carta Fundamental, sino que tan sólo en términos de un beneficio. No obstante ello, cierta doctrina constitucional reconoce que esos son los medios a través de los cuales se cumple con el artículo $19 \mathrm{n}^{\circ} 3$ inciso $3^{\circ} \mathrm{de}$ la CPR. Actualmente las CAJ, prestan asistencia jurídica en materias civiles ${ }^{1064}$, de

\footnotetext{
1062 En un principio los consultorios se habilitaron en un principio en las cárceles para la defensa de los condenados en procedimientos penales, posteriormente la atención se extendió, tratando temas como: Sección Civil, Criminal y Menores. La sección civil trataba materias de jurisdicción contenciosa (juicios de trabajo y gestiones de carácter administrativo) y voluntaria (demandas por comodato precario, juicios de nulidad de matrimonio divorcio e interdicciones). La sección criminal tramitaba procesos por delitos de robo, hurto, homicidios, lesiones, abigeato, incendio, vagancia y violación. Esta sección solo existió en los consultorios de Santiago y Valparaíso. La sección de menores tramitaba legitimaciones, reconocimiento de hijos naturales, adopciones guardas, tuiciones y alimentos. Al igual que la sección criminal estos temas solo existieron en los consultorios de Santiago y Valparaíso.

${ }^{1063}$ LEY 18.632. Crea Corporación de Asistencia Judicial de las Regiones de Tarapacá y de Antofagasta y le concede Personalidad jurídica, de 24 de julio de 1987.

${ }^{1064}$ CAJ REGION METROPOLITANA. Cuenta pública participativa 2019. "Se estima que las causas civiles representan un 24,3\% de las causas ingresadas. Entre éstas destacan, las causas de acciones reivindicatorias,
} 
familia ${ }^{1065}$ y laborales ${ }^{1066}$, además de algunos procedimientos especiales en cortes $^{1067 .}$

Producto de la reforma procesal penal, las CAJ dejaron de tener competencia de defensa en materia penal en cuanto a defensa procesal del imputado, aunque existan ciertas materias de índole penal que siguen siendo de competencia de la CAJ, como la tramitación de eliminación de antecedentes y solicitudes de prescripción de pena. Es dable señalar que las CAJ, cuentan con una línea de servicio de atención a víctimas de delitos violentos a través de los Centros de Atención a Víctimas de Delitos Violentos ${ }^{1068}$.

Otra finalidad de las CAJ es proporcionar los medios para efectuar la práctica profesional de los futuros abogados ${ }^{1069}$. Esta obligación se encuentra mayormente regulada en el Decreto Supremo del Ministerio de Justicia $n^{\circ} 265$, de 2 de octubre de $1985^{1070 .}$

arriendo, comodato, cobro de pesos, demarcación y cerramiento, ejecutivas, indemnización de perjuicios, interdicción por demencia, otras voluntarias, etcétera”.

1065 IBIDEM. Se estima que las causas de familia representan un 64,6\% del total de las causas ingresadas. Entre éstas destacan, las materias de alimentos, autorización para salir del país, cuidado personal, curatelas, declaración de bien familiar, divorcios, patria potestad, relación directa y regular, violencia intrafamiliar.

1066 Mediante la creación el año 2009 de las Oficinas de defensa Laboral, encargadas de representar en sede judicial a los trabajadores, contando con cobertura nacional a través de oficinas desplegadas en las regiones del País. Sólo prestan el servicio abogados y los criterios de focalización dicen relación con el promedio de las ultimas remuneraciones, que no puede exceder 2.36 IMM, actuales 767.000 pesos. Representan el $8 \%$ de las causas totales que son atendidas en la CAJ, según la cuenta participativa 2019. Entre éstas, se pueden mencionar despido injustificado, nulidad de despido y tutela laboral.

${ }^{1067}$ La CAJ de la Región Metropolitana cuenta con algunos consultorios especializados que desarrollan su función de asistencia jurídica gratuita en las Cortes de Apelaciones y la Corte Suprema, como la oficina especializada de Derechos Humanos (que tramitan recursos de protección y de amparo, por ejemplo).

1068 Denominados CAVI, con cobertura en todas las regiones del país, están a cargo de la representación a víctimas de delitos violentos y/o familiares. Los servicios presentados dicen relación con la presentación de la querella y representación en el proceso judicial velando por los intereses de la víctima que pueden distar de los del ministerio público. En este contexto se puede solicitar indemnizaciones civiles. Aparte de la representación legal, se contempla la intervención social y el apoyo psicológico.

1069 También deriva de lo que ocurría antes con los consultorios de los colegios de abogados, ya que era allí donde los egresados de la carrera de derecho realizaban su práctica profesional. En la actualidad los egresados de derecho deben realizar ese trámite en este organismo, en los diversos consultorios generales o especiales dependientes o asociados a las corporaciones.

1070 Sin perjuicio de ello, es dable señalar que la CAJ ha celebrado convenio con otras instituciones para que la práctica profesional se pueda realizar en esas instituciones, pero bajo los lineamientos y visación de informes por parte de la CAJ, Algunas de estas instituciones, corresponden a SERNAMEG, Servicio Nacional de Consumidor, Ministerio Público y DPP. Es dable señalar que por el carácter profesionalizado de estos servicios, la actuación de los postulantes es de soporte administrativo y de análisis de casos. 
Las líneas de servicio de las CAJ se sintetizan en:

a) Asistencia Judicial Gratuita. La asistencia judicial gratuita se entiende como la representación de personas o grupos de personas ante un órgano jurisdiccional, abogando por el reconocimiento de una pretensión de carácter legal, ya sea en asuntos de carácter contencioso o judicial no contencioso. La asistencia judicial se otorga a las personas de escasos recursos mediante el patrocinio en la representación y tramitación de las causas judiciales ente los tribunales de justicia competentes $^{1071}$. En virtud de lo consignado en el sitio oficial de la CAJ Región Metropolitana, se desprende que tanto el patrocinio y la línea de Solución Colaborativa de Conflictos (SCC), en cuanto al logro de acuerdos homologables a sentencias, conforman en su conjunto el servicio de asistencia judicial gratuita ${ }^{1072}$.

Es dable señalar que la dirección jurídica del caso, recae en el abogado bajo su responsabilidad, siendo el estudiante de derecho o postulante, un colaborador, en la gestión de la causa.

b) Orientación e información jurídica y social. Se ofrece la asesoría de un profesional abogado y/o asistente social de una unidad de atención, quien entrega información socio-jurídica respecto del problema o conflicto jurídico consultado, además de la ilustración de los deberes y derechos del usuario, y la manera más adecuada de hacer efectivo el ejercicio de los mismos. Este es un servicio que se otorga sin necesidad de calificación socioeconómica ${ }^{1073}$.

\footnotetext{
${ }^{1071}$ CAJ REGION METROPOLITANA. http://www.cajmetro.cl/presentacion/ [Consulta 20 de mayo de 2020]. "la asistencia judicial, que comprende los servicios de carácter resolutivo, cuyo objetivo es reconocer y/o ejercer un derecho, satisfaciendo una pretensión jurídica o poniendo fin a un conflicto jurídico o a una situación de abuso a través de una sentencia ejecutoriada o un equivalente jurisdiccional y, en algunos casos, obtener la reparación del mal causado producto de esta vulneración.

1072 IBIDEM. "Así, la asistencia judicial comprende el patrocinio judicial y el servicio de SCC, cuya solución generalmente es homologada en sede judicial, o bien, vía acuerdo privado entre las partes o acuerdo en escritura pública, y la Intervención Interdisciplinaria (Apoyo integral), comprendiendo en este último caso, a la atención integral a víctimas de delitos de alta lesividad a través de los Centros de Atención a Víctimas de Delitos Violentos, y la representación jurídica de NNA a través del programa MI Abogado”.

1073 IBIDEM. "La Asesoría Jurídica, cuyo objeto es otorgar información jurídica y profesional relevante para abordar un conflicto puntual, o una problemática presente o futura a todas las personas, independientemente de su condición económica. Para esto, se cuenta con las líneas de orientación e Información en derechos, y la de prevención de conflictos y promoción de derechos”.
} 
Esta orientación jurídica dice relación con la necesaria asesoría, consejo, ilustración, que requiere la persona para prevenir un conflicto y para determinar también, cuales son las alternativas de solución resultan más viables. Además dentro de la asistencia jurídica gratuita, se encuentra el estudio de viabilidad del caso, desde un punto de vista jurídico, y de ponderación de las posibilidades reales de obtención de los resultados esperados por el consultante.

Se proporciona este servicio de orientación, principalmente en 2 tipos de casos:

b.1) Conflicto entre partes. En este caso la orientación legal busca proponer, cuando sea pertinente, vías alternativas a la judicial para la solución del conflicto. Con este objeto se cita a las partes a un comparendo en el que buscan una SCC por los implicados, a través de la línea de Resolución Alternativa de Conflictos (RAC). La SCC se presentan en los Centros Jurídicos Sociales (CJS) de las CAJ en la línea RAC, y las SCC también la ofrecen las CAJ a través de los Centros de Mediación (CMED).

b.2) Consultas legales administrativas. La orientación de este tipo, dice relación con los derechos y obligaciones de las personas en el ámbito de derecho público, considerándose las relativas a pago de tributos, trámites ante ministerios y otros organismos públicos, etcétera. Se considera mayoritariamente que esta labor debería ser realizada por asistentes sociales de la CAJ, salvo en aquellos casos en que la complejidad del asunto obligue a derivarlo a un abogado del mismo servicio.

c) Resolución alternativa de conflictos. Dentro de la línea de SCC nos encontramos con el RAC que se ofrece en todos los CJS y la mediación que se brinda en los CMED. Ofrecen la posibilidad de solucionar problemas sin necesidad de recurrir a los tribunales de justicia, a través de las llamadas formas alternativas de resolución de conflictos (Mediación-Negociación-Conciliación), y con énfasis en el dialogo entre las partes ${ }^{1074}$. Precisamente, con la finalidad de favorecer y potenciar la cultura

1074 CAJ REGION METROPOLITANA. (2013). Resolución alternativa de Conflictos: Una opción democrática de acceso a la justicia: Una forma de intervención humanizante en la asistencia jurídica gratuita. Santiago, Editorial Jurídica de Chile. p.46.” La resolución alternativa de conflictos de las CAJ presenta las siguientes características i) La aplicación de un método no adversarial alternativo en el que participan voluntariamente dos o más personas que enfrentan un conflicto de connotación jurídico- social, en el que a 
del dialogo en la comunidad, es que las CAJ cuentan con los indicados CMED, en las ciudades más importantes del país ${ }^{1075}$.

d) Prevención y difusión de derechos: Se trata del desarrollo de actividades comunitarias de prevención y promoción de derechos y deberes ciudadanos sobre diversas materias jurídicos-sociales de interés, realizadas por profesionales, en forma de charlas, talleres u otras actividades de difusión. Se busca por ende, informar y educar a las personas.

e) Gestiones Extrajudiciales: Trámites realizados por profesionales de una unidad de atención para resolver situaciones y/o conflictos jurídico-sociales que no requieren de intervención judicial, como escritos o informes sociales favorables solicitados por un tribunal de familia para acceder a mediación gratuita. En este ámbito se considera la confección de escrituras y acciones realizadas ante entes administrativos. Para acceder a este servicio se requiere de calificación socioeconómica.

\subsection{Organización y Estructura de las CAJ}

través del proceso se aborda el problema y se construyen soluciones mutuamente satisfactoria a los intereses de las partes. ii) La participación de un tercero facilitador del proceso, cuyo rol principalmente consiste en equilibrar a las partes y asesorarlas en la clarificación e identificación de los factores intervinientes en el conflicto, el marco legal vigente y las alternativas de solución. iii) La utilización en el desarrollo de las sesiones de elementos técnicos tales como: observación, entrevista, socio gramas, dinámicas participativas, negociación, mediación y/o conciliación. iv) Si las partes logran acuerdos, estos se formalizan en un documento denominado transacción y se solicita su aprobación al tribunal”.

1075 Los CMED son unidades especializadas en resolución alternativa y colaborativa de conflictos. Para ello cuentan con un equipo multidisciplinario compuesto por abogados, asistentes sociales y psicólogos, capacitados en la conducción de procesos de mediación que involucra a personas que, voluntariamente, deseen solucionar sus conflictos de convivencia vecinal, laboral, de herencia, deslindes y cualquier otro de índole vecinal, comunitario y civil, siempre guiados por el profesional mediador, que actúa de manera imparcial y sin tomar decisiones por las personas. Los CMED además coordinan y realizan charlas y talleres de promoción y difusión de la resolución pacífica de conflictos y cultura del dialogo para dirigentes vecinales y comunidad en gene 
Las CAJ desempeñan su cometido a través de sus unidades operativas, que son los CJS, los que a su vez se encuentran agrupados generalmente por territorios, pero también pueden estarlo por especialidad.

Los equipos de cada CAJ están conformados por abogados, secretarias y en los CMED u otros centros especializados como el Centro de Atención a Víctimas de Delitos Violentos, por asistentes sociales y psicólogos.

El presupuesto de esta institución está dado principalmente por aporte fiscal y en algunos casos por recursos provenientes de convenios municipales. Dentro de los convenios, se encuentran los aportes de carácter económico, como también los que se traducen en comodatos de inmuebles.

La estructura de la institución puede variar según su ubicación geográfica, pero en general las CAJ se estructuran organizacionalmente de la siguiente manera:

a) Consejo Directivo. Este es un órgano colegiado cuya función es adoptar acuerdos en sesiones ordinarias y extraordinarias relativas a las materias entregadas a su decisión, en virtud de la Ley 17.995.

b) Dirección General. El Director General es nombrado por el Consejo Directivo. Tiene por función administrar la institución, siendo el responsable de su buen funcionamiento, además es quien debe velar por el cumplimiento de los objetivos, fines y metas que el Ministerio de Justicia y el propio Consejo Directivo instruyen. Esta dirección cuenta con un departamento jurídico.

c) Dirección de Administración y Finanzas. Su finalidad es la gestión operacional del servicio, y se encuentra compuesta por departamento de recursos humanos, informática, administración y de finanzas.

d) Unidades asesoras. La función principalmente es servir de soporte técnico a la Dirección General, constituida por unidad de planificación y desarrollo, de comunicaciones y departamento de auditoría y gestión de control. 
El funcionamiento de las CAJ se analizará además, desde los siguientes puntos de vista $^{1076}$ :

a) Régimen de trabajo del postulante. La práctica profesional para los egresados de derecho que postulan al título profesional de abogado es obligatoria, de ahí su nombre de postulante. La práctica tiene una duración por regla general 6 meses, la que comienza con la solicitud del estudiante para iniciar dicha práctica ${ }^{1077}$. El régimen de trabajo de los postulantes es exigente, pues va siendo evaluado constantemente y además cuenta con una evaluación final del trabajo realizado durante su tiempo de práctica efectuada por el abogado jefe del CJS. Los criterios a evaluar son por ejemplo: responsabilidad, puntualidad, criterio jurídico, sentido social, colaboración, honorabilidad, puntualidad.

b) Factores de elegibilidad de los patrocinados. La CPR y también los estatutos de las respectivas CAJ definen en forma genérica a las personas que son acreedoras de este servicio, como aquella población que no puede procurarse asesoría ni defensa jurídica por si misma o aquella población de escasos recursos, respectivamente.

c) Procedimiento de atención a los usuarios. Este mecanismo varía de un CJS a otro, dependiendo de los recursos humanos y de infraestructura, con que cuente cada uno de ellos para la atención del público. Cuando un consultante asiste al consultorio es recibido en primera instancia por la secretaria, asistente social o por el abogado, según el caso, quienes en definitiva determinan, si tanto el solicitante como la consulta, se enmarcan dentro de los criterios que ha establecido la propia CAJ para ser atendidos ${ }^{1078}$.

\footnotetext{
1076 IBIDEM.

1077 Este periodo será siempre que el postulante no sea reprobado o sancionado, ya que, en este caso dicha duración puede ser extendida de 1 a 6 meses más. El postulante debe trabajar en los respectivos consultorios, atendiendo a los consultantes cómo mínimo 2 veces por semana, 3 horas por día. Sin embargo, dicho trabajo se extiende no solo a la atención de un gran número de personas, sino que también deben adecuar su horario con la asistencia a tribunales, que no siempre coinciden con su día de atención.

1078 "En el caso que sea recibido es necesario optar si enviar el caso a la sección jurídico-social del consultorio o a la judicial, para otorgarle al consultante un tratamiento más efectivo. La sección jurídico-social entrega orientación e información para lograr la solución de su conflicto. La sección judicial debe obtener el privilegio de pobreza para el solicitante y, de este modo, puede comenzar la tramitación de la causa ante el tribunal
} 
En cuanto a la estructura, se reitera que las CAJ son órganos públicos, descentralizados, organizados sobre la base de una administración central y cuyas unidades básicas son los CJS, ubicados generalmente cerca de los sectores poblacionales donde viven sus potenciales usuarios $^{1079}$. Se destacan en su estructura organizativa, los siguientes niveles:

a) Nivel corporativo: Conformado por la Dirección General. Esta dirección a cargo del Director General, cumple principalmente 2 funciones. Tanto, del ámbito interno, en que básicamente se preocupa de las directrices y de generar políticas de gestión para que la CAJ alcance sus objetivos. Por su parte, en el aspecto externo, vela por mantener y manejar las relaciones del servicio con otros entes relacionados y con la opinión pública.

b) Nivel divisional: Constituido por la Dirección Regional. Esta dirección a cargo del Director Regional, tiene como función principal velar por el cumplimiento de los fines del servicio, para lo cual debe supervigilar la actuación de los consultorios bajo su jurisdicción. También debe cuidar las relaciones con los municipios velando por la suscripción de nuevos convenios y el mejoramiento de las condiciones en los ya vigentes, debiendo propender a mantener ambientes laborales óptimos y mejorar las condiciones materiales existentes.

c) Nivel operacional: Integrada por el abogado jefe. Es el encargado de los CJS y, desde allí debe velar por el cumplimiento de los objetivos del servicio. Para ello, debe fijar las políticas de atención a los usuarios, guiar la buena marcha de los juicios que tramite el abogado y el postulante, como asimismo cautelar por un comportamiento ético de los funcionarios en general, supervisando el cumplimiento de metas institucionales.

competente”. Se emite este certificado de beneficio de asistencia jurídica o privilegio de pobreza, no obstante, que por el artículo 600 del COT, los patrocinados por la CAJ gozan de este privilegio de pobreza por el solo ministerio de la ley.

1079 Tomemos a modo de ejemplo la composición de la CAJ Metropolitana. En el año 1995 a través de resolución interna $\mathrm{n}^{\circ} 860$, la Región Metropolitana se dividió en 5 zonas, se restructuró su organización territorial la que quedo compuesta por 3 niveles principales: corporativo, divisional y operacional- 


\subsection{Recursos humanos y financieros de las CAJ}

A nuestro entender, la eficiencia y eficacia de una determinada organización, se encuentra marcada por las personas que desempeñan funciones en ella, y también por los recursos asociados, tanto, las destinadas a la cobertura de las remuneraciones, y a la operatividad de la misma. En cuanto a las personas que desempeñan funciones en el servicio, se destaca, que del total de los funcionarios de las CAJ, se distribuye en abogados, asistentes sociales, personal administrativo, secretarias y auxiliares, con contratos regidos por el derecho privado y de jornada variable, pues aún persisten funcionarios contratados por hornadas de 20025 horas semanales, que a todas luces resulta insuficiente ${ }^{1080}$. En cuanto a los recursos económicos o dotación financiera, la Ley n 17.995 que creó las CAJ, no contempló un financiamiento acorde con la envergadura del proyecto, por lo que estos servicios nacen y continúan hasta hoy con un escaso presupuesto.

Existen 3 vías de financiamiento de las CAJ: i) Fiscal: En los últimos años se ha observado un fuerte aumento del ingreso por esta vía. ii) Municipal: Este aporte es de monto variable, pero ha sufrido una disminución en algunas comunas, pues se entiende que es un derecho constitucional a favor de las personas residentes en sus territorios, que no se podría supeditar al aporte o ausencia de este, por parte de

\footnotetext{
1080 UNIVERSIDAD DIEGO PORTALES. (2017). “Acceso a la justicia en Chile”. Op. Cit., p. 195. "Por otro lado las asistentes sociales cumplen un rol de gran relevancia, ya que por una parte informan y educan; y por la otra, propenden a los acuerdos entre las partes con el fin de evitar el inicio de un proceso que signifique ingreso excesivo de causas al consultorio. El número de postulantes es variable, según el número de causas tramitadas en cada consultorio y el territorio que abarca cada servicio, y es, sobre ellos donde recae la mayor parte de la tarea de la asistencia judicial, ya que cada postulante puede llevar un máximo de 80 causas, pero, por cuestiones de hecho en varias ocasiones deben llevar entre 120 y 130 causas aproximadamente. Esta situación de hecho, responde a la creciente demanda de atención por parte de los usuarios, lo que atenta contra la entrega de un servicio de mejor calidad. Ante esta situación en la década de los 90' la institución dio un fuerte impulso a la contratación de nuevo personal incorporando nuevos funcionarios, entre ellos, asistentes sociales, psicólogo laboral, secretarias y alrededor de 40 abogados, estos últimos destinado a los consultorios con mayor demanda, mejorando con ello la calidad de la atención y alivianando la carga de los postulantes. El número de personas con que cuentan los CJS son variables, con un promedio de 4 o 5 personas que integran el promedio de los consultorios nacionales. En cada unidad hay un abogado jefe, a cargo del consultorio y 1 o 2 abogados tramitadores, dependiendo de los recursos del consultorio".
} 
una determinada municipalidad ${ }^{1081}$. iii) Ingresos propios: Estos se determinan por las costas de los juicios ${ }^{1082}$.

De las fuentes de financiamiento de la CAJ Región Metropolitana durante el año 2016 , el $78,4 \%$ provino de recursos del Ministerio de Justicia y un $21,6 \%$ a los otros tipos de ingresos. Las transferencias de dineros fiscales se destinan exclusivamente al pago de los honorarios profesionales, mientras que los otros ingresos se utilizan para gastos de operación ${ }^{1083}$.

El informe anual del año 2017 de la Universidad Diego Portales expresa que "el presupuesto anual de la CAJ no permite la contratación de más abogados, de modo que la idea de profesionalizar el sistema de asistencia jurídica gratuita es viable solo si va aparejada de la decisión política de incremento sustancial de recursos. Ante esta realidad presupuestaria, las CAJ están destinadas a seguir utilizando a los postulantes como un pilar fundamental de la provisión de sus servicios"1084. En cuanto al presupuesto en comparación con la DPP, es diametralmente más bajo el de la CAJ'1085.

En cuanto a los medios físicos, las CAJ prestan sus servicios en inmuebles que en su mayoría son de particulares, arrendados a costa del presupuesto fiscal, pues la institución no cuenta con inmuebles propios.

\footnotetext{
${ }^{1081}$ El compromiso municipal con las personas de más escasos recursos, también se ha reflejado en los aportes en equipamiento e infraestructura para los respetivos consultorios. Incluso, en algunos casos las comunas han entregado en comodato algunos locales para que la atención a las personas se realice en condiciones más dignas.

${ }^{1082}$ UNIVERSIDAD DIEGO PORTALES. (2017). “Acceso a la justicia en Chile”. Op. Cit., p. 195

1083 IBIDEM.

${ }^{1084}$ IBIDEM. P. 192.

${ }^{1085}$ GOBIERNO DE CHILE. MINISTERIO DE JUSTICIA. DIRECCION DE PRESUPUESTOS. http://www.dipres.gob.cl/597/w3-multipropertyvalues-14490-25190.html. [Consulta 7 de junio de 2020]. "Para el año 2020, la DPP tiene asignada un presupuesto de $\$ 62.192 .366$ pesos y las cuatro CAJ un presupuesto final total de \$ 46.651 .759 pesos. En este sentido, es difícil entender como una institución que otorga asistencia jurídica gratuita en al menos tres tipos de materias distintas (familia, civil, laboral), y con una mayor cobertura territorial, tenga un menor presupuesto que administra una institución con la misma finalidad, pero que comprenden la defensa solo un tipo de asuntos: los asuntos penales”.
} 


\subsection{Debilidades de la estructura organizacional y críticas desde una perspectiva constitucional en torno a las CAJ}

Desde a un tiempo a esta parte, el debate sobre la necesidad de articular un sistema nacional de carácter profesional ha vuelto al tapete con la discusión de las últimas reformas judiciales. Es el caso de la reforma procesal penal del año 2000, la estructura de los nuevos procedimientos basados en la oralidad, inmediación y contradicción, exigía la intervención de letrados. Razón por la cual no era posible entregar a los postulantes al título de abogado el manejo de las causas. Estas y otras razones avalaron la creación de una nueva institucionalidad, la DPP, que ya revisamos, y cuya misión era primeramente la defensa en juicio de los imputados pobres, fundamentalmente. Sin embargo no ocurrió lo mismo con otras reformas "al menor", como las de justicia de familia del año 2005 y laboral del año 2007, respectivamente, las que pese a contemplar procedimientos similares a los penales, no cuentan con dispositivos institucionales de asesoría letrada para las personas de escasos recursos o derechamente vulnerables. Por ello, lo que ha ocurrido, es que no habiendo otras instituciones públicas que puedan entregar estos servicios, el legislador hace recaer, de una forma u otra, la defensa de los más pobres o vulnerables en la CAJ1086.

Dentro de los aspectos que se pueden calificar como deficientes de la estructura y funcionamiento de las CAJ, podemos mencionar factores relacionados con la organización propia de este organismo, como asimismo debilidades en cuanto a la prestación del servicio ${ }^{1087}$. En cuanto a un análisis particular de las debilidades que se presentan en las CAJ, señalaremos las siguientes:

\footnotetext{
1086 Se contratan más abogados para dar cobertura a los nuevos procedimientos de familia, que requieren especialización en la materia y además en litigación, y además se crean las ODL, que si bien dependen de la CAJ, reciben los lineamientos técnicos del Ministerio de Justicia. Si bien para este objetivo se les dota a la CAJ de presupuestos adicionales, consideramos que éstos no pasan de ser un paliativo para enfrentar los nuevos requerimientos y desafíos.

1087 ARAYA, F (2016). Asistencia Legal para personas de escasos recursos. Curso Interamericano en preparación y evaluación de proyectos. Santiago. Instituto de Economía de la Pontificia Universidad Católica de Chile., p. p 21-23. "Falta de profesionalización, rotación de postulantes, responsabilidad para los postulantes,
} 
a) Escasa dotación financiera. El financiamiento es insuficiente, además de complejo. La demanda por servicios es altísima y los CJS no son capaces de satisfacerla, ya que trabajan con recursos limitados ${ }^{1088}$.

b) Falta de Profesionalización. Desde un punto de vista constitucional se visualizan dos aspectos negativos en cuanto a la falta de profesionalización del servicio, pues la orgánica de las CAJ, incluyen la intervención de postulantes, lo que se relaciona también con la escases de recursos financieros y por ende, de profesionales abogados de planta ${ }^{1089}$. El servicio prestado por postulantes es inconstitucional, ya que no es prestado por un letrado en conformidad al artículo $19 \mathrm{n}^{\circ} 3$ inciso $2^{\circ}$ y desde esta forma existe una desigualdad en la distribución de las cargas públicas, en conformidad al artículo $19 \mathrm{n}^{\circ} 20$ de la CPR ${ }^{1090}$. Sin perjuicio de ello, debemos recalcar que la existencia de postulantes no puede considerarse por sí misma una debilidad, sino debe analizarse casuísticamente, porque en muchas ocasiones la participación de los egresados de la carrera es una fortaleza para una institución, que la principal debilidad que presenta, es la escasa dotación funcionaria, especialmente de abogados, por lo cual la no presencia de los postulantes haría colapsar el sistema de asistencia jurídica gratuita. No obstante el invaluable aporte de los estudiantes o postulantes, el problema principal del rol de los egresados de derecho dentro del esquema de las CAJ, radica en el carácter no profesional de los servicios prestados, que no se ajusta con el mandato constitucional y con el debido proceso ${ }^{1091}$.

condiciones de trabajo e infraestructura, Condiciones de trabajo, control y fiscalización, burocracia y centralismo y falta de representación en otros ámbitos fuera de lo meramente judicial-contencioso".

${ }^{1088}$ Los convenios que se suscriben con las Municipalidades son, por lo general, de corta duración, dan lugar a desigualdades dentro del servicio, pues pueden establecer condiciones de contratación ventajosas para algunos profesionales en relación con los recursos de la comuna y la calidad de atención que se desea brindar. ${ }^{1089}$ CASTRO, R (2017). El derecho fundamental de acceso a la justicia y a defensa letrada: Mecanismos de protección a través de sus agentes estatales. Santiago. Editorial Santiago de Chile. pp. 110-112.

${ }^{1090}$ IBIDEM. "Desde la perspectiva constitucional se ha planteado severas críticas al desenvolvimiento de esta organización como aseguradora del derecho a la asistencia jurídica gratuita. El principal argumento que rechaza una interpretación optimista del cumplimiento de esta obligación constitucional, radica en que a pesar del crecimiento presupuestario y de la cantidad y calidad del profesional contratado, la asistencia efectiva de defensa jurídica descansa principalmente en los postulantes que allí realizan su práctica profesional. Más allá de los cuestionamientos constitucionales que, al igual que en el caso de los abogados de turno, podría generar el trabajo sin remuneración que desempeñan los egresados de derecho que realizan su práctica profesional, el principal problema radica en que con esa labor no se garantiza un elemento esencial del derecho a la defensa, cual es la defensa técnica y letrada”.

1091 UNIVERSIDAD DIEGO PORTALES. (2017). “Acceso a la justicia en Chile”. Op. Cit., p. 193. “A pesar del posible buen trabajo que algunos postulantes puedan realizar, su desempeño no puede ser 
c) Carencia de unidad organizacional. La administración autónoma de cada CAJ impide una gestión coordinada e integrada de los servicios en el ámbito nacional. En términos generales, las cuatro CAJ poseen estructuras orgánicas y modelos financieros similares, consultorios fijos y móviles, aporte fiscal y municipal, recurso humano compuesto por abogados y postulantes, entre otras, pero se rigen por criterios y procedimientos diferentes (por ejemplo, en materia de definición de áreas prioritarias, sistema de calificación económica de los usuarios, tipo y número de centros especializados, reglas de contratación y remuneración de sus profesionales y funcionarios, entre otras ${ }^{1092}$. En el aspecto territorial, tal como lo consigna el Informe de Derechos Humanos del año 2017 de la Universidad Diego Portales, "el estudio realizado por C.P.U e INVERTEC IGT respecto de la CAJ Metropolitana, indica que la organización interna de la institución es extremadamente compleja, pues existen dos niveles paralelos de organización que no armoniza el territorial y el técnico o por materia. También adolecen de un desorden territorial y sin una debida correspondencia, debido fundamentalmente a una burocracia centralista"1093.

d) Limitada Cobertura en cuanto a materias atendidas. Dentro de los aspectos cualitativos, la escasa cobertura respecto de las materias atendidas ha aquejado a las $\mathrm{CAJ}$, lo que ha ido paultatinamente mejorando, especialmente en la atención profesional, competencia e intervención en la justicia de familia y laboral ${ }^{1094}$.

constitucionalmente aceptable porque simplemente una defensa letrada implica una defensa ejercida por un profesional ya titulado. Y lo anterior no sólo vulnera el derecho a la defensa sino que también otros elementos del debido proceso, como la igualdad de armas, por ejemplo. Nos parece obvio que los postulantes, al margen de cualquier eufemismo legal para considerarlos como abogados, no revisten tal calidad y, por ende, encomendarles a ellos la defensa de un imputado importa un quebrantamiento de la exigencia constitucional. En segundo lugar la temporalidad de la práctica atenta contra la necesaria vinculación con la institución. La rotación de los postulantes provoca, asimismo, un efecto negativo en la atención de los usuarios y en la calidad de los servicios. Rara vez un caso en sede judicial, sobre todo en el área civil finaliza antes de seis meses, razón por la cual es común que una causa sea tramitada por dos o más postulantes, lo que resulta poco comprensible para los usuarios y justifica una sensación de cierta incertidumbre acerca de la persona responsable de su caso”.

1092 IBIDEM.

1093 IBIDEM. Por ejemplo, la CAJ Región Metropolitana tiene bajo su dependencia las regiones sexta, séptima y duodécima.

${ }^{1094}$ IBIDEM. Como es posible suponer, en muchos casos esos organismos simplemente no existían, y ya se ha dicho lo ineficiente que resulta el sistema del turno de los abogados, quedando el justiciable en esos casos en indefensión "Ese problema logró solución recién con la dictación de la ley № 20.286 y el posterior Reglamento sobre Patrocinio de las Corporaciones de Asistencia Judicial en juicio ante los Tribunales de familia (Decreto No 639 de 2008, del Ministerio de Justicia)”. 
Institucionalmente se han dejado fuera del conocimiento de las CAJ una serie de materias, excluida por razones que no son justificables y nunca discutidas públicamente, que se consideran como expresamente descartadas de atención, sumada a la exclusión de atención por cuantía del pleito o valor de la cosa disputada, independientemente de la materia. Tal como lo expresa Rodrigo Castro "en el caso que el consultante sea elegible para la atención, por regla general se reciben todas sus consultas legales y se tramitan todas las causas judiciales. Sin embargo, existen dos áreas excluidas; en atención a la cuantía del asunto o por tratarse de materias expresamente excluidas por la propia CAJ"1095. En cuanto a la cuantía entiende este autor que "cuando la cuantía del asunto controvertido es alta, se presume que la capacidad económica del individuo está probada, por lo tanto tiene la posibilidad de conseguir un abogado por sus propios medios, pagándole directamente o que esté dispuesto a tramitar el asunto sujetando su remuneración al resultado de la causa. Por lo tanto en este caso no se justifica que la CAJ intervenga, ya que se malgastarían recursos públicos, como asimismo por razones de carácter éticas, que pudiesen desaconsejar su utilización ${ }^{1096 .}$

Siguiendo la jurisprudencia de la Corte IDH, si lo que se pretende es la efectiva realización de los derechos de las personas, no es suficiente la existencia formal de mecanismos idóneos y efectivos para conseguir su cometido ${ }^{1097}$. No basta entonces con la presencia de un orden normativo, sino que la conducta debe asegurar la

\footnotetext{
1095 CASTRO, R. Op. Cit. p. 112. "Tratándose de la materia, como causal de no atención por la CAJ, ésta situación presenta un grado de conflicto mayor, puesto que varían de acuerdo a los criterios y motivos de cada CAJ. Se señala que hay ciertos casos donde existe una presunción de capacidad económica como son las materias de protesto de cheques, sociedad y contratos, las que corresponden a personas de un nivel económico tal que pueden contratar un abogado. Además se hace referencia a algunos procedimientos ante autoridades administrativas o jueces de policía local, se argumenta en estos casos que no es necesaria la intervención de abogado y por tanto de la CAJ. Por último hay casos que por factores éticos no es aconsejable su atención, como por ejemplo narcotráfico, que por lo demás por razón de materia, es de competencia de la DPP”.

1096 IBIDEM. “Ante estas exclusiones efectuadas por la CAJ, ya sea, por motivos éticos, económicos o meramente pragmáticos hay ciertos autores que sostienen que discriminar en función del tipo penal o materia civil del objeto del litigio es ilegal. Además sostienen que es inconstitucional, puesto que atenta contra el artículo $19 \mathrm{n}^{\circ} 3$ de la CPR, citado anteriormente, en el sentido que la norma asegura el asesoramiento y defensa jurídica a quienes no pueden procurárselo por sí mismos, sin hacer ninguna excepción al respecto”.

${ }^{1097}$ UNIVERSIDAD DIEGO PORTALES. (2017). “Acceso a la justicia en Chile”. Op. Cit., p. 193.
} 
existencia en la realidad, de una eficaz garantía del libre y pleno ejercicio de los derechos humanos ${ }^{1098}$.

\subsection{Aspectos positivos, desafíos y recomendaciones de Mejora de las CAJ}

Si bien, se han descrito debilidades orgánicas y funcionales de las CAJ, no es menos cierto, que también presenta aspectos positivos, como la gratuidad del servicio, existencia de CJS a lo largo del país, ampliación de la cobertura de atención, experiencia de los profesionales, y percepción ciudadana, la que será analizada pormenorizadamente en el apartado 6 del presente capítulo.

Con todo, no podemos de dejar de señalar que las CAJ constituyen el soporte principal del sistema de asistencia jurídica gratuita e Chile, pues pese a las deficiencias, especialmente las presupuestarias y falta de profesionalización absoluta, ofrecen servicios en prácticamente todo el territorio nacional y han hecho trabajo de vanguardia en muchas áreas, como, por ejemplo, en materia de derechos humanos, atención a víctimas de delitos violentos y en la práctica de la mediación, donde han sido pioneras ${ }^{1099}$.

El Estado chileno debe tomar conciencia y tratar con seriedad el tema del acceso efectivo a la justicia a través de una reforma sustancial al actual sistema, con el objetivo de fortalecer aquellos aspectos que podrán dar un mejor servicio a la comunidad, como entregar mayor información a los usuarios, aumentar el número de abogados en las CAJ para una mejor distribución de causas y mejorar los canales de comunicación entre usuarios y abogados.

Además se debe destinar más fondos para las CAJ, no solo para solucionar la carencia de insumos presente en cada sede, sino que también con la finalidad de mejorar las condiciones laborales, los espacios comunes y si es posible incentivar

\footnotetext{
1098 IBIDEM.

1099 IBIDEM. p.194.
} 
a los postulantes que realizan su práctica profesional a través de bonos de traslado o alimentación ${ }^{1100}$.

Como lo sostiene Marianela Barriga, "se trata entonces de instituciones (CAJ) altamente rutinizadas que se encuentran siempre sobrepasadas de requerimientos y carentes de recursos que no alcanzan a evaluar programas o fiscalizar su desempeño habitual. La organización funcional y territorial de las actuales CAJ adolece de deficiencias. El financiamiento es percibido como insuficiente, existiendo una alta demanda por crear nuevos consultorios y ampliar los existentes. Los convenios suscritos con las municipalidades son, en general, de corta duración. Finalmente, el haber estructurado el sistema de atención gratuita en base a los servicios que prestan obligatoriamente y no remuneradamente los postulantes genera una serie de problemas"1101.

Sin perjuicio de la aceptable percepción ciudadana del servicio, existe consenso, que esta institución debería decantar en una institucionalidad orgánica, unitaria y profesionalizada, cuyas principales propuestas ya han sido revisadas en el desarrollo de nuestra tesis.

En cuanto a los desafíos que se requieren para alcanzar la prestación de un servicio de asistencia jurídica gratuita bajo estándares jurídicos, acorde con el bloque de constitucionalidad chileno, tomaremos las ideas planteadas en el Foro sobre Acceso a la Justicia del año 2016, según lo desarrolla Barriga ${ }^{1102}$.

Dentro de este Foro se conformaron diversos paneles de discusión siendo el panel de los abogados y el acceso a la justicia el que se centró en este punto. Este panel estuvo compuesto por un gran número de abogados quienes plantearon como desafío, superar las debilidades del sistema, aprovechando y potenciando sus

\footnotetext{
${ }^{1100}$ IBIDEM. "Sin embargo, el panorama es poco alentador y no puede sino llevarnos a la conclusión de la necesidad de reformar el sistema de asistencia jurídica en forma urgente, ya que los mecanismos existentes incumplen la Constitución y los tratados internacionales de derechos humanos ratificados en Chile”.

1101 IBIDEM.

1102 BARRIGA, M (2016). Op. Cit., p.76.
} 
fortalezas y virtudes, para eso propusieron una intervención en tres áreas, las que pasaré a señalar a continuación:

a) Respecto a si misma y su contenido; La intervención en esta área consiste en:

a1) Reducir las actividades y responsabilidades que deben asumir los postulantes en la prestación de asistencia jurídica gratuita, vigilando por una apropiada tutela de esta experiencia, estableciendo un número máximo de postulantes por consultorio y abogado tutor.

a2) Debe concebirse la práctica profesional, como una experiencia de doble contenido: Por un lado formativo para los futuros profesionales, adecuando el perfil de los abogados tutores a los requerimientos propios que demanda este proceso de conducción e introducción a un ejercicio profesional responsable y ético; y por otro, de "asistencia jurídica", respecto de los usuarios, velando por mejorar el servicio y la implementación profesional en la atención.

a3) Entregar a los postulantes la posibilidad de realizar la práctica profesional en otras líneas de intervención, además del patrocinio judicial, como la orientación e información de derechos, solución colaborativa de controversias, prevención de conflictos y promoción de derechos, entre otras.

a4) Ampliar los campos de especialización temática en que puede desarrollarse la práctica, respondiendo a los intereses de los futuros profesionales.

a5) Brindar en la experiencia práctica un espacio de participación adecuada de los postulantes en instancias de solución colaborativa de conflictos, reconociendo en estas alternativas la posibilidad de generar una cultura de dialogo y paz social que promueve soluciones desde las partes en conflicto, y por tanto, las hace responsables de la sustentabilidad de estos acuerdos.

a6) En la línea promocional, cabría involucrar a los abogados y postulantes en actividades de prevención de conflictos y difusión de derechos, empoderando a los usuarios hacía un ejercicio positivo y responsable de sus prerrogativas legales y/o constitucionales. 
a7) En cuanto al sistema de evaluación, se propone uniformar los mecanismos entre las distintas CAJ, respecto de esta experiencia de práctica forense, valorando además de conocimientos teóricos, las competencias, habilidades, destrezas propias del ejercicio, como asimismo, la relación con el usuario, destacando la empatía y la vocación de servicio público.

b) En cuanto a su relación con las Universidades ${ }^{1103}$. Resultaría interesante compartir con las Universidades las evaluaciones de sus egresados, a fin de establecer un sistema de retroalimentación que les permita a estas, conocer el desempeño práctico de sus estudiantes y contribuir a mejorar su labor formativa académica. Además de la realización de esta práctica obligatoria para optar a título de abogado, se deberían ofrecer pasantías en diversos espectros de lo jurídico a los estudiantes de pregrado, considerando que en la actualidad se encuentra absolutamente probado que el aprendizaje del derecho debe adquirirse en forma teórica y práctica, simultánea y complementariamente.

c) En cuanto la interacción con otros agentes de la sociedad ${ }^{1104}$. Acá se visualiza y se percibe la relación de las CAJ con la comunidad social, entendiendo por tal, a los sindicatos, juntas de vecinos, centros de madres, centros de alumnos, etcétera. Este es un gran punto, porque permite que el común de la gente se interiorice sobre temas de interés jurídico, facilitando sus relaciones con otros agentes de la sociedad. Se intenta que la sociedad valore los servicios prestados por las CAJ y se cree un nexo de información y difusión de derechos.

Desde otro punto de vista, tenemos la opinión del panel de especialistas que evalúo la $\mathrm{CAJ}^{1105}$. En opinión de este panel, existe acuerdo entre los servicios que prestan orientación y defensa jurídica, en el sentido de la necesidad de éste, pero al mismo tiempo existe consenso en el hecho de que debe ser modificado en la forma que es prestado y en la institucionalidad de respaldo. Po ello, se manifiestan ciertas recomendaciones que permitan mejorar la prestación del servicio que dependen

\footnotetext{
1103 IBIDEM. p. 77.

1104 IBIDEM. p. 78.

1105 GOBIERNO DE CHILE. MINISTERIO DE JUSTICIA. DIRECCION DE PRESUPUESTOS. Síntesis ejecutiva n8. Corporación de Asistencia Judicial. Evaluación 2015-2018.
} 
exclusivamente del propio programa, y además otras de carácter extremo al sistema, que dicen relación con la modificación de normas, leyes, etcétera.

Las primeras corresponden a recomendaciones de carácter operativas y las otras de carácter estratégicas.

a) Recomendaciones operativas ${ }^{1106}$ :

a1) Efectuar a nivel de consultorios una auditoría administrativa que permita conocer las unidades de análisis que se registran para cada uno de los componentes.

a2) Realizar estudios que permitan definir la demanda de servicios jurídicos en población de escasos recursos o grupos vulnerables.

a3) Desarrollar un estudio acerca de las competencias en materias de atenciones jurídicas que considere los roles que le corresponden a otros organismos. Así se delimitarían las funciones de cada uno, promoviéndose convenios entre ellos, logrando de esta forma, una mayor y mejor atención para los usuarios.

a4) Implementar un programa de difusión pública que promueva la utilización de RAC en los sectores vulnerables de la población.

a5) Generar evaluaciones técnico económico en toda inversión física, programas nuevos o sus ampliaciones, de manera que haya claridad en la conveniencia, justificación, financiamiento y sostenibilidad de ellos, especialmente en las diferentes líneas de acción implementadas actualmente, como los CMED, consultorios móviles y Centros de Atención a Víctimas de Delitos Violentos.

b) Recomendaciones estratégicas ${ }^{1107}$ :

b1) Elaboración de una Ley de Asistencia Jurídica Gratuita que reordene la institucionalidad existente.

b2) Redefinición del modelo de asistencia jurídica y judicial gratuita.

\footnotetext{
1106 IBIDEM. p.79.
}

${ }^{1107}$ IBIDEM. 
b3) Profesionalizar el sistema, que se traduce en un mayor número de abogados que atienden a los beneficiarios. En el caso de los postulantes estos deben reducir su participación, adoptando la calidad de estudiante en práctica, con un rol más formativo, en cuanto a observar y adquirir destrezas por parte de los abogados, que deben ser prestadores directos del servicio de asistencia jurídica gratuita. Este rol formativo y de colaboración por parte de los postulantes, se debería traducir en primer lugar, en cuanto a revisión de doctrina y jurisprudencia para para la redacción de demandas y/o recursos, elaboración de escritos de mera tramitación y asistencia a audiencias en calidad de público o con intervenciones reducidas y progresivas, en atención al tiempo de desarrollo de la práctica profesional; y en segundo lugar, en tanto, aportar en la construcción de la estrategia jurídica en que será abordado el caso, como asimismo avocarse a la atención de público en forma conjunta con el abogado tutor, constituyéndose de esta manera, en un nexo necesario, entre las consultas del usuario y el accionar del abogado.

\subsection{Percepción ciudadana del servicio de Asistencia Jurídica Gratuita brindado por las CAJ}

\subsubsection{Finalidad del estudio y criterios evaluados}

Las CAJ, como lo hemos revisado, forma parte de uno de los instrumentos que se contemplan para dar cumplimiento al mandato constitucional de entregar asesoramiento y defensa jurídica a quienes no puedan procurárselo por sí mismos.

Dentro del análisis que se ha realizado de la asistencia jurídica gratuita en Chile y de la CAJ, se han estudiado diversas dimensiones, dentro de las cuales se incluye, la determinación de los usurarios, que se ven directamente beneficiados con su funcionamiento. 
Justamente, respecto de los beneficiarios, cabe preguntarse qué tan efectivo resulta para ellos, el funcionamiento de las CAJ. Recordemos que este organismo asesora y detenta la representación de un sector vulnerable en nuestra sociedad, por lo cual medir la satisfacción usuaria mediante instrumentos fidedignos resulta fundamental, para constatar la percepción de calidad de las personas que recurren a este servicio, y de esta forma evaluar la justificación de su existencia y permanencia y precisar si el servicio de asistencia jurídica en chile cumple con los estándares de calidad y adecuación que revisamos en el Capítulo IV.

Estimamos necesario mostrar datos objetivos, de percepción y/o satisfacción del servicio recibido por usuarios, específicamente de la CAJ Región Metropolitana, a través de un estudio interno de 30 de julio de 2019, titulado "Medición de un indicador a nivel multipropósito que dé cuenta del seguimiento de los acuerdos y resultados favorables de casos, soluciones colaborativas y causas judiciales", que si bien no se encuentra publicado oficialmente, fue socializado a los funcionarios del organismo, por el departamento de control de la institución, para efectos de visualizar la percepción ciudadana del servicio y así poder evaluar estrategias para mejora de las diversas líneas de trabajo ${ }^{1108}$.

Este estudio no fue azaroso, sino que fue encomendado por el Departamento de Asistencia Jurídica, dependiente del Ministerio de Justicia, evaluándose los siguientes criterios:

a) Calidad de atención. Para establecer este parámetro, se formularon las preguntas signadas con el $n^{\circ} 1,2,3,4,5$ de la encuesta.

b) Sostenibilidad de los acuerdos. Las preguntas $n^{\circ} 6,7,8$ se enfocaron en medir este criterio.

c) Fidelidad. Las preguntas $n^{\circ} 10$ y 11, permitieron determinar el grado de adhesión a la institución, especialmente en lo concerniente a volver a solicitar el servicio, si fuese requerido, o recomendarlo.

\footnotetext{
${ }^{1108}$ Información remitida por Departamento de Panificación y Control de Gestión correo electrónico de 11 julio de 2019.
} 
d) Infraestructura y equipamiento. Este criterio de satisfacción se midió a través de la pregunta no9.

e) Cumplimiento de expectativas. Para la determinación del cumplimiento de este estándar, se formuló la pregunta $n^{\circ} 12$.

En lo sucesivo se extractará lo más relevante de este estudio en que se analizó la línea judicial, constituida por los CJS y las ODL y la línea de SCC, conformada por dos sublíneas, que corresponden al RAC realizado por los CJS y el servicio de mediación realizado por los CMED, también dependientes de la CAJ.

Este estudio, fue reflejo y resultado de encuestas telefónicas realizadas a usuarios de los CJS, de las 4 regiones que componen la CAJ RM, que corresponden a la Metropolitana, de O'Higgins, Maule y Magallanes, que recibieron atención el año 2018, en lo que respecta a su línea RAC como judicial. Además se entrevistó a usuarios de las ODL y del CMED, de estas regiones, lo que en total arroja un universo de 2201 personas.

En cuanto al marco maestral se tiene a la vista el catastro de usuarios de la Institución que contaban con registro telefónico y habían concluido o terminado un proceso judicial o en solución alternativa de conflictos dentro del año 2018, con acuerdo, sentencia favorable, desfavorable o avenimiento.

En cuanto a la muestra, esta corresponde a $5 \%$ de usuarios de las ODL y servicio judicial de los CJS, y el 25\% de los casos para usuarios de los CMED y RAC, siendo los datos ponderados según la segmentación predeterminada por el Departamento de Asistencia Jurídica del Ministerio de Justicia.

De las encuestas válidamente respondidas se verifica que la línea de RAC y Judicial asociada a los CJS concentran el $40 \%$ y $36 \%$ respectivamente del universo encuestado. Los usuarios de los CMED representaron el $16 \%$ de los encuestados y las ODL con el 8\%, se completó el total maestral.

En el marco de los compromisos asociados a las metas ministeriales 2019, en la actividad de medición de un Indicador a nivel de propósito, que dé cuenta del seguimiento a los acuerdos y resultados favorables, se estableció como 
compromiso de continuidad el aplicar la encuesta en forma anual, en base a una muestra de casos de soluciones colaborativas y causas Judiciales del año 2018 y que cumplen con diversos criterios. Como valor agregado al proceso, se incorporaron preguntas asociadas a la percepción de la calidad del servicio a los usuarios encuestados, incluyendo el establecimiento de la evaluación global de satisfacción usuaria, aperturada a nivel de línea, direcciones regionales y CJS. En este punto, "la calidad" desde la perspectiva de la percepción usuaria, se entiende como una opinión más integral del bien o servicio y de carácter duradero ${ }^{1109}$

En búsqueda de determinar la calidad y conformidad del servicio recibido, se hace necesario analizar la percepción de las personas que acuden a la CAJ, para resolver un problema jurídico o judicial, pues la experiencia usuaria entrega elementos relevantes respecto al cumplimiento de los objetivos trazados al crear una determinada política pública, en este caso, de asistencia jurídica gratuita. En este aspecto de cumplimiento de ítems determinantes, resulta esencial la identificación de los factores críticos que pueden incidir en una futura percepción de la calidad del servicio, desde la cual se pueden construir y desarrollar procesos de mejora.

\subsubsection{Análisis de los resultados de la encuesta en relación a los criterios establecidos}

A continuación, se presenta los resultados por cada pregunta de la encuesta aplicada. La revisión de cada una de ellas, considera en primera instancia, la entrega del resultado general alcanzado, para luego consolidar los logros a nivel de línea de servicio.

1. Cuando concluyó su causa, ¿quién le informó este resultado?.

\footnotetext{
${ }^{1109}$ Es decir, se asocia a largo plazo, o la percepción que prevalece pasado el momento del consumo. Mientras que la "satisfacción" se asocia a un juicio de carácter transitorio y en lo fundamental es "susceptible de ser cambiada".
} 
Esta primera consulta sólo se aplica en la línea judicial, es decir, a usuarios de las ODL y de los CJS. Los resultados generales de la consulta, dan cuenta de que un $46 \%$ de los usuarios en la línea judicial fueron informados del término de su causa por el abogado a cargo de la tramitación; en segundo lugar, se encuentran los casos en que dicha gestión fue realizada por los postulantes (18\%), seguido en $3^{\circ}$ lugar por la respuesta "nadie me informó" con un 15\% y un 12\% de los usuarios señaló que "otro funcionario o persona lo informó"; en tanto un $9 \%$ de los usuarios consultados informan que "no sabe o no recuerda" quien le informó del término de su proceso judicial.

A nivel de línea de servicio se refleja una diferencia importante en la participación del abogado patrocinante en la entrega de información respecto del término de la causa. En la línea ODL alcanza un 61\%, mientras que en los CJS un 42,7\%. Ello se explica principalmente porque en las ODL no se ha incorporado a postulantes en la gestión de causas, salvo en el área cumplimiento.

2. ¿Recibió copia de la sentencia o el acuerdo en el que se contenía ese resultado?.

De dicha consulta, se desprende otro atributo de la perspectiva de calidad del servicio y tiene que ver con los aspectos tangibles de la prestación.

Los resultados alcanzados a nivel global, señalan que un $52,7 \%$ efectivamente recibió copia de la sentencia o acuerdo, un 38\% no lo recibió y un $9,7 \%$ no sabe o no recuerda.

En cuanto a nivel e línea de servicio se observa un comportamiento homólogo entre los consultantes en la línea judicial y la línea de SCC, ambas en torno al 52-53\%.

3. ¿Considera que la información recibida fue clara? El $82,7 \%$ de los usuarios entrevistados tienen una opinión favorable respecto a la claridad de la información recibida. En la línea SCC la opinión favorable alcanza el 87,2\%. En la línea judicial, se obtiene un $76,9 \%$, lo que representa una diferencia de 10 puntos porcentuales entre ambas áreas. Se observa en particular, que en las ODL, 1 de cada 4 personas encuestadas señala con respecto a la claridad de la información recibida, que no 
está de acuerdo con la calidad de la información recibida. En los CJS la percepción negativa, respecto a la claridad de la información recibida, alcanza un $17,3 \%$. En tanto la línea de SCC muestra que en los CMED y CJS, la valoración negativa no sobrepasa del $10 \%$ de los consultados.

4. Cómo considera que fue la información recibida ¿oportuna?. En relación a la oportunidad de la información otorgada durante el servicio, un 84,7\% de los usuarios encuestados señalan estar muy de acuerdo o de acuerdo con aquella afirmación, mientras un $10,8 \%$ de los consultados opinan negativamente al respecto. Al aperturar la consulta por línea y sublímela se aprecia que en SCC la valoración positiva del atributo alcanza mayor significancia con un 90,3\%, sobre el área judicial que obtiene un $77,6 \%$, distando casi 13 puntos porcentuales entre ambas.

5. ¿Cómo evalúa la atención recibida?. En cuanto a la pregunta de cómo evalúa la atención recibida, un $88.5 \%$ de los consultados señalan que la atención recibida, fue "buena" o "muy buena"1110.

6. Desde el término de su caso/causa, ¿se logró el cumplimiento de los acuerdos o de la sentencia?. El resultado de cumplimiento total a nivel institucional alcanza un $69,4 \%$ y adicionado a éste, el cumplimiento parcial, se da cuenta de un resultado de un $79,9 \%$. Los resultados por línea de servicio ubican a la SCC con el mejor desempeño a nivel comparado, registrando que un $73,4 \%$ de los usuarios atendidos corroboran totalmente los acuerdos alcanzados un año después del término de su caso. En el extremo se encuentran las ODL, consignándose que el $54,1 \%$ de los usuarios lograron los acuerdos de la sentencia, y más aún, el 26,2\% de los usuarios de las ODL, señalan que no se cumplió en "nada" los acuerdos o la sentencia.

7. ¿Le explicaron qué debe hacer en caso de que no se cumplan los acuerdos (o la sentencia)?. Se relaciona con la claridad de la información proporcionada respecto

\footnotetext{
${ }^{1110}$ Un 93,5\% de los usuarios de SCC tienen una opinión favorable (muy buena o buena) respecto a la atención recibida, mientras en la línea judicial la misma percepción representa al 82,2\% de los entrevistados. Un 20\% de los usuarios atendidos en ODL asignan una evaluación negativa a la atención recibida, concentrándose principalmente en este servicio las opiniones adversas en comparación con las otras líneas que se mueven entre un $11 \%-4,3 \%$.
} 
a qué hacer en caso de que no se cumplan los acuerdos o sentencia. Al respecto, los consultados en un $36 \%$ señala que si le explicaron que hacer, mientras un $46 \%$ contestó que no y un $18 \%$ señala que no sabe o no lo recuerda.

La línea SCC es la que obtiene más alta votación, consignando que el 39\% de sus usuarios encuestados señalan que fueron informados respecto a qué hacer si no se cumple el acuerdo suscrito. La línea Judicial, se sitúa 7 puntos porcentuales más abajo, con un $32 \%$.

8. ¿A qué cree usted que se debe el no cumplimiento de los acuerdos?. Al profundizar el no cumplimiento de los acuerdos, se apertura una nueva consulta que busca determinar cuáles son los factores que más inciden en ello. De los resultados analizados, se constata que la opción más votada es "otro" con el 35\%. En segundo lugar se encuentra la opción "falta de voluntad o irresponsabilidad" con un 29,1\%, y en tercer lugar, se encuentra la opción "no sabe" con un 14,7\%. La falta de claridad en el acuerdo recoge el $13 \%$ de las preferencias más votadas, quedando un último lugar la falta de recursos con el 8,3\%. De lo anterior, se desprende que la opción "otro", que consigna la mayoría de las preferencias, no logra dar una respuesta más precisa del porqué del incumplimiento de los acuerdos.

La composición a nivel de línea e servicio da cuenta de la distinta realidad de cada servicio. En las ODL, pesa más la opción "falta de voluntad o irresponsabilidad" consignado el $43 \%$ de la opinión de los usuarios, quedando en segundo lugar la opción "otro" con el 25,4\%. En cambio, en los CJS la opción más votada fue "otro" y en segundo lugar quedó la respuesta "falta de voluntad o irresponsabilidad". También se aprecia que en los CJS alcanza una alta preferencia la opción "falta de recursos económicos" con un 16\%, mientras que en las otras sublíneas dicha opción no supera el dígito.

9. ¿Cómo evalúa las instalaciones y mobiliario disponible en el CJS para su atención?: El 81,1\% de los usuarios encuestados señala que las instalaciones y mobiliario son buenos o muy buenos, mientras un $12,5 \%$ opina lo contrario (malo o muy malo). 
A opinión de los consultados, la línea SCC es aquella que registra mejores instalaciones a opinión del $84,1 \%$ de los usuarios, a diferencia de la línea Judicial que registra el $77,4 \%$ de aceptación ${ }^{1111}$.

10. En base a su nivel de satisfacción por el servicio brindado, ¿usted recomendaría el servicio a un amigo o familiar?. Otro atributo que mide la encuesta es la fidelidad de los usuarios atendidos. En este caso el atributo de calidad se monitorea a través de la pregunta de si luego de utilizado el servicio, el usuario lo recomendaría. Esto significa que cuando el usuario recomienda el servicio a otra persona, su satisfacción global es evaluada positivamente. Por el contrario, si no recomienda el servicio lo más probable es que se sienta insatisfecho. Al respecto los resultados son categóricos en señalar que el 89,7\% de los usuarios recomendaría el servicio. Sólo un $2 \%$ señala indiferencia al respecto, y un 8,3\% no lo haría.

Un 93,4\% de los consultados en la línea SCC recomendarían el servicio, en tanto en los CJS, lo harían un 84,9\%, distando casi 9 puntos de diferencia entre éstas. Las ODL cuenta de menor nivel de satisfacción (78,1\% lo recomendaría) y una alta opinión negativa del servicio (ya que un $18,7 \%$ los usuarios señalan que no lo recomendaría).

11. ¿Usted volvería a solicitar atención y asesoría de los profesionales de la CAJ?.

Es este caso la tasa de reutilización alcanzada por la CAJ del total de encuestados es de un 93,1\%, cual da cuenta de muy alto nivel de satisfacción de los consultados. Siendo menos del $5 \%$ de significancia el porcentaje de usuarios que señala que no lo haría. La tasa de reutilización por línea de servicio deja al área judicial con un 90,2\%. Es decir, de cada 10 usuarios encuestados 9 volverían a atenderse a la CAJ. En tanto la línea de SCC alcanza una tasa de reutilización del 95,4\%, es decir 5,2 puntos porcentuales por sobre la anterior. Destaca el nivel de fidelidad alcanzado

\footnotetext{
${ }^{1111}$ Respecto de los CMED el 91,8\% y en lo relativo a las ODL un 88,7\% de sus usuarios opinan favorablemente respecto a la infraestructura y mobiliario de los centros, marcando una diferencia de más de 7 puntos respecto de la línea judicial y de SCC. Así también se observa que no existe evaluación "muy mala” de las instalaciones de ODL y CMED, sin embargo, si se presenta evaluación “muy malas instalaciones” en los CJS.
} 
en los CMED, donde el 96,3\% de los encuestados señalan que volvería a solicitar la asesoría de los profesionales de la CAJ.

12. Luego de terminado el proceso, ¿se logró cumplir con sus expectativas del caso?. Otro aspecto interesante de analizar es el comportamiento de los usuarios respecto de las brechas entre las expectativas del servicio esperado y percepción efectiva de ésta luego de su utilización (calidad percibida). Según los entendidos, la calidad percibida se alcanza o se obtiene cuando se integran variables de índole cognitivo y afectivo en la experiencia usuaria.

La literatura es extensa en plantear una relación entre la calidad percibida y la satisfacción de los usuarios, que en sicología se denomina "disconfirmación", que significa que el resultado del servicio es inferior o superior a lo que el consumidor o usuario esperaba cuando realiza una decisión de utilizar el bien o servicio, con implicancias negativas (o positivas) para la experiencia del servicio. Es así que se plantea que la suma de las experiencias satisfactorias/insatisfactorias que una persona experimenta al utilizar el servicio determinará finalmente en la calidad percibida. Es por ello que se hace necesario explorar respecto a esta variable, ya que aporta elementos centrales para comprender la opinión del usuario respecto del servicio que brinda las CAJ, y asimismo proyectar las posibilidades de mejora.

De esta forma, existe una correlación entre el cumplimiento de las expectativas y la satisfacción global que experimenta un usuario respecto del servicio. Por ello, es relevante la medición de ésta, ya que las expectativas determinan el estándar con que el usuario comparará los atributos que experimenta en la atención recibida.

En la evaluación general de las CAJ, se obtiene que el 70,1\% de los usuarios cumplen totalmente con sus expectativas del caso/causa que dio origen al servicio. No es menor el porcentaje que disiente al respecto, ya que un $11,4 \%$ señala que "para nada cumplió sus expectativas" y un 4,3\% dice que ésta fue "por debajo de lo esperado", ambos suman el 15,7\%. 
Se observa una diferencia de 10 puntos entre el cumplimiento de las expectativas por línea de servicio, donde la Judicial (CAJS y ODL) alcanza el 64,6 y la SCC registra un $74,4 \%$.

En la línea de RAC que se da lugar en los CJS, es la instancia en donde los usuarios registran la más alta evaluación respecto del cumplimiento total de sus expectativas (marcando que el 76,4\%), siendo en las ODL, donde se obtiene el nivel más bajo de cumplimiento de las expectativas (50\%). De esta forma, el cumplimiento de las expectativas marca un antecedente relevante respecto del servicio y la evaluación que realizan los usuarios respecto del mismo.

13. Desde el ingreso de su caso al CJS, al término de su caso-causa, ¿cómo evalúa el tiempo transcurrido: El 74,3\% de los usuarios encuestados, señala que el tiempo transcurrido desde que ingreso a la CAJ y el término de su caso/causa fue adecuado o muy adecuado. Mientras un $21,6 \%$ de los consultados señala que el tiempo transcurrido fue inadecuado o muy inadecuado.

La línea RAC en los CJS, obtiene un 81,6\%, apareciendo mejor evaluada que la judicial (con un $67,1 \%$ ) o que deja una distancia de 14,5 puntos porcentuales entre ambas.

El Departamento de Asistencia Jurídica estableció una tabla de ponderación a partir de los distintos atributos evaluados en la encuesta aplicada.

La encuesta se estructuró con la medición de los siguientes atributos:

a) Calidad de la atención. Equivale al 30\% de la ponderación de la encuesta.

b) Sostenibilidad de los acuerdos. Equivale al $30 \%$ de la ponderación de la encuesta.

c) Fidelidad: Equivale al 20\% de la ponderación de la encuesta.

d) Infraestructura y equipamiento. Equivale al $10 \%$ de la ponderación de la encuesta. 
e) Cumplimiento de expectativas. Equivale al 10\% de la ponderación de la encuesta.

El resultado de medición del índice de calidad en base a las preguntas realizadas entrega como resultado que el $53 \%$ de los usuarios encuestados evalúa de manera satisfactoria el servicio. Eso se construye a través de la sumatoria del total, que reporta un índice global bueno y muy bueno, calculado sobre el total evaluado. Sin perjuicio de lo anterior, las ponderaciones del Departamento de Asistencia jurídica son perjudiciales para las CAJ, pues si se hubiesen promediado todas las preguntas con un mismo valor porcentual, el grado de satisfacción habría sido de un 75,9 \%.

Estos resultados, se justifican por estrategias de factorización, categorizaciones de ciertas respuestas y sesgo, en cuanto a la incorporación de índices en determinadas categorías que hacen variar los porcentajes de percepción final ${ }^{1112}$.

Sostenemos, a modo ejemplar, que el criterio de sostenibilidad de los acuerdos o del cumplimiento de las sentencias y del cumplimiento de las expectativas, no depende en exclusividad de la institución, sino de factores externos, como la falta de recursos económicos del demandado que debía cumplir una prestación, o la voluntad en realizarlo, lo que claramente repercute en la sostenibilidad de los acuerdos o en el cumplimiento efectivo de las sentencias.

En base a esta categorización, la ODL registra un índice de satisfacción del 50\%, en tanto en los CJS el índice general alcanza el 58,3\%. Para los centros de la línea SCC, a través de los CMED se obtiene un $63 \%$ de índice general de satisfacción, mientras en la línea RAC se observa un $44,8 \%$.

\footnotetext{
1112 a) Problemas en la factorización de la línea SCC al momento de ponderar la fórmula de cálculo por encuesta. b) Mala categorización de la respuesta "no sabe/ no recuerda", ya que corresponde a una respuesta neutra, y por ende el puntaje asignable es de categoría Indiferente, y no valorizarse como una respuesta negativa con puntaje 0 , ya que castiga el resultado. c) El índice de satisfacción debió ser parte de una de las preguntas de la encuesta aplicada y no de una definición determinada. Es decir, se debió considerar una pregunta que busque determinar la evaluación global del servicio. Ya que esta pregunta de la evaluación global, permite contrastar los hallazgos respecto al grado de cumplimiento de las expectativas del servicio y la evaluación global del servicio.
} 
Los resultados por región, que se presentan diversas en características demográficas, dan cuenta de resultados heterogéneos e igualmente divergentes respecto a los resultados por cada variable analizada ${ }^{1113}$.

Como conclusión, más allá de la factorización de los criterios evaluados en este estudio, se presenta al servicio como muy bien percibido por los usuarios que lo utilizan, más allá de algún prejuicio o análisis académico crítico, enfocados fundamentalmente en la escasez de recursos y reducida dotación profesional con los que dispone el servicio.

\footnotetext{
${ }^{1113}$ Magallanes obtiene la evaluación global más baja, consignando que el 47\% de sus usuarios se encuentran satisfechos con el servicio. Dicho resultado, contrasta con los resultados parciales por pregunta, donde en la mayoría de ellas obtuvo el primer lugar a nivel comparado entre regiones. Le sigue O’Higgins con el 44,9\% de opinión favorable del servicio a nivel global, en tercer orden se encuentra la Región Metropolitana con el 53,4\%, quedando en primera posición la región del Maule con un 56,8\% de opinión favorable.
} 


\section{CONCLUSIONES}

A propósito de nuestra Tesis Doctoral, hemos podido extraer las siguientes conclusiones.

\section{En cuanto a los Capítulos I y II:}

\section{PRIMERA.-}

El acceso a la justicia comprende una multiplicidad de elementos que convergen en la posibilidad que tiene toda persona sin ningún tipo de distinción, de ejercer los derechos que el ordenamiento jurídico les confiere. Esta concepción obedece a una perspectiva amplia, que estuvo precedida de dos olas de acceso a la justicia, orientadas a la ayuda legal de pobres y a la protección de intereses difusos, respectivamente. Actualmente y en atención a la evolución de los derechos humanos, el acceso a la justicia se proyecta en tres dimensiones:

a) Como el derecho a la tutela judicial efectiva y las garantías del debido proceso.

b) Como la obligación del Estado en cuanto a la remoción de obstáculos lingüísticos, geográficos, procesales e institucionales, de género, socioeconómicos, entre otros, que impidan o limiten el desarrollo personal en condiciones de igualdad.

c) Como un derecho prestacional tendiente a la satisfacción de las necesidades jurídicas singulares de cada grupo vulnerable, con la consiguiente obligación estatal en cuanto a su satisfacción.

SEGUNDA.- El Estado, a través del Poder Judicial y organismos administrativos, debe atender las necesidades especiales de cada grupo en condición de vulnerabilidad, para que exista un acceso a un remedio eficaz para entregar solución a la situación que los afecta, y que se posibilite de esta manera el ejercicio real de los derechos. Los derechos que el ordenamiento jurídico confiere, especialmente a las personas que pertenecen a los grupos en condición de vulnerabilidad, no solo 
se refieren a los que consagra la ley nacional, sino que también los que se han incorporado por la adhesión a tratados internacionales de protección de derechos humanos, bajo la construcción dogmática del bloque de constitucionalidad que adopta nuestra CPR en el artículo 5 número 2, y que se ha ampliado a la incorporación de la jurisprudencia protectora internacional, mediante la consolidación de la teoría del control de convencionalidad.

TERCERA.- Chile se encuentra en una etapa constitucionalmente relevante, pues el día 25 de octubre de 2020 se celebrará plebiscito para decidir sobre la creación de una nueva Constitución, y de la forma en que eventualmente se implementaría, en caso de aprobación. Constitución de 1980, actualmente vigente, que desde su génesis está cubierta de un manto de ilegitimidad, por su promulgación durante el gobierno militar que dirigió el país desde 1973 a 1990. El acceso a la justicia, la asistencia jurídica gratuita, y otros derechos sociales relevantes, deben ser contemplados en una hipotética nueva Constitución, propiciando medios efectivos de cumplimiento, en garantía de los mismos. Los ideales de justicia que debería representar una nueva Constitución, deben contemplar estándares de calidad, universales, sin privilegios, equitativos y sin distinción del nivel socioeconómico u otros factores desigualitarios o discriminatorios, con la correspondiente inclusión de recursos financieros para implementar políticas públicas adecuadas.

En Chile, como en todo el orbe, el nuevo corona virus, ha ocasionado lamentables y dolorosos efectos. El Estado a través de Leyes, Decretos y Auto Acordados de la Corte Suprema, ha hecho prevalecer para todas las actuaciones judiciales, los principios de protección de la vida y salud pública, acceso a la justicia, transparencia y continuidad del servicio judicial, promoviendo la utilización de medios tecnológicos, garantizando el debido proceso. Es necesario implementar medidas para garantizar el acceso a la justicia de las personas en situación de vulnerabilidad y proteger su seguridad, atendido que debido a las características de esta crisis sanitaria y a las medidas necesarias para enfrentarlas, pueden verse expuestas a un mayor riesgo de afectación de sus derechos, incluida su vida e integridad física, 
y además, que su acceso a los sistemas de protección en general, se dificulta en las actuales circunstancias.

\section{En cuanto al Capítulo III:}

CUARTA.- Como se ha sostenido por el PNUD en el año 2005, y en las Reglas de Brasilia del año 2008, los sistemas de justicia deben ser concebidos como medios de defensa de derechos, siendo el acceso a la justicia un instrumento de transformación de las relaciones de poder que perpetúan la exclusión, la pobreza y dependencia de tales grupos. Se propugna de esta forma, no solo ofrecer textos declarativos y mayores canales de litigiosidad, sino que una justicia más efectiva y menos costosa, que contemple mecanismos alternativos de resolución de conflictos. El Protocolo Iberoamericano de Actuación Judicial para Mejorar el Acceso a la justicia de Personas con Discapacidad, Migrantes, Niñas, Niños y Adolescentes, Comunidades y Pueblos Indígenas del año 2014 y el Protocolo Judicial Chileno de Grupos Vulnerables del año 2020, en consonancia con las mencionadas Reglas de Brasilia, señalan que los colectivos que se encuentran en especial dificultad para el ejercicio de los derechos que el ordenamiento jurídico les confiere, entre otros, son los siguientes:

a) Niñas, Niños y Adolescentes

b) Personas con discapacidad

c) Personas migrantes y sujetos de protección internacional.

d) Personas, comunidades y pueblos indígenas

e) Mujeres víctimas de violencia de género.

El catálogo de grupos vulnerables no es taxativo, pues la concreta determinación de las personas en condición de vulnerabilidad en cada país dependerá de sus características específicas, o incluso de su nivel de desarrollo social o económico, por lo cual los mapas de vulnerabilidad nacionales pueden distar entre uno y otro. En Chile, existen grupos no considerados en las Reglas de Brasilia, o en el 
Protocolo Iberoamericano referido, que también se reconocen vulnerables, como las personas con adicciones a las drogas y/o alcohol, o en situación de calle.

QUINTA.- Los NNA por su edad y grado de madurez se encuentran en una situación de mayor indefensión. El interés superior de ellos resulta prioritario, en cuanto al logro de una mayor efectividad de sus derechos. Cuando un NNA no tiene la contención y el apoyo familiar, o sufre negligencia o violencia de cualquier tipo dentro de este entorno u otro, no pudiéndosele respetar y reconocer la dignidad que merece, debe el Estado intervenir generando una legislación e institucionalidad acorde con su situación particular. En Chile, un Sistema legal integral de garantías y un nuevo servicio que supere las graves deficiencias del SENAME facilitaría el acceso a la justicia de este grupo.

En cuanto a las personas en situación de discapacidad se presentan barreras, especialmente actitudinales y de infraestructura, que impiden propiciar un acceso a la justicia adecuado en torno a generar ajustes razonables para subsanar las deficiencias de acceso a mecanismos de resolución, de determinación y ejercicio de derechos. Resulta imprescindible que el abordaje de la discapacidad se realice desde el modelo social de los derechos humanos, por lo cual se deben tomar en cuenta las circunstancias particulares de cada persona con discapacidad a los que les aplica la ley en miras de impulsar su autonomía individual.

La jurisprudencia interamericana en lo relativo a las comunidades indígenas, se ha pronunciado sobre las condiciones que debe garantizar el Estado para que se les otorgue protección efectiva, debiendo considerarse variables culturales, sociales, económicas e idiomáticas, propiciándose que puedan comprender los procedimientos y actuaciones procesales. En Chile, al no reconocimiento de los pueblos originarios y de sus formas de resolución de conflictos, se le suma escasez de políticas públicas que se ajusten a las normas internacionales de protección, especialmente al Convenio 169 de la Organización Internacional del Trabajo.

La migración es un derecho humano que tiene como causas principales la pobreza e inestabilidad política. Referente a la población migrante en nuestro país, los obstáculos normativos derivados de la legislación aplicable, promueven una 
migración selectiva, que debe ser modificada y ajustada a los requerimientos de un proceso justo y debido, de la cual carece el procedimiento administrativo que actualmente rige. Los tribunales superiores de justicia en orden a enmendar estas falencias normativas, han acogido sostenidamente en el último lustro, recursos de reclamación y amparo a favor de los migrantes en casos de expulsiones ilegales, mediante la aplicación de estrategias jurídicas como "el germen de arraigo" y "la exigencia de denuncia penal previa".

Los Patrones socioculturales hegemónico machistas y dispositivos psicológicos sitúan a la violencia contra las mujeres, por motivaciones de género, como un flagelo dentro de la realidad latinoamericana y chilena. La Ley 20066, que establece la Ley de Violencia Intrafamiliar, de 7 de octubre de 2005, no dialoga con la normativa protectora internacional, pues solo sanciona los hechos producidos en el ámbito familiar, presentando además otras falencias, como la baja entidad de las sanciones y el escaso control de las medidas de protección respecto de la mujer agredida. La ruta crítica que debe transitar una mujer desde la denuncia hasta que se aplica la eventual sanción, la que por lo demás no conlleva el aspecto de seguridad deseado, imposibilita la prevención, reparación y erradicación de la violencia, sea física, psicológica, sexual, económica o de otro carácter. En tiempos de Covid 19 se intensifican los factores ambientales que condicionan los niveles de violencia, especialmente al interior de los hogares. Las medidas de protección especiales adaptadas a la crisis sanitaria lamentablemente no han podido aminorar la magnitud del flagelo.

SEXTA.- La pobreza no es patrimonio de los grupos vulnerables, no obstante que en estos se presenta con mayor frecuencia y crueldad. La condición de pobreza tiene una dimensión jurídica, al vincularla con la obligación del Estado de proveer asistencia jurídica gratuita, la que no se circunscribe al nombramiento formal de abogado, sino a la proporción de todos los medios para que las personas deprivadas socioeconómicamente, puedan ser asesorados y representados en juicio, sin deber costear los costos asociados al litigio, como asimismo acceder a dispositivos estatales, comunitarios o de otra índole, para resolver sus conflictos en forma directa 
y colaborativa, como es el caso de la mediación, la negociación, la conciliación, todas las que tienden a propiciar el ejercicio y tutela de los derechos en forma diversa que la meramente judicial.

\section{En cuanto al Capítulo IV:}

SÉPTIMA.- El derecho a la defensa es uno de los elementos que conforman el debido proceso y facilita que un justiciable pueda hacer valer sus derechos y defender sus intereses en forma efectiva y en condiciones de igualdad procesal con otros justiciables, pues garantiza que sus alegaciones y planteamientos sean considerados por el juez o por cualquier autoridad, idealmente con el asesoramiento y representación de abogado. En este orden de ideas, la defensa personal o auto defensa es considerada como un mal menor, debido al carácter cada vez más técnico que reviste el derecho sustantivo y el procedimiento, que hace exigible la presencia de un profesional capacitado para descifrar las normas y ceñirse a las formalidades y ritos procesales.

La asistencia jurídica gratuita emerge cuando la persona no se encuentra en condiciones de litigar en condiciones de igualdad por carencia de medios, derecho reconocido en el artículo $19 \mathrm{n}^{\circ} 3$ de la Constitución Chilena y en los tratados internacionales que ingresan al bloque de constitucionalidad. Se justifica la fundamentalidad de este derecho, por el carácter instrumental del mismo, pues propicia que los derechos subyacentes al proceso, como la vida, la libertad y propiedad, puedan ser reconocidos y garantizados.

La asistencia jurídica gratuita, no corresponde a un derecho absoluto e ilimitado, sino que se trata de un derecho social de naturaleza prestacional cuyo contenido y concretas condiciones de ejercicio corresponde delimitar al legislador. Así pues, éste tiene un amplio margen de discrecionalidad para definir y, en su caso, fijar el alcance de la prestación de asistencia jurídica que la propia constitución garantiza.

El orden constitucional Chileno fija un marco muy flexible y de fácil mutabilidad, de modo que caben muy diversas formas de estructurar una asistencia jurídica compatible con la Carta Fundamental, que garantice que favorezca a las personas 
que carecen de recursos socio económicos o que por formar parte de un grupo de vulnerabilidad, no puedan procurarse la defensa jurídica por sus propios medios.

El legislador tiene libertad para exigir o no la asistencia jurídica gratuita como requisito del debido proceso. Si bien la jurisprudencia latinoamericana no ha tenido la oportunidad de definir el término irrenunciable, es importante destacar que la OC 11/90 sobre Excepciones al Agotamiento de los Recursos Internos de la Corte IDH, de 10 de agosto de 1990, ha sostenido que "las circunstancias de un procedimiento en particular, su significación, su carácter y su contexto en un sistema legal particular, son factores que fundamentan la determinación sí, la representación legal es o no necesaria para el debido proceso". En concordancia con lo señalado, la ley 18.120, que Establece Normas sobre Comparecencia en Juicio, permite en atención a materia, procedimiento y a cuantía, la eximición de la obligación de ser representado por abogado.

\section{En cuanto al Capítulo V:}

OCTAVA.- En base al cotejo de distintos parámetros, se sostiene que existe conformidad convencional entre las respuestas que ha dado el Estado chileno a una serie de directrices y criterios jurisprudenciales o consultivos, que respecto de la asistencia jurídica gratuita han establecido los organismos de protección internacional, como la Corte IDH, por una parte, a través de sus sentencias y OC, y por otra, el Comité de Derechos Humanos, mediante sus informes y dictámenes.

Dentro de estos estándares de asistencia jurídica destaca la determinación de la existencia o no de requisitos para ejercer este derecho. En este punto, la posición de la CADH dista a la del PIDCP, en tanto que éste último exige un menoscabo económico para solicitarlo y un "interés de la justicia", su par americano, en cambio, le otorga un carácter irrenunciable.

Estos lineamientos se extienden a todo tipo de procesos, y no solo restringido a lo penal, como asimismo existe una armonización parcial a los rangos de adecuación y calidad de la asistencia jurídica gratuita del Estado, instándose por superar el acto formal de nombramiento. Los alcances de la asistencia jurídica gratuita se han 
ampliado igualmente a las diversas actuaciones del proceso, como el asesoramiento, el derecho a estar presente en las declaraciones del afectado, ofrecer y rendir prueba, etcétera. La normativa interamericana delega a Los Estados la responsabilidad de determinar si la asistencia jurídica será o no gratuita, en atención a la limitada y diversa capacidad financiera que presentan los distintos países de la región.

NOVENA.- En nuestro país, se establecen vías idóneas de cumplimiento o sanciones, según sea el caso, ante un no otorgamiento de asistencia jurídica gratuita o que su prestación no cumpla con los estándares constitucionales y convencionales exigidos. Entre estos mecanismos, destaca el recurso de apelación, de nulidad, de protección, y la acción de indemnización de perjuicios.

Sin perjuicio de no encontrarse incluida la asistencia jurídica gratuita dentro del catálogo de derechos, cuya infracción permite solicitar a la respectiva CA, su correspondiente reestablecimiento, existe una tesis, que ha tenido cierta acogida jurisprudencial, que insta a su reconocimiento, sustentándose en el hecho que los ciudadanos tienen un derecho de propiedad respecto de todos los derechos, y en atención a que el de propiedad está cautelado por este recurso, es totalmente aplicable su interposición, en caso de privación, perturbación o amenaza del derecho de asistencia jurídica gratuita.

DÉCIMA.- Cuando surge una necesidad social el Estado debe diagnosticarlas, satisfacerlas y garantizarlas, adoptando aquellas medidas adecuadas para darle respuesta, que se traducen en diversos objetivos, decisiones y acciones que se implementan en pos de estos objetivos. En este escenario, los estudios de los años 1993, 1995 y 2016, categorizan las necesidades jurídicas por sector socioeconómico y de vulnerabilidad, en que la falta de recursos para contratar a un abogado se priorizan por la ciudadanía en cuanto a su identificación y necesidad de satisfacción.

En los últimos 30 años se han presentado diversos proyectos por una nueva institucionalidad de asistencia jurídica gratuita en Chile, en pos de la construcción 
de una política pública que ayude a la creación de un servicio integral. Estos proyectos no han visto la luz, y solo han sido aprobados los que apuntan a reformas al por "menor", o por área jurídica, en materia laboral y de familia, siguiendo la pauta de la reforma procesal penal.

La nueva agenda social anunciada por el gobierno del presidente Sebastián Piñera con fecha 22 de octubre de 2019, en el contexto del denominado "estallido social" que vivenció Chile hasta diciembre del mismo año, incluyó la asistencia jurídica gratuita pero acotada a lo políticamente sostenible, la víctimas de las delincuencia. El veredicto sobre si Chile cambió o no lo entregará la historia, no así aquel relativo al devenir del acceso a la justicia y su necesario complemento, la asistencia jurídica gratuita.

\section{En cuanto al Capítulo VI:}

UNDÉCIMA.- Existen tres organismos en Chile encargados de brindar asistencia jurídica gratuita; a saber: Abogado de turno, DPP y las CAJ. Con luces y sombras representan nuestra institucionalidad en la materia, obedeciendo a modelos diversos.

En cuanto al abogado de turno, a la luz de lo resuelto por el TC, en sentencia causa rol 1254-2008, de 29 de julio de 2009, se declaró la inconstitucionalidad del precepto procesal civil que lo establece, pues la gratuidad de su otorgamiento pugna con derechos constitucionales de igualdad ante la ley, libertad de trabajo y la igual repartición de las cargas públicas.

La DPP, ha cumplido su rol en el aseguramiento de los derechos del imputado conforme al CPP, acogiendo un modelo mixto, que presenta ventajas orientadas a la profesionalización y a una óptima asignación presupuestaria.

DUODÉCIMA.- Las CAJ representan un eje central en la asistencia jurídica gratuita en Chile, tanto por constituir una institución que cuenta con una raigambre histórica de casi 40 años, y por otorgar asistencia jurídica gratuita a gran parte de la población, en diversas materias y líneas de servicio. Pese a críticas que se han 
formulado desde diversos frentes, especialmente académicos, por la escasa dotación financiera que dispone, y por la presencia mayoritaria de alumnos egresados de derecho no remunerados, en la gestión de casos, la labor de la CAJ se valora por la cobertura usuaria, territorial, de materias atendidas y de vanguardia en las reformas que se han implementado.

En cuanto a cobertura usuaria los criterios de ingreso automático propician la atención de la CAJ por sobre la focalización económica basada fundamentalmente en la información constatada en el registro social de hogares, superando criterios puros de determinación de pobreza. En cuanto a la proyección territorial, destaca la presencia de unidades operativas en prácticamente todas las subdivisiones territoriales administrativas del país. En lo que respecta a las líneas de servicio se comprenden las de orientación e información con su carácter universal, patrocinio judicial, prevención y promoción de derechos y la línea de SCC, con énfasis la función de los CMED y la sublínea de RAC que llevan a cabo los CJS.

El estudio de percepción ciudadana que se presentó nos permite constatar que la CAJ es una institución valorada por sus propios usuarios en atención a la calidad de atención recibida, lo que se refleja en la fidelidad percibida en cuanto a volver a utilizar o recomendar el servicio.

DECIMOTERCERA.- Al finalizar este ruta esperamos haber cumplido con los objetivos trazados al iniciarla, y haber ofrecido, desde una perspectiva teórica y práctica, una visión procesal constitucional de diversos tópicos relacionados con el acceso a la justicia y con la asistencia jurídica gratuita, especialmente en lo que respecta a los grupos en condición de vulnerabilidad, adhiriéndonos de esta manera plenamente a un enfoque integral de acceso a la justicia. 


\section{BIBLIOGRAFÍA \\ TODAS LAS FUENTES CITADAS}

\section{MONOGRAFÍAS, PARTICIPACIÓN EN OBRAS COLECTIVAS Y ARTÍCULOS CIENTÍFICOS}

ALDUNATE, Eduardo. (2008). Derechos Fundamentales. Santiago. Editorial Thomson Reuter.

ALDUNATE, Eduardo. (2009). "La fuerza normativa de la Constitución y el sistema de fuentes del derecho". EN Revista de Derecho de la Pontificia Universidad Católica de Valparaíso.

ALDUNATE, Eduardo. (2010). "Neo constitucionalismo" EN Anuario de Derecho público Universidad Diego Portales.

ALMAGRO, José. (1984). Constitución y Proceso. Barcelona. Editorial Librería Bosh.

ALMELA. Carlos. (2020). Manual para la Construcción de políticas públicas sobre acceso a la justicia de personas en condición de vulnerabilidad. Madrid. Euro social. ANDRADE, Pablo y PUYANA, Alicia. (2010). La Pobreza en América Latina ¿Una dimensión olvidada de la integración económica regional?. Santiago. Clacso Libros. ARAYA, Fernando. (2016). Asistencia Legal para personas de escasos recursos. Curso Interamericano en preparación y evaluación de proyectos. Santiago. Instituto de Economía de la Pontificia Universidad Católica de Chile. 
ARBELAEZ DE TOBON, Lucía y RUIZ, Esmeralda. (2018). Cuadernos de Buenas Prácticas para incorporar la Perspectiva de Género en las Sentencias. Santiago. Poder Judicial.

AYLWIN, Miguel. (1988). Justicia y Sectores de bajos ingresos. Santiago. Editorial Jurídica Conosur.

BARRIGA, Marianela. (2016). La defensa de los pobres; Instituciones que amparan el ejercicio de sus derechos. Concepción. Universidad Católica de Concepción.

BARROS, Luis. (1997). Opiniones de los sectores urbanos en torno a la justicia. Santiago. Corporación de Promoción Universitaria.

BARROS, Luis; CORREA, Jorge. (1993). Justicia y marginalidad, percepción de los pobres. Santiago. Corporación de promoción universitaria.

BASSO, Gina (2013). "Ley de inclusión de discapacitados: Una gran deuda del Estado de Chile". EN CIPER ACADEMICO.https://ciperchile.cl/2013/08/08/ley-deinclusion-de-discapacitados-una-gran-deuda-del-estado-de-chile/.

BATES, Luis. (1978). Reflexiones sobre el problema de la asistencia legal en Chile. Santiago. Pontificia Universidad Católica de Chile.

BIBLIOTECA DEL CONGRESO NACIONAL (2018). Infancia: Agenda legislativa de los últimos años.

BIBLIOTECA NACIONAL DE CHILE. http://www.memoria chilena.gob.cl/602/w3article-781.html.

BIRGIN, H y KOHE, B. (2006). "El acceso a la justicia como derecho" EN BIRGIN, $\mathrm{H}$ y KOHE, B. Acceso a la Justicia como garantía de igualdad, instituciones, actores y experiencias comparadas. Buenos Aires. Biblos.

BÖCKENFÖRDE, Ernst. (1987). Estudios sobre el Estado y la Democracia. Madrid. Editorial Trotta. 
BORDALÍ, Andrés. (2010). "La unidad en la interpretación jurisdiccional de los derechos fundamentales: una tarea pendiente en el derecho chileno". EN Revista Chilena de Derecho. Vol. 34 número 3.

BORDALÍ, Andrés. (2011). "Análisis Crítico de la jurisprudencia del tribunal constitucional sobre el derecho a la tutela judicial". EN Revista Chilena de Derecho. Vol. 38 número 2.

BRAVO, David; ORDENES, Claudia. (2018). Percepción del servicio de la Defensoría Penal Pública. Santiago. Centro U.C Encuestas y estudios longitudinales.

BUENOSAIRESCIUDAD.https://www.buenosaires.gob.ar/guiajuridicagratuita/oficin a-multipuertas.

CABANELLAS, Guillermo. (2008). Diccionario Enciclopédico de Derecho Usual. Buenos Aires. Editorial Helenista.

CAJ REGION METROPOLITANA. http://www.cajmetro.cl/presentacion/

CAJ REGION METROPOLITANA. (2013). Resolución alternativa de Conflictos: Una opción democrática de acceso a la justicia; Una forma de intervención humanizante en la asistencia jurídica gratuita. Santiago. Editorial Jurídica de Chile.

CAJ REGION METROPOLITANA. Cuenta pública participativa 2019. http://www.cajmetro.cl/wp-content/ARCHIVOS_DPAC/

CAJ REGION METROPOLITANA. http://www.cajmetro.cl/prevencion-y-promocionde-derechos/

CALAMANDREI, Piero. (1960). Demasiados Abogados. Buenos Aires. Ediciones Jurídicas Europa- América.

CANALES, Patricia y LOISEAU, Virginie. (2004). La Asistencia Jurídica Gratuita en la legislación de Chile, Alemania, España, Francia, Italia y Suecia. Santiago. Biblioteca del Congreso Nacional de Chile. 
CANALES. Javiera. (2020). "El peregrinaje de las víctimas de violencia de género para acceder a la justicia en tiempos de Covid 19". EN CIPER ACADEMICO. https://ciperchile.cl/2020/05/02/el-peregrinaje-de-las-victimas-de-violencia-degenero-para-acceder-a-la-justicia-en-tiempos-de-covid-19/.

CAPELLETTI, Mauro y GARTH, Bryant. (1996). El acceso a la justicia. La tendencia en el movimiento mundial para hacer efectivos los derechos. Ciudad de México. Fondo de Cultura Económica.

CARBONELL, Miguel. (2016). Introducción General al Control de Convencionalidad. Ciudad de México. Editorial Porrúa.

CAROCCA, Alex (1997). "El debido proceso en el ordenamiento jurídico chileno y el nuevo Código procesal". EN lus et Praxis vol. 5 número 1.

CASSARINO, Mario. (2004). Manual de Derecho Procesal. Santiago. Editorial jurídica de Chile.

CASTRO, Rodrigo (2017). El derecho fundamental de acceso a la justicia y a defensa letrada: Mecanismos de protección a través de sus agentes estatales. Santiago. Editorial Santiago de Chile.

CEA, José Luis. (2012). Derecho Constitucional Chileno. Santiago. Ediciones Universidad Católica de Chile.

CENTRO DE ESTUDIOS DE LA JUSTICIA DE LAS AMERICAS (2016). Informe Reforma Procesal Penal y Pueblos indígenas. Santiago.

CENTRO LATINOAMERICANO PARA EL DESARROLLO RURAL. CENTRO DE ESTUDIOS DE LA JUSTICIA DE LAS AMERICAS (2016). Informe Reforma Procesal Penal y Pueblos indígenas. Santiago.

CIDH (2007). Acceso a la justicia para las mujeres víctimas de violencia en las Américas. Washington D.C. 
COMIISIÓN ECONÓMICA PARA LATINA Y EL CARIBE (2017). Estrategia de Montevideo para la implementación de la Agenda Regional de Género en el Marco del Desarrollo Sostenible hacía el 2030.

COMISIÓN ECONÓMICA PARA AMERICA LATINA Y EL CARIBE. www.cepal.org/es/infografia.

COMITÉ CEDAW. (2004). Recomendación General número 25 sobre medidas especiales de carácter temporal.

COMITÉ CEDAW. (2015). Recomendación General número 33 sobre el acceso de las mujeres a la justicia.

COMITÉ DE DERECHOS EL NIÑO (2018). Informe de la investigación relacionada en Chile, en virtud del Artículo 13 del Protocolo Facultativo de la Convención sobre los Derechos del Niño relativo a un procedimiento de comunicación.

CONFERENCIA DE MINISTROS DE JUSTICIA DE LOS PAISES IBEROAMERICANOS Y MINISTERIO DE JUSTICIA DE CHILE. (2007). Reunión de expertos en acceso a la justicia. Santiago de Chile 28, 29 y 30 de noviembre de 2007.

CORREA, Jorge. (2005). Curso de Derecho Procesal Tomo I. Santiago. Ediciones Jurídicas de Santiago.

CORREA, Jorge. (2009). Derecho Procesal de Familia. Santiago. Editorial Thompson Reuters Puntolex.

COX, Sebastián. (2006). Acceso a la Justicia en Realidades-Tendencias y Propuestas. Santiago.

CRUZ, Pedro. (1989). "Formación y evolución de los derechos fundamentales". EN PECES-BARBA, Gregorio. (1995). Curso de Derechos Fundamentales. Teoría General. Madrid. Universidad Carlos III.

DEFENSORIAPENALPUBLICA.http://www.dpp.cl/pag/92/256/aranceles_y_tramos. 
DEFENSORIAPENALPUBLICA.http:/www.dpp.cl/pag/169/381/defensa_de_person as_extranjeras_y_migrantes>.

DIARIO EL MOSTRADOR. https://www.elmostrador.cl/dia/2020/07/10.

DIARIO ELECTRONICO EN ESTRADO. http://enestrado.com/imputado-porviolacion-pedia-aplicacion-de-norma-que-rebajaria-su-pena-tribunal-constitucionalacoge-inaplicabilidad-por-inconstitucionalidad.

DIARIOCONSTITUCIONAL.https://www.diarioconstitucional.cl/noticias/asuntos-deinteres-publico/2019/01/11/cs-acoge-proteccion-contra-corporacion-de-asistenciajudicial-de-valparaiso/.

DIARIOCONSTITUCIONAL.https://www.diarioconstitucional.cl/noticias/proyectosde-reforma-constitucional/2019/05/27/nuevo-proyecto-otorga-reconocimientoconstitucional-a-los-pueblos-indigenas.

DIARIOELECTRONICOELDESCONCIERTO.https://www.eldesconcierto.cl/2019/0 7/29/violencia-y-exclusion-en-la-vida-de-ninos-ninas-y-adolescentes-enresidencias-del-sename-la-urgencia-de-una-politica-publica/.

DIARIOELMERCURIO.https://www.emol.com/noticias/Nacional/2020/07/09/99150 8/Gobierno-veta-Servicio-Proteccion-Ninez.proteccion-a-la-ninez-y-adolescenciaen-reemplazo-del-sename/.

DIEZ-PICAZO, Luis. (2005). Sistema de derechos fundamentales. Madrid. Thomson Civitas.

DIPPEL, Horst. (2005). "Constitucionalismo moderno. Introducción a una historia que necesita ser escrita". EN Revista electrónica historia Constitucional número 6.

DOHYHARCABAL, Solange. (1983). "Asistencia Jurídica en el Derecho Romano", EN Revista Chilena de Historia del Derecho. número 9. 
DOUGNAC, Antonio. (1978). "Notas históricas en torno a la asistencia jurídica gratuita y la práctica forense en Chile". EN Revista de Derecho Procesal Universidad de Chile. Año 3. número 5.

ESPARZA, Iñigo. (1995). El principio del proceso debido. Barcelona. J.M Bosch Editor.

EVANS, Enrique. (1986). Derechos Constitucionales. Santiago. Editorial Jurídica de Chile.

FERNANDEZ, Miguel. (2006). Los derechos fundamentales en 25 años de jurisprudencia del tribunal constitucional 1980-2005. Santiago. Cuadernos del Tribunal Constitucional número 33.

FERRAJOLI, Luigi. (1999). Derechos y Garantías. La ley del más débil. Madrid. Editorial Trotta.

FIX ZAMUDIO, Héctor. (1988). En Latinoamérica: Constitución, Proceso y derechos humanos. Ciudad de México. Editorial Porrúa

FRIAS, Pedro. (1992). El Constitucionalismo Actual, EN Revista Chilena de Derecho, Pontificia Universidad Católica de Chile. Vol. 19. número 1.

FUENZALIDA,Pablo.(2019).https://www.elmercurio.com/Legal/Noticias/Analisis-

Juridico/2019/11/06/Acceso-a-la-justicia-y-nueva-agenda-social.aspx.

FUNDACION PROBONO. http www.probono.cl

GARCIA HUIDOBRO. Cristóbal. (2012). "El Reglamento Constitucional Provisorio de 1812: Reflexiones para un Bicentenario". EN Revista Chilena de Derecho. Vol. 39 número 1.

GARCIA, Gonzalo y CONTRERAS, Pablo. (2013). "El derecho a la tutela judicial efectiva y al debido proceso en la jurisprudencia del Tribunal Constitucional Chileno". EN Estudios Constitucionales vol.11, número 1. 
GARCIA, Sergio. (2006). Anuario de Derecho Constitucional Latinoamericano. Ciudad de México. Publicaciones \& Fomento editorial.

GFK ADIMARK S.A (2016). Encuesta nacional de necesidades jurídicas y acceso a justicia. http:/biblioteca.digital.gob.cl

GOBIERNO DE CHILE. MINISTERIO DE JUSTICIA. DIRECCION DE PRESUPUESTOS.(2019).http://www.dipres.gob.cl/597/w3-multipropertyvalues14490-25190.html

GODOY, R y DIDIER, M (2014). "Comentarios de la jurisprudencia de la Corte Suprema y el Tribunal Constitucional sobre derechos de las personas migrantes durante el año 2013". EN Anuario de Derechos Humanos número 10.

GOMEZ COLOMER, Juan. (1981). El beneficio de Pobreza (La solución española al problema del acceso gratito a la justicia). Barcelona. Editorial José Bosch S.A.

GOMEZ COLOMER, Juan. (1998). Derecho Jurisdiccional Parte General. Valencia. Editorial Tirant Lo Blanch.

GOMEZ, Gastón. (2013). Las Sentencias del TC y sus efectos sobre la jurisdicción común. Santiago. Edición Universidad Diego Portales.

GONZALEZ, Jesús. (2017). La Dignidad de la persona. Navarra. Editorial Aranzadi. GOZAINI, Osvaldo. (2017). El Debido Proceso. Estándares de la Corte Interamericana de Derechos Humanos. Buenos Aires. Rubinzal - Culzoni Editores.

GUERRA, María. (2018). Justicia de Paz en el Perú: Un Servicio de Justicia eficiente. Lima. Ediciones Universidad Católica de Lima.

HEIM, Daniela. (2014). Mujeres y Acceso a la Justicia. De la tradición formalista del derecho a un derecho androcéntrico. Barcelona. Tesis Doctoral Universitat Autónoma de Barcelona. 
HENRIQUEZ, Miriam. (2015). "Los pueblos indígenas y su reconocimiento constitucional pendiente". En Reforma Constitucional. Santiago. Editorial Lexis Nexis.

HITTERS, Juan. (2008)¿Son vinculantes los pronunciamientos de la Comisión y de la Corte Interamericana de Derechos Humanos? Buenos Aires. Editorial La Ley.

HUERTA, L. (2003). El debido proceso en las decisiones de la Corte Interamericana de Derechos Humanos. Comisión Andina de Juristas. Lima.

HUMERES, H. (2009). "El Abogado de Turno: Un trabajo forzado". EN: Sentencias destacadas. Una mirada desde la perspectiva de las políticas públicas. Libertad y Desarrollo.

INFORME DE LA COMISION DE CONSTITUCION, LEGISLACION, JUSTICIA Y REGLAMENTO, de 29 de mayo de 2018, recaído en proyecto de ley refundido que modifica el Código Orgánico de Tribunales en materia de práctica profesional para obtener el título de abogado.

INSTITUTO DE DEFENSA LEGAL/RED ANDINA DE JUSTICIA DE PAZ Y COMUNITARIA (2005). La justicia de paz en los Andes, Estudio regional. Lima.

INSTITUTO NACIONAL DE DERECHOS HUMANOS. (2018). Informe de Derechos Humanos 2018.

INSTITUTO NACIONAL DE ESTADISTICA. (2020). Informe técnico. Estimación de personas extranjeras residentes habituales en Chile al 31 de diciembre de 2019.

LA ROSA CALLE, Javier. (2014). "Acceso a la justicia: elementos para incorporar en un enfoque integral de política pública" EN Acceso a la Justicia en el mundo rural. Lima.

LEONE, Giovanni. (1989). Tratado de Derecho Procesal Penal. (Traducción de Santiago Sentís Melendo). Buenos Aires. Ediciones Jurídicas Euro- América. 
LOVATÓN, David. (2010). "Experiencias de acceso a la justicia en Latinoamérica". EN Revista Interamericana de Derechos Humanos. San José de Costa Rica. Litografía Universal S.A.

MAQUEO, María. (2011). Elementos económicos y constitucionales en el análisis de la asistencia jurídica gratuita. Tesis Doctoral. Universidad de Salamanca.

MARINONI, Luis; PEREZ, Álvaro; NUÑEZ, Raúl. (2010). Fundamentos del Proceso Civil: Hacía una teoría de la adjudicación. Santiago. Abeledo perrot.

MAURIZ, Benito. (1999). El privilegio de pobreza en la asistencia legal en Chile. Ponencia Asistencia Legal en Pontificia Universidad Católica de Chile. Santiago.

MEDINA, Cecilia. (2005). La Convención Americana, teoría y jurisprudencia. Santiago. Centro de Derechos Humanos Facultad de Derecho Universidad de Chile. MEDINA, Cecilia; NASH, Claudio. (2003). Manual de Derecho Internacional de los Derechos Humanos para Defensores Penales Públicos. Parte I. Doctrina. Santiago, Centro de Documentación Defensoría Penal Pública.

MEDINA, Rodrigo; MORALES, Luis; DORN, Carlos. (2007). Manual de derecho procesal penal. Santiago. Lexis Nexis.

MINISTERIO DE DESARROLLO SOCIAL. (2015). Encuesta del segundo estudio nacional de discapacidad.

MINISTERIO DE DESARROLLO SOCIAL. http://www.registrosocial.gob.cl/.

MINISTERIO DE JUSTICIA Y DERECHOS HUMANOS DE LA NACION. (2013). "Protocolo para el Acceso a la Justicia de las Personas con Discapacidad. Propuestas para un trato adecuado" EN Colección de Documentos de Política número 2, Área Justicia. Buenos Aires. Euro social, Programa para la Cohesión Social en América Latina,

MINISTERIO PÚBLICO. (2019). Boletín Institucional de Fiscalía de Chile año 2019. 
MINISTERIO SECRETARIA GENERAL DE GOBIERNO. DIRECCION DE ORGANIZACIONES SOCIALES. https://dos.gob.cl/congreso-aprobo-proyecto-deley-que-crea-el-servicio-nacional.

\section{MINISTERIO DE DESARROLLO SOCIAL.}

http://www.desarrollosocialyfamilia.gob.cl/noticias/comision-de-familia-apruebapor-unanimidad-la-idea-de-legislar-el-proyecto-de-ley-de-garantias.

MINISTERIO DE JUSTICIA DE ESPAÑA. https://www.mjusticia.gob.es/cs/Satellite/Portal/es/servicios-ciudadano/tramitesgestiones-personales/asistencia-juridica-gratuita.

MOHOR, S; VARAS, P. (1998). "Procedencia del Recurso de Protección frente a las disposiciones del artículo 19 no 3 de la Constitución". EN Revista Chilena de Derecho. número especial.

MONTERO, Diana; SALAZAR, Alonso. (2013). Derecho de Defensa en la Jurisprudencia de la Corte Interamericana de Derechos Humanos. San José de Costa Rica, Editorial Isolma.

NASH, Claudio; NUÑEZ, Constanza; TRONCOSO, Camila. (2017). “¿Existe en Chile una garantía efectiva del acceso a la justicia en condiciones de igualdad y particularmente en grupos en situación de discriminación?". EN C. Nash (coord.). Derecho de Acceso a la justicia. Aporte para la construcción de un acervo latinoamericano. Ceja - JSA.

NAVARRETE, Carmen. (2008). La Gratuidad como base de la Administración de Justicia y sus Excepciones: La asistencia Judicial. Santiago Chile. Editorial Santiago NOGUEIRA, Humberto. (2003). "Los Derechos Esenciales o Humanos contenidos en los Tratados Internacionales y su ubicación en el ordenamiento jurídico nacional: Doctrina y Jurisprudencia". EN Revista lus et Praxis vol.9 número 1.Talca.

NOGUEIRA, Humberto. (2006). Lineamientos de interpretación constitucional y del bloque constitucional de derechos. Santiago. Editorial Librotecnia. 
NOGUEIRA, Humberto. (2007). El Debido Proceso en la Constitución y Sistema Interamericano. Doctrina y Jurisprudencia. Santiago, Librotecnia.

NOGUEIRA, Humberto. (2015). "El Bloque Constitucional de Derechos en Chile, El parámetro y consideraciones comparativas con Colombia y México: Doctrina y Jurisprudencia". EN Estudios Constitucionales, Vol. 13 número 2.

O'DONNELL, Daniel. (2007). Derecho internacional de derechos humanos. Normativa, Jurisprudencia y doctrinas de los Sistemas universal e interamericano. Oficina México del alto Comisionado de Derechos Humanos.

OBSERVATORIO DE EQUIDAD DE GÉNERO Y SALUD. (2018). Violencia de Género en Chile.

OBSERVATORIO JUDICIAL. (2018). "La Corte, defensora del inmigrante. ¿Cómo aplica la Corte Suprema la legislación migratoria?" EN Revista Radar número 2.

ONU. (1990). Principios Básicos sobre la Función de los Abogados relativo a las salvaguardias especiales en asuntos penales, aprobados por el Octavo Congreso de las Naciones Unidas sobre Prevención del Delito y Tratamiento del Delincuente. La Habana.

ORGANIZACIÓN DE NACIONES UNIDAS (2012). Resolución de 24 de septiembre de 2012. Declaración de reunión de alto nivel de la Asamblea General sobre el Estado de Derecho.

OYANEDEL, Juan. (2018) y ORTUZAR, Harry. "Sistematización de una experiencia piloto de implementación de una sala Gesell para entrevistas de niños en un Tribunal de Familia". EN Revista Chilena de Pediatría Vol. 89 número 6.

PEÑA. Antonio. (1997). La garantía en el Estado constitucional de derecho. Madrid. Editorial Trotta.

PEREIRA, Hugo. (1996). Curso de Derecho Procesal. Santiago. Editorial Jurídica Conosur. 
PEREZ LUÑO, Antonio. (2000). La tercera generación de derechos humanos. Navarra. Ed. Aranzadi.

PFEIFFER, Emilio. (1997). Derecho Constitucional. Tomo I. Santiago. Editorial Jurídica de Chile.

PICCOLI, Emmanuelle. (2019). "Las Rondas Campesinas y su reconocimiento estatal, dificultades y contradicciones de un encuentro: un enfoque antropológico sobre el caso de Cajamarca" EN Nueva Antropología Vol. 22 número 71. México.

PODER JUDICIAL DE CHILE. (2020). Protocolo de Acceso a la Justicia de Grupos Vulnerables. Santiago.

PODER JUDICIAL DE CHILE. http://www.reinsercionsocial.gob.cl/tribunales-detratamiento-de-drogas-yo-alcohol/.

PODERJUDICIALCOSTARICA.https://accesoalajusticia.poderjudicial.go.cr/index.p hp/noticias-ninnos/671-poder-judicial-lanza-aplicacion-empoderate-dirigida-aninos-ninas-y adolescentes.

PODERJUDICIALDEPUERTORICO.http://www.ramajudicial.pr/orientacion/informe s/rama/Plan-estrategico-2012-2015.pdf

PROGRAMA DE NACIONES UNIDAS (2017). Informe sobre desarrollo humano. Nueva York.

PROGRAMA DE NACIONES UNIDAS PARA EL DESARROLLO (2005). Manual de políticas públicas para el acceso a la justicia. Buenos Aires. Ediciones del Instituto.

QUISPE, Florabel. (2010). El Debido Proceso en el Derecho Internacional y en el Sistema Interamericano. Valencia. Tirant lo Blanch.

RADIOBIOBIO.https://www.biobiochile.cl/especial/resumen-denoticias/2019/08/27. RED CHILENA CONTRA LA VIOLENCIA HACIA LAS MUJERES. (2018). Dossier Informativo. www.nomasviolenciacontramujer. 
REVENGA, Miguel. (1992). Los retrasos judiciales ¿Cuándo vulnera el derecho a un proceso sin dilaciones indebidas. Colección de jurisprudencia práctica. Madrid. Tecnos.

REVENGA, Miguel. (2013).El Derecho a la asistencia jurídica gratuita en la Jurisprudencia del Tribunal Europeo de Derechos Humanos. http://info5.juridicas.unam.mx/ libros/6/2562/35.pdf

RHUDY, Robert. (1999). "Acceso a la justicia: modelos de asistencia jurídica". EN BIEBESHEIMER, C y CORDOVEZ, C. La justicia más allá de nuestras fronteras. Experiencia de reformas útiles para América Latina y el Caribe. Banco Interamericano de Desarrollo. Washington DC.

RIBOTTA, Silvia. "Reglas de Brasilia sobre Acceso a la Justica de las Personas en Condición de Vulnerabilidad. Vulnerabilidad, Pobreza y Acceso a la Justicia". EN Revista Electrónica Iberoamericana. Vol. 6. Número 2.

RIEGO Cristian; LILLO, Ricardo (2015) “¿Que se ha dicho sobre el funcionamiento de la justicia civil en Chile? Aportes para la reforma". EN Revista Chilena de derecho privado. Santiago. Número 25.

RIVAS, Antonia. (2019). "Derechos Humanos de los pueblos indígenas en Chile". EN: Universidad Diego Portales. Informe Anual de Derechos Humanos 2019.

ROJO, Ignacio. (2020). "Ejerce el Poder Judicial Control de Constitucionalidad". EN DIARIO CONSTITUCIONAL.https://www.diarioconstitucional.cl/articulos/buenoejerce-el-poder-judicial-control-de-constitucionalidad/.

SCHNEIDER, Hans-Peter. (1979). "Peculiaridad y función de los derechos fundamentales de un estado constitucional democrático". EN Revista de estudios políticos. Madrid.

SENADIS. https://www.senadis.gob.cl/pag/2/1144/introduccion. 
SENADIS.https://www.senadis.gob.cl/sala_prensa/d/noticias/5622/senadis-y-elcolegio-de-arquitectos-firman-convenio-que-promueve-la-inclusion-y-laaccesibilidad-de-personas-con-discapacidad.

SENADO DE LA REPUBLICA. (2006). Reformas Constitucionales 2005, Historia y tramitación. Santiago. Edición Senado de la República.

SENAME. (2019). https://www.sename.cl/web/index.php/nuestra-institucion/.

SEPULVEDA, Nicolás; GUZMAN, Juan. (2018). "El Brutal Informe de Policía de Investigaciones sobre abusos en el SENAME que permaneció oculto desde diciembre". EN CIPER ACADEMICO (2018). https://ciperchile.cl/2019/07/02/elbrutal-informe-de-la-pdi-sobre-abusos-en-el-sename-que-permanecio-ocultodesde-diciembre/.

SERNAMEG. www.sernameg.gob.cl

TAMAYO, Miguel. (1997). "El Análisis de las Políticas Públicas", EN Bañón y Carrillo. (1997): La Nueva Administración Pública. Madrid. Alianza Editorial.

THOMPSON, José. (2000). Acceso a la justicia y equidad: estudio en siete países de América Latina. San José de Costa Rica. Banco Interamericano de DesarrolloInstituto Interamericano de Derechos Humanos de Costa Rica.

TUSHNET, Mark (2017). Constitucionalismo y Judicial Review. Lima. Palestra Editores.

UNICEF (2020). Niños, Niñas o Adolescentes en Chile. www.unicef.cl/informes

UNIVERSIDAD DE CHILE. (2016). Anuario de Derechos Humanos 2016.

UNIVERSIDAD DIEGO PORTALES (2017). Informe Anual de Derechos humanos 2017. Santiago.

UNIVERSIDAD DIEGO PORTALES (2019). Informe Derechos Humanos 2019. Santiago. 
UNIVERSIDAD DIEGO PORTALES. (2008). "Acceso a la Justicia en Chile" EN Informe Anual de Derechos Humanos en Chile 2008. Santiago.

UNIVERSIDAD DIEGO PORTALES. (2017). "Acceso a la justicia en Chile" EN Informe Anual sobre derechos humanos en Chile 2017.Santiago.

UNIVERSIDADCOOPERATIVADECOLOMBIA.http://www.ucc.edu.co/noticias/pren sa/academia/El-Consultorio-Juridico-y-Centro-de-Conciliacion-del-Campus-

Medellin-se-especializa-en-la-atencion-de-personas-con-discapacidad.

UREÑA, B. (2014). Derechos Fundamentales Procesales. Navarra. Editorial Aranzadi.

VALENZUELA, Ester y CORREA, Paula. (2019). "Derechos Humanos de Niños, Niñas y Adolescentes. La infancia primero: Lo prometido es deuda". EN Informe Anual Derechos Humanos 2019. Santiago. Universidad Diego Portales.

VILLEGAS, Mirna. (2014). "Sistemas sancionatorios indígenas y derecho penal. ¿Subsiste el AZ-Mapu?". EN: Política criminal vol.9. número 17.

\section{LEGISLACIÓN DE LA REPÚBLICA DE CHILE POR ORDEN CRONOLÓGICO}

\subsection{CONSTITUCIONES}

REGLAMENTO CONSTITUCIONAL, de 26 de octubre de 1812.

PROYECTO DE CONSTITUCIÓN PROVISORIA PARA EL ESTADO DE CHILE, de 23 de octubre de 1818.

CONSTITUCIÓN POLÍTICA DEL ESTADO DE CHILE, de 30 de octubre de 1822.

CONSTITUCIÓN POLÍTICA DE LA REPUBLICA DE CHILE, de 8 de agosto de 1828. 
CONSTITUCIÓN POLÍTICA DE LA REPUBLICA DE CHILE, de 25 de mayo de 1833.

CONSTITUCIÓN POLÍTICA DE LA REPUBLICA DE CHILE, de 18 de septiembre de 1925.

CONSTITUCIÓN POLÍTICA DE LA REPUBLICA DE CHILE, de 21 de octubre de 1980.

\subsection{LEYES}

LEY DE ORGANIZACIÓN Y ATRIBUCIONES DE LOS TRIBUNALES, de 15 de octubre de 1875.

LEY 4.409. Establece Ley orgánica del Colegio de Abogados, de 8 de septiembre de 1928.

LEY 16.618. Fija el Texto definitivo de la Ley de Menores, de 8 de marzo de 1967.

LEY 17.995. Que concede personalidad jurídica a los servicios de asistencia jurídica que se indican en las regiones que se señalan, de 8 de mayo de 1981.

LEY 18.120. Establece Normas sobre Comparecencia en Juicio, de 18 de mayo de 1982.

LEY 18.600. Establece Normas sobre Deficientes Mentales, de 19 de febrero de 1987.

LEY 18.632. Crea Corporación de Asistencia Judicial de las Regiones de Tarapacá y de Antofagasta y le concede Personalidad jurídica, de 24 de julio de 1987.

LEY 19.123. Crea la Corporación Nacional de Reparación y Reconciliación, Establece pensión de reparación y otorga otros beneficios en favor de personas que señala, de 8 de febrero de 1992. 
LEY 19.253. Que establece las normas sobre protección, fomento y desarrollo de los indígenas y crea la Corporación Nacional de Desarrollo Indígena, de 5 de octubre de 1993.

LEY 19.418, Establece normas sobre juntas de vecinos y demás Organizaciones comunitarias, de 20 de marzo de 1997.

LEY 19.718. Crea la Defensoría Penal Pública, de 27 de febrero de 2001.

LEY 19.880. Establece Bases de los Procedimientos Administrativos que rigen los Actos de los Órganos de la Administración del Estado, de 29 de mayo de 2003.

LEY 19.954. Modifica la Ley 18.600, en lo relativo al Procedimiento de Interdicción de los Discapacitados Mentales, de 14 de julio de 2004.

LEY 19.966. Que establece un régimen de garantías en salud, de 3 de septiembre de 2004.

LEY 19.968. Crea los Tribunales de Familia, de 30 de agosto de 2004.

LEY 19.980. Que modifica la ley 19.123, Ley de Reparación, ampliando o estableciendo beneficios en favor de las personas que indica, de 9 de noviembre de 2004.

LEY 20.066. Establece Ley de Violencia Intrafamiliar, de 7 de octubre de 2005.

LEY 20.084. Que Establece un Sistema de Responsabilidad de los Adolescentes por Infracciones a la Ley Penal, de 7 de diciembre de 2005.

Ley 20.405. Que crea el Instituto Nacional de Derechos Humanos, de 10 de diciembre de 2009.

LEY 20.422. Que establece normas sobre igualdad de oportunidades e inclusión social de personas con discapacidad, de 10 de febrero de 2010. 
LEY 21.057. Que regula entrevistas grabadas en video y otras medidas de resguardo a menores de edad, víctimas de delitos sexuales, de 20 de enero de 2018.

Ley 21.067. Que crea la Defensoría de los Derechos de la Niñez de 29 de enero de 2018.

LEY 21.212. Modifica el Código Penal, el Código Procesal Penal y la Ley 18.216 en materia de Tipificación del Femicidio, de 4 de marzo de 2020.

LEY 21.226. Establece un Régimen Jurídico de Excepción para los procesos judiciales, en las audiencias y actuaciones judiciales y para los plazos y ejercicio de las acciones que indica, por el impacto de la enfermedad Covid 19 en Chile, de 2 de abril de 2020.

\subsection{CóDIGOS}

CODIGO CIVIL, de 1 de enero de 1857.

CODIGO PENAL, de 1 de marzo de 1875.

CODIGO DE PROCEDIMIENTO CIVIL, de 30 de agosto de 1902.

CODIGO ORGANICO DE TRIBUNALES, de 9 de julio de 1943.

CODIGO PROCESAL PENAL, de 12 de octubre de 2000.

\subsection{AUTO ACORDADOS, DECRETOS Y ORDINARIO}

DECRETO SUPREMO 1.064. Crea Comisión de Estudios para una Nueva Constitución, de 12 de noviembre de 1973.

DECRETO LEY 1.094. Establece normas sobre extranjeros en Chile, de 19 de julio de 1975. 
DECRETO LEY 1.552. Aprueba Acta Constitucional número 3, de 13 de septiembre de 1976.

DECRETO LEY 3.621. Fija normas sobre Colegio Profesionales, de 3 de febrero de 1981.

DECRETO CON FUERZA DE LEY 995. Aprueba Estatutos por los cuales se regirá la Corporación de Asistencia Judicial de la Región Metropolitana de Santiago, de 21 de septiembre de 1981.

ORDINARIO 685 MINISTERIO DE JUSTICIA. Mecanismo de Focalización Socioeconómica para la atención en la Línea Judicial de las Corporaciones de Asistencia Judicial, de 2 de febrero de 2018.

DECRETO 43.286. Establece visto consular de turismo a nacionales de la República bolivariana de Venezuela, de 20 de junio de 2019.

AUTO ACORDADO 41- 2020. Regula el teletrabajo y el uso de videoconferencia en el poder judicial, de 18 de marzo de 2020.

AUTO ACORDADO 53- 2020. Funcionamiento del Poder Judicial Durante la Emergencia Sanitaria Nacional provocada por el Brote del Nuevo Corona Virus, de 8 de abril de 2020.

\section{TRATADOS INTERNACIONALES, CARTAS CONSTITUTIVAS, DOCUMENTOS PUBLICOS, CONSTITUCIONES Y LEYES EXTRANJERAS}

CARTA DE DERECHOS DE LAS PERSONAS ANTE LA JUSTICIA EN EL

ESPACIO IBEROAMERICANO, 27 a 29 de noviembre del año 2002.

CARTA ORGANIZACIÓN ESTADOS AMERICANOS, de 30 de abril de 1948

CONSTITUCIÓN DE PERÚ, de 29 de diciembre de 1993.

CONSTITUCIÓN ESPAÑOLA, de 29 de diciembre de 1978. 
CONVENCIÓN AMERICANA DE DERECHOS HUMANOS, de 22 de noviembre de 1969.

CONVENCIÓN DE LAS NACIONES UNIDAS CONTRA LA DELINCUENCIA ORGANIZADA TRANSNACIONAL Y SUS PROTOCOLOS CONTRA EL TRÁFICO ILÍCITO DE MIGRANTES POR TIERRA, MAR Y AIRE Y PARA PREVENIR, REPRIMIR Y SANCIONAR LA TRATA DE PERSONAS, de 15 de noviembre de 2000.

CONVENCIÓN DE VIENA SOBRE RELACIONES CONSULARES, de 5 de marzo de 1968.

CONVENCIÓN EUROPEA DE DERECHOS HUMANOS, de 4 de noviembre de 1950.

CONVENCIÓN INTERAMERICANA PARA LA ELIMINACIÓN DE TODAS LAS FORMAS DE DISCRIMINACIÓN CONTRA LAS PERSONAS CON DISCAPACIDAD, de 7 de junio de 1999.

CONVENCIÓN INTERAMERICANA PARA PREVENIR, SANCIONAR Y ERRADICAR LA VIOLENCIA CONTRA LA MUJER, de 6 de septiembre de 1994.

CONVENCIÓN INTERNACIONAL DE LOS DERECHOS DEL NIÑO, de 20 de noviembre de 1989.

CONVENCIÓN INTERNACIONAL SOBRE ELIMINACIÓN DE TODAS FORMAS DE DISCRIMINACIÓN RACIAL, de 21 de diciembre de 1965.

CONVENCIÓN INTERNACIONAL SOBRE LA PROTECCIÓN DE TODOS LOS TRABAJADORES MIGRANTES Y DE SUS FAMILIARES DE 1990, de 24 de septiembre de 1993.

CONVENCIÓN SOBRE ASPECTOS CIVILES DEL SECUESTRO INTERNACIONAL DE NIÑOS, de 27 de octubre de 1989. 
CONVENCIÓN SOBRE EL ESTATUTO DE LOS APÁTRIDAS, de 28 de septiembre de 1954.

CONVENCIÓN SOBRE EL ESTATUTO DE REFUGIADOS, de 28 de julio de 1951. CONVENCIÓN SOBRE ELIMINACION DE TODA FORMA DE DISCRIMINACION CONTRA LA MUJER, de 18 de diciembre de 1999.

CONVENCIÓN SOBRE LOS DERECHOS DE LAS PERSONAS CON DISCAPCIDAD, de 13 de diciembre de 2006.

CONVENIO 169 ORGANIZACIÓN INTERNACIONAL DE TRABAJO, de 27 de junio de 1989.

DECLARACIÓN AMERICANA DE LOS DERECHOS Y DEBERES DEL HOMBRE, de 1948.

DECLARACIÓN DE CARTAGENA DE REFUGIADOS, de 19 a 22 de noviembre de 1984.

DECLARACIÓN DE NACIONES UNIDAS SOBRE LOS DERECHOS DE LOS PUEBLOS INDÍGENAS, de 13 de septiembre de 2007.

DECLARACIÓN UNIVERSAL DE DERECHOS HUMANOS, de 10 de diciembre de 1948.

DIRECTRICES DE ACCIÓN SOBRE EL NIÑO EN EL SISTEMA DE JUSTICIA PENAL, de 20 de noviembre de 2009.

INFORME COMISIÓN INTERAMERICANA DE DERECHOS HUMANOS. Acceso a la justicia para las mujeres víctimas de violencia en las Américas. Washington D.C, de 20 de enero de 2007.

LEY 1 /1996 de Asistencia Jurídica Gratuita, de 10 de enero de 1996. 
OBSERVACIÓN GENERAL DEL COMITÉ SOBRE LOS DERECHOS DE LAS PERSONAS CON DISCAPACIDAD DE LAS NACIONES UNIDAS, 31 de marzo a 11 de abril de 2014.

PACTO INTERNACIONAL DE DERECHOS CIVILES Y POLITICOS, de 16 de diciembre de 1966.

PACTO INTERNACIONAL DE DERECHOS ECONOMICOS, SOCIALES Y CULTURALES, de 16 de diciembre de 1966.

PROTOCOLO IBEROAMERICANO DE ACTUACIÓN JUDICIAL PARA MEJORAR EL ACCESO A LA JUSTICIA DE PERSONAS CON DISCAPACIDAD, MIGRANTES, NIÑAS. NIÑOS, ADOLESCENTES, COMUNIDADES Y PUEBLOS INDÍGENAS, 2 a 4 de abril de 2014, en el marco de la XVII Cumbre Judicial Iberoamericana.

PROTOCOLO PARA PREVENIR, REPRIMIR Y SANCIONAR LA TRATA DE PERSONAS, ESPECIALMENTE DE MUJERES Y NIÑOS, QUE COMPLEMENTA A LA CONVENCIÓN DE NACIONES UNIDAS CONTRA LA DELINCUENCIA ORGANIZADA INTERNACIONAL, de 15 de noviembre de 2000.

REGLAS DE BRASILIA SOBRE ACCESO A LA JUSTICIA DE LAS PERSONAS EN CONDICION DE VULNERABILIDAD, 4 a 6 de marzo de 2008, en el marco de la XIV Cumbre Judicial Iberoamericana.

REGLAS MÍNIMAS DE LAS NACIONES UNIDAS PARA LA ADMINISTRACIÓN DE JUSTICIA DE MENORES, de 29 de noviembre de 1985

\section{JURISPRUDENCIA DE TRIBUNALES CHILENOS POR ORDEN CRONÓLOGICO}

\subsection{JURISPRUDENCIA DEL TRIBUNAL CONSTITUCIONAL}


Sentencia causa rol 248-1996, de 22 de octubre de 1996.

Sentencia causa rol 755-2007, de 31 de marzo de 2008.

Sentencia causa rol 1254-08, de 29 de julio de 2009.

Sentencia causa rol 1470-2009, de 27 de octubre de 2009.

Sentencia causa rol 1535-2010, de 28 de enero de 2010.

Sentencia causa rol 11580-2009, de 17 de enero de 2011.

Sentencia causa rol 2042-2015, de 10 de julio de 2012.

Sentencia causa rol 1994, de 21 de septiembre de 2012.

Sentencia causa rol 2273-2013, de 4 de julio de 2013.

Sentencia causa rol 2495-2013, de 31 de julio de 2014.

Sentencia causa rol 1254-2009, de 29 de julio de 2019.

\subsection{JURISPRUDENCIA DE LA CORTE SUPREMA}

Sentencia causa rol 24.847, de 26 de enero de 1995.

Sentencia causa rol 24.470, de 31 de enero de 1995.

Sentencia causa rol 921-2012, de 5 de abril de 2012.

Sentencia causa rol 11.964-2014, de 12 de enero de 2015.

Sentencia causa rol 5.851-2015, de 16 de mayo de 2015.

Sentencia causa rol 8.778-2015, de 7 de septiembre de 2015.

Sentencia causa rol 16.034-2016, de 1 de marzo de 2016. 
Sentencia causa rol 65.406-2016, de 15 de septiembre de 2016.

Sentencia causa rol 27.543-2016, de 3 de octubre de 2016.

Sentencia causa rol 10.1756-2016, de 4 de enero de 2017.

Sentencia causa rol 7.007-2017, de 7 de marzo de 2017.

Sentencia causa rol 11.650-2017, de 10 de abril de 2017.

Sentencia causa rol 19.144-2017, de 22 de mayo de 2017.

Sentencia causa rol n 37160- 2017, de 21 de agosto de 2017.

Sentencia causa rol 38057-2017 de 21 de agosto de 2017.

Sentencia causa rol 19.253-2019, de 2 de enero de 2019.

\subsection{JURISPRUDENCIA DE CORTES DE APELACIONES Y JUZGADOS}

CORTE DE APELACIONES DE TEMUCO. Sentencia causa rol $n^{\circ} 208-2004$, de 30 de abril de 2004

TRIBUNAL ORAL EN LO PENAL DE CALAMA. Sentencia causa rit 66-2007, de 6 de octubre de 2007.

CORTE DE APELACIONES DE SANTIAGO. Sentencia causa rol 1244-2008, de 24 de julio de 2008.

CORTE DE APELACIONES DE PUNTA ARENAS. Sentencia causa rol 28-2012, de 4 de mayo de 2012.

CORTE DE APELACIONES DE CONCEPCIÓN. Sentencia causa rol 195-2014, de 2 de mayo de 2014. 
CORTE DE APELACIONES DE CONCEPCIÓN. Sentencia causa rol 3606-2014, de 25 de noviembre de 2014.

CORTE DE APELACIONES DE SANTIAGO. Sentencia causa rol 1369-2014, de 31 de enero de 2015.

CORTE DE APELACIONES DE COPIAPO. Sentencia causa rol 290-2015, de 20 de octubre de 2015.

CORTE DE APELACIONES DE LA SERENA. Sentencia causa rol 159-2016, de 31 de mayo de 2016.

CORTE DE APELACIONES DE SANTIAGO. Sentencia causa rol 983-2016, de 6 de diciembre de 2016.

CORTE DE APELACIONES DE SANTIAGO. Sentencia causa rol 10.530-2017, de 8 de junio de 2018

CORTE DE APELACIONES DE VALPARAISO. Sentencia causa rol 5262-2018, de 2 de agosto de 2018.

21 JUZGADO CIVIL DE SANTIAGO. Sentencia causa rol 13.189-2015, de 12 de julio de 2017.

\section{JURISPRUDENCIA DE TRIBUNALES INTERNACIONALES POR ORDEN CRONÓLOGICO}

\subsection{JURISPRUDENCIA DE LA CORTE INTERAMERICANA DE DERECHOS HUMANOS}

\section{a. Casos Contenciosos}

Caso Velásquez Rodríguez vs. Honduras, Sentencia de 29 de julio de 1988.

Caso Loayza Tamayo vs Perú, Sentencia de 17 de septiembre de 1997. 
Caso Suarez Rosero vs Ecuador, Sentencia 12 de noviembre de 1997.

Caso Blake vs Guatemala, Sentencia de 24 de enero de 1998.

Caso Castillo Petruzzi vs Perú, Sentencia de 30 de mayo de 1999.

Caso Villagrán Morales vs Guatemala, Sentencia 19 de noviembre de 1999.

Caso Tribunal Constitucional vs Perú, Sentencia 31 de enero de 2001.

Caso Ivcher Bronstein vs Perú, Sentencia 6 de febrero de 2001.

Caso Mayagna (Sumo) Awas Tingni vs Nicaragua, Sentencia de 31 de agosto de 2001.

Caso Cantoral Benavides vs Perú, Sentencia de 3 de diciembre de 2001.

Caso Ricardo Baena y otros vs Panamá, Sentencia de 2 de febrero de 2002

Caso Hilaire, Constantine y Benjamín y otros contra Trinidad Tobago, Sentencia 21 de junio de 2002.

Caso Myrna Mack Chang vs Guatemala, Sentencia de 25 de noviembre de 2002. Voto Concurrente razonado del Juez Sergio García Ramírez.

Caso Cantos vs Argentina, Sentencia de 28 de noviembre de 2002.

Caso Instituto de Reeducación del Menor vs Paraguay, Sentencia de 2 de abril de 2004.

Caso Herrera Ulloa Vs Costa Rica, Sentencia de 2 de julio de 2004.

Caso 19 comerciantes vs Colombia, Sentencia de 5 de julio de 2004.

Caso Tibi vs. Ecuador, Sentencia de 7 de septiembre de 2004.

Caso Lori Berenson vs Perú, Sentencia de 25 de noviembre de 2004.

Caso Comunidad Yakie Axa vs Paraguay, Sentencia de 17 de junio de 2005.

Caso Fermín Gutiérrez vs Guatemala, Sentencia de 20 de junio de 2005. 
Caso Palamara Iribarne Vs. Chile, Sentencia de 22 de noviembre de 2005.

Caso García Asto Vs Perú, Sentencia de 25 de noviembre de 2005.

Caso Niñas Yean y Bosico vs República Dominicana, Sentencia de 8 de diciembre de 2005.

Caso López Álvarez vs Honduras, Sentencia de 1 de febrero de 2006.

Caso Ximenes Lopes vs Brasil, Sentencia de 4 de julio de 2006.

Caso Claude Reyes y otros vs chile, Sentencia de 19 de septiembre de 2006.

Caso Servellon García vs Honduras, Sentencia de 21 de septiembre de 2006.

Caso Almonacid Arellano y otros vs Chile, Sentencia de 26 de septiembre de 2006.

Caso Aguado Alfaro vs Perú, Sentencia de 24 de noviembre de 2006.

Caso Saramaka vs Surinam, Sentencia de 28 de noviembre de 2007.

Caso Apitz Barbera y Otros vs Venezuela, Sentencia de 5 de agosto de 2008.

Caso Tiu Tojin vs Guatemala, Sentencia 26 de noviembre de 2008.

Caso González y otras vs México, Sentencia de 16 de noviembre de 2009.

Caso Barreto Leiva vs Venezuela, Sentencia de 17 de noviembre de 2009.

Caso Usón Ramírez vs Venezuela, Sentencia 20 de noviembre de 2009.

Caso Radilla Pacheco vs México, Sentencia de 23 de noviembre de 2009.

Caso comunidad indígena Xámok Kásek vs Paraguay, Sentencia de 24 de agosto de 2010.

Caso Fernández Ortega vs México, Sentencia de 30 de agosto de 2010.

Caso Rosendo Cantú vs México, Sentencia de 31 de agosto de 2010.

Caso Vélez Loor vs Panamá, Sentencia de 23 de noviembre de 2010. 
Caso Gelman vs Uruguay, Sentencia de 24 de febrero de 2011.

Caso Atala Riffo y niñas vs Chile, Sentencia de 24 de febrero de 2012.

Caso Kichwa de Saroyaku vs Ecuador, Sentencia de 27 de junio de 2012.

Caso Furlan y Familiares vs Argentina, Sentencia de 31 de agosto de 2012.

Caso Nadege Dorzema y otros vs República Dominicana, Sentencia de 24 de octubre de 2012.

Caso trabajadores de la hacienda Brasil Verde vs Brasil, Sentencia de 20 de octubre de 2016.

\section{b. Opiniones Consultivas e informes}

OC 11/90. Excepción al agotamiento de los recursos internos, de 10 de agosto de 1990.

OC 16/99. El derecho a la información sobre la asistencia consular en el marco de las garantías del debido proceso legal, de 1 de octubre de 1999.

OC/17 sobre la Condición jurídica y los derechos humanos del niño de 28 de agosto de 2002.

OC 18/03. Condición Jurídica y Derechos de los Migrantes indocumentados, de 17 de septiembre de 2003.

Caso Kelly Vs Jamaica, Informe 15 de septiembre de 1987.

\subsection{JURSIPRUDENCIA DEL COMITÉ DE DERECHOS HUMANOS}

Caso Reid (Carlton) vs Jamaica, Observación de 20 de julio de 1990. 
Caso Hill y Hill vs España, Dictamen de 2 de abril de 1997.

\subsection{JURISPRUDENCIA DEL TRIBUNAL EUROPEO DE DERECHOS HUMANOS}

Caso Golder vs Reino Unido, Sentencia de 21 de febrero de 1975.

Caso Airey vs Irlanda, Sentencia de 9 de octubre de 1979.

Caso Ártico vs Italia, Sentencia de 13 de mayo de 1980.

Caso Pakelli vs Alemania, Sentencia de 25 de abril de 1983.

Caso Pretto y otros vs Italia, Sentencia de 8 de diciembre de 1983.

Caso Poitrimol contra Francia, Sentencia del 23 de noviembre de 1993. 